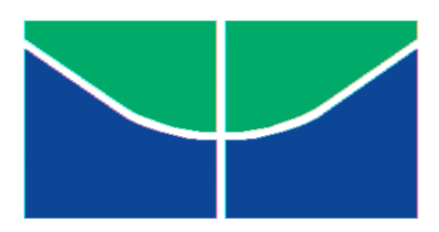

Universidade de Brasília

Faculdade de Educação

Programa de Pós-Graduação em Educação

\title{
GGBOOK: UMA PLATAFORMA QUE INTEGRA O SOFTWARE DE GEOMETRIA DINÂMICA GEOGEBRA COM EDITOR DE TEXTO E EQUAÇÕES A FIM DE PERMITIR A CONSTRUÇÃO DE NARRATIVAS MATEMÁTICAS DINÂMICAS
}

Doutorando: Jorge Cássio Costa Nóbriga

Orientador: Professor Doutor Gilberto Lacerda Santos

Brasília 


\section{GGBOOK: UMA PLATAFORMA QUE INTEGRA O SOFTWARE DE GEOMETRIA DINÂMICA GEOGEBRA COM EDITOR DE TEXTO E EQUAÇÕES A FIM DE PERMITIR A CONSTRUÇÃO DE NARRATIVAS MATEMÁTICAS DINÂMICAS}

Tese apresentada ao Programa de PósGraduação em Educação da Universidade de Brasília - UnB, como requisito parcial para a obtenção do título de Doutor em Educação, na área de confluência Educação, Tecnologias e Comunicação, sob a orientação do Professor Doutor Gilberto Lacerda Santos. 


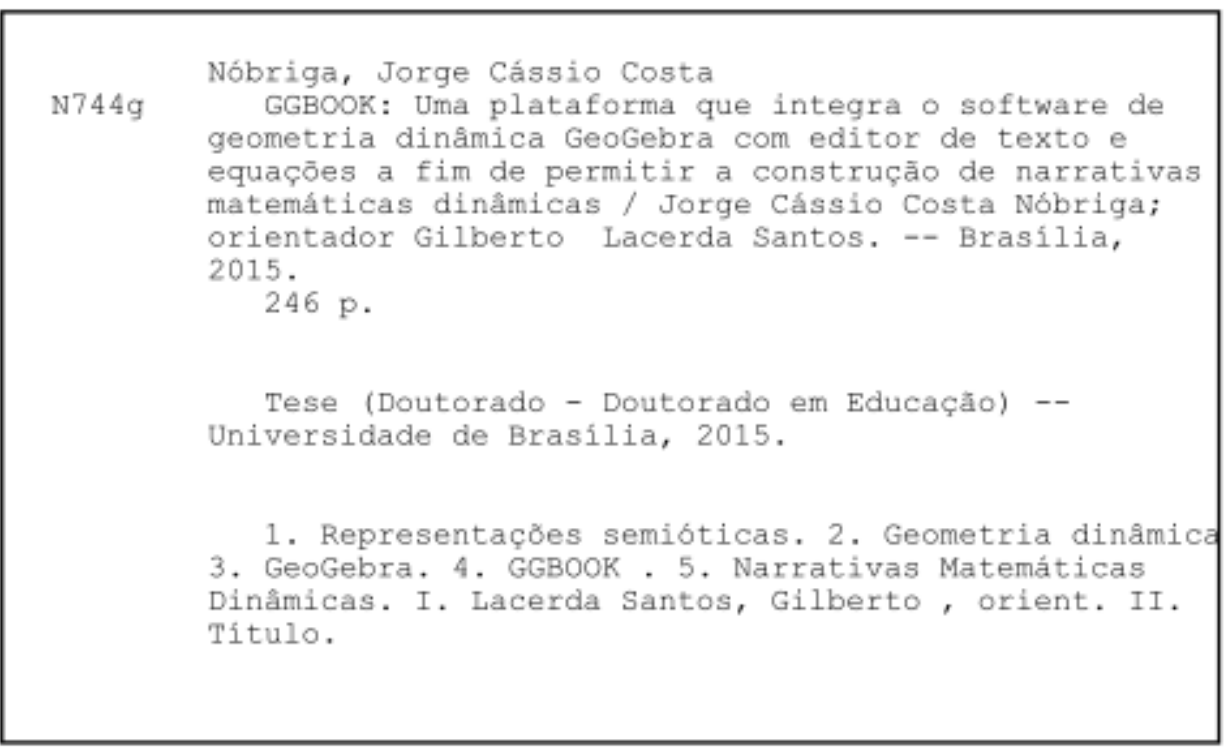


Universidade de Brasília

Faculdade de Educação

Programa de Pós-Graduação em Educação

TESE DE DOUTORADO

GGBOOK: UMA PLATAFORMA QUE INTEGRA O SOFTWARE DE GEOMETRIA DINÂMICA GEOGEBRA COM EDITOR DE TEXTO E EQUAÇÕES A FIM DE PERMITIR A CONSTRUÇÃO DE NARRATIVAS MATEMÁTICAS DINÂMICẢS

Jorge Cássio Costa Nóbriga

Orientador:

Dr. Gilberto Lacerda Santos

Banca examinadora:

Dr. Cristiano Alberto Muniz-UnB

Dr. Marcelo de Carvalho Borba- Unesp

Dr. ${ }^{\text {a }}$ Regina da Silva Pina- UnB

Dr. Carlos Ferreira - Ulisboa

Dr. Antônio Villar Marques de Sa-UnB 
Ao meu pai Jordão Nóbriga da Silva (in memoriam) 


\section{AGRADECIMENTOS}

A Deus, por ter me dado todas as condições de desenvolver este trabalho.

À minha família, que sempre me apoiou e me incentivou. Em especial, à minha companheira Juliana.

Ao meu amigo e orientador, Gilberto Lacerda, com quem aprendi muito! Muito mesmo! Aprendizagens que extrapolaram bastante os puros conhecimentos acadêmicos.

Ao meu amigo, professor Cristiano Muniz, que desde a graduação me incentivou, apoiou e acreditou no meu trabalho. Tenho certeza de que uma conversa que tive com ele, em 1999, influenciou diretamente esta conquista. Agradeço demais por todos os ensinamentos.

Ao professor Carlos Ferreira, por todo apoio que me deu durante o período de estágio de doutorado sanduíche em Lisboa.

À professora Regina Pina e ao professor Marcelo Borba, pelas sugestões e participação na banca.

Ao amigos Bruno Ferreira e Renan de Lima, pela programação do GGBOOK.

Ao amigo, Luís Cláudio, pelos testes e feedbacks.

Ao amigo, Thomas Petit, pela tradução do resumo para o francês.

À amiga, professora Vera Lúcia Cordeiro, pela revisão do texto.

Aos professores e colegas do Programa de Pós-Graduação.

À CAPES, pelo apoio financeiro para estágio de doutorado sanduíche em Lisboa, e aos estudantes que participaram da pesquisa. 


\section{RESUMO}

Neste trabalho, apresentamos uma pesquisa que teve por objetivo analisar as possibilidades de construção de Narrativas Matemáticas Dinâmicas a partir das interações realizadas em uma plataforma que integra editores de texto e equações com o software educativo GeoGebra, a qual denominamos GGBOOK. Para fundamentar e construir o conceito de Narrativas Matemáticas Dinâmicas, buscamos suporte em autores que tratam de Representações Semióticas, Linguagem, Linguagem Matemática, Narrativas e Narrativas Matemáticas. Buscamos também autores que tratam de Informática Educativa e de Geometria Dinâmica. Para o desenvolvimento do GGBOOK, usamos a metodologia da Prototipação que norteou os trabalhos de uma equipe composta por pesquisadores, professores de Matemática e programadores. Para a parte da pesquisa, optamos pela análise de conteúdo. Foram feitos experimentos, usando o GGBOOK, com 10 estudantes de um curso de Licenciatura em Matemática. Os resultados mostraram que o GGBOOK contribuiu para a produção e a integração das representações de forma a facilitar o trabalho do estudante e do professor na análise/interpretação daquilo que o estudante fez. Ou seja, o GGBOOK permite que se possam desenvolver compreensões a respeito de objetos matemáticos e comunicá-los, ao mesmo tempo em que auxilia também numa interpretação mais fácil e factível das compreensões ou incompreensões dos estudantes por meio de suas representações.

Palavras-chave: Representações semióticas. Geometria dinâmica. GeoGebra. GGBOOK. Narrativas Matemáticas Dinâmicas 


\begin{abstract}
In this work, we present a research whose objective was to analyze the possibilities of building Dynamic Mathematical Narratives from interactions held on a platform which integrates word and equation processors with the educative software GeoGebra, which we denominated GGBOOK. In order to build a concept foundation of Dynamic Mathematical Narratives, we looked for support of authors who deal with Semiotic Representations, Language, Mathematical Language, Narratives, and Mathematical Narratives. We also looked for authors who deal with Education Technology and Dynamic Geometry. In the GGBOOK development, we used the proto-participation methodology, which guided the work of a team formed by researchers, mathematics teachers, and programmers. For the research part, we opted for the content analysis. Experiments were done, using the GGBOOK, with 10 students of an undergraduate licensure course in Mathematics. The results showed that the GGBOOK contributed to the integration and the production of form representations, facilitating the work of both the student and the teacher in the analysis and interpretation of what the student did. That is, the GGBOOK allows the development of comprehensions about mathematical objectives and their communication, at the same time that it also assists, by means of their representations, in an easier and more factibel interpretation of students' comprehensions or incomprehensions.
\end{abstract}

Keywords: Semiotic Representations. Dynamic Geometry. GeoGebra. GGBOOK. Dynamic Mathematical Narratives. 


\section{RÉSUMÉ}

La recherche présentée dans ce travail avait pour objectif d'analyser les possibilités de construction de Récits Mathématiques Dynamiques à partir des interactions réalisées sur la plateforme GGBOOK, créée pour l'occasion, qui intègre des éditeurs de textes et des équations dans le logiciel éducatif GeoGebra. Afin de construire et soutenir le concept de Récits Mathématiques Dynamiques, nous nous sommes appuyés sur des auteurs qui étudient les Représentations Sémiotiques, le Langage, le Langage Mathématique, les Récits et les Récits Mathématiques, ainsi que des auteurs qui s'intéressent à l'Informatique Éducative et à la Géométrie Dynamique. La méthodologie de Prototypage a été adoptée pour le développement du GGBOOK, afin d'orienter les travaux d'une équipe composée de chercheurs, de professeurs de mathématiques et de développeurs. Des expérimentations du GGBOOK ont été réalisées avec 10 étudiants d'un cours de Licence en Mathématiques. Les résultats, interprétés à travers une analyse de contenu, montrent les contributions du GGBOOK au niveau de la production et de l'intégration des représentations de manière à faciliter le travail de l'étudiant et du professeur dans l'interprétation de l'activité réalisée par l'étudiant. Le GGBOOK permet donc une meilleure compréhension et communication des objets mathématiques, tout en aidant à rendre plus facile et faisable l'interprétation des compréhensions et incompréhensions des étudiants à travers leurs représentations dévoilées dans les récits.

Mots clés : Représentations Sémiotiques ; Géométrie Dynamique ; GeoGebra ;

GGBOOK ; Récits Mathématiques Dynamiques. 


\section{Lista de figuras}

Figura 1-Papiro com a proposição 5 dos Elementos de Euclides ..........................................17

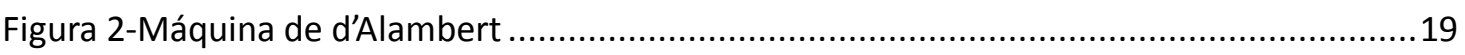

Figura 3-Exemplo para verificação de caráter congruente ou não congruente (SANTOS, 2011,

p. 44)

Figura 4-Modelo da representação centrada sobre a função de tratamento ..........................51

Figura 5-Modelo centrado sobre a função de objetivação......................................................51

Figura 6- Designações verbais de uma das unidades figurais discerníveis..............................55

Figura 7-Operação Figural para produzir um contraexemplo que mostra um polígono que tem

os lados de mesma medida e não é regular.

Figura 8-Um tratamento puramente figural para a percepção do valor da soma dos ângulos internos de um triângulo.

Figura 9-Desconstrução para a identificação das unidades de sentido cateto oposto e

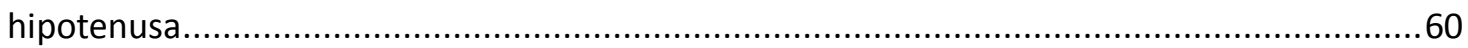

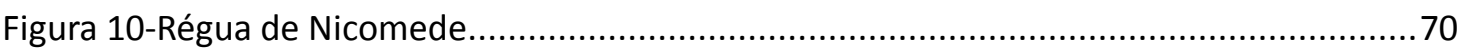

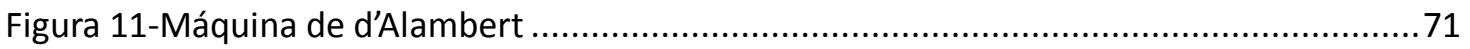

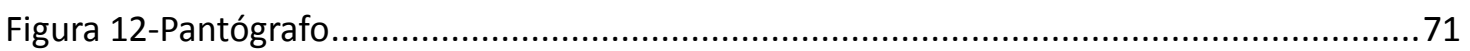

Figura 13-Construção para auxiliar a compreensão do problema "Tesouro dos piratas" ..........75

Figura 14-Construção feita no GeoGebra para compreensão do Teorema de Pitágoras ...........75

Figura 15-Construção feita no GeoGebra para dedução da fórmula da área do círculo ............76

Figura 16-Construção feita no Cabri 3d para visualização do tronco de pirâmide ...................77

Figura 17-Interface do Geogebra com a disposição "Álgebra e Gráficos" ................................81

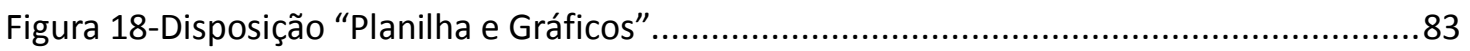

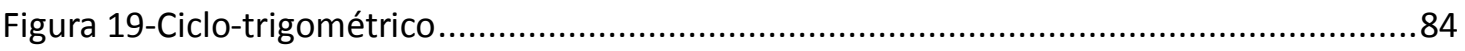

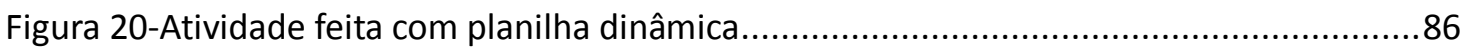

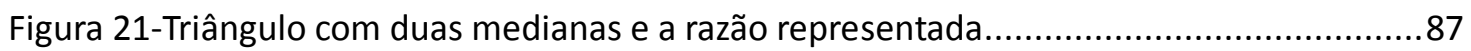

Figura 22-Triângulo com duas medianas, a razão e oresultado representado ...........................88

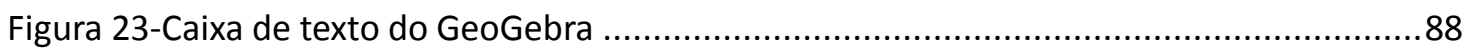

Figura 24-Construção feita no GeoGebra para explorar o gráfico da função cosseno..............99

Figura 25-Construção com textos dinâmicos feita no GeoGebra para explorar a equação do 20ㅡ․

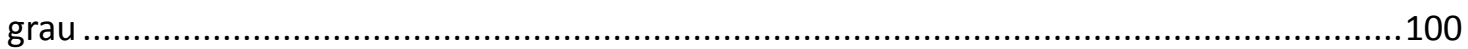

Figura 26-Construção com textos dinâmicos feita no GeoGebra .........................................101

Figura 27-Representação proposta por um grupo de estudantes (NOTARE, 2009, p.91) .......104

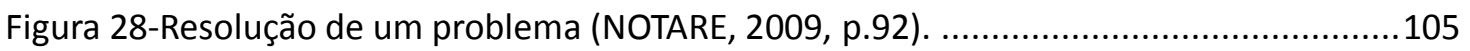

Figura 29-Continuação da resolução do problema (NOTARE, 2009, p.93) .............................106

Figura 30-Modelo de Prototipação (PRESSMAN, 2002) ...................................................111

Figura 31-O processo de engenharia de Requisitos (SOMMERVILLE, 2003) .........................111

Figura 32-Esboço do layout da interface da 1a versão do GGBOOK ....................................113

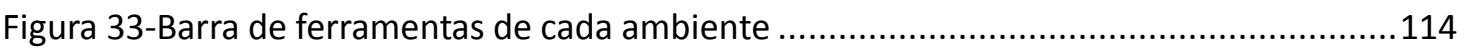

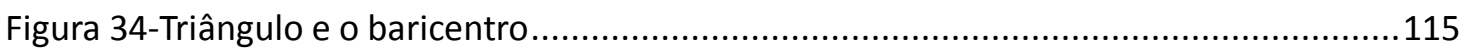

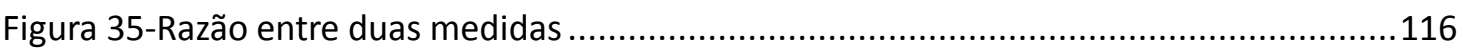

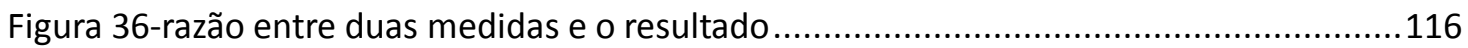

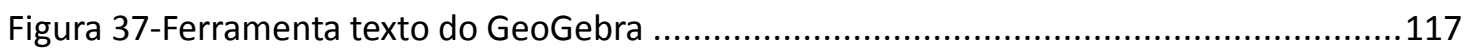

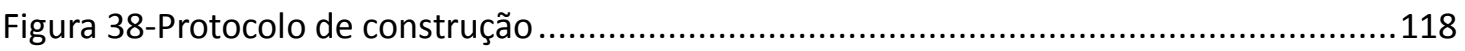


Figura 39-Atividade sobre a lei dos senos feita na primeira versão do GGBOOK ...................119

Figura 40-Resposta do estudante para a primeira atividade ............................................120

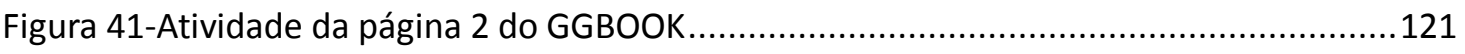

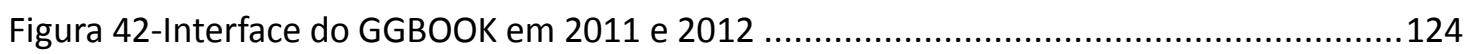

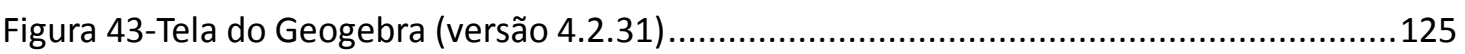

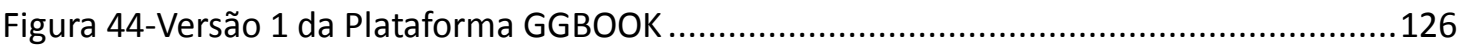

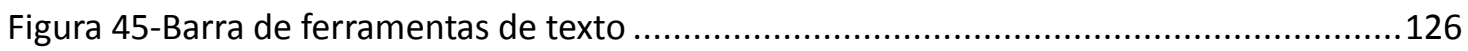

Figura 46-Barra de Ferramentas de equações da versão 1 do GGBOOK................................127

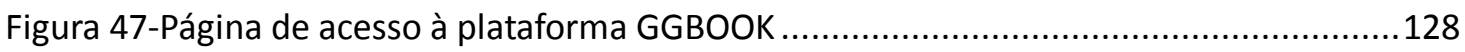

Figura 48-Página para criação de livros na plataforma GGBOOK .......................................129

Figura 49-Tela para criação de livros na plataforma GGBOOK............................................129

Figura 50-Divisão dos espaços na tela inicial da plataforma GGBOOK .................................130

Figura 51-Barra de ferramenta de texto e equações da plataforma GGBOOK ........................130

Figura 52-Exemplo de utilização da plataforma GGBOOK.................................................131

Figura 53-Exemplo de fazer uma operação na plataforma GGBOOK .....................................131

Figura 54-Conversão para o registro simbólico, usando dois registros diferentes .................143

Figura 55-Conversão para o registro de representação linguístico, usando dois registros

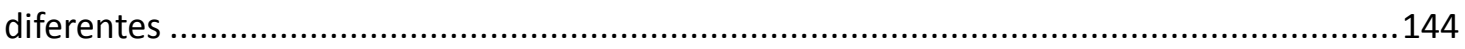

Figura 56-Atividade para a produção da Narrativa Matemática sobre a lei dos Senos ...........145

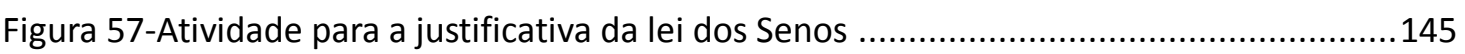

Figura 58-Atividade para a continuação da justificativa da lei dos Senos ...............................146

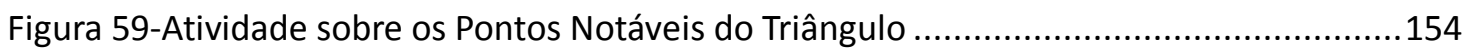

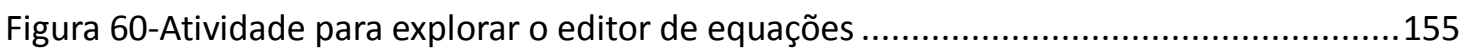

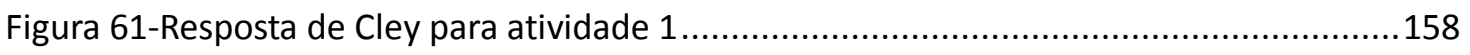

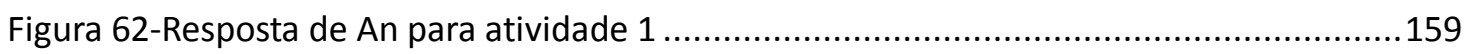

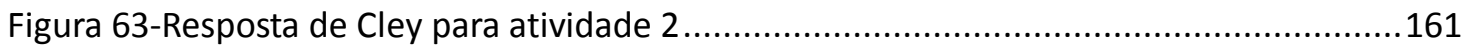

Figura 64-Figura construída por Mar para responder a atividade 2 …................................162

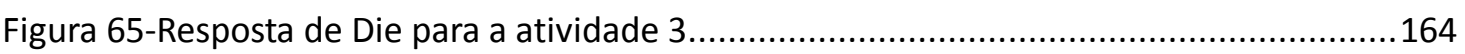

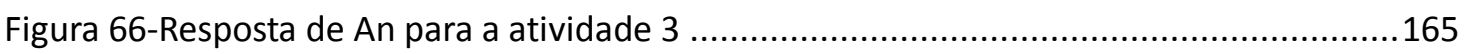

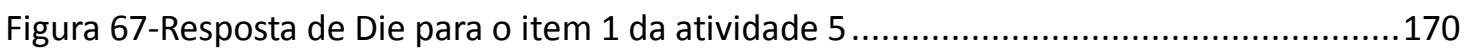

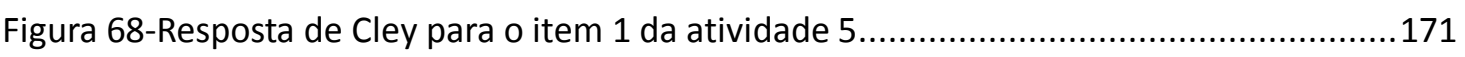

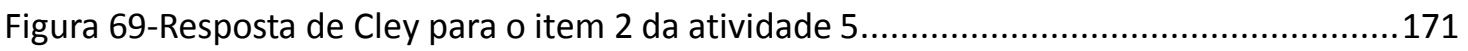

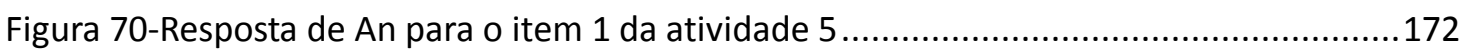

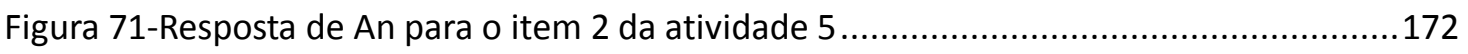

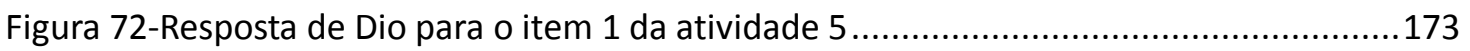

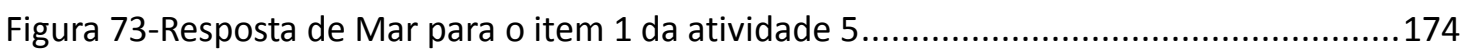

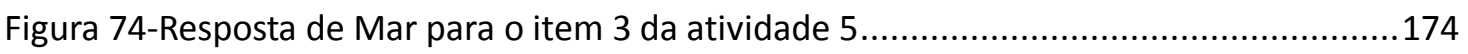

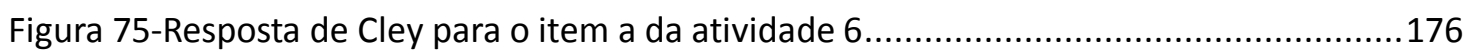

Figura 76-Triângulo que estava na tela do GeoGebra de Mar na atividade 6 .........................177

Figura 77-Triângulo que estava na tela do GeoGebra de Dio na atividade 6 ........................178

Figura 78-Desconstrução necessária para a identificação das unidades de sentido hipotenusa

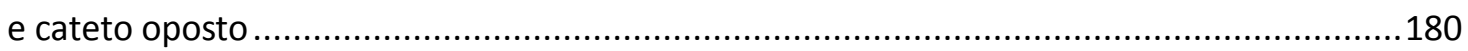

Figura 79-Representação simbólica feita por An para o item 2 da atividade 5 ......................185

Figura 80-Comandos que precisam ser inseridos no editor de texto do Geogebra ................186

Figura 81-Conectivo usado por Die para integrar as representações simbólica e linguística..188 
Figura 82-Diferentes representações feitas por Cley para atividade 2 .................................188

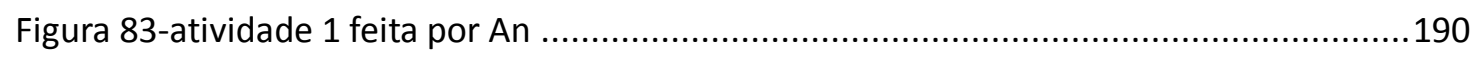

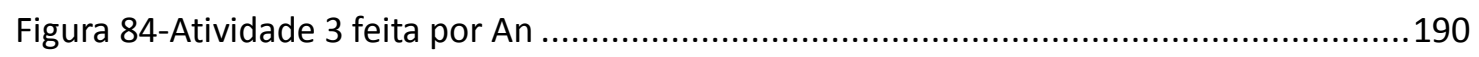

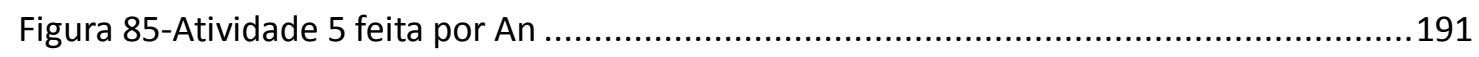

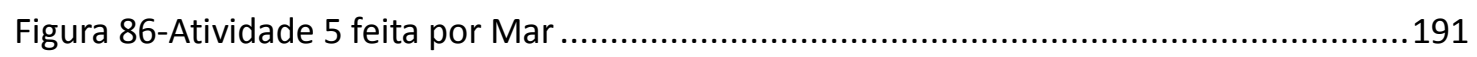

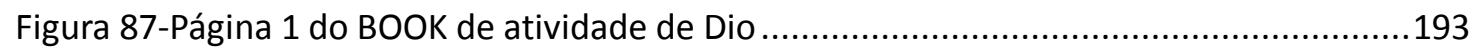

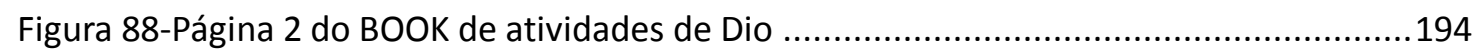

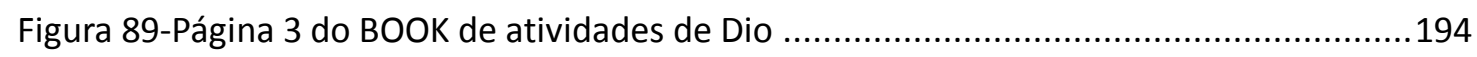

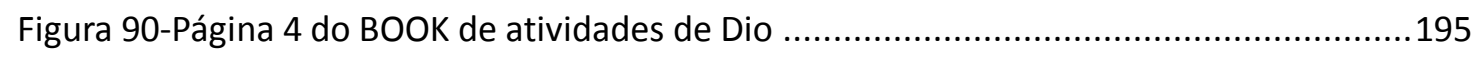

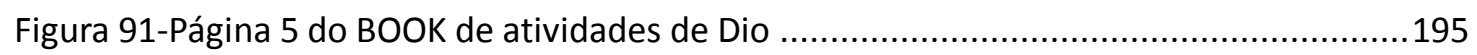

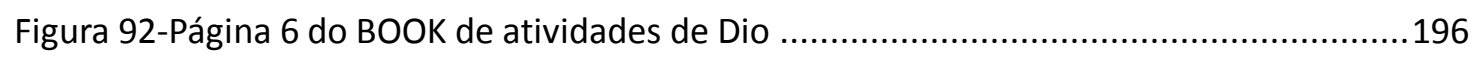

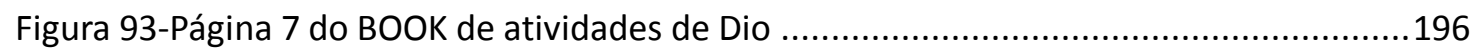

\section{Lista de Tabelas}

Tabela 1-Comparação de registros e códigos (DUVAL, 2011, p. 7) ............................................35

Tabela 2-Classificação dos registros de representação dos sistemas semióticos dos objetos

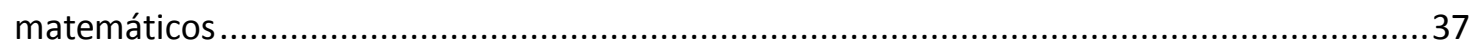

Tabela 3-Exemplo de tradução matemática em que há congruência das representações .......47

Tabela 4-Exemplo de tradução matemática em que as representações são não congruentes. 48 Tabela 5-Possível relação entre as unidades de sentido que os estudantes fariam na atividade

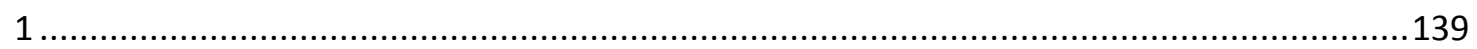

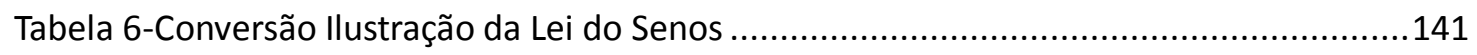

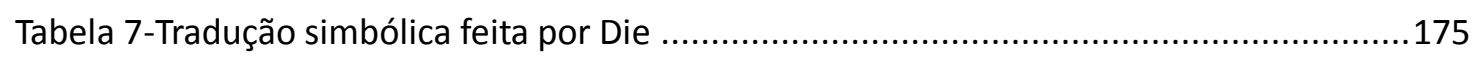

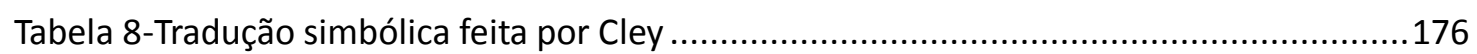

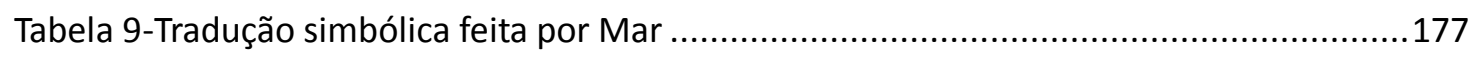

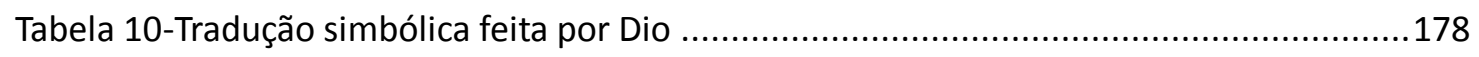




\section{SUMÁRIO}

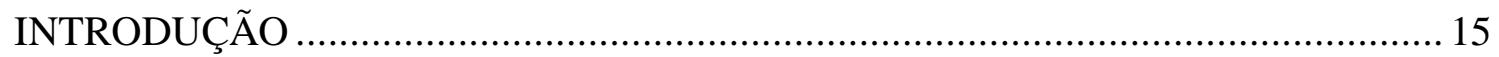

1. CONTEXTO E EXPLICITAÇÃO DO OBJETO DE PESQUISA …………….......25

2. A TEORIA DAS REPRESENTAÇÕES SEMIÓTICAS DE DUVAL …………..... 33

2.1 Noções Iniciais: Sistemas Semióticos, Registros de Representações

Semióticas, Códigos, Representações Não Semióticas, Representações Mistas e

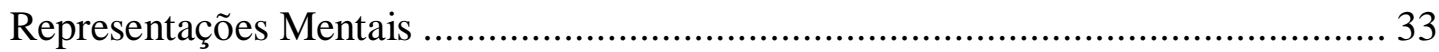

2.2 Atividades cognitivas: Formação, Tratamento e Conversão …………………... 41

2.3 Variações de Congruência, de não congruência e Heterogeneidade dos dois

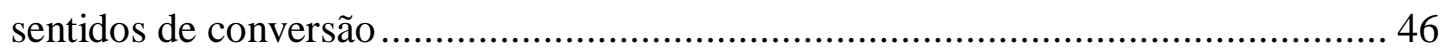

2.4 Ferramenta de Análise Cognitiva das Atividades Matemáticas ........................53

2.5 Um exemplo de análise cognitiva: o caso da Geometria ................................ 57

2.6 Uso do Computador e as Representações Semióticas.......................................... 62

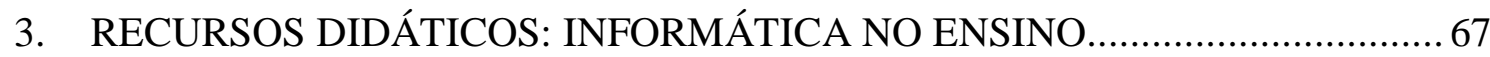

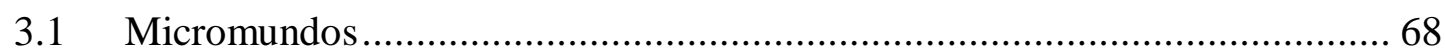

3.2 Micromundos de Geometria Dinâmica …………………………………........ 69

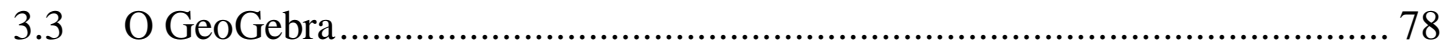

3.3.1 A interface do GeoGebra.......................................................................... 81

3.3.2 Algumas possibilidades de exploração do GeoGebra .........................................84

3.3.3 Alguns limites e dificuldades operacionais do GeoGebra ...................................87

4. LINGUAGEM, LINGUAGEM MATEMÁTICA, NARRATIVA E

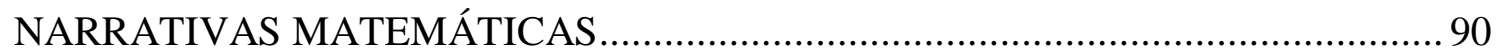

4.1 Linguagem e Linguagem Matemática.......................................................... 90

4.2 Narrativas e Narrativas Matemáticas …………………………………........ 91

4.3 Novas maneiras de se representar, fazer questões e registros com os programas de Geometria Dinâmica ....................................................................................... 97

4.4 Narrativas Matemáticas Estáticas e Narrativas Matemáticas Dinâmicas ..... 102

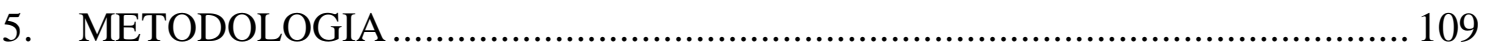

5.1 Metodologia para o desenvolvimento da plataforma: Prototipação ............... 109

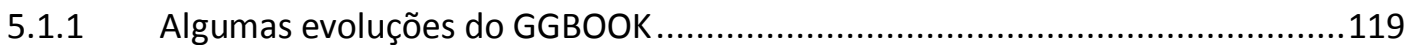

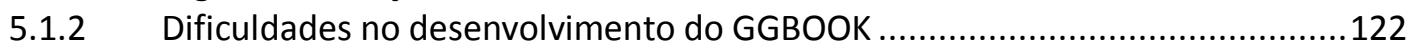

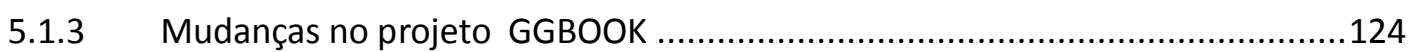

5.1.4 A plataforma GGBOOK (versão 0.15.1-Beta 5) …............................................128

5.2. Proposta metodológica para validação do software ................................... 132

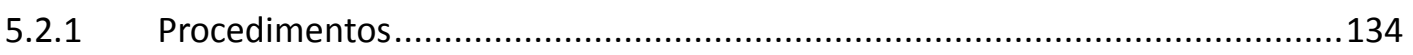




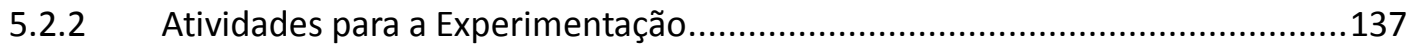

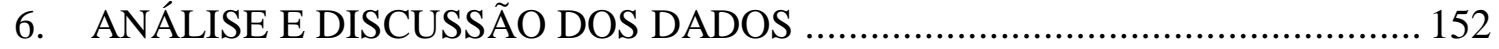

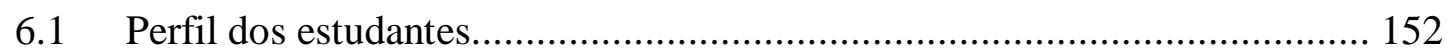

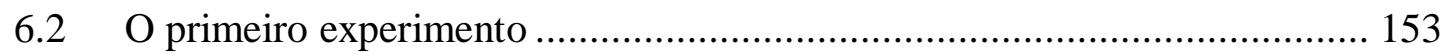

6.3 Aprendizagem dos conceitos matemáticos............................................... 156

6.4 Produção das Narrativas nos dois ambientes.............................................. 183

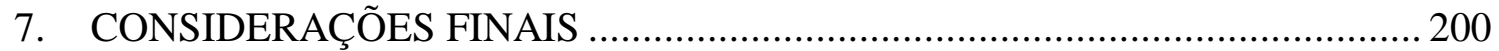

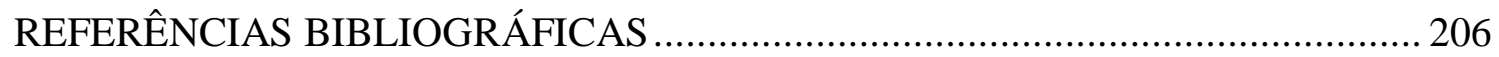

APÊNDICE A: RELATÓRIOS DO GGBOOK 2013 …........................................ 211

APÊNDICE B: RELATÓRIOS DO GGBOOK 2013 (2 SEMESTRE) ...................... 216

APÊNDICE C- RELATÓRIOS DO GGBOOK 2014 ............................................. 245

APÊNDICE D: TERMO DE CONSENTIMENTO ................................................ 247 


\section{INTRODUÇÃO}

Uma boa forma de começar este texto é perguntando: como ocorre o conhecimento matemático? Qual a origem do conhecimento matemático? Tais perguntas nos remeteriam a origem do conhecimento e respondê-las seria o mesmo que responder se o conhecimento tem origem na razão, na experiência ou nos dois. Se recorrermos aos estudos de filósofos (HESSEN, 2003), constataremos que a pergunta sobre a origem do conhecimento humano pode ter tanto um sentido psicológico quanto lógico. Psicologicamente falando, como se daria o conhecimento no sujeito pensante? Por outro lado, no sentido lógico, as perguntas seriam: Em que se baseia a validade do conhecimento? Quais são seus fundamentos lógicos? O mesmo autor alerta que tais questões não têm sido separadas na história da filosofia. De fato, nem poderiam ser separadas, porque existe uma ligação interna entre esses dois pontos de vista.

A resposta à questão da validade pressupõe uma perspectiva psicológica determinada. Quem enxerga no pensamento humano, na razão, o único fundamento do conhecimento, está convencido da independência e especificidade psicológica do processo de pensamento. Por outro lado, quem fundamenta todo o conhecimento matemático na experiência negará independência, mesmo sob o aspecto psicológico, ao pensamento (HESSEN, 2003, p. 48)

A partir do questionamento sobre a origem do conhecimento, surgiram "correntes" que defendiam diferentes pontos de vistas. Os racionalistas (de ratio, razão) acreditavam que o pensamento (ou a razão) era a principal fonte do conhecimento humano. Eles argumentavam dizendo que um conhecimento só pode ser de fato autêntico se tiver validade universal. Por exemplo, "existem infinitos números". Isso não se trata de juízo que está baseado numa experiência qualquer, mas no pensamento. É possível constatar que existem infinitos números na medida em que se representa claramente o conceito "número" e encontra-se nele a característica "infinitos". Os juízos baseados no pensamento possuem necessidade lógica e validade universal e são diferentes de outros conhecimentos em que ao invés de dizer "é assim" pode-se apenas dizer "deve ser assim". O conhecimento matemático talvez seja o melhor modelo para a interpretação racionalista do conhecimento. Pois se trata de um conhecimento predominantemente dedutivo e conceitual. Tomemos, por exemplo, a geometria euclidiana em que todos seus conceitos são derivados de axiomas e conceitos anteriores (superiores). Tais conceitos independem da experiência, porque seguem suas próprias leis.

Não estamos querendo entrar no mérito da discussão sobre qual é a origem do conhecimento. Nem mesmo defender que a Matemática é o verdadeiro ou único conhecimento autêntico. O que queremos dizer é que concordamos que a origem do 
conhecimento matemático está, sobretudo, na razão. Não é que achemos que não houve motivações empíricas. Nem que achemos que todos seus conceitos independem totalmente da experiência e que as ideias são inatas, mas que seus conceitos são, essencialmente, abstratos. O que entendemos por conceito abstrato? De acordo com Hessen (2003, p. 21) podem-se dividir os objetos em reais e ideais:

Chamamos de objetos reais ou efetivos todos que nos são dados na experiência externa ou interna ou são inferidos a partir dela. Comparados a eles, os objetos ideais aparecem como irreais, meramente pensados. Esses objetos ideais são, por exemplo, as estruturas matemáticas, os números e as figuras geométricas.

Dito de outra forma, os objetos reais seriam materiais ou concretos ${ }^{1}$ e os objetos ideais seriam os abstratos. Assim, a Matemática é abstrata e seu acesso não poderia ser dado empiricamente, como no caso da botânica. “O critério de verdade em matemática não é o que é dado empiricamente, mas o possível que podemos construir” (DUVAL, 2011, p. 66). Então como acessar o conhecimento matemático? Não é possível ser acessado sem as representações! A representação é o modo pelo qual se torna possível a visibilidade, a transparência e, assim, a ordenação dos objetos do conhecimento. A representação como suporte que possibilita a mediação entre dois polos: o do sujeito e o do objeto (FLORES, 2006). Uma diferença intrínseca entre a representação e o próprio objeto é a variabilidade de uma e a invariabilidade da outra. Diferentemente do objeto, suas representações mudam segundo os pontos de vista considerados e os sistemas utilizados para produzir a representação. O objeto aparece como o invariante do conjunto de variações possíveis de suas representações. Assim, o triângulo não é nenhuma das figuras particulares por meio das quais o representamos (DUVAL, 2011).

Da Idade Antiga até a Idade Média, a Matemática era representada quase que totalmente de forma retórica, ou seja, usando a língua materna (ou linguagem natural). Podese observar isso nos Elementos de Euclides em que, basicamente, usava-se a representação linguística e figural.

\footnotetext{
${ }^{1}$ Não há nada mais incerto e mais variável que a linha divisória entre o que é intuitivo e o que não é, entre o que é concreto e o que não é (DUVAL, 2011, p. 60)
} 


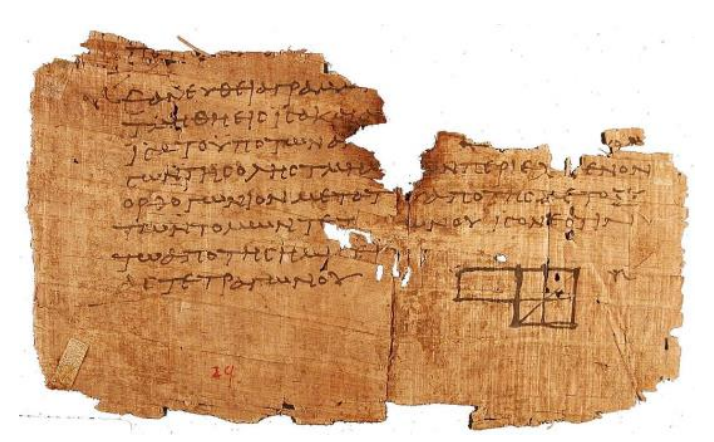

Figura 1-Papiro com a proposição 5 dos Elementos de Euclides

A aritmética e o cálculo não existiam da forma como é hoje. Tratava-se de uma forma de geometria métrica. Ou seja, "Para os gregos, uma variável correspondia ao comprimento de um segmento, o produto de duas variáveis à área de algum retângulo e o produto de três variáveis ao volume de algum paralelepípedo retângulo" (EVES, 2004, p.384). No sistema matemático antigo, a geometria não fornecia apenas uma notação à aritmética: as figuras geométricas eram consideradas como sendo, de fato, os próprios números. Nesse sentido, Flores (2006) diz que se concebia o número com estatutos diferentes, grandezas conhecidas ou desconhecidas com gêneros diferentes, de modo que cada qual possui uma "marca distintiva": as grandezas quadradas, as grandezas cúbicas.

A partir do renascimento, no fim do século XVI e início do século XVII, Viète e Descartes fundamentam uma nova linguagem em que uma escritura simbólica era usada para representar cálculos e que vigora até hoje. Com a Geometria Analítica de Descartes, em 1637, via-se um sistema de escritura que apresentava estruturas inteiramente novas, em detrimento das escrituras retóricas da Matemática grega e medieval. Tinha-se, assim,

[...] a passagem histórica progressiva entre uma escritura "grega" das matemáticas, puramente retórica, quer dizer, inscrita na língua comum, onde tudo se diz e se calcula em palavras, a uma escritura simbólica onde o texto é quase reduzido a uma concatenação de signos (letras, números, ou signos figurados), que é preciso de início decifrá-los, depois interpretar segundo regras sintáxicas e semânticas prescritas. (SERFATI, 1997 citado por FLORES, 2006, p.9).

De acordo com Eves (2004, p. 309), "Viète introduziu a prática de se usar vogais para representar incógnitas e consoantes para representar constantes. A convenção atual de usar as últimas letras do alfabeto para indicar as incógnitas e as primeiras para as constantes foi introduzida por Descartes em 1637”. Assim, a escritura e o cálculo se reorganizavam em torno de uma convenção universal de interpretação, o que antes era em torno da geometria unida à retórica. Dessa forma, com a invenção do simbolismo matemático de Viète e de Descartes, surge a primeira versão de escritura simbólica em Matemática, dando ordem à Matemática e ao seu pensamento e originando a geometria analítica (DESCARTES e FERMAT). De 
posse da nova linguagem simbólica e das regras de cálculos, foi possível fazer vários tipos de cálculos, mesmo aqueles que antes não eram realizados. Isso possibilitou a Leibniz, em 1676, criar o método de cálculo infinitesimal, definindo, dessa forma, as operações de integração e derivação.

Após essa breve contextualização a respeito dos tipos de representações ao longo da história da Matemática, podemos retomar a questão inicial sobre a origem do conhecimento (agora com um viés voltado para o conhecimento matemático). Havíamos dito que a pergunta sobre a origem do conhecimento humano pode ter tanto um sentido psicológico quanto lógico. Interessa-nos o sentido psicológico: como se daria o conhecimento matemático no sujeito pensante? A resposta para essa pergunta está relacionada com as representações. Para Duval (2009), o problema da aquisição dos conhecimentos no âmbito da história das ciências e da Matemática está muito próximo daquele do individual, ou seja, da aprendizagem. Por isso, compreender o modo de elaboração dos conceitos matemáticos, implica em retomar sua significação, como também seus processos de aquisição e funcionamento.

A história mostra que o uso das representações não foi importante apenas para comunicar. Com as novas formas de representação simbólica, muitos conhecimentos novos surgiram. Por exemplo: a escrita algébrica e as representações gráficas abriram acesso às funções. No entanto, o uso das representações não é importante apenas para a comunicação e para a criação de novos conhecimentos matemáticos, ela também é necessária para a compreensão. Quando se leva em consideração a história da origem do conhecimento matemático, percebe-se que o acesso a seus objetos é diferente das demais áreas. "Os problemas específicos de compreensão que os alunos enfrentam na matemática têm sua origem na situação epistemológica particular do conhecimento matemático, e não somente nas questões de organização pedagógica das atividades” (DUVAL, 2011, p. 9).

Assim, a compreensão em Matemática exige um funcionamento cognitivo diferente das demais áreas. Para isso, a primeira atividade cognitiva é a explicitação da representação. Em se tratando da explicitação das representações em língua natural ou simbólica, não parece ter havido muitas dificuldades para o homem, porque tais atividades podiam ser feitas a mão livre. No entanto, as explicitações das representações gráficas ou figurais, em muitos casos, não eram tão simples assim e exigiram a utilização de instrumentos adicionais ao lápis ou ao giz. Pode-se dar um exemplo simples que é a utilização do compasso para a representação figural do círculo. Por outro lado, pode-se dar um exemplo mais complexo como a Máquina de d'Alambert para representar gráficos de funções de $2^{\circ}$ grau. 


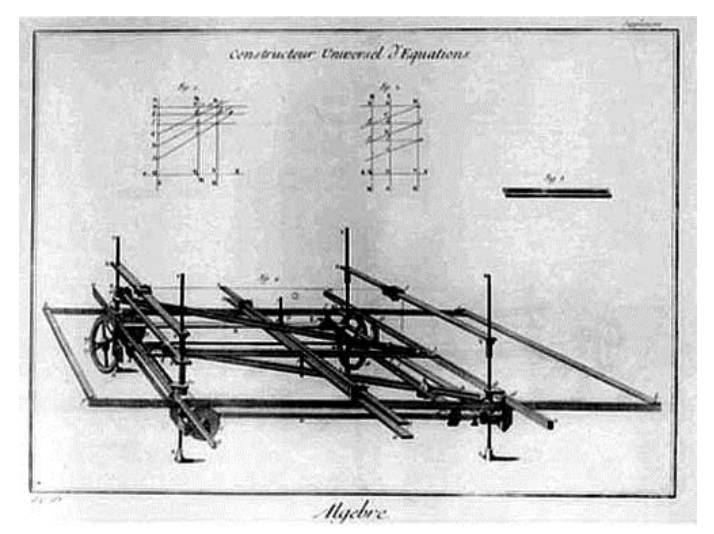

Figura 2-Máquina de d'Alambert

É provável que D`Alambert tenha criado tal instrumento para poder visualizar melhor a representação do conceito. No entanto, apenas a representação não era suficiente, porque o conhecimento matemático não começa com as representações dos conceitos ou objetos matemáticos, mas com as transformações (DUVAL, 2011). Ou seja, não bastava apenas saber representar, mas também transformar e conectar as representações, percebendo suas relações. Isso é válido tanto para a produção de novos conhecimentos quanto para a compreensão dos já existentes. $\mathrm{O}$ ábaco é um exemplo de instrumento usado há bastante tempo que permite fazer algumas representações e transformações dos números decimais. Tal instrumento pode ser considerado como uma calculadora. No entanto, a primeira calculadora, formalmente considerada com tal, foi inventada por Pascal e tinha como finalidade ajudar a computar os impostos. Ela fazia operações de adição e de subtração, que se pode chamar de transformações na representação simbólica do número.

A invensão dos primeiros computadores teve como propósito inicial, sobretudo, fazer cálculos automáticos. Com o passar do tempo, tornaram-se uma máquina capaz de fazer variados tipos de tratamento automático de informações em diferentes formas de representações. Isso contribuiu para o surgimento de novas formas de se fazer Matemática. Boa parte do conhecimento no campo da geometria fractal só foi possível graças ao auxílio dos computadores e há pesquisas (SOUSA, 2001) quem mostram que a prova do teorema das 4 cores só foi possível com o computador. Contudo, a principal contribuição de tal recurso para a Matemática está relacionada com sua utilização para a compreensão, ou seja, para o processo de aprendizagem e ensino. Talvez o primeiro software educativo que tenha contribuído para isso tenha sido o LOGO. Borba, Scucuglia e Gadanidis (2014) dizem que se trata de uma linguagem de programação que é utilizada para a compreensão do significado de execução dos comandos em relação à sua representação. Por exemplo, pode-se fazer a 
representação figural de um quadrado, usando comandos "lógicos" (ParaFrente, ParaTrás, GireDireita e GireEsquerda). Os mesmos autores dizem que a experimentação com o LOGO oferece condições para que o estudante possa estabelecer relações entre representações algébricas (os comandos) e representações geométricas dinâmicas (os movimentos executados pela tartaruga).

Depois surgiram os primeiros softwares de Geometria Dinâmica (GD) CabriGéomètre e o Geometer's Sketchpad. Tais softwares permitiam formação e transformações de diferentes representações visuais (figuras e gráficos). As propriedades geométricas e relações entre objetos usados dentro de uma construção, nesses softwares, são mantidas porque ao manipular um objeto também se modificam objetos dependentes dele (manipulação direta). Alguns programas de GD fornecem algumas características algébricas básicas, exibindo equações de retas, cônicas e outras expressões matemáticas que normalmente não podem ser modificadas diretamente pelo usuário. Paralelamente, foram surgindo softwares mais específicos de álgebra computacional (Maple, WxMaxima, etc) que, simbolicamente, trabalham com álgebra, geometria analítica e cálculo. Usando equações de objetos geométricos, um usuário de software de álgebra computacional poderia decidir sobre a posição em relação ao outro e exibir as suas representações gráficas. Geralmente, a representação geométrica dos objetos não pode ser diretamente modificada pelo usuário. Numa tentativa de integrar esses dois tipos de softwares foi criado o GeoGebra, em que a geometria, a álgebra e o cálculo são tratados de forma integrada.

De fato, o GeoGebra é considerado uma grande revolução para formação e transformação das representações matemáticas, porque ele integra, dinamicamente, as diferentes representações do objeto matemático. Isso possibilita que se percebam mais facilmente as relações entre as representações, sobretudo as representações simbólicas e gráficas. No entanto, tal software possui limites no que diz respeito à formação e à integração das representações simbólicas e linguísticas. Isso é evidenciado quando se quer integrar tais representações para escrever, por exemplo, “A razão entre os segmentos $\mathrm{AB}$ e $\mathrm{AC}$ é igual a $\frac{A B}{A C}$, . Para isso, o usuário precisa digitar no campo texto o seguinte comando:

$$
\text { Al;razãol;entrel;os\;segmentosl;AB\;el;BCl;él;iguall;alfrac }\{\mathrm{AB}\}\{\mathrm{AC}\} \text { ". }
$$


Ou seja, a digitação não é da mesma forma como se lê ou fala ${ }^{2}$. O "l;" é um comando para dar um espaço. $\mathrm{O} \backslash \operatorname{frac}\{\}\{\}$ é o comando para gerar o símbolo de fração. Se o usuário quiser ver o resultado da fração (divisão), deverá escrever outros comandos. Como se pode perceber, o procedimento não é intuitivo. Isso acontece porque o GeoGebra usa em seu editor de texto o recurso $\mathrm{LaTeX}^{3}$. Trata-se de um recurso poderoso para edição de textos em alta qualidade, mas que é de difícil utilização para usuários pouco familiarizados com tal recurso.

Outro limite do GeoGebra está relacionado com o espaço disponibilizado em sua interface para a edição de textos. Ao que parece tal ferramenta foi concebida para criação apenas de pequenos textos. Textos apenas para explicar algumas características de algum objeto ou colocar alguma orientação de manipulação. Talvez, tal ferramenta tenha sido concebida a partir de uma visão de que a representação linguística é necessária apenas para a comunicação ou designação de objetos.

A interface com o computador elimina a linguagem, isto é, todas as operações discursivas. Sua utilização se reduz ao emprego de um léxico ou de palavras-chave. Podemos, mesmo, curtocicuitá-las completamente trocando palavras por ícones. Na realidade, o modo de exposição no monitor só é inovador para registros diferentes da língua natural (DUVAL, 2011, p. 139).

Acreditamos que tal visão desvaloriza a importância de tal representação. Concordamos com Duval (2011, p.81) que é "[...] preciso se exprimir para si e para os outros para poder tomar consciência e a expressão verbal abre via para o pensamento". Exprimir-se não é codificar um pensamento já explícito, mas objetivá-lo por si mesmo, tomar consciência, mesmo quando endereçamos a outro. A expressão linguística é um ato oposto da codificação, à medida que o pensamento só emerge com as palavras que começam a dizê-lo, ou seja, a língua não tem apenas função de comunicação, mas também função cognitiva.

Levando em consideração as funções de comunicação e de cognição, como se exprimir em Matemática sem a representação linguística? Será que é possível exprimir-se sobre os objetos matemáticos apenas com a representação simbólica e figural? Acreditamos que isso não é possível. Para que o indivíduo possa tomar consciência em Matemática, acreditamos que ele precisa se exprimir de forma escrita usando os registros de representação linguístico, simbólico e visual (gráfico, figuras, tabelas, etc). Tudo de forma integrada e simultânea. É evidente que isso só é possível com a ajuda de algum recurso tecnológico

\footnotetext{
2 a fração tambem não é escrita da forma como se lê. No entanto, trata-se de uma representação conhecida pelos estudantes desdes as séries iniciais.

${ }^{3}$ LaTeX é um sistema ou programa de marcação para a editoração de documentos de alta qualidades tipográfica específico para a elaboração de textos científicos
} 
(afinal, as pessoas não têm três mãos para fazer as três representações ao mesmo tempo). Como vimos, apesar dos limites em relação às representações linguística e simbólica, o GeoGebra é o software que mais se aproxima de tal recurso. Então o que precisa ser feito é um software mais amplo que integre o GeoGebra com um editor de texto e equações, intuitivo e com tamanho adequado na interface, a fim de permitir a integração simultânea das diferentes representações. É preciso conceber o que nós chamamos de GGBOOK! Tal nome é uma integração dos termos "GGB" e "BOOK". GGB vem das extensões dos arquivos do software educativo GeoGebra e BOOK é a palavra "livro", traduzida para o inglês.

De posse de tal ferramenta, de que forma a integração das representações deve ser expressa? Acreditamos que não basta dispor a ferramenta para que a integração ocorra naturalmente e a compreensão aconteça. É preciso pensar numa estratégia de forma que a expressão não seja apenas para a comunicação, mas também para a objetivação. Dessa forma, acreditamos que tal expressão deve ser feita por meio de Narrativas Matemáticas. Narrativas que podem proporcionar a expressão do entendimento, dos significados e das construções relacionadas a um tema de estudo ou experimentados pelos estudantes, constituindo-se numa oportunidade de organizarem-se de forma ordenada no tempo e evolvendo a produção, o registro e socialização (SCHEFFER, 2001). Além disso, as narrativas podem ser um meio para os estudantes se manifestarem sobre determinado tema, expressando o modo como vivenciam, experimentam ou contam sobre uma situação. Enfim, que possam explicitar, de maneira organizada, suas representações mentais. Isso pode permitir ao professor a interpretação de um modo de pensamento do estudante. Mais especificamente, estamos interessados nas Narrativas Matemáticas no sentido de "[...] escritas expressivas, reveladoras de ideias e sentimentos, centralizadoras de regras e expressões simbólicas, utilizadas pelos estudantes para descrever certo evento, um gráfico, leis matemáticas e demais interpretações" (SCHEFFER, BRESSAN e CORRÊA, 2010, p.51).

Mas as Narrativas Matemáticas que estamos visualizando para o GGBOOK têm características diferentes das habituais narrativas matemáticas feitas em ambientes usuais (papel, editores de texto, softwares convencionais etc). Uma primeira característica está no fato de se integrar dinamicamente, num mesmo ambiente, os diferentes registros de representações dos objetos da Matemática. Tal integração não pode ser feita de forma separada, ou seja, uma representação mais outra representação é igual a essa narrativa matemática. Na construção de uma narrativa sobre um objeto matemático, as diferentes representações desse objeto aparecem simultaneamente e estão conectadas. Por exemplo, na 
construção de uma narrativa que envolve o conceito de função, as representações geométrica e algébrica estão conectadas de forma que, quando se alteram as propriedades desse objeto, as diferentes representações também alteram e se adéquam às modificações, mantendo a coerência da narrativa matemática. Acreditamos que uma contribuição dessa conexão é que o estudante pode ver qual a relação que existe entre as diferentes representações, ou seja, quando se altera algo no registro algébrico o que acontece no registro geométrico. Isso não acontece em narrativas matemáticas feitas nos ambientes usuais. Nesse caso, pode-se até fazer as diferentes representações dos objetos da Matemática, mas essas são feitas de forma separada e em momentos diferentes, ou seja, para fazer a narrativa matemática com as diferentes representações, o estudante ou o professor precisam fazer uma de cada vez. Além disso, eles precisam saber (previamente) quais as relações que existem entre as diferentes representações para que possam fazer a narrativa com coerência.

Uma segunda característica é que, além da integração das diferentes representações dos objetos da Matemática, é possível integrar a essas a representação textual dinâmica. Isso é possível graças aos textos dinâmicos, ou seja, textos que mesclam diversos símbolos matemáticos e variáveis que podem ser alterados pelo usuário. Tais textos alteram seu conteúdo a partir da manipulação dos diferentes objetos com os quais se relacionam. Além disso, é possível fazer cálculos automáticos dentro do próprio texto, usando valores ou medidas de objetos matemáticos pertencentes à narrativa. Tais resultados dos cálculos podem ser alterados automaticamente se as medidas ou valores desses objetos forem alterados. Outra característica importante está no fato de se poder identificar, através de ferramentas de revisão, elementos importantes para verificação de aspectos de historicidade da narrativa, ou seja, é possível identificar a ordem em que os objetos foram feitos. Isso nem sempre é possível nas Narrativas Matemáticas feitas nos ambientes usuais.

Como se pode ver, as Narrativas Matemáticas que propomos para o GGBOOK têm características diferentes das narrativas matemáticas feitas em ambiente usuais. Sobretudo, porque pensamos nas Narrativas Matemáticas mais com o propósito de objetivação do que simplesmente comunicação. Por isso, propomos um nome diferente para as narrativas com as características que descrevemos: Narrativas Matemáticas Dinâmicas. Trata-se de um conceito "hipoteticamente" novo que só fará sentido se tivermos um software que permita sua produção (validação). Dessa forma, neste trabalho nos propomos a analisar as possibilidades de construção de Narrativas Matemáticas Dinâmicas a partir das interações realizadas em uma plataforma que integra ambientes de texto e gráfico. 
Neste primeiro, capítulo o propósito foi de apresentar o problema e o que virá nos próximos capítulos. No capítulo seguinte, trataremos do contexto da pesquisa e explicitação do problema e dos objetivos. No $3^{\circ}$ capítulo abordaremos a Teoria das Representações Semióticas de Duval. Nele, falaremos sobre os Sistemas Semióticos, Registros de Representações Semióticas, Tratamentos, Conversões, entre outros assuntos necessários para a compreensão da teoria. No $4^{\circ}$ capítulo, abordaremos a informática educativa com destaque para o conceito de Micromundos de Geometria e o GeoGebra. No $5^{\circ}$ capítulo, falaremos a respeito da Linguagem, Linguagem Matemática, Narrativa e Narrativas Matemáticas. O $6^{\circ}$ capítulo será o da Metodologia no qual falaremos sobre nossas estratégias metodológicas para desenvolvimento e experimentação do GGBOOK. Definida a metodologia, passaremos para o $6^{\circ}$ capítulo que contempla a Análise e a Discussão dos dados. Nele, apresentaremos as análises dos dados coletados, buscando responder nossas indagações iniciais. No último capítulo, apresentaremos as considerações finais da investigação em que retornaremos às nossas questões iniciais, buscando mostrar o que foi (ou não) respondido. Apresentaremos também as contribuições da pesquisa, bem como novas questões a serem verificadas em investigações subsequentes. 


\section{CONTEXTO E EXPLICITAÇÃO DO OBJETO DE PESQUISA}

Para que se possa compreender melhor todo o contexto em que esta pesquisa nasceu, faz-se necessário reportar um pouco à minha trajetória. Como isso é muito pessoal, usarei a primeira pessoa do singular.

Desde criança, a minha disciplina predileta sempre foi Matemática. Essa foi a que sempre tive mais facilidade. Adorava resolver problemas, fazer as continhas, saber a tabuada na ponta da língua, etc. A Matemática para mim era um desafio, a ponto de competir com colegas para ver quem tirava as melhores notas. Porém, tal facilidade não me levou a escolher o curso de Matemática no primeiro vestibular. Naquele momento, sabia que teria que escolher um campo de formação profissional relacionado com a Matemática, mas não me passava pela cabeça escolher exatamente esse curso, pois não pensava em ser professor. Nem mesmo achava que levava jeito para isso. Então, o primeiro vestibular que fiz foi para Ciência da Computação. Apesar de naquele momento não saber nem mesmo ligar um computador, escolhi tal curso por ter ouvido falar que ele envolvia muita Matemática e que era ideal para os amantes dessa disciplina. Não fui aprovado no $1^{\circ}$ vestibular que prestei para Ciência da Computação na Universidade de Brasília-UnB. Durante o período do pré-vestibular, no ano seguinte, pensei em fazer o vestibular para Matemática, pois, caso fosse aprovado, poderia mudar depois para Computação e aproveitar as disciplinas que havia cursado. Foi o que fiz. Fui aprovado no vestibular e entrei no curso de Matemática, no $2^{\circ}$ semestre de 1996.

No $1^{\circ}$ semestre, cursei algumas disciplinas da Matemática e uma da Computação: "Introdução a Ciências da Computação". Tal disciplina era obrigatória para os alunos de Matemática. Gostei dela, mas não ao ponto de achar que o curso de Ciência da Computação era o que realmente queria. Já com as disciplinas da Matemática, havia me identificado muito mais. Porém, ainda não tinha certeza se era mesmo o curso que queria seguir, pois tinha certeza que não levava jeito para ser professor. A vida acabou me surpreendendo.

No segundo semestre de curso, fui convidado para estagiar numa escola na qual cursei meu Ensino Médio. No estágio, teria que acompanhar as aulas dos professores durante o meio de semana e ficar num plantão de dúvidas aos sábado. Naquele momento, comecei a perceber que levava algum jeito para ser professor. $\mathrm{O}$ fato de vários alunos virem aos sábados para tirar dúvidas comigo me contagiou muito. Durante as aulas que acompanhava, ficava elaborando maneiras de explicar o conteúdo de forma que o estudante pudesse compreender melhor. No sábado, aplicava o que havia elaborado nos atendimentos aos estudantes. Devido à grande 
quantidade de estudantes que estava vindo, chegou um momento em que já não podia mais fazer atendimento individual no plantão de dúvidas. Então tive que ir para frente do quadro, peguei o giz e ali dei aula para a minha primeira turma. Foi fascinante. Naquele momento, vi que tinha superado um dos maiores bloqueios da minha vida, pois minha timidez nunca me deixava à vontade em situações onde era "centro das atenções". Mas ali eu estava totalmente à vontade. Sentia-me bem. Comecei a perceber que ali era o meu lugar.

Fui continuando no estágio, sempre na mesma condição de acompanhar as aulas e depois oferecer o plantão de dúvidas. Até que um dia, o coordenador me pegou de surpresa, falando que o professor de Matemática não poderia vir. Perguntou se eu me sentia seguro para substituí-lo. Tenho que admitir que seguro mesmo eu não estava. As pernas tremeram na hora. Seria a $1^{\mathrm{a}}$ vez que entraria em sala de aula na condição de professor, no horário regular e com turma cheia. Aceitei o desafio, mas confesso que foi a primeira e última aula que ministrei sem planejar. Já no semestre seguinte, o diretor da escola me ofereceu umas turmas de $8^{\mathrm{a}}$ série $\left(9^{\circ}\right.$ ano), e assumi então a condição de professor efetivo. Foi assim que me tornei professor.

De uma maneira geral, os professores acabam explicando os conteúdos aos seus estudantes da mesma forma como aprenderam. Não posso negar que tive vários professores inspiradores e que hoje muitos deles são pessoas nas quais busco me espelhar. No entanto, sempre gostei de preparar minhas aulas. Gosto de planejar e de tentar criar maneiras diferentes e mais simples para que o estudante possa compreender. Um exercício que fazia era tentar me imaginar no lugar do aluno na hora de uma explicação. A partir daí, eu buscava imaginar quais seriam suas possíveis dúvidas e o que seria difícil para eles entenderem. Depois, buscava desenvolver maneiras de fazê-los compreender, seja elaborando outras formas de explicação ou usando recursos didáticos. Com o tempo, comecei a perceber que tal exercício de "imaginação" era pura ilusão. Não é com a imaginação que se vai identificar o que o estudante não compreende.

Um tema que achava difícil trabalhar com os alunos era o de Geometria, apesar de ser o campo da Matemática de que sempre gostei mais. Muitas vezes, minhas tentativas de fazêlos compreender tal tema eram em vão. Buscando encontrar as causas disso, percebi que entre elas, a questão da visualização era uma das principais. Muitas vezes, os alunos não conseguiam compreender as definições, propriedades e tampouco resolver os problemas porque não conseguiam visualizar o objeto geométrico e suas propriedades. Consequentemente, não conseguiam compreender os conceitos geométricos. E para piorar, 
percebi que o problema não estava somente neles. Estava também em mim, pois não sabia fazer bem as representações dos conceitos e propriedades das figuras geométricas, por meio do desenho, recurso esse, fundamental para a compreensão desses conceitos.

Naquele momento, reportei aos meus tempos de Ensino Básico, tentando lembrar como aprendia geometria e como os meus professores me ensinaram. Percebi que todos eles, tinham muita facilidade para desenhar. Faziam verdadeiras pinturas no quadro. Adorava ver os desenhos dos sólidos geométricos. Como era fácil compreender quando o professor desenhava no quadro! No entanto, para resolver um problema de geometria, eu nunca usava do artifício do desenho. Eu imaginava a figura com os dados do problema e passava para o papel apenas os cálculos (as representações simbólicas!) com a solução. Porém, na condição de professor, não poderia fazer meus alunos compreenderem, apenas pedindo para eles “imaginarem e passarem os cálculos para o papel” (naquele momento, eu acreditava que as representações só tinham função de comunicação!). Eu precisava representar as figuras por meio do desenho. Isso era um martírio, porque usando instrumentos (lápis, régua, compasso, papel, borracha etc), mesmo sozinho, sem ninguém me olhando, já achava difícil. Numa situação onde estavam 40 estudantes me vendo desenhar era ainda mais difícil. Era comum, ao término do desenho, começar a explicação dizendo "suponham que este desenho representa um...”. Os alunos, com muita boa vontade e entendendo a minha total falta de habilidade para desenhar, tentavam supor como eu pedia.

Essa pouca habilidade fez com que eu procurasse outros recursos para explicar os assuntos de geometria. Usava transparências e materiais concretos. Mas, mesmo com tais materiais, percebia que os estudantes ainda sentiam muita dificuldade para aprender os assuntos relacionados à geometria. Foi quando, no $4^{\circ}$ semestre do curso de graduação, comecei a cursar a disciplina de Geometria I. Tal disciplina tinha 6 créditos e era ministrada em 3 dias da semana, sendo que dois dias eram de aulas teóricas e um dia de aula no Laboratório de Informática. Foi nessas aulas no Laboratório de Informática que tive o primeiro contato com a Geometria Dinâmica, conhecendo o software educativo CabriGéomètre I. Posso dizer que foi paixão à primeira vista! Um dos motivos para isso foi quando percebi que, a partir daquele momento, ter habilidade para desenhar não seria imprescindível para que os alunos entendessem minha explicação. Não que a figura deixasse de ser essencial na explicação, mas para obtê-la, usando o Cabri, teria "apenas" que saber as propriedades dela. Ou seja, sabendo as propriedades da figura geométrica, bastava apenas ter habilidade com o mouse, dar alguns cliques e pronto: ali estava a figura na tela do computador. $\mathrm{E}$ o 
melhor: se quisesse mostrar a figura de outra maneira, não precisaria, necessariamente, fazer novamente. Bastava movimentar alguns objetos na tela. Com o passar do tempo e muito estudo sobre o programa, passei a perceber que as vantagens do Cabri não se limitavam apenas às colocadas anteriormente. Isso me motivou a estudar ainda mais.

Em 1999, tive o primeiro contato com a área de Educação Matemática, quando participei do $1^{\circ}$ EBREM (Encontro Brasiliense de Educação Matemática). Naquele momento, comecei a perceber uma área pela qual poderia me interessar enquanto pesquisador. Mas foi somente no ano de 2000 (quase final do curso), quando cursei a disciplina "Matemática para Início de Escolarização 1", ministrada pela professor Cristiano Muniz, que percebi que ali de fato era onde queria atuar. Tal professor era também um entusiasta da Geometria Dinâmica e, percebendo minha motivação para o tema, sugeriu que montássemos um Grupo de Estudos sobre Cabri. O grupo não avançou muito, mas foi fundamental para que despertasse em mim o interesse pela pesquisa. No final do ano de 2000, me formei e decidi o que queria fazer a partir dali: Mestrado na área de Educação Matemática, pesquisando o uso da Geometria Dinâmica na Educação.

Apesar da vontade de ingressar no mestrado logo após a graduação, não foi possível participar da seleção naquele momento. No entanto, continuei estudando muito o Cabri e desenvolvendo formas de levá-lo para a sala de aula. A convite do professor Cristiano, ministrei várias oficinas de Cabri para professores. Era bastante motivador trabalhar nessas oficinas. Os professores se encantavam muito com as possibilidades do Programa. Mas apesar disso, eles não o aplicavam com seus estudantes. Procurei entender o porquê disso por meio de conversas com alguns professores. Era comum eles me dizerem que, apesar de acharem que o Programa tinha muitas vantagens, era difícil e até mesmo inviável a sua aplicação. Vários eram os argumentos deles para isso, mas o que se destacava era a necessidade que eles tinham de um material didático voltado para o aluno, material esse que pudesse auxiliar o trabalho do professor com os alunos, nas aulas com o Cabri. A partir daí, começou a germinar a ideia de escrever um livro de aplicações para o Cabri, que pudesse suprir essa carência do professor.

Em 2001, soube que um dos "pais" da Geometria Dinâmica, o professor Franck Bellemain, tinha se mudado para o Brasil. Ele estaria no VII ENEM (Encontro Nacional de Educação Matemática) no Rio de Janeiro. Reuni todos os meus trabalhos relacionados ao Cabri, me inscrevi na oficina que o professor Franck ministraria e fui para o Rio. Levei 
algumas construções fractais que tinha feito no Cabri e no Geometriks (outro software de Geometria Dinâmica). Fractal é um tema que sempre me fascinou e, até então, não tinha visto nenhum trabalho com Geometria Dinâmica nessa área. Achei que poderia fazer um trabalho interessante com tal tema na área de Educação Matemática. Esperava encontrar lá alguém que topasse trabalhar isso comigo. Alguém que pudesse me orientar. A ideia despertou o interesse de alguns pesquisadores, a ponto de ter motivado uma discussão sobre o assunto num GT (Grupo de trabalho) sobre Novas Tecnologias. Esse encontro foi ótimo, pois pude conhecer e manter contato com vários pesquisadores. Pude também entender melhor "o que é" e "como se" pesquisa em Educação Matemática. Serviu para eu ter certeza sobre o campo em que queria pesquisar: "Novas Tecnologias na Educação Matemática". A ideia de escrever o livro cresceu ainda mais quando não identifiquei nesse encontro nenhum livro com o propósito que procurava.

Após o término do VII ENEM, continuei mantendo contato com o professor Franck. Mandei para ele algumas dúvidas, sugestões e bugs que havia encontrado no Cabri. Talvez isso, somado ao meu interesse em trabalhar na área, tenha colaborado para ele me convidar para ser debouguer da nova versão do Cabri II que estava sendo desenvolvida. Isso me deixou muito orgulhoso e me deu mais ânimo para trabalhar, dando-me ainda, mais confiança para acreditar de fato na ideia do livro.

Comecei a escrever e, no começo de 2002, publiquei a $1^{\text {a }}$ edição dos livros “Aprendendo Matemática com o Cabri-Géomètre II (volumes I e II)". No mesmo ano, essa edição foi utilizada com alunos por mim e por outros professores de Brasília. Experimentar os livros com alunos foi muito importante, pois pude perceber as falhas e os pontos onde poderia melhorá-los. Percebi também que muitos pontos que podiam estar claros para os professores, poderiam não estar para os alunos. Assim, tive que reescrevê-los. E, em 2003, lancei a $2^{\text {a }}$ edição dos dois volumes. Essa edição foi usada por mim e por vários outros professores, tendo resultados positivos. Em 2004, lancei a $3^{\text {a }}$ edição apenas para corrigir pequenos erros de impressão.

Durante o período em que estava escrevendo os livros, procurei estar sempre a par das pesquisas na área de Educação Matemática, pois sabia que não ficaria satisfeito apenas com a publicação dos livros. Assim, nesse período, fiz um curso de extensão universitária ministrado pelo professor Marcelo Borba, da Unesp-Rio Claro, cujo título era "Tendências em Educação Matemática”. Tal curso ampliou muito os meus conhecimentos a respeito da pesquisa na área 
e me indicou um tema para pesquisar: queria estudar as potencialidades da Geometria Dinâmica na exploração do estudo dos Fractais.

Em 2004, me mudei de Brasília para Recife para fazer o Mestrado com o professor Franck Bellemain em Ensino das Ciências, na Universidade Federal Rural de Pernambuco (UFRPE). Tal programa de mestrado não tinha uma linha de pesquisa específica relacionada com Novas Tecnologias no Ensino, mas tinha a linha de pesquisa "Formação de Professores". Era só adaptar a ideia inicial para estudar as potencialidades da Geometria Dinâmica na exploração do estudo dos Fractais em um curso de formação de professores. No final, o resultado da pesquisa não teve muita relação com a ideia inicial, mas contribuiu muito para que eu pudesse aprender mais sobre processos de compreensão em Matemática, porque investigamos os efeitos de um método para a explicitação das antecipações das práticas pedagógicas de professores de Matemática. Constatamos que tais antecipações são úteis para formadores e pesquisadores no sentido de compreender melhor as metodologias e identificar elementos de análise a priori dos professores.

Após o término do mestrado, em 2007, retornei a Brasília e, a convite da professora Regina Pina, comecei a atuar como docente do curso de licenciatura em Matemática da Faculdade Jesus Maria José - FAJESU. Nessa instituição ministrei várias disciplinas (Geometria, Matemática Computacional, Seminários de Tópicos Especiais, Estágio, Trabalho de Conclusão de Curso, entre outras). Tais disciplinas permitiram que eu trabalhasse não apenas sobre o ensino do conteúdo, mas também sobre como ensinar o conteúdo. Nesse processo de como ensinar, sempre que possível, enfatizava o uso de recursos didáticos e, mais especificamente, o uso de softwares educativos. Apesar de perceber um déficit na formação básica dos meus alunos, sempre fui otimista quanto aos futuros professores que tenho formado, sobretudo para ensinar usando novas tecnologias.

Paralelamente aos trabalhos acadêmicos e profissionais, continuei escrevendo livros. Após o lançamento da nova versão do Cabri (Cabri-Géomètre II-plus), senti a necessidade de fazer adaptações no livro e incluir novos capítulos. Assim, em 2007, publiquei “Aprendendo Matemática com o Cabri-Géomètre II e II-plus" (volume único). Nesse mesmo ano, havia conhecido o GeoGebra. Fiquei encantado com suas possibilidades. Assim, convidei um amigo (Prof. Luís Cláudio) para escrevermos um livro de aplicações para o GeoGebra. Em 2010, publicamos o livro "Aprendendo Matemática com o GeoGebra”. 
Alguns anos de experimentação do livro de GeoGebra me deixaram com alguns incômodos e não se tratava apenas de fazer uma nova edição, porque não eram de falhas que poderiam ser corrigidas, fazendo um novo livro. Os anos de experimentação me mostraram que a maior dificuldade era em relação aos feedbacks para o estudante. Para isso, precisava ter mais acesso ao que o estudante não compreendia. Isso era um tanto difícil, porque ele usava o livro e o software de maneira separada, ou seja, lia as orientações no livro, executava procedimentos no software e retornava ao livro para fazer anotações. Em geral, eu usava apenas as anotações para analisar a produção do estudante e dar os feedbacks. Isso não me dava condições de poder de fato analisar as incompreensões dos estudantes, porque não podia integrar o que eles haviam escrito com o que tinham construído no GeoGebra. Nesse momento, percebi que não bastava fazer um livro novo. Era preciso um ambiente novo para criar as atividades. Um ambiente em que o livro e o software não ficassem separados. Tal ambiente não existia. A partir daí percebi que precisaria estudar mais. Precisava estudar mais não apenas sobre informática educativa, mas também sobre ergonomia e metodologia de desenvolvimento de softwares educativos.

Naquele momento, procurei conversar com alguns colegas sobre as minhas ideias. Foi mediante conversas com a professora Regina Pina que recebi recomendações para ler os trabalhos do professor Gilberto Lacerda. Ela tinha sido orientada no mestrado por esse professor e sabia que ele trabalhava com ergonomia de softwares educativos. Logo nas primeiras leituras, me identifiquei com os trabalhos e decidi que queria fazer doutorado com o professor Gilberto. Em 2011, ingressei no doutorado em Educação da UnB para produzir o GGBOOK! Um ambiente que integraria múltiplas representações para o ensino de Matemática e que permitiria a produção de livros digitais e dinâmicos da disciplina.

Ao longo do curso, a ideia foi sendo amadurecida e aperfeiçoada. Por meio dos conhecimentos adquiridos nas orientações, nas disciplinas e das sugestões vindas da banca de qualificação, pude delinear melhor as ideias e daí surgiu o problema de pesquisa de minha tese de doutorado. Com o objetivo de analisar as possibilidades de construção de Narrativas Matemáticas Dinâmicas a partir das interações realizadas em uma plataforma que integra ambientes de texto e gráfico, propusemos $^{4}$ o seguinte problema de pesquisa:

\footnotetext{
${ }^{4}$ Neste momento, o texto volta para a $1^{\mathrm{a}}$ pessoa do plural porque considero que a partir dali o texto deixa de ser pessoal e passa a ser meu e do meu orientador.
} 
Como uma plataforma que integra um editor de texto e equações com o GeoGebra pode auxiliar na construção de Narrativas Matemáticas Dinâmicas e, consequentemente, na construção do conhecimento matemático?

Com o propósito de responder a questão anterior, foram definidos os seguintes objetivos específicos:

- Desenvolver uma plataforma que integre um editor de texto e equações com o GeoGebra de forma que permita a edição de maneira intuitiva de fórmulas, símbolos, expressões matemáticas e sem a necessidade de se saber operar com comandos LaTeX;

- Validar a plataforma, analisando como ocorre a construção de Narrativas Matemáticas Dinâmicas e identificando, por meio das análises das narrativas, o processo de tomada de consciência de conceitos matemáticos; e

- Verificar como a plataforma pode contribuir para a uma melhor interpretação, por parte do professor, das compreensões ou incompreensões do estudante.

Evidentemente, também estávamos atentos para identificar os possíveis limites da plataforma para a construção de Narrativas Matemáticas Dinâmicas. A identificação de tais limites era importante para a continuação do desenvolvimento do software, que certamente, não se encerraria com o término desta pesquisa. 


\section{A TEORIA DAS REPRESENTAÇÕES SEMIÓTICAS DE DUVAL}

\subsection{Noções Iniciais: Sistemas Semióticos, Registros de Representações Semióticas, Códigos, Representações Não Semióticas, Representações Mistas e Representações Mentais}

Para melhor compreender a teoria das Representações Semióticas de Duval é preciso inicialmente entender alguns conceitos. O primeiro deles é o de semiótica. De acordo com Santaella (2002, p.2) a "semiótica é a ciência que tem por objeto de investigação todas as linguagens possíveis, ou seja, que tem por objetivo o exame dos modos de constituição de todo e qualquer fenômeno como fenômeno de produção de significação e de sentido". Tal conceito se origina dos termos semiósis e noésis. Semiósis é a apreensão ou a produção de uma representação semiótica. A noésis são os atos cognitivos como apreensão conceitual de um objeto, a discriminação de uma diferença ou a compreensão de uma inferência.

Parece então evidente inferir que a noésis é independente da semiósis ou, ao menos, a dirige. Todavia, de acordo com Duval (2009), para que ocorra a aprendizagem em Matemática, as representações semióticas não são apenas imprescindíveis para a comunicação, mas também nos procedimentos para efetuar as transformações sobre os objetos matemáticos. Então, poder-se-ia inferir que sem a representação semiótica, o estudante ficaria impossibilitado de compreender o objeto? Ao longo deste capítulo, acreditamos que tal questão será respondida.

Em relação aos Registros de Representações Semióticas ou simplesmente Representações semióticas, Duval (2009, p.32) diz que

[...] A especificidade das representações semióticas consiste em serem relativas a um sistema particular de signos, a linguagem, a escritura algébrica ou os gráficos cartesianos, e em poderem ser convertidas em representações "equivalentes" em outro sistema semiótico, mas podendo tomar significações diferentes para o sujeito que as utiliza. A noção de representação semiótica pressupõe, então, a consideração de sistemas semióticos diferentes e de uma operação cognitiva de conversão das representações de um sistema semiótico para um outro. Essa operação tem sido primeiramente descrita como uma "mudança de forma".

Em geral, a literatura no campo da Educação Matemática não faz distinção entre Sistemas Semióticos e Sistemas de Representações Semióticas. Ou seja, em muitos casos Registros de Representações e Sistemas de Representações se confundem. No caso desse trabalho, consideraremos Sistemas de Representações Semióticas como algo maior que envolve vários Registros de Representações Semiótica, pois existem Sistemas Semióticos que 
são mais específicos de outras linguagens e outros mais relacionados com a Matemática. Este é o que nos interessa. Mais a frente, será apresentada uma tabela em que poderá ser entendido melhor isso. Antes disso, é preciso entender o que é Registro de Representação Semiótica, buscando diferenciar do código.

Duval (2011) considera que um registro de representação semiótica ou simplesmente um registro, é algo cognitivamente criador que precisa identificar as operações de produção de representações que ele permite executar de maneira geral e específica. Ele cumpre a função cognitiva de objetivação ${ }^{5}$ e tratamento das transformações internas das representações semióticas. Um exemplo é o sistema de escrita dos números. Assim, um registro de representação semiótica é, evidentemente, um sistema semiótico, mas um particular que não funciona como código, nem como sistema formal. Ele se caracteriza essencialmente pelas operações cognitivas que ele permite efetuar. Mais um exemplo que podemos considerar é a linguagem discursiva que consiste primeiro nas operações discursivas e não nas palavras de um léxico e uma gramática. Outro exemplo mais relacionado com a Matemática são as figuras geométricas, pois a mobilização delas permite efetuar operações figurais de visualização, que são as transformações de uma figura em outra, de forma heurística ou fazendo aparecer invariâncias, e que não podemos fazer com outros tipos de imagens.

Diferentemente dos registros, os códigos são sistemas semióticos que cumprem a função de comunicação, porque permitem transmitir as informações, ou mudar o suporte físico da comunicação como, por exemplo, o sistema de escrita são códigos que têm a particularidade de se fundir ${ }^{6}$ seja com a produção fonética de uma língua (alfabetos), seja com as ideias que a língua permite produzir vocalmente (ideograma). De acordo com Duval (2011) os códigos não remetem a nada e, portanto, não representam nada.

Os registros são sistemas cognitivamente produtores, ou mesmo criadores, de representações sempre novas. A produção de novas representações permite criar novos objetos. Por exemplo, os registros representações gráficas permitiram criar novos tipos de curvas (diferentes das secções cônicas). O conteúdo das representações produzidas por um registro apresenta sempre duas propriedades: referir-se a um objeto (função cognitiva) e se inscrever em um continuum de sentido que permite discriminar e colocar em correspondência

\footnotetext{
${ }^{5}$ A passagem do não consciente ao consciente é um processo de objetivação para o sujeito tomar consciência, ou seja, corresponde à descoberta por si mesmo de alguma coisa que até então ele não havia notado, mesmo que alguém lhe houvesse explicado.

${ }^{6}$ Duval diz que a fusão só funciona realemente quando ela se torna automática ou espontânea.
} 
as diferentes unidades de sentido ${ }^{7}$ o que permite passar de uma representação a outra ou reconhecer um mesmo objeto em suas diferentes representações (DUVAL, 2011). Para entender melhor a diferença entre registro e código vejamos a tabela 1:

\begin{tabular}{|c|c|c|c|c|}
\hline & & $\begin{array}{l}\text { TIPO DE PRODUÇÃO } \\
\text { SEMIÓTICA }\end{array}$ & $\begin{array}{c}\text { POSSIBILIDADE } \\
\text { DE } \\
\text { TRANSFORMAC̃̃̃O } \\
\text { DAS PRODUCÕES }\end{array}$ & $\begin{array}{c}\text { MUDANÇA DE } \\
\text { SISTEMA } \\
\text { SEMIÓTICO }\end{array}$ \\
\hline $\begin{array}{l}\text { SISTEMAS } \\
\text { produtores de } \\
\text { representações } \\
\text { que se referem } \\
\text { aos objetos } \\
\text { (continuum do } \\
\text { sentido) }\end{array}$ & $\begin{array}{l}\text { REGISTROS } \\
\text { Linguas, } \\
\text { figuras, } \\
\text { gráficos, etc }\end{array}$ & $\begin{array}{l}\text { UM CONTEÚDO } \\
\text { ARTICULANDO } \\
\text { VÁRIAS UNIDADES } \\
\text { DE SENTIDO } \\
\text { conforme dois ou três } \\
\text { niveis de organização }\end{array}$ & $\begin{array}{c}\text { SUBSTITUIÇÃo } \\
\text { por equivalência } \\
\text { referencial } \\
\text { OPERAÇÕES } \\
\text { SEMIÓTICAS } \\
\text { PRÓPRIAS DE } \\
\text { CADA REGISTRO }\end{array}$ & $\begin{array}{c}\text { CONVERSÕES } \\
\text { por } \\
\text { correspondência } \\
\text { das unidades de } \\
\text { sentido } \\
\text { Não } \\
\text { reversibilidade }\end{array}$ \\
\hline $\begin{array}{c}\text { SISTEMAS } \\
\text { Transmissores ou } \\
\text { conversores do } \\
\text { modo físico de } \\
\text { transmissão } \\
\text { (discretização da } \\
\text { informação) }\end{array}$ & $\begin{array}{l}\text { CÓDIGOS } \\
\text { Código } \\
\text { binário, } \\
\text { alfabetos etc }\end{array}$ & $\begin{array}{c}\text { SEQUENCIA DE } \\
\text { CARACTERES } \\
\text { Cada caractere da } \\
\text { sequência resulta de uma } \\
\text { escolha de codificação } \\
\text { dos dados (estados } \\
\text { sucessivos, sons, ...) e não } \\
\text { de regra de combinação }\end{array}$ & $\begin{array}{c}\text { Somente a } \\
\text { programação externa } \\
\text { de ações sobre a } \\
\text { sequências de valores } \\
\text { binários (máquina de } \\
\text { Turing) }\end{array}$ & $\begin{array}{c}\text { Codificação } \\
\leftarrow \rightarrow \\
\text { Decodificação }\end{array}$ \\
\hline
\end{tabular}

Tabela 1-Comparação de registros e códigos (DUVAL, 2011, p. 7)

Saber se um sistema é um código ou registro não é algo simples. Duval (2011) exemplifica isso perguntando se a linguagem (línguas naturais) são códigos ou registros. Como foi dito anteriormente o código privilegia as funções de comunicação, já o registro as funções cognitivas. Nesse sentido, a linguagem cumpriria ambas as funções e assim poderia ser vista como código ou registro. Por outro lado, o mesmo autor diz que em grande parte dos trabalhos de Didática da Matemática, a linguagem é vista apenas como função de comunicação. A compreensão dos enunciados de problemas, por exemplo, seria um caso de decodificação das informações que teriam sido codificadas no enunciado. Assim, há a separação entre a linguagem e o funcionamento cognitivo do pensamento. A expressão verbal vindo para comunicar, explicar ou fixar o resultado do trabalho do pensamento:

O problema de tal separação é que ela não permite nem analisar a utilização espontânea da linguagem natural por todos os indivíduos, nem descrever a utilização especializada que é feita na matemática quando, por exemplo, se trata de definir uma propriedade ou de utilizar teoremas (DUVAL, 2011, p. 75).

O mesmo autor alerta que exprimir-se não é codificar um pensamento já explícito, mas objetivá-lo por si mesmo, tomando consciência, mesmo quando endereçamos a outro. A expressão é um ato oposto da codificação, na medida em que o pensamento só emerge com as

\footnotetext{
${ }^{7}$ Esse é um conceito chave na teoria das Representações Semióticas. Veremos mais sobre isso no decorrer do texto. Em curtas palavras, as unidades de sentido são os dados ou informações, matematicamente pertinenetes (DUVAL, 2011, p. 103)
} 
palavras que começam a dizê-lo. Da mesma forma, compreender não seria decodificar uma sequência de palavras ou de frases, mas discriminar as unidades de sentido em função dos diferentes níveis de organização dos discursos e, eventualmente, reformulá-los. É evidente que há diferenças entre o que é compreender do ponto de vista de um matemático e de um estudante, ou seja, compreender do ponto de vista matemático e cognitivo. A compreensão do ponto de vista matemático é evidenciada pela justificativa, validação, prova e demonstração. Do ponto de vista cognitivo, é evidenciada pelo reconhecimento dos objetos estudados por meio de suas múltiplas representações ou manifestações possíveis. Mas, voltando à linguagem, acreditamos que sua utilização não poderia ser reduzida a uma simples atividade de comunicação. Ela cumpre mais ou menos, segundo as situações e domínios, as funções cognitivas e isso nos leva a considerá-la não como um código, mas como um registro.

Outra distinção que é preciso ficar clara é entre Registro de Representação Semiótica e Signo. De acordo com Duval (2011), os signos não têm nenhuma realidade sensível própria, seja ela fônica ou gráfica. Pode-se distingui-los apenas como unidades de sentido com base em suas relações de oposição com outros signos, o que possibilitaria a condição de interpretação. Resumidamente, o mesmo autor distingue as representações semióticas dos signos da seguinte maneira:

As representações semióticas são as frases em linguagem natural, as equações e não
as palavras, os algarismos e as letras. São as figuras, os esquemas, os gráficos e não
os pontos raramente visíveis, ou os traços. Muitas vezes, associamos os signos a
essas unidades elementares de sentido, que são apenas caracteres para codificar:
letras, siglas, algarismos, às vezes, palavras-chave, ou gestos da mão. O que
equivale a considerar os signos como as coisas pelas quais é preciso começar a dar
sentido (DUVAL, 2011, p. 38).

Existe uma variedade de representações semióticas. Neste trabalho estamos interessados nos registros de representação que compõem o Sistema Semiótico da Matemática. Buscamos distinguir os registros da seguinte forma: 


\begin{tabular}{|c|c|c|c|}
\hline \multicolumn{4}{|c|}{ SISTEMAS SEMIÓTICOS DOS OBJETOS MATEMÁTICOS } \\
\hline & \multicolumn{2}{|c|}{ CUNHO DISCURSIVO } & $\begin{array}{l}\text { CUNHO NÃO } \\
\text { DISCURSIVO } \\
\end{array}$ \\
\hline $\begin{array}{c}\text { Registros de } \\
\text { Representações }\end{array}$ & $\begin{array}{c}\text { Registro de representação } \\
\text { linguística } \\
\text { (Linguagem retórica, } \\
\text { lingua natural, lingua } \\
\text { materna, registro } \\
\text { discursivo) }\end{array}$ & $\begin{array}{l}\text { Registro de } \\
\text { representação } \\
\text { simbólica } \\
\text { (Linguagem formal, } \\
\text { representação } \\
\text { aritmética e } \\
\text { representação } \\
\text { algébrica) }\end{array}$ & $\begin{array}{c}\text { Registro de } \\
\text { representação visual } \\
\text { (Representação } \\
\text { Figural, } \\
\text { Representação } \\
\text { Gráfica, } \\
\text { Representação } \\
\text { icônica (2d)) }\end{array}$ \\
\hline $\begin{array}{l}\text { Signos (ou } \\
\text { unidades de } \\
\text { sentido) }\end{array}$ & $\begin{array}{c}\text { Frases ou expressões que } \\
\text { combinam ao menos duas } \\
\text { palavras }\end{array}$ & $\begin{array}{c}\text { Expressões algébricas, } \\
\text { expressões aritméticas, } \\
\text { equações, sistemas de } \\
\text { equações, matrizes, entre } \\
\text { outros. }\end{array}$ & $\begin{array}{c}\text { Figuras, gráficos, } \\
\text { diagramas, tabelas, } \\
\text { esquemas, entre outros }\end{array}$ \\
\hline $\begin{array}{c}\text { Caracteres para } \\
\text { codificar }\end{array}$ & $\begin{array}{l}\text { Letras, siglas, alguns } \\
\text { símbolos }(\cdot \text {, ? ! }\end{array}$ & $\begin{array}{l}\text { Letras, letras gregas, } \\
\text { algarismos, símbolos de } \\
\text { operações }(+,- \\
\text {, / , x,^), símbolos de } \\
\text { "demarcadores" ( } \\
\{\},[],(),) \text {; símbolos de } \\
\text { comparações }<,>,=\text {, } \\
\leq, \geq, \neq ; \text { símbolos } \\
\text { lógicos } \leftarrow, \rightarrow, \leftrightarrow,\end{array}$ & $\begin{array}{l}\text { Ponto, linha (reta ou } \\
\text { curva) e plano }\end{array}$ \\
\hline
\end{tabular}

Tabela 2-Classificação dos registros de representação dos sistemas semióticos dos objetos matemáticos

De acordo com Duval (2011), a linha divisória cognitiva está entre as representações semióticas e as não semióticas. A primeira é produzida intencionalmente pela mobilização de um sistema semiótico de representação, a língua natural sendo o primeiro registro. A segunda é produzida automaticamente, e de maneira não intencional, quando não se trata de instrumentos. Ela é o efeito mais ou menos direto do objeto agindo sobre os sistemas receptores. Por exemplo, a maquete é o representante do objeto real, ela pode ser submissa a ações que permitem estudar os efeitos que as ações análogas podem ter sobre o objeto real nas condições reais. Tal análise não pode valer para as representações semióticas. Duval (2009) diz que as representações do tipo maquete não são representações semióticas, porque as operações suscetíveis de transformá-las são ações físicas que seguem leis físicas e não ações sobre os signos regidos por regras. Em tal representação o representante e o representado têm as mesmas características fenomenológicas fundamentais: são objetos físicos situados no espaço de três dimensões. Nesse caso, pode-se agir no representante e no representado. Isso não acontece nas representações semióticas, pois o representante e o representado não pertencem a um mesmo espaço. Além disso, as representações semióticas não podem ser

\footnotetext{
${ }^{8}$ As unidades de sentido correspondentes à designação dos objetos não são as palavras, mas as expressões que combinam ao menos duas palavras (DUVAL, 2011, p.78)
} 
transformadas por ações físicas. Tais representações permitem operações que preenchem as funções de objetivação, de tratamento ou expressão, e não um modo particular de tratamento. Assim, as representações do tipo maquete são chamadas de representações não semióticas.

Outro exemplo seria a fotografia. Há também as representações semióticas que são representações mistas. Elas resultam da superposição ou da fusão de dois tipos de representações. Ex.: reta graduada, reta numérica ou reta real que resultam da superposição dos registros simbólico e visual.

Duval (2009) diz que fazer uso de diversas formas de representar um mesmo objeto, além da língua materna ou das imagens, tais como tabelas, gráficos, símbolos, diagramas, escritas algébricas ou esquemas, são atividades cognitivas necessárias para a aprendizagem em Matemática. Ele defende isso ao argumentar que “[...] não se pode ter compreensão em matemática, se nós não distinguirmos um objeto de sua representação” (DUVAL, 2009, p.14). Por exemplo, suponhamos que se queira saber o que é o conceito "triângulo". É a figura seguinte?

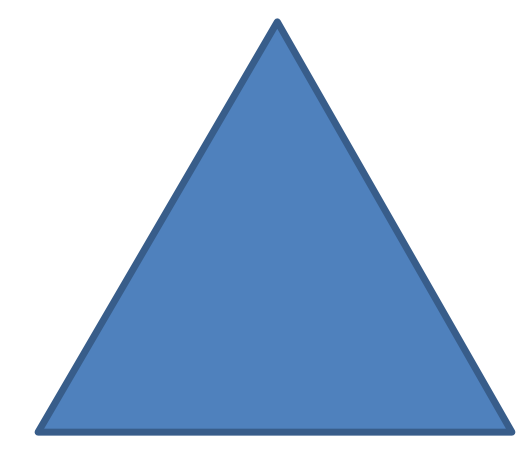

Apenas com tal figura é possível compreender tal conceito? A distinção entre o objeto e sua representação é difícil e gera um problema comum no processo de aprendizagem e ensino da Matemática. Concordamos que a representação não define o objeto. Então o que define? Flores (2006) cita Lefebvre (2001) em que matemáticos entrevistados numa pesquisa foram confrontados com a questão "O que é um objeto matemático?” A mesma autora diz que definir o objeto matemático não é uma tarefa simples, mas a distinção entre o objeto matemático e sua representação é um fato resolvido. Conforme explica Lefebvre, o termo objeto envolve três dimensões: a do objeto material (uma representação); a conceitual (o conceito); e de uma "idealidade matemática" (a entidade). Por exemplo, o conceito de "parábola" pode ser resumido como "o lugar geométrico dos pontos do plano que equidistam de uma reta (diretriz) e de um ponto (foco)." A entidade matemática é, para o filósofo Desanti, 
"o que está apreendido pela consciência na forma de unidade" . As representações de uma parábola são múltiplas, podendo ser simbólica (sob a forma, por exemplo, de uma equação: $\left\{(\mathrm{x}, \mathrm{y}) \in \mathrm{R}^{2} / y=\frac{x^{2}}{4 p}\right\}$ ), linguística (a palavra "parábola") ou, ainda, visual (desenho de uma parábola). Então, de posse das três dimensões do objeto, o indivíduo já pode compreender o conceito? O que pode fazer de fato com que o indivíduo compreenda o conceito? As propriedades? As características? As relações entre as representações? Ao longo do texto, esperamos chegar às respostas dessas questões. Neste momento, vale destacar o que Duval (2009, p. 14) diz sobre "[...] toda confusão entre o objeto e sua representação provoca, com o decorrer do tempo, uma perda de compreensão". Caso isso aconteça, essas representações semióticas dos objetos matemáticos seriam secundárias e extrínsecas, pois os conhecimentos tornam-se rapidamente esquecidos fora do contexto de aprendizagem.

O mesmo autor diz que a necessidade de representações semióticas para o conhecimento matemático abrange dois problemas distintos:

- Referência do objeto - o acesso aos objetos é pela percepção concreta? Ou há a necessidade de representações semióticas? No caso dos números Naturais e das figuras simples em geometria poder-se-ia inferir que é apenas percepção concreta. $\mathrm{O}$ uso das representações semióticas seria necessário quando a grandeza ou complexidade dos objetos fossem além das nossas capacidades limitadas de intuição ou de memória imediata, ou quando abandonamos os domínios do finito e do discreto. Todavia, até mesmo os primeiros números são dados como objetos em uma atividade de contagem, e isso exige uma representação semiótica, mesmo que rudimentar.

- Cognitiva - transformação em outras representações semióticas- o trabalho matemático ou funcionamento do pensamento em Matemática depende da mobilização de conceitos e da capacidade de raciocínio ou depende das representações semióticas mobilizadas?

Para melhor compreender tais problemas, precisamos entender o que são as representações mentais. Duval (2009) diz que é o conjunto de imagens e conceitos que um indivíduo pode ter sobre o objeto. As representações mentais são todas as que permitem uma visão do objeto sem que haja um significante perceptível. São identificadas às "imagens mentais" como entidades psicológicas tendo uma relação com a percepção. Contudo, as representações possuem um domínio mais amplo do que o das imagens. É necessário 
relacionar conceitos, ideias, crenças e todas as projeções e os valores que um sujeito divide com o seu meio, grupo particular ou as que refletem seus próprios desejos.

As representações mentais estão interligadas com as representações semióticas, como um meio de comunicação para o indivíduo explicitar, tornando-se visíveis e acessíveis com o meio exterior. Por outro lado, cabe questionarmos: Como as representações semióticas poderiam de fato explicitar as representações mentais? Existem instrumentos que permitem de fato produzir as representações mentais? Para responder tais questões, primeiramente deveríamos nos questionar se as representações mentais são estáticas. Sem perder o sentido, podemos relacionar as representações mentais com os modelos mentais.

Modelos mentais são representações dinâmicas e generativas que podem ser
manipuladas mentalmente para prover explicações causais de fenômenos físicos e
fazer previsões sobre estados de coisas do mundo físico. Supõe-se que muitos
modelos mentais são criados na hora para resolver questões de situações
problemáticas específicas. Contudo, é possível que alguns modelos mentais, ou parte
deles, que foram úteis uma vez, sejam armazenados como estruturas separadas e
recuperados da memória de longo prazo quando necessário. (MOREIRA,
1996,p.220)

Acreditamos que os modelos mentais não servem apenas para prover explicações do mundo físico. Servem também para explicar situações do mundo abstrato, como é o caso da Matemática. Usando papel e lápis (instrumentos estáticos), como explicitar tais modelos por meio das representações semióticas? As representações com tais instrumentos não dificultariam a percepção das relações entre as representações? Como se daria a percepção de tais relações? A percepção das relações entre as representações é uma condição para se colocar em correspondência as unidades de sentido próprias de cada representação, assim como a colocação em correspondência das unidades de sentido próprias de cada representação é condição para a percepção das relações. Isso é a condição cognitiva para poder reconhecer um mesmo objeto em suas diferentes representações.

Por outro lado, o problema não está apenas em "representar". De acordo com Duval (2011), a característica fundamental dos encaminhamentos em Matemática consiste em transformações de representações semióticas dadas ou obtidas no contexto de um problema proposto em outras representações semióticas (diferentemente de outros encaminhamentos científicos em física, química, etc). Trabalhamos com as representações semióticas para transformá-las em outras. Assim, uma representação semiótica só é interessante à medida que ela pode se transformar em outra representação, e não em função do objeto que ela representa. Para poder concretizar essas transformações é preciso efetuar implícita ou explicitamente uma 
ida e volta constante entre as transformações de um tipo de representação e a de outro. No tópico seguinte, falaremos das transformações das representações semióticas.

\subsection{Atividades cognitivas: Formação, Tratamento e Conversão}

Como dissemos anteriormente, a compreensão do ponto de vista cognitivo, requer o reconhecimento dos objetos estudados por meio de suas múltiplas representações ou manifestações possíveis. Para isso, de acordo com Duval (2009) é preciso saber:

- reconhecer quando representações semióticas diferentes representam um mesmo objeto a partir da correspondência entre as unidades de sentido entre os conteúdos respectivos das duas representações. Então, para duas formas de representação tais como uma reta desenhada sobre um sistema de eixos coordenados e uma relação do tipo $\mathrm{y}=\mathrm{ax}+\mathrm{b}$, o que elas têm em comum não será um dado, mas, como mostra Bkouche, uma construção historicamente datada, isto é, a invenção da geometria analítica por Descartes e Fermat;

- que não podemos isolar diretamente as unidades de sentido que formam o conteúdo de uma representação e, mais: existem diferentes maneiras para discriminar as unidades de sentido em função do nível de organização que se focaliza;

- que algumas representações semióticas são representações mistas. Elas resultam da superposição ou da fusão de dois tipos de representação. Ex.: reta graduada, reta numérica, reta real; e

- distinguir a transformação de partida e de chegada.

As mudanças nas formas de uma representação revelam ser para muitos alunos nos diferentes níveis de ensino, muitas vezes, um processo difícil e até mesmo impossível. Como se a compreensão de um conteúdo ficasse limitada à forma de representação. Duval (2009) cita estudos de Schoenfeld (1986) em que tal constatação é evidenciada e ocorre a "compartimentalização inapropriada", pois os estudantes não fizeram conexões entre domínios e sistema de símbolos de conhecimentos adquiridos. Tais dificuldades não estão relacionadas apenas com as questões didáticas, mas cognitivas também. Assim, para solucionar tal problema é preciso reconhecer que o modo como o funcionamento do pensamento e de como o conhecimento se desenvolve está na variedade dos tipos de signos que podem ser utilizados e não no emprego deste ou daquele tipo de signo. 
Duval (2008) diz que os sistemas semióticos devem permitir três atividades cognitivas inerentes a toda representação. A formação de representações é a primeira atividade. Trata-se de uma forma de exprimir uma representação mental ou evocar um objeto real. Essa formação implica a seleção do conjunto de caracteres e determinações de um conteúdo percebido, imaginado ou já representado em função de possibilidades de representação próprias ao registro escolhido. As outras duas são a sua transformabilidade em outras representações que conservam todo o conteúdo da representação inicial ou uma parte desse conteúdo. A característica fundamental dos encaminhamentos em Matemática consiste nessa transformabilidade de representações semióticas dadas ou obtidas no contexto de um problema proposto, em outras representações semióticas. Trabalhamos apenas com as representações semióticas para transformá-las em outras. Assim, uma representação semiótica só é interessante à medida que ela pode se transformar em outra representação, e não em função do objeto que ela representa (DUVAL, 2011). Conforme dissemos anteriormente, para poder efetuar essas transformações é preciso efetuar implícita ou explicitamente uma ida e volta constante entre as transformações de um tipo de representação e a de outro. Portanto, todas podem ter localmente uma função de antecipação ou de controle, sem que possamos atribuir essas funções respectivamente às representações por montagem de unidades ou pela escrita de uma expressão numérica.

Duval (2009) diferencia as transformações que ocorrem dentro de um mesmo registro das transformações que ocorrem de um registro para o outro. De acordo com ele, o tratamento é uma transformação que se efetua no interior de um mesmo registro, aquele em que as regras de funcionamento são utilizadas. $O$ tratamento mobiliza apenas um registro de representação. Por exemplo, ao desenvolver a expressão $(x+2)^{2}$ de forma que fique $x^{2}+4 x+4$ tem-se um exemplo da função de tratamento no registro algébrico. Há necessidade de tratamentos diferentes para registros de representações diferentes. Por exemplo, os tratamentos para efetuar as operações $0,5+0,5=1,0 \mathrm{e} \frac{1}{2}+\frac{1}{2}=1$ são diferentes. Isso possibilita saber quando duas representações de um mesmo registro se referem a um mesmo objeto.

A conversão é, ao contrário, uma transformação que se efetua ao se passar de um registro a outro e isso requer então a coordenação dos registros no sujeito que a efetua. "O estudo dessa atividade de conversão deve então apenas permitir compreender a natureza de um laço estrito entre semiósis e noésis" (DUVAL, 2009, p. 39). Por exemplo, na conversão do registro algébrico para registro gráfico tem-se focado nos tratamentos em um mesmo sistema de registro, enfatizando procedimentos de técnicas algébricas, e somente após o estudante 
dominar esses tratamentos, realiza-se a conversão para o registro gráfico. Seria importante também o professor priorizar, nas atividades a serem ensinadas, a conversão de diferentes registros de um mesmo objeto de forma alternada e simultânea, para que fique clara a diferença entre o objeto e sua representação. Em atividades envolvendo o estudo das funções, é comum a conversão do registro algébrico para o gráfico, mas não o contrário.

De acordo com Duval (2009), ao separar as atividades de tratamento e as de conversão, é fácil notar as dificuldades suscetíveis referentes ao processo de conversão e a importância de fechamento dos registros. As questões centrais para as aprendizagens intelectuais aparecem na possibilidade de favorecer a coordenação dos registros. E essa coordenação é simplesmente causa e consequência da aprendizagem de um conceito. Tal coordenação tem a ver com o que dissemos anteriormente sobre o que evidencia a compreensão de um conceito. Assim, é necessário saber quais são os princípios e condições que devem ser usados em situações de aprendizagem para promover a coordenação dos registros de representação, levando-se em consideração que a mudança de um registro de representação a outro não é somente mudar o modo de tratamento, mas explicar as propriedades ou aspectos diferentes de um mesmo objeto.

A partir das atividades de formação, tratamento e conversão, Duval (2009) sugere as tarefas de produção e compreensão. De acordo com ele, a produção de uma resposta, por meio de um texto ou de um esquema, mobiliza simultaneamente a formação de representações semióticas e seu tratamento. Já a compreensão, aquela de um texto ou de uma imagem, de uma questão mobiliza atividades de conversão e de formação ou as três atividades cognitivas. Como se pode ver, a conversão é um aspecto fundamental no processo de compreensão.

Mais detalhadamente, Duval (2009, p.58) diz que “[...] converter é transformar a representação de um objeto, de uma situação ou de uma informação dada num registro em outra representação desse mesmo objeto, dessa mesma situação ou da mesma informação num outro registro". Para tal transformação, usam-se operações usualmente chamadas de "tradução", “ilustração", "transposição", “interpretação", "codificação", etc. Ele diz que ilustração é "[...] a colocação em correspondência de uma palavra, de uma frase, ou de um enunciado com uma figura ou com um de seus elementos" (DUVAL, 2009, p. 59). Poderíamos dizer que é a conversão do registro de representação linguística para o registro de representação visual. $\mathrm{O}$ inverso, da passagem de uma figura a um texto, pode ser uma descrição ou interpretação. A colocação em forma de equação dos dados de um enunciado de um problema ou teorema, ou seja, a operação de conversão do registro de representação 
linguística para o registro de representação simbólica pode ser chamada de tradução matemática. Por exemplo, o teorema "Em todo triângulo as medida dos lados são proporcionais aos senos dos ângulos opostos" pode ser escrito através da equação $\frac{a}{\operatorname{sen}(A)}=$ $\frac{b}{\operatorname{sen}(B)}=\frac{c}{\operatorname{sen}(C)}$ (onde a, b e c, representam as medidas dos lados do triângulo e A, B e C representam as medidas dos ângulos internos do triângulo). A conversão inversa chamaremos de "Tradução Linguística".

As operações de conversão do registro de representação simbólica para o registro de representação visual chamaremos, de "Transposição Visual". Por exemplo, dada a equação de uma função, fazer o gráfico que a representa. A operação inversa chamaremos de "Transposição Simbólica". Por exemplo, dado um gráfico de uma parábola, escrever a equação que a representa. Como se pode perceber mediante os exemplos, os elementos em cada sistema de representação são muito diferentes. Em muito casos, há a necessidade de uso de dois registros de representação para se fazer a conversão para um terceiro. Um desses registros seria auxiliar e provisório. "A conversão requer que se perceba a diferença entre o que Frege chamava de sentido e a referência dos símbolos ou signos, ou entre o conteúdo de uma representação e aquilo que ela representa" (DUVAL, 2009, p. 59).

Para o tratamento, tal percepção também é importante, pois, sem ela as transformações tornam-se impossíveis ou incompreensíveis. Por exemplo, tomemos 3 registros diferentes de representação do número: escritura decimal, escritura fracionária e escritura com potências de 10. Para poder operar com tais registros é necessário “[...] distinguir a significação operatória fixada ao significante e o número representado" (DUVAL, 2009, p.59). Como a significação operatória é diferente para os números $0,5, \frac{1}{2}$ e $5 \times 10^{-1}$ então os procedimentos de tratamento que permitem efetuar adições com esses números também são. O problema está em como efetuar essa diferenciação.

Diversas pesquisas têm apontado que transitar entre as diferentes representações de um objeto não é algo simples. Um estudo relacionado com as dificuldades das mudanças de representações de um conceito matemático foi realizado por Kaput (1987) e chegou-se à conclusão que essas dificuldades estão relacionadas com a ideia de considerar as representações de um mesmo tipo, junto com as operações que se podem realizar por regras pré-estabelecidas, como em um sistema. Feio (2009) fala das dificuldades de estudantes em fazer a conversão da língua natural para a linguagem matemática. Argumenta que isso tem relação com o contexto do estudante. Kaleff (2007) diz que mesmo professores com ampla 
experiência profissional e escolaridade avançada não se movem com naturalidade entre diferentes registros semióticos, deixando de realizar conversões entre aqueles de características diversas, principalmente entre os registros discursivos e os registros gráficos. Ela ainda alerta que estes profissionais se apresentarão pouco preparados para a implementação de práticas pedagógicas inovadoras e relacionadas a conversões de registros, as quais possibilitam a desejada compreensão integrativa dos conceitos matemáticos.

Os resultados de pesquisas realizadas por Duval (1988) apontam dificuldades no que concerne à atividade de conversão: grande parte dos alunos do seconde não reconheceu a diferença entre uma reta que passa pela origem, daquela que não passa, e até mesmo da escrita algébrica dessas retas. De acordo com o autor, isso acontece porque o ensino privilegia apenas a aprendizagem das regras concernentes ao tratamento, e o lugar reservado à conversão das representações de um registro em outro é mínimo, ou até mesmo nulo. Essa afirmação é baseada em inúmeras observações e investigações feitas pelo autor, e os resultados apontaram que a "[...] conversão das representações semióticas constitui a atividade cognitiva menos espontânea e mais difícil para grande maioria dos alunos" (DUVAL, 2009, p.63), e não somente a conversão, mas também a coordenação entre diferentes registros, criando dificuldades para a compreensão de conceitos, pois a coordenação de diferentes tipos de representação é condição necessária para a compreensão. Tais dificuldades estão relacionadas com os processos de tratamento e conversão e com a confusão entre as representações e o objeto representado. Duval (2011, p. 25) diz ainda que isso não é “[...] um problema quando os dois sistemas de representações funcionam cognitivamente em sinergia". A nosso ver, o grande problema está em como promover tal sinergia.

Em alguns casos, pode haver regras de conversão claras. Por exemplo, a passagem da representação algébrica para a gráfica pode ser feita associando-se um ponto do plano a um par de números. Todavia, tais regras de conversão não são as mesmas para o processo inverso. Ou seja, as regras de conversão são diferentes no segundo sentido, no qual a mudança de registro é efetuada. Para superar tal dificuldade, Duval (1988) diz que é necessário dar início a uma interpretação global para perceber os diferentes valores possíveis das variáveis visuais no registro gráfico e relacioná-los com os símbolos correspondentes na representação algébrica. $\mathrm{O}$ autor defende que atividade fundamental para aprendizagem é a conversão das representações, sendo tão importante quanto as de formação e tratamento: ao utilizar a conversão, pode-se favorecer a coordenação dos registros de representações. 
Sabe-se que das três atividades cognitivas relatadas anteriormente, o ensino privilegia a formação das representações semióticas e as regras concernentes ao seu tratamento. Isso é evidente nos registros numéricos e simbólicos em que há aprendizagem dos algoritmos de cálculo numérico ou algébrico. As regras de tratamento relacionadas ao registro das figuras geométricas são pouco abordadas:

As tarefas de construção de figuras solicitam somente a coordenação entre o registro discursivo (mais especificamente um emprego especializado da língua natural) e regras de formação que são sempre confundidas com os meios técnicos utilizados para a realização das figuras. Mas, sobretudo, o lugar reservado à conversão das representações de um registro em outro é mínimo, se não nulo (DUVAL, 2009, p. 62).

Como dissemos anteriormente, alguns motivos para isso são: a inexistência de regras de conversão e uso da conversão com finalidade de economia de tratamento, entre outros. De fato, a conversão das representações semióticas não é uma atividade cognitiva espontânea e é mais difícil de adquirir para a maioria dos estudantes. Apesar disso, é comum vermos em livros de Matemática e de diversas outras áreas, várias representações em uma mesma página: frases em língua natural, fórmulas, figuras geométricas, gráficos cartesianos etc. A conexão entre as representações ficam a cargo do leitor, como se atividade de conversão fosse algo espontâneo. A ausência de orientação para coordenação entre os diferentes registros gera dificuldades de aprendizagem. As regras de conversão não podem ser simples atos mecânicos. Até mesmo a conversão do registro na língua materna para os registros geométricos e algébricos parece algo sem regras claras. É preciso conhecer mais sobre os processos de conversão. Veremos mais sobre isso no tópico seguinte.

\subsection{Variações de Congruência, de não congruência e Heterogeneidade dos dois sentidos de conversão}

De acordo com Duval (2008), a natureza cognitiva, própria da atividade de conversão, aparece em dois tipos de fenômenos:

a) As variações de congruências e de não congruências;

b) A heterogeneidade dos dois sentidos de conversão.

O fenômeno de congruência é aquele em que ao analisar uma representação terminal em que na representação de partida, a conversão está próxima de uma situação de simples codificação comparando com o registro de chegada. Como exemplo, consideremos a conversão seguinte: 
"O conjunto dos pontos cuja ordenada é menor que a abscissa"

$$
\mathrm{y}<\mathrm{x}
$$

Nesse caso, pode-se observar que bastam corresponder termo a termo as unidades significantes (unidades de sentido) respectivas para efetuar a tradução matemática (conversão do registro em língua natural para o registro algébrico).

\begin{tabular}{|c|c|c|}
\hline Registros & $\begin{array}{c}\text { Representação de Partida: } \\
\text { Registro de representação } \\
\text { linguística }\end{array}$ & $\begin{array}{c}\text { Representação de } \\
\text { Chegada: } \\
\text { Registro de } \\
\text { representação } \\
\text { simbólica }\end{array}$ \\
\hline Representações & $\begin{array}{c}\text { o conjunto dos pontos cuja } \\
\text { ordenada é menor que a } \\
\text { abscissa }\end{array}$ & $\mathrm{y}<\mathrm{x}$ \\
\hline $\begin{array}{c}\text { Signos (ou } \\
\text { unidades de } \\
\text { sentido) }\end{array}$ & $\begin{array}{c}\text { o conjunto dos pontos cuja } \\
\text { ordenada }\end{array}$ & $\mathrm{y}$ \\
\hline $\begin{array}{c}\text { Signos (ou } \\
\text { unidades de } \\
\text { sentido) }\end{array}$ & é menor que & \\
\hline $\begin{array}{c}\text { Signos (ou } \\
\text { unidades de } \\
\text { sentido) }\end{array}$ & Abscissa & $\mathrm{x}$ \\
\hline
\end{tabular}

Tabela 3-Exemplo de tradução matemática em que há congruência das representações

Na Tabela 3, é possível ver que, se trocarmos a representação de partida para o registro de representação simbólica, o procedimento para tradução linguística (conversão para o registro de representação linguística) será o mesmo. Todavia, a conversão de qualquer um dos dois registros para o registro de representação visual (representação gráfica) não seria tão imediata. Vejamos agora outro exemplo:

"O conjunto dos pontos que tem ordenada negativa"

$$
\mathrm{y}<0
$$

Nesse caso, vemos que falta na representação algébrica uma unidade significante que corresponda a negativo. Assim, é preciso combinar duas unidades significantes $(<, 0)$ para amenizar tal ausência. Nesse caso, falamos de não congruência das representações. 


\begin{tabular}{|c|c|c|}
\hline Registros & $\begin{array}{c}\text { Representação de } \\
\text { Partida: } \\
\text { Registro de } \\
\text { representação linguística }\end{array}$ & $\begin{array}{c}\text { Representação de } \\
\text { Chegada: } \\
\text { Registro de } \\
\text { representação } \\
\text { simbólica }\end{array}$ \\
\hline Representações & $\begin{array}{c}\text { o conjunto dos pontos que } \\
\text { tem ordenada negativa }\end{array}$ & $\mathrm{y}<0$ \\
\hline $\begin{array}{c}\text { Signos (ou unidades } \\
\text { de sentido) }\end{array}$ & $\begin{array}{c}\text { o conjunto dos pontos que } \\
\text { tem ordenada }\end{array}$ & $\mathrm{y}$ \\
\hline $\begin{array}{c}\text { Signos (ou unidades } \\
\text { de sentido) }\end{array}$ & Negativa & $<0$ \\
\hline
\end{tabular}

Tabela 4-Exemplo de tradução matemática em que as representações são não congruentes

De acordo com Duval (2009, p.66)

Nos fenômenos de conversão em que ocorre a não congruência, não apenas o tempo de tratamento aumenta, mas a conversão pode se revelar impossível de compreender, se não houver aprendizagem prévia concernente às especificidades semióticas de formação e tratamento de representação que são próprias a cada um dos registros em presença.

A conversão é quase imediata nos casos de congruência das representações. O que não acontece nos casos de não congruência entre as representações. Assim, um dos problemas do processo de ensino e aprendizagem está em determinar os critérios de congruência (ou não congruência) entre as representações. De acordo com Duval (2009) tais critérios são:

- Possibilidade de uma correspondência "semântica" dos elementos significantes. A cada unidade significante simples de uma das representações, pode-se associar uma unidade significante elementar ${ }^{9}$. O exemplo das representações "o conjunto dos pontos cuja ordenada é menor que a abscissa" e " $y<x$ " ilustra bem tal critério.

- Univocidade "semântica" terminal. A cada unidade significante elementar da representação de partida, corresponde uma só unidade significante elementar no registro de representação de chegada.

- Ordem dentro da organização das unidades compondo cada uma das duas representações.

Assim, há congruência quando os três critérios são satisfeitos e, naturalmente, não há congruência quando pelo menos um dos critérios não é satisfeito. A dificuldade de conversão pode depender do grau de não congruência das representações.

A heterogeneidade do sentido da conversão é o segundo fenômeno que aparece, pois nem sempre a conversão acontece quando se invertem os registros de partida e de chegada,

\footnotetext{
${ }^{9}$ É toda unidade significante que se destaca do "léxico" de um registro.
} 
porque as regras não são as mesmas. "Isso pode mesmo conduzir a contrastes muito fortes de acerto quando se inverte o sentido de conversão" (DUVAL, 2008, p. 20). Geralmente, no ensino, um sentido de conversão é privilegiado pela ideia de que o treinamento efetuado num sentido estaria automaticamente treinando a conversão no outro sentido. Os exemplos propostos aos alunos são propositadamente escolhidos, evidentemente, nos casos de congruência. Nesses casos, as regras são as mesmas, mas esses não são os casos mais frequentes. Vejamos um exemplo na Figura 3.

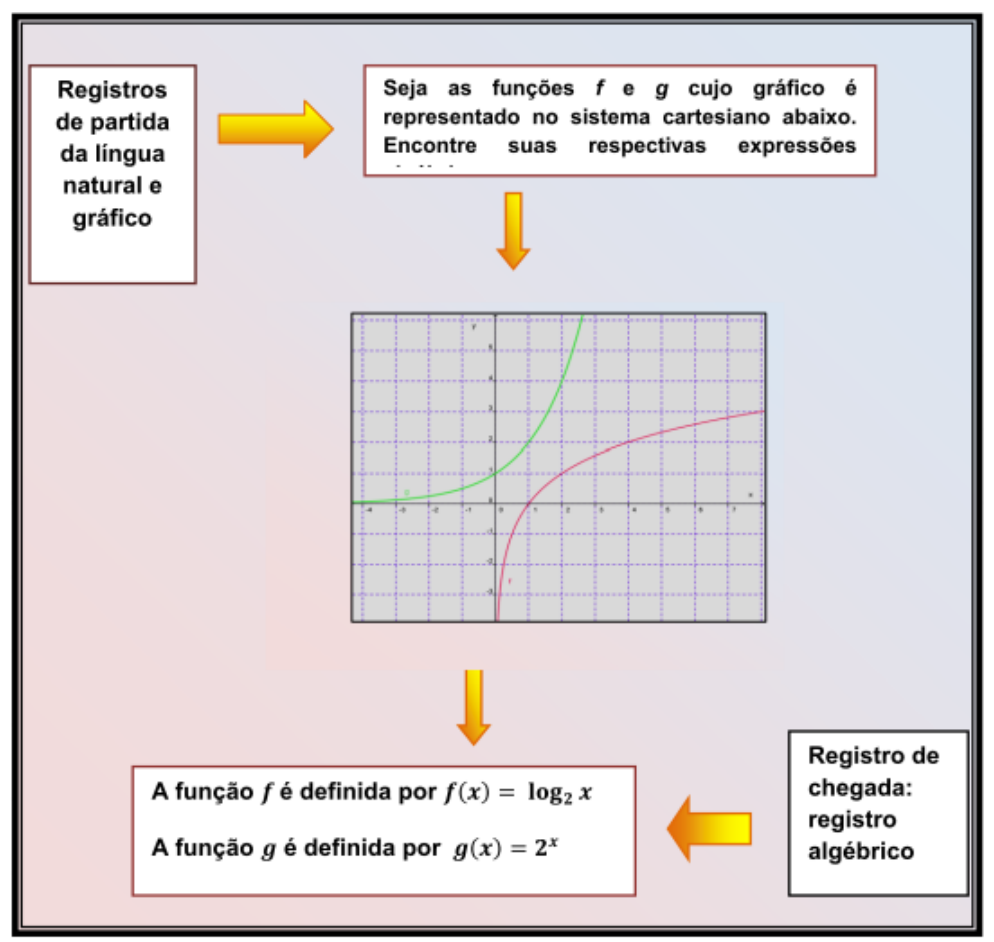

Figura 3-Exemplo para verificação de caráter congruente ou não congruente (SANTOS, 2011, p. 44)

Na Figura 3, temos uma situação de fenômeno de heterogeneidade, pois as regras para encontrar a expressão algébrica no conjunto de chegada a partir do gráfico de uma função não são as mesmas que se fosse realizado no sentido contrário. Para se determinar a representação gráfica a partir da expressão algébrica basta encontrar pares ordenados $\left(x, \log _{2} x\right)$ e $\left(x, 2^{x}\right)$ e para isso, é necessário fazer tratamentos no registro algébrico, ou seja, procedimentos de resoluções de equações exponenciais e logarítmicas. Os procedimentos não são os mesmos para determinar a expressão algébrica a partir da representação gráfica.

Também há a heterogeneidade no sentido do tratamento. Sobre isso Barufi e Brolezzi, (2007) trazem um exemplo de tratamento em um mesmo registro, em que na Escola Básica só é privilegiado um único sentido: ao trabalhar com o registro algébrico, os alunos, no decorrer da formação básica, foram de certa forma, treinados a efetuar operações. Dessa maneira, dada 
uma operação entre dois números ou duas expressões, procurar o resultado é uma tendência em geral automática. Assim, não causa nenhum espanto e é um fato naturalmente aceito por meio de manipulações algébricas necessárias, ou seja, realizando tratamento no interior do mesmo registro. Para os autores, a leitura da igualdade da direita para a esquerda causa certo desconforto, pois "pensar ao contrário" não é automático. Vejamos o exemplo a seguir:

$$
-\frac{2}{x}-\frac{2}{x^{2}}+\frac{2}{x-2}=\frac{2 x+4}{x^{2}(x-2)}
$$

Quais são as regras (operações, manipulações) que devem se usadas para sair da direita e chegar à esquerda? São as mesmas que para sair da esquerda e chegar à direita?

Pelo que foi relatado, percebe-se que as atividades de tratamento e conversão não são simples. Nesse sentido é importante diversificar os registros de representação semiótica. Tal importância para o funcionamento do pensamento é justificada pelas diferenças de custo ou de limitação para a função de tratamento, por aquelas possibilidades de apresentar para a função de comunicação, que existem entre registros (DUVAL, 2009). Ou seja, um registro pode permitir efetuar certos tratamentos de uma maneira menos trabalhosa e mais eficiente que outro. Isso é evidente em procedimentos de cálculo, pois os registros de representação aritmética ou algébrica são mais eficientes que o registro na linguagem natural. Como calcular "trezentos vezes duzentos e cinquenta" sem fazer uso do registro simbólico (representação aritmética)?

Anteriormente nos perguntamos se a atividade conceitual depende da atividade semiótica. Diante de tudo que foi levantado até aqui, apesar de existirem argumentos em favor de uma resposta negativa, tudo leva a crer que sim e pode-se até postular que para que um indivíduo possa discriminar o representante e o representado, ou a representação e o conteúdo conceitual que essa representação exprime, é necessário que ele seja capaz de atingir o estado de coordenação de representações semioticamente heterogêneas: “[...] a compreensão conceitual aparece ligada à descoberta de uma invariância entre as representações semioticamente heterogêneas" (DUVAL, 2009, p. 83). Nesse sentido, Duval (2009) primeiramente sugere um esquema que está descrito na Figura 4. 


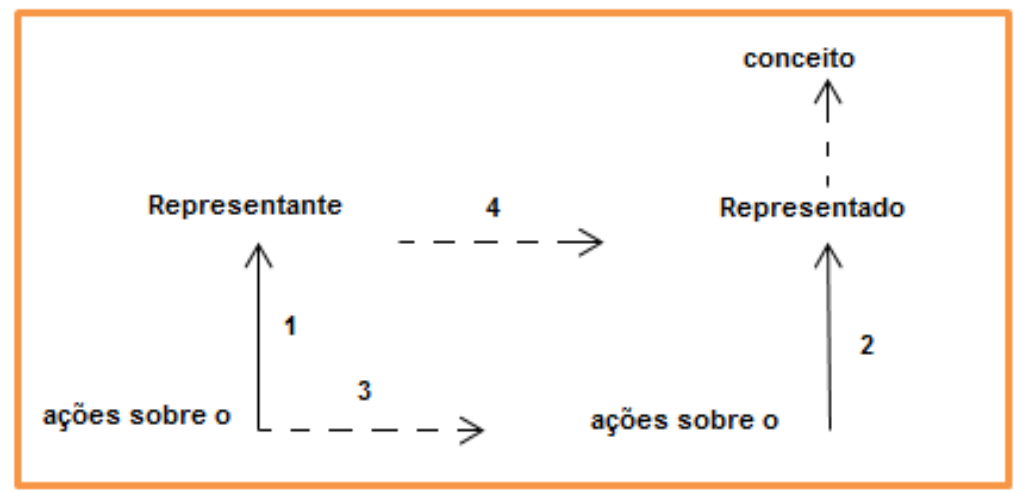

Figura 4-Modelo da representação centrada sobre a função de tratamento por simulação (DUVAL, 2009, p.87)

Como se pode perceber no modelo não há a restrição da representação à simples relação 4, ou seja, há também a integração das ações e tratamentos aos quais uma representação pode dar lugar (flechas 1 e 2). Nesse caso, a relação entre os dois sistemas de ação (flecha 3) torna-se predominante. Duval (2009, p.87 e 88) sugere a simulação para exemplificar como tal modelo de representação: o caso da maquete citado anteriormente é um exemplo disso.

A função de objetivação é importante para analisar a relação entre a diversidade de registros e o funcionamento cognitivo do pensamento. Assim, Duval (2009) sugere um novo modelo centrado sobre a função de objetivação.

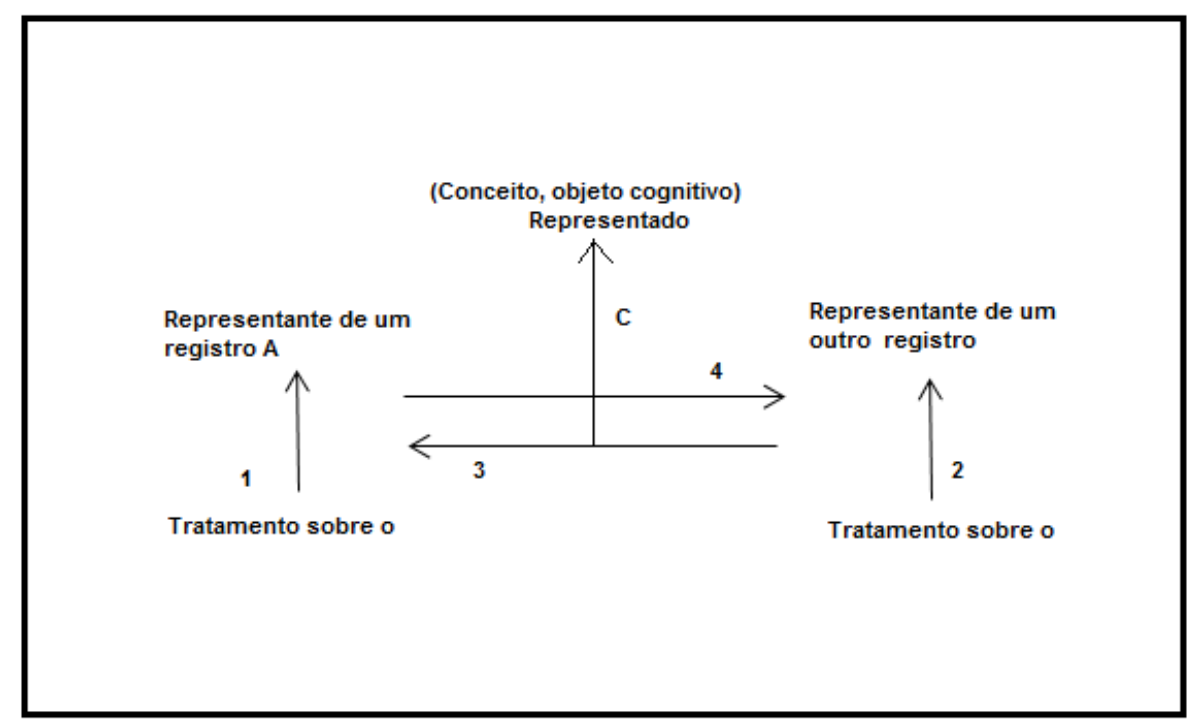

Figura 5-Modelo centrado sobre a função de objetivação

No modelo da Figura 5, as flechas 1 e 2 correspondem às transformações internas (tratamento) a um registro, enquanto as flechas 3 e 4 correspondem às transformações externas (conversões). A flecha C corresponde ao que Duval (2009) chama de compreensão 
integrativa de uma representação que supõe a coordenação de pelo menos dois registros. Com tal modelo, podemos analisar a produção de conhecimento a partir de dois planos. Uma parte de conhecimentos construídos a partir da formação e do tratamento das representações semióticas e outra parte, aquele funcionamento cognitivo que permite essa construção. A construção de conhecimentos produzidos em apenas um quadro elementar de execução de tarefas (respostas a questões, resumo etc) pode restringir a apenas um registro de representação. Isso pode levar a confusão entre representante e representado. Saber reproduzir ou perceber uma representação não significa que se sabe diferenciar representante e representado:

Fazer efetuar essa discriminação parece muito fácil quando o representado é um objeto que pode ser mostrado fora de toda representação, como é o caso de tudo o que se revele de uma experiência perceptiva na qual o objeto pode ser visto, apontado, tocado e manipulado. Mas a situação muda quando não se existe acesso intuitivo direto ao próprio objeto (DUVAL, 2009, p.90)

Nesse sentido, é importante dispor de diversos registros de representação semioticamente heterogêneos e, além disso, saber coordená-los, porque toda representação é cognitivamente parcial quanto ao que ela representa. Assim, todas as figuras e, de maneira geral, todas as representações analógicas, somente podem representar estados, configurações ou transformações e para representar operações, é preciso um registro que tenha as propriedades de uma linguagem, língua natural ou álgebra. Duval (2009) alerta que um indivíduo que sabe coordenar bem os registros pode até se ater às representações de apenas um registro. Todavia, ele provavelmente dispõe de representações que se destacam de outros registros e que ficam associadas de maneira latente àquelas que ele utiliza.

O ensino que privilegia a forma de compreensão via uso de apenas um registro gera dificuldades nas transferências, ou seja, quando se sai do contexto em que se fez a aprendizagem, a maior parte das pessoas se revela incapaz de mobilizar os conhecimentos que sabe. Assim, é necessária uma aprendizagem centrada sobre a conversão de representações e efetuada fora das tarefas de tratamento. Porém, não basta oferecer algumas tarefas que solicitem conversão dos registros.

A conversão das representações requer a identificação das unidades significantes nos registros de saída e de chegada, pois a discriminação das unidades significantes é condição necessária para toda atividade de conversão e para o desenvolvimento dos registros de representação. Tais unidades que compõem a representação (enunciado, fórmula ou um texto) não aparecem separadas e independentes umas das outras. Duval $(2009$, p.101) diz que “[...] a discriminação das unidades significantes de uma representação, e então a possibilidade de 
uma apreensão daquilo que ela representa, depende da variação de um campo de variações possíveis relativamente à significância num registro". Dessa forma, o ensino deve "[...] possibilitar a exploração de todas as variações possíveis de uma representação num registro fazendo prever, ou observar, as variações concomitantes de representação em outro registro" (p.101). Isso pode ser relativamente fácil quando queremos coordenar as representações gráficas cartesianas e a escritura algébrica das relações. Tais registros têm natureza diferente, ou seja, as unidades significantes (plano cartesiano, reta, ponto etc) do registro gráfico cartesiano não são separáveis, pois são integradas numa só forma percebida, enquanto as da escritura algébrica são discretas. Por exemplo, no caso da representação gráfica de retas, a exploração de variações sistemáticas próprias a um registro, as unidades significantes são determinadas por 8 valores visuais correpondendo à associação de três variáveis visuais pertinentes (não separáveis): o sentido de inclinação da reta, a posição de sua intersecção com o eixo das ordenadas, ou a sua posição no que concerne a uma divisão simétrica de dois quadrantes opostos. Para fazer discriminar todos esses valores visuais, é preciso fazer variar uma das três variáveis visuais pertinentes mantendo constantes os valores das outras duas. A cada uma dos valores qualitativos dessas três variáveis corresponde uma variação na escritura da equação da reta (DUVAL, 2009). Em tal trabalho de exploração e obervação, não há a necessidade de cálculos, mas tratamentos no registro visual.

\subsection{Ferramenta de Análise Cognitiva das Atividades Matemáticas}

A primeira etapa para elaboração de uma ferramenta de análise cognitiva das atividades matemáticas é a distinção e classificação dos tipos de representação semiótica utilizados na Matemática. O sistema de produção de uma representação é tão importante quanto o objeto representado na determinação do conteúdo de uma representação. Por exemplo, a similaridade de uma foto com o objeto fotografado é da mesma natureza ou de natureza diferente que a de uma imagem desenhada conforme o objeto representado? As unidades de sentido que formam o conteúdo da representação mudam em função do sistema semiótico mobilizado (DUVAL, 2011).

Duval (2011) diz que a utilização da língua não pode se reduzir a uma simples atividade de comunicação, ela cumpre mais ou menos, segundo as situações e domínios, as Funções Cognitivas. Ela repousa nas operações discursivas que cumprem as funções 
cognitivas e que todo ato de expressão e de compreensão de um discurso produz mobilizando os diversos graus. Assim, as ideias essenciais para compreender e analisar o tipo de atividade de pensamento que requer a utilização da língua natural para poder se completar são:

- Ideia metodológica: todo discurso produzido oralmente ou em um gesto de escrita, se decompõe em unidades de sentido. Essas, por sua vez, podem também ser decompostas em outras unidades de sentido, mas em nível de organização inferior. As operações discursivas é que determinam as unidades de sentido. Pode-se partir das unidades de sentido para identificar as operações discursivas ou, inversamente, partir das operações discursivas para segmentar um discurso produzido em unidades de sentido;

- Cognitiva e lógica: a unidade fundamental de sentido não importa o tipo de discurso é a frase, tratando-se de narração, descrição, explicação, argumentação etc. Só podemos compreender a língua por meio da frase. A frase é a primeira na produção de um discurso.

O mesmo autor continua, dizendo que existem 3 tipos de operações discursivas:

- A enunciação (determina uma frase-afirmação, negação, interrogação, ordem etc.), começa na forma de um discurso e inicia ou prolonga uma explicação, uma descrição, uma exposição e quase sempre provoca uma resposta ou uma réplica;

- A designação (sobre o que, a propósito de que) precisa ao menos duas palavras, pois uma análise de discurso feita com base em palavras não leva a nada, se o seu objetivo é a análise de um encaminhamento matemático, ou de um raciocínio, ou mais amplamente, de um conhecimento científico, pois as palavras não dizem nada e não designam nada, com exceção de nomes próprios. Se elas têm um sentido é primeiro por oposição com outras palavras que pertencem ao mesmo léxico. Tal operação pode ser mais ou menos complexa, em razão da insuficiência do número de palavras em relação a todos os objetos que podemos ser levados a querer designar. A designação das unidades figurais, mesmo sobre as figuras geométricas mais elementares, é um caso. As operações discursivas de designação não se constroem de nenhuma maneira da aplicação de regras. Elas devem somente responder a uma exigência de unicidade de designação. Não basta conhecer as palavras. É preciso saber designar muitas coisas com as palavras que se dispõe e isso só acontecerá com a tomada de consciência das operações de designação. Um exemplo simples está na Figura 6: 


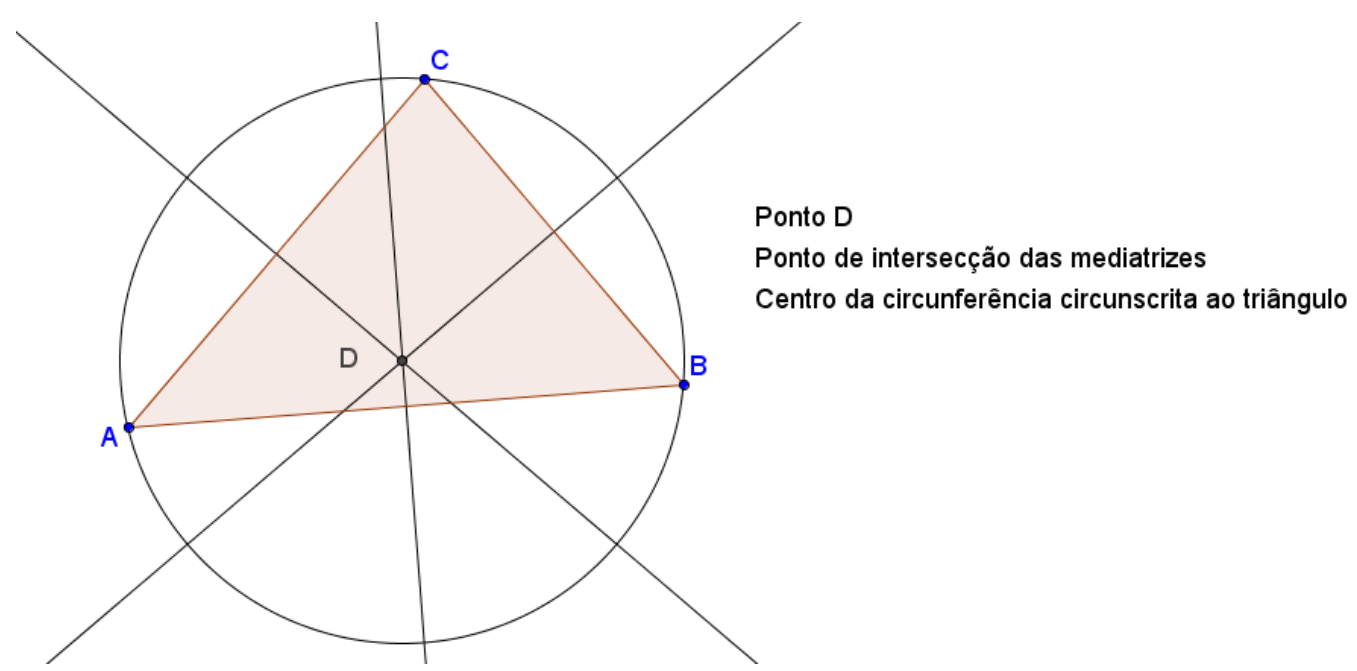

Figura 6- Designações verbais de uma das unidades figurais discerníveis

- As operações de expansão discursivas do conteúdo proposicional de uma frase são aquelas que organizam uma sequência de frases em unidades com um mesmo propósito e lhe dão uma coerência. São essas operações de expansão que criam a diferença cognitiva entre um raciocínio e uma descrição ou explicação, como elas criam a diferença entre uma demonstração matemática e uma argumentação em um debate. Elas religam uma proposição a outra, de forma coerente.

Como exemplo, Duval (2011) apresenta a seguinte atividade para alunos de 10 a 11 anos:

1-Traçar um segmento AC;

\section{2- B é o meio de AC;}

3 - Traçar o círculo de centro em B passando por A e C;

4 - D é o meio de $\mathrm{AB}$;

5 - Traçar o círculo de centro em D passando por A e B; e

6- E é o meio de BC.

$\mathrm{Na}$ atividade, em cada instrução, foi preciso designar ao menos uma unidade figural, que não é apenas empregar um termo geométrico, sendo necessário situá-lo em relação à outra unidade figural (no exemplo, segmento ou círculo). Pode-se então ver que a unidade entre duas instruções é assegurada cada vez pela dupla designação verbal de uma mesma unidade figural (caracteres em negrito), ou seja, pelo mecanismo de expansão discursiva que Frege descreveu para explicar o funcionamento dos encaminhamentos do pensamento matemático (DUVAL, 2011). 
O mesmo autor resume, dizendo que toda produção verbal apresenta duas características:

- Deve conter pelo menos a inclusão de dois níveis de organização discursiva: as operações de designação em uma operação de enunciações e as operações sucessivas de enunciações nas unidades de um propósito cuja coerência depende de operações de expansão discursivas.

- As unidades de discurso significativas que podemos distinguir em uma formulação resultam das operações discursivas efetuadas. Uma produção verbal se segmenta em função das operações discursivas.

As operações discursivas são operações cognitivas. Elas não são irredutíveis à aplicação de regras sintáticas e ao conhecimento de um vocabulário. Elas situam no ponto exato em que o conhecimento, compreensão e conscientização - e, portanto, progresso para o conhecimento - são inseparáveis. Assim, é preciso se exprimir para si e para os outros para poder tomar consciência. A expressão verbal abre a via para o pensamento e não o inverso (MERLEAU-PONTY, 1960 citado por DUVAL, 2011, p. 81).

Entre os três tipos de operações discursivas características de uma língua, o mais importante é a enunciação das frases. Tais operações relativas para essa enunciação constituem os atos intencionais fundamentais do pensamento, que essa enunciação seja oral ou que ela se elabore por meio da objetivação escrita. A predominância da prática oral da língua tende sempre a ocultar a importância e a complexidade dessas operações discursivas. A produção escrita exige que realizemos de maneira controlada esses três tipos de operações discursivas, a prática espontânea da fala incita a eliminar tal realização. A operação de designação fica ignorada na produção oral e só é descoberta quando a produção escrita é exigida (DUVAL, 2011). A produção oral homogeneíza e oculta as diferenças intensas entre demonstrar, argumentar em uma discussão, ou ainda explicar, em proveito de uma hipotética capacidade geral de raciocínio. "Para ter consciência das operações discursivas próprias aos raciocínios matemáticos é preciso passar por uma produção escrita” (DUVAL, 2011, p. 82). Todavia a redação na Matemática exige um trabalho explícito de tomada de consciência das operações discursivas próprias aos raciocínios matemáticos

Duval (2011) alerta que as dificuldades metodológicas para analisar as produções verbais surgem do desconhecimento da necessidade das operações discursivas. Procura-se analisar o corpus dessas produções em função das unidades linguísticas de superfície. Mas esse critério de análise de produções leva a um impasse, pois não é pertinente em relação à 
compreensão dos alunos, já que não oferece nenhum critério controlável para relacionar a análise do que os alunos dizem com o conhecimento dos conceitos ou das propriedades matemáticas. "Para interpretar é preciso complementar com o que os alunos dizem ou mal dizem" (DUVAL, 2011, p.82). No tópico seguinte, falaremos como a análise cognitiva pode ser feita.

\subsection{Um exemplo de análise cognitiva: o caso da Geometria}

Como exemplo de análise cognitiva, Duval (2011) sugere as representações que permitem ver: as figuras na geometria. Elas apresentam 3 características que lhes dão um poder cognitivo particular:

- valor intuitivo "se vê sobre a figura", não exigindo nenhuma explicação complementar;

- dão lugar a um reconhecimento quase imediato sobre os objetos que elas representam como imagens desenhadas; e

- diferentemente das outras imagens, elas são construídas instrumentalmente seja com régua, com compasso ou software.

Apesar da maior importância das duas primeiras características, o ensino tem privilegiado a construção instrumental das figuras para conscientizar que a organização das figuras repousa nas propriedades geométricas. Essa construção, sobretudo utilizando softwares, confere às figuras uma confiabilidade e uma objetividade que permitem efetuar verificações e observações. Por outro lado aqui também ver é importante, pois a utilização eficaz de uma ferramenta exige que possamos antecipar as produções (DUVAL, 2011).

A análise cognitiva da figura diz respeito à maneira de ver que elas necessitam para que sejamos capazes de utilizá-las na resolução de um problema ou no reconhecimento da aplicação de uma propriedade em situações reais. Mas o que seria ver? Seria simplesmente observar as imagens e perceber os objetos reais? É necessário subordiná-la a um conhecimento conceitual de que ela dependerá e que a guiará? Ou, ao contrário, ela depende das operações de reorganização puramente visuais das figuras que seriam próprias da maneira matemática de ver? Duval (2011) diz que as figuras formam um registro de representação semiótico específico. Para mostrar, é preciso descrever as operações puramente figurais que permitem, independentemente ou mesmo antes, a utilização de uma propriedade matemática. São essas operações que permitem transformar qualquer figura em outra, com a finalidade de 
fazer aparecer uma solução ou de produzir um contraexemplo ou ainda de modelar uma situação. A tomada de consciência dessas operações figurais que permitem entrar na maneira matemática de ver em geometria. Vejamos um exemplo na figura:

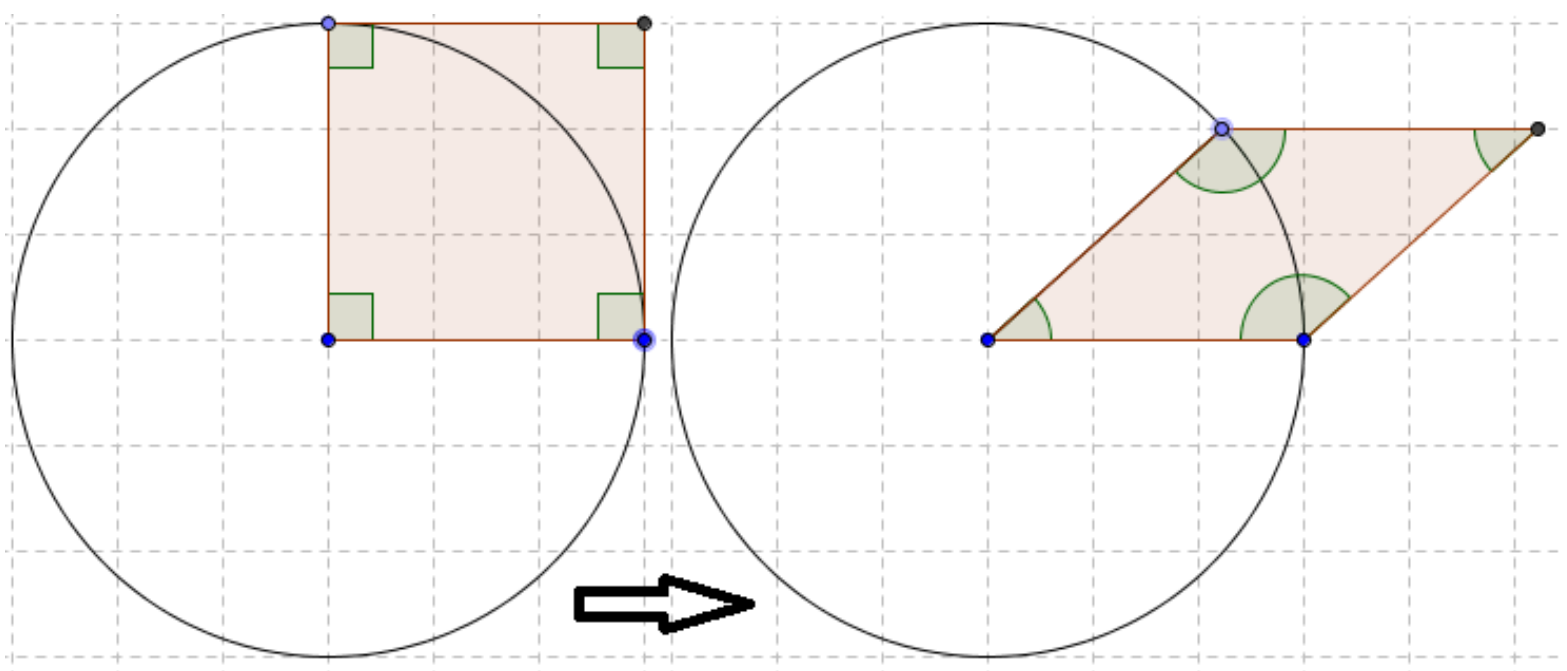

Figura 7-Operação Figural para produzir um contraexemplo que mostra um polígono que tem os lados de mesma medida e não é regular

Ver uma figura é reconhecer imediatamente as formas, ou seja, os contornos fechados justapostos, superpostos e separados. As formas reconhecidas podem também ser distinguidas com as formas ou contornos de objetos da realidade. Esse segundo reconhecimento que é notado. O primeiro fica transparente mais ou menos como no emprego das palavras. A figura é vista como uma imagem mais ou menos esquematizada. "Uma configuração parece com um objeto da realidade à medida que as relações de vizinhança entre as formas que reconhecemos conservam as relações de vizinhança entre as partes desse objeto" (Duval, 2011, p.85). Em relação à distinção entre as figuras geométricas e todas as outras representações visuais, Duval (2011) diz que isso se dá pelo fato de existirem sempre várias maneiras de reconhecer as formas ou as unidades figurais, mesmo que o reconhecimento de umas exclua a possibilidade de conhecer outras. Em outras palavras, para ver matematicamente uma figura ou um desenho é preciso mudar o olhar sem que a representação visual no papel ou no monitor seja modificada.

Para analisarmos o funcionamento cognitivo dessa mudança de olhar, devemos considerar a dimensão das unidades_figurais. As que reconhecemos podem ser:

- os cubos, as pirâmides, as esferas (3D);

- os polígonos, os círculos (2D); 
- as retas ou curvas (1D);

-os pontos (0D). Apenas os notáveis (vértices, extremidades, intersecção) são notados (os outros pontos devem ser marcados por um código).

Também é preciso distinguir as Representações Físicas dessas unidades figurais: maquetes de cubo (3D/3D), fios estendidos (1D/3D); representações semióticas em perspectiva (3D/2D). Toda passagem de uma dimensão a outra representa para o numerador da "fração" ( $\mathrm{mD} / \mathrm{nD})$ um salto cognitivo considerável, e, analogamente a passagem de uma representação física para uma representação numérica (mudança de denominador). Geralmente, é sempre a unidade figural da dimensão superior que se impõe imediatamente à percepção e que bloqueia a dimensão inferior que ela envolve potencialmente e funde visualmente.

Em resumo, ver geometricamente uma figura é operar uma desconstrução dimensional das formas que reconhecemos imediatamente em outras formas que não enxergamos à primeira vista, e isso sem que nada mude na figura afixada no monitor ou construída no papel.

\begin{tabular}{|c|c|c|c|}
\hline \multirow{2}{*}{$\begin{array}{c}\text { Figuras 2D/2D } \\
\text { (configuração global) }\end{array}$} & \multicolumn{2}{|c|}{$\begin{array}{l}\text { Duas decomposições VISUALMENTE } \\
\text { INCOMPATÍVEIS em unidades figurais 2D/2D (=formas } \\
\text { ou contornos fechados reconhecidos) }\end{array}$} & $\begin{array}{l}\text { E uma terceira em } \\
\text { unidade figurais } \\
\text { 1D/2D }\end{array}$ \\
\hline & $\begin{array}{c}\text { Acoplamento/decomposição } \\
\text { por JUSTAPOSIÇÃO }\end{array}$ & $\begin{array}{c}\text { Acoplamento/decomposição } \\
\text { por SUPERPOSIÇÃO }\end{array}$ & $\begin{array}{l}\text { Construção } \\
\text { instrumental }\end{array}$ \\
\hline & $\begin{array}{l}9 \text { formas poligonais (8 } \\
\text { triângulos e um octógono) } \\
\text { (não icônica) }\end{array}$ & 2 quadrados & $\begin{array}{l}\mathbf{8} \text { arestas de } \\
\text { unidades } 2 \mathrm{D} / 2 \mathrm{D}(\mathrm{ou} \\
\text { lados) }\end{array}$ \\
\hline
\end{tabular}

Tabela 5-Pelo menos três maneiras de ver uma figura geométrica plana

De acordo com Duval (2011) a maneira matemática de ver as figuras em geometria exige que possamos passar espontânea e rapidamente de uma para a outra. E, para a formulação de propriedades, ela privilegia o reconhecimento de unidades 1D/2D. A maneira matemática de ver exige mesmo que possamos reconhecer os pontos (OD/2D) como unidades figurais. Todavia, os únicos pontos "visíveis" de uma figura são os vértices ou cruzamentos de retas. Assim, existe um salto cognitivo considerável entre a maneira normal e a maneira matemática de ver. Na maneira normal de ver não levamos jamais em conta a dimensão das unidades figurais que reconhecemos e não temos a preocupação de fazer variar essa dimensão para reconhecer outras unidades figurais que não vemos, mas que vão se tornar mais 
importantes que aquela que vemos. Isso é uma variação que se opera no olhar e não por um deslocamento do monitor. Naturalmente, isso exige um longo treinamento, pois vai contra o funcionamento automático do reconhecimento perceptual das formas. Uma figura é uma boa representação semiótica se permite ser transformada em outra representação. Elas dão lugar a dois tipos de operações figurais:

- Aquelas que se apoiam diretamente na percepção e que transformam unidades figurais 2D/2D (ou objetos 3D/3D) em outras de mesma dimensão. São executadas desde o começo da geometria. Elas apresentam a particularidade de poder ser realizadas por manipulações sobre objetos materiais. Como exemplo, temos a Figura 8. Nela vemos a separação de uma unidade figural 2D em três unidades figurais $2 \mathrm{D}$. Ao final a justaposição das unidades formando uma reconfiguração.

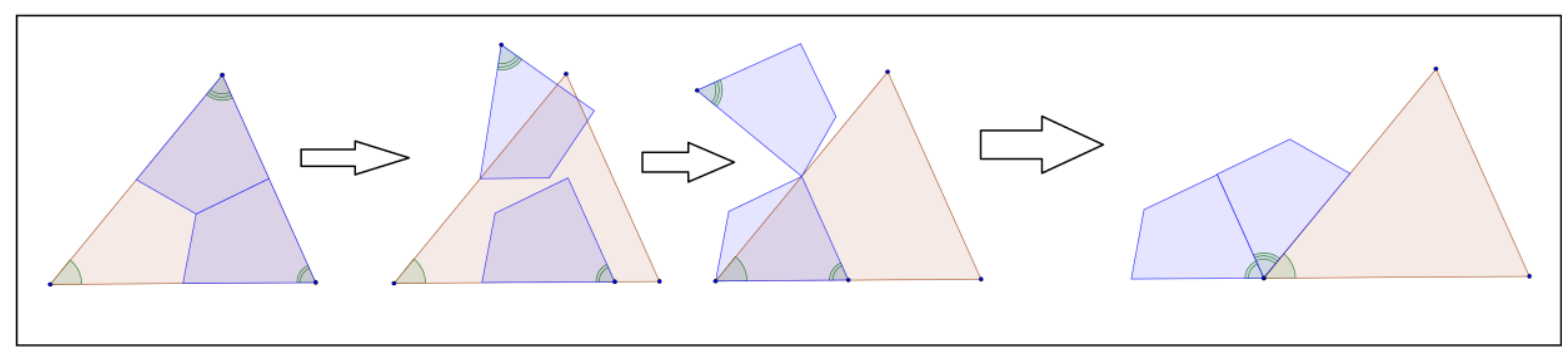

Figura 8-Um tratamento puramente figural para a percepção do valor da soma dos ângulos internos de um triângulo

- Aquelas que dependem de operações de desconstrução dimensional (nenhuma manipulação material pode simulá-las). A desconstrução dimensional das formas $(\mathrm{nD}) \rightarrow(\mathrm{n}-1) \mathrm{D}$ permite analisar a transformação de uma forma dada em outra forma de mesma dimensão mesmo que ela pareça completamente diferente.

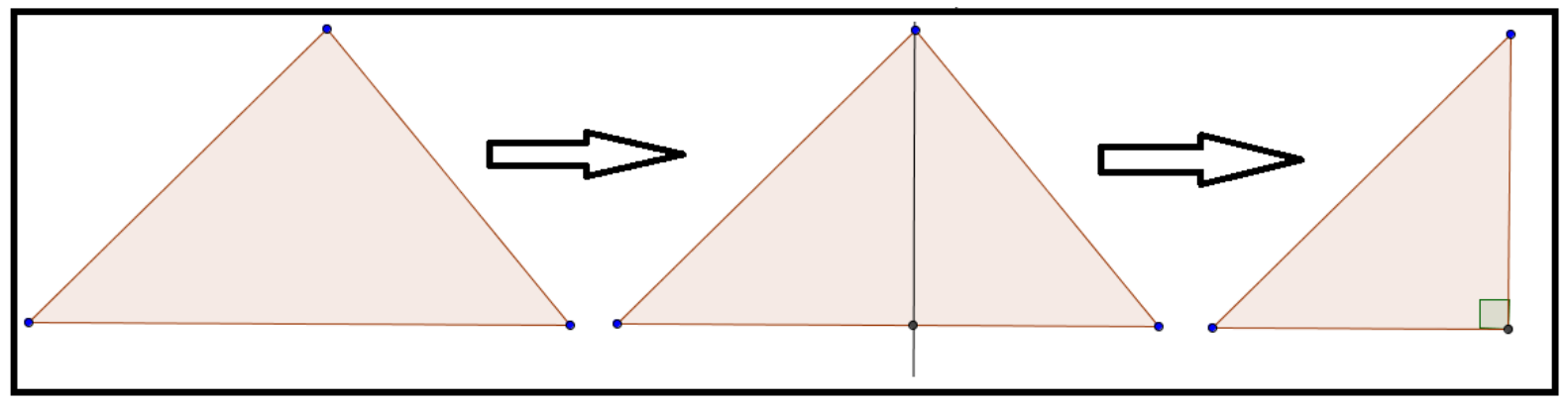

Figura 9-Desconstrução para a identificação das unidades de sentido cateto oposto e hipotenusa

Então a operação essencial relativa às figuras geométricas não é construí-las, mas desconstruir dimensionalmente todas aquelas que são construídas instrumentalmente ou com um software. Para isso, Duval (2011) diz que uma forma seria prolongar sistematicamente todos os segmentos de maneira a sair do contorno fechado a figura em qualquer figura, e 
prolongando-as até a obtenção de pontos de intersecção que vão permitir a produção de novas retas.

Em relação à oposição frequente feita entre desenho e figura, Duval (2011) diz que o desenho é a configuração particular que mostra no papel, no quadro negro ou no monitor do computador, enquanto a figura seria as propriedades do objeto representado pelo desenho ou, ainda, a classe de todos os desenhos que podem ser representações visuais desse objeto. Ele questiona a pertinência cognitiva de tal distinção e apresenta duas consequências para o ensino:

- Primeiramente, a distinção entre imagens desenhadas e os desenhos que construímos com instrumentos que produzem traços visuais $1 \mathrm{~d}$ conforme uma constante geométrico-visual (um traço "reta" ou um arco de círculo). São essas constantes nos traços ou a regularidade de variações que distinguem as figuras geométricas de imagens ou esquemas.

- Suprime a importância do olhar e da visualização. A figura é identificada pelas propriedades que não vemos porque nenhum desenho as mostra em sua generalidade. Essas propriedades só podem ser aprendidas por conceitos, isto é, os termos definidos nos enunciados. O que reflete nesse conglomerado de produções instrumentais e semióticas que se chama de figura no ensino. Ela consiste na associação do que é dado a ver com um código ou indicações verbais fixando esse "é dado" como "propriedade" ou como objeto a ser reconhecido. Não se pode jamais ter certeza se o que é dado a ver representa realmente a propriedade desejada. Naturalmente para um mesmo desenho, podem-se ter hipóteses diferentes. Porém, supõe-se que os alunos vão olhar a configuração produzida com os óculos verbais das hipóteses.

Duval (2011, p. 92) conclui dizendo que:

É preciso ter tomado consciência dos tipos de operações figurais e ter adquirido mobilidade de focalização dimensional do olhar para reconhecer as múltiplas unidades figurais que se fundem no reconhecimento imediato de qualquer forma 2D. A oposição entre desenho e figura ignora a complexidade da maneira matemática de ver para poder utilizar em um encaminhamento o que é dado a ver.

E recomenda que:

- Proponham tarefas em que se exclua toda atividade de medida e de cálculo. Para aprender a ver os alunos precisam aprender a trabalhar sem recorrer primeiro aos aspectos métricos. A interiorização das operações figurais é sempre condição necessária para poder efetuar uma enumeração, ou aplicar as fórmulas do cálculo de 
área, perímetro, ou ainda poder aplicar uma propriedade geométrica no quadro de uma situação real.

- A organização das tarefas não pode ser a mesma para as operações merológicas de reconfiguração e para aquelas de desconstrução dimensional. As operações merológicas de reconfiguração se apoiam sobre a percepção. $O$ simples reconhecimento perceptivo das figuras pode ser uma ajuda ou ao contrário, um obstáculo para resolver um problema. Assim é preciso organizar as tarefas fazendo variar a figura, depois a situação que ajuda a ver a solução até aquelas em que, ao contrário, torna-se difícil ou impossível vê-la. O que possibilita a identificar os fatores figurais que ajudam e inibem um tratamento figural.

Duval diz que organizar tarefas para tomar consciência da desconstrução dimensional é muito mais complexo, porque ela se faz contra a percepção, isto é, contra o reconhecimento imediato de unidades figurais $2 \mathrm{~d} / 2 \mathrm{~d}$ ou $3 \mathrm{~d} / 2 \mathrm{~d}$ que se impõem à primeira vista e que bloqueiam o reconhecimento de outras unidades. Por exemplo: a solução de um problema de geometria no espaço exige outro olhar, aquele que permite ver a forma $2 \mathrm{~d}$ obtida pela intersecção de um sólido com um plano qualquer no espaço. Isso requer todo um trabalho para passar de um objeto $3 \mathrm{~d} / 3 \mathrm{~d}$ e suas múltiplas representações possíveis $3 \mathrm{~d} / 2 \mathrm{~d}$.

Retornando ao que Duval (2009, p. 101) disse sobre a necessidade de se "[...] possibilitar a exploração de todas as variações possíveis de uma representação num registro fazendo prever, ou observar, as variações concomitantes de representação em outro registro", perguntamo-nos: Como possibilitar isso? Quais instrumentos possibilitariam uma exploração que permita prever ou observar as variações concomitantes de representação em outro registro? Entendemos que concomitantes significa ao mesmo tempo ou simultaneamente. É possível perceber tais variações em registros estáticos? Duval fala também do uso do computador e relaciona com as representações semióticas. Veremos isso no tópico seguinte.

\subsection{Uso do Computador e as Representações Semióticas}

É sabido que o uso de softwares pode possibilitar diversas construções e explorações. Por outro lado, sua utilização é suficiente para desenvolver nos alunos a capacidade de antecipar as diferentes transformações possíveis de uma dada figura em outras que não são semelhantes? Ele permite ver as correspondências respectivas entre os valores visuais dos 
gráficos e os termos das equações para quais eles são as representações? (DUVAL, 2011). Ele pode permitir de fato a formação e a transformação dos diferentes registros de representações?

Em relação às contribuições do computador sobre os modos de representações semióticas, Duval (2011) diz que tal ferramenta não constitui um novo registro de representação, porque as representações que eles exibem são as mesmas que aquelas produzidas graficamente no papel para uma apreensão visual. Ou seja, ver uma figura geométrica no monitor ou no papel exige que nosso olhar faça uma desconstrução dimensional ou antecipe as mesmas operações merológicas. Assim, para interpretar os gráficos em um monitor, é necessário que sejamos capazes de reconhecer os valores visuais matematicamente pertinentes e coordená-los com os termos das representações correspondentes. De fato, os softwares não constituem outro registro de representação. O que eles de fato fazem é possibilitar novas formas de explicitar as representações e suas transformações ${ }^{10}$. Ou seja, os computadores constituem um modo de produção de representações radicalmente novo, sobretudo, para as atividades cognitivas de formação, tratamento e conversão. Aceleram-se muito tais processos. Sem receio de estarmos exagerando, podemos dizer que eles exibem as representações no monitor tão rapidamente quanto a produção mental, mas com uma potência de tratamento ilimitada em comparação com as possibilidades da modalidade gráfico-visual. Arriscamo-nos a dizer que mesmo que ele não constitua um novo registro de representação, permite sim criar novos signos para esses registros (fractais, por exemplo).

Com auxílio de softwares apropriados, é possível tornar manipuláveis as representações semióticas como se fossem objetos concretos. Podem-se fazer tais representações sem ter, necessariamente, "habilidades manuais". Por exemplo, em softwares de geometria dinâmica, o procedimento para fazer um círculo não é o mesmo do que o de fazer um desenho de um círculo no papel. Em geral, a produção no papel, como o desenho de um círculo, é uma simples reprodução de uma figura já vista. Em softwares de geometria dinâmica, constrói-se a partir das propriedades da figura, ou seja, constrói-se o círculo a partir de um ponto (centro) e raio, constrói-se a partir de três pontos etc. Pode-se também manipulálas de diferentes maneiras, de forma contínua e o mais interessante: fazer de forma simultânea diferentes representações de um mesmo objeto. Esse aspecto dinâmico é apenas uma consequência da potência ilimitada do tratamento que permite desempenhar uma função que

\footnotetext{
${ }^{10}$ Por outro lado há quem defenda que as representações feitas em alguns softwares de geometria dinâmica possuem características específicas e por isso a chama de Representações Dinâmicas.
} 
nenhum dos outros modos fenomenológicos permite: a função de simulação que possibilita a exploração heurística de objetos matemáticos (DUVAL, 2011). Sobre a utilização do computador, o mesmo autor ainda diz que a interface real entre o computador e o individuo não é o que o monitor exibe, mas o que permite comandar uma exibição, isto é, o menu de comando para as instruções. Isso é que fará com que o monitor "apresente uma resposta a uma pergunta".

\begin{tabular}{|c|c|c|}
\hline Menu de Comando & Ação & Atividade cognitiva mobilizada \\
\hline $\begin{array}{c}\text { Uma lista de termos designando os } \\
\text { objetos matemáticos e as operações } \\
\text { matemáticas ou não. }\end{array}$ & $\begin{array}{c}\text { Escolher um termo para a instrução } \\
\text { ou compor uma sequência de } \\
\text { várias instruções. }\end{array}$ & $\begin{array}{c}\text { Conhecimento dos termos } \\
\text { matemáticos e DECOMPOSIÇÃO } \\
\text { DA FIGURA ESPERADA EM } \\
\text { FUNÇÃO DOS TERMOS DO } \\
\text { MENU. }\end{array}$ \\
\hline Lugar vazio para uma equação & Escrever uma equação & $\begin{array}{c}\text { Conversão automática de uma } \\
\text { equação também já dada, ou } \\
\text { COORDENAÇÃO PRELIMINAR } \\
\text { PARA ESCOLHER O TIPO DE } \\
\text { EQUAÇÃO A FIM DE OBTER O } \\
\text { TIPO DE CURVA OU A } \\
\text { SUPERFÍCIE ESPERADA. }\end{array}$ \\
\hline Uma tabela de ícones ${ }^{11}$ & Apoiar sobre um ícone & $\begin{array}{c}\text { Reconhecimento do ícone que } \\
\text { codifica a instrução correspondente } \\
\text { ao pedido }\end{array}$ \\
& & \\
\hline O mouse ou tablete & Deslocar manualmente o mouse & $\begin{array}{c}\text { Coordenação do gesto e da visão } \\
\text { para manipular a figura obtida. }\end{array}$ \\
\hline
\end{tabular}

Tabela 6-Análise das tarefas cognitivas requeridas pela utilização de um computador (DUVAL, 2011, p. 138)

Duval (2011) diz que um menu de comando pode funcionar como um filtro muito vinculativo e restritivo, se não redutor, que pode ir contra a maneira de ver ou formular nos outros modos fenomenológicos de produção (mental, oral, gráfico/visual). Ele diz que a maior parte dos softwares possui menus que privilegiam um registro de representação para obter representação correspondente em outro registro. Por exemplo, os menus do winplot $^{12}$ e do Maple $^{13}$ privilegiam a entrada pela escrita das equações sem, para tanto, permitir a entrada unicamente pela representação gráfica para obter a equação correspondente (entrada inversa). Acrescenta que é difícil fazer um trabalho de observação ou de comparações sobre as variações de representações gráficas em relação às variações de forma na escrita das

\footnotetext{
${ }^{11}$ Símbolo que está ligado àquilo que representa por meio de alguma similaridade

${ }^{12}$ Disponível em <http://www.mat.ufmg.br/ espec/tutoriais/winplot/>

${ }^{13}$ Disponível em <http://maple-17.softonic.com.br/>
} 
equações, porque exige uma visão sinóptica de todas as variações feitas. Todavia, atualmente, existem softwares como o GeoGebra que possui menus com ambas as entradas, permitindo não apenas a observação e comparações sobre as variações de representações gráficas em relação às variações de forma na escrita das equações, como também variações em outras representações (tabelas, figuras etc.).

Duval (2011) diz que outra dificuldade é que para construir uma figura, um menu "verbal" impõe que antecipemos a desconstrução da figura em unidades figurais 0D (pontos), 1D (retas, curvas) em subconfigurações de unidades figurais 2D (polígonos, círculos). Essa decomposição imposta pelas primitivas do menu pode ser fortemente não congruente como o olhar que vê uma possível decomposição de uma figura. Isso acontece, por exemplo, para construir um triângulo no Cabri-Géomètre $\mathrm{II}^{14}$, é preciso criar os vértices (pontos) e depois os lados (linhas). Até mesmo para o GeoGebra, que permite que se crie um triângulo usando a entrada por meio da linguagem natural "Polígono(A,B,C)", é necessária a desconstrução, porque, para construir o triângulo com o comando em língua natural, é necessário que existam na tela três pontos.

Concordamos com Duval (2011, p. 139) quando ele diz que:

[...] a interface com o computador elimina a linguagem, isto é, todas as operações discursivas. Sua utilização se reduz ao emprego de um léxico ou de palavras-chave. Podemos, mesmo, curtocicuitá-las completamente trocando palavras por ícones. $\mathrm{Na}$ realidade, o modo de exposição no monitor só é inovador para registros diferentes da língua natural.

Mas ficamos um pouco confusos quando ele diz

Os "tratamentos de textos" só auxiliam na formatação, isto é, em um trabalho de edição e não na produção discursiva. Evidentemente isso não tem importância, salvo quando a linguagem, em período de formação inicial e aprendizagem, só tem papel marginal que acreditamos mesmo em matemática (p.139).

Apesar de estar escrito que os tratamentos de textos não têm importância, pelo contexto, acreditamos que toda citação tem um tom irônico e, na realidade, ele defende que os "tratamentos de texto" são importantes para as operações discursivas. Além disso, achamos igualmente importante a conversão dos registros de representação na língua natural para outros. Assim como sua conversão inversa.

No capítulo seguinte falaremos de forma mais ampla sobre o uso da Geometria Dinâmica (GD) no ensino de Matemática e como ela pode contribuir para responder às questões levantadas no início deste tópico sobre o uso do computador: sua utilização é suficiente para desenvolver nos alunos a capacidade de antecipar as diferentes transformações

\footnotetext{
${ }^{14}$ Disponível em http://www.cabri.com/download-cabri.html
} 
possíveis de uma dada figura em outras que não são semelhantes? Ele permite ver as correspondências respectivas entre os valores visuais dos gráficos e os termos das equações para as quais eles são as representações? (DUVAL, 2011). Ele pode permitir de fato a formação e transformação dos diferentes registros de representações? 


\section{RECURSOS DIDÁTICOS: INFORMÁTICA NO ENSINO}

Antes de falarmos da Geometria Dinâmica propriamente dita, faz-se necessário fazer um breve histórico da informática no ensino, relacionando as tendências de abordagem com as teorias de aprendizagem.

As teorias comportamentalistas foram as que primeiro influenciaram o uso do computador no ensino. A instrução programada de Skiner foi uma delas. Segundo Moreira (1999), tal instrução caracteriza-se pelos seguintes princípios:

- A divisão do conteúdo a ser ensinado em pequenas e fáceis etapas: com isso, as possibilidades de reforço das respostas consideradas adequadas ao conteúdo ensinado aumentam e a possibilidade de erro diminui;

- O aluno participa de cada etapa e, com isso, aprende melhor;

- O aluno pode verificar sua resposta imediatamente, aprendendo mais;

- Cada aluno tem um tempo próprio, podendo trabalhar mais rápido ou lentamente, de acordo com o ritmo que determinar;

- O programa pode ser testado pelas respostas dos alunos; quando ele apresenta falhas em alguma página, terá repercussão nas respostas dos alunos.

O uso do computador, nessa perspectiva, consiste apenas em apresentar informações e dar conhecimento ao estudante, dizendo se sua resposta está certa ou não. Tal abordagem segue a tendência Behaviorista. Nela a ênfase está no comportamento observável e no papel do reforço sobre um sujeito passivo. Nessa categoria, aparecem os primeiros softwares educativos que foram desenvolvidos (Teaching Machine ${ }^{15}$ ) e os sistemas de treinamento (como, por exemplo, o simulador de voo Whirlwind).

Papert (1994) chamou de Instrucionismo a abordagem de uso do computador que se fundamenta no princípio da ação de ensinar fortemente ligada à transmissão de informação (instrução) ao aluno. Em geral, os softwares que seguem o modelo instrucionista consistem na automatização, pelo computador, das formas tradicionais de ensino. A questão da aprendizagem é considerada como uma questão de transmissão de informação. O computador contribui, permitindo uma organização não linear da informação (utilização de hipertextos) e a criação de múltiplas formas de apresentação das informações, incluindo animações. Nessa categoria, colocamos os sistemas multimídias de apresentação de aulas como os sistemas de

\footnotetext{
${ }^{15}$ Sidney L. Pressey em 1924 e B.F. Skinner desenvolveram rote-and-drill teaching machine baseadas sobre princípios de condicionamento. Não eram propriamente softwares.
} 
autoria de aulas multimídias (courseware). Alguns dos limites da utilização do computador nessa visão de ensino são que a informação não é o conhecimento e o sujeito somente manipula elementos ativos (zona hipertexto, botões, menus) e não os próprios conhecimentos.

Influenciado pelo Construtivismo, Papert propõe o Construcionismo. Nele o aprendizado é encarado como uma atitude ativa, na qual o estudante constrói seu conhecimento. Tal proposta parte do pressuposto de que as pessoas aprendem melhor descobrindo “[...] por si mesmas o conhecimento específico de que precisam" (PAPERT, 1994, p.125). O construcionismo integra fortemente a programação na construção. Nessa ótica, Carraher (1992) diz que o uso do computador teria que permitir ao aluno oportunidades de descobrir princípios, propriedades, relações de ordem lógica, matemática, científica, linguística ou histórica. Tais oportunidades estão relacionadas com o que Duval fala sobre as conexões entre as diferentes representações. Para que isso ocorra, os softwares precisam oferecer condições e ferramentas para expressão e resolução de problemas. Nessa categoria, enquadram-se os micromundos e simulações. A seguir falaremos sobre os micromundos e, mais especificamente, sobre os micromundos de Geometria Dinâmica.

\subsection{Micromundos}

De acordo com Noss e Hoyles (1996) citados por Bellemain (2003), a origem do termo micromundo nasceu no início da década de 1970, na comunidade de Inteligência Artificial, tendo sido influenciado pelos trabalhos de Minsky e Papert. Inicialmente, esse termo foi usado para definir um sistema que permitisse simular ou reproduzir um domínio do mundo real. Ainda segundo esses autores, o objetivo do micromundo é abordar e resolver uma classe de problemas, pois a resolução de problemas é um dos princípios para o desenvolvimento conceitual.

De acordo com Bellemain (2003), os micromundos matemáticos são descritos por Thompson e em seguida por Laborde como sistemas compostos de objetos, relações e operadores, transformando objetos e relações e podendo ser expandidos pela criação de novos objetos, relações e operadores. Para esse autor, trata-se de um meio de fornecer um sistema próximo de um sistema axiomático que permita expressar e resolver um conjunto de problemas. São exemplos de micromundos matemáticos os programas de Geometria Dinâmica e o Logo. 
Uma das contribuições dos micromundos para a aprendizagem é que ele permite, através de seu campo de experimentação, que o sujeito manipule objetos e relações por meio de operadores (de criação, manipulação de objetos e relações), favorecendo assim, a construção do conhecimento sobre esses objetos e relações (BELLEMAIN, 2003, p.52).

O que entendemos quando Bellemain diz que o "sujeito manipule objetos e relações" é que "sujeito manipule representações e transformações". Assim, a GD permite criar e experimentar diferentes representações dos objetos matemáticos.

Apesar de o micromundo fornecer condições que permitem a elaboração de situações que favorecem a construção de conhecimentos pelo sujeito, ele sozinho, não pode ensinar coisa alguma. Para que haja aprendizagem efetiva com micromundo, é necessária a elaboração de situações de uso. A resolução de problemas tem um papel central nessa elaboração. Sendo assim, deve-se criar ou escolher bons problemas que sejam adaptados à exploração do micromundo do ponto de vista das estratégias de resolução que ele permite desenvolver.

Aqui se volta à discussão anterior em relação às distinções entre desenho e figura. Elas ficam mais evidentes ainda no uso de softwares de GD, porque com o efeito produzido pelas novas formas de representação permitidas pelos micromundos, novas formas de apresentar o problema também aparecem. Por exemplo, uma situação de construção de um quadrado num micromundo não se trata de produção do desenho, mas de um procedimento de construção de um quadrado, em que se mobilizam conceitos que dão sustentação aos objetos. Ou seja, ao construir uma representação do conceito quadrado, usam-se outros conceitos necessários para tal construção. Dessa forma, pode-se perceber que a representação por meio do desenho não é o próprio objeto quadrado.

Trataremos a seguir dos Micromundos de Geometria Diâmica, explicitando seus fundamentos e contribuições para o ensino.

\subsection{Micromundos de Geometria Dinâmica}

Bellemain e Correia (2004) definem a Geometria Dinâmica ${ }^{16}$ (GD) como sendo o estudo das propriedades dos conjuntos de desenhos representando uma mesma figura ou respeitando um mesmo conjunto de especificações. Já Isotani e Brandão (2006) dizem que a

\footnotetext{
${ }^{16}$ Recentemente o conceito de Geometria Dinâmica foi ampliado para Matemática Dinâmica (MD) que seria uma extensão da definição de "Geometria Dinâmica". Softwares de Matemática Dinâmica, além de explorarem objetos geométricos, dão um caráter dinâmico a outros objetos matemáticos como funções, gráficos, números, fórmulas, entre outros, o que justifica a expressão "Matemática Dinâmica". Neste trabalho não faremos distinção entre a GD e a MD. Assim, daqui para frente falaremos apenas da GD.
} 
GD é a implementação computacional da "geometria tradicional", aquela de régua e compasso. Eles afirmam que o termo "dinâmico" do nome pode ser mais bem entendido como oposição à estrutura "estática" das construções da geometria tradicional. Na GD, após o aluno realizar uma construção, ele pode alterar as posições e estruturas dos objetos iniciais e o Programa redesenha a construção, preservando as propriedades originais. Isso auxilia as atividades cognitivas de formação, tratamento e conversão das representações e, consequentemente, na percepção das relações entre elas.

Apesar de a GD estar sendo discutida há apenas cerca de 30 anos, quando surgiram os primeiros softwares de GD (Cabri-Géomètre e o Geometer's Sketchpad), essa ideia não é tão recente assim. Há muito tempo, os matemáticos usavam o artifício de imaginar figuras dinâmicas para resolver problemas. Porém, em tais casos, o movimento da figura era evocado ou simulado a partir de figuras estáticas, cujo objetivo era, sobretudo, explicar um fenômeno geométrico, sem servir de elemento de demonstração. Pode-se dizer que os primeiros instrumentos que traziam em si os princípios da GD foram os sistemas mecânicos que envolviam propriedades de Geometria e serviam para representar certas curvas e resolver alguns problemas de Geometria. Talvez um dos mais antigos desses sistemas seja a Régua de Nicomede (Figura 10), que servia para representar cissoides e conchoides e que teria permitido a exploração do famoso problema da Trissecção de Ângulos ${ }^{17}$.

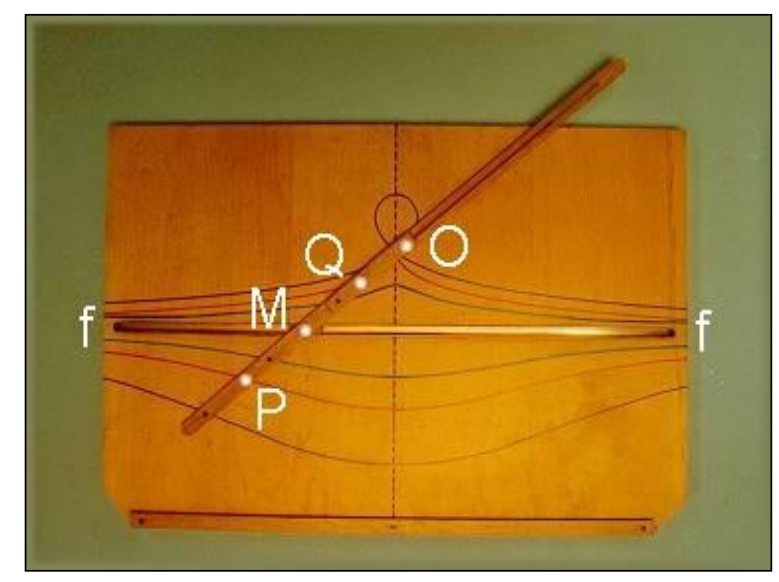

Figura 10-Régua de Nicomede

Outros exemplos desses sistemas são a Máquina de d'Alambert (Figura 11), para representar curvas de $2^{\circ} \mathrm{Grau}$, e o Pantógrafo (Figura 12), usado primeiramente por artistas.

\footnotetext{
${ }^{17}$ Trissecção de ângulos - Dado um ângulo, construir outro ângulo com um terço da amplitude.
} 


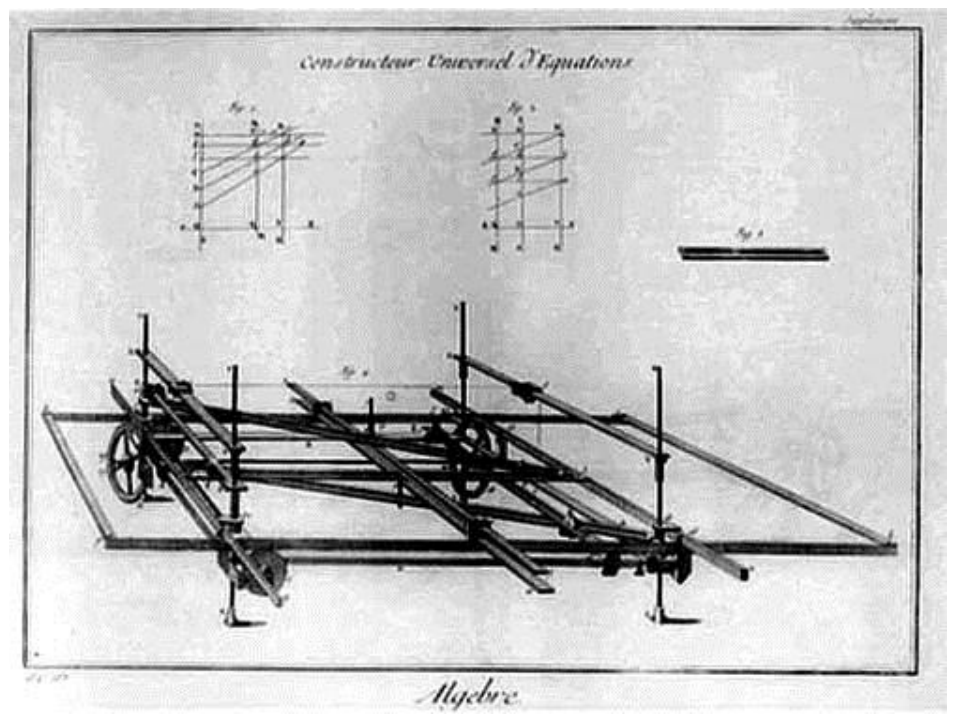

Figura 11-Máquina de d'Alambert

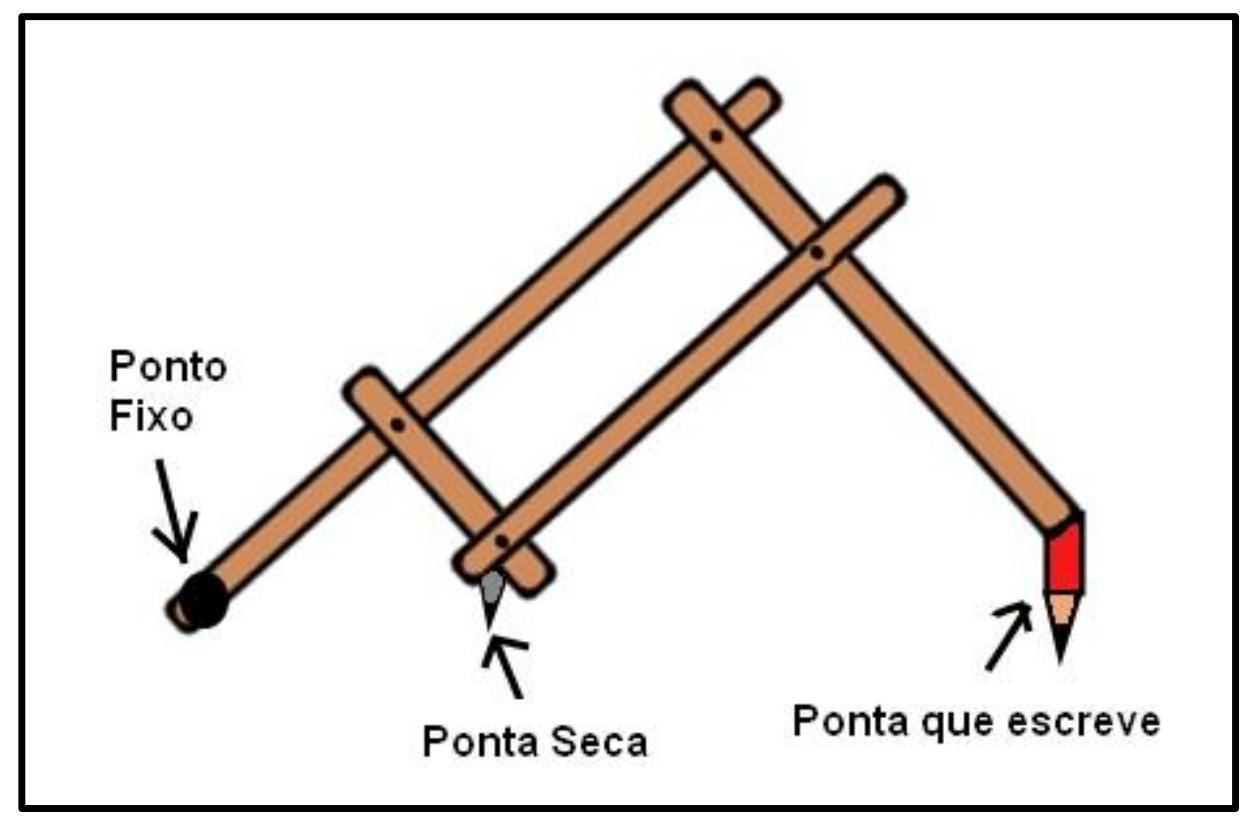

Figura 12-Pantógrafo

Contudo, foi apenas com o desenvolvimento dos softwares de GD: Cabri-Géomètre e o Geometer's Sketchpad que a ideia de GD pôde se tornar concreta e, materializando-se, permitiu aprofundar reflexões sobre questões antigas e levantar novas, sobretudo no que diz respeito ao processo de ensino e de aprendizagem. Segundo Bellemain e Correia (2004) os programas de GD nasceram da conjunção de três elementos: 
- Um estudo epistemológico sobre o papel do desenho na evolução e na resolução de problemas de Geometria;

- Uma reflexão sobre as possíveis contribuições do computador ao processo de ensinoaprendizagem da Geometria; e

- E o desenvolvimento de interfaces, implementando o princípio de manipulação direta.

Não aprofundaremos nos $1^{\circ}$ e $3^{\circ}$ itens citados anteriormente, pois o que nos interessa neste momento são as possíveis contribuições do computador (em especial, os softwares de GD) ao processo de ensino e de aprendizagem, sobretudo no que diz respeito às atividades cognitivas de formação, tratamento e conversão das representações. No entanto, aqui cabe destacar a importância do papel do desenho geométrico, pois esse é uma representação do conceito. Sendo assim, ele é essencial no processo de abstração. De acordo com Bellemain e Correia (2004), o desenho seria o intermediário entre os objetos formais e o espaço físico, ligando elementos perceptivos e abstratos. Assim, o desenho teria duas funções:

- como síntese do espaço físico, sendo resultado de uma esquematização e uma abstração, onde é tirado desse espaço o que é pertinente relativamente à problemática geométrica; e

- como representação dos objetos de Geometria, reorganizando os elementos formais para permitir o trabalho da percepção e a construção de significados dos objetos de Geometria.

Por outro lado, o desenho pode ser também considerado um obstáculo à aprendizagem, sobretudo, quando:

- A leitura do desenho, que possui dimensões perceptivas, depende dos conhecimentos prévios do leitor. Por exemplo, para interpretar uma representação plana, em perspectiva, de um cubo, é necessário que o leitor relacione as propriedades do objeto espacial com as propriedades planas do desenho, entendendo que todos os ângulos das faces do cubo em perspectiva, representam $90^{\circ}$ (mesmo que o desenho não demonstre isso). Isso reforça ainda mais o que dissemos anteriormente sobre a necessidade de se entender que a representação (o desenho) não é objeto;

- No desenho podem existir elementos espaciais que podem ser lidos e não são, necessariamente, pertinentes à problemática geométrica, por exemplo, tamanho e cor. 
Sobre as contribuições da GD para o ensino, Bellemain (2001, p.1314) afirma que “[...] a Geometria Dinâmica permite considerar e conceber uma representação de objetos matemáticos abstratos em várias configurações, podendo modificar suas posições relativas". Ao permitir modificar suas posições e estruturas, permite também fazer tratamentos e conversões das representações. Assim, os programas de GD podem contribuir para o ensino em diversos aspectos:

- A GD permite construir. Como observa Brandão e Isotani (2003), num antigo ditado atribuído a Confúcio: "O aluno ouve e esquece, vê e se lembra, mas só compreende quando faz" (p. 1487). Sendo assim, a construção auxilia a atividade cognitiva de formação das representações.

- A partir da construção da representação, o estudante pode visualizar e manipular: a GD possibilita visualizar uma mesma construção de diversas formas, e dessa maneira, facilita a compreensão do comportamento geométrico dos elementos envolvidos (RODRIGUES, 2002). A manipulação permite diferentes e rápidos tratamentos nas representações. Essa característica permite uma distinção dos elementos variantes e invariantes nos diferentes registros de representação e isso facilita a compreensão do comportamento geométrico dos elementos envolvidos e de suas propriedades. Anteriormente, havíamos falado sobre a importância da percepção da invariância para a compreensão das relações entre as representações.

- O aluno pode experimentar e conjecturar: a Geometria Dinâmica evidencia uma nova abordagem ao aprendizado geométrico, em que conjecturas são feitas a partir da experimentação e criação de objetos geométricos. Desse modo, pode-se introduzir o conceito matemático dos objetos a partir do retorno gráfico oferecido pelo programa de GD, surgindo naturalmente daí o processo de argumentação e dedução (GRAVINA, 1996). Isso contribui para que o estudante possa antecipar as diferentes transformações possíveis de uma dada figura em outras que não são semelhantes.

- “Auxilia na elaboração de ideias mudando a função do desenho de representante de objetos materiais para representação de noções abstratas." (SANTOS, 2003, p.63).

- Possibilita registrar os procedimentos para serem revisitados tanto pelo próprio aluno/autor como pelo professor/pesquisador. 
- Os programas de GD podem ser comparados a laboratórios virtuais nos quais os estudantes podem manipular, investigar e aprender Matemática (ARCAVI; HADAS, 2000).

Apesar das grandes possibilidades de contribuição dos programas de GD para o ensino, eles sozinhos não ensinam coisa alguma. Bellemain (2001) diz que a tarefa de utilizar os programas de GD não é simples, pois embora esses programas permitam elaborar situações que favoreçam a construção de conhecimentos por parte do aluno, eles em si não ensinam nada. Assim, cabe ao professor criar boas atividades que possam ser exploradas com os estudantes. Para que ele possa criar tais atividades é necessária uma releitura crítica de suas práticas. Sem essa releitura, o uso das novas tecnologias terá consequências mais devastadoras do que construtivas (MATHIAS, 2010, p.3). Para Santos e Sola (2001), as atividades baseadas na resolução de exercícios são importantes no ensino de Geometria, pois ajudam o aluno a fazer e testar conjecturas e, dessa forma, adquirir o conhecimento necessário para entender os conceitos e aplicá-los posteriormente.

Müller e Lieban (2012) propõem algumas categorias de atividades com os softwares de GD:

- Arquivos de exploração livre, que têm especial contribuição no processo de “conjecturação" dos usuários, uma vez que vão experimentando as diferentes situações que o software permite e, a partir de observações pela interação, estabelecem relações e refinam suas percepções sobre o conteúdo em questão. Nesse caso, as representações já estão feitas para o estudante. O que ele terá que fazer é manipular para poder perceber as relações entre as representações, ou seja, fazer tratamentos e conversões nas representações. Na Figura 13, tem-se uma construção em que o estudante pode manipular as posições das rochas e da palmeira e perceber quando a posição do tesouro varia ou não. Ou seja, o estudante faz tratamento puramente figural no registro geométrico. 


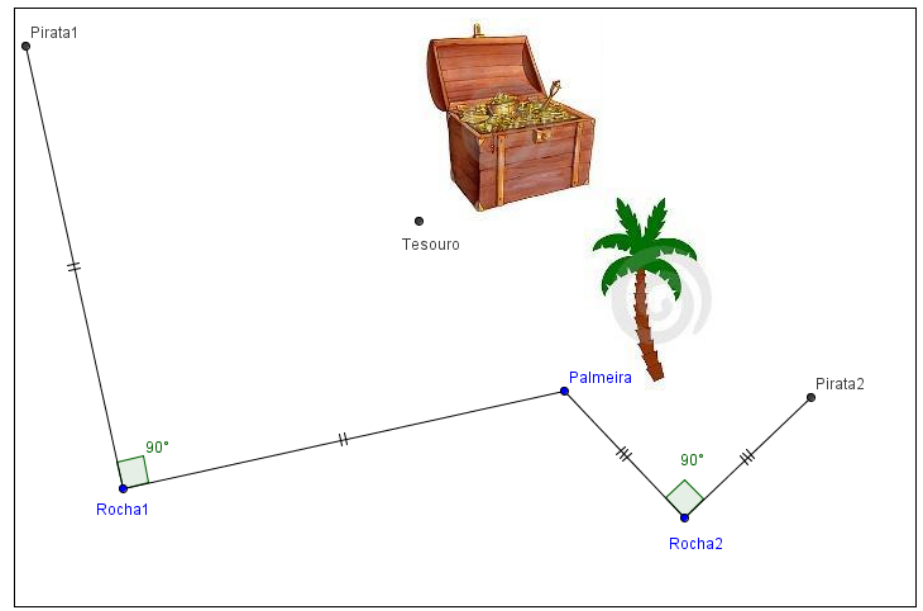

Figura 13-Construção para auxiliar a compreensão do problema "Tesouro dos piratas"

- Arquivos de exploração direcionada, que buscam sugerir orientações para os usuários de maneira que essas o conduzam a um resultado desejado, seja com questionamentos ou dicas, que aparecem como elementos clicáveis, reforçando a interação do usuário com o utilitário. Na Figura 14, há uma representação de uma construção em que o estudante pode manipular o ponto $\mathrm{P}$ e observar as operações figurais (tratamentos) que são feitos no registro geométrico. A ideia é que a partir desse tratamento o estudante possa fazer uma conversão para um registro algébrico ou na lingua materna de forma que possa expressar que compreendeu o teorema de Pitágoras.

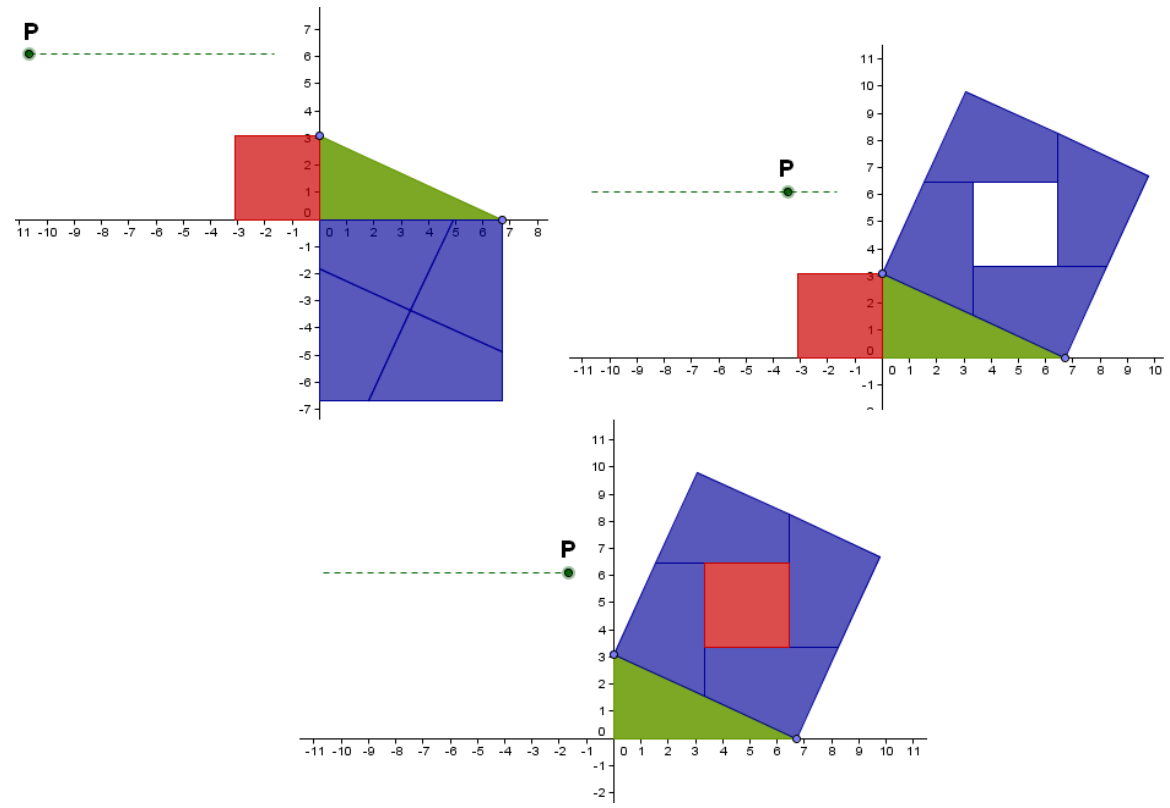

Figura 14-Construção feita no GeoGebra para compreensão do Teorema de Pitágoras 
- Arquivos de recurso/suporte para demonstrações ou deduções de resultados clássicos. A Figura 15 contém uma construção para que o estudante possa "deduzir" a fórmula da área do círculo. Existe na construção a possibilidade de se fazer tratamentos no registro geométrico, além da integração com os registros na lingua materna e algébrica. Espera-se que o estudante possa fazer a conversão para representação algébrica da área $\left(A=\pi r^{2}\right)$.

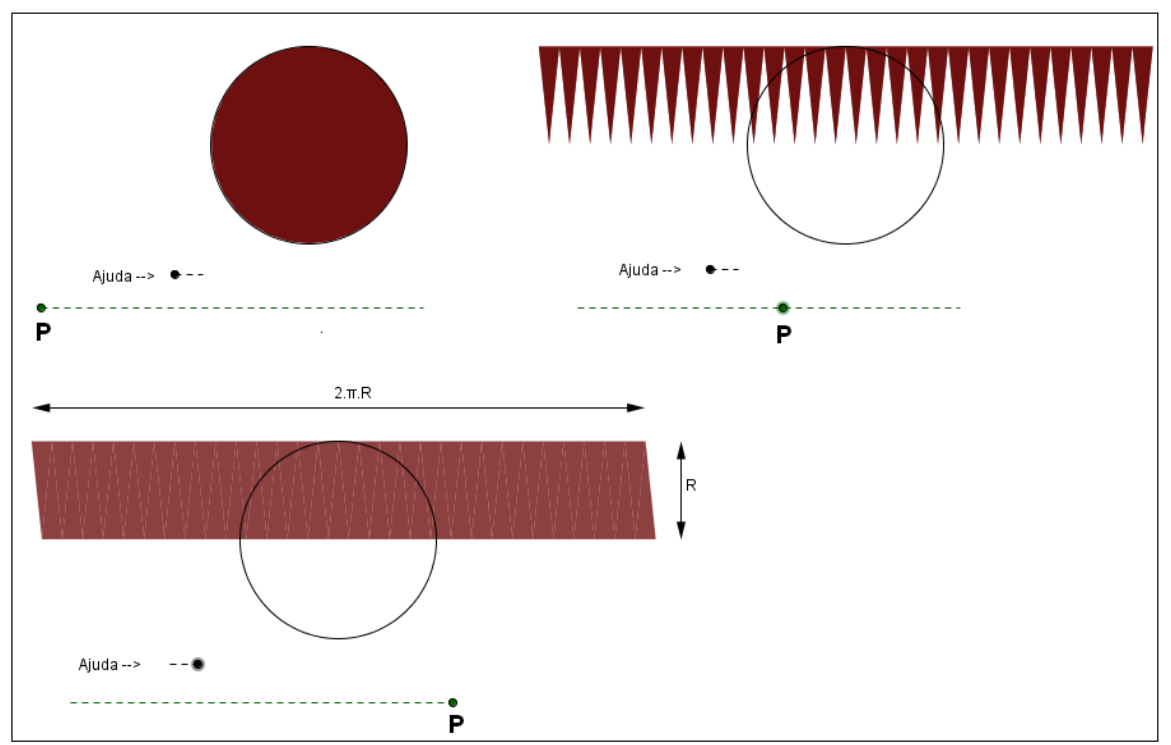

Figura 15-Construção feita no GeoGebra para dedução da fórmula da área do círculo

- Arquivos que sirvam como recurso didático na elucidação de conceitos, procurando auxiliar na visualização ou comportamento de procedimentos nos quais os alunos costumam apresentar dificuldades. A Figura 16 contém uma construção em que o estudante pode visualizar um tronco de pirâmide. Em tal construção é possível perceber como os softwares de GD podem auxiliar o tratamento dos registros de representações geométricas. 


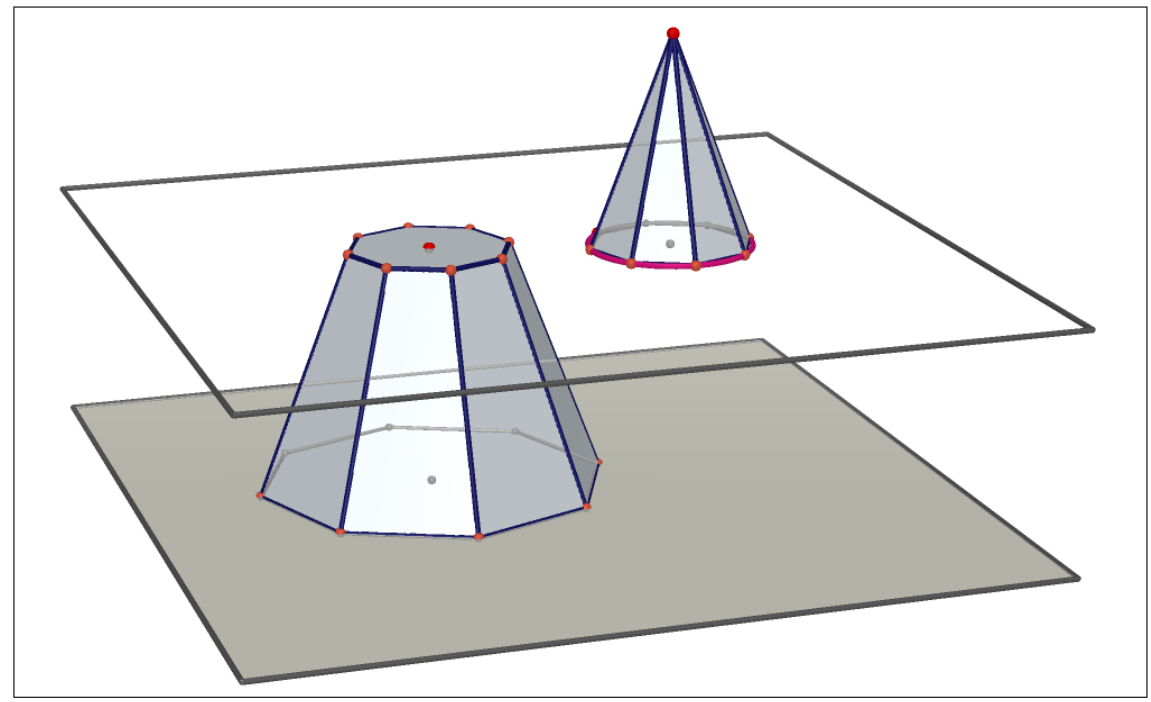

Figura 16-Construção feita no Cabri 3d para visualização do tronco de pirâmide

Tais construções podem ser feitas pelo professor e disponibilizadas ao estudante para que ele manipule, ou podem ser feitas pelo próprio estudante. É evidente que existem construções mais laboriosas, exigindo além de conhecimento matemático, maior conhecimento técnico do software. Nesse caso, materiais didáticos de apoio podem auxiliar o trabalho do professor. Mattos, Moraes e Guimarães (2010) sugerem roteiros de apoio, orientados à promoção de discussões e de análises de procedimentos matemáticos que atuam como mediadores na aprendizagem, já que propõem estratégias e caminhos a serem seguidos pelos professores e estudantes durante o trabalho com o software.

A transição do método tradicional de ensino para o ensino auxiliado por computador pode afetar não apenas o professor como também o aluno. Assim como o professor já habituado ao ensino tradicional precisa adaptar-se aos recursos computacionais, o mesmo pode ocorrer com o aluno que precisará adaptar-se aos sistemas de ensino por computador e abandonar o comportamento passivo. Devido às possibilidades de experimentação e de outros pontos positivos já citados, a GD pode incentivar a maior participação do aluno em seu próprio aprendizado, o que pode produzir resultados sensivelmente positivos (HOLLEBRANDS, 2003 citado por ISOTANI, 2005). Neste contexto, após o período de adaptação, o estudante precisa estar constantemente buscando desafios e, sempre que possível, compartilhando suas dúvidas e experiências com os colegas e professor. É por meio desta interação e da superação das dificuldades encontradas durante as atividades propostas pelo professor, que o estudante atinge a maturidade para compreender o conteúdo apresentado. 
Outra questão que surge com a inserção dos programas de GD (e de outros programas para ensino por computador) é a dificuldade, por parte do professor, em validar a resposta do estudante durante a realização de um exercício e acompanhá-lo durante as atividades propostas (BELLEMAIN, 2003) e também avaliar o trabalho do estudante. A razão disso é que a maior parte da interação ocorre entre aluno-computador e o professor, na maioria das vezes, não tem acesso a essa interação. Alguns autores como Isotani e Brandão (2006) acreditam que as ferramentas que facilitam a produção, a validação e o gerenciamento de exercícios podem ser importantes para auxiliar o professor na elaboração e análise das atividades com os programas de GD. Assim, os programas que permitem ao professor desenvolver exercícios práticos, que podem ser resolvidos utilizando diferentes estratégias, são os mais recomendados para o ensino de Matemática.

Os mesmos autores sugerem o programa de GD iGeom que possui funcionalidades para facilitar o gerenciamento, a produção e a validação de exercícios (BRANDÃO e ISOTANI, 2003; ISOTANI e BRANDÃO, 2004). Tal programa é gratuito, funcionando localmente no micro, na forma de aplicativo ou num navegador Web na forma de applet. Além disso, o iGeom permite a comunicação com sistemas de gerenciamento de curso, viabilizando o armazenamento e o gerenciamento das soluções encaminhadas pelo estudante bem como a construção de bibliotecas de aulas e de exercícios. Apesar das possibilidades de construção e validação automática, o iGeom tem algumas limitações, tais como o fato de não permitir que o usuário possa fazer anotações na tela, dificuldades para o professor criar suas atividades, as respostas pré-programadas etc.

Além dos já citados Cabri-Géomètre, Geometer's Sketchpad e do iGeom, existem outros softwares de GD. Dentre eles, o GeoGebra vem se destacando mundialmente. No tópico seguinte falaremos sobre esse programa.

\subsection{O GeoGebra}

O GeoGebra é um software educativo de Matemática Dinâmica desenvolvido para auxiliar o processo de ensino e aprendizagem da Matemática do nível fundamental ao superior. O software integra as potencialidades dos softwares de Geometria Dinâmica com as 
potencialidades dos softwares de álgebra computacional ${ }^{18}(\mathrm{CAS})$. Tal software permite construções que possibilitam a visualização de conceitos e propriedades matemáticas, experiências matemáticas e exploração interativa. Dessa forma, pode contribuir para o ensino integrado da geometria, álgebra e até mesmo do cálculo.

Como foi dito anteriormente, os softwares de GD permitem que os usuários criem e modifiquem dinamicamente construções euclidianas. As propriedades geométricas e relações entre objetos usados dentro de uma construção são mantidas porque, ao manipular um objeto também se modificam objetos dependentes dele (manipulação direta). Alguns programas de GD fornecem algumas características algébricas básicas, exibindo equações de retas, cônicas e outras expressões matemáticas que, normalmente, não podem ser modificados diretamente pelo usuário. Por outro lado, existem softwares de álgebra computacional (Maple, WxMaxima, etc) que, simbolicamente, trabalham com álgebra, geometria analítica e cálculo. Usando equações de objetos geométricos, um usuário de software de álgebra computacional pode decidir sobre a posição em relação ao outro e exibir as suas representações gráficas. Geralmente, a representação geométrica dos objetos não pode ser diretamente modificada pelo usuário. Assim, o GeoGebra é uma tentativa de integrar esses dois tipos de softwares, sendo que a geometria, a álgebra e o cálculo são tratados de forma integrada. O software oferece duas representações de cada objeto: a componente numérica e algébrica mostra as coordenadas dos pontos, as equações explícitas ou implícitas, ou na forma paramétrica, enquanto que a componente geométrica exibe a representação correspondente (HOHENWARTER, 2002, p.3). Ou seja, o software permite construir diferentes representações num mesmo ambiente. Os softwares anteriores permitiam, basicamente, a manipulação de apenas um registro de representação semióticas, possibilitando tratamento, mas pouca conversão.

No GeoGebra, ambas as representações podem ser alteradas diretamente pelo usuário. A representação geométrica pode ser modificada, arrastando-a com o mouse e a representação algébrica é alterada simultaneamente. Por outro lado, a representação algébrica pode ser alterada por meio do teclado, fazendo o GeoGebra ajustar automaticamente a representação geométrica relacionada. Isso permite reconhecer um objeto matemático nas suas diferentes representações, bem como transitar entre elas, dando uma nova dinâmica entre as múltiplas representações matemáticas dos objetos, abrindo um vasto leque de novas possibilidades de aplicação de softwares de geometria dinâmica para o processo de aprendizagem e ensino da

$\overline{{ }^{18} \mathrm{CAS}-\text { Computer Algebra System }}$ 
Matemática e promovendo a compreensão de conceitos matemáticos de uma forma que não era possível há alguns anos (PREINER, 2008). Tal reconhecimento é necessário para a compreensão das relações entre os diferentes registros de representações do conceito matemático.

O GeoGebra é um software livre, ou seja, possui código aberto sob a Licença Pública Geral GNU. Isso permite alterações e adaptações. Está gratuitamente disponível no endereço www.geogebra.org. O software tem versões offline para instalação no computador, podendo ser usado sem necessidade de internet e a versão AppletStart para a qual não há necessidade de instalação no computador, mas é preciso ter de acesso à internet. Está disponível para os diversos sistemas operacionais (Windows, MAC ou Linux) e traduzido para 55 idiomas.

De acordo com Preiner (2008), a popularidade do GeoGebra vem crescendo rapidamente em todo o mundo. Em março de 2008 a página oficial na Internet recebia mensalmente cerca de 300000 visitantes de 188 países diferentes. O desenvolvedor do programa estimava que mais de 100000 professores já utilizavam o GeoGebra.

O desenvolvimento do GeoGebra começou em 2001 com dissertação de mestrado de Markus Hohenwarter da Universidade de Salzburg, na Áustria. Depois de estudar Educação Matemática e Engenharia da Computação, ele começou a implementar sua ideia de programar um software que integrasse a GD e a álgebra computacional. Duas áreas que outros softwares tratavam separadamente. O principal objetivo era criar um software educativo que combinasse as potencialidades dos softwares de GD com as potencialidades dos softwares de álgebra computacional. Tal recurso poderia ser usado por professores e alunos do nível secundário ao superior. Em 2002, após a publicação na internet de um protótipo do software, professores da Áustria e da Alemanha começaram a usar GeoGebra para o ensino da Matemática. Naquele momento, o autor foi surpreendido por uma grande quantidade de e-mails relatando comentários positivos de professores que estavam usando o programa (HOHENWARTER; LAVICZA, 2007, p. $49-50)$.

Em 2002, Hohenwarter recebeu, em Ronneby (Suécia), o prêmio Europeia Academic Software Award - EASA. Isso o inspirou a continuar com o desenvolvimento do GeoGebra, a fim de melhorar a sua usabilidade e aumentar suas funcionalidades. A continuação do desenvolvimento do GeoGebra foi financiada por uma bolsa de estudos concedida a Hohenwarter pela Academia Austríaca de Ciências o que também lhe permitiu concluir seu doutorado em um projeto que examinou aplicações pedagógicas do GeoGebra em escolas 
secundárias austríacas. Durante os quatro anos seguintes, o GeoGebra ganhou diversos prêmios de softwares e mídias em diferentes países europeus, incluindo Áustria, Alemanha e França (HOHENWARTER; LAVICZA, 2007).

Nos últimos anos, com a estreita colaboração de professores de Matemática do ensino básico e superior, o GeoGebra vem sendo melhorado mediante a inclusão de uma série de características importantes, tais como a criação de ferramentas definidas pelo usuário e simplificação significativa dos passos necessários para a criação de materiais instrucionais interativos e de planilhas dinâmicas. A seguir falaremos sobre a interface e algumas potencialidades do GeoGebra.

\subsubsection{A interface do GeoGebra}

Pelo fato do GeoGebra integrar geometria e álgebra no computador, a interface de usuário contém componentes adicionais que não podem ser encontrados nos outros softwares puros de Geometria Dinâmica. Assim, sua interface é dividida em janelas contendo representações algébricas e gráficas de objetos, além de componentes que permitem ao usuário entrar com objetos em ambas as representações, bem como o menu que faz parte da interface do usuário. A Figura 17 apresenta a interface padrão do GeoGebra (versão 4.0.38.0 de 14 de julho de 2012).

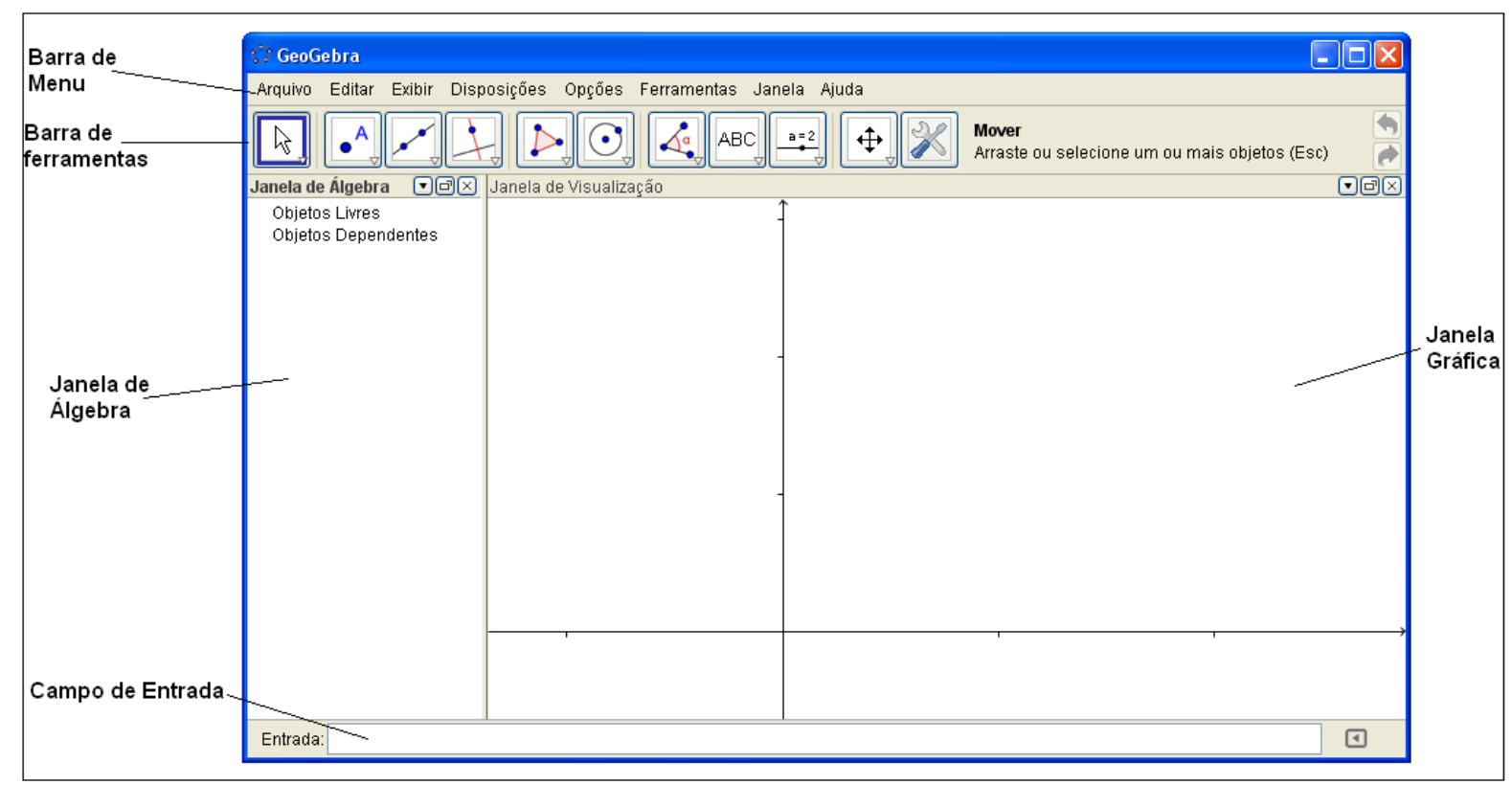

Figura 17-Interface do Geogebra com a disposição “Álgebra e Gráficos” 
A Janela Gráfica, colocada do lado direito da interface do GeoGebra contém um bloco de desenho em que as representações geométricas dos objetos são exibidas. Os eixos coordenados podem ser escondidos ou uma grade de coordenadas pode ser exibida pelo usuário. Nessa janela, os objetos existentes podem ser modificados diretamente, arrastando-os com o mouse, enquanto que novos objetos podem ser criados por meio da Barra de Ferramentas de geometria. Tal recurso consiste em um conjunto de ferramentas no qual a Geometria Dinâmica do GeoGebra está organizada. Tais ferramentas podem ser ativadas e usadas por meio do mouse de forma intuitiva. O nome da ferramenta ativada e uma ajuda aparecem do lado da barra de ferramentas. No canto direito da barra de ferramentas existem botões de Desfazer e Refazer. Isso permite ao usuário desfazer erros, passo a passo.

A Janela de Álgebra, colocada do lado esquerdo da interface do GeoGebra, contém as representações numéricas e algébricas dos objetos. As representações são organizadas em dois grupos:

- Objetos livres que podem ser modificados diretamente pelo usuário e não dependem de qualquer outro objeto; e

- Objetos dependentes que são os resultados dos processos de construção e dependem de outros objetos. Apesar de não se poder modificar diretamente tais objetos, eles são alterados quando os objetos livres dos quais dependem são modificados. Além disso, a definição de um objeto dependente pode ser alterada a qualquer momento.

Os formatos das expressões algébricas podem ser alterados diretamente na Janela de Álgebra. Por exemplo, coordenadas cartesianas e polares de pontos, equações paramétricas, reduzida ou geral da reta, permitindo assim, tratamento para os registros de representação algébrica. A Janela de Álgebra pode ser ocultada por meio do menu "Exibir". O Campo de Entrada fica na parte inferior da interface do GeoGebra. Por meio dele podem-se entrar expressões algébricas diretamente pelo do teclado e visualizar a representação geométrica na janela gráfica. Não apenas isso, pode-se também entrar com comandos representados na língua materna. Por exemplo: Polígono $(\mathrm{A}, \mathrm{B}, \mathrm{C}, \mathrm{D})$ gera na janela gráfica um polígono a partir dos pontos A, B, C e D. Uma grande quantidade de comandos está pré-definida e disponível para ser aplicada em objetos existentes ou para criar novos.

A Barra de Menu fica acima da barra de ferramentas e oferece uma grande quantidade de itens de menu que permitem ao usuário salvar, imprimir, exportar construções, alterar 
configurações padrão do programa, criar ferramentas personalizadas, personalizar a barra de ferramentas, revisar construção por meio do protocolo e barra de navegação "passo a passo".

A versão contém ainda a disposição "Planilha e gráficos" (vide Figura 18). Isso permite a representação simultânea dos registros gráfico, planilha e equações.

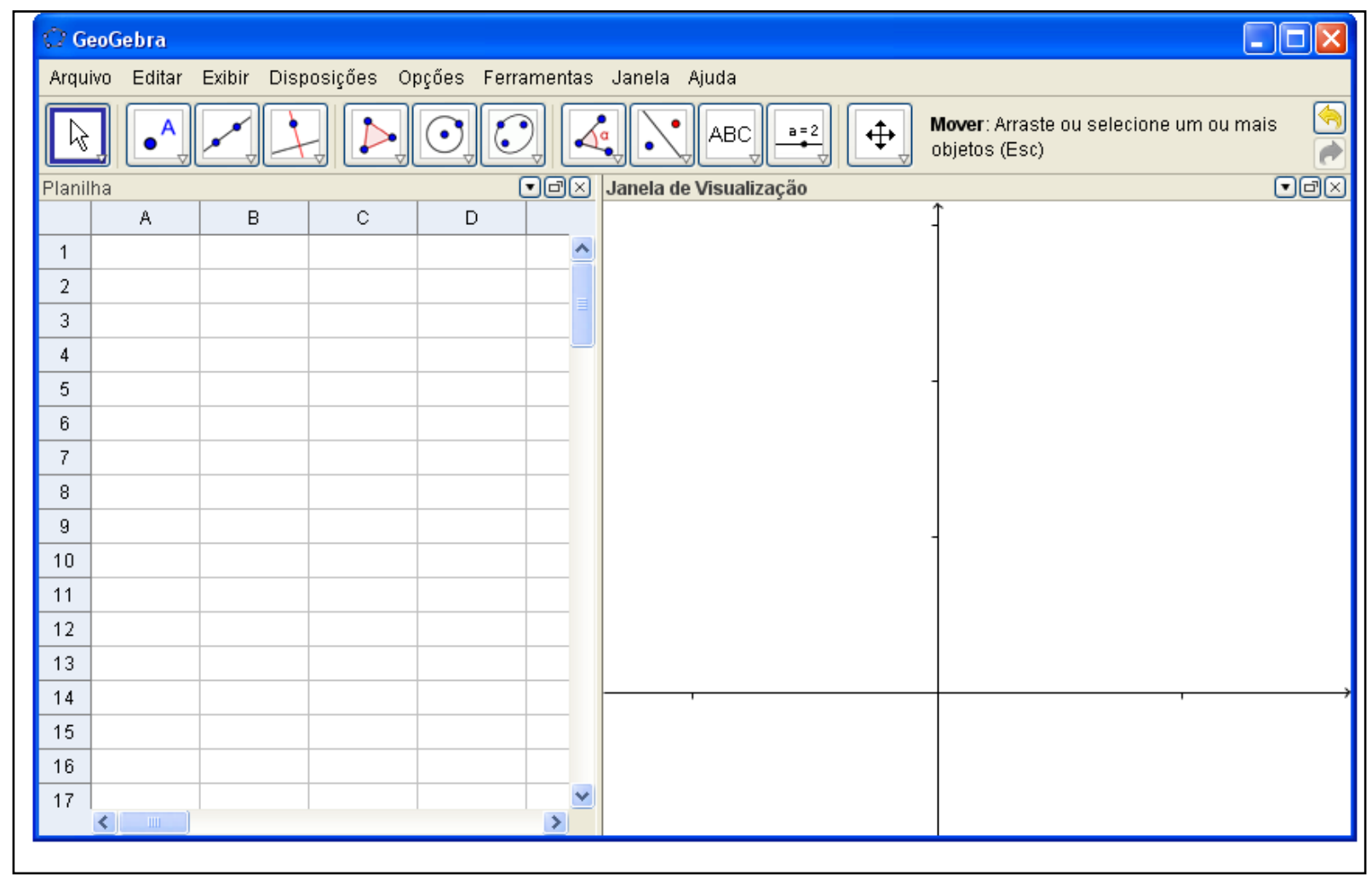

Figura 18-Disposição "Planilha e Gráficos"

A interface do GeoGebra contém vários elementos. Todavia, alguns elementos podem ser ocultados conforme a necessidade do usuário. De acordo com Hohenwarter (2006) a concepção do GeoGebra é baseada no princípio KISS, termo usado na Engenharia da Computação que significa keep it short and simple, ou seja, tal termo expressa o propósito de se fazer programas pequenos e simples, mantendo sua usabilidade. No caso do GeoGebra, o desenvolvedor projetou a interface do usuário do software de uma maneira direta e clara, dando suporte ao modelo de processos cognitivos para a aprendizagem com multimídia e reduzindo a carga cognitiva para o benefício de mais uma aprendizagem bem sucedida (CLARK e MAYER, 2003, citado por PREINER, 2008 p. 40). 


\subsubsection{Algumas possibilidades de exploração do GeoGebra}

Como se percebe pela descrição da interface e das ferramentas, o GeoGebra pode ser um recurso poderoso para o processo de aprendizagem e ensino da Matemática. Todavia, como dissemos anteriormente, os softwares de Geometria Dinâmica sozinhos não ensinam coisa alguma. Assim, é necessário que o professor crie atividades para a exploração eficaz do software. A seguir, apresentaremos algumas formas de exploração do GeoGebra:

- Construções prontas. Nesse tipo de atividade, o professor prepara um arquivo com uma construção pronta para ele ou o estudante manipular no momento da aula. Esse tipo de atividade é normalmente usado quando o processo de construção é mais trabalhoso ou quando para compreender o conceito não é necessário que o estudante faça a construção. Como exemplo, na Figura 19, tem-se uma representação de um arquivo contendo uma construção com um ciclo-trigonométrico. Nessa construção, o usuário pode manipular o ponto $\mathrm{O}$ e visualizar a medida do ângulo sendo alterada. Há uma integração entre os registros geométricos e a lingua materna. Mediante essa construção, espera-se que o estudante possa compreender algumas propriedades e conceitos relacionados com a trigonometria.

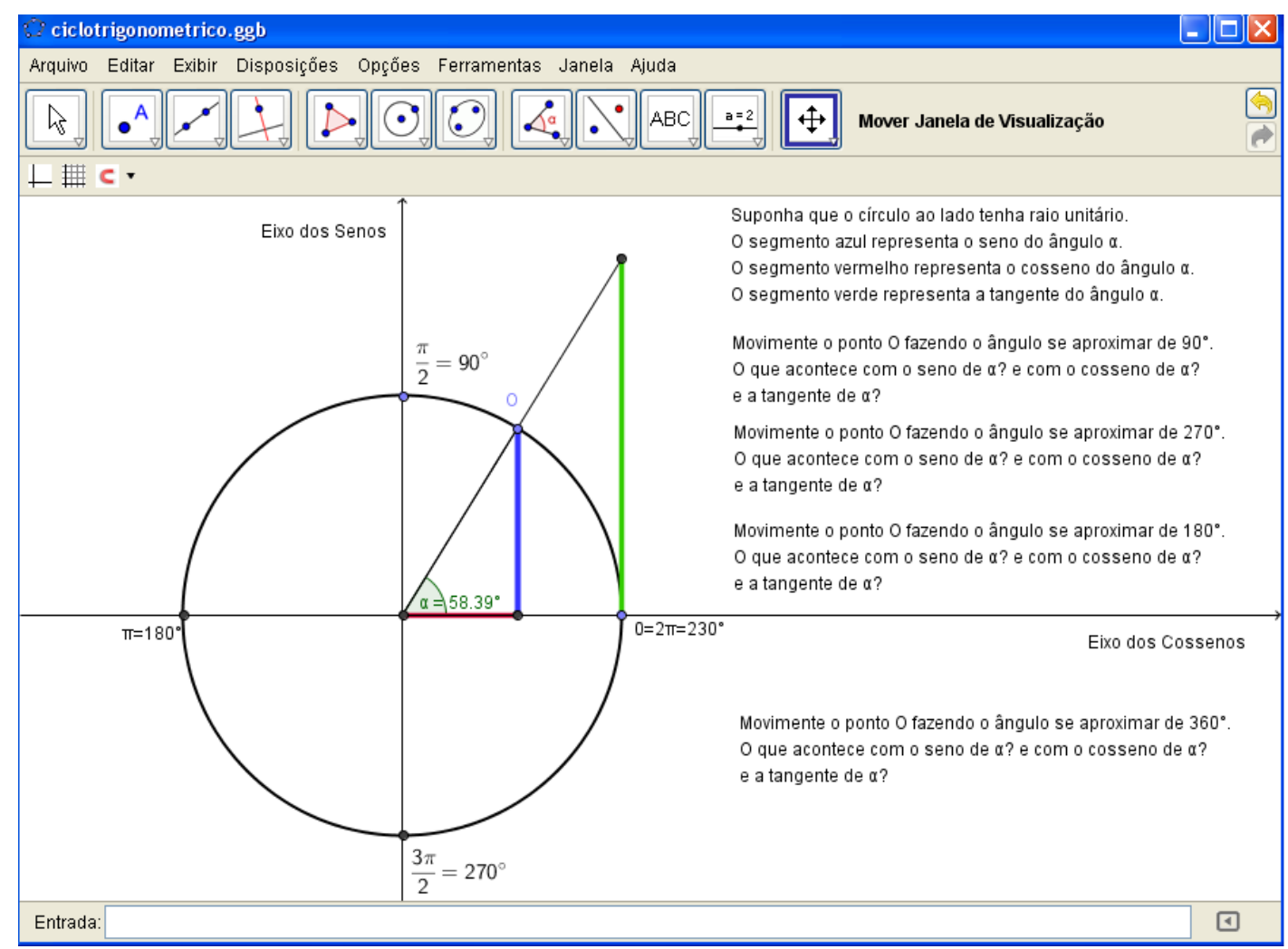

Figura 19-Ciclo-trigométrico 
- $\quad$ Atividades que exigem construção. Existem propriedades e conceitos que, para serem bem compreendidos, é importante que se faça uma construção, para depois fazer a manipulação. Assim, ficam mais perceptíveis as propriedades que envolvem a construção. Nesse caso, o professor pode sugerir um roteiro, contendo o "passo a passo" para a construção. Além do roteiro, o professor pode colocar orientações de como manipular a figura, afim de que se percebam as propriedades desejadas. Atividades de resolução de problemas são exemplos de atividades em que o processo de resolução pode ser importante. Atualmente, existem alguns livros (ARAÚJO; NÓBRIGA, 2010, ÁVILA; ARAÚJO, 2012) contendo sugestões de atividades para serem exploradas no GeoGebra.

- $\quad$ Atividades feitas em planilhas dinâmicas. Planilhas dinâmicas são páginas de internet que contêm uma figura dinâmica (no caso de GeoGebra, um Applet Java interativo) e correspondentes explicações, bem como questões e tarefas para os alunos. Elas podem contribuir para uma melhor compreensão de conceitos matemáticos, pois permitem manipulações interativas da figura dinâmica. Além disso, as planilhas dinâmicas podem apoiar a aprendizagem por descoberta guiada e incentivar a autoaprendizagem, bem como as investigações matemáticas (BRUNER, 1961, JOOLINGEN, 1999, citado por PREINER, 2008 p. 44). A Figura 20 apresenta uma atividade feita com planilha dinâmica. 


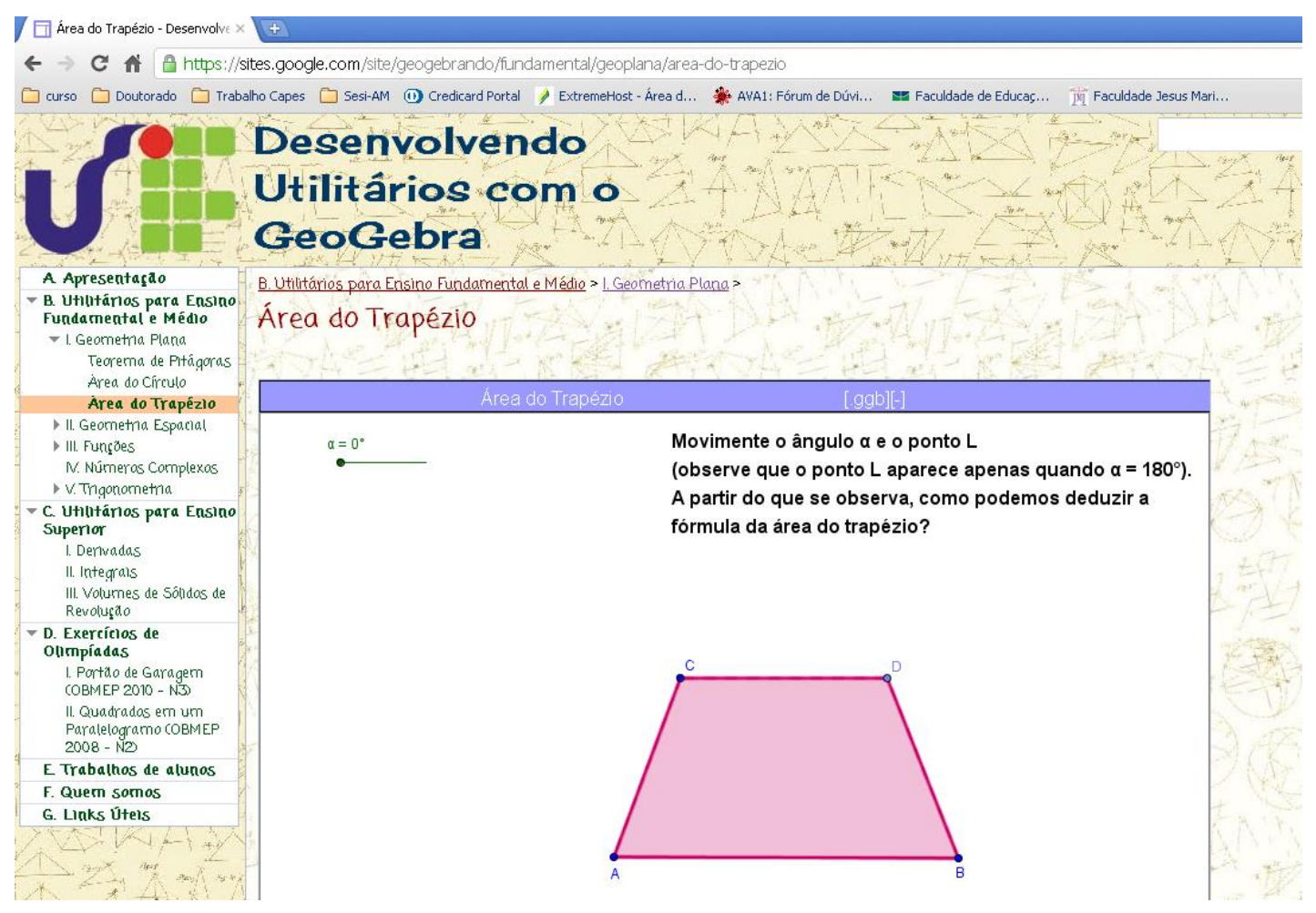

Figura 20-Atividade feita com planilha dinâmica

As planilhas dinâmicas podem conter a barra de menu, barras de ferramentas, campo de entrada e enfim, todas as ferramentas do GeoGebra. Ou seja, nas atividades feitas com planilhas dinâmicas, é possível fazer novas construções. Para usuários mais familiarizados com a linguagem HTML e com programação, o GeoGebra oferece uma interface JavaScript para applets interativos de planilhas dinâmicas. Por meio desse recurso, elementos adicionais, tais como campos de texto ou botões, podem ser inseridos na página web, permitindo uma maior interatividade com a planilha dinâmica. É possível criar exercícios interativos que verificam a resposta do estudante para um problema e dar feedback sobre o seu progresso.

Tais exemplos não esgotam todas as formas de utilização do GeoGebra. Atualmente, existe muito material disponível na internet, contendo sugestões de atividades, construções, vídeos e que podem auxiliar o trabalho do professor e estudante. Muitos exemplos podem ser obtidos em https://www.geogebratube.org/.

É claro que não existem softwares educativos perfeitos. O GeoGebra não foge a essa regra. No tópico seguinte, falaremos sobre alguns limites e dificuldades operacionais do programa. 


\subsubsection{Alguns limites e dificuldades operacionais do GeoGebra}

O ambiente texto do GeoGebra utiliza o recurso LaTeX para a representação de expressões matemáticas. Apesar de ser uma ferramenta poderosa para edição de texto em alta qualidade, tal recurso não é intuitivo e exige do usuário conhecimentos de comandos necessários para especificar a estrutura lógica do texto. Vejamos um exemplo de como o LaTeX é usado no GeoGebra. Na Figura 20, suponhamos que o usuário queira fazer a razão

entre as medidas dos segmentos BF e FD. Então ele deverá clicar sobre o ícone ${ }^{:} \bar{b}$. Abrirá o campo $\backslash$ frac $\{a\}\{b\}$. Deverá substituir o "a" pela medida de BF e o "b" pela medida de FD. Só que ao fazer isso, o rótulo da medida também é inserido.

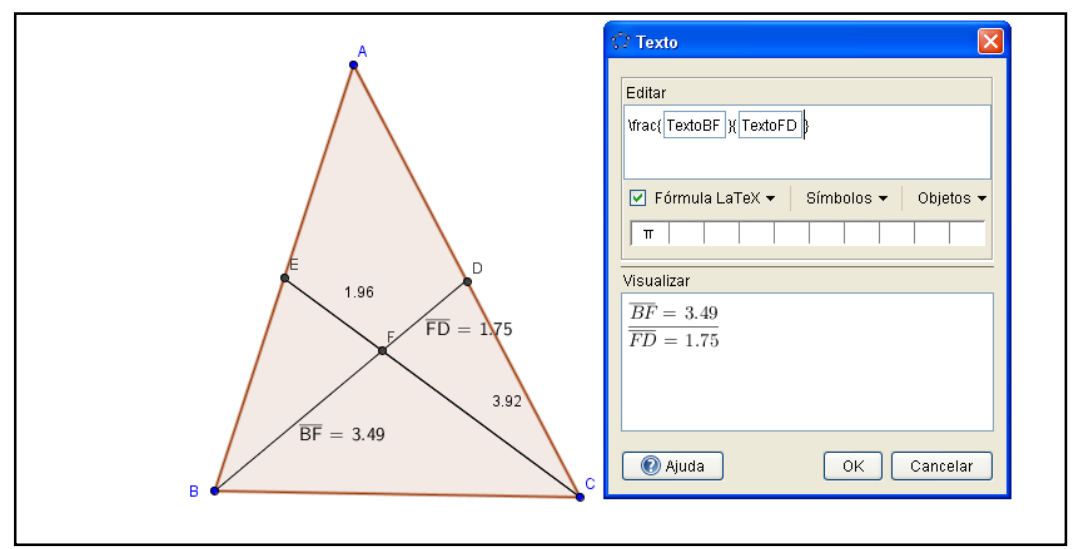

Figura 21-Triângulo com duas medianas e a razão representada

É possível perceber que temos três representações diferentes: língua materna, representação simbólica e linguagem de programação. O usuário deverá fazer duas conversões: linguagem materna para simbólica e simbólica para linguagem de programação. Deverá relacionar as unidades de sentido da representação simbólica " $\mid \operatorname{frac}\{a\}\{b\}$ " (linguagem látex) com a representação simbólica $\frac{a}{b}$. Outro problema é que o comando não mostra o resultado da razão. Para que o usuário possa ver o resultado da razão deverá digitar o seguinte comando: "\frac $\{"+$ distânciaBF+" $\}\{$ "+distânciaFD+" $\}="+($ distânciaBF/distânciaFD). Vejamos na Figura 22: 

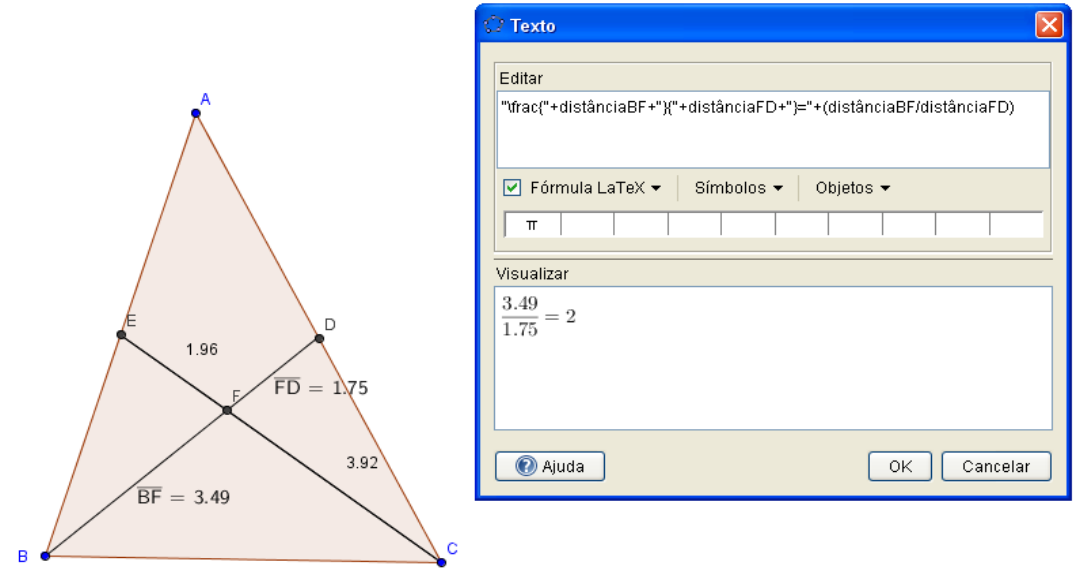

Figura 22-Triângulo com duas medianas, a razão e oresultado representado

Outro problema da ferramenta texto é a integração de textos e equações. Por exemplo, suponhamos que se queira escrever dentro do ambiente texto a seguinte frase: “A razão $\frac{\mathrm{a}}{\mathrm{b}} \mathrm{e}$ 0.95". Ao se ativar a opção "fórmula LaTeX" o programa reconhece tudo como comando LaTeX. Dessa forma, as palavras ficam todas juntas. O comando espaço é $\underline{\text {; }}$ (barra e ponto e vírgula). Assim, o usuário deverá digitar o seguinte comando: "A \; $\operatorname{razão\backslash ;} \backslash \operatorname{frac}\{\mathrm{a}\}\{\mathrm{b}\} \backslash ; \dot{e} \backslash ; "$ $+(\mathrm{a} / \mathrm{b})$.

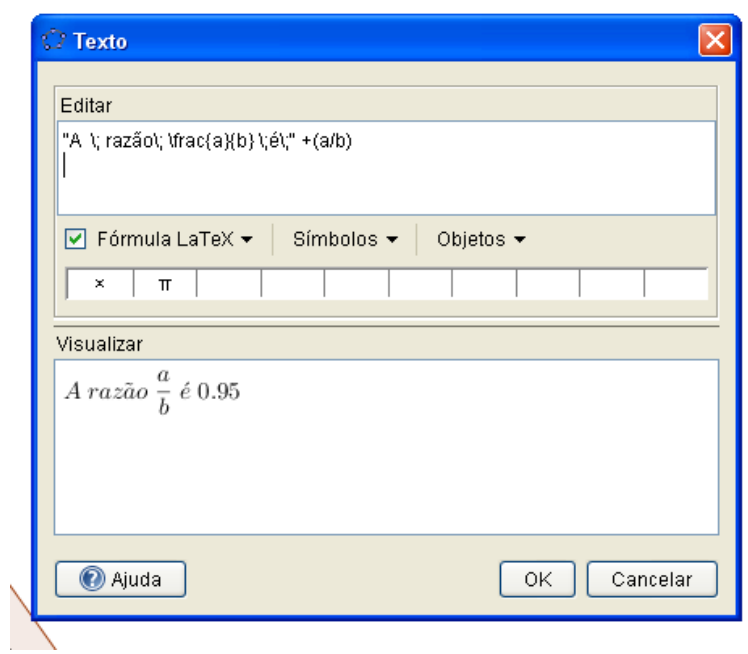

Figura 23-Caixa de texto do GeoGebra

Como se pode ver, a ferramenta texto com os comandos LaTeX não é, por assim dizer, "didática”. Os signos $\frac{a}{b}$ e " $\mid \operatorname{frac}\{a\}\{b\} "$ são dois registros de representação semiótica que representam o mesmo objeto matemático. Todavia, "\frac $\{a\}\{b\}$ " é uma linguagem que não é normalmente usada no ensino básico. Nessa linguagem, o processo de escrita não é natural. Isso pode dificultar a expressão de Narrativas Matemáticas que necessitam do uso de funções, 
expressões e símbolos matemáticos. Consequentemente, pode atrapalhar o processo de comunicação e interação. Processos esses imprescindíveis para que o estudante aprenda.

No capítulo seguinte serão abordados conceitos relacionados com a Comunicação Matemática. 


\section{LINGUAGEM, LINGUAGEM MATEMÁTICA, NARRATIVA E NARRATIVAS MATEMÁTICAS}

Como foi dito anteriormente, umas das funções das representações semióticas é a comunicação. Ensinar e aprender são na sua essência atos de comunicação. Saber Matemática implica necessariamente no domínio dessa linguagem. Como a linguagem é manifestada? Como a comunicação ocorre? Assim, faz-se necessário fazer uma breve revisão dos conceitos Linguagem, Linguagem Matemática, Narrativa e Narrativas Matemáticas.

\subsection{Linguagem e Linguagem Matemática}

A linguagem é um elemento fundamental no processo de ensino e aprendizagem, uma vez que é por meio dela que o estudante poderá adquirir discernimento, experimentar e expressar suas realizações, frustrações, receios, dúvidas, etc. Menezes (2000) diz que a linguagem corresponde a um meio de comunicação utilizado por uma comunidade para transmitir mensagens. Em sentido mais estrito, a linguagem é vista como um sistema de signos diretos ou naturais; pressupõe um sujeito falante e implica fenômenos ligados à transmissão da mensagem dentro de um contexto espaço-temporal e cultural chamado situação. A linguagem não está restrita à escrita e à fala, pois, como se sabe, ela pode ser manifestada por meio de outros meios como desenhos, sinais, gestos, etc. É o caso da Matemática que faz uso de uma linguagem própria, constituída por códigos específicos que apresentam registros orais, escritos e diversos níveis de elaboração de acordo com a competência dos interlocutores que a utilizam (MENEZES, 2000). Muitas vezes a Matemática é tratada como a linguagem universal da ciência.

No que diz respeito à aprendizagem da linguagem da Matemática, o mesmo autor alerta que as aulas têm passado por diversas fases, tendo-se, em algumas delas, concedido um destaque excessivo em questões puramente formais em detrimento das questões de conteúdo. A aprendizagem de um meio de comunicação deve estar subordinada ao ato de comunicar, ou seja, a aprendizagem de um código e das suas regras de funcionamento não deve, nem pode ser desconectada do que pretende ser comunicado.

A linguagem Matemática também necessita do complemento da linguagem natural, assumindo as linguagens oral, escrita e pictórica. A linguagem verbal ou escrita, materializada 
por meio da língua natural, pode ser um suporte para a elaboração do pensamento matemático e elucidação dos seus registros, propiciando ao estudante trabalhar com conceitos e termos matemáticos na sua própria linguagem, pois permite que por meio da fala ou da escrita sejam encorajados a expressarem seus conhecimentos (SCHEFFER; BRESSAN; CORRÊA, 2010). Por outro lado, para que a comunicação possa ser efetiva, é necessário que nos registros escritos sejam usadas diferentes representações: expressões, funções, simbologia, figuras, etc. De acordo com Notare (2009), os símbolos envolvem uma relação entre o signo e significado e servem para representar um conhecimento pessoal (o significado) que é explicitado por meio do símbolo. Servem também para facilitar a comunicação e expressão matemática, tornando-a precisa e objetiva (NOTARE e BEHAR, 2009). Tal integração é imprescindível para que as Narrativas Matemáticas possam acontecer.

\subsection{Narrativas e Narrativas Matemáticas}

Não há consenso quanto à definição precisa de narrativa (RIESSMAN, 1993). Se procurarmos em dicionários, encontraremos que a narrativa é uma sequência que expressa, descreve e comunica pensamentos, entendimentos e vivências de experiências na atribuição de significados de forma oral ou escrita (FERREIRA, 1999). Para Connelly e Clandinin (1990), a narrativa é o estudo das diferentes maneiras como os seres humanos experimentam o mundo.

Quando se fala em narrativa é comum se associar tal termo a uma história que se refere a acontecimentos passados. Todavia para Riessman (1993), nem todas as narrativas são histórias no sentido linguístico do termo. De acordo com Galvão (2005, p. 329)

[...] os indivíduos relatam suas experiências usando uma variedade imensa de gêneros narrativos que reconhecemos pela persistência de certos elementos convencionais que nos encaminham para perspectivas diferentes. Diz aquela autora, que quando ouvimos histórias esperamos ter protagonistas, contextos e acontecimentos, mas nem todas as narrativas os possuem. Dá, como exemplo, outros gêneros narrativos: narrativas habituais, em que os acontecimentos existem repetidamente, não existindo um culminar da ação; narrativas hipotéticas, que relatam acontecimentos que não existiram; narrativas temáticas, que relatam eventos passados, ligados tematicamente entre si.

Concordamos que não há uma definição precisa quanto ao termo narrativa. Todavia a definição de Scholes (1981) citada por Carter (1993, p.6) é a que melhor pode apresentar o sentido que queremos: "Uma narrativa é a apresentação simbólica de uma sequência de 
acontecimentos ligados entre si por determinado assunto e relacionados pelo tempo. Sem relação temporal apenas temos uma lista. Sem continuidade de assunto temos outro tipo de lista” (p. 6). Diz, além disso, que qualquer conjunto de acontecimentos sequenciados pode ser narrado, mas uma história é uma narrativa com uma forma sintática muito específica. É composta por começo-meio-fim ou situação-transformação-situação e com um assunto, conteúdo, que permite ou encoraja a projeção de valores humanos a partir dela. É interessante a visão de Elbaz-Luwisch (2002) citada por Galvão (2005) ao considerar que, tal como na física, o espaço e o tempo interagem na narrativa, são relativos um ao outro e que o espaço em que a ação decorre é curvo. Essa representação permite-nos compreender como a narrativa funciona, por vezes de uma forma claramente contraintuitiva, embora próxima do modo como as pessoas vivem e conquistam esse espaço e esse tempo.

Nesse sentido, estamos interessados nas narrativas que podem proporcionar a expressão do entendimento, dos significados e das construções relacionadas a um tema de estudo ou experienciados pelos estudantes, constituindo-se numa oportunidade de organizarem-se de forma ordenada no tempo e evolvendo a produção, o registro e socialização (SHEFFER, 2001 p. 40). Além disso, as narrativas podem ser um meio para os estudantes se manifestarem sobre determinado tema, expressando o modo como vivenciam, experimentam ou contam sobre uma situação. Enfim, que possam explicitar, de maneira organizada, suas representações mentais. Isso pode permitir ao professor a interpretação de um modo de pensamento do estudante. Ressalta-se ainda que a interação e a comunicação se promovem nos espaços de aprendizagem por meio do diálogo e permeadas por narrativas. A narrativa, nesse contexto, coloca em foco o contar sobre o processo de produção de conhecimento em busca de explicitar ou clarificar ideias e conceitos (FREITAS; FIORENTINI, 2007).

As narrativas oferecem possibilidades de expressão oral e escrita. Bastos (1994) citado por Scheffer (2001, p. 41) salienta uma diferença fundamental nas modalidades de língua oral e escrita:

Na oral, o discurso enunciado ocorre ao mesmo tempo em que a enunciação. Já na escrita, apenas o enunciado é apresentado ao leitor, que deve recuperar no texto a situação de enunciação. O leitor dispõe apenas de enunciado porque não está no lugar da enunciação. Isso nos leva a atribuir uma especial importância para a situação de enunciação, aqui identificada como uma possibilidade de manifestação da fala.

A mesma autora diz que a coerência dos textos narrativos estabelece-se tanto no nível da estrutura de uma narrativa propriamente dita, como no nível da inserção dela numa 
situação de interlocução, fortalecendo-se desse modo as relações entre língua escrita e língua oral no trabalho escolar. Tal coerência se estabelece em dois níveis que confirmam o papel que as narrativas assumem na comunicação com os atos de fala, conversação com o outro e representação textual escrita:

- no nivel do narrar como ato de fala: coerência narrativa; e

- no nivel da inserção do texto numa situação de comunicação: coerência ligada à interlocução.

Tais níveis determinam diferentes tipos de narrativas, seja no plano verbal, figurativo, icônico etc. Além disso, existem autores que propõem etapas para a construção de narrativas. Riessman (1993) propõe as seguintes etapas: o viver ou participar da experiência, o contar a experiência (pelo sujeito que a viveu); o transcrever a experiência; o analisar a experiência, implicando a elaboração; e o ler, pressupondo uma recontagem da experiência.

Como dissemos anteriormente, não há consenso quanto à definição do termo "narrativa". No entanto, consideraremos o significado de tal termo a partir da concepção de Scheffer (2001) segundo a qual narrativa é uma organização discursiva, contendo texto com temporalidade, que descreve modos de manifestação e que pode levar à interpretação de como os estudantes experienciam, expressam e contam suas vivências nas diferentes situações com as quais se deparam.

Em relação às Narrativas Matemáticas, essas podem ser "consideradas escritas expressivas, reveladoras de ideias e sentimentos, centralizadoras de regras e de expressões simbólicas, utilizadas pelos estudantes para descrever certo evento, um gráfico, leis matemáticas e demais interpretações” (SCHEFFER, BRESSAN; CORRÊA, 2010, p.51). Para Nemirovsky (1996), os estudantes elaboram e interpretam narrativas em qualquer idade, podendo criar e discutir representações para diferentes situações que mereçam reflexão. Para tal autor é evidente a relação entre as narrativas e as representações. Ele diz ainda que a construção de Narrativas Matemáticas tem algumas implicações no ensino e na aprendizagem, tais como:

- Elas representam uma substituição do foco usual das relações entre variáveis, voltando-se para as conexões entre narração e tratamento das expressões simbólicas. Ao que parece o autor não desmerece o valor das relações entre as variáveis, mas valoriza mais a narrativa pelas possibilidades de integração e tratamanto dos diferentes registros de representação. 
- As variáveis numa narrativa não são experienciadas isoladamente, elas estão situadas nas ações que podem ser reais ou imaginárias, e que combinam elementos de mudança e permanência. Nesse caso, estamos entendendo variáveis como os diferentes registros de representação.

- Há sempre muitas possibilidades de narrativas para a mesma situação, dependendo de quais aspectos estão envolvidos.

- Uma narrativa envolvida por um fenômeno que inter-relaciona muitas dimensões reflete uma complexa rede de mudanças e permanências.

Nemirovsky (1996) apresenta 4 aspectos envolvidos na construção e materialização de Narrativas Matemáticas:

- Situações funcionais: a materialização tem sucesso pelo envolvimento dos estudantes em ambientes que eles possam construir e experimentar com suas próprias narrativas. Os ambientes de GD permitem isso, ou seja, permitem a construção ao mesmo tempo em que experimentam.

- Funções: os estudantes são encorajados a usar funções com diferentes expressões para diferentes intervalos do domínio, na descrição de certo fenômeno, tornando as Narrativas Matemáticas dos estudantes mais naturais e ricas, pois possibilitam a observação das variações de certo fenômeno, a partir da interpetação e construção de gráficos, tabelas ou lista de números.

- Causas e intenções: as narrativas podem ser consequência do estudo das causas de um fenômeno.

- Contextualização: a vivência da experiência com o fenômeno pode contribuir para o surgimento de noções.

Nas Narrativas Matemáticas, aspectos relacionados com a argumentação são valorizados, tais como conjecturar, raciocinar, discutir, deduzir e concluir. De acordo com Scheffer, Bressan e Corrêa (2010, p.52)

[...] a valorização da capacidade argumentativa nas atividades matemáticas torna-se, na medida em que a exploração acontece, um terreno vasto para a experimentação, observação, demonstração, elaboração e construção de conjecturas, o que conduz à manifestação de explicações para diferentes fenômenos.

Nesse sentido, o processo de aprendizagem e ensino da Matemática precisa valorizar ações como comunicação e expressão, por meio de atividades que exijam a argumentação e a justificativa, de modo a incentivar o estudante a refletir sobre suas ações e explicar seu 
raciocínio, tomando consciência de seus atos. Concordamos com Notare e Behar (2009) quando dizem que um sujeito que consegue se expressar, argumentando sobre determinado conceito ou assunto, está em um nível mais elevado de compreensão, se comparado àquele sujeito que apenas resolve numericamente um problema, mediante a utilização de uma fórmula, regra ou equação, ou seja, usando apenas um registro de representação semiótica. Isso reforça ainda mais a necessidade de se incentivar o estudante a pensar e expressar o que pensa, seja falando ou escrevendo, de modo a justificar suas ideias e refletir sobre suas concepções.

Para que isso aconteça é preciso que se proponham atividades que permitam explicitar tais aspectos por meio das Narrativas Matemáticas. Atividades com foco na resolução de problemas podem ser boas estratégias porque podem promover a participação, discussão e resolução em conjunto, de modo a construir o conhecimento matemático relacionado aos conceitos estudados. Além das atividades com resolução de problemas, a prática envolvendo atividades com tecnologia matemática também pode propiciar grande possibilidades de exploração e discussão, encorajando a comunicação entre os estudantes em relação à aprendizagem matemática, à linguagem e a diferentes representações (SCHEFFER; BRESSAN; CORRÊA, 2010). Tais atividades podem ainda permitir diferentes formas de construção, de manipulação, de experimentação e de representação, o que pode estimular a busca de argumentos para validação de conjecturas.

Para que as Narrativas Matemáticas possam ser profícuas é importante que o professor saiba fazer boas questões. Sobre isso, Menezes (2000) diz que a formulação de perguntas ocupa um lugar de destaque no discurso da aula de Matemática, sendo aplicadas em situações diversificadas e com intuitos variados. Os questionamentos podem ser usados nas escolas para que o professor possa aumentar e melhorar a participação dos alunos e com isso detectar dificuldades de aprendizagem, ter e dar feedback sobre aprendizagens, motivar o estudante e ajudá-lo a pensar. Além de fazer boas questões, é papel também do professor ensinar o estudante a fazer bons questionamentos. É comum, ao final de uma explicação do professor, os estudantes dizerem que não entenderam coisa alguma. Talvez isso aconteça por não saberem como perguntar o quê não entenderam. Assim, é preciso que o professor ensine os estudantes a fazerem questões que possam explicitar o que não entenderam, que busquem a reflexão, criação de novas ideias e, enfim, questões que postam despertar o senso-crítico. 
Para que se obtenham bons questionamentos em aula, McCullough e Findley (1983), Cohen e Manion (1992) e Johnson (1982), citados por Menezes (2000), enumeram um conjunto de aspectos que o professor deve levar em consideração:

- Preparar algumas questões antecipadamente;

- Fazer questões claras e concisas;

- Variar o nível de dificuldade, tentando envolver a maioria dos alunos da turma;

- Promover um tempo de pausa a seguir às questões;

- Colocar as questões a todo o grupo e só depois individualizá-las;

- Colocar questões que proporcionem ao professor feedback sobre a aprendizagem dos alunos;

- Evitar fazer um grande número de perguntas cuja resposta é um simples "sim" ou "não";

- Evitar responder às perguntas formuladas;

- Após a resposta de um estudante, perguntar "por quê?";

- Evitar a formulação de um grande número de perguntas que apelem, sobretudo, para a memória;

- Tentar que os alunos se pronunciem sobre as respostas dos colegas;

- Evitar fazer perguntas que contenham a resposta; e

- Fazer perguntas abertas.

Hargie (1978) diz que, na sala de aula, as perguntas orais mostram-se mais eficazes que as perguntas escritas. Todavia, há ressalvas com relação a isso, principalmente nas aulas de Matemática. Notare e Behar (2009, p. 4) dizem que:

[...] a comunicação em Matemática é realizada, basicamente, de forma escrita. As línguas naturais faladas podem até descrever objetos matemáticos e suas propriedades, mas o simbolismo permite descrever a mesma propriedade de forma direta, rápida e precisa, ou seja, quando as propriedades estruturais tornam-se mais complexas, sua descrição torna-se difícil de ser falada e compreendida sem a utilização de símbolos.

Além disso, em geral, o tempo para responder as perguntas orais feitas em sala pode ser insuficiente. Sobretudo, se levar em conta que para responder boas perguntas, é necessário fazer e conectar diferentes registros de representação, sendo importante fazer cálculos, verificar, exemplificar, testar e assim poder respondê-las com coerência.

O controle das produções escritas abre para o indivíduo um circuito de atividades cognitiva mais ampla e mais potente que o circuito constituído apenas pelas produções orais ou mentais. Existe a Matemática puramente oral que se confronta rapidamente com a 
impossibilidade de desenvolvimento, e existe a Matemática que se desenvolve primeiro com a escrita, depois com a invenção de novos registros de representação. A produção escrita é essencial para as operações discursivas (DUVAL, 2011).

Outro fato que se deve levar em conta é que muitas vezes o estudante pode não se sentir à vontade para responder oralmente. Nesse sentido, as perguntas escritas poderiam ser mais eficazes, tendo em vista que o estudante teria mais tempo, podendo ler mais vezes e obtendo uma melhor compreensão da pergunta. O professor poderia ainda produzir a pergunta, usando diferentes tipos de representação (textual, simbólica ou visual) o que poderia melhorar a compreensão do estudante com relação à pergunta.

Em relação às respostas aos questionamentos, a representação escrita parece ser mais eficaz, tendo em vista que o estudante teria também a oportunidade de registrar de diferentes formas, além de poder também organizar melhor as ideias. Tais registros podem ser ainda mais eficazes como recursos para feedbacks dos professores e estudos posteriores dos estudantes. Enfim, como último argumento, ressaltamos que a produção oral só parece realmente eficaz para expressar os registros de representação linguísticos. Como expressar o registro de representação visual (figuras, por exemplo) através da produção oral?

Com o advento das Tecnologias Digitais de Informação, Comunicação e Expressão TDICEs (LACERDA SANTOS, 2013), surgem também novas formas de se fazer questões, assim como novas maneiras de responder, representar e registrar. No tópico seguinte, veremos como isso pode ser feito em programas de GD e como as possibilidades para narrativas escritas podem ser ampliadas.

\subsection{Novas maneiras de se representar, fazer questões e registros com os programas de Geometria Dinâmica}

Concordamos com Notare e Behar (2009, p.4) quando dizem que se pode perceber que a representação e a abstração são processos complementares. Elas explicam isso afirmando que: 
Por um lado, um conceito matemático pode ser abstraído de várias representações e, por outro lado, representações são sempre representações de algum conceito abstrato, melhor dito, formal. Quando várias representações de um mesmo objeto são consideradas simultaneamente, a relação com o conceito abstrato formal torna-se presente e importante. Enfim, compreende-se que a aprendizagem de Matemática é um processo que envolve, entre outras características, o exercício da expressão, argumentação, justificativa, em paralelo com a capacidade de reconhecer e trabalhar com as diferentes representações.

Como foi dito anteriormente o GeoGebra permite fazer, simultaneamente, várias representações de um mesmo objeto. Além disso, ampliam-se as possibilidades para se fazerem representações e atividades que proporcionam boas questões e registros. Sobretudo, porque é possível integrar de maneira dinâmica e simultânea, numa mesma questão, os registros de representações linguísticos, simbólicos e visuais.

Mas o que seria "integrar de maneira dinâmica e simultânea"? Para que se possa entender isso, apresentaremos duas situações de ensino de um mesmo conteúdo. Suponhamos uma situação em que o professor queira explorar a influência dos coeficientes de uma equação algébrica que representa uma função trigonométrica no comportamento de um gráfico. Primeiramente, ele poderia propor uma atividade no papel em que colocaria uma função trigonométrica do tipo $\mathrm{f}(\mathrm{x})=2+3 \cos (2 \mathrm{x}+2)$, com seu respectivo gráfico. Depois faria um tratamento no registro simbólico, mudando a equação da função para $f(x)=3+3 \cos (2 x+2)$ e pediria para o estudante esboçar o gráfico. Ao final, solicitaria que o estudante comparasse os dois gráficos e perguntaria: O que mudou? Qual a influência do coeficiente alterado no comportamento do gráfico? Apenas com os dois gráficos, o professor poderia esperar que o estudante já pudesse ter compreendido a propriedade. Vejamos agora na Figura 24 a mesma situação sendo explorada no GeoGebra. 


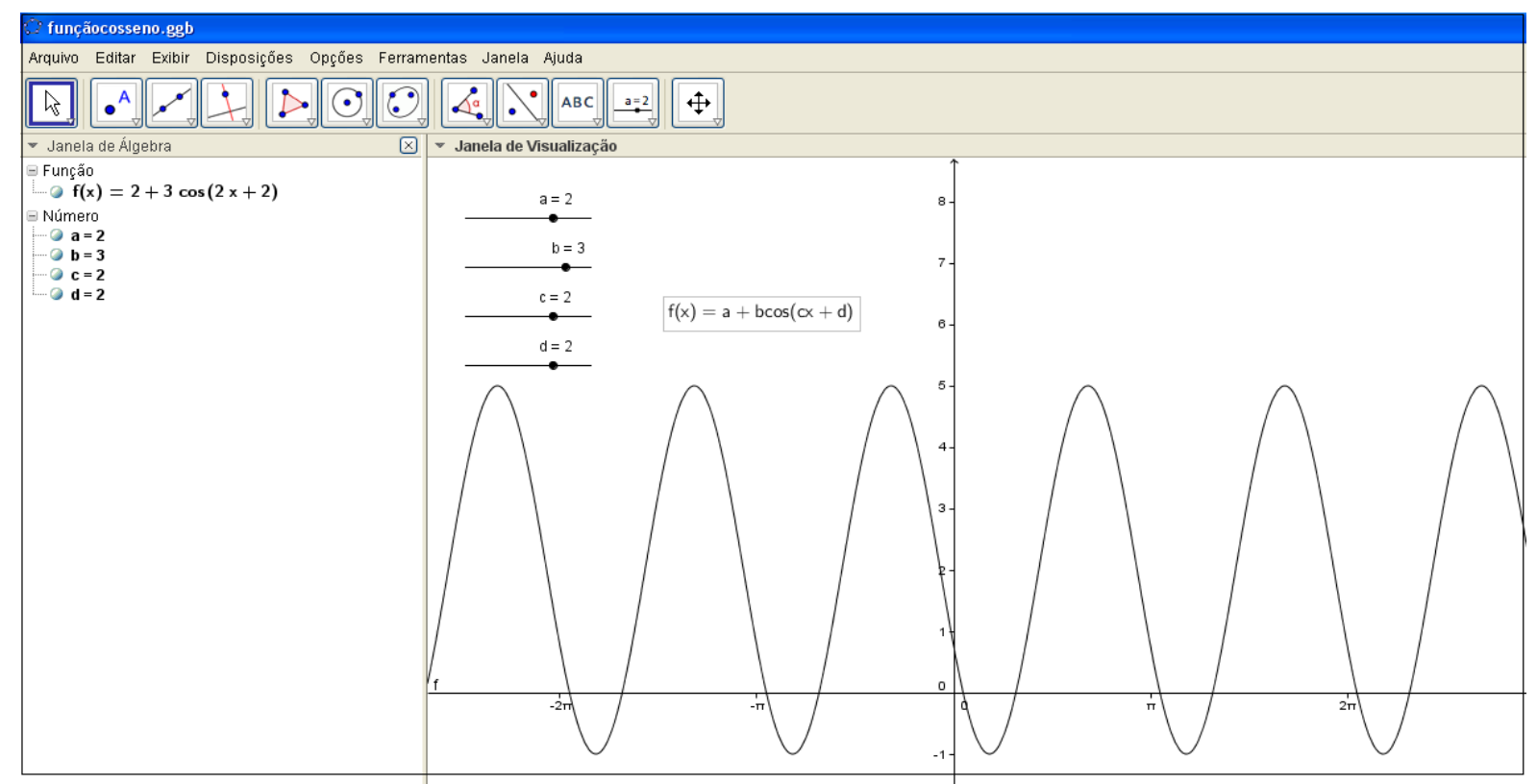

Figura 24-Construção feita no GeoGebra para explorar o gráfico da função cosseno

A mesma função e gráfico propostos no exemplo anterior estão representados na construção da Figura 24. Além disso, existem seletores que representam os parâmetros da função e que podem ser alterados. Dessa forma, o professor poderia pedir para o estudante alterar o parâmetro "a" e fazer a mesma pergunta: "Qual a influência do parâmetro alterado no comportamento do gráfico?”. A grande diferença em relação à atividade anterior está no dinamismo, ou seja, ao alterar o parâmetro "a" o estudante poderá ver simultaneamente e continuamente $^{19}$ o gráfico sendo modificado. Poderia modificar quantas vezes quisesse, fazendo diferentes tipos de experimentos e conjecturas ("e quando o parâmetro é negativo, o comportamento é o mesmo?”). Poderia ainda pedir para alterar os outros coeficientes e perguntar qual a influência de cada um deles no comportamento do gráfico. Espera-se com isso que o estudante possa fazer a correspondência entre as unidades de sentido entre os conteúdos respectivos das duas representações e compreender a influência dos parâmetros da função cosseno no comportamento do gráfico. Finalmente, espera-se ainda que ele possa, posteriormente, esboçar os gráficos sem ter que necessariamente fazer cálculos e perceber as relações entre as diferentes representações, construindo assim o conceito de função cosseno.

Para continuar a explicação da expressão "de maneira dinâmica e simultânea", vejamos uma atividade que contém construções com textos dinâmicos. Tal recurso permite mesclar diversos símbolos matemáticos e variáveis que podem ser alterados pelo usuário.

${ }_{19}$ O que queremos dizer com "continuamente" é que o estudante poderá manipular o parâmetro de forma gradativa: 2.1, 2.2, 2.3, 2.4, ...até o 3,0 e ver, sem saltos, o que acontece com o gráfico. 
Trata-se de uma verdadeira inovação nas formas de produzir registros de representação linguísticos. Vejamos um exemplo:

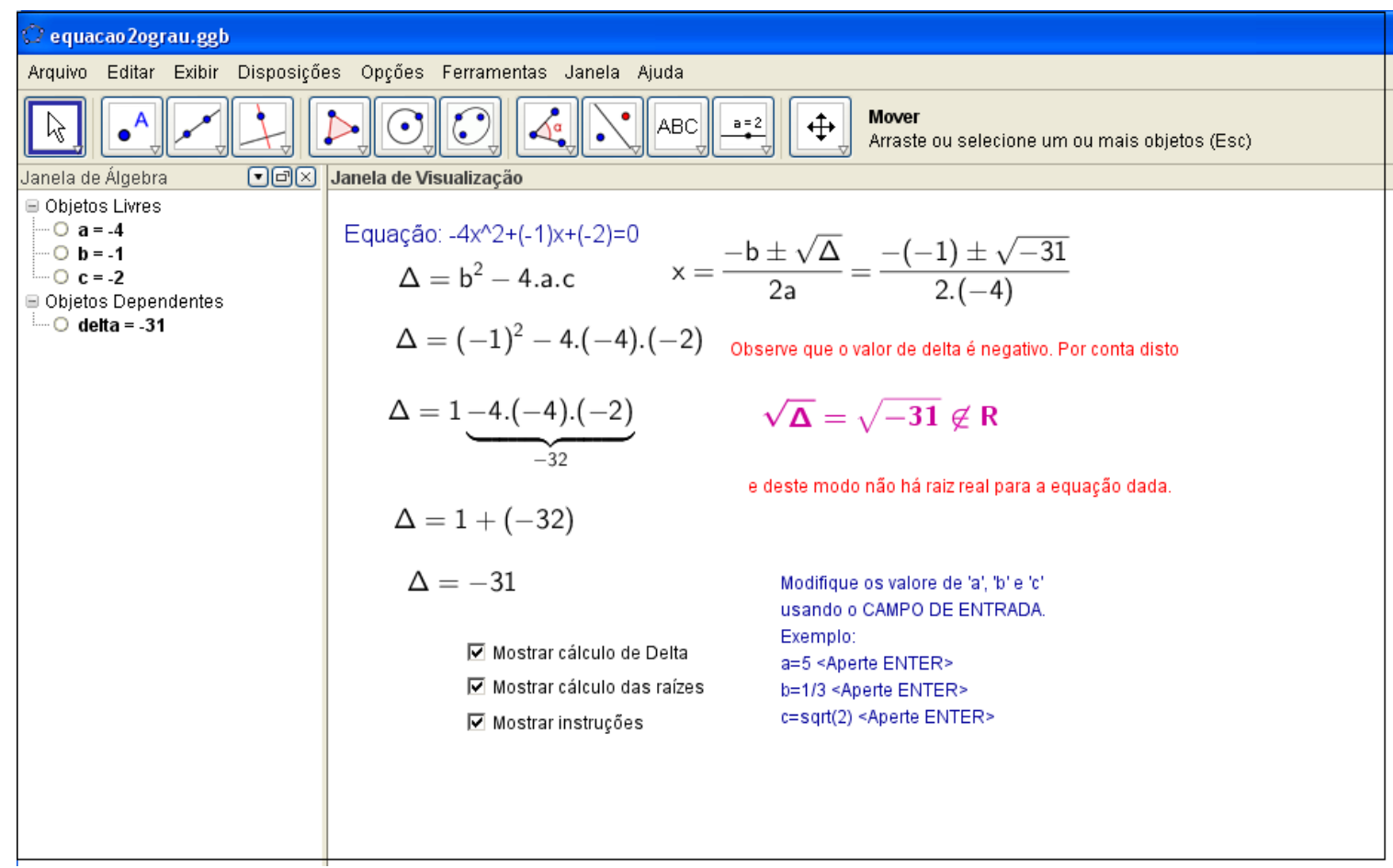

Figura 25-Construção com textos dinâmicos feita no GeoGebra para explorar a equação do $2^{\circ}$ grau

Na construção apresentada na Figura 25 o usuário pode alterar os parâmetros "a", "b" ou "c" na Janela de Álgebra e observar o que altera no processo de resolução da equação do $2^{\circ}$ grau. Tanto os valores quanto os textos são alterados. O conteúdo do texto se adéqua a partir dos resultados. Ou seja, estamos vendo como se podem fazer tratamentos nas expressões algébricas, interagindo os registros de representação simbólico com os registros de representação linguísticos.

Na Figura 25 há uma mensagem explicando o que acontece quando o delta é negativo. Vejamos, na Figura 26, o que acontece quando o usuário coloca "a” igual a 0. 


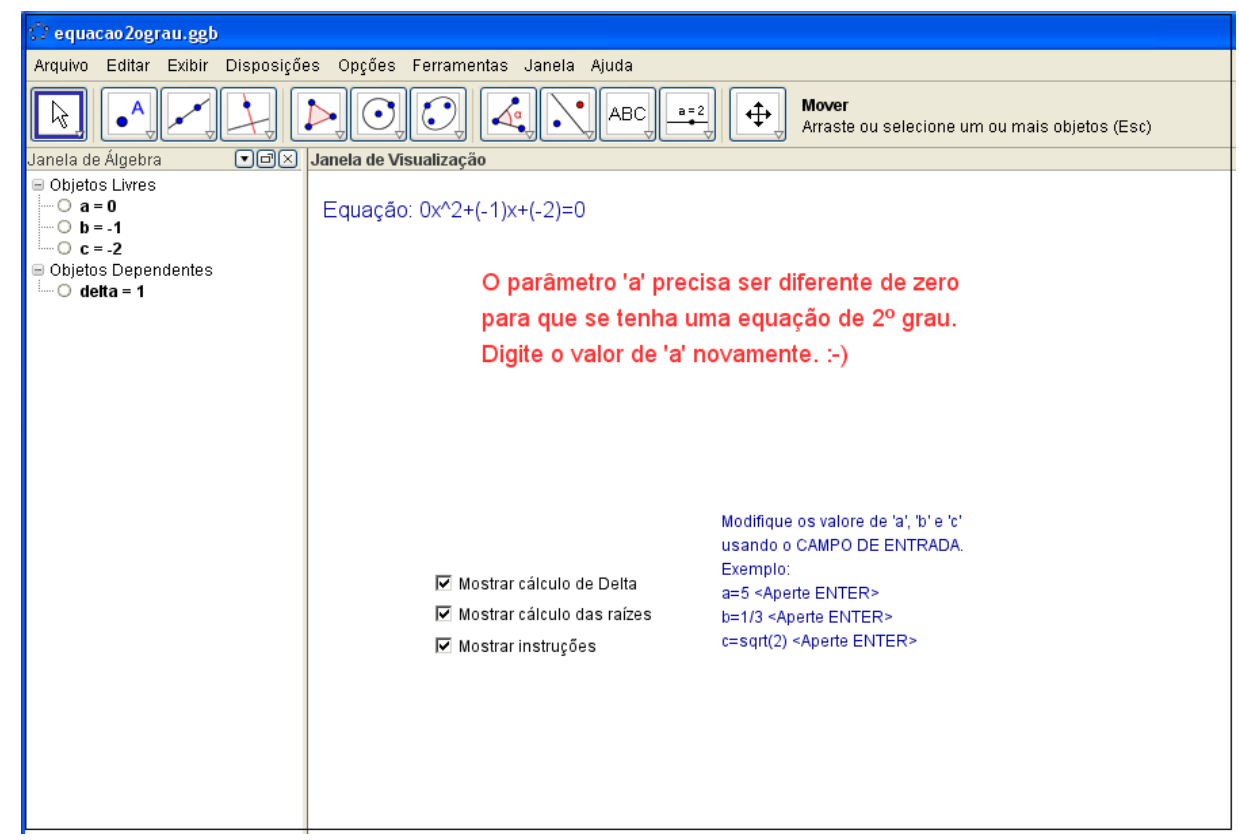

Figura 26-Construção com textos dinâmicos feita no GeoGebra

Na Figura 26, é possível observar uma mensagem explicando o que acontece com a equação quando "a" é igual a 0 e sugerindo que o usuário digite um novo valor. $\mathrm{O}$ professor pode usar esse recurso para fazer questões também dinâmicas, ou seja, elas podem mudar dependendo de como o estudante manipula a construção. $O$ estudante também pode usar tal recurso em suas respostas. Todavia, para fazer bons textos dinâmicos no GeoGebra é necessário saber usar a linguagem $\mathrm{LaTeX}$ e, como foi dito anteriormente, tal recurso não é de fácil utilização, pois se trata de um recurso que faz uso de uma linguagem pouco conhecida pelos estudantes.

Além dos recursos anteriores, o GeoGebra possui ainda ferramentas ${ }^{20}$ que permitem revisar, passo a passo, tudo o que foi feito na tela. Tais ferramentas são excelentes recursos para que o professor possa avaliar e dar feedbacks sobre o trabalho do estudante. Além do fato de poder auxiliar o estudante nas argumentações sobre o que fez, contribuindo assim para construção das Narrativas Matemáticas.

Por meio dos exemplos anteriores, pode-se perceber que as ferramentas do GeoGebra podem ser excelentes recursos para possibilitar a construção e o registro de Narrativas Matemáticas, além de poder auxiliar a contemplação das etapas para a construção de narrativas propostas por Riessman (1993): o viver ou participar da experiência, o contar a experiência (pelo sujeito que a viveu); o transcrever a experiência; o analisar a experiência,

\footnotetext{
${ }^{20}$ As ferramentas são a barra de navegação para passos da construção e protocolo de construção.
} 
implicando a elaboração; e o ler, pressupondo uma recontagem da experiência. Isso acontece porque tais ferramentas permitem:

- fazer experimentos, construções, manipulações, conjecturas, testes etc;

- fazer registros escritos de forma digital e usando diferentes registros de representação: linguístico, simbólico e visual. As diferentes representações ficam conectadas de forma que quando uma é alterada, a outra se adéqua, mantendo a coerência na descrição da narrativa; e

- revisar e acompanhar todos os passos da construção da narrativa matemática, na ordem em que foram feitos. Essa é uma importante contribuição, sobretudo, para a verificação do elemento "historicidade" da narrativa.

Os recursos podem contribuir ainda com os 4 aspectos envolvidos na construção e materialização de Narrativas Matemáticas e que foram apresentados por Nemirovsky (1996): Situações funcionais, Funções, Causas e intenções e Contextualização.

Acreditamos ainda que, com tais recursos, as possibilidades de construção de Narrativas Matemáticas são ampliadas, deixando de ser Narrativas Matemáticas Estáticas, passando a ser Narrativas Matemáticas Dinâmicas.

\subsection{Narrativas Matemáticas Estáticas e Narrativas Matemáticas Dinâmicas}

Para podermos caracterizar e diferenciar as Narrativas Matemáticas Estáticas e Narrativas Matemática Dinâmicas, primeiramente devemos deixar claro que estamos falando de narrativas que são expressas de forma escrita, mediante diferentes registros de representação semiótica (linguístico, simbólico e visual) e que podem ser representadas no papel ou computador. Também estamos interessados no conceito de narrativa no sentido de contar sobre o processo de produção de conhecimento em busca das explicitações ou clarificações de ideias e conceitos (FREITAS; FIORENTINI, 2007). Mais especificamente as Narrativas Matemáticas que podem ser “[...] consideradas escritas expressivas, reveladoras de ideias e sentimentos, centralizadoras de regras e expressões simbólicas, utilizadas pelos estudantes para descrever certo evento, um gráfico, leis matemáticas e demais interpretações” (SCHEFFER, BRESSAN e CORREAA, 2010, p.51). Posto isso, podemos passar para os termos. 
Alguns poderiam pensar, intuitivamente, que Narrativas Matemáticas Estáticas são aquelas feitas no papel, enquanto Narrativas Matemáticas Dinâmicas são aquelas feitas no computador. De fato, as Narrativas Matemáticas Dinâmicas precisam do computador para existir e mais especificamente precisam dos softwares de GD. Todavia, nem toda narrativa matemática feita no computador é dinâmica. Não basta ser feita de forma digital para ser Narrativa Matemática Dinâmica.

Uma primeira característica da Narrativa Matemática Dinâmica está no fato de se integrarem dinamicamente, num mesmo ambiente, os diferentes registros de representações dos objetos da Matemática. Tal integração não pode ser feita de forma separada, ou seja, essa representação mais essa representação é igual a essa narrativa matemática. Até porque "Não é suficiente justapor representações de registros diferentes para que os alunos "vejam" as correspondências entre as unidades de sentido matematicamente pertinentes das diferentes representações justapostas" (DUVAL, 2011, p. 100). Na construção de uma narrativa sobre um objeto matemático, as diferentes representações desse objeto aparecem simultaneamente e estão conectadas. Por exemplo, na construção de uma narrativa que envolve o conceito de função as representações geométrica e algébrica estão conectadas de forma que quando se alteram as propriedades desse objeto, as diferentes representações também alteram e se adéquam às modificações, mantendo a coerência da narrativa matemática. Uma contribuição dessa conexão é que o estudante pode ver qual a relação que existe entre as diferentes representações, ou seja, quando se altera algo no registro algébrico o que acontece no registro geométrico. Isso não acontece em Narrativas Matemáticas Estáticas. Nesse caso, pode-se até fazer as diferentes representações dos objetos da Matemática, mas essas são feitas de forma separada e em momentos diferentes, ou seja, para fazer a narrativa matemática com as diferentes representações, o estudante ou professor precisa fazer uma de cada vez. Além disso, precisa saber (previamente) quais as relações que existem entre as diferentes representações para que possa fazer a narrativa com coerência. Nesse sentido, as Narrativas Matemáticas têm apenas a função de comunicação e não de objetivação.

Nas Narrativas Matemáticas Dinâmicas, além da integração das diferentes representações dos objetos da Matemática, é possível integrar a essas a representação textual dinâmica. Isso é possível graças aos textos dinâmicos, ou seja, textos que mesclam diversos símbolos matemáticos e variáveis que podem ser alterados pelo usuário. Tais textos alteram seu conteúdo a partir da manipulação dos diferentes objetos com os quais se relacionam. Além disso, é possível fazer cálculos automáticos dentro do próprio texto, usando valores ou 
medidas de objetos matemáticos pertencentes à narrativa. Tais resultados dos cálculos podem ser alterados automaticamente se as medidas ou valores desses objetos forem alterados.

Outra característica importante das Narrativas Matemáticas Dinâmicas está no fato de se poderem identificar, por meio de ferramentas de revisão, elementos importantes para verificação de aspectos de historicidade da narrativa, ou seja, é possível identificar a ordem em que os objetos foram feitos. Isso nem sempre é possível nas Narrativas Matemáticas Estáticas.

Para que fiquem mais claras as diferenças entre as Narrativas Matemáticas Estáticas e Narrativas Matemáticas Dinâmicas, vejamos uma situação de Narrativa Matemática Estática. Notare (2009) apresenta um editor científico chamado Roda Exata que tem por objetivo viabilizar a comunicação matemática online. A pesquisadora analisa as narrativas produzidas no ambiente fórum com tal ferramenta. Basicamente, ela propõe problemas de cálculo aos estudantes e esses precisam resolver e relatar no fórum, explicando e argumentando sobre o processo de resolução. Vejamos um problema proposto no fórum: "Um recipiente em forma de um paralelepípedo com base quadrado deve ter o volume de $2000 \mathrm{~cm}^{3}$. Ache as dimensões do paralelepípedo de menor custo". A Figura 27 apresenta uma proposta de solução de estudantes que usa, basicamente, dois registros de representação semiótica: linguístico e visual.

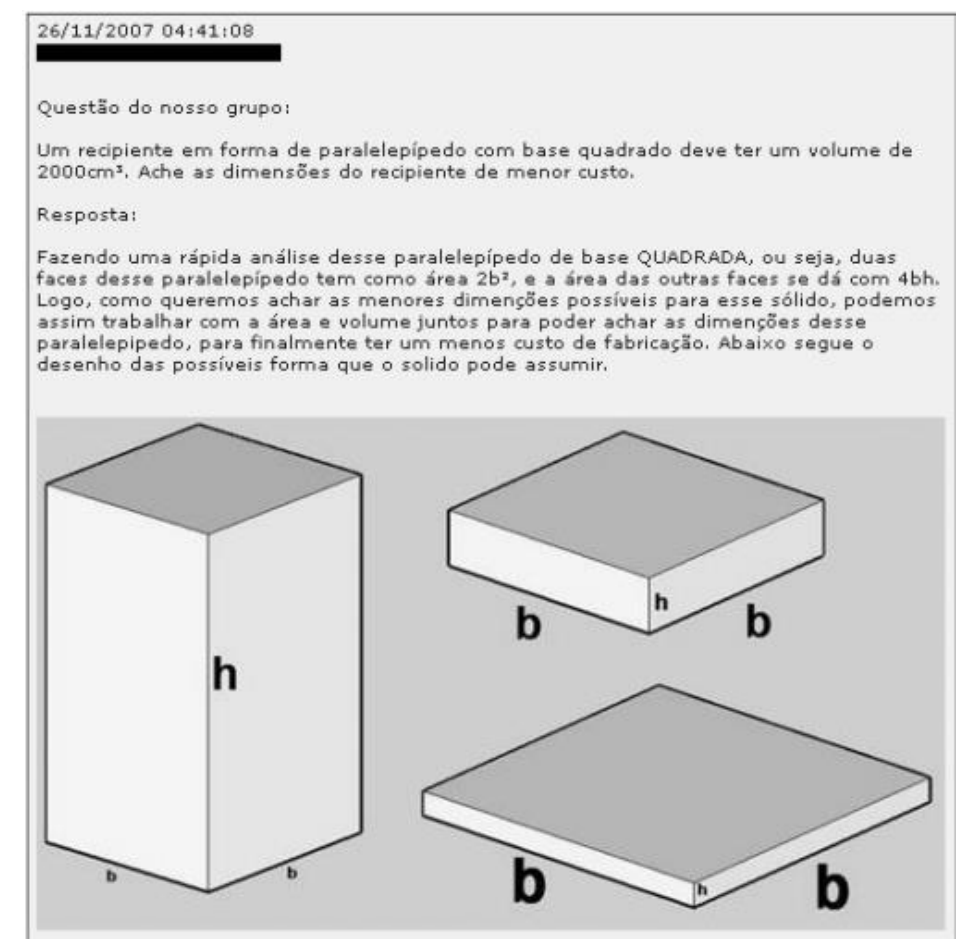

Figura 27-Representação proposta por um grupo de estudantes (NOTARE, 2009, p.91) 
$\mathrm{Na}$ Figura 27, pode-se ver a primeira atividade cognitiva desenvolvida pelos estudantes: a formação das representações. Depois disso, o mesmo grupo propõe a solução analítica do problema, fazendo tratamentos nos registros algébricos e integrando com os registros linguísticos. A Figura 28 representa uma tela do fórum contendo o relato do grupo de estudantes.

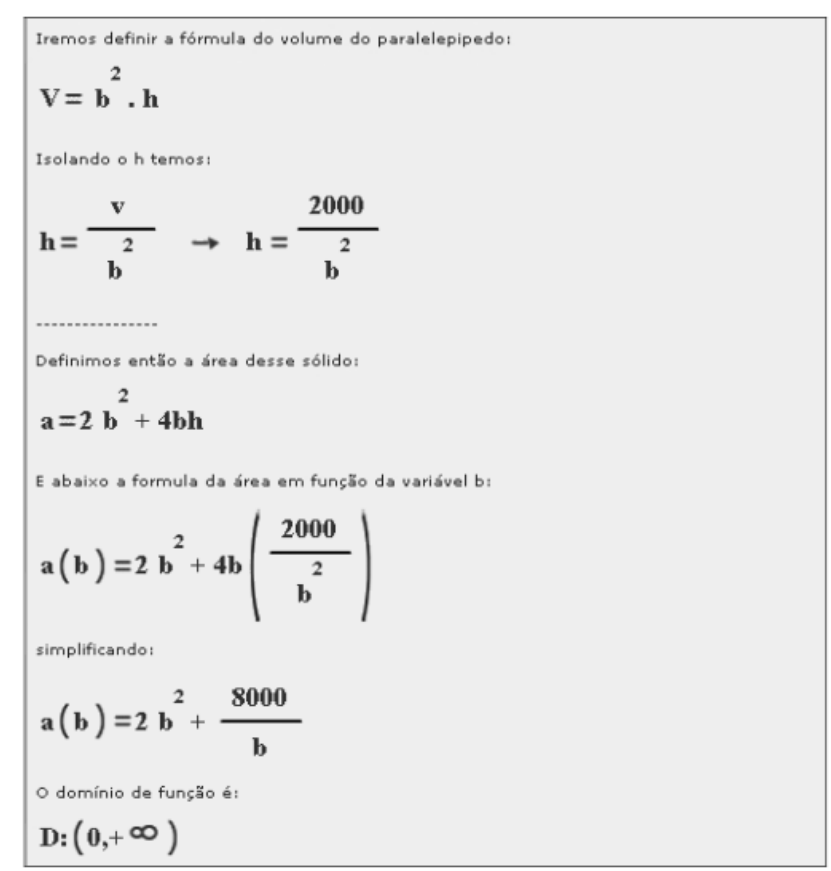

Figura 28-Resolução de um problema (NOTARE, 2009, p.92).

A figura seguinte apresenta a continuação. 


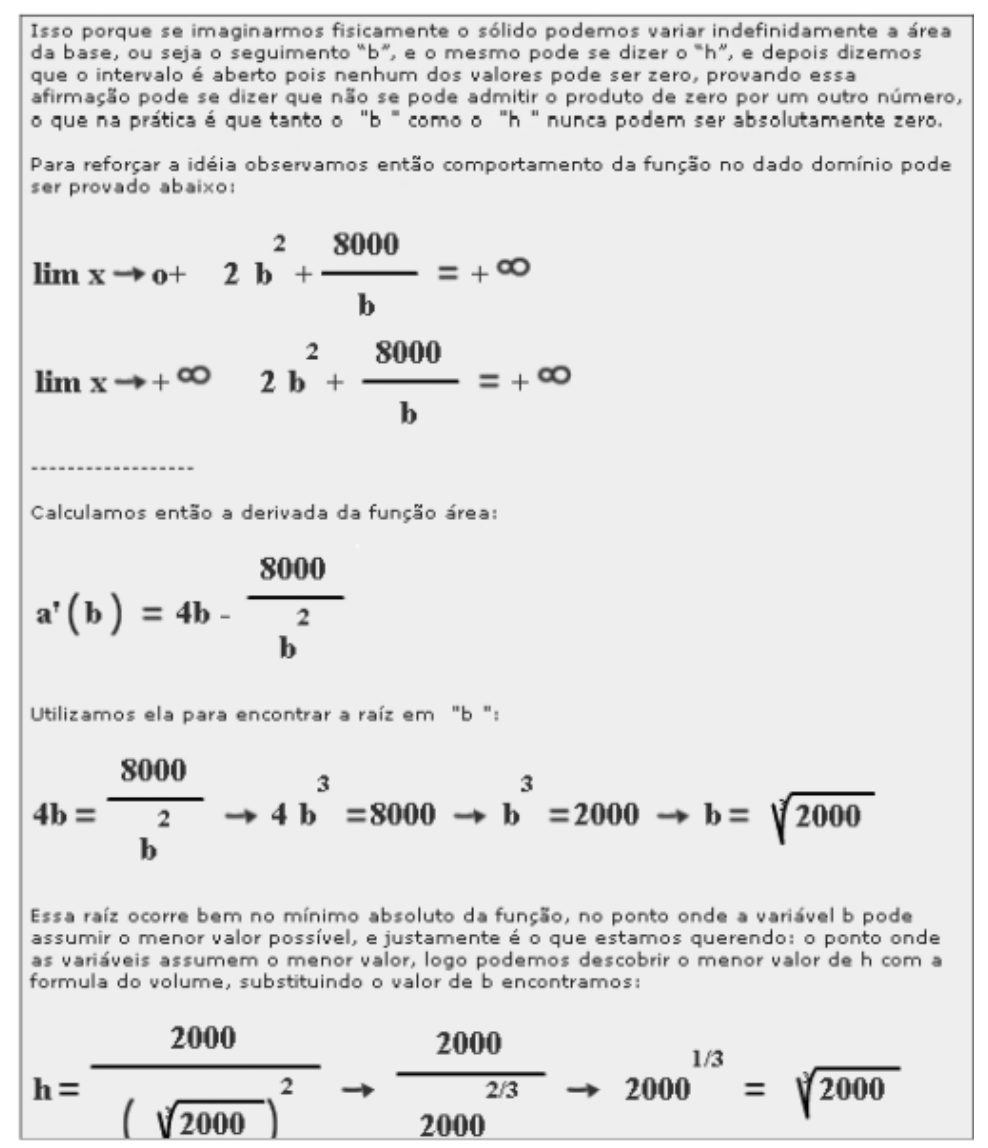

Figura 29-Continuação da resolução do problema (NOTARE, 2009, p.93).

Analisando as três mensagens, é possível perceber que se trata de uma Narrativa Matemática, pois trazem “[...] escritas expressivas, reveladoras de ideias e sentimentos, centralizadoras de regras e expressões simbólicas, utilizadas pelos estudantes para descrever certo evento, um gráfico, leis matemáticas e demais interpretações" (SCHEFFER, BRESSAN; CORRÊA, 2010, p.51). Contudo, não é uma Narrativa Matemática Dinâmica. Vejamos os porquês:

- A figura que representa o paralelepípedo é estática, ou seja, não é possível alterar suas dimensões;

- O texto também é estático, ou seja, não é possível, por exemplo, alterar o volume do paralelepípedo para $4000 \mathrm{~cm}^{3}$ e perceber as alterações no texto de forma a manter a coerência da narrativa; e

- Não há integração dinâmica entre os diferentes registros de representações do conceito estudado, ou seja, nenhuma variável da figura está vinculada à solução analítica do grupo de estudantes; 
Além disso, o editor não gera resultado automático. Por exemplo, a última linha da narrativa na Figura 29 é um "cálculo braçal" e poderia ter sido feito automaticamente. Ao que parece, os estudantes elaboraram todas as estratégias e soluções fora do ambiente e deixaram para usar o editor e a plataforma apenas para comunicar a solução. O ambiente em si não auxiliou para a compreensão e a resolução do problema. Ou seja, a representação feita pelos estudantes teria apenas a função de comunicação e não de objetivação. A autora diz que se percebe que os alunos chegam ao nível da correta resolução do problema, da descrição dos cálculos, muitas vezes justificam e analisam qualitativamente as etapas de resolução, mas parecem não demonstrar compreensão dos conceitos envolvidos. Ela apresenta algumas justificativas para isso e uma delas seria o fato de os estudantes terem dificuldade para expressar integralmente suas ideias. Acrescentando ainda que, para evidenciar o que entendeu era preciso saber expressar-se. "A expressão auxilia na concretização do pensamento e na reflexão das ideias" (NOTARE, 2009, p.94). Concordamos com a autora, mas questionamos: como expressar algo que evoca movimento em um ambiente estático? Em determinado momento os estudantes dizem "Se imaginarmos fisicamente o sólido, podemos variar indefinidamente a área da base...o segmento b". Os estudantes estão tentando explicitar suas representações mentais. Supomos que as imagens mentais são de registros de representações visuais (figuras geométricas), mas usam registros de representação linguísticos. O ambiente não permite a construção de registros de representação visual do sólido com movimento. Assim, como os estudantes poderiam mostrar que perceberam as relações entre as diferentes representações? Será que o ambiente permite de fato a expressão integral das ideias? Tais questionamentos nos levam a acreditar que o ambiente pode limitar bastante a explicitação das ideias por meio das narrativas.

Um exemplo de como a Narrativa Matemática Dinâmica pode ser feita será apresentado mais À frente. Todavia, já se pode perceber que os principais requisitos para se ter uma Narrativa Matemática Dinâmica estão relacionados com o movimento e a integração simultânea das diferentes representações dos objetos da Matemática. Assim, para que se possam construir Narrativas Matemáticas Dinâmicas é preciso ter um ambiente que permita a integração dinâmica das diferentes representações, tenha um editor intuitivo de texto e equações, além de espaços específicos para as diferentes representações. O GeoGebra é o software de Geometria Dinâmica que mais se aproxima desse ambiente. Porém, ele possui alguns limites que dificultam a criação das Narrativas Matemáticas Dinâmicas. Dessa forma, foi necessário fazer uma reengenharia em tal programa, buscando adaptar e desenvolver as 
funcionalidades necessárias para a criação de Narrativas Matemáticas Dinâmicas. Era preciso fazer o que chamamos de GGBOOK. No capítulo seguinte falaremos como ele foi feito e a estratégia metodológica de validação. 


\section{METODOLOGIA}

Tendo em vista a configuração desse problema de pesquisa, propomo-nos a desenvolver e testar, junto a alunos de licenciatura em Matemática, uma plataforma que foi chamada de GGBOOK. Portanto, temos configurada uma investigação do tipo P e D (Pesquisa e Desenvolvimento), em que um objeto tecnológico é desenvolvido e depois aplicado para avaliação de seus resultados. Em se tratando de uma pesquisa de doutoramento em Educação, o foco do trabalho se situou na aplicação do objeto tecnológico, por meio da qual pudemos analisar as possibilidades de construção de Narrativas Matemáticas Dinâmicas a partir das interações realizadas nessa nova interface que integra os ambientes texto e gráfico. Contudo, a etapa prévia do desenvolvimento se tornou uma etapa incontornável do trabalho proposto, pois visava justamente à concepção de um software educativo com as características propostas. Uma investigação do tipo P \& D tem, então, duas vertentes distintas e complementares: a do Desenvolvimento e a da Pesquisa. Para cada uma dessas vertentes, o pesquisador deve fazer escolhas metodológicas específicas. Nos tópicos que se seguem detalharemos nossas escolhas.

\subsection{Metodologia para o desenvolvimento da plataforma: Prototipação}

Antes de se começar o desenvolvimento de um software educativo, é necessário levar em consideração que:

Um processo de desenvolvimento de softwares educativos tem especificidades que
o distinguem bastante de um procedimento de desenvolvimento de aplicativos
comerciais, bancários ou domésticos. O engenheiro de softwares educativos não tem
diante de si um sistema fechado no qual usuários e proprietários de sistemas e
subsistemas interagem entre si através de procedimentos pré-estabelecidos,
previsíveis e perfeitamente traduzíveis em operações automáticas e informatizáveis.
Pelo contrário, um sistema educativo, por mais simples que seja, traduz e delimita
conhecimentos em processo dinâmico de comunicação e percepção.
Consequentemente, o engenheiro de softwares educativos deve lidar com um
conjunto de aspectos subjetivos que caracterizam o fenômeno educativo. Estes vão
desde a consideração da natureza dos conhecimentos a serem veiculados e das
estratégias mais adequadas para fazê-lo até a compreensão do próprio processo de
ensino e das interações entre um indivíduo em processo de aprendizagem e um saber
de referência, por meio de um mediador informatizado (LACERDA SANTOS,
2009,p18).

A partir de tal consideração o mesmo autor elenca alguns critérios para que o software educativo seja pedagogicamente interessante: 
a) objetivos educacionais consistentes e condizentes com o contexto mais amplo, com a organização do trabalho pedagógico do professor, com a missão da escola e com as demandas da sociedade;

b) adequabilidade curricular para subsidiar tanto a construção de conhecimentos formais propostos pela escola quanto à valorização dos conhecimentos produzidos pelo próprio aluno;

c) possibilidade de integração de diferentes linguagens de comunicação;

d) valorização e potencialização do aluno e das múltiplas inteligências do indivíduo;

e) integração entre, de um lado, interfaces psicológica e ergonomicamente viáveis e, de outro, conteúdos pedagógica e socialmente coerentes;

f) possibilidade de subsidiar trabalhos colaborativos;

g) possibilidade de apoiar e de integrar o trabalho do professor, sem funcionar como camisa de força que impeça o uso criativo do software e limitando suas possibilidades;

h) grau de complexidade que permita a manifestação da singularidade do processo de aprendizagem, que varia de indivíduo para indivíduo;

i) integração de modelos de avaliação condizentes com abordagens educativas mais flexíveis e menos quantitativas;

j) interação do aluno com o software, fator importante para facilitar a aprendizagem, exigindo posicionamentos conceituais capazes de provocar conflitos cognitivos, remetendo a reflexões, questionando saberes já instituídos, retirando o aluno da passividade (LACERDA SANTOS, 2009, p. 22)

A concepção do GGBBOOK levou em consideração tais critérios. Evidentemente, não pretendíamos contemplar todos. Focamos, sobretudo, nos critérios “c”, “d”, “e”, "g”, "h" e “j”. A partir de tais critérios, para o desenvolvimento da plataforma, foi montada uma equipe interdisciplinar composta por pesquisadores, programadores e professores de Matemática. Como metodologia para o desenvolvimento foi escolhido o modelo da Prototipação. De acordo com Sommerville (2003, p. 145):

Um protótipo é uma versão inicial de um sistema de software, que é utilizado para mostrar conceitos, experimentar opções de projetos e, em geral, para conhecer mais sobre os problemas e suas possíveis soluções. $\mathrm{O}$ desenvolvimento rápido de um protótipo é essencial para que (...) os usuários possam fazer experiência com o protótipo no início do processo de software.

Apesar de no momento inicial do desenvolvimento sabermos qual era o público alvo do software ${ }^{21}$, ainda não se conhecia totalmente seu contexto com suas características e dificuldades. Também não havia sido definido o conteúdo específico de Matemática que seria explorado na experimentação do SE. Assim, acreditávamos que o modelo de Prototipação era o mais adequado para esse tipo de situação, pois segundo Lacerda (2007, p. 24), tal modelo é comumente usado "[...] quando não se conhece o domínio da aplicação, quando existem pontos de vista diferentes a acerca do conteúdo do software, quando há grandes chances de descobrir possibilidades não imaginadas e quando a base para a construção é a discussão entre a equipe responsável pelo processo".

A figura seguinte representa os passos do modelo baseado na prototipação:

\footnotetext{
${ }^{21}$ Inicialmente chamamos o projeto de software. Depois mudamos para plataforma. Isso será explicado mais a frente.
} 


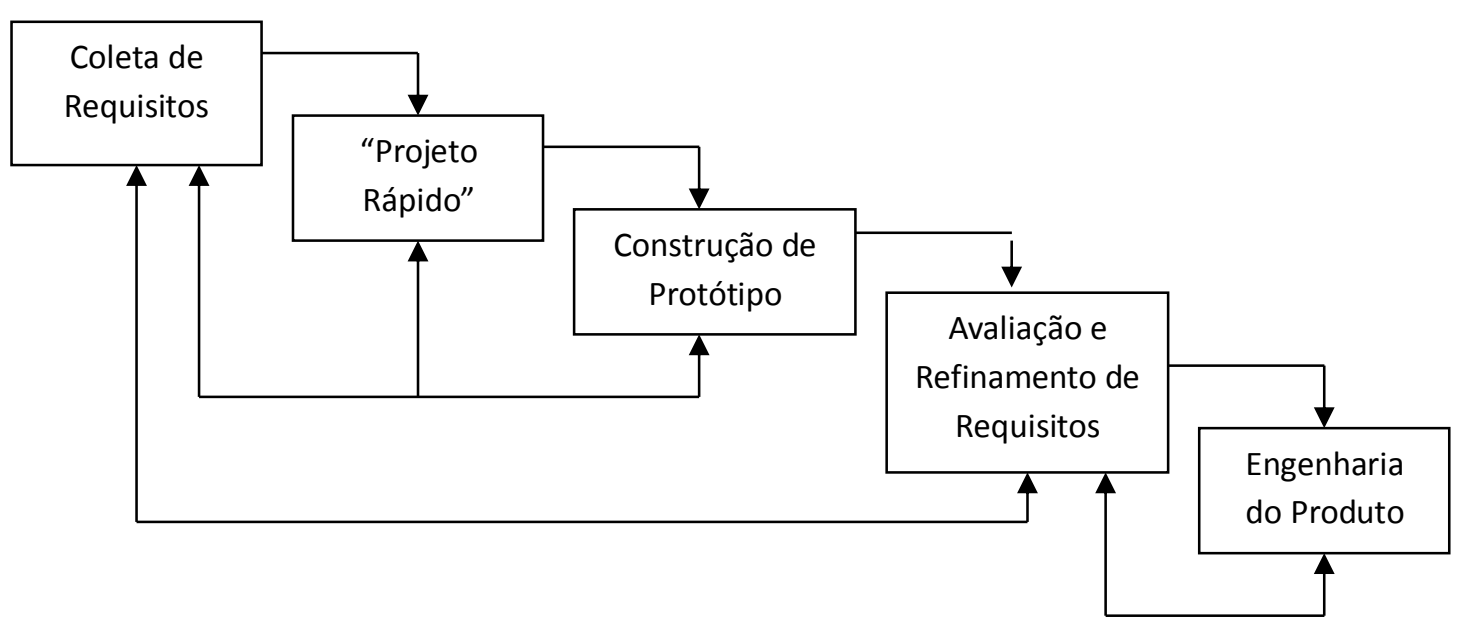

Figura 30-Modelo de Prototipação (PRESSMAN, 2002)

Para a fase de "Coleta de Requisitos" foi preciso determinar as especificações do software (ou engenharia de requisitos). Segundo Sommerville (2003) a especificação de software estabelece quais funções são requeridas pelo sistema e as restrições sobre a operação e o desenvolvimento do sistema. Tal fase é dividida em etapas principais, como mostra a Figura 31:

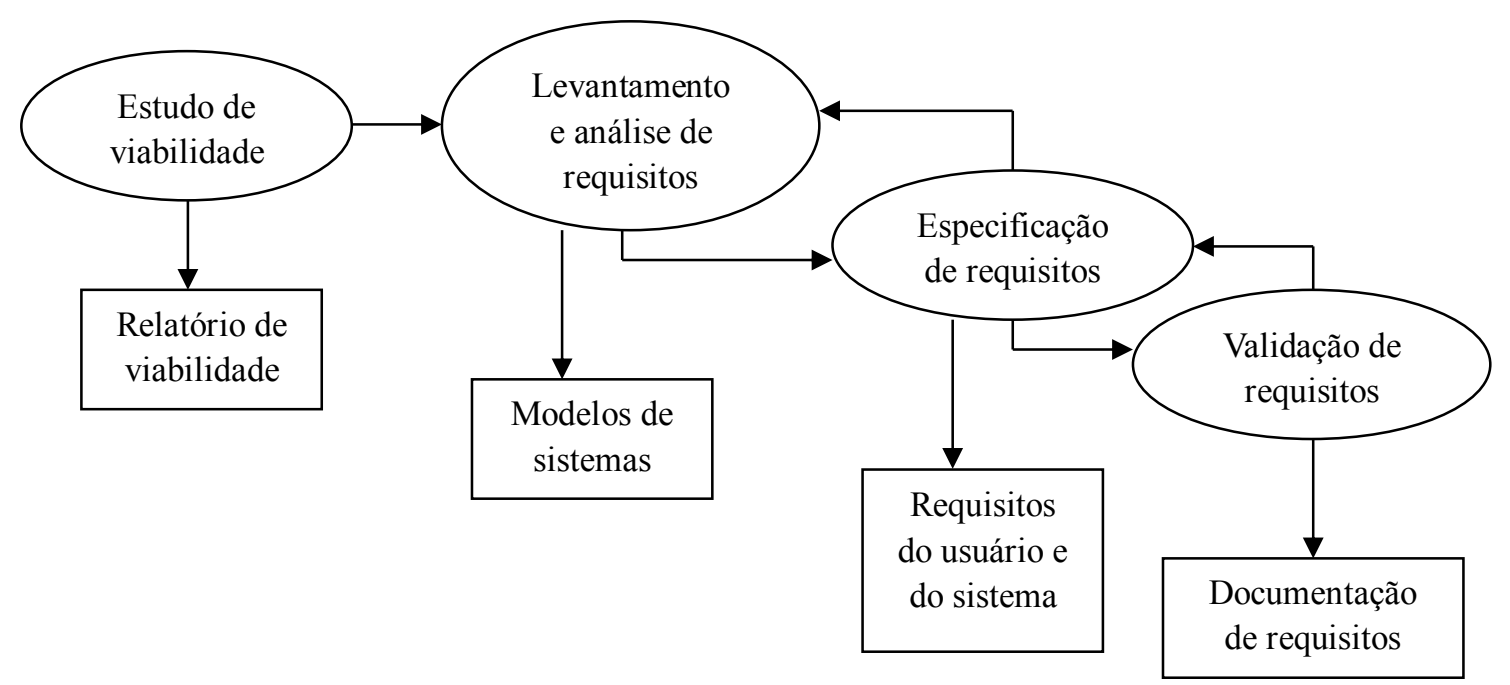

Figura 31-O processo de engenharia de Requisitos (SOMMERVILLE, 2003)

A descrição do processo está no quadro seguinte. 
Quadro1: Descrição do Processo de engenharia de requisitos

\begin{tabular}{cl}
\hline Fases do Processo & \multicolumn{1}{c}{ Descrição da Fase } \\
\hline \multirow{2}{*}{ Estudo de Viabilidade } & $\begin{array}{l}\text { É uma estimativa para verificar se as necessidades dos usuários que foram } \\
\text { levantadas podem ser satisfeitas com a utilização das atuais tecnologias de } \\
\text { hardware e software. Este estudo decidirá se o sistema proposto é viável } \\
\text { financeiramente ou não. }\end{array}$ \\
\hline $\begin{array}{c}\text { Levantamento e análise } \\
\text { de requisitos }\end{array}$ & $\begin{array}{l}\text { Processo de identificação de requisitos pela observação dos sistemas existentes, } \\
\text { pela conversa com usuários e compradores em potencial, pela análise de tarefas, } \\
\text { entre outras. }\end{array}$ \\
\hline Especificação de & $\begin{array}{l}\text { É a atividade de traduzir as informações coletadas durante a atividade de análise } \\
\text { em um documento que defina um conjunto de requisitos. }\end{array}$ \\
\hline \multirow{2}{*}{ Validação de requisitos } & $\begin{array}{l}\text { Essa atividade verifica os requisitos quanto a sua pertinência, consistência e } \\
\text { integralidade. Durante esse processo inevitavelmente são encontrados erros na } \\
\text { documentação de requisitos. Os requisitos devem então ser modificados, } \\
\text { objetivando corrigir esses problemas. }\end{array}$ \\
\hline
\end{tabular}

Fonte: Sommerville (2003)

A fase de "estudo de viabilidade" foi feita pelos pesquisadores e desenvolvedores. A viabilidade, no caso do desenvolvimento do nosso SE, estava mais relacionada com a possibilidade de se adaptarem as ferramentas disponibilizadas no GeoGebra para atender aos propósitos que queríamos para o ambiente. Inicialmente, pensávamos que haveria necessidade de usar diferentes softwares, mas com os primeiros estudos e análises, percebemos que praticamente todas as ferramentas que precisávamos estavam no GeoGebra. Por outro lado, seria necessário fazer adaptações na interface e criar um novo editor de equações para a ferramenta Texto. Nas primeiras versões do GGBOOK, usamos apenas o GeoGebra. Nas versões finais, tivemos que usar outro software para integrar com o GeoGebra. Isso será explicado mais à frente.

Os propósitos para os softwares estavam relacionados com a fase de "levantamento e análise de requisitos". O que se esperava para o software era que ele tivesse as funcionalidades de um livro de Matemática digital e dinâmico. A partir do debate entre o pesquisador e os desenvolvedores, foi esboçado um layout para o software. Tal layout e as especificações que compõem o primeiro “projeto rápido" estão representados na Figura 32. 


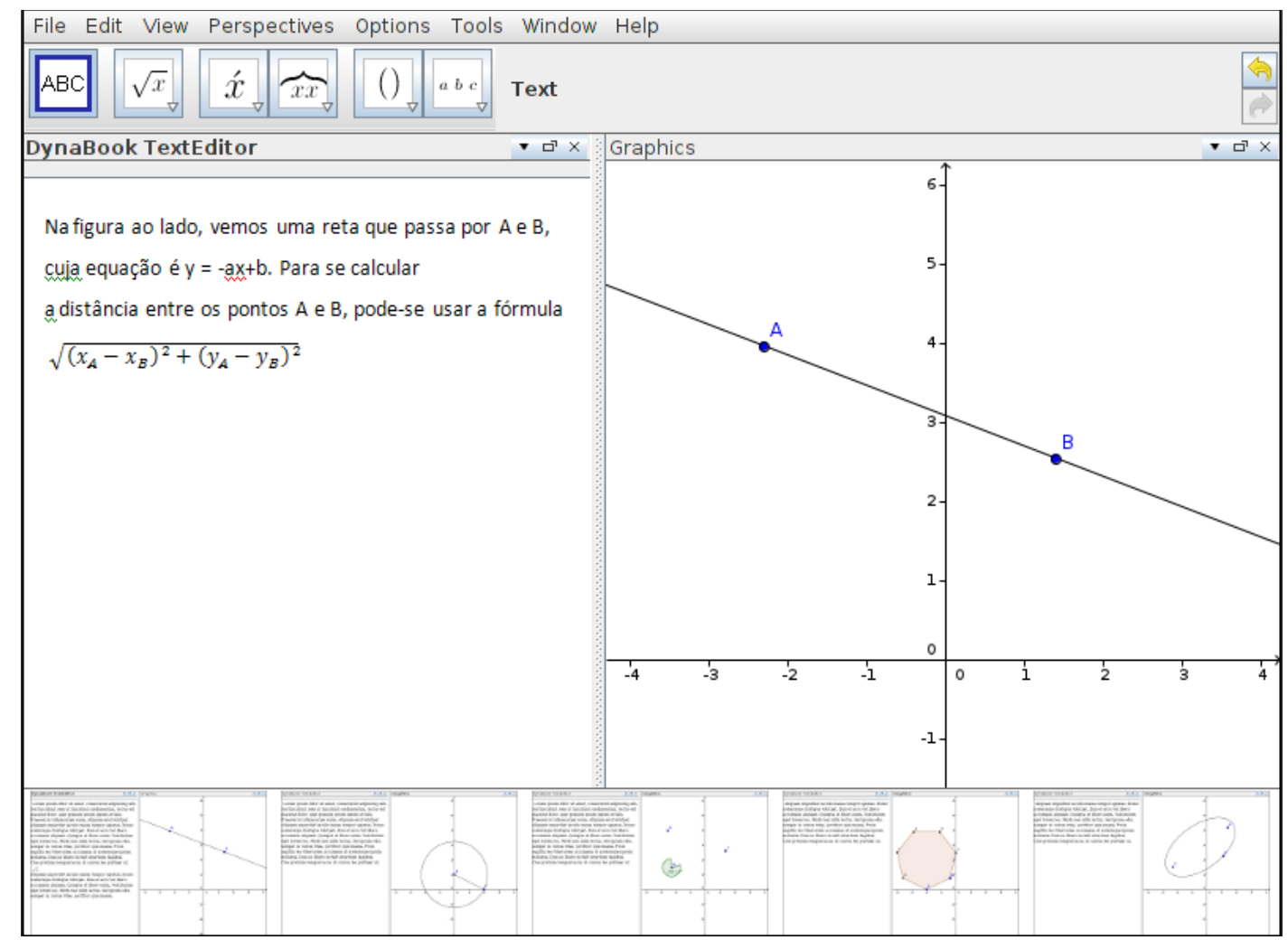

Figura 32-Esboço do layout da interface da $1^{\mathrm{a}}$ versão do GGBOOK

Como se pode ver na Figura 32, a interface planejada para o GGBOOK estava dividida em dois ambientes: Texto e Gráfico. O grupo estabeleceu algumas características de cada ambiente na interface. Tais características compõem o documento sobre "especificações de requisitos" do protótipo inicial do sistema:

○ Os dois ambientes precisariam se "comunicar" de forma dinâmica de maneira que quando se alterassem as propriedades de um objeto no ambiente gráfico, os valores a ele remetidos no ambiente texto também alterariam. No entanto, inicialmente não pretendíamos que o contrário acontecesse, ou seja, alterar um cálculo ou medida no ambiente texto e mudar as propriedades do objeto no ambiente gráfico;

- A barra de ferramentas de cada ambiente deveria aparecer conforme o clique do mouse, ou seja, quando o usuário clicasse no ambiente texto, apareceriam as ferramentas de texto e equações. Quando clicasse no ambiente gráfico apareceriam as ferramentas de geometria. Vejamos a Figura 33. 


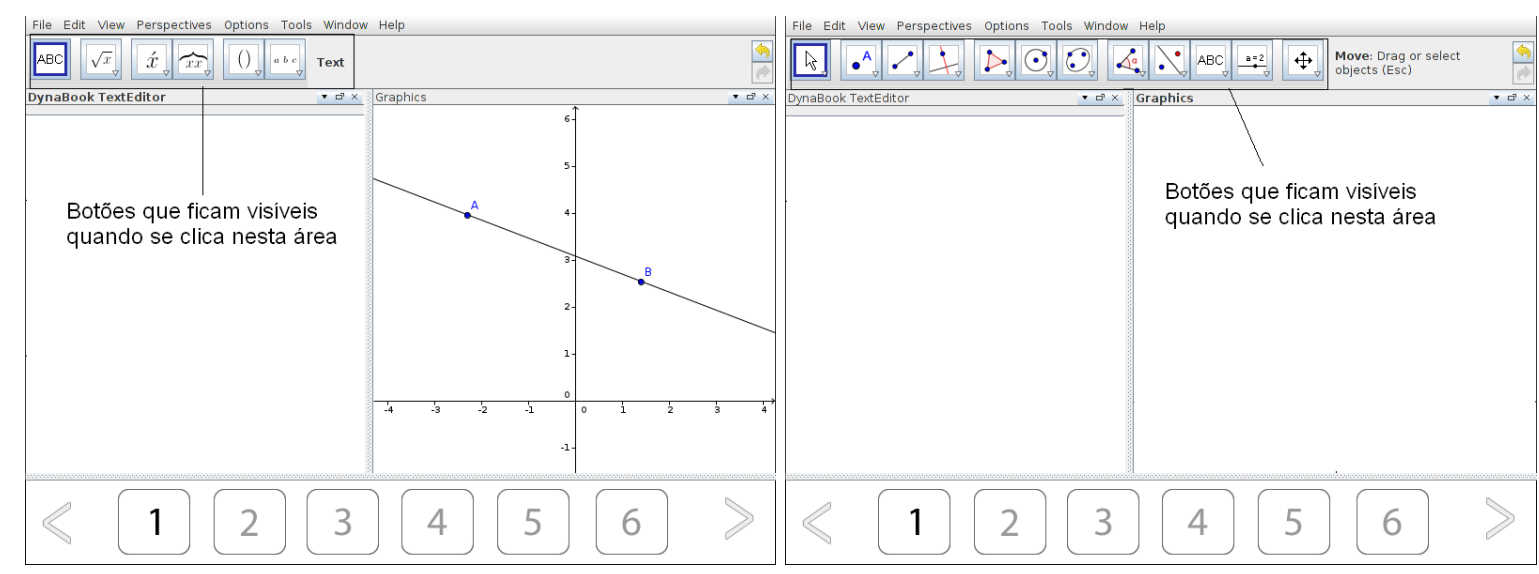

Figura 33-Barra de ferramentas de cada ambiente

- Cada ambiente deveria ter possibilidades de alteração dos espaços na tela, dependendo do conteúdo que se queira explorar. $\mathrm{O}$ ambiente texto teria ainda uma barra de rolagem;

○ No rodapé da interface deveríamos ter pequenas janelas que funcionariam como páginas de um livro;

○ O ambiente texto deveria possuir ferramentas para edição de texto: possibilidades variadas de fontes, sublinhar, negritar, centralizar e alinhar, entre outras. Já existia parte dessas ferramentas dentro do ambiente texto do GeoGebra.

○ Deveria ter ferramentas intuitivas para a edição de equações e símbolos matemáticos. Já existia parte dessas ferramentas dentro do ambiente texto do GeoGebra. No entanto, como relatado anteriormente, elas são difíceis de usar para quem não conhece o LaTeX. Mais adiante falaremos como funcionará o editor de equações.

No GGBOOK deveria haver duas interfaces diferentes: uma para o professor e outra para o estudante. A interface para o professor permitiria que ele colocasse o conteúdo no ambiente texto e gráfico. Além disso, ele poderia habilitar as ferramentas necessárias para a exploração de determinados conteúdos. A interface para o estudante permitiria que ele pudesse fazer manipulações e novas construções no ambiente gráfico. Poderia também digitar textos e equações no ambiente texto, mas não poderia editar o texto colocado pelo professor.

Ainda em relação à fase de coleta de requisitos, foi necessário ver quais funcionalidades necessitaríamos adaptar e quais teríamos que desenvolver. Para isso, estudamos as ferramentas disponíveis na versão 4.0 e identificamos algumas dificuldades para o usuário. Dessa forma, buscamos desenvolver no nosso protótipo soluções para tais dificuldades. 
O primeiro trabalho foi desenvolver uma interface dividida em dois ambientes: Texto e Gráfico. Como foi dito anteriormente a versão 4.0 do GeoGebra possuía as seguintes opções de interfaces: ${ }^{22}$ Álgebra e Gráficos; Geometria; Geometria Básica e Tabela e Gráficos. A nova interface seria chamada de Texto e Gráfico. A versão 4.0 do GeoGebra permitia colocar textos apenas na janela gráfica. Para isso, o usuário deveria selecionar na "Barra de Ferramentas" a opção "Inserir Texto" e clicar no lugar onde quisesse que aparecesse o texto. Ao que parecia, tal ferramenta foi concebida para criação de pequenos textos. Textos apenas para explicar algumas características de algum objeto ou colocar alguma orientação de manipulação. Acreditávamos que seria necessário ter na interface um espaço maior e com local específico. Isso permitiria ao professor colocar instruções sobre a atividade e ainda deixar um espaço para que o estudante pudesse responder aos questionamentos. Todavia, não queríamos dizer que o usuário não pudesse mais colocar textos no ambiente gráfico. Poderia sim, mas pequenos textos.

Uma primeira grande dificuldade enfrentada foi com a ferramenta texto do GeoGebra. A equipe constatou que a ferramenta "texto" da versão 4.0 havia ficado melhor principalmente para os usuários que não conheciam os comandos LaTeX, pois, nessa versão, existiam botões que representavam as operações. Assim, ao clicar sobre o botão, aparecia o código LaTeX na janela "editar" e a janela "visualizar" mostrava como ficava a saída. Apesar das evoluções, percebíamos ainda algumas dificuldades:

a) Muitos botões. Alguns desnecessários para uso em nível básico.

b) Ainda era difícil fazer operações entre as medidas de objetos que estavam na área de visualização. Vejamos um exemplo: na Figura 34, o estudante queria fazer, no ambiente texto, a razão entre as medidas AF e FE.

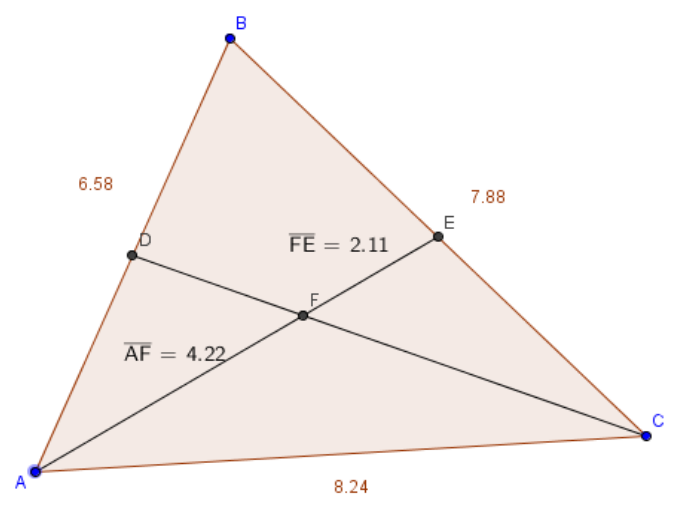

Figura 34-Triângulo e o baricentro

\footnotetext{
${ }^{22}$ No GeoGebra são chamadas de "disposições"
} 
Nesse caso, o estudante teria que colocar no campo "editar" o comando: "|frac $\{\mathrm{AF}\}\{\mathrm{FE}\}="+($ distânciaAF/distânciaFE). Isso mostra que mesmo com os botões de operações, era difícil para o usuário pouco familiarizado com LaTeX, porque mesmo clicando

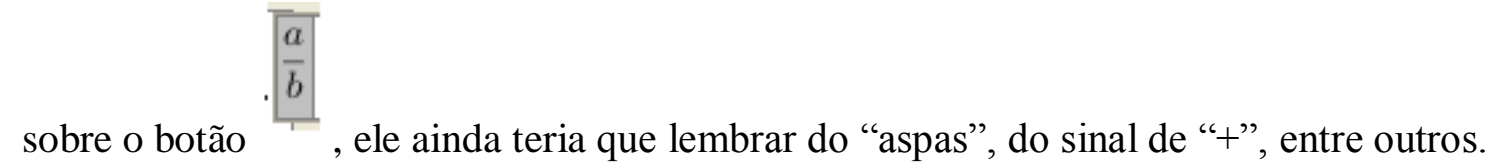
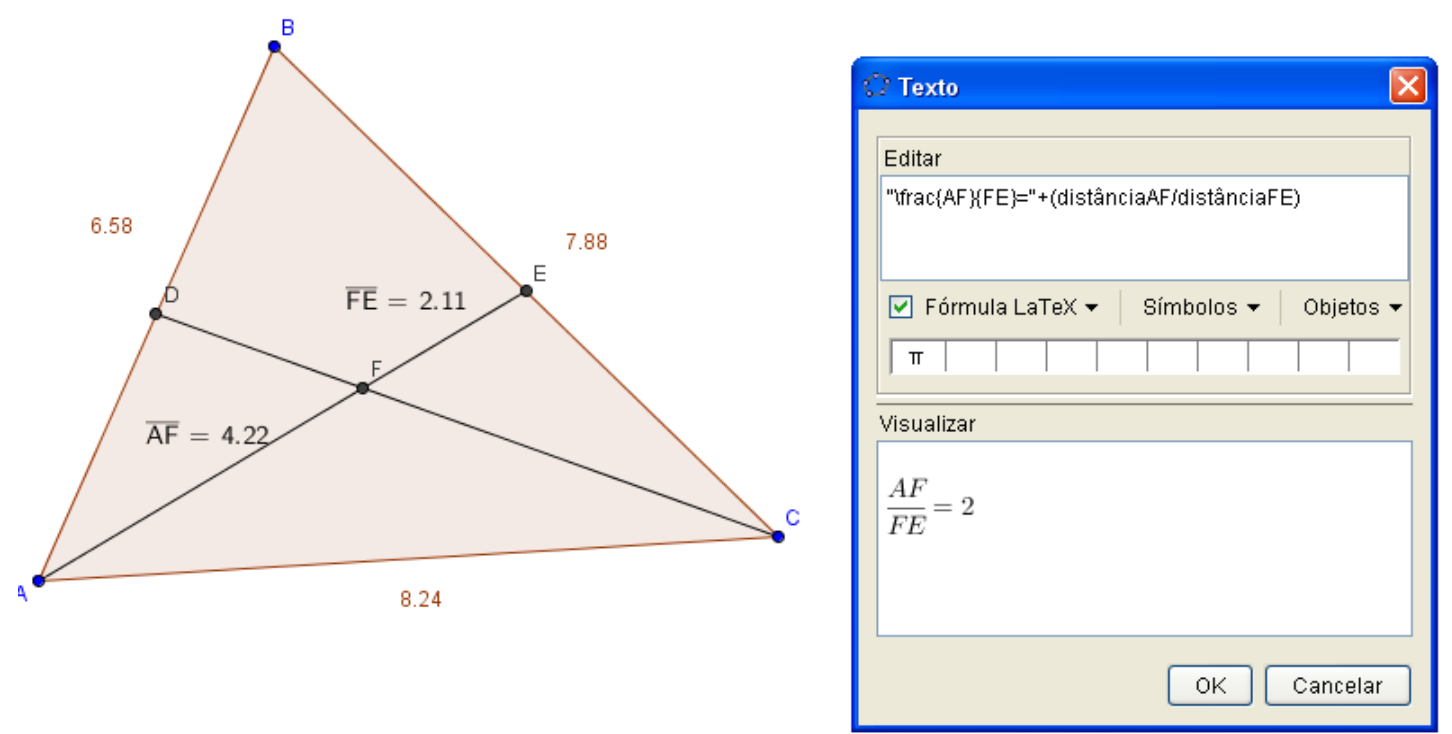

Figura 35-Razão entre duas medidas

Se o estudante quisesse que aparecessem os valores das medidas ao invés de seus nomes, teria que digitar o comando:

"\frac $\{$ "+distânciaAF+" $\{$ "+distânciaFE+" \}="+(distânciaAF/distânciaFE).
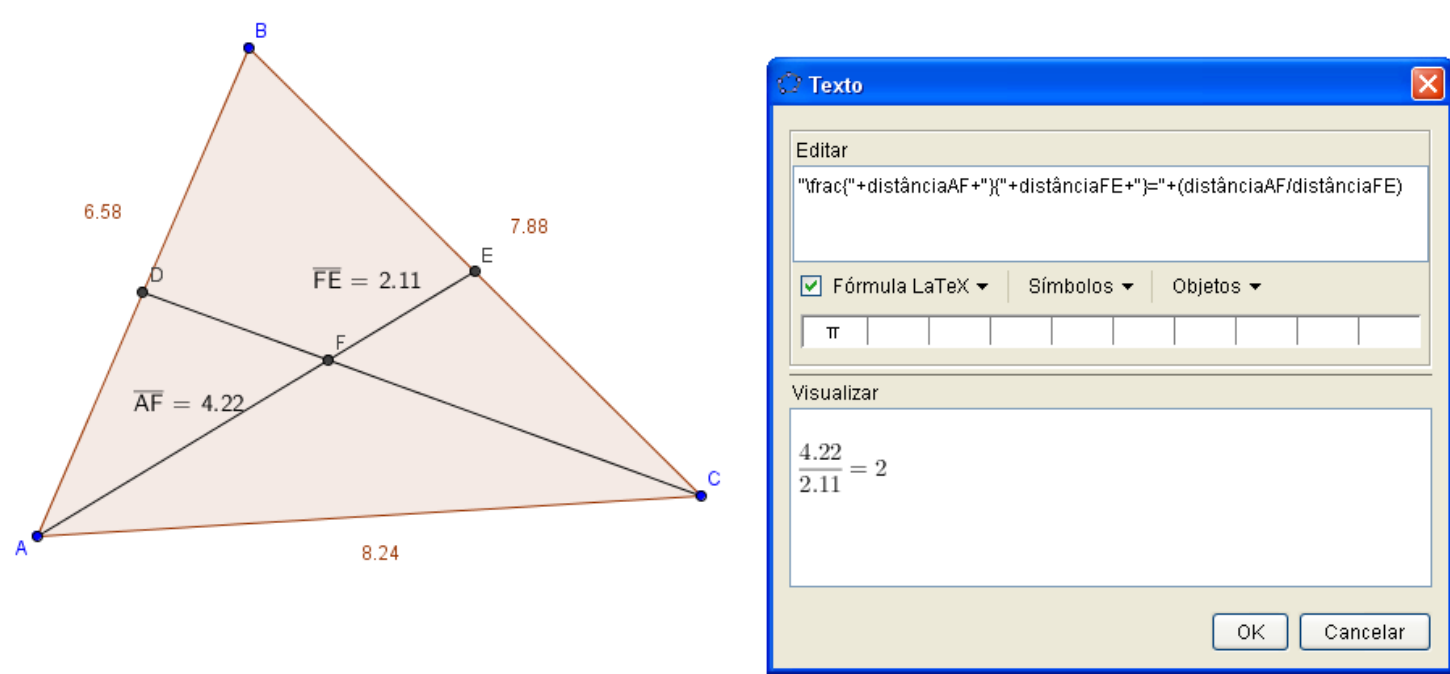

Figura 36-razão entre duas medidas e o resultado 
c) Outro problema era que quando se ativava a opção "Fórmula LaTeX" o programa reconhecia tudo que estava escrito como LaTeX, mesmo o que era texto. Vejamos um exemplo:

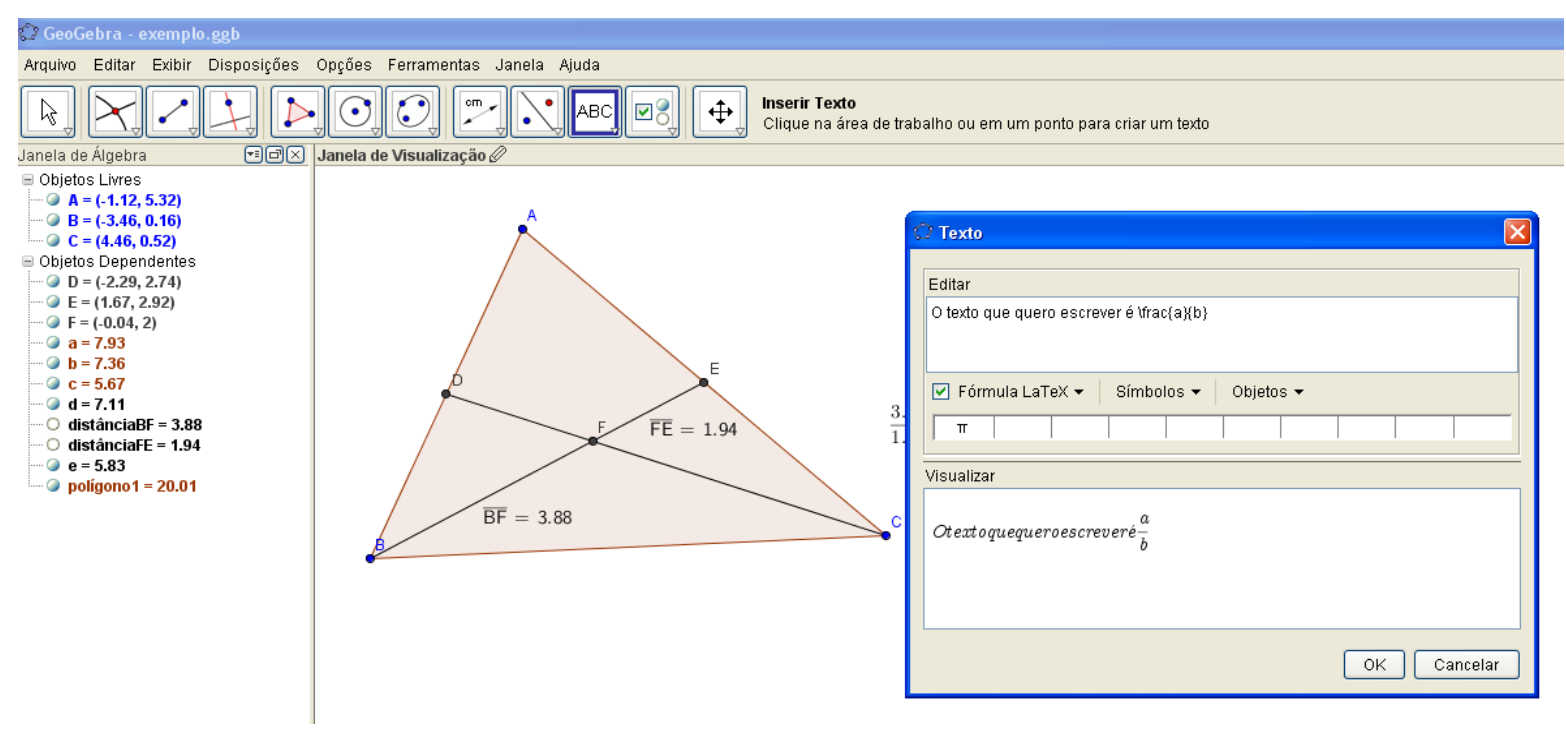

Figura 37-Ferramenta texto do GeoGebra

Na Figura 37, é possível perceber que o texto escrito fica com todas as palavras juntas no ambiente visualizar. Isso acontecia quando era ativada a função "Fórmula LaTeX". Ou seja, no ambiente texto não era possível mesclar, de forma intuitiva, texto e fórmulas LaTeX, ou seja, os registros linguísticos e simbólicos.

A partir das dificuldades levantadas, o grupo levantou as seguintes sugestões para solucionar:

○ Eliminar o campo "editar";

○ Quando se clicar no botão da operação desejada, ela já deve aparecer na janela texto, faltando apenas os espaços onde seriam colocados os valores (como no caso do editor de equações equation do Word). Por exemplo, suponha que o usuário deseje fazer a operação anterior AF/FE. Para isso, ele deveria clicar no ícone $\sqrt{\frac{\bar{a}}{b}}$. Feito isso apareceria no campo visualizar a figura $=$. O cursor já deve ficar sobre o numerador. Para colocar o valor, o usuário deve clicar sobre a medida. $\mathrm{O}$ valor será inserido no numerador. Para ir para o denominador o usuário deve clicar sobre o espaço que o representa e depois clicar sobre a outra medida. Para finalizar e aparecer o resultado o usuário deve 
clicar com o botão direito do mouse e selecionar a opção "mostrar resultado". Essa solução resolve também o problema da integração de texto e fórmulas no ambiente texto.

Outros requisitos estabelecidos pelo grupo estavam relacionados com a possibilidade de se salvar o arquivo para posterior análise do estudante ou do professor. A ferramenta "barra de navegação para passos da construção" deveria funcionar não só para objetos construídos no ambiente gráfico do GeoGebra, mas também para o que foi escrito no ambiente texto. Dessa forma, o professor poderia revisar, na ordem em que os objetos foram construídos, tudo que o estudante fez. Nesse caso, percebemos que teríamos que fazer algumas adaptações na ferramenta de revisão do GeoGebra já que tal ferramenta revisava apenas os objetos geométricos construídos. Os textos feitos só apareciam no final e não ficava explícito como o aluno havia chegado ao texto, ou seja, ele poderia ter usado comandos LaTeX para fazer algum cálculo e o professor poderia não saber qual era. Para isso, teríamos que usar a ferramenta "protocolo de construção". Essa ferramenta resolveria os dois problemas. No entanto, o "protocolo de construção" mostrava objetos que não eram, necessariamente, feitos pelos alunos. Como exemplo, vejamos a Figura 38:

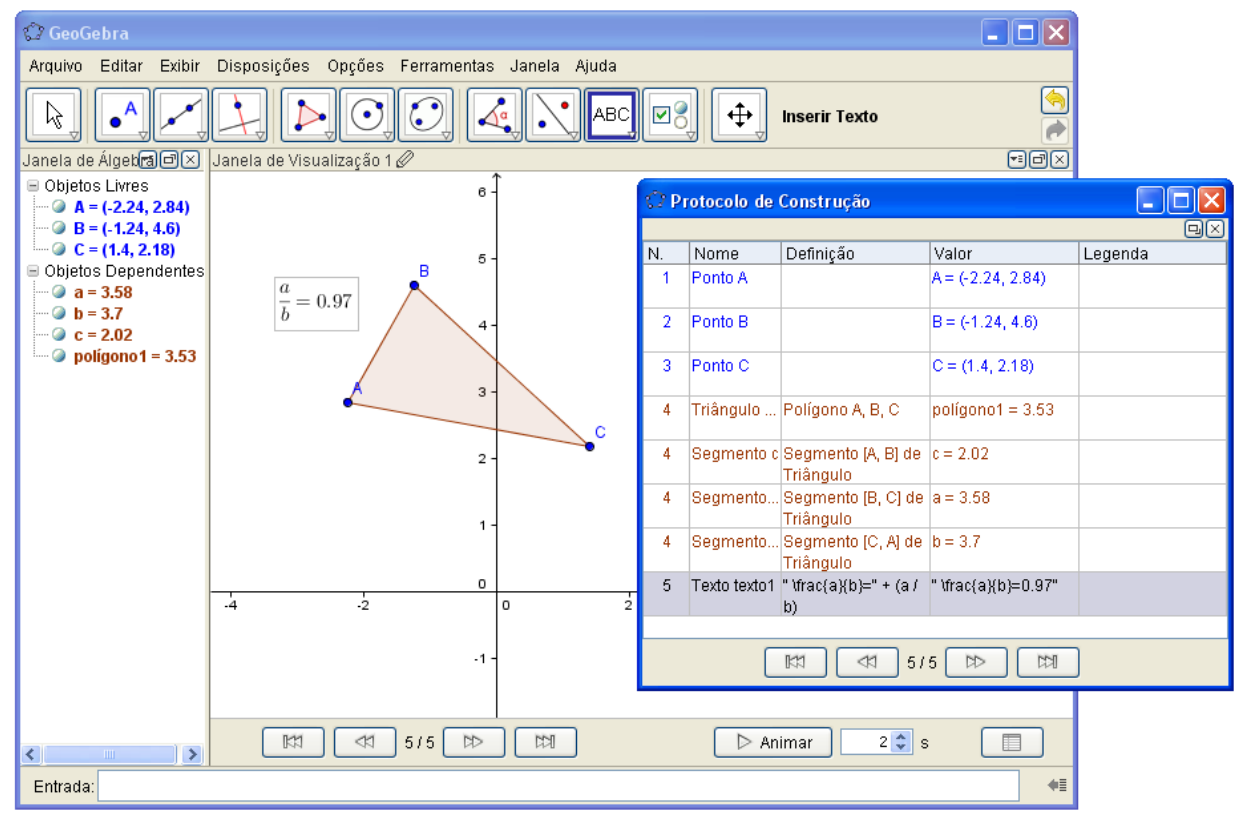

Figura 38-Protocolo de construção

Na construção acima o estudante fez um triângulo e a razão entre dois lados. Os passos 4 mostrados no "protocolo de construção" não foram feitos pelo aluno, ou seja, para criar o triângulo, ele apenas clicou em três lugares distintos. Os segmentos que compõem os lados triângulos foram automaticamente feitos e medidos pelo programa. Na barra de navegação 
para passos da construção era preciso criar instrumentos de forma a deixar bem claro o que foi de fato feito pelo estudante.

Para a fase de "Validação de Requisitos" planejamos pequenos testes com o protótipo inicial. De acordo com Lacerda (2007) o processo de validação deve estar presente em todas as fases do processo de software, desde a definição de requisitos até o desenvolvimento do programa. Dessa forma, antes de experimentarmos o software com estudantes, foram feitos alguns pequenos testes para que pudéssemos identificar problemas ou pequenos bugs.

\subsubsection{Algumas evoluções do GGBOOK}

Em Nóbriga et al.(2012), foram apresentadas as primeiras evoluções do GGBOOK. Algumas funcionalidades e implementações já haviam sido feitas. Para exemplificar como o software estava funcionando naquele momento, apresentamos uma situação de ensino. Suponhamos que o professor quisesse explorar a "lei dos Senos" no GGBOOK. Ele poderia criar uma atividade como a mostrada na Figura 39.

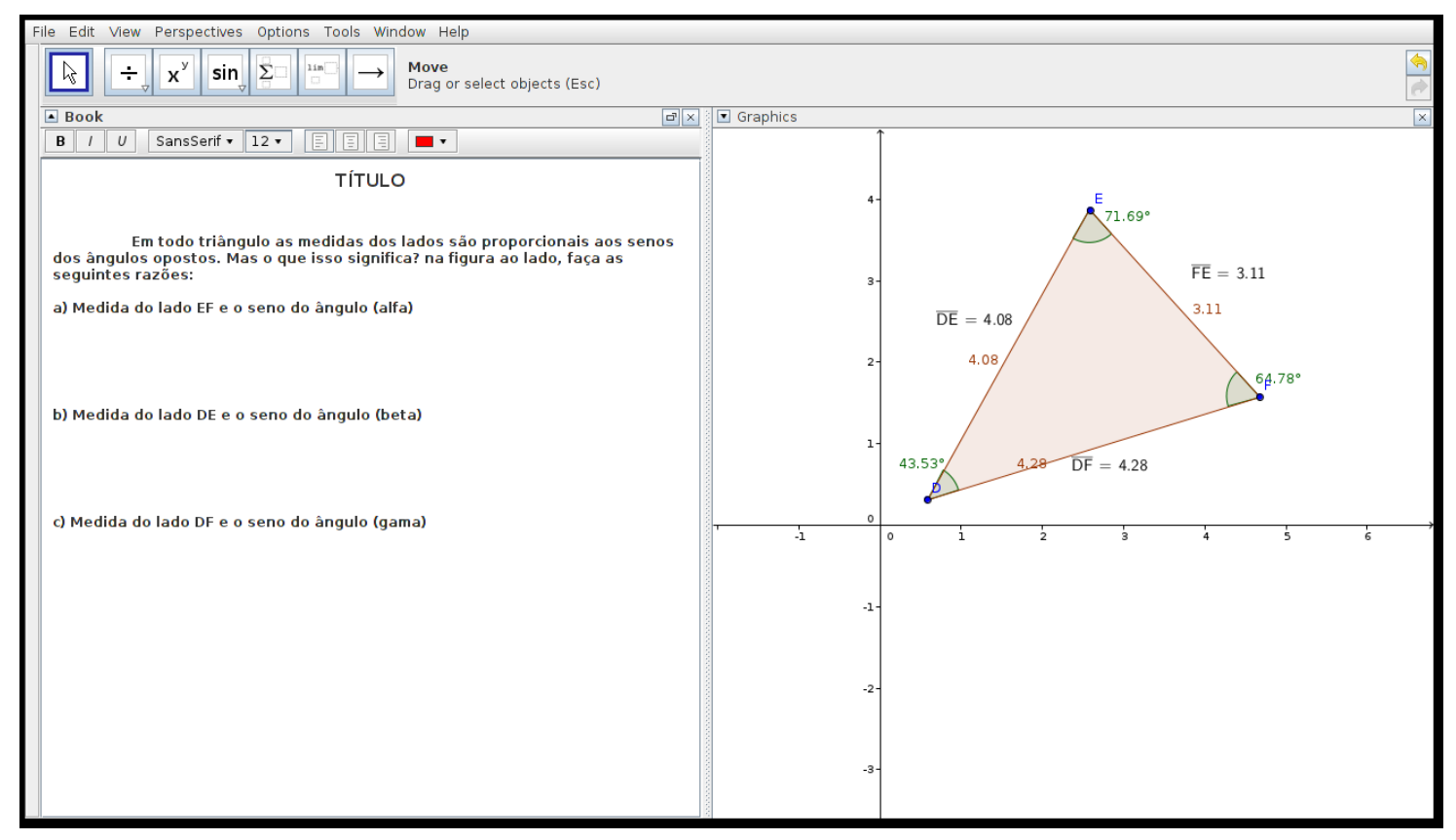

Figura 39-Atividade sobre a lei dos senos feita na primeira versão do GGBOOK

Para efetuar as razões, o estudante deveria clicar no espaço destinado à resposta. Depois disso, selecionaria na barra de ferramentas o ícone que representava a divisão. Para inserir o valor do numerador, deveria clicar sobre a medida do lado BC. Em seguida, clicaria 
no espaço destinado ao denominador e selecionaria o ícone que representava o seno. Finalmente clicaria sobre a medida do ângulo $\alpha$. Ao final, clicaria o com o botão direito do mouse e selecionaria calculate result e o resultado apareceria, conforme mostrado na Figura 40.

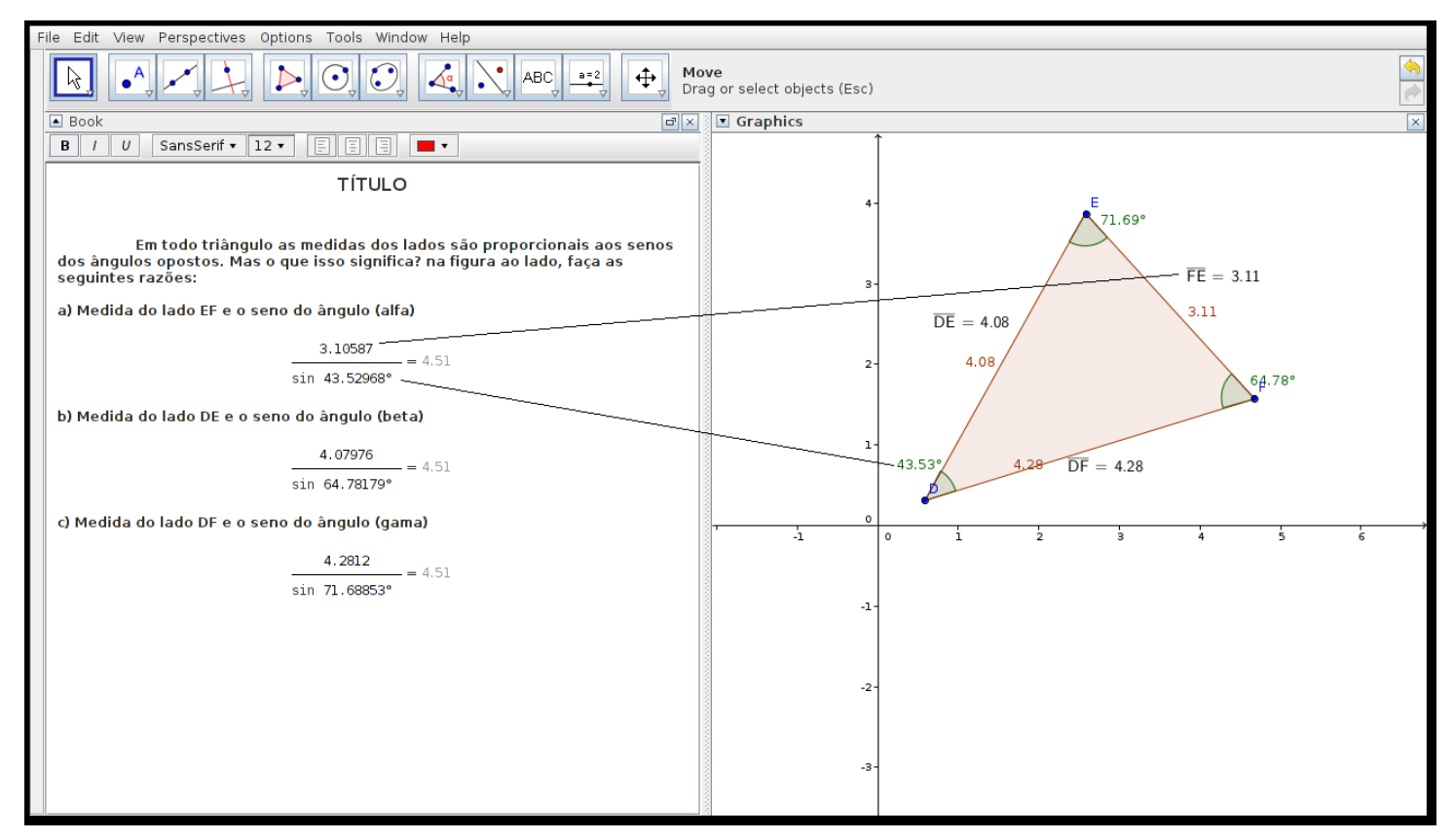

Figura 40-Resposta do estudante para a primeira atividade

Para fazer os outros cálculos, o processo era igual. Assim, o estudante poderia perceber que os resultados das razões eram iguais. Depois disso, poderia movimentar o ponto A e perceber que as medidas dos lados e ângulos se alteravam no ambiente gráfico e no ambiente texto, mas os resultados das razões continuariam iguais, evidenciando uma característica dos textos dinâmicos.

Suponha ainda que o professor quisesse mostrar outra propriedade da lei dos senos. $\mathrm{O}$ estudante deveria clicar na caixa 2 do rodapé da interface. Apareceria a nova página, conforme a Figura 41. 


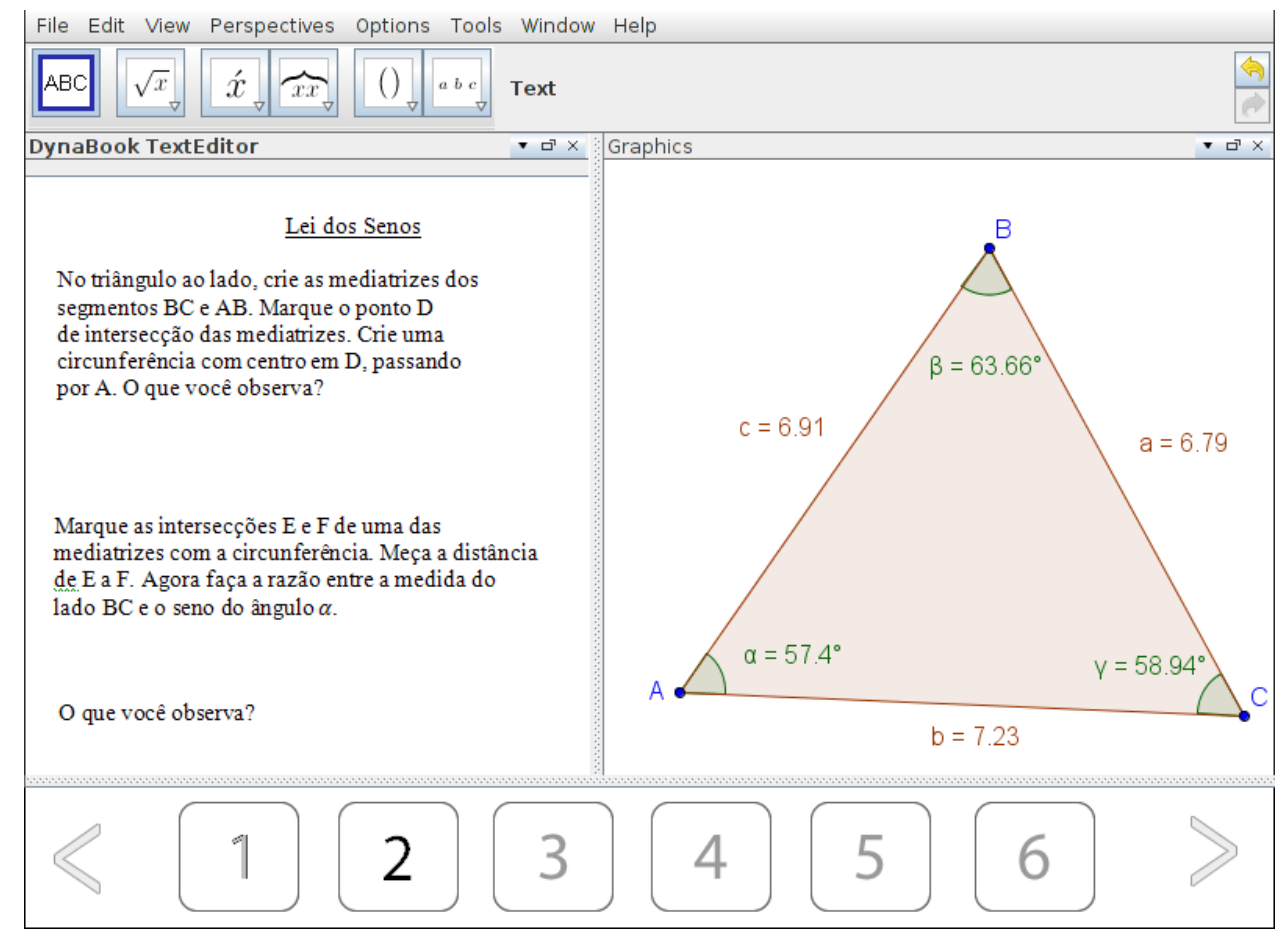

Figura 41-Atividade da página 2 do GGBOOK

Para fazer as atividades propostas pelo professor, o estudante clicaria na janela gráfica. Assim, a barra de ferramentas de geometria ficaria visível. Selecionaria as ferramentas necessárias para a construção pedida pelo professor. Depois da construção, esperar-se-ia que o aluno percebesse que a circunferência ficaria circunscrita ao triângulo. Na atividade seguinte, o estudante teria que fazer novamente a razão que fez na página anterior. Em seguida, mediria o diâmetro da circunferência e poderia perceber que o diâmetro era igual à razão calculada anteriormente.

Apesar de não haver no exemplo uma Narrativa Matemática Dinâmica, propriamente dita, podem-se perceber no software algumas características que permitiam a construção de tais narrativas. Vejamos:

- Integração dinâmica dos diferentes registros de representação do objeto matemático. No caso do exemplo, o objeto é a "Lei dos Senos" que diz que em todo triângulo as medidas dos lados são proporcionais aos senos dos ângulos opostos. Temos aí um objeto matemático, representado com registro de representação linguístico. Para que o estudante pudesse compreendê-lo, deveria fazer uma conversão do registro linguístico para o registro simbólico (tradução matemática). Para isso, deveria também usar um registro de representação visual do conceito triângulo, por meio de uma figura. Os lados e ângulos internos do triângulo eram representados no ambiente texto por suas 
medidas que seriam alteradas automaticamente, caso o triângulo sofresse modificações.

- Integração das diferentes representações do objeto matemático com os textos dinâmicos. Na Figura 40, a expressão $\frac{3,1058}{\sin 43,52^{\circ}}=4,51$ apresenta um exemplo de tal integração. O número 3,1058 representa a medida de um lado do triângulo. O número $43,52^{\circ}$ representa a medida de um ângulo interno do triângulo e 4,51 é o resultado da razão entre a medida de um lado e o seno do ângulo oposto. Quando se modifica o triângulo, os valores da expressão anterior são alterados também. Todavia, as outras partes do texto (por exemplo, a expressão $\sin$ ) não são alteradas. Ou seja, nos textos dinâmicos do exemplo só são alterados as expressões que contêm variáveis associadas com a figura. Isso contribui para manutenção da coerência do texto.

Além das características citadas, vale também destacar as possibilidades de cálculo automático de resultados e as possibilidades de revisão passo a passo do trabalho feito pelo estudante. Por exemplo, na atividade da Figura 41, o professor poderia verificar como o estudante fez para resolver: fez a construção das mediatrizes, marcou a intersecção, fez a circunferência e depois respondeu questão? Ou fez a construção das mediatrizes, marcou a intersecção, fez a circunferência, criou e mediu os segmentos, fez a razão e respondeu as duas questões? Dessa forma, seria possível identificar elementos de historicidade da narrativa feita pelo estudante.

\subsubsection{Dificuldades no desenvolvimento do GGBOOK}

No início dos trabalhos de desenvolvimento, estabeleceu-se que o nosso trabalho não seria um projeto à parte do GeoGebra. Ou seja, nosso interesse era trabalhar em parceria com o grupo oficial de desenvolvedores do GeoGebra. Dessa forma, não ficaríamos longe do que era praticado como padrões de desenvolvimento da comunidade. Além disso, nossas implementações poderiam ser disponibilizadas futuramente na versão oficial do software. A partir de tal pressuposto, buscamos fazer o desenvolvimento sempre buscando preservar as características básicas do software, sobretudo no que diz respeito aos aspectos de layout, usabilidade e a filosofia keep it short and simple.

Em 2011 apresentamos o trabalho "GGBOOK: uma interface que integrará os ambientes de texto e gráfico no GeoGebra" (NÓBRIGA et al., 2012b) na $1^{\text {a }}$ Conferência 
Latino-Americana de GeoGebra. Nessa oportunidade, pudemos apresentar o que estávamos desenvolvendo para representantes do grupo oficial do GeoGebra. Tais representantes se entusiasmaram com nossas ideias e fomos convidados para participar oficialmente do grupo de desenvolvimento. Com isso, fomos integrados ao grupo de discussão dos desenvolvedores (geogebra-dev@googlegroups.com) e foi criado um Branch ${ }^{23}$ dentro do repositório de códigos do projeto oficial, com o intuito de se gerar um desenvolvimento do nosso projeto em paralelo.

De acordo com os desenvolvedores, os softwares privados e comunitários têm como convenção o uso de repositórios de códigos, a fim de se mantê-los versionados. Essa convenção utiliza o conceito de Branches, Tags e Trunk (organização feita em pastas):

- A pasta trunk contém os projetos que estão em desenvolvimento. Todas as atualizações efetuadas dia a dia são armazenadas na pasta trunk;

- A pasta branches é aquela que contém "linhas de desenvolvimento" de tal projeto e que entre elas poderia haver poucas diferenças, porém uma não dependia da outra;

- Quando os testes efetuados em cima de um Branch estão completos, a versão que se encontra lá é copiada para a pasta Tags, formando assim um release ou uma versão "liberada".

Para o desenvolvimento das implementações feitas até aquele momento, a maior dificuldade foi a criação do editor matemático. Para isso, foi criado um projeto à parte que foi chamado de Ábacus que era um software de escrita matemática, integrável com softwares escritos em Java por meio de interfaces. Com ele o usuário poderia montar uma expressão matemática complexa de forma simples e intuitiva, podendo exportá-la para linguagens de marcação matemática tais como LaTeX e mathml. Poderia também calcular o resultado das expressões matemáticas construídas e ainda algumas interações particulares de acordo com a fórmula gerada, como por exemplo, poder-se-ia inverter o numerador pelo denominador na construção de frações.

Para o desenvolvimento do Ábacus, a maior dificuldade foi conseguir criar uma engenharia para a construção das expressões matemáticas, de forma que se pudesse desenhar qualquer expressão matemática, em qualquer nível de complexidade. A geração dos resultados foi também difícil, tendo em vista que a linguagem de programação não fazia cálculos

\footnotetext{
${ }^{16}$ Branch significa ramo.
} 
matemáticos complexos de maneira nativa. Assim, tivemos que usar a estratégia de primeiro gerar o LaTeX e depois usar uma aplicação de apoio para resolver o LaTeX.

A Figura 42 apresenta a interface de 2011 e 2012:

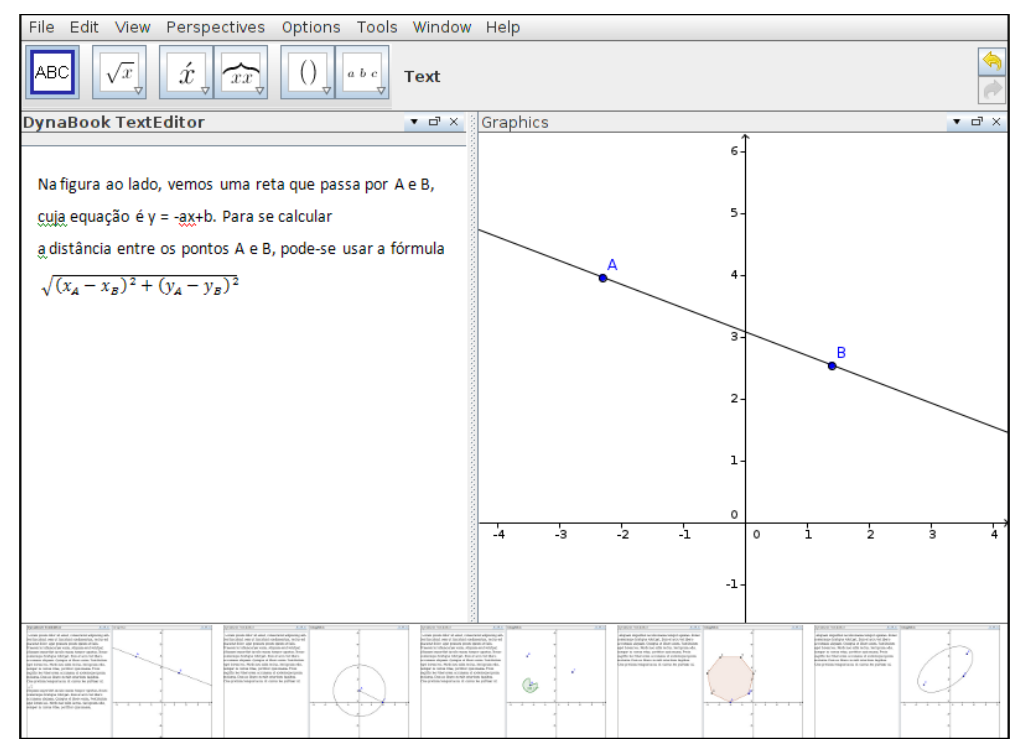

Figura 42-Interface do GGBOOK em 2011 e 2012

No decorrer do desenvolvimento muitas dificuldades foram surgindo e tivemos que fazer mudanças no projeto inicial. Veremos isso no tópico seguinte.

\subsubsection{Mudanças no projeto GGBOOK}

Desde 2012, os esforços do grupo de desenvolvimento do GeoGebra estavam sendo direcionados para a migração do GeoGebra para o HTML5. A principal vantagem era que o software poderia ser usado em dispositivos que usam tela sensível ao toque. A Figura 43 apresenta a tela do GeoGebra (versão 4.2.31) 


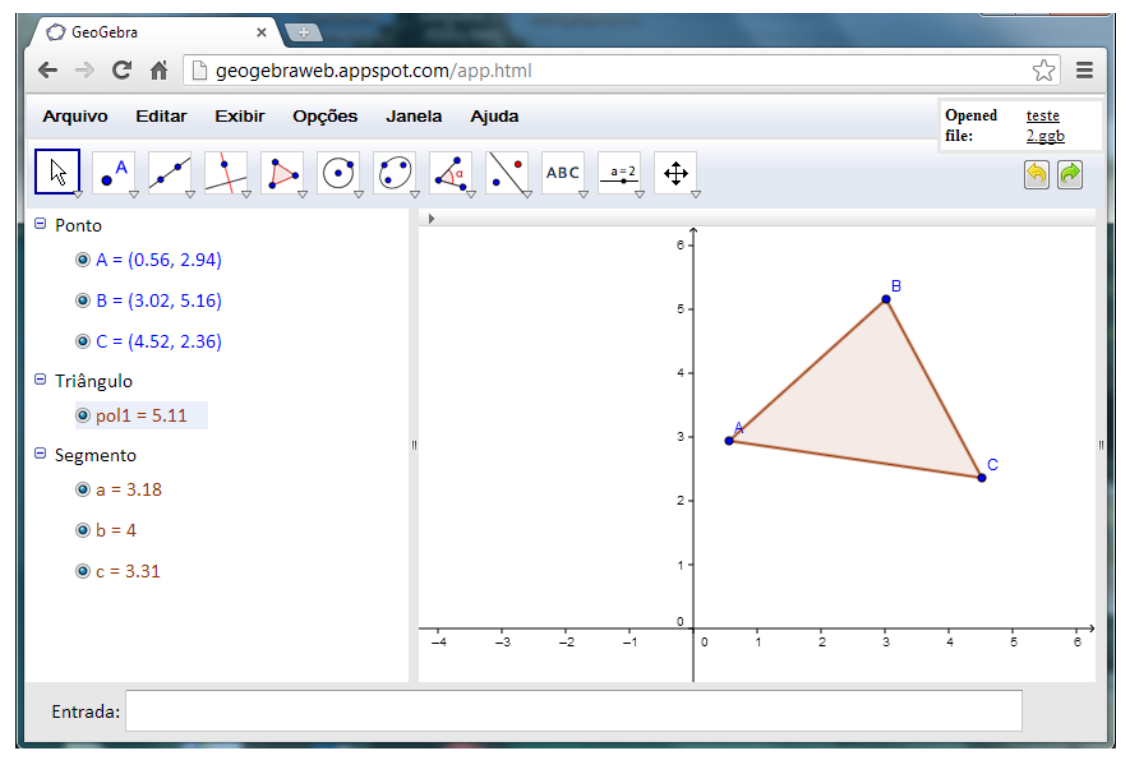

Figura 43-Tela do Geogebra (versão 4.2.31)

Basicamente tal versão possuía as mesmas funcionalidades da versão desktop. Todavia, existiam algumas vantagens, como por exemplo, a possibilidade de fazer um login no google e poder salvar o arquivo no Google drive. Assim, poder-se-ia acessar o arquivo em qualquer outro computador que tivesse acesso à internet.

A partir da percepção dessa migração para o HTML5, nosso grupo de desenvolvimento questionou sobre qual rumo deveria ser tomado: continuar o desenvolvimento com a versão anterior ou migrar o desenvolvimento para a nova versão? Como o propósito dessa pesquisa era também ter um produto que pudesse ser de fato útil para muitas pessoas em todo o mundo, resolvemos que migraríamos. Todavia, faríamos um projeto mais independente do GeoGebra. Um dos motivos que nos levou a tomar tal decisão foi o fato de percebermos resistência dos líderes de desenvolvimento do GeoGebra em relação à implementação na versão oficial da perspectiva “Texto". Ou seja, eles gostaram da ideia do editor de equações, mas não achavam necessária a perspectiva texto. Assim, seria inútil criarmos uma nova perspectiva, pois ela não seria implementada na versão oficial.

Outra vantagem de fazer um trabalho mais independente era de que teríamos mais liberdade, ou seja, não precisaríamos trabalhar dentro do Branch do Geogebra, nem seguir toda a filosofia do grupo GeoGebra. Enfim, teríamos mais autonomia. Assim, decidimos que faríamos um software com os requisitos que estabelecemos inicialmente, mas com outra "cara". A partir daquele momento deixamos de chamar software GGBOOK e passamos a chamar Plataforma GGBOOK. A tela da plataforma está representada na Figura 44. 


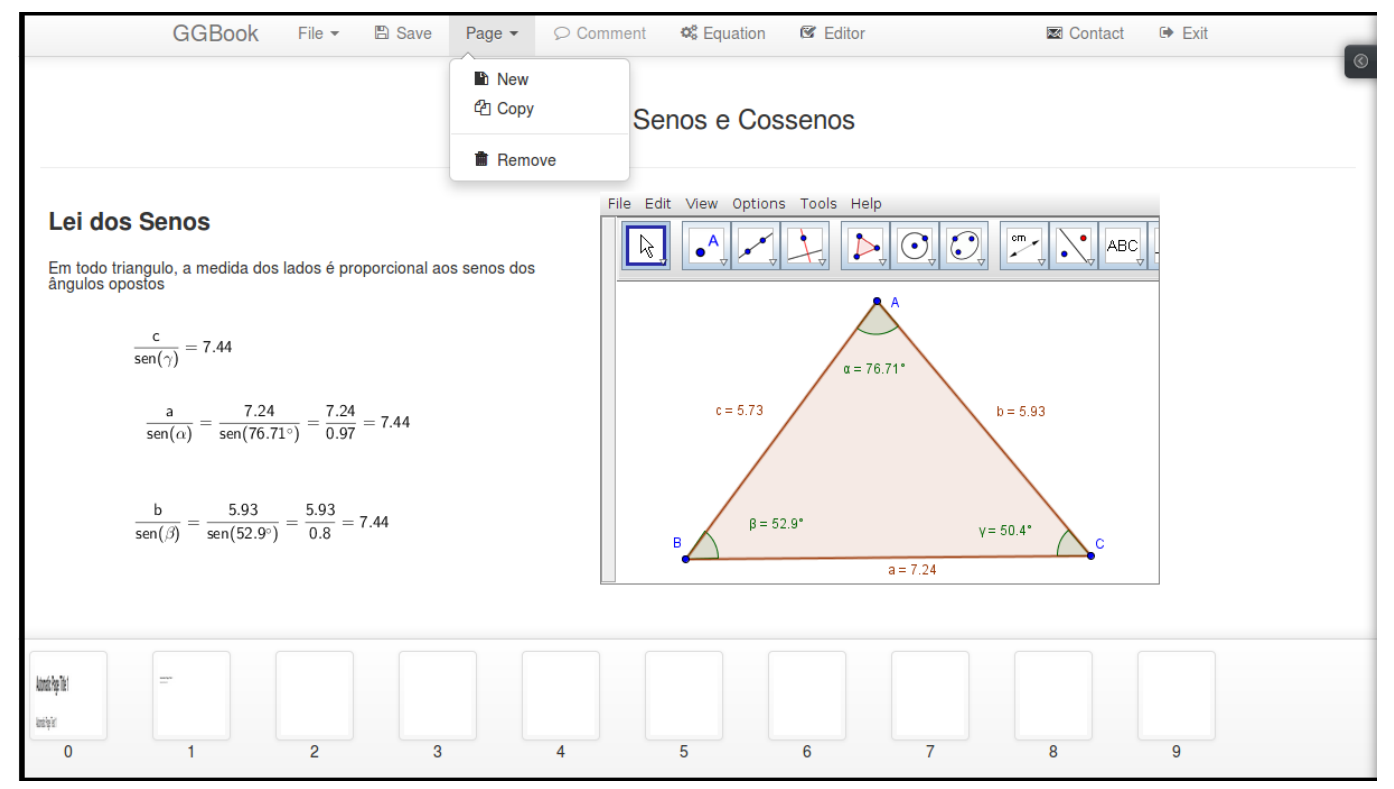

Figura 44-Versão 1 da Plataforma GGBOOK

Assim como o GeoGebra da versão HTML5, a Plataforma GGBOOK funciona a partir de um navegador da internet. Como se pode ver na Figura 44, a Plataforma GGBOOK está dividida em ambiente texto e o GeoGebra. Anteriormente, o ambiente texto estava dentro do GeoGebra (conforme se pode verificar na Figura 42). Assim, como estabelecido anteriormente, os ambientes se comunicam de forma dinâmica, ou seja, quando se alteram as propriedades de um objeto no ambiente GeoGebra, os valores a ele remetidos no ambiente texto também alteram. A barra de ferramentas do ambiente texto aparece conforme o clique do mouse, ou seja, quando o usuário clica no ambiente texto, aparecia a barra flutuante com as ferramentas de texto.

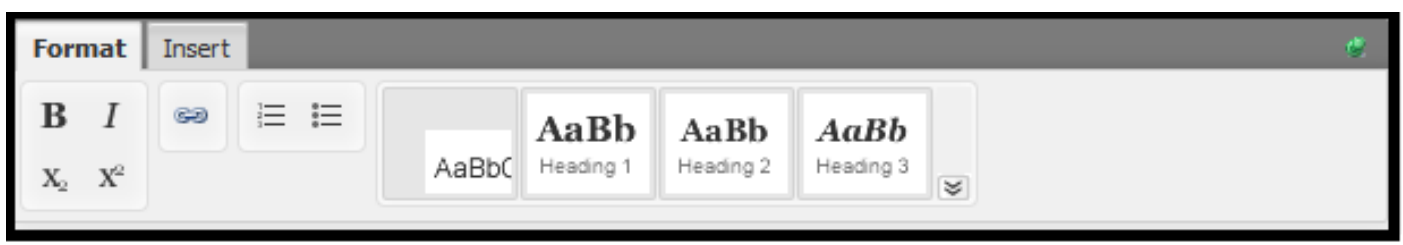

Figura 45-Barra de ferramentas de texto

Quando se clicava na opção "Equation” aparece a barra de ferramentas de equações. 


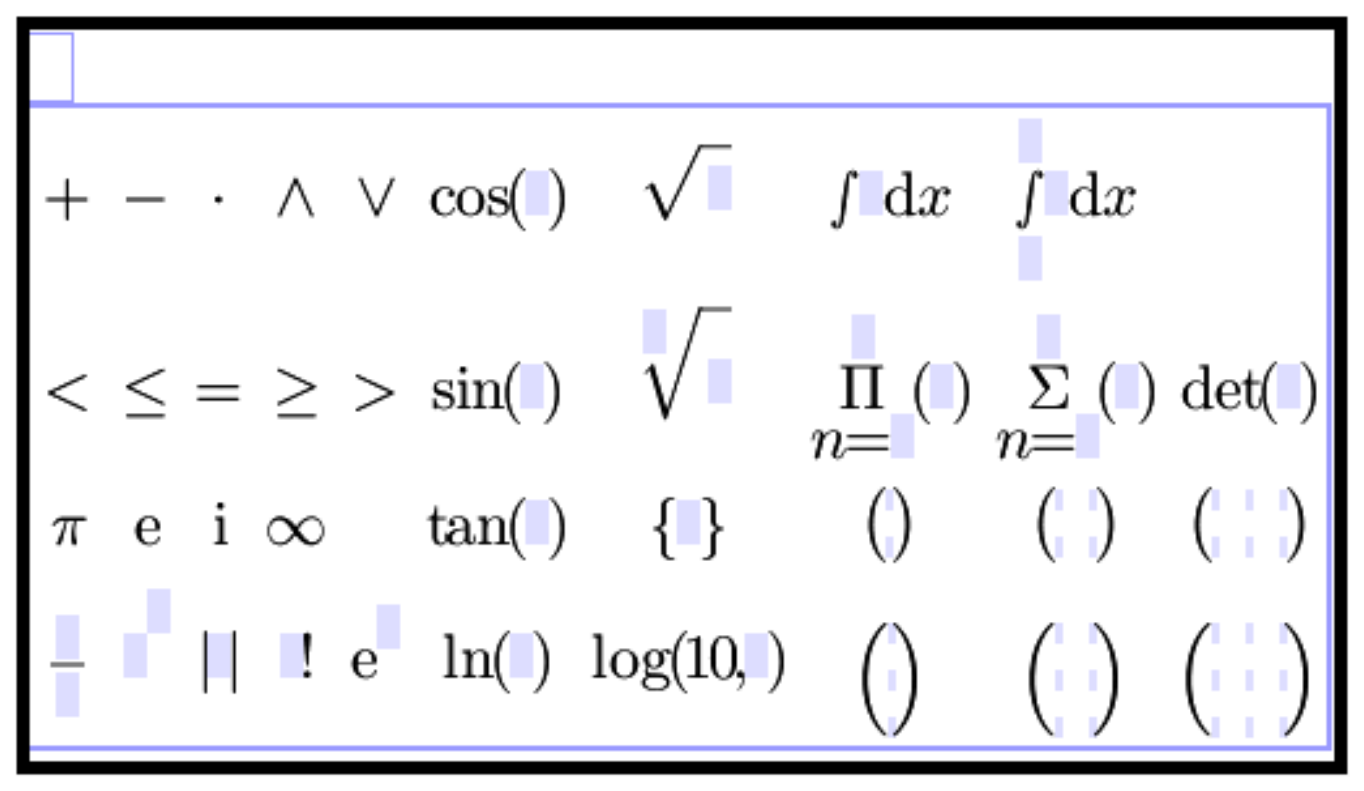

Figura 46-Barra de Ferramentas de equações da versão 1 do GGBOOK

Nessa nova perspectiva de desenvolvimento, percebemos que não seria mais necessário criar um novo editor, pois já existia o editor MATHDOX ${ }^{24}$ que era perfeitamente integrável ao GeoGebra. Assim, tivemos que usar editores de texto e equações já existentes. O principal desafio era integrar esses editores com o GeoGebra de forma que eles se comunicassem simultaneamente.

Após vários testes, percebemos alguns problemas em relação à integração dos ambientes. Era possível inserir dados do ambiente GeoGebra no ambiente texto de forma que ficassem dinâmicos e integrados, mas em alguns casos os resultados ficavam incorretos, ou algum dado sumia inesperadamente das operações. Também não estava permitindo salvar o conteúdo do ambiente "Texto", apenas o do ambiente GeoGebra. Observou-se também que a barra de ferramenta de equações tinham alguns símbolos desnecessários. Assim, resolvemos retirar alguns e os relatórios de testes dessa versão estão no apêndice A.

Outros relatórios, que estão no apêndice B, mostram que apesar das melhorias, os problemas de integração entre os ambientes permaneciam. Chegou-se à conclusão que o problema estava no editor de texto. Mudou-se o editor e a integração entre os ambientes ficou mais estável. Além disso, o novo ambiente texto permitia também a inserção de vídeo e as ferramentas de equações não estavam mais em barras flutuantes. Tais inovações foram

\footnotetext{
${ }^{24} \mathrm{O}$ editor de fórmulas MathDox é um editor baseado na web para fórmulas matemáticas. Atualmente está sendo desenvolvida na Technische Universiteit Eindhoven como um meio para que os alunos introduzam fórmulas em um ambiente de e-learning (http://mathdox.org/formulaeditor/)
} 
bastante benéficas. Por outro lado os problemas passaram a ocorrer quando compartilhávamos a atividade. Ver apêndice C.

Após a correção dos principais problemas, obtivemos uma versão estável para teste. No tópico seguinte falaremos sobre a utilização dessa versão.

\subsubsection{A plataforma GGBOOK (versão 0.15.1-Beta 5)}

Para acessar a plataforma, o usuário deveria digitar no navegador ${ }^{25}$ o endereço http://dev.ggbook.com.br/ e apareceria a página que está representada na Figura 47.

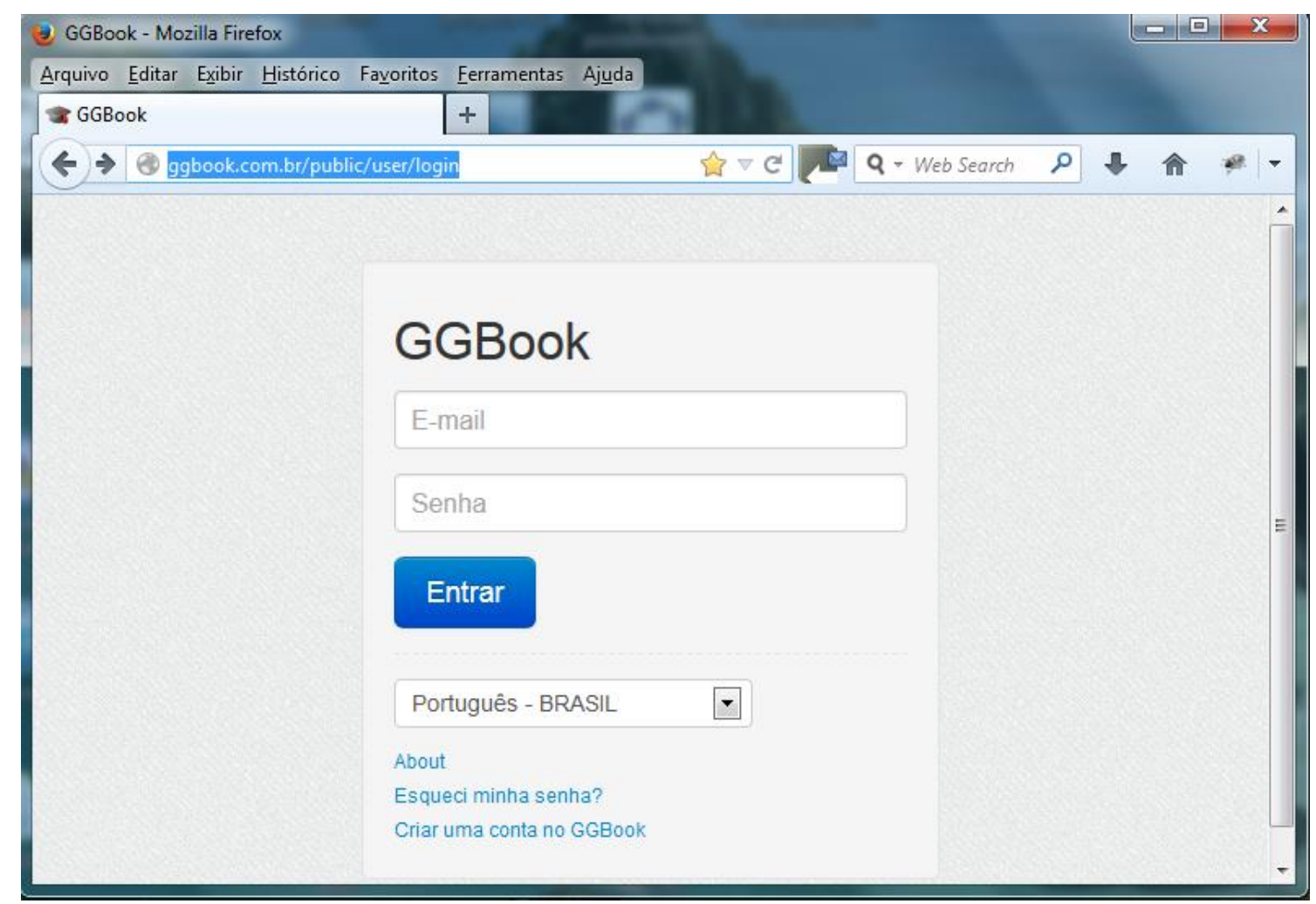

Figura 47-Página de acesso à plataforma GGBOOK

Para o acesso, o usuário deve cadastrar uma conta com o perfil adequado (administrador, professor ou aluno). Em seguida, deve voltar à página inicial, colocar o e-mail e senha cadastrados e escolher a língua (português, inglês, espanhol ou francês). Ao logar (como professor), aparece uma página como a representada na Figura 48.

\footnotetext{
${ }^{25}$ Os testes foram feitos no navegado Mozilla Firefox
} 


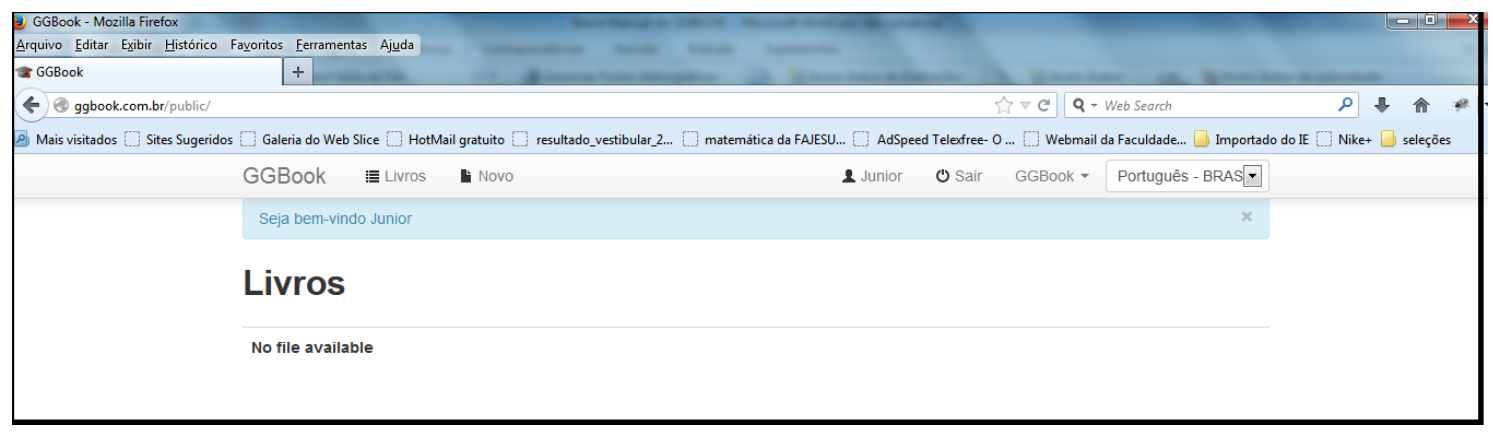

Figura 48-Página para criação de livros na plataforma GGBOOK

Deve selecionar a opção $N_{o v o}{ }^{26}$. Aparece uma caixa em que pode dar um título e criar o livro. Em seguida, aparece uma tela como a representada na Figura 49.

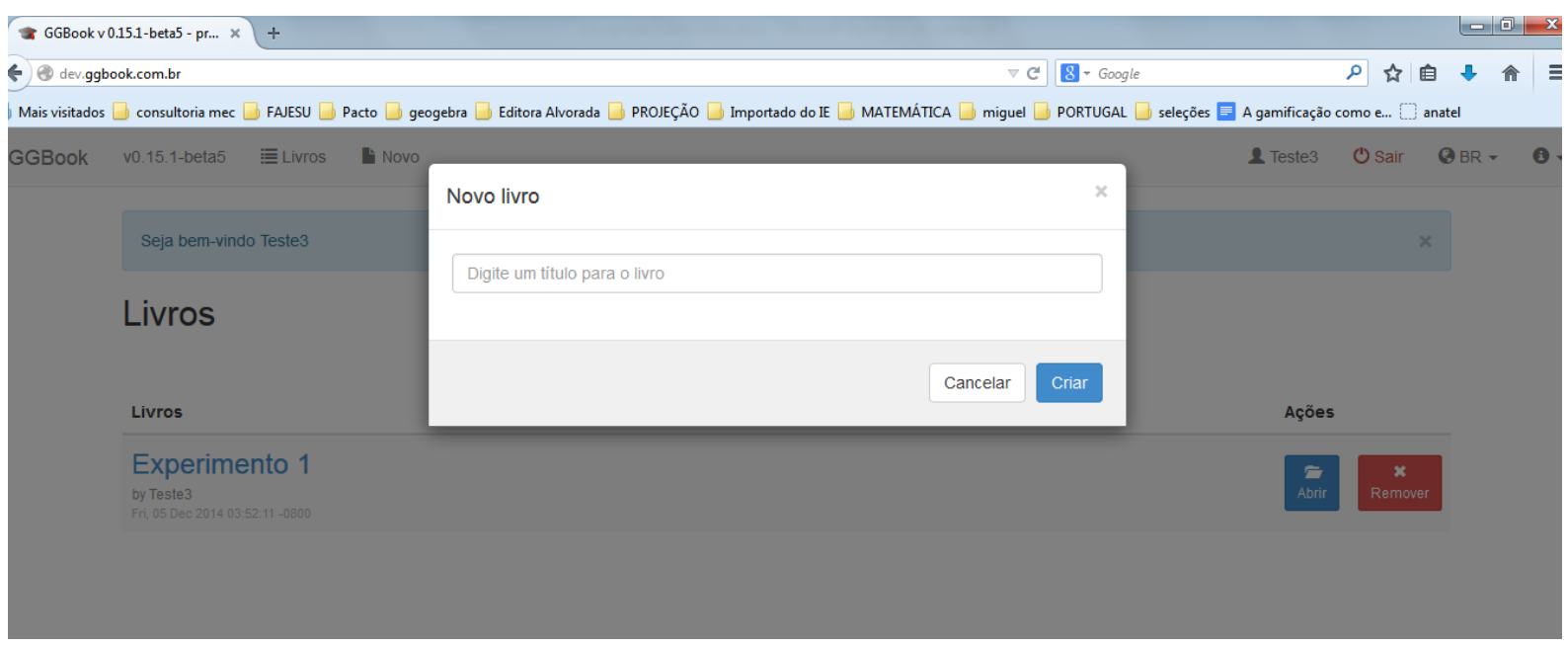

Figura 49-Tela para criação de livros na plataforma GGBOOK

A tela está dividida com espaços para título, subtítulo, texto, GeoGebra e páginas, conforme mostrados na Figura 50.

\footnotetext{
${ }^{26}$ Eventualmente pode aparecer alguma mensagem pedindo alguma autorização para rodar o applet Java. Nesse caso é necessário habilitar o navegador para sempre autorizar o aplicativo.
} 


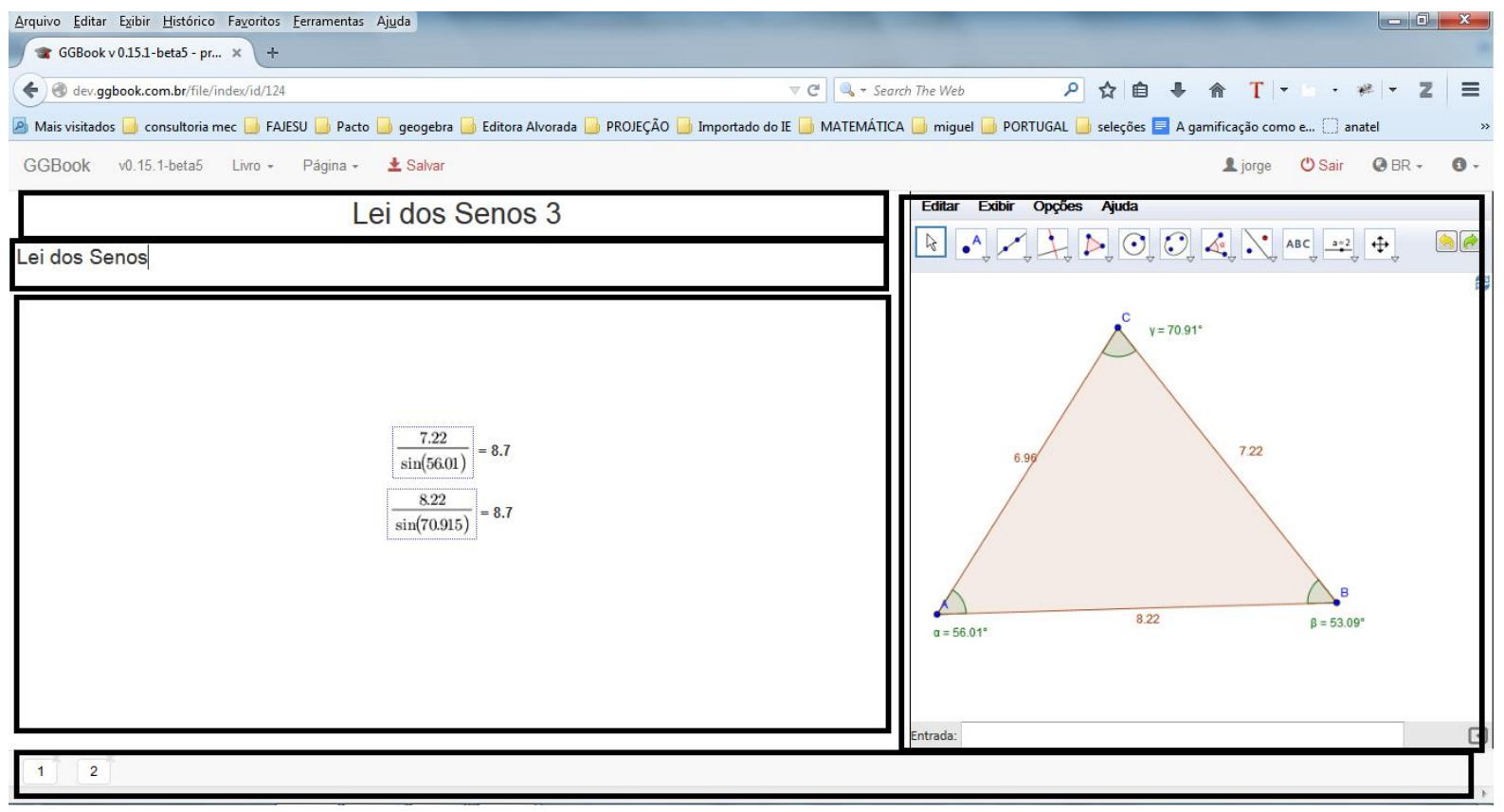

Figura 50-Divisão dos espaços na tela inicial da plataforma GGBOOK

A barra de ferramentas de texto e equações aparece quando o usuário clica no ambiente texto. A barra está apresentada na Figura 51.

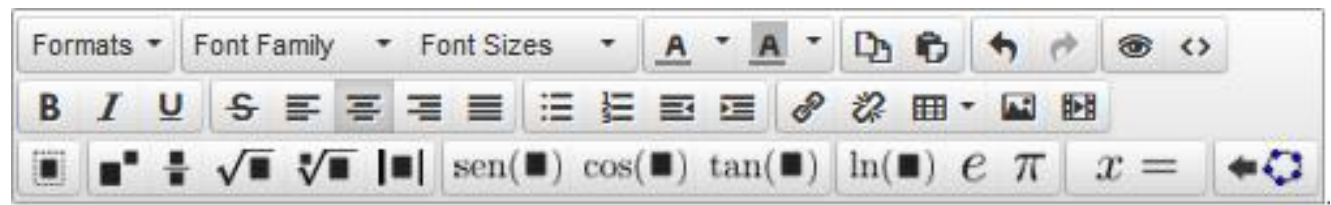

Figura 51-Barra de ferramenta de texto e equações da plataforma GGBOOK

Como forma de mostrar como a plataforma pode ser utilizada, apresentaremos um exemplo. O usuário pode criar alguns segmentos na tela do GeoGebra e medi-los. No espaço para o subtítulo pode escrever algo e depois clicar no ambiente texto. Em seguida, pode fazer algumas operações com as medidas dos segmentos. Para isso, deve clicar num lugar da caixa de texto onde quer que apareça a operação. Em seguida, clicar no ícone que representa a fração, conforme Figura 52. 


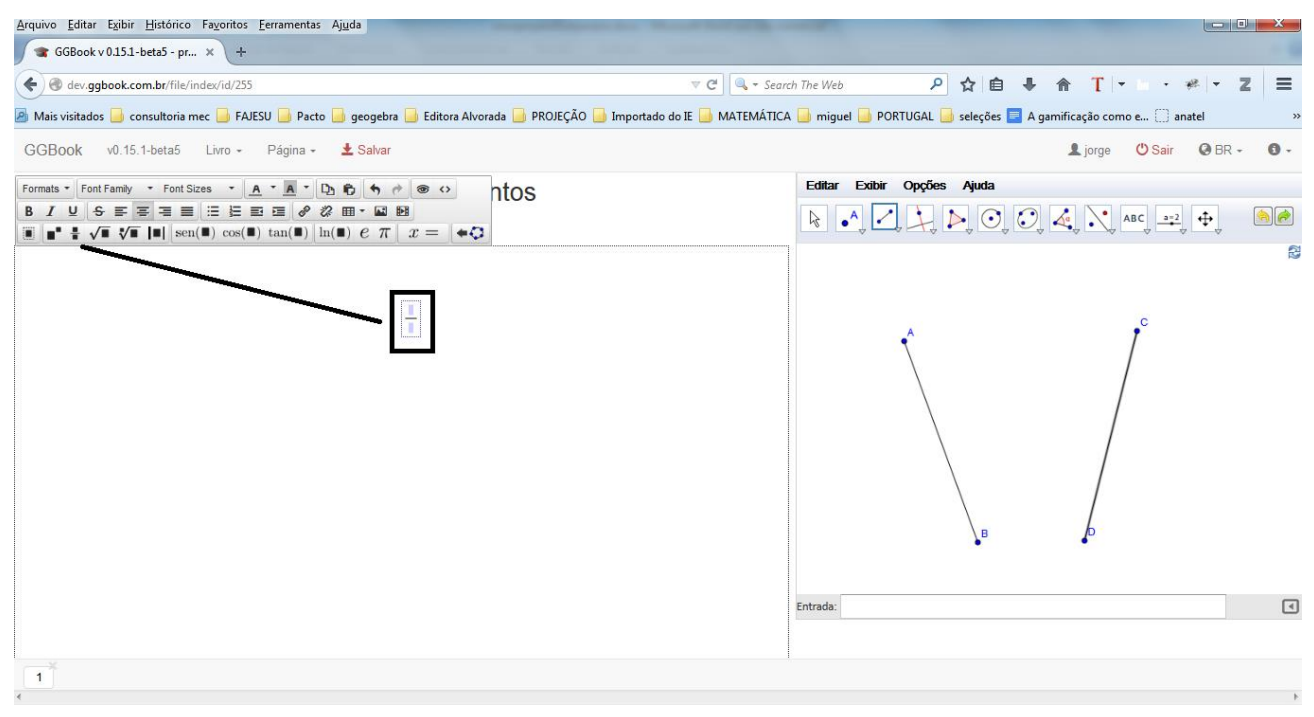

Figura 52-Exemplo de utilização da plataforma GGBOOK

Posteriormente deve clicar dentro da caixa, no numerador. Em seguida, deve apertar a tecla "ctrl" (a fração ficará marcada com a cor vermelha) e clicar sobre o segmento ou sobre sua medida. O valor será inserido no numerador. Depois, clicar no denominador e na outra medida. Para visualizar o resultado da operação, deverá clicar sobre o ícone que tem " $\mathrm{x}=$ ".Ao final, aparecerá algo como mostrado na Figura 53.

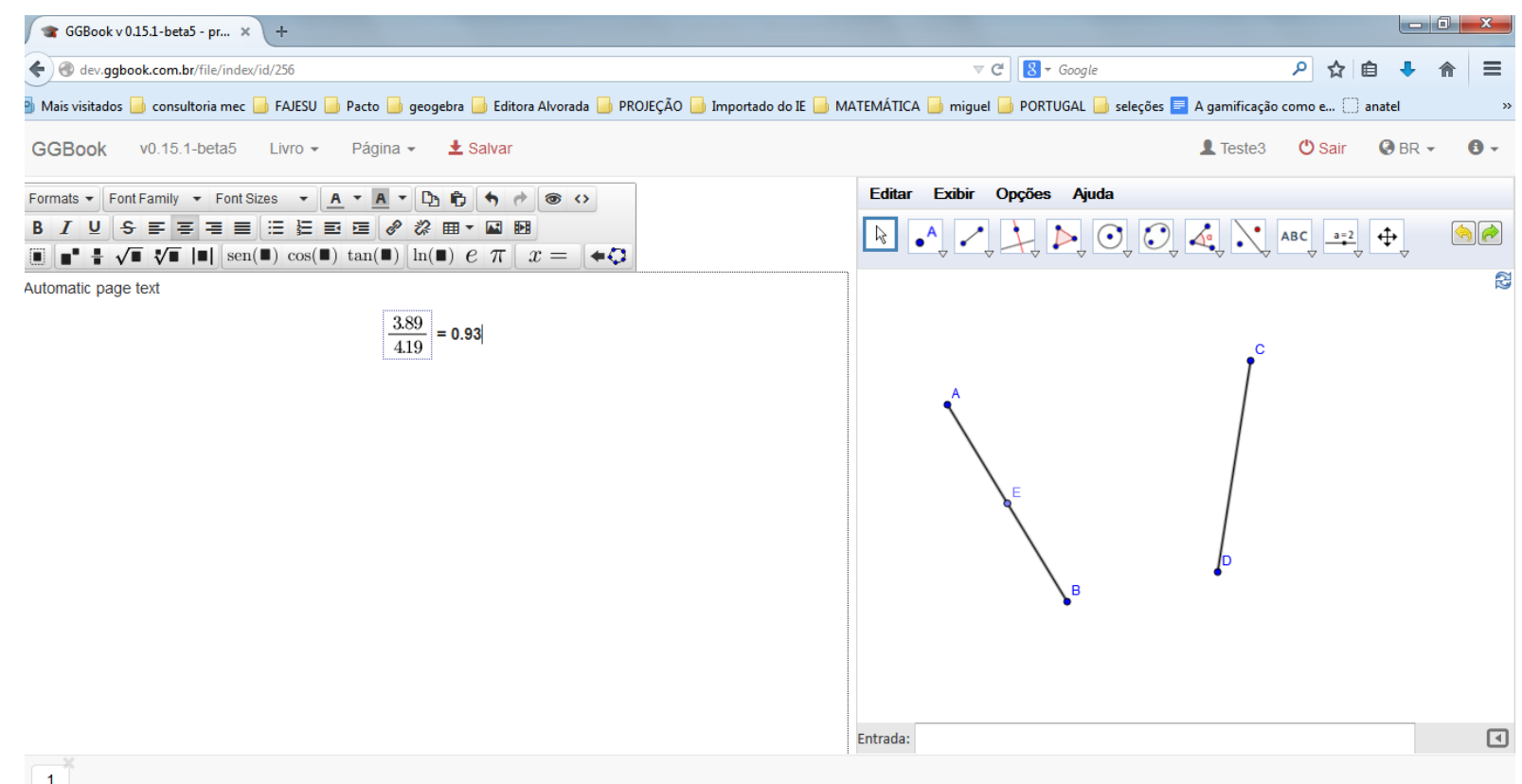

Figura 53-Exemplo de fazer uma operação na plataforma GGBOOK

Depois, o usuário pode arrastar os pontos A, B, C ou D para visualizar as alterações nas medidas dos segmentos. 
Para inserir uma nova página, o usuário deve clicar em Página e depois em Novo. Para criar novos livros, deve clicar em Livro e depois Novo. A função de compartilhamento não estava funcionando de maneira estável. Dessa forma, para a experimentação, achamos melhor retirá-la da versão.

Após a finalização do processo de desenvolvimento, partimos para a experimentação. No tópico seguinte, apresentaremos a metodologia para validação da plataforma.

\subsection{Proposta metodológica para validação do software}

Estávamos interessados em analisar as possibilidades de construção de Narrativas Matemáticas Dinâmicas a partir das interações realizadas em uma plataforma que integrasse ambientes de texto e gráfico. Entre outras contribuições, acreditávamos que assim poderíamos ter acesso às incompreensões dos estudantes. Assim, achamos que deveríamos investigar o conteúdo de tais narrativas. Dessa forma, optamos pela análise de conteúdo. Para Bardin (2007, p.38),

A análise de conteúdo pode ser considerada como um conjunto de técnicas de análises de comunicações, que utiliza procedimentos sistemáticos e objetivos de descrição do conteúdo das mensagens [...] A intenção da análise de conteúdo é a inferência de conhecimentos relativos às condições de produção e de recepção das mensagens, inferência esta que recorre a indicadores.

De acordo com Moraes (1999), tal proposta ajuda a interpretar mensagens e a atingir uma compreensão de seus significados em um nível que vai além da leitura comum. Permite também ao pesquisador fazer inferências sobre qualquer um dos elementos da comunicação.

Para Franco (2008, p.24):

Toda comunicação é composta por cinco elementos básicos: uma fonte ou emissão; um processo codificador que resulta em uma mensagem e se utiliza de um canal de transmissão; um receptor, ou de detector de mensagem, e seu respectivo processo decodificador.

No caso da nossa pesquisa, o emissor é o estudante, a mensagem foi feita por meio da narrativa que utilizará o computador ou o papel e lápis. O receptor é o professor que é também o pesquisador. Temos interesse em produzir inferências a partir das características do texto da mensagem e os efeitos da forma de comunicação. Evidentemente que os resultados deverão refletir os objetivos da pesquisa e ter como apoio indícios manifestos e capturáveis no âmbito das comunicações emitidas (FRANCO, 2008). 
O ponto de partida da análise de conteúdo é a mensagem:

As mensagens expressam as representações sociais na qualidade de elaborações mentais construídas socialmente, a partir da dinâmica que se estabelece entre a atividade psíquica do sujeito e o objeto do conhecimento. Relação que se dá na prática social e histórica da humanidade e que se generaliza via linguagem. (FRANCO, 2008, p. 12)

Ou seja, em outras palavras, poderíamos dizer que as mensagens são expressas mediante registros de representações semióticas e explicitam as elaborações (representações) mentais.

As fontes de dados para a análise de conteúdo podem ser qualquer material advindo de comunicação verbal (oral ou escrita), tais como, cartas, gravações, entrevistas e vídeos, entre outros. Há também os dados advindos da comunicação videográfica, que é a comunicação mediada preponderantemente pela imagem (figuras, vídeo, construções dinâmicas apresentadas na tela do computador). É importante não desprezar a possibilidade de se analisar o conteúdo "oculto" das mensagens e das entrelinhas, o que nos encaminha para além do que pode ser identificado, quantificado e classificado para o que pode ser decifrado mediante códigos especiais e simbólicos. Nesse sentido, é importante levar em consideração os contextos sociais e históricos nos quais foram produzidos (FRANCO, 2008). Além disso, para interpretar é preciso complementar com o que os alunos dizem ou mal dizem (DUVAL, 2011).

No caso desta pesquisa, a principal fonte de dados foi obtida das produções das atividades feitas pelos estudantes do curso de Licenciatura em Matemática de uma faculdade particular do Distrito Federal. Mais à frente explicaremos mais detalhadamente as atividades.

Franco (2008) alerta que a análise de conteúdo requer que as descobertas tenham relevância teórica. Nesse sentido, é importante que um dado sobre o conteúdo de uma mensagem deve, necessariamente, estar relacionado no mínimo a outro dado. Tal relação deve ser representada por alguma forma de teoria. Assim, “[...] toda análise de conteúdo implica comparações contextuais" (FRANCO, 2008, p. 16). Os tipos de comparações podem ser multivariados, sendo direcionados a partir da sensibilidade, intencionalidade e competência teórica do pesquisador. No caso desta pesquisa, fizemos relações entre conteúdos advindos de diferentes fontes de mensagens (registros escritos, simbólicos e visuais) em diferentes ambientes: dinâmico e estáticos. Em outras palavras, fizemos comparações entre as mensagens advindas de narrativas feitas no papel e no GGBOOK.

De acordo com Moraes (1999) a análise de conteúdo constitui-se de 5 etapas: 
1 - Preparação das informações. Tal etapa consiste na leitura do material e seleção daquilo que é efetivamente necessário para a pesquisa, ou seja, aquilo que é de fato representativo e pertinente aos objetivos da análise;

2 - Unitarização ou transformação do conteúdo em unidades. Tal etapa consiste na releitura do material com a finalidade de definir as unidades de análise (palavras, frases, documentos, desenhos, etc), obtendo mensagens divididas em elementos menores;

3 - Categorização ou classificação das unidades em categorias. Tal etapa consiste em agrupar os dados, considerando o que há de comum entre eles, ou seja, a redução ou síntese dos dados;

4 - Descrição. Tal etapa consiste em comunicar o resultado;

5 - Interpretação. Tal etapa consiste na realização de uma compreensão mais aprofundada do conteúdo das mensagens, indo além da mera descrição.

Franco (2008, p. 29) fala da importância da inferência:

Se a descrição (a enumeração das características do texto, resumida após tratamento) é a primeira etapa necessária e se a interpretação (a significação concedida a estas características) é a última fase, a inferência é o procedimento intermediário, que vem permitir a passagem, explícita e controlada, da descrição à interpretação.

É importante ressaltar que para o desenvolvimento da primeira etapa, no qual fizemos a leitura e seleção do material, usamos mecanismos que gravam tudo que estava sendo feito na tela do computador. Também filmamos as atividades que foram feitas no ambiente estático. Acreditamos que isso facilitaria o processo de inferência, sobretudo porque poderíamos ter acesso ao histórico da execução das atividades pelos estudantes.

\subsubsection{Procedimentos}

Como procedimento para coleta de dados, fizemos experimentos de ensino compostos por sequências de sessões que ocorreram entre o professor (pesquisador) e os estudantes, contendo atividades relacionadas com o tema em pesquisa. Inicialmente, realizamos um experimento piloto com os estudantes com o propósito de prepará-los para o uso do GGBOOK. Com isso pudemos também verificar indicadores de usabilidade do GGBOOK, identificando elementos que evidenciassem possibilidades de criação de atividades, registros, representações e construções dos conceitos matemáticos. Além disso, foi também uma oportunidade de identificarmos uma falha no ambiente: em alguns casos, o resultado das divisões feitas no ambiente texto não ficavam salvas corretamente quando a plataforma era 
fechada e aberta novamente. Assim, decidimos que faríamos o experimento de forma presencial no laboratório de informática. Nesse caso, não haveria necessidade de fechar e abrir a plataforma.

Em relação à escolha dos estudantes que participariam da amostra, optamos por fazer o experimento com estudantes do $2^{\mathrm{a}}$ período do curso de Licenciatura em Matemática. $\mathrm{O}$ principal requisito para a escolha dos estudantes ${ }^{27}$ era não saber o conteúdo que seria abordado ou ao menos não lembrar claramente. Colocamos os estudantes em uma situação em que teriam que desenvolver uma sequência de atividades matemáticas em dois ambientes diferentes. Em determinado momento das atividades deveriam produzir uma explicação escrita, usando diferentes tipos de representações. A produção da Narrativa Matemática se daria ao longo de todas as atividades. O conteúdo explorado foi o de trigonometria, mais especificamente, a Lei dos Senos. Escolhemos tal conteúdo porque, para a sua compreensão, é ainda mais evidente a necessidade da utilização de múltiplos registros de representação semiótica. Além disso, tal conteúdo permite também a construção da narrativa, usando diferentes tipos de representações, além da reflexão, argumentação e expressão.

Para a experimentação, a amostra de 10 estudantes foi dividida em dois grupos:

- $\mathrm{O} 1^{\circ}$ grupo fez a atividade usando o GGBOOK; e

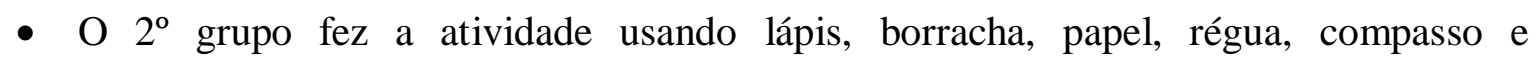
calculadora.

Basicamente, o motivo pelo qual optamos por dois grupos foi o fato de querermos comparar e identificar diferenças entre as Narrativas Matemáticas feitas no GGBOOK e no Papel:

- De que forma esses diferentes ambientes influenciariam a construção das narrativas? De que forma essas diferenças influenciariam a compreensão do professor sobre as narrativas feitas pelos estudantes? Como elas poderiam influenciar na aprendizagem dos conceitos estudados? De que forma eles permitiriam o tratamento e conversões entre os registros? De que forma elas permitiriam a identificação das unidades de sentido?

- De que forma elas possibilitariam “[...] a exploração de todas as variações possíveis de uma representação num registro fazendo prever, ou observar, as variações concomitantes de representação em outro registro"? (DUVAL, 2011, p.101).

\footnotetext{
${ }^{27}$ No capítulo seguinte falaremos mais sobre o perfil dos estudantes.
} 
Tínhamos algumas primeiras hipóteses. O grupo que usaria papel, lápis, régua e calculadora faria Narrativas Matemáticas Estáticas e acreditávamos que, em algum momento, deveríamos perceber algumas dificuldades dos estudantes na compreensão dos conceitos. Tais dificuldades seriam influenciadas ou geradas pelo fato de as atividades cognitivas de formação, tratamento e conversão dos diferentes registros de representações serem mais difíceis de efetivar com tais recursos. Acreditamos que com tais recursos fica difícil perceber as relações entre as representações. Os recursos serviriam mais para comunicar do que para "tomar consciência" (objetivação). Em relação ao outro grupo, acreditávamos que os estudantes fariam Narrativas Matemáticas Dinâmicas. Poderíamos ver a integração dinâmica das diferentes representações influenciando a compreensão dos conceitos estudados.

Com as primeiras análises das atividades de cada grupo determinamos dois conjuntos de categorias: Aprendizagem dos Conceitos Matemáticos e Produção das narrativas nos dois ambientes.

Para analisarmos a categoria Aprendizagem dos Conceitos Matemáticos consideramos as seguintes questões:

- É possível para o estudante perceber as relações entre as representações?

- De que forma os aspectos dinâmico e estático influenciaram (ou não) na compreensão e resolução das atividades?

- É possível perceber o processo de construção da narrativa influenciando na compreensão dos conceitos estudados? Ou seja, queríamos verificar se a representação auxilia na construção da compreensão e não apenas para a comunicação.

- Houve tomada de consciência (objetivação) com relação aos conceitos matemáticos? Quais?

- Como os estudantes lidam com os fenômenos de congruência e não congruência nos diferentes ambientes?

- Como os estudantes agem numa situação de heterogeneidade de conversão? Qual tipo de conversão é mais difícil para o estudante?

- O ambiente e a forma em que foram apresentadas as atividades contribuíram para uma melhor compreensão do enunciado?

- Por meio da narrativa produzida na atividade 5, é possível identificar os diferentes níveis de ação ${ }^{28}$ em que o estudante está?

${ }^{28}$ Adaptado de Notare (2009) 
Com relação à última questão, estabeleceram-se os seguintes níveis:

- Não sabe fazer, ou seja, não criou a Narrativa Matemática;

- Sabe fazer, mas não demonstra compreender. Ou seja, fez a Narrativa Matemática, com diferentes representações, mas não as integrou coerentemente de forma que evidenciasse a compreensão.

- $\quad$ Sabe fazer, parece compreender, mas não sabe registrar de forma escrita. Ou seja, fez a narrativa, integrou as representações, mas não soube explicar com a representação linguística.

- $\quad$ Sabe fazer, compreende e sabe registrar de forma escrita. Ou seja, fez a narrativa, integrou as representações e soube explicar com a representação linguística.

A análise da categoria Produção das narrativas nos dois ambientes buscou responder as seguintes questões:

- Permitem as três atividades cognitivas: formação, tratamento e conversão?

- De que forma permite a integração entre os diferentes registros de representação do objeto matemático?

- É possível se expressar matematicamente?

- É possível fazer as atividades com diferentes tipos de conversões?

- Há dificuldades de manipulação dos recursos? Quais?

- É possível por meio da narrativa do estudante identificar a "ordem cronológica" em que foi feita? Ou seja, de que forma pode-se perceber o elemento historicidade da narrativa produzida pelo estudante? Isso influencia a compreensão da narrativa por parte do professor?

- O ambiente contribui ou dificulta a identificação, por parte do estudante, das unidades de sentido dos diferentes registros?

- De que forma as funcionalidades do GGBOOK superam alguns limites do GeoGebra? Com isso esperávamos responder nossa questão de pesquisa.

No tópico seguinte, falaremos das atividades que foram elaboradas para a experimentação.

\subsubsection{Atividades para a Experimentação}

De maneira geral, as atividades elaboradas para a experimentação foram feitas, seguindo a recomendação de Duval (2008, p. 24): 
Os métodos a serem utilizados numa pesquisa são sempre relativos à natureza dos fenômenos a estudar [...] os fenômenos cognitivos reveladores da atividade matemática concernem à mobilização de vários registros de representação semiótica e à conversão dessas representações. É preciso, então, desenvolver um método que permita observar verdadeiramente esses fenômenos nas produções dos alunos (...) é necessário distinguir cuidadosamente o que sobressalta no tratamento em um registro e aquilo que sobressalta em uma conversão, esta consistindo em uma simples mudança de registro ou em uma mobilização em paralelo de dois registros diferentes.

As tarefas que elaboramos foram, basicamente, do tipo "tarefas de reconhecimento". Duval (2011) diz que a escolha das tarefas de reconhecimento é feita em função das variáveis cognitivas definidas pelo método de análise das produções matemáticas que visam distinguir as unidades de sentido matematicamente pertinentes no conteúdo da representação. A tarefa de reconhecimento deve ser espontânea e não levar muito tempo. É à margem do reconhecimento espontâneo de que o aluno dispõe que lhe abre ou fecha a porta para novas aprendizagens. Com efeito, a capacidade de iniciativa e do controle na resolução de um problema depende do reconhecimento dos dados colocados no problema, isto é, da discriminação das variações de representações em um ou vários registros.

Outro fator levado em consideração na elaboração das atividades, sobretudo para o ambiente dinâmico, é o fato de o GGBOOK ter sido concebido a partir de uma visão de software educativo que proporciona um deslocamento da ênfase do ensinar para o aprender, cedendo espaço à aprendizagem por livre descoberta, à aprendizagem colaborativa e construtiva que realimentam e redimensionam a prática do professor (LACERDA SANTOS, 2009).

A seguir apresentaremos as atividades que foram exploradas com os estudantes. As atividades estão divididas em páginas tanto no GGBOOK quanto no ambiente estático. $\mathrm{Na}$ medida do possível, buscamos explorar, em cada página da atividade, um tipo de conversão dos registros (Tradução linguística, Tradução matemática, Ilustração, Descrição, Transposição Visual e Transposição Simbólica). Conversões nos dois sentidos, porque isso é necessário para que haja coordenação sinérgica de vários registros. Evidentemente, nem todo conceito permite uma conversão direta. Em muitos casos, há necessidade de uso de uma representação auxiliar para a conversão. Quando isso acontecer, explicaremos os porquês. 


\section{Atividade para o GGBOOK: A Lei dos Senos}

Na página 1 foi apresentada na janela de texto a equação $\frac{a}{\operatorname{sen}(A)}=\frac{b}{\operatorname{sen}(B)}=\frac{c}{\operatorname{sen}(C)}$ e uma solicitação para que os estudantes escrevessem, com as palavras deles, o que achavam que a equação significava. Trata-se de uma situação de monorrepresentação em que um sentido de conversão é imposto. Evidentemente, não se esperava que os estudantes relacionassem tal equação já com a Lei dos Senos. Não há nada na representação simbólica (equação) que possa fazê-los perceber que os caracteres "a", "b" e "c", "A", "B" e "C" estão relacionados com os lados e ângulos internos de um triângulo. O que achávamos mais provável era que eles escrevessem da maneira como fazem a leitura da equação. Na Tabela 7, apresentamos uma hipótese que tínhamos em relação a como os estudantes relacionariam as unidades de sentido em cada registro de representação.

\begin{tabular}{|l|c|c|}
\hline \multicolumn{1}{|c|}{ Registros } & $\begin{array}{c}\text { Registro de representação } \\
\text { simbólica }\end{array}$ & $\begin{array}{c}\text { Registro de } \\
\text { representação } \\
\text { linguística }\end{array}$ \\
\hline $\begin{array}{l}\text { Signos (ou } \\
\text { unidades de } \\
\text { sentido) }\end{array}$ & a & A \\
\hline $\begin{array}{l}\text { Signos (ou } \\
\text { unidades de } \\
\text { sentido) }\end{array}$ & - & Dividido \\
\hline $\begin{array}{l}\text { Signos (ou } \\
\text { unidades de } \\
\text { sentido) }\end{array}$ & $\operatorname{sen}(\mathrm{A})$ & Seno de A \\
\hline Representações & $\frac{a}{\operatorname{sen}(A)}$ & $\begin{array}{c}\text { a dividido por seno de } \\
\text { A }\end{array}$ \\
\hline
\end{tabular}

Tabela 5-Possível relação entre as unidades de sentido que os estudantes fariam na atividade 1

Dessa forma, $\frac{a}{\operatorname{sen}(A)}$ é "a dividido por seno de A". Assim, escreveriam "a dividido por seno de A é igual a b dividido por seno de B e é igual c dividido por seno de C". Olhando dessa forma, a equação é transparente ${ }^{29}$, pois quase se pode ver através dela qual o enunciado que se deve escrever. Assim, seriam representações congruentes. Poderiam achar estranho os 2 sinais de igualdade na equação, porque isso não é comum no registro de representação algébrico. A representação $\frac{a}{\operatorname{sen}(A)}=\frac{b}{\operatorname{sen}(B)}$ também poderia ser lida "a e b são proporcionais

\footnotetext{
${ }^{29}$ Termo usado por Duval (2011).
} 
ao seno de A e seno de B". Todavia, a palavra "proporcionais" não pode ser lida diretamente na equação, porque não há uma unidade de sentido explícita na representação algébrica que corresponda à "proporcional". Assim, era preciso combinar duas unidades significantes = (igual) e --- (dividido) para suprir tal ausência. Nesse caso, tratava-se de um caso de nãocongruência das representações.

Na página $2^{30}$ foi apresentado o registro de representação linguística da lei dos senos "Em todo triângulo, as medidas dos lados são proporcionais aos senos dos ângulos opostos" e uma solicitação para que o estudante escrevesse o que leu, usando símbolos matemáticos. Mais um caso de monorrepresentação, mas que agora trata da conversão inversa em relação à atividade da página anterior. Nessa atividade, acreditávamos que os estudantes sentiriam necessidade de fazer um registro de uma representação auxiliar (a figura de um triângulo). Mais especificamente, acreditávamos que sentiriam falta de uma representação mista (um triângulo com as medidas dos lados e ângulos representadas). Afinal, qual unidade significante no registro simbólico corresponderia à unidade significante "triângulo" do registro de representação linguístico? Quais unidades significantes no registro simbólico corresponderiam às unidades significantes "medidas dos lados" e "senos dos ângulos opostos" do registro de representação linguístico? Assim como na atividade anterior, esperava-se que os estudantes tivessem dificuldades com a unidade de sentido "proporcionais".

Como preparar atividades para a lei dos senos de forma que contemplassem as operações de conversão "Ilustração", "Descrição", "Transposição Visual” e "Transposição Simbólica"? Primeiramente, vamos analisar a Ilustração. Como fazer a conversão de um registro de representação linguístico de tal teorema diretamente para um registro de representação visual? Mesmo que usássemos uma representação mista com um triângulo e suas medidas de lados e ângulos internos, não seria possível converter o registro de representação linguístico para o registro de representação visual de forma que se possa representar exatamente o que o conceito quer dizer. Vejamos a Tabela 8 seguinte:

\footnotetext{
${ }^{30}$ Para alguns estudantes mudamos a ordem das atividades 1 e 2 , porque queríamos ver de que forma as conversões inversas seriam influenciadas.
} 


\begin{tabular}{|c|c|c|}
\hline Registros & $\begin{array}{c}\text { Registro de } \\
\text { representação } \\
\text { linguístico }\end{array}$ & Registro de representação visual \\
\hline Signos (ou unidades de sentido) & Triângulo & \\
\hline Signos (ou unidades de sentido) & Medidas & \\
\hline Signos (ou unidades de sentido) & Lados & \\
\hline Signos (ou unidades de sentido) & Proporcionais & \\
\hline Signos (ou unidades de sentido) & Senos & \\
\hline Signos (ou unidades de sentido) & $\begin{array}{c}\text { Ângulos } \\
\text { medidas dos lados são } \\
\text { senos dos ângulos } \\
\text { opostos }\end{array}$ & \\
\hline & & \\
\hline
\end{tabular}

Tabela 6-Conversão Ilustração da Lei do Senos 
Quais unidades de sentido no registro de representação visual corresponderiam às unidades de sentido do registro de representação linguístico "medidas", "proporcionais", "senos" e "opostos"? Mesmo que se fizesse uma representação mista no registro de representação visual, integrando símbolos e figuras, ainda assim não seria possível fazer corresponder os dois registros de representação de forma que ambas pudessem mostrar o mesmo conceito.

Agora vejamos o caso da conversão "Descrição", que trata da conversão do registro de representação visual para o registro de representação linguístico. Como fazer uma figura que, pura e simplesmente, represente a lei dos senos? Como fazer uma figura em que o estudante ao vê-la possa escrever "Em todo triângulo, as medidas dos lados são proporcionais aos senos dos ângulos opostos"? Perguntas parecidas poderiam ser feitas para os casos das conversões "transposição Visual" (conversão do registro de representação simbólico para o registro de representação visual) e "transposição simbólica" (conversão do registro de representação visual para o registro de representação simbólica): Como por meio da equação $\frac{a}{\operatorname{sen}(A)}=$ $\frac{b}{\operatorname{sen}(B)}=\frac{c}{\operatorname{sen}(C)}$ o estudante poderia fazer uma figura que a representasse? Como fazer uma figura em que o estudante possa, ao vê-la, fazer a equação $\frac{a}{\operatorname{sen}(A)}=\frac{b}{\operatorname{sen}(B)}=\frac{c}{\operatorname{sen}(C)}$ ? Nesse sentido, acreditamos que existem conceitos, teorema e propriedades em que as representações não podem ser convertidas diretamente. Ou seja, há a necessidade de uso de dois tipos de registros diferentes para que se possa converter para um terceiro. Não se trata apenas de uma representação auxiliar passageira. Nas atividades seguintes, mostraremos isso.

$\mathrm{Na}$ página 3, foi apresentada uma atividade em que aparecia na janela de texto o registro linguístico da lei dos senos e na janela GeoGebra um triângulo com as medidas dos lados e ângulos internos, conforme a Figura 54. 

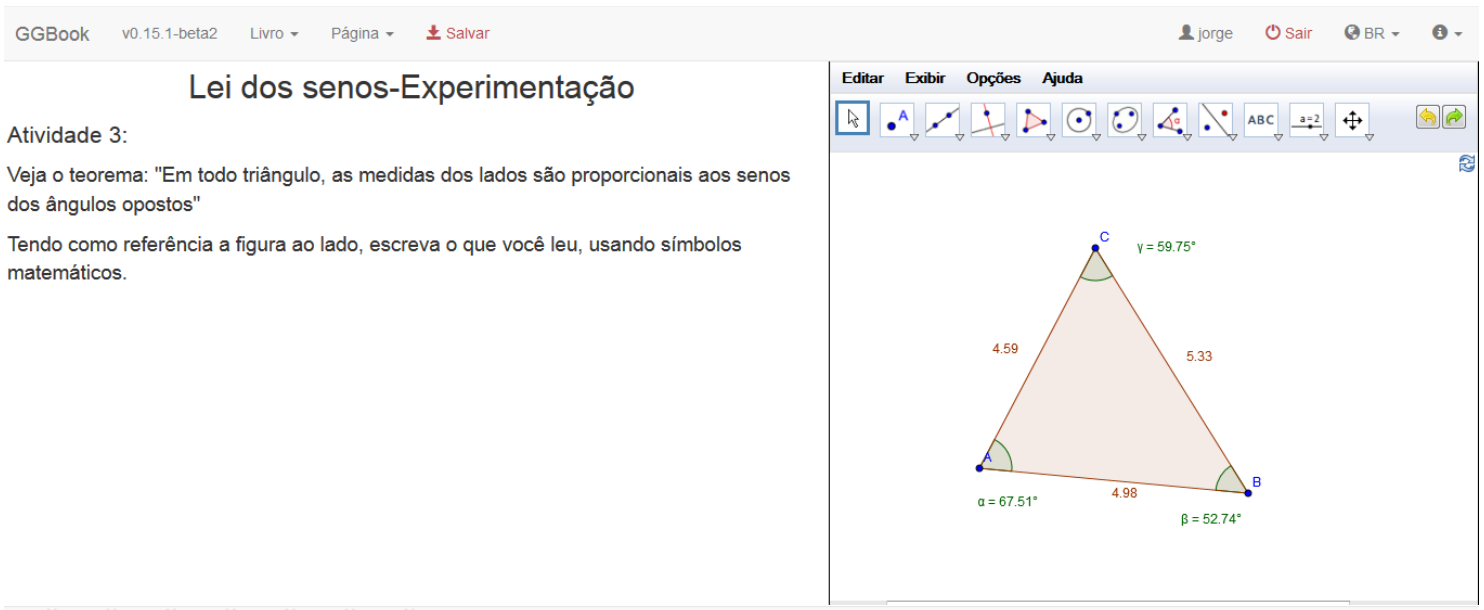

Figura 54-Conversão para o registro simbólico, usando dois registros diferentes

Nessa atividade, o estudante poderia usar o editor de equações não apenas para fazer a representação simbólica. Ele poderia fazer cálculos automáticos. Ou seja, fazer as seguintes razões: $\frac{\mathbf{5 , 3 3}}{\operatorname{sen}(\mathbf{6 2 , 5 1 )}} \mathbf{e} \frac{\mathbf{4 , 5 9}}{\operatorname{sen}(\mathbf{5 2 , 7 4 )}}$ e observar os resultados. Poderia também deformar o triângulo e ver o que aconteceria. Acreditávamos que o estudante relacionaria com as atividades anteriores para fazer a representação simbólica. O que mais estávamos interessados era na conversão para o registro simbólico. A representação visual (triângulo) não pode ser considerada como uma mera representação auxiliar que pode ser desprezada após a compreensão do conceito. Conforme alertamos anteriormente, como a unidade de sentido "triângulo" poderia ser designada na representação simbólica $\frac{a}{\operatorname{sen}(A)}=\frac{b}{\operatorname{sen}(B)}=\frac{c}{\operatorname{sen}(C)}$ ?

Na página 4, foi apresentada uma atividade em que aparecia na janela de texto duas razões que mostravam o mesmo resultado e na janela GeoGebra um triângulo com as medidas dos lados e ângulos internos. Os valores que estão nas razões são medidas de lados e ângulos do triângulo da janela do GeoGebra, conforme Figura 55. 


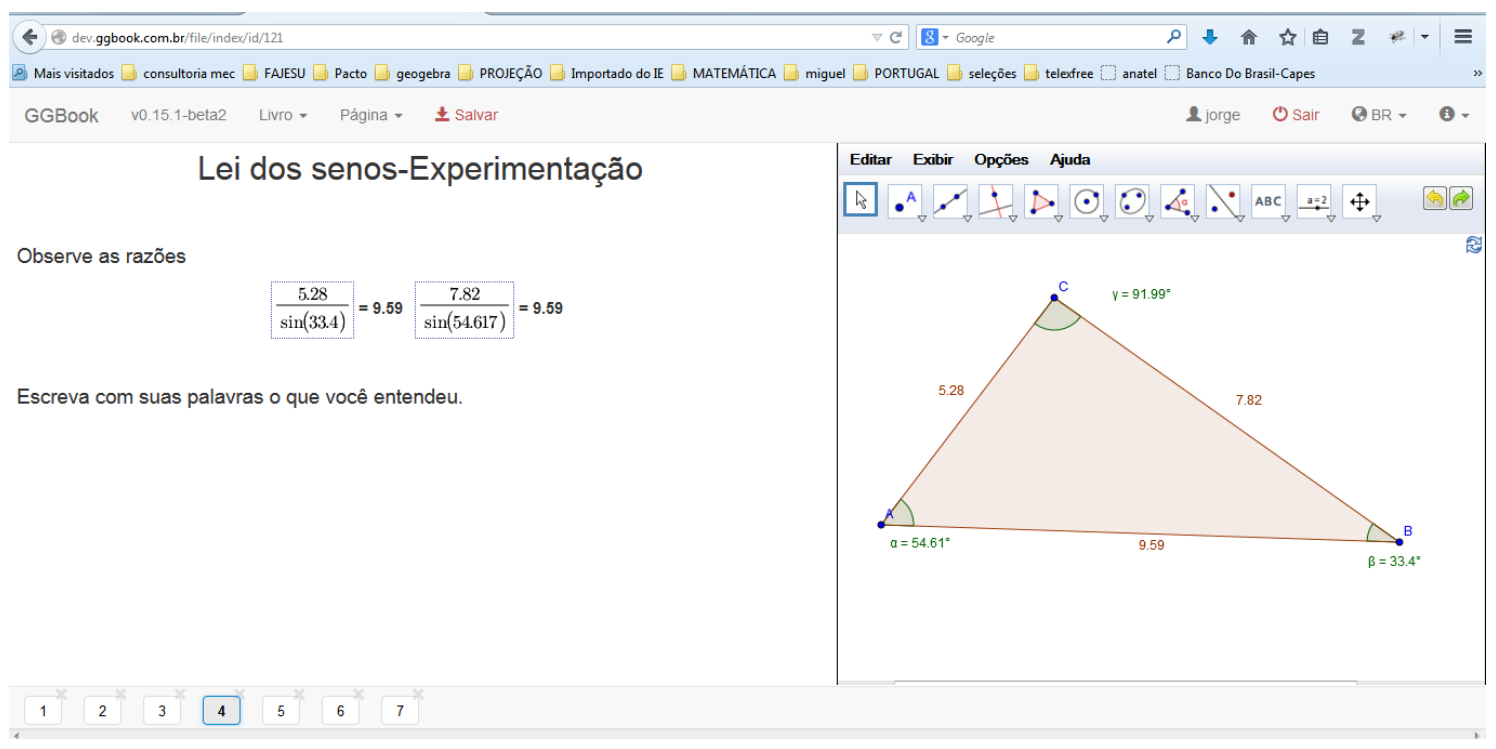

Figura 55-Conversão para o registro de representação linguístico, usando dois registros diferentes

Era provável que o estudante escrevesse algo que mostrasse que havia percebido que as razões eram iguais. Porém, será que perceberia que tais razões estavam relacionadas com lados e ângulos opostos? Faria a terceira razão? Usaria a palavra "proporcional"? Nessa página, há algo especial: o estudante poderia fazer tratamentos nos registros simbólico e visual, ou seja, ao movimentar os vértices do triângulo, mudaria as medidas de lados e ângulos do triângulo. Isso, por sua vez, alteraria as razões, ocasionando pequenas transformações (tratamentos) no registro simbólico. Tal procedimento seguiu a regra de interpretação sugerida por Duval $(2008$, p.26) “[...] as únicas variações de representações que são cognitivamente importantes no registro de partida são aquelas que provocam uma modificação da representação concomitante no registro de chegada, porque isso implica um novo objeto denotado". Assim, se o estudante apenas deslocasse (transladasse) o triângulo, nada aconteceria com a representação simbólica. Isso seria uma variação cognitivamente neutra.

Na página 5, foi apresentada a última atividade para a compreensão da Lei dos Senos. Nela, os estudantes deveriam dizer o que entenderam sobre a Lei dos Senos, usando três registros de representação. Supúnhamos que eles integrariam de maneira dinâmica os registros de representação visual e simbólico, explicitando assim, as principais características do que chamamos de Narrativa Matemática Dinâmica. 


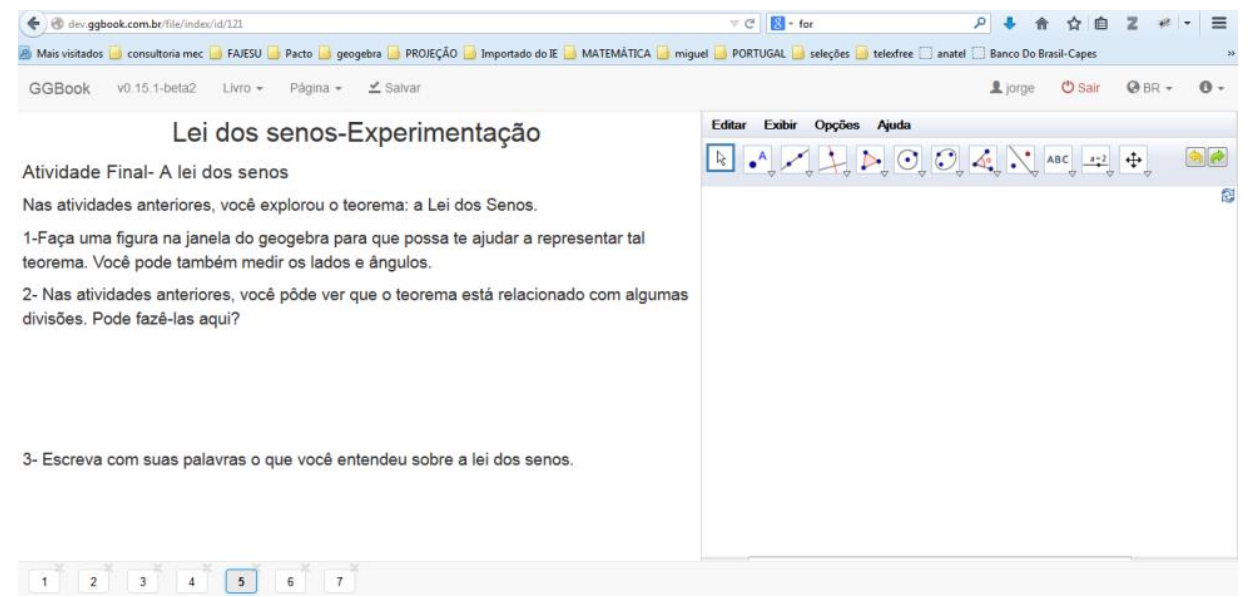

Figura 56-Atividade para a produção da Narrativa Matemática sobre a lei dos Senos

Na página 6 (Figura 57), foi apresentada uma atividade para introduzir a justificativa sobre a Lei dos Senos. Nela, os estudantes deveriam dizer o que era o seno e o que era o seno de um dos ângulos internos de um triângulo apresentado na tela do GeoGebra. Não se tratava de calcular o seno do ângulo, mas dizer o que é. Esperávamos que o estudante relacionasse com as unidades de sentido "cateto oposto" e "hipotenusa". Acontece que o triângulo não era retângulo e as unidades de sentido não estavam explícitas na figura. Tentariam construir algo a mais no registro de representação visual? Considerariam o lado oposto como cateto oposto?

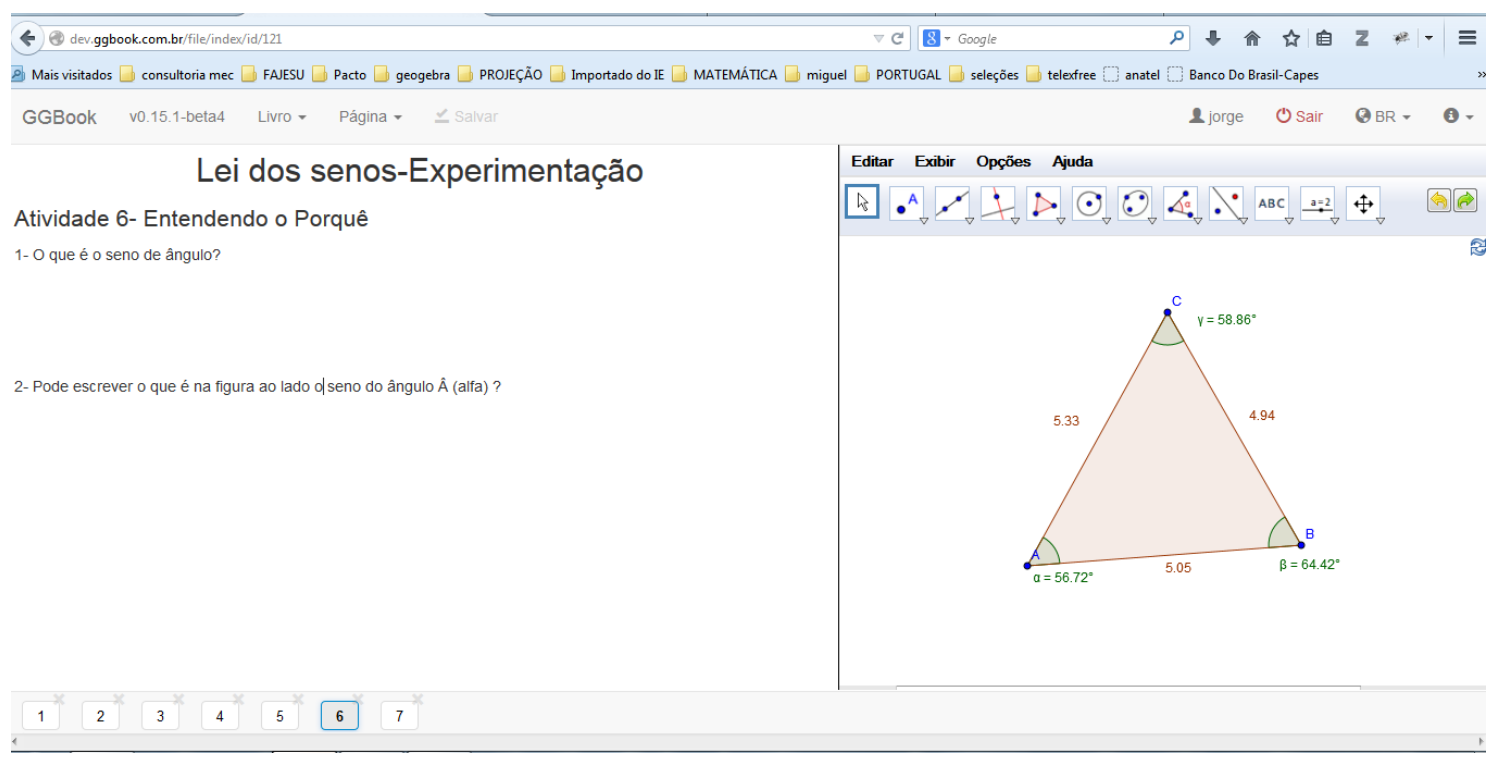

Figura 57-Atividade para a justificativa da lei dos Senos

Na página 7 (Figura 58) foi apresentada uma construção na janela do GeoGebra em que poderiam visualizar uma altura do triângulo. Esperávamos com isso que eles pudessem identificar dois triângulos retângulos na mesma figura. Esse é o modo de ver matemático para 
a demonstração da Lei dos Senos. Na janela de texto, foi pedido para os estudantes dizerem o que era o seno de A e seno de B.

Tratava-se de uma necessidade implícita de uma operação discursiva de designação verbal das unidades figurais (hipotenusa e cateto oposto), sendo necessário relacioná-las com a operação de divisão. Pode-se ver (Figura 58) que a unidade entre as instruções 2 e 3 é assegurada pela dupla designação verbal de uma mesma unidade figural (g que representa o cateto oposto), ou seja, pelo mecanismo de expansão discursiva que Frege descreveu para explicar o funcionamento dos encaminhamentos do pensamento matemático (DUVAL, 2011).

As instruções 2 e 3 eram para que fizessem um tratamento nas equações de forma a obter uma equação para $\mathrm{g}$ em função de a e seno de A e outra equação para $\mathrm{g}$ em função de $\mathrm{b}$ e seno de B. Esperava-se com isso que eles percebessem que a.sen(B) é igual a $b \cdot \operatorname{sen}(A)$. Mas não sabíamos se os estudantes fariam algum tratamento nos registros de representação algébrico de forma a obter $\frac{b}{\operatorname{sen}(B)}=\frac{c}{\operatorname{sen}(C)}$ ?

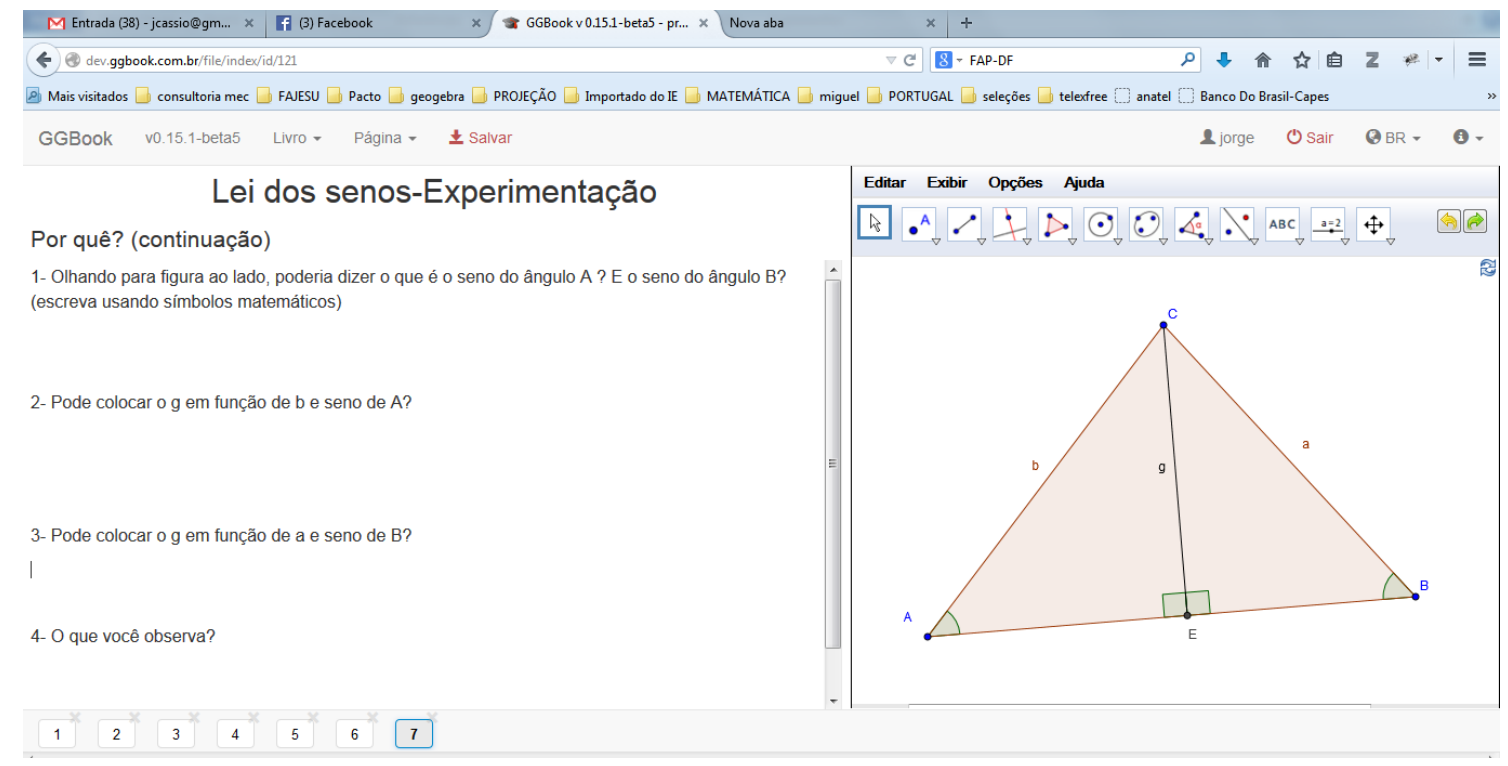

Figura 58-Atividade para a continuação da justificativa da lei dos Senos

Não propomos mais uma atividade para a conclusão da justificativa, porque queríamos saber se o estudante já estaria convencido ou se sentiria falta da igualdade com a outra razão. Caso isso acontecesse, solicitaríamos que ele buscasse justificar em outra página do GGBOOK. Nesse caso, ele teria que explicitar todas as representações, inclusive a figura que não estaria feita. Isso evidenciaria a compreensão da justificativa.

A seguir, apresentaremos as atividades para o ambiente estático. 


\section{Atividades para o ambiente estático: a Lei dos Senos}

Praticamente, foram repetidas as mesmas atividades do GGBOOK. Mas, neste caso, foram usados papel, lápis, régua e calculadora. Na página 1, foi colocada a seguinte atividade:

Considere a equação $\frac{a}{\operatorname{sen}(A)}=\frac{b}{\operatorname{sen}(B)}=\frac{c}{\operatorname{sen}(C)}$. Escreva, com suas palavras, o que acha que a equação significa.

Assim como relatamos na atividade para o GGBOOK, não esperávamos que os estudantes relacionassem tal equação já com a Lei dos Senos, porque não havia nada na representação simbólica (equação) que pudesse fazê-los perceber que os caracteres "a", "b" e "c", "A", "B" e "C" estavam relacionados com os lados e ângulos internos do triângulo. O que seria mais provável era que eles escrevessem da maneira como fazem a leitura da equação. A atividade trata de um caso de não congruência das representações. Para essa atividade não esperávamos muitas diferenças influenciadas pelo tipo de ambiente em que foi trabalhado. Até porque mesmo no ambiente GGBOOK a atividade não solicita uma integração dinâmica das representações.

Na página 2, colocamos a atividade:

Considere o seguinte teorema: "Em todo triângulo, as medidas dos lados são proporcionais aos senos dos ângulos opostos". Escreva o que você leu, usando símbolos matemáticos.

Assim como na atividade para o GGBOOK, acreditávamos que os estudantes sentiriam necessidade de fazer uma representação visual (a figura de um triângulo). Mais especificamente, sentiriam falta de uma representação mista (um triângulo com as medidas dos lados e ângulos representadas). Isso pelos mesmos motivos que relatamos anteriormente na atividade para o GGBOOK. Todavia, o ambiente para a resolução da atividade pode influenciar o desenvolvimento, já que no ambiente GGBOOK há o GeoGebra que permite fazer o triângulo, medir lados e ângulos, além do editor de equações na janela texto. $\mathrm{O}$ processo de construção de um triângulo, medição de lados e ângulos são diferentes no ambiente estático e dinâmico. 
Na página 3, colocamos a atividade:

Considere o Teorema: Em todo triângulo, as medidas dos lados são proporcionais aos senos dos ângulos opostos". Tendo como referência a figura abaixo, escreva usando símbolos matemáticos, o que você leu.

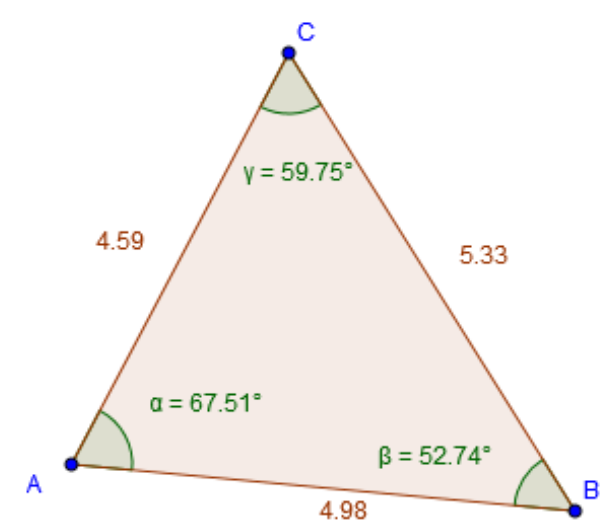

Nessa atividade, diferentemente da do GGBOOK, o estudante não tem um editor de equações para fazer a representação simbólica. Até aí não há muita diferença entre os dois ambientes, mas no GGBOOK há a possibilidade de resposta automática para os cálculos. Ou seja, no ambiente estático, para obter os resultados das razões $\frac{5,33}{\operatorname{sen}(62,51)} \boldsymbol{e} \frac{4,59}{\operatorname{sen}(52,74)}$, o estudante terá que usar a calculadora. Com isso, poderiam perceber que as razões eram iguais, mas se quisessem ver com outro triângulo, teriam que desenhar, medir os lados e ângulos e fazer os cálculos.

Na página 4, colocamos a atividade:

Considere a figura e os cálculos seguintes:

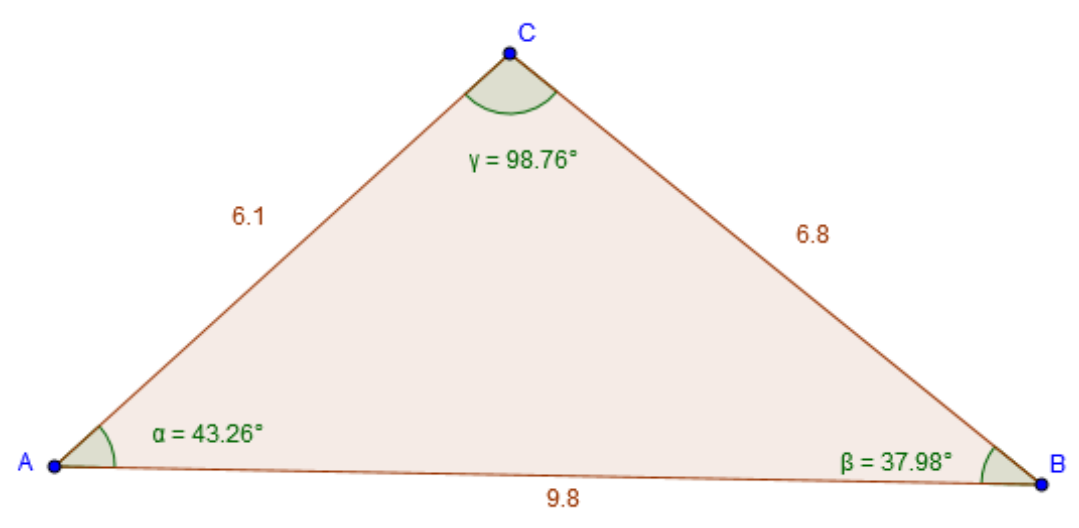

$$
\frac{6,8}{\operatorname{sen}(43,26)}=9,92 \text { e } \frac{9,8}{\operatorname{sen}(98,76)}=9,92
$$


Escreva com suas palavras o que você entendeu.

Assim como relatamos na atividade para o GGBOOK, acreditávamos que o estudante escreveria algo que mostrasse que percebeu que as razões eram iguais. Porém, perceberia que tais razões estavam relacionadas com lados e ângulos opostos? Faria a terceira razão? Usaria a palavra "proporcional"? No ambiente GGBOOK, o estudante podia movimentar os vértices do triângulo, mudando as medidas de lados e ângulos do triângulo. Isso, por sua vez, alteraria as razões, ocasionando pequenas transformações (tratamentos) no registro simbólico. No ambiente estático não poderia fazer isso. Acreditávamos que o estudante poderia ter mais dificuldade para perceber a relação entre as representações sem a integração dinâmica.

As atividades das páginas 5 foram as seguintes:

Nas atividades anteriores, exploramos a Lei dos Senos.

1-Faça uma figura que possa te ajudar a representar tal teorema. Você pode também medir os lados e ângulos.

2- Nas atividades anteriores, você pôde ver que o teorema está relacionado com algumas divisões. Pode fazê-las aqui?

3- Escreva com suas palavras o que você entendeu sobre a Lei dos Senos.

Nessa atividade, os estudantes deveriam dizer o que entenderam sobre a Lei dos Senos, usando três registros de representação. Supomos que eles tentariam integrar os registros de representação visual e simbólico para poder produzir um registro de representação linguístico que mostrasse o que entenderam sobre a Lei dos Senos. Todavia, os procedimentos não seriam os mesmos do ambiente GGBOOK, porque o processo de construção de um triângulo no GeoGebra é diferente do que é feito num ambiente lápis e papel. No papel, pode-se tratar de uma simples reprodução de um desenho já visto anteriormente. Além disso, o processo de representação das equações é mais rápido do que no ambiente GGBOOK. Por outro lado, a principal diferença que esperávamos para essa atividade era em relação a como a não integração dinâmica das representações poderia influenciar na identificação das incompreensões dos estudantes.

As instruções da atividade da página 6 foram iguais à apresentada anteriormente para o GGBOOK.

Considere a seguinte figura 


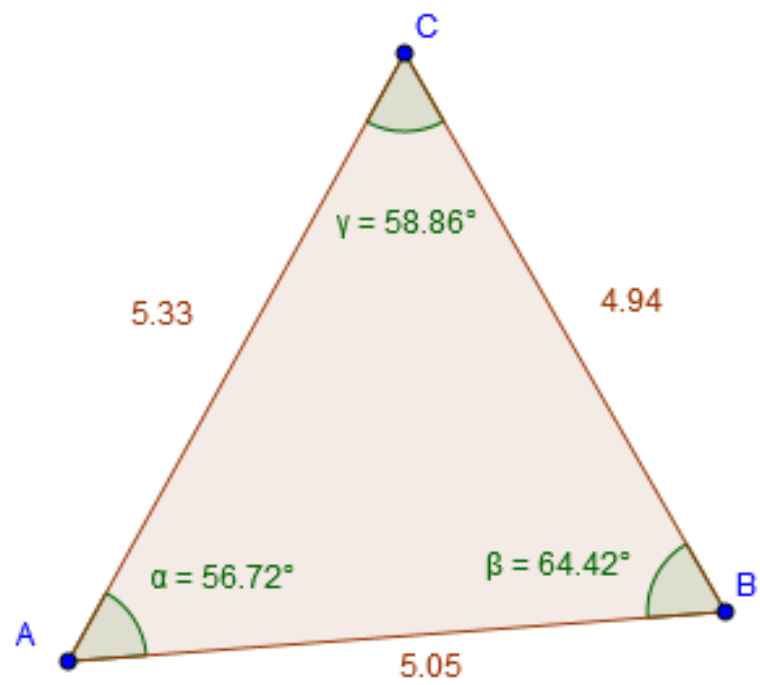

1- O que é o seno de ângulo?

2- Pode escrever o que é na figura anterior o seno do ângulo Â (alfa)?

Para essa atividade, não tínhamos hipóteses de diferenças entre os dois ambientes.

Na página 7, colocamos a seguinte atividade:

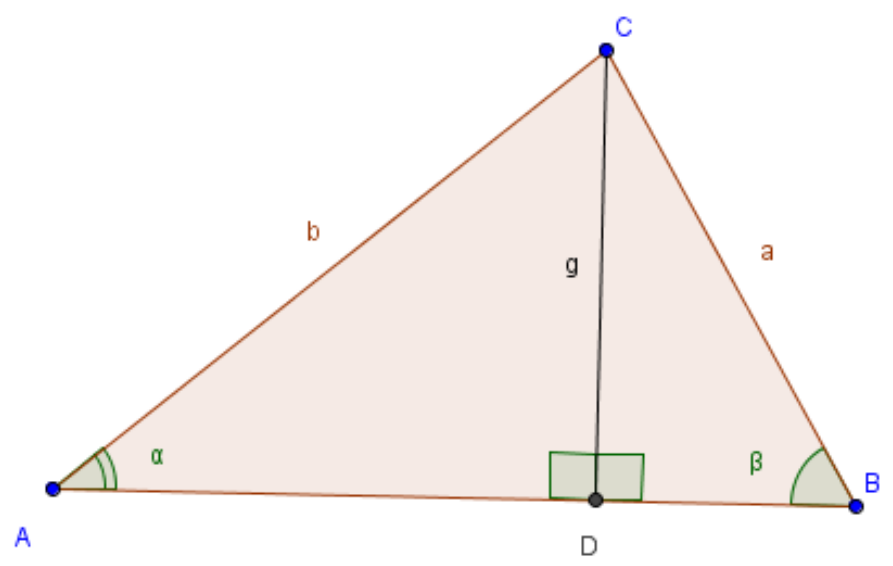

1- Olhando para figura anterior, poderia dizer o que é o seno do ângulo A? E o seno do ângulo B? (escreva usando símbolos matemáticos)

2- Pode colocar o g em função de b e seno de A?

3- Pode colocar o g em função de a e seno de B?

4- O que você observa? 
Nessa atividade foi apresentado um triângulo que poderiam visualizar uma altura. Assim como na atividade do GGBOOK, esperava-se com isso que eles pudessem ver dois triângulos retângulos na mesma figura. Depois, foi pedido para os estudantes dizerem o que era o seno de A e seno de B. Deveriam fazer isso, colocando em função de a, b e g. Depois disso, deveriam fazer um tratamento nas equações de forma a obter uma equação para $\mathrm{g}$ em função de a e seno de A. Depois outra equação para g em função de b e seno de B. Esperavase com isso que eles percebessem que a.sen(B) é igual a b.sen(A). Será que fariam algum tratamento nos registros de representação algébrico de forma a obter $\frac{b}{\operatorname{sen}(B)}=\frac{c}{\operatorname{sen}(C)}$ ? Em relação ao que propomos para o GGBOOK, acreditávamos que os estudantes poderiam fazer mais rapidamente tais atividades, porque a representação simbólica é mais acelerada. 


\section{ANÁLISE E DISCUSSÃO DOS DADOS}

Este capítulo tem o propósito de analisar os dados coletados por meio dos ambientes GGBOOK e estático (papel, lápis, régua e calculadora). Em curtas palavras, a análise tem como finalidade verificar as possibilidades de construção de Narrativas Matemáticas em ambos ambientes. Acreditávamos que as Narrativas Matemáticas desenvolvidas nos dois ambientes teriam características diferentes e isso permitiria a identificação e interpretações diferentes das incompreensões dos estudantes. Lembrando que compreender não é decodificar uma sequência de palavras ou de frases, mas discriminar as unidades de sentido em função dos diferentes níveis de organização dos discursos e eventualmente reformulá-los (DUVAL, 2011).

Nos tópicos seguintes, será apresentado o perfil dos estudantes, a análise do primeiro experimento e das categorias Aprendizagem dos Conceitos Matemáticos e Produção das narrativas nos dois ambientes.

\subsection{Perfil dos estudantes}

Foram convidados para participar da pesquisa 10 estudantes do $2^{\circ}$ semestre de um curso de Licenciatura em Matemática. Desses, 7 participaram de fato de todas as atividades. Com intuito de conhecer melhor o perfil dos estudantes foi aplicado um questionário (quadro 2).

Questionário de Caracterização

Este questionário preservará seu anonimato. As informações de caráter pessoal serão extremamente importantes para a análise de nossos resultados, por isso contamos com sua colaboração.

1) Nome:

2) Formação:

a) Quando concluiu o Ensino Médio?

b) Qual escola?

3) Informações técnicas

a) Já usou algum software educativo para estudar Matemática? Qual?

b) Conhece o Geogebra? Já usou?

4) Informações conceituais

a) Já estudou a Lei dos Senos? Escreva o que sabe sobre a "Lei dos Senos".

Quadro 2: Questionário para o perfil dos estudantes

A partir do questionário, pôde-se constatar que dos 7 participantes: 
- 1 tinha concluído o Ensino Médio em 2013, 1 tinha concluído em 2012, 1 tinha concluído em 2008, 1 em 2007, 1 em 2004 e dois em 2002;

- Todos estudaram em Escolas Públicas;

- Três estudantes nunca haviam usado softwares educativos. Um havia usado o Wolfran Alpha e 3 haviam usado um pouco o Geogebra;

Quanto ao fato de saber algo sobre a Lei dos Senos, tivemos as seguintes respostas ${ }^{31}$ :

- An: Sim. Sei que a partir da Lei dos Senos consigo achar os valores dos lados de um triângulo qualquer (não necessariamente o triângulo retângulo).

- Her: Já. Para calcular a área de um triângulo qualquer.

- Kel: Já. Não lembro quase nada. Vi superficialmente.

- Dio: Não lembro

- Mar: Só sei que o seno é cateto oposto sobre hipotenusa.

- Cley: $\operatorname{Sim} \cdot \operatorname{sen}(\alpha)=\frac{c o}{h}$

- Die: O seno de um ângulo é a divisão do cateto adjascente pela hipotenusa.

Como se pode perceber por meio das respostas, a maior parte dos estudantes tinha o perfil que desejávamos para a pesquisa. A estudante An parece saber para que serve a Lei dos Senos, mas não escreveu nada que mostrasse de fato que sabe o que é tal conceito.

\subsection{O primeiro experimento}

Dez estudantes participaram do primeiro experimento que teve duração de 3 horas. Para que os estudantes pudessem se familiarizar com o GGBOOK, sobretudo a parte GeoGebra da plataforma, foi elaborado um Book no qual seriam explorados os Pontos Notáveis do triângulo (Figura 59).

\footnotetext{
${ }^{31}$ Os nomes foram abreviados para preservar o anonimato.
} 


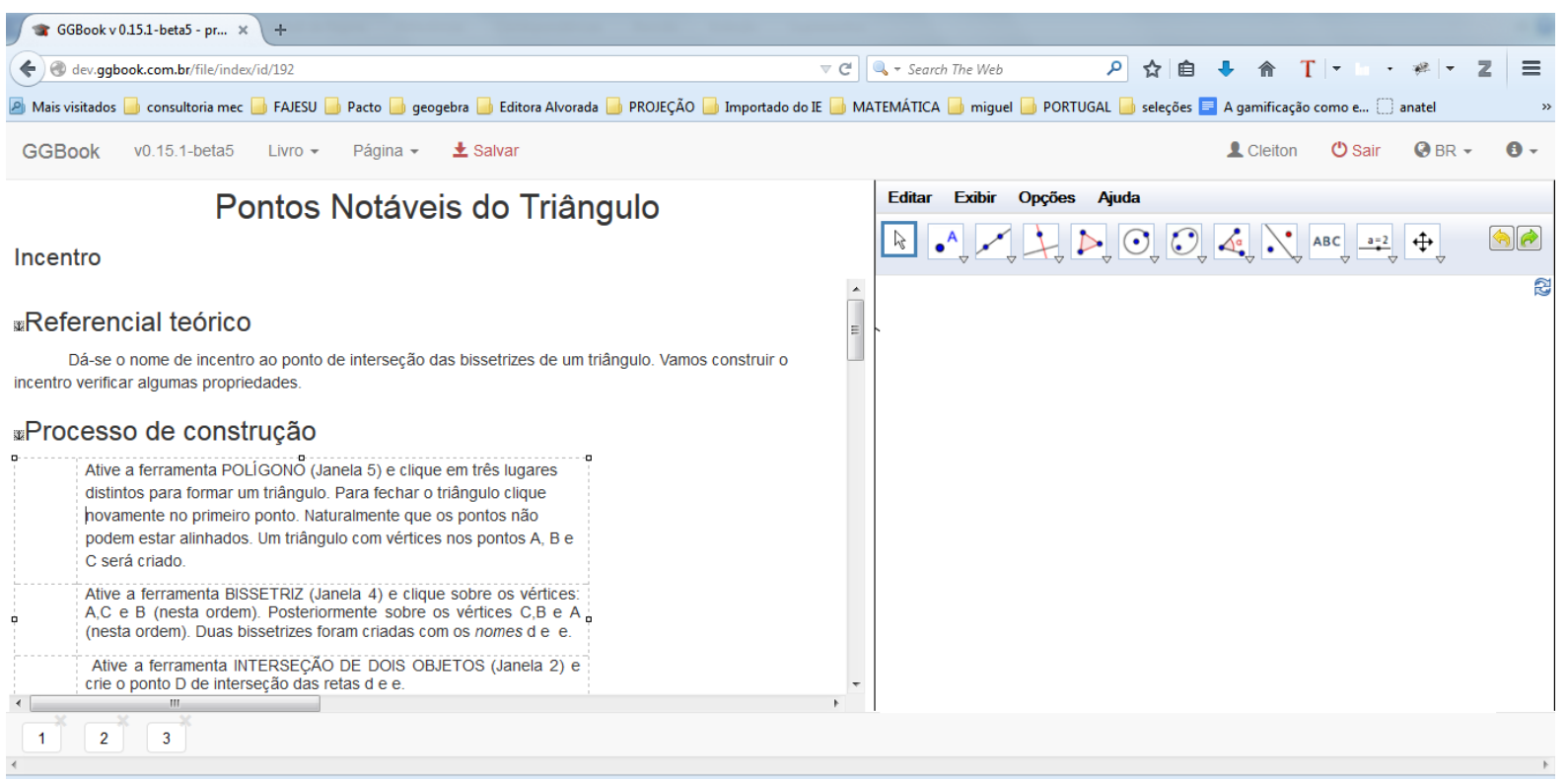

Figura 59-Atividade sobre os Pontos Notáveis do Triângulo

Cada estudante recebeu um login e senha. Ao logar, na primeira página havia o Book "Pontos Notáveis do Triângulo". O BOOK era composto por 3 atividades: a primeira era para explorar o Incentro, a segunda era para explorar o Circuncentro e a terceira para explorar o editor de equações do GGBOOK. Nas duas primeiras atividades, os estudantes precisavam ler as instruções na janela e executar no ambiente GeoGebra. Inicialmente, o professor (pesquisador) foi fazendo junto com os estudantes, depois os estudantes fizeram sozinhos. Não houve maiores dificuldades quanto à execução das duas primeiras atividades, a não ser para criar uma perpendicular. Um erro na utilização da ferramenta é bastante comum. Os estudantes ao lerem o comando Ative a ferramenta RETA PERPENDICULAR (Janela 4), clique no ponto Incentro e no lado $c$ do triângulo (que liga os pontos $A$ e B) muitas vezes acabam achando que precisam clicar em três pontos: no incentro e nos pontos A e B. Em alguns casos, isso pode não fazer diferença, porque o GeoGebra acabará interpretando o segundo clique sobre o ponto A ou B como um clique sobre o segmento AB. Entretanto, se o estudante mudar a ordem e clicar primeiramente nos pontos A ou B, a perpendicular não será criada corretamente.

Na terceira página, para que os estudantes pudessem aprender a usar o editor de equações foi solicitado que criassem, na janela GeoGebra, um triângulo com as medidas dos lados. Depois, deveriam calcular o perímetro e fazer a razão entre dois lados quaisquer (Figura 60). 


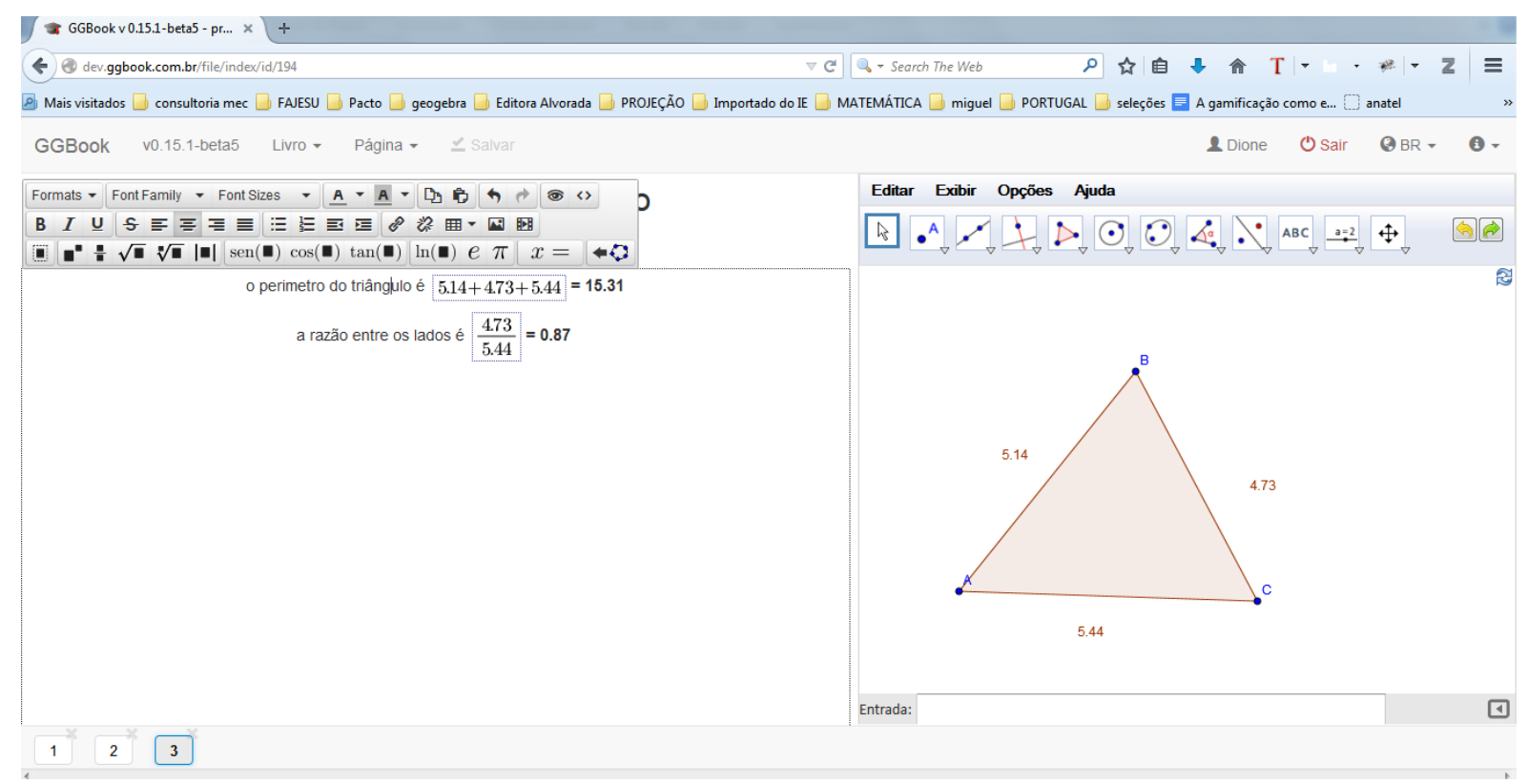

Figura 60-Atividade para explorar o editor de equações

O editor de equações pode ser usado como uma calculadora em que os dados não precisam ser, necessariamente, vindos do ambiente GeoGebra. Ou seja, pode-se calcular $2+3+5$, simplesmente, digitando os valores. Para inserir um valor do GeoGebra no editor de equações é preciso apertar a tecla "Ctrl" e clicar na medida. Às vezes, os estudantes não se atentavam para isso e acabavam não conseguindo fazer alguns cálculos, mas foi uma dificuldade logo superada. Após fazer os cálculos, os estudantes movimentavam os vértices do triângulo e podiam ver as medidas dos lados se alterando na janela GeoGebra e no ambiente texto.

Após esse experimento, combinamos com os estudantes que eles seriam divididos em dois grupos para executarem as próximas atividades. O grupo foi dividido por sorteio e combinou-se o dia para experimentação.

A seguir apresentaremos as análises na categoria "Aprendizagem dos conceitos matemáticos”. 


\subsection{Aprendizagem dos conceitos matemáticos}

Participaram efetivamente da experimentação sete estudantes ( $\operatorname{cinco}^{32}$ no ambiente dinâmico e dois no ambiente estático). Três estudantes que participariam da experimentação no ambiente estático faltaram, sem dar nenhuma justificativa. A experimentação em cada ambiente durou, aproximadamente, 2 horas e 30 minutos. Para o ambiente dinâmico, foi utilizado um programa ${ }^{33}$ que grava tudo o que está sendo feito na tela do computador. As ações do estudante Dio também foram filmadas. No ambiente estático, as ações do estudante Cley foram filmadas.

Com relação às perguntas que elaboramos na metodologia, as que estão relacionadas com esta categoria são as seguintes:

- É possível para o estudante perceber a relação entre as representações?

- De que forma os aspectos dinâmico e estático influenciaram (ou não) na compreensão e resolução das atividades?

- É possível perceber o processo de construção da narrativa influenciando na compreensão dos conceitos estudados? Ou seja, queríamos verificar se a representação auxilia na construção da compreensão e não apenas para a comunicação.

- Houve tomada de consciência (objetivação) com relação aos conceitos matemáticos? Quais?

- Como os estudantes lidam com os fenômenos de congruência e não congruência nos diferentes ambientes?

- Como os estudantes agem numa situação de heterogeneidade de conversão? Qual tipo de conversão é mais difícil para o estudante?

- Por meio da narrativa produzida na atividade 5, é possível identificar os diferentes níveis de ação em que o estudante está?

Com relação à última questão, estabeleceram-se os seguintes níveis:

- Não sabe fazer, ou seja, não criou a Narrativa Matemática;

\footnotetext{
${ }^{32}$ Dois estudantes tiveram problemas com o gravador de tela e as ações não foram gravadas. Os dados desses estudantes foram desconsiderados na análise.

${ }^{33}$ Gravador de Tela Grátis da Apowersoft
} 
- Sabe fazer, mas não demonstra compreender. Ou seja, fez a Narrativa Matemática, com diferentes representações, mas não as integrou coerentemente de forma que evidenciasse a compreensão.

- $\quad$ Sabe fazer, parece compreender, mas não sabe registrar de forma escrita. Ou seja, fez a narrativa, integrou as representações, mas não soube explicar com a representação linguística.

- $\quad$ Sabe fazer, compreende e sabe registrar de forma escrita. Ou seja, fez a narrativa, integrou as representações e soube explicar com a representação linguística.

Para a primeira atividade:

Considere a equação $\frac{a}{\operatorname{sen}(A)}=\frac{b}{\operatorname{sen}(B)}=\frac{c}{\operatorname{sen}(C)}$. Escreva, com suas palavras, o que acha que a equação significa.

Die, que fez no ambiente estático, respondeu que $A$ divisão de um dos lados do triângulo pelo seno do ângulo oposto a ele será constante. O estudante relaciona bem as unidades de sentido da representação simbólica $\frac{a}{\operatorname{sen}(A)}$ com divisão de um dos lados do triângulo pelo seno do ângulo. Mas, qual unidade de sentido na representação simbólica (equação) levou o estudante a relacionar com a unidade de sentido lados do triângulo? E oposto a ele ? Como o estudante poderia inferir por meio da equação que se tratava de um triângulo? Para alguns estudantes mudamos a ordem de aplicação das atividades 1 e 2 e a primeira atividade que Die fez foi a 2. Assim, talvez o estudante tenha sido induzido pela atividade anterior em que apareciam os termos "triângulo" e "ângulos opostos". Por outro lado, o estudante pode ter relacionado com triângulo pelo fato de associar o seno do ângulo sempre com o triângulo.

Já Cley, que também trabalhou no ambiente estático, fez os registros de representação linguística e simbólica que estão na figura seguinte: 


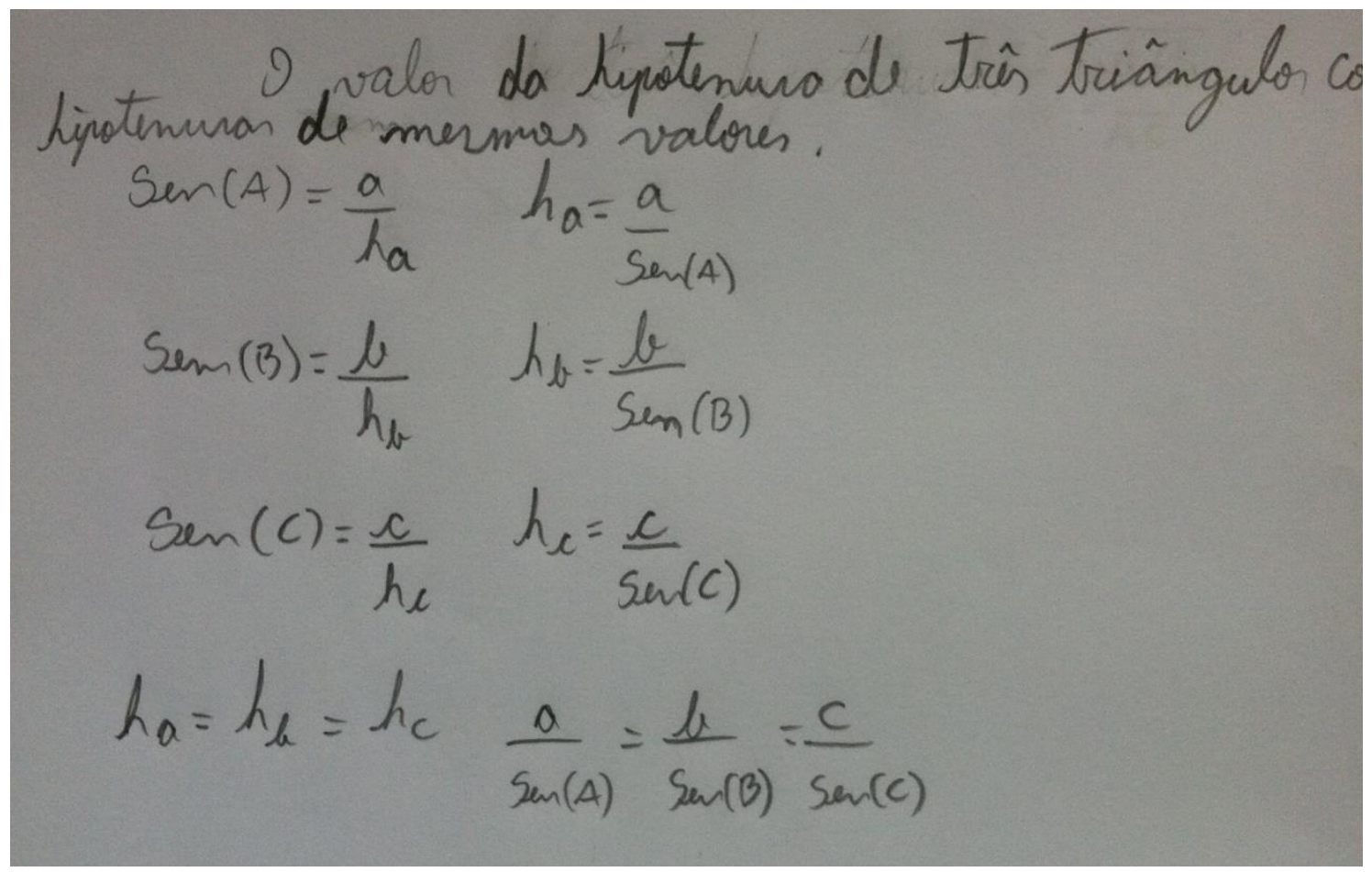

Figura 61-Resposta de Cley para atividade 1

Diferentemente de Die, Cley não tinha visto anteriormente nenhuma outra atividade. Ele parece saber que a relação seno tem a ver com a unidade de sentido hipotenusa do triângulo retângulo e diz que a relação é válida se as hipotenusas de três triângulos tiverem mesmos valores. Para justificar, faz um tratamento no registro simbólico. A resposta é, de certa forma, coerente para a situação: Dados três triângulos retângulos. Se todos tiverem hipotenusas com mesmas medidas, então vale a relação:

$$
\frac{a}{\operatorname{sen}(A)}=\frac{b}{\operatorname{sen}(B)}=\frac{c}{\operatorname{sen}(C)}
$$

Onde a, b e c são catetos opostos aos ângulos $\mathrm{A}, \mathrm{B}$ e $\mathrm{C}^{34}$, respectivamente.

A estudante An $\left(\operatorname{Din}^{35}\right)$ respondeu o que está representado na Figura 62.

\footnotetext{
${ }^{34}$ A é um ângulo interno de triângulo retângulo, B é um ângulo interno de outro triângulo retângulo e C é um ângulo interno de outro triângulo retângulo.

${ }^{35}$ Identificaremos os estudantes com as siglas Din para os que fizeram no ambiente dinâmico e Est para os que fizeram no ambiente estático.
} 
Em todo triangulo a medida seus lados podem ser representadas por: $\frac{\text { ladoa }}{\operatorname{sen} b}+\frac{\text { ladob }}{\operatorname{senc}}+\frac{\operatorname{lado}}{\operatorname{sena}}$

Figura 62-Resposta de An para atividade 1

Ela associou a equação com o triângulo e fez alguns tratamentos na equação inicial. Mas, o que levou a estudante a trocar a unidade de sentido "=” por “+”? Ela também faz mudanças nas variáveis que estão no numerador. Ao que parece, pode ter pensado em manipular o registro simbólico, separando a equação da seguinte maneira:

$$
\begin{aligned}
& \frac{a}{\operatorname{sen}(A)}=\frac{b}{\operatorname{sen}(B)} \\
& \frac{a}{\operatorname{sen}(A)}=\frac{c}{\operatorname{sen}(C)} \\
& \frac{b}{\operatorname{sen}(B)}=\frac{c}{\operatorname{sen}(C)}
\end{aligned}
$$

Todavia, não há nada na gravação que mostre isso. Também não usou nenhum rascunho de papel.

Já os estudantes Mar (Din) e Dio (Din) foram os que apresentaram respostas mais próximas do que supúnhamos que responderiam. Mar respondeu que a equação significa que a sobre $\operatorname{sen}(A)$ e $b$ sobre $\operatorname{sen}(B)$ e c sobre sen $(C)$ são iguais, sendo Seno a um lado de triângulo retângulo. Essa foi a resposta que mais se aproximou do que imaginávamos que responderiam, pois se tratava de um fenômeno de congruência das representações. A primeira parte $a$ sobre sen $(A)$ e b sobre sen $(B)$ e c sobre sen $(C)$ são iguais é a tradução linguística do registro simbólico $\frac{a}{\operatorname{sen}(A)}=\frac{b}{\operatorname{sen}(B)}=\frac{c}{\operatorname{sen}(C)}$. Porém, no final ele associa seno de A com a medida de um lado do triângulo. Ou seja, faz equivocadamente a correspondência entre as unidades de sentido seno de A e lado de um triângulo retângulo.

O estudante Dio respondeu: seno de a sobre A é igual seno de b sobre B e c sobre $C$. Ao converter o registro simbólico para o registro linguístico, ele inverteu o numerador e denominador. Ele parece saber que se mudar de posição as unidades de sentido do numerador e denominador, a equação ainda fará sentido. Todavia, ele trocou os códigos "a" e "A". Será que foi apenas um equívoco? Ou estudante achava que tinha que mudar para a equação 
continuar fazendo sentido? Será que ele sabia que o código "a" representava um número e o código "A" representava um ângulo?

De maneira geral, o que se percebe na análise da primeira atividade de todos os estudantes é que não parece ser possível fazer, diretamente, a tradução linguística da Lei dos Senos. Ou seja, como esperávamos, observando apenas o registro de representação simbólico $\frac{a}{\operatorname{sen}(A)}=\frac{b}{\operatorname{sen}(B)}=\frac{c}{\operatorname{sen}(C)}$, dizer que essa equação representa o teorema "Em todo triângulo, as medidas dos lados são proporcionais aos senos dos ângulos opostos". Nem mesmo, a tradução direta a sobre seno de A é igual a b sobre seno de B que é igual a c sobre seno de C os estudantes fizeram corretamente. Na realidade, esperávamos que os estudantes tratassem a atividade como um fenômeno de congruência de conversão (ver tabela 7), ou seja, um fenômeno em que ao analisar uma representação terminal e a representação de partida, a conversão está próxima de uma situação de simples codificação, comparando com o registro de chegada (DUVAL, 2011).

Tratava-se de uma atividade que exigia a utilização matemática da língua. Sua utilização com as operações de designação de objetos são mais difíceis de ultrapassar do que na simples utilização comum. Isso se deve ao fato de que não são as mesmas operações discursivas que mobilizamos e desenvolvemos na prática espontânea da fala e no discurso matemático. E isso pode ter acontecido porque tudo foi feito para reduzir o lugar e o papel da língua natural no pensamento matemático (DUVAL, 2011). Em geral, a língua natural é um registro utilizado em Matemática para formular definições, teoremas, efetuar raciocínios matemáticos e para justificar soluções. Já no ensino de Matemática, a língua natural é mais usada em enunciados de problemas dados aos alunos ou em problemas de aplicação de conhecimento.

Em relação à $2^{\mathrm{a}}$ atividade

"Em todo triângulo, as medidas dos lados são proporcionais aos senos dos ângulos opostos". Escreva o que você leu, usando símbolos matemáticos.

Die (est) respondeu que Em um triângulo quanto maior for um ângulo maior será o comprimento do segmento de reta oposto a ele. Como se pode ver Die não usou o registro simbólico para tentar expressar o que leu. Apesar de ser correto o que ele escreveu, usando a representação linguística, não se trata da Lei dos Senos. Ele relacionou a unidade de sentido "proporcionais" com “quanto maior for... maior será". 
Cley (est) fez os registros de representação linguística, simbólico e visual que estão na Figura 63:

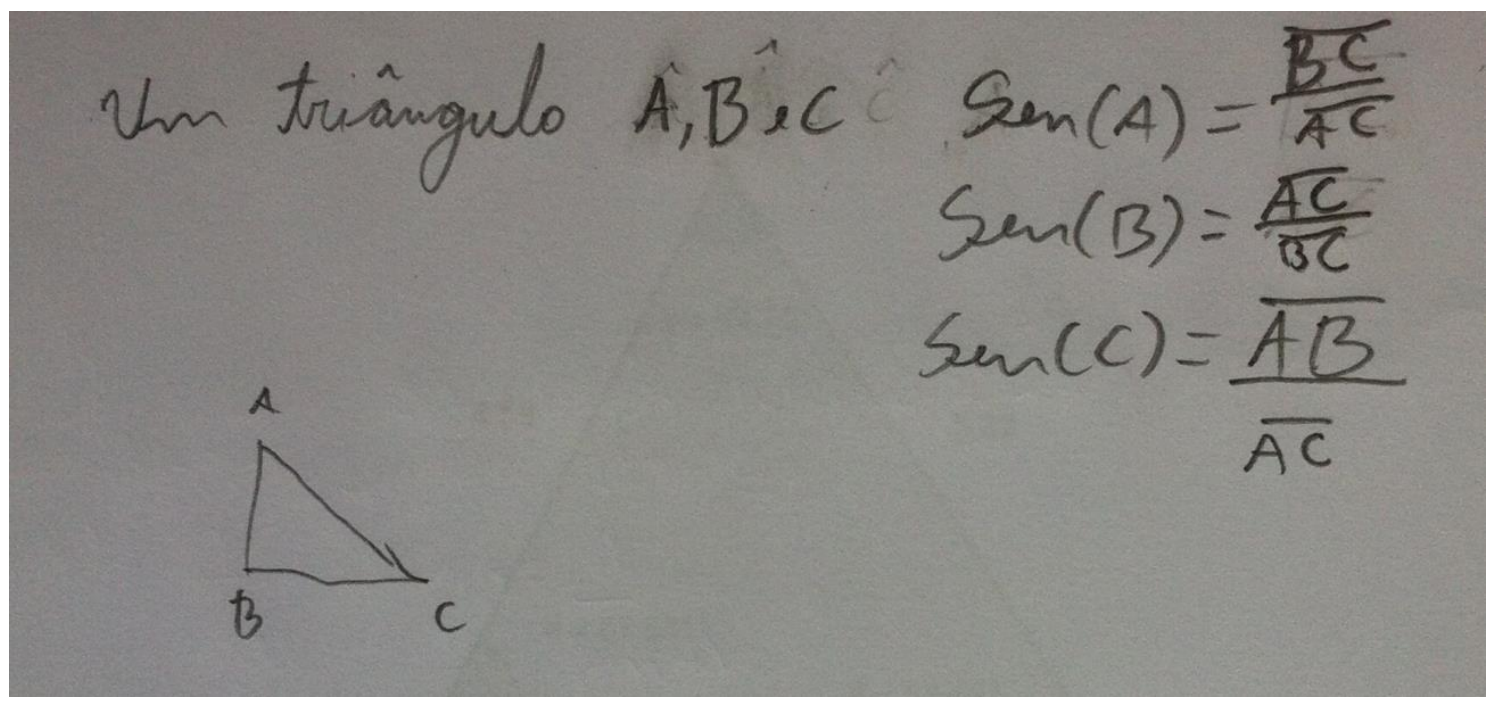

Figura 63-Resposta de Cley para atividade 2

Apesar de pedirmos para usar símbolos matemáticos, o estudante desenhou um triângulo para explicar o que a Lei dos Senos (em registro de representação linguística) significava. Ele desenha um triângulo, aparentemente, retângulo e mostra o que são os senos de A, B e C. Todavia, não parece mostrar que faz relação dessa atividade com a anterior, ou seja, parece não perceber que as atividades tratam do mesmo objeto.

A estudante An (din) respondeu que Ela representa a Lei dos Senos, que estabelece a proporcionalidade dos lados de um triângulo em relação aos ângulos opostos a esse lado. Como se pode ver An não usou o registro simbólico para tentar expressar o que leu. Tenta explicar, usando o registro representação linguística, mas falando de outra maneira. No questionário de caracterização, quando foi questionada se sabia algo sobre a Lei dos Senos, a estudante havia dito que Sim. Sei que a partir da lei dos senos consigo achar os valores dos lados de um triângulo qualquer (não necessariamente o triângulo retângulo). Ou seja, ela deve ter lembrado que o que estava escrito tinha relação com a Lei dos Senos, todavia não parecia lembrar claramente do teorema. Ela também não relacionou a atividade anterior com esta. Se ela se lembrasse claramente do teorema, era de se esperar que percebesse que a equação da atividade anterior era a resposta para esta.

O estudante Mar (din) constrói a Figura 64 no ambiente GeoGebra. 


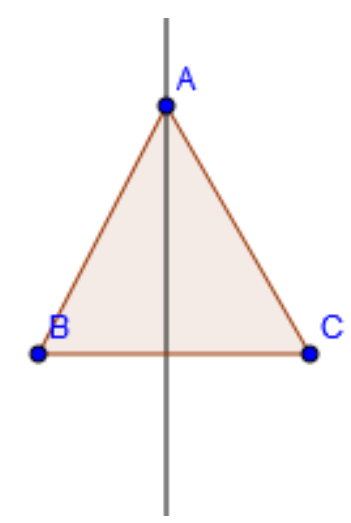

Figura 64-Figura construída por Mar para responder a atividade 2

O estudante pareceu sentir necessidade de um registro de representação visual para compreender o que o registro de representação linguística quer dizer e converter para a representação simbólica. A unidade de sentido "triângulo" no registro de representação linguística é clara para ele. Interessante notar que ele fez um triângulo isósceles e não um triângulo retângulo. Ou seja, ele percebe que a unidade de sentido triângulo não está, necessariamente, relacionada com o triângulo retângulo. Todavia, na atividade anterior, ele havia respondido que a equação significa que a sobre $\operatorname{sen}(A)$ e $b$ sobre $\operatorname{sen}(B)$ e c sobre $\operatorname{sen}(C)$ são iguais, sendo Seno a um lado de triângulo retângulo. Parece haver nesse momento um processo de objetivação pelo estudante, ou seja, ele parece tomar consciência de que não se trata apenas do triângulo retângulo. Movimentou o cursor sobre a janela do GeoGebra como que tentando encontrar ferramentas para as unidades de sentido "proporcionais" e "seno dos ângulos opostos". Ao final, responde no ambiente texto Não lembro.

O estudante Dio (din) fica aproximadamente 6 minutos pensando e responde Tenho algumas lembranças, mas não me recordo perfeitamente. Na atividade anterior havia respondido que a equação $\frac{a}{\operatorname{sen}(A)}=\frac{b}{\operatorname{sen}(B)}=\frac{c}{\operatorname{sen}(C)}$ significava seno de a sobre A é igual seno de b sobre $B$ e c sobre $C$. Era pouco provável que ele relacionasse o registro de representação linguístico seno de a sobre A é igual seno de b sobre B e c sobre C com o registro Em todo triângulo, as medidas dos lados são proporcionais aos senos dos ângulos opostos e assim percebesse que tratavam da mesma representação simbólica.

A conclusão que se chega com a análise dessa atividade é que os estudantes parecem relacionar "proporcionalidade" com "quanto maior for o seno de um ângulo, maior será o lado oposto a ele". Para que pudessem fazer a conversão para o registro simbólico deveriam relacionar a unidade de sentido "proporcional" com a razão entre dois valores de uma grandeza (medidas dos lados do triângulo) ser igual à razão entre dois valores correspondentes 
da outra grandeza (senos dos ângulos opostos). Se o registro de representação linguístico estivesse apresentado dessa forma, poderíamos considerar a transformação como um fenômeno de congruência das representações e eles poderiam fazer mais facilmente a tradução simbólica:

$$
\frac{a}{b}=\frac{\operatorname{sen}(A)}{\operatorname{sen}(B)}
$$

Talvez assim pudessem perceber que esta atividade tinha relação com a anterior. Ou seja, tratava-se apenas de inversão das transformações de partida e chegada, em que, na primeira atividade, a partida era o registro de representação simbólico e a chegada era o registro de representação linguístico. Na segunda atividade era o inverso. Todavia, o registro de representação linguística que apareceu não foi "a razão entre dois lados do triângulo é igual a razão entre dois senos dos ângulos opostos" e sim "Em todo triângulo, as medidas dos lados são proporcionais aos senos dos ângulos opostos". Dessa forma, tratava-se de um fenômeno não congruência das representações e era necessário combinar as unidades significantes $(\operatorname{sen}(\mathrm{A}), \operatorname{sen}(\mathrm{B}), \mathrm{a}, \mathrm{b}, \backslash)$ para converter a unidade de sentido "proporcionais" do registro linguístico para o simbólico.

De acordo com Duval (2011) o que torna difícil a conversão dos enunciados da língua natural para as representações em outro registro é o fato de existir entre a língua natural e os outros registros uma distância cognitiva considerável, mesmo os outros registros discursivos próprios da Matemática ou da Lógica. Para poder colocar em evidência as correspondências regulares entre as variações dos enunciados (ou de encaminhamento de enunciados) e as variações de conteúdo no outro registro, é preciso passar por representações auxiliares de transição. Não é qualquer representação que pode cumprir essa função e, ainda mais, não são as mesmas representações que permitem analisar os enunciados dos problemas, os funcionamentos dos raciocínios matemáticos ou mesmo dos textos. Mas, todas as representações auxiliares devem cumprir a mesma condição semiótica: ser representações bidimensionais. Concordamos com Duval em relação à necessidade de representações auxiliares, mas é difícil acreditar que a representação mista do triângulo com as medidas dos lados e ângulos seja apenas provisória para a compreensão da lei dos senos. Na atividade seguinte é explicitada essa representação auxiliar.

Em relação à atividade 3 : 
Considere o Teorema: Em todo triângulo, as medidas dos lados são proporcionais aos senos dos ângulos opostos". Tendo como referência a figura abaixo, escreva usando símbolos matemáticos, o que você leu.

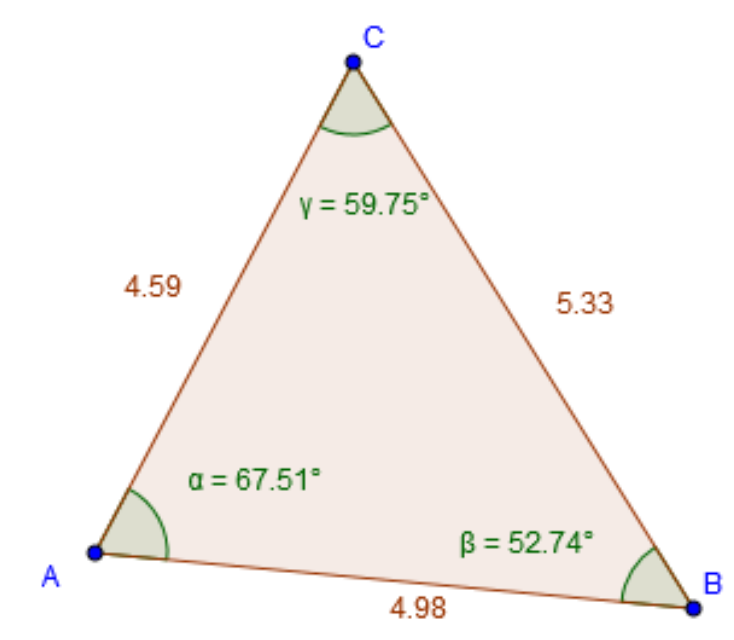

A resposta de Die (est) está apresentada na Figura 65:

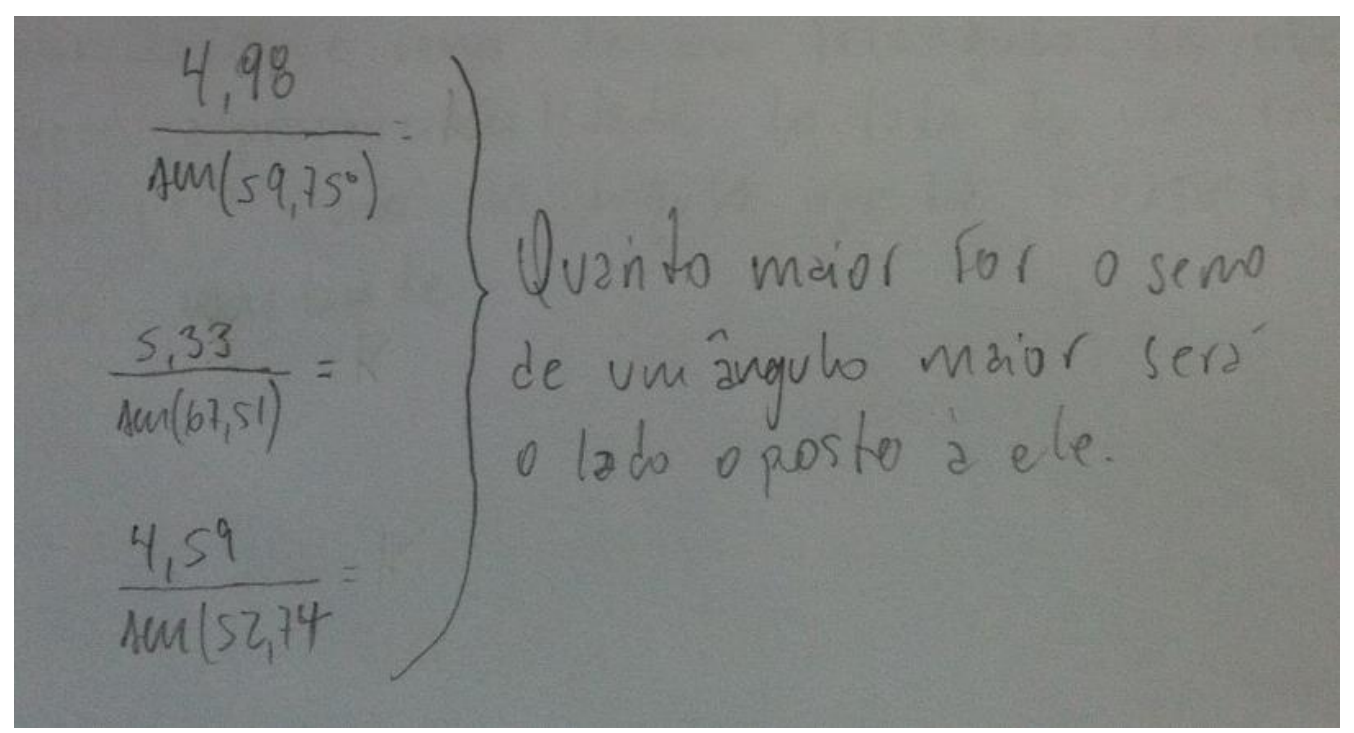

Figura 65-Resposta de Die para a atividade 3

Die relaciona as unidades de sentido dos registros de representação linguístico e visual para fazer a conversão para o registro de representação simbólica. Apesar disso, continua relacionando o termo "proporcionais" com Quanto maior for o seno de um ângulo, maior será o lado oposto a ele. Ou seja, a representação simbólica (divisões) não parece ter vindo da unidade de sentido "proporcionais". Ao que parece, ele inferiu isso a partir das atividades 
anteriores. No entanto, o registro do estudante não mostra que ele percebe que as razões são iguais. É preciso também notar uma diferença em relação ao que escreveu na atividade 2: Em um triângulo quanto maior for um ângulo maior será o comprimento do segmento de reta oposto a ele. Por que agora ele considera "seno do ângulo" e não apenas o "ângulo"? Não parece ser possível perceber por meio do registro feito pelo estudante porque ele mudou. Apesar de ter recebido a calculadora, ele não calculou as razões. Ao que parece, ele está convicto de que a unidade de sentido "proporcionais" está relacionada apenas com "quanto maior for...maior será". Ele pode ter chegado a essa conclusão pelo registro de representação visual (triângulo com as medidas dos lados e ângulos internos). Viu que os lados maiores tinham ângulos opostos também maiores. Mas por que colocou "seno dos ângulos" e não simplesmente "ângulos"? Será que ele sabia que para $0<\alpha, \beta<180$ se $\alpha<\beta$, então $\operatorname{sen}(\alpha)<\operatorname{sen}(\beta) ?$

Já a resposta de Cley (est) foi $\operatorname{sen}(\beta)=\frac{4,59}{5,33}, \operatorname{sen}(\alpha)=\frac{5,33}{4,59} \operatorname{e~} \operatorname{sen}(\gamma)=\frac{4,98}{5,33}$. Para fazer a representação simbólica solicitada, o estudante representa a divisão entre o lado oposto ao ângulo e outro lado (que pode estar no sentido horário ou anti-horário). Apesar de ter disponível uma calculadora, o estudante não calcula os resultados. Como supúnhamos inicialmente, o estudante considerou elementos de um triângulo retângulo em um triângulo que não era retângulo. Apesar de na atividade 2 (ver Figura 63) o estudante ter feito um triângulo (visualmente retângulo) e algumas razões que sugeriam que ele sabia que o seno era cateto oposto dividido pela hipotenusa, não conseguimos saber se o estudante entendia que, num triângulo retângulo, o seno é a razão entre o cateto oposto ao ângulo e a hipotenusa ou se o seno é a razão entre um lado oposto ao ângulo e outro lado qualquer. No caso da atividade 3, temos um triângulo que não é retângulo. Nesse caso, o cateto oposto seria a altura relativa a um lado qualquer do triângulo. Acontece que essa unidade de sentido não estava visível no registro visual. Assim, ele tomou como referência para cateto oposto o lado oposto ao ângulo. Para hipotenusa, tomou como referência outro lado qualquer.

An (din) movimenta um pouco os vértices do triângulo e, mesmo sem calcular as razões, digita no ambiente texto, o que está na Figura 66:

A proporcionalidade dos lados de um triangulo é dada por:

$\frac{C B}{\operatorname{sen} A}: \frac{C B}{\operatorname{sen} A}=\frac{B A}{\operatorname{sen} Y}=\frac{A C}{\operatorname{sen} B}: \frac{B A}{\operatorname{sen} Y}: \frac{B A}{\operatorname{sen} Y}$


Nessa atividade, An já parece tomar consciência (objetivação) em relação ao objeto estudado. Parece ter relacionado com as atividades anteriores para escrever corretamente a representação simbólica do objeto. Todavia, no registro linguístico relaciona "proporcionalidade" com "proporcionalidade dos lados" e não dos lados com os senos dos ângulos opostos, como fez no registro simbólico.

Mar (din) parece procurar no editor de textos algum símbolo para "proporcionais" e “opostos". Depois digita no ambiente texto Para todo triângulo, os lados são=aos senos dos ângulos opostos. Mar relaciona a unidade de sentido "proporcionais" com a unidade de sentido “=” do registro simbólico. É possível ver que ele, praticamente, substitui no registro linguístico a palavra "proporcionais" pelo símbolo “=”. Isso nos leva a acreditar que ele estava procurando o símbolo "=" no editor de texto.

Dio (din) movimenta um pouco os vértices do triângulo, observa as medidas dos lados e ângulos internos e digita no ambiente texto: 4.95=alfa, 5.21=béta, 5.84=ipslon. Ele relaciona corretamente as unidades de sentido do registro de representação linguística "lados" e "ângulos opostos" com as unidades de sentido do registro de representação visual "4,95", "5,21", "5,84", “alfa", "beta" e "ipslon"36. Ele parece saber que a unidade de sentido "proporcionais" está relacionado com o símbolo "=", mas não combina corretamente com as outras unidades de sentido para gerar a representação simbólica adequada para o objeto.

Apesar de An ter feito corretamente a conversão, todos os estudantes parecem ainda continuar com dificuldades em relação ao termo "proporcionais". Tal termo poderia ser a designação verbal de qual unidade figural da representação visual (triângulo)? Ao que tudo indica, a combinação dos dois registros (linguístico e visual) e as atividades anteriores não foram suficientes para que os estudantes fizessem corretamente a conversão para o registro simbólico e compreendessem a Lei do Senos. Na atividade seguinte, veremos o que acontece quando se combinam os registros visual e simbólico para a conversão ao registro linguístico.

Em relação à atividade 4:

\footnotetext{
${ }^{36}$ Confundiu com gama.
} 
Considere a figura e os cálculos da figura seguinte:

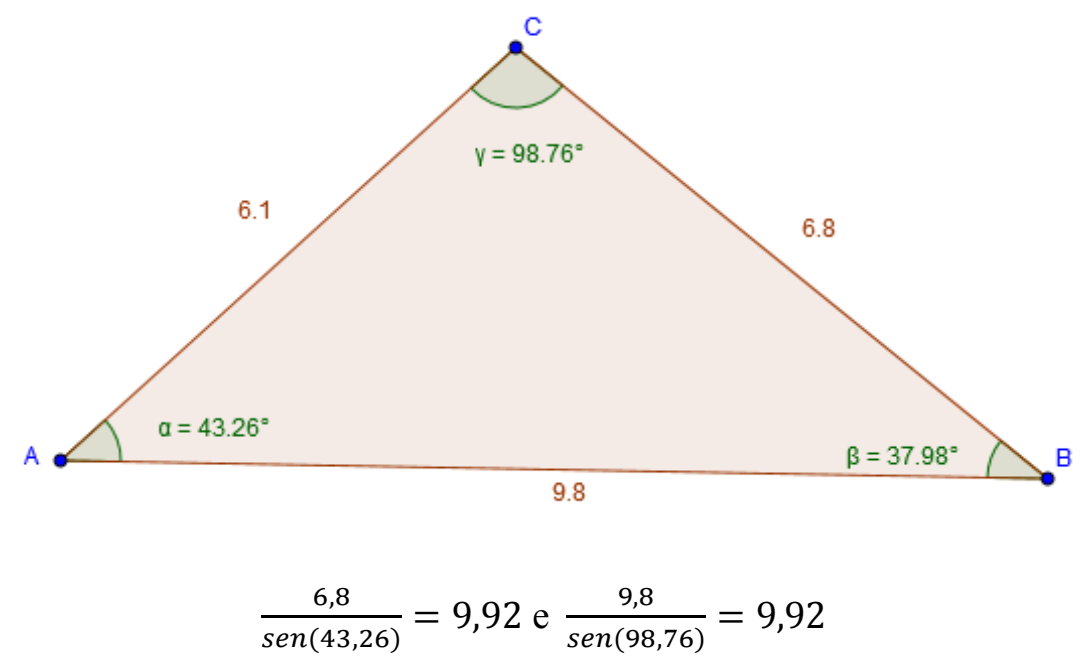

Escreva com suas palavras o que você entendeu.

Die (est) responde que independentemente do valor de qualquer lado e seno de um triângulo se obedecer a proporcionalidade do lado de um triângulo pelo seno do ângulo oposto o resultado será constante. Na resposta, Dio já parece relacionar "proporcionalidade" com a divisão. Para constatarmos isso, basta substituirmos na resposta dele a palavra "proporcionalidade" por "divisão". Por meio da fala, é possível inferir que ele parece ter percebido que a razão entre a medida de um lado do triângulo e o seno do ângulo oposto é igual à razão entre a medida de outro lado do triângulo e o seno do ângulo oposto. Mas acha que isso é ser constante. O que ele entende por constante? Será que ele estava pensando que se variasse a medida do lado e ângulo oposto a ele, os resultados da divisão continuariam igual ao anterior? Ou será que ele estava pensando que se variasse as medidas de dois lados e ângulos opostos a eles, as razões permaneceriam iguais? De que forma ele poderia ter as respostas a essas questões apenas com o exemplo apresentado na atividade? Para que pudéssemos ter de fato tais respostas, ele deveria variar as medidas dos lados e ângulos, fazendo novas construções e novos cálculos. Ou seja, era preciso fazer variar, de maneira sistemática, o conteúdo da representação de partida (registro visual) e efetuar uma nova conversão para cada variação feita, porque a eficácia cognitiva da conversão depende da maneira pela qual fazemos variar aquilo que queremos converter (DUVAL, 2011).

Já Cley (est) escreve que São os valores equivalente (sic) a hipotenusa. O valor do maior lado do triângulo era 9,8 e as razões têm resultado igual a 9,92. Ele parece também 
relacionar hipotenusa com o maior lado de qualquer triângulo. Ao que parece, Cley relaciona valores equivalente com o resultado das razões. Como são números próximos, o estudante parece relacionar o resultado das razões com o maior lado (que ele chama de hipotenusa). $\mathrm{Ou}$ ele pode ter feito mentalmente o seguinte tratamento no registro simbólico:

$$
\frac{6,8}{\operatorname{sen}(43,26)}=9,92 \rightarrow \frac{6,8}{9,92}=\operatorname{sen}(43,26)
$$

Ou seja, como 9,92 está no denominador e seno é igual ao cateto oposto sobre a hipotenusa, então 9,92 é a hipotenusa.

An (din) passa o cursor sobre os lados e ângulos internos do triângulo, mas não faz qualquer alteração nos objetos. Ela parece apenas relacionar as medidas de tais objetos com as razões que estão na janela de texto e responde Entendi que a partir dessas fórmulas podemos obter a razão (proporção) do tamanho dos lados de um triângulo. Assim como na atividade anterior, a estudante continua não relacionando a proporção com os lados e senos dos ângulos opostos. Relaciona somente com os lados. Todavia, ela já usa pela primeira vez o termo "razão".

Mar (din) passa o cursor sobre um lado e sobre o ângulo oposto a ele. Como que conferindo as razões. Movimenta um dos vértices do triângulo, percebe que as medidas mudam, mas os resultados das razões continuam iguais. Depois, responde que as razões acima, mostra (sic) que o segmento oposto ao vértice em forma de fração, chega a um resultado que quando alterado o valor do ângulo os resultados não muda. Apesar de não se expressar corretamente, o estudante parece perceber a propriedade. O que ele quer dizer com o os resultados não muda (sic) é que todos os resultados das razões permanecem iguais.

Dio (din) volta nas páginas anteriores, movimenta os vértices do triângulo, percebe que as medidas mudam, mas os resultados de todas as razões continuam iguais. Movimenta o mouse, apontando para um ângulo e seu lado oposto. Após isso, responde que o cateto de um triangulo (sic) dividido pelo seno oposto é igual para qualquer um dos lados. Apesar de não se tratar de um triângulo retângulo, o estudante chama o lado oposto de cateto oposto. Ele também suprime a palavra "ângulo" e escreve apenas "seno oposto". Todavia, o estudante parece tomar consciência (objetivação) da propriedade. Ao que pareceu, o movimento inicial que o estudante fez no triângulo contribuiu para isso.

Nesta atividade, diferentemente das anteriores, percebem-se mais diferenças entre as possibilidades dois ambientes. Trata-se da primeira atividade em que, no ambiente dinâmico, 
o estudante poderia variar uma representação e ver a relação dos registros de representação visual no ambiente GeoGebra com os registros de representação simbólica no ambiente texto. É o que Duval (2011) chama de uma operação figural que se apoia diretamente na percepção e que transformam unidades figurais 2D/2D. As operações figurais de visualização que a mobilização das figuras permite efetuar são operações para as quais transformamos uma figura produzida em outra, de forma heurística ${ }^{37}$, ou fazendo aparecer as invariâncias, e que não podemos fazer com outros tipos de imagens. Assim, foi possível a identificação e relação das unidades de sentido em cada representação. Dio e Mar se valeram dessa característica e puderam elaborar respostas que mostram mais compreensão da Lei dos Senos. An não movimenta a figura e dá uma resposta mais prática do que entendeu. A resposta de Cley é incorreta. Já a resposta de Die, conforme dissemos anteriormente, não nos permite dizer que ele compreendeu a Lei dos Senos.

Percebemos também certa dificuldade dos estudantes para se expressarem matematicamente usando a língua materna. Por exemplo, Mar (din) diz as razões acima, mostra (sic) que o segmento oposto ao vértice em forma de fração, chega a um resultado que quando alterado o valor do ângulo os resultados não muda (sic). Novamente temos mais uma confirmação do que Duval (2011) diz sobre o fato da utilização da língua em Matemática não ter muito a ver com a forma com que ela é utilizada espontaneamente fora da Matemática. Apesar de termos entendido a maneira muito espontânea de Mar ao usar a língua materna para explicar e compreendido o que ele quis dizer, percebemos que a espontaneidade comprometeu a explicação do que havia entendido. A representação linguística em Matemática exige certo "rigor matemático". Em muitos casos, tal rigor é necessário para garantir a coerência e a lógica da argumentação. Isso por sua vez facilita a interpretação. Pode-se dizer que Mar explicitou um raciocínio heurístico que não é considerado como final e rigoroso, mas provisório e plausível (POLYA, 1957 citado por BORBA; SCUCUGLIA; GADANIDIS, 2014), cujo objetivo foi mostrar o que entendeu.

Em relação à atividade 5

\footnotetext{
${ }^{37}$ Refere-se a arte relativa a descoberta ou invenção
} 
Nas atividades anteriores, exploramos a Lei dos senos.

1-Faça uma figura para que possa te ajudar a representar tal teorema. Você pode também medir os lados e ângulos.

2- Nas atividades anteriores, você pôde ver que o teorema está relacionado com algumas divisões. Pode fazê-las aqui?

3- Escreva com suas palavras o que você entendeu sobre a lei dos senos.

Para o item 1, Die (est) fez os seguintes registros de representação visual e simbólico (Figura 67):

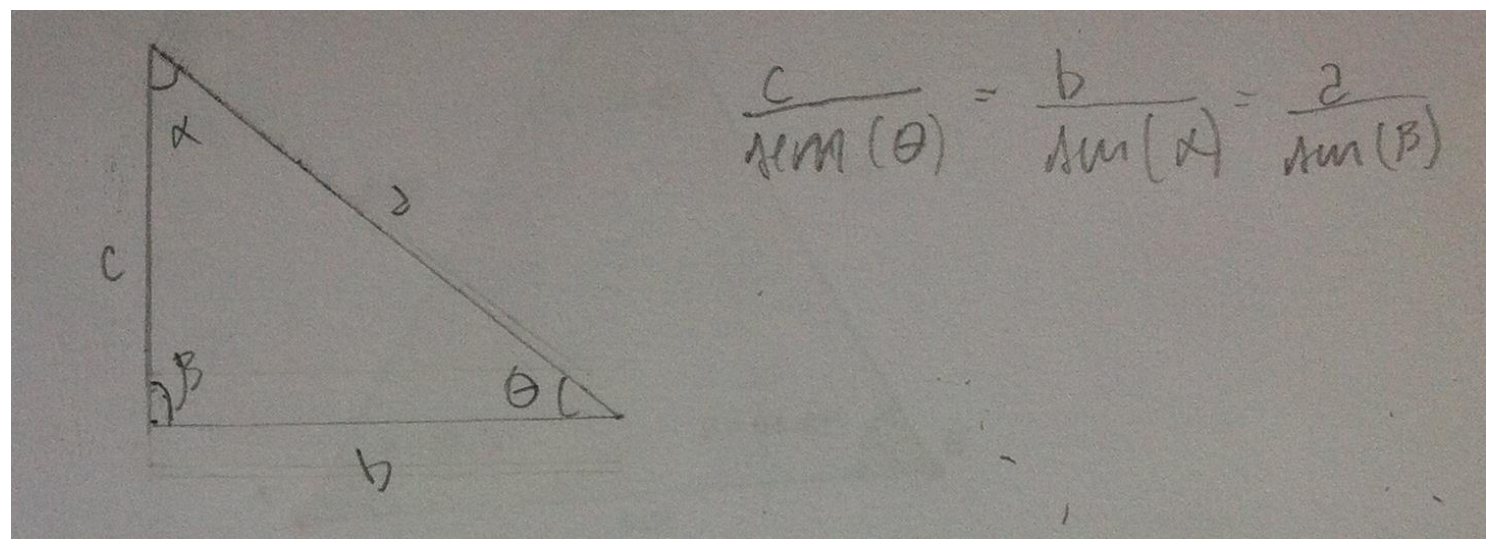

Figura 67-Resposta de Die para o item 1 da atividade 5

Apesar de não representar a marca de ângulo reto, o estudante fez um triângulo aparentemente retângulo. Inicialmente, isso nos fez acreditar que ele ainda relacionava o seno de um ângulo sempre com o triângulo retângulo. Todavia, no item 2, Die ao invés de escrever a representação simbólica que fez para o item anterior, escreve: Sim. São divisões de valores encontrados em triângulo qualquer onde segue a proporcionalidade de lado por seno de um ângulo oposto a ele. Apesar de ter feito anteriormente um triângulo aparentemente retângulo, o estudante escreve agora triângulo qualquer. Para o item 3, ele escreve Em todo triângulo há relação de proporcionalidade, onde o lado de um triângulo está para seno do ângulo oposto. O estudante apresenta indícios de que entendeu o teorema. Inclusive, a unidade de sentido "proporcionalidade". Faltou completar a frase com assim como outro lado está para o seno do ângulo oposto. Die sabe fazer, parece compreender, mas não sabe registrar de forma escrita. Ou seja, fez a narrativa, integrou as representações, mas não soube explicar com a representação linguística.

Para o item 1, Cley (est) fez os seguintes registros de representação visual e simbólico (Figura 68): 


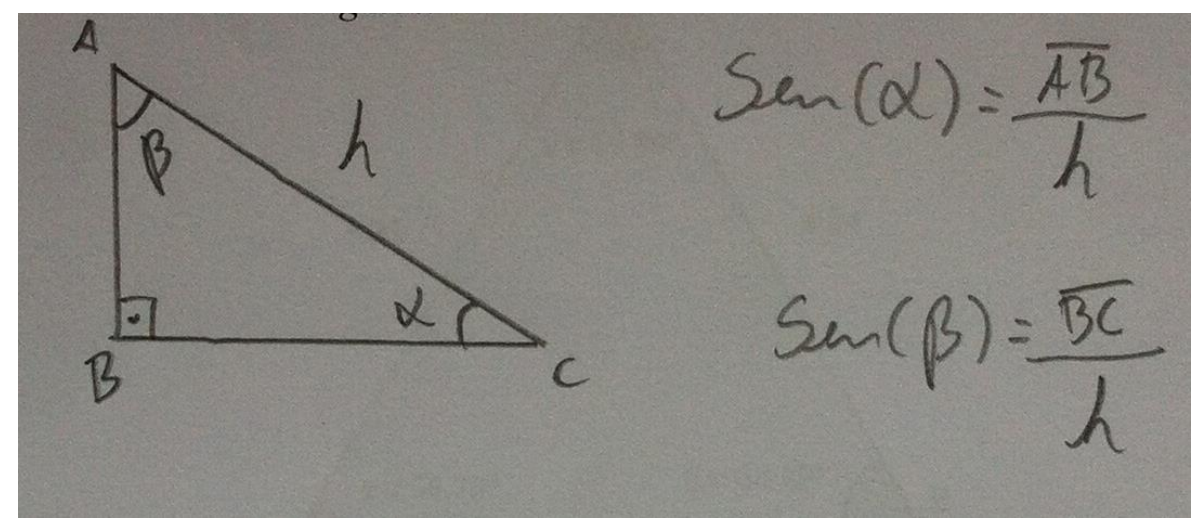

Figura 68-Resposta de Cley para o item 1 da atividade 5

Assim como Die, Cley faz também um triângulo retângulo. Inclusive representa um ângulo com marca de ângulo reto e indica a representação dos senos dos ângulos agudos. Para o item 2, Cley faz os seguintes registros de representação simbólica:

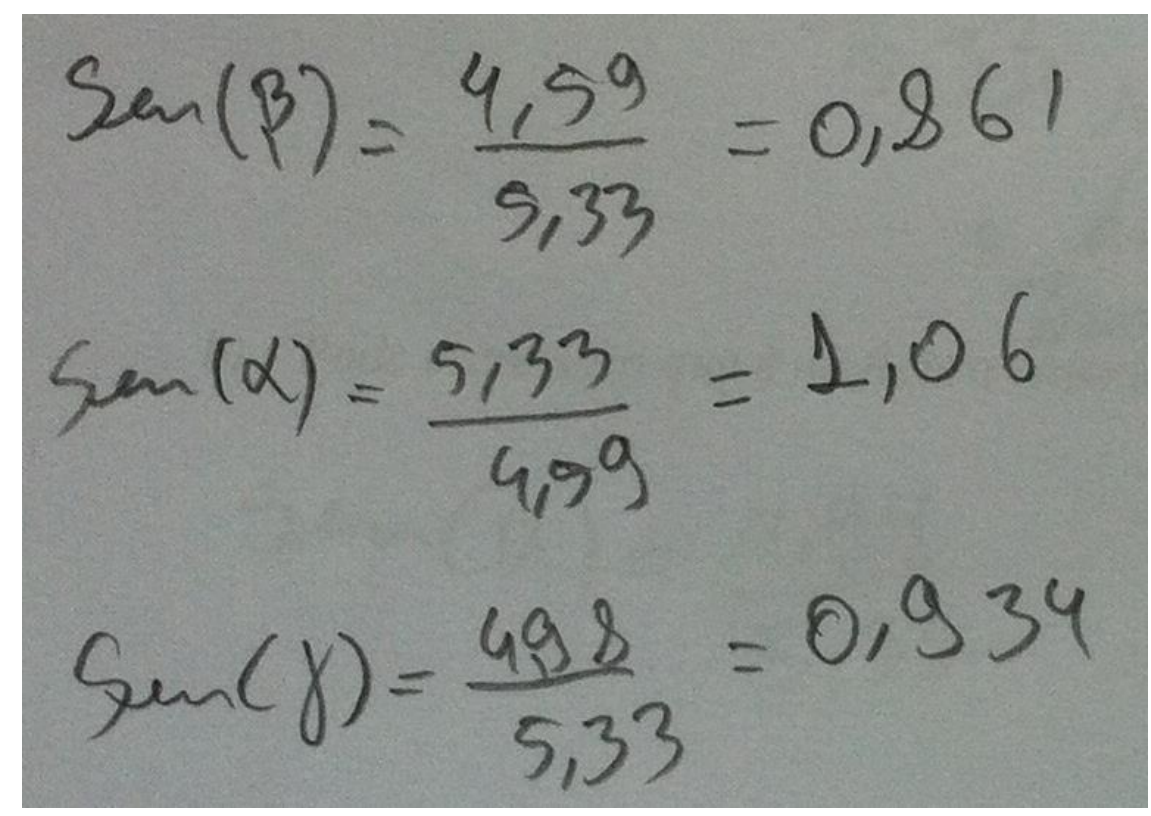

Figura 69-Resposta de Cley para o item 2 da atividade 5

Ele retoma a atividade 3, faz novamente as razões, mas dessa vez mostra os resultados. Trata-se das divisões entre medida do lado oposto a um ângulo e outro lado qualquer do triângulo da atividade 3. Para o item 3, ele escreve: $O$ valor do seno de um ângulo pode ser medido por cateto oposto dividido pelo valor da hipotenusa, podendo ser usados para quaisquer triângulos obtendo assim o valor do seno do seu ângulo. O estudante fala corretamente o que é o seno do ângulo. Todavia, afirma que isso é para quaisquer triângulos, ou seja, o estudante acredita que em qualquer triângulo haverá explícitas as unidades de sentido "cateto oposto" e "hipotenusa". Em seus cálculos nos triângulos diferentes de triângulo retângulo, ele estabelece que o cateto oposto é o lado oposto ao ângulo, mas não fica 
claro qual o critério que ele usou para identificar qual lado é a hipotenusa. Cley não parece ter compreendido o objeto "Lei dos Senos". De certa forma, ele parece saber representar os registros necessários para a compreensão, mas não sabe relacioná-los coerentemente de forma que compreendesse o teorema. Parece que associou tal teorema à pura definição do seno.

Para o item 1, An (din) fez o seguinte registro de representação visual:

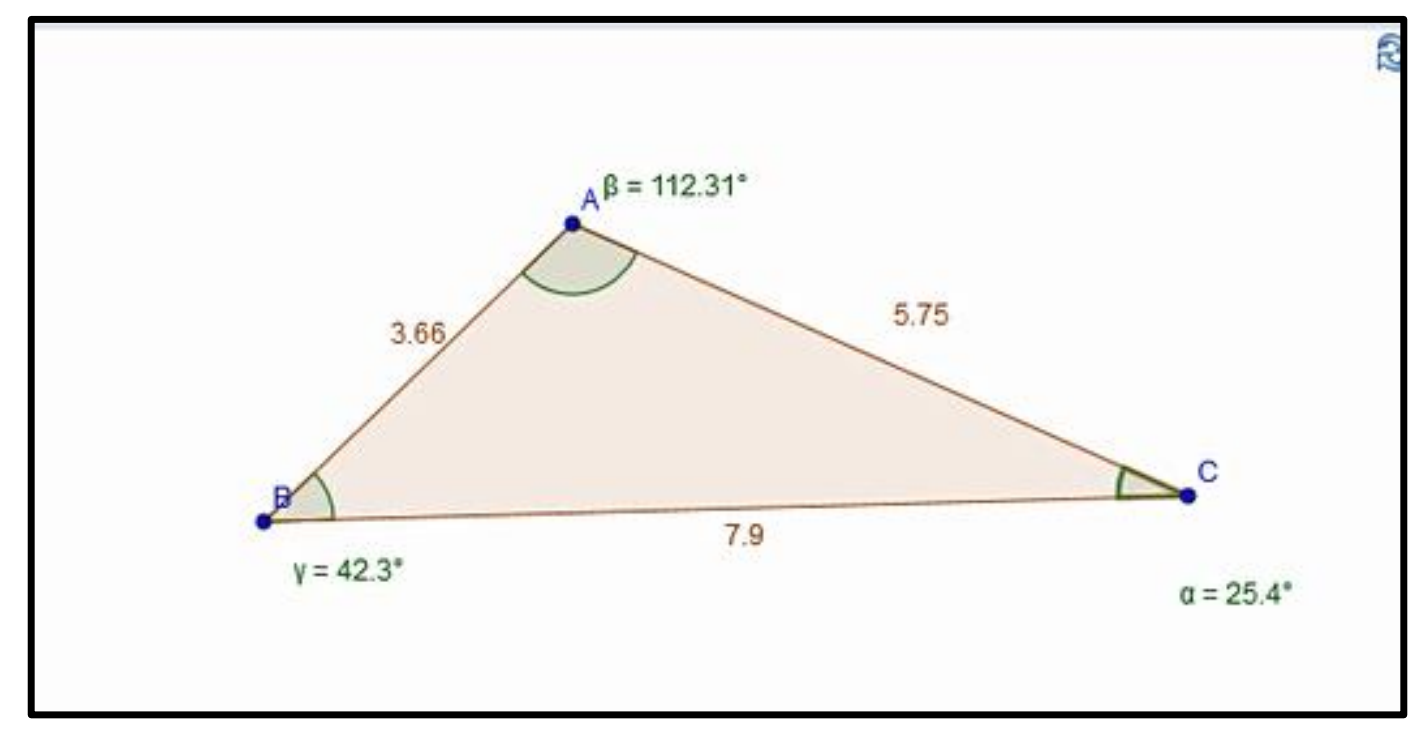

Figura 70-Resposta de An para o item 1 da atividade 5

An fez um triângulo qualquer, mediu seus lados e ângulos internos. Para o item 2, An usou o editor de equações e os dados do triângulo que estavam no ambiente GeoGebra. Primeiramente, fez um registro de representação simbólico da lei (equação da Lei dos Senos). Depois faz as razões com os dados do triângulo. Movimenta um dos vértices e percebe que as razões continuam iguais.

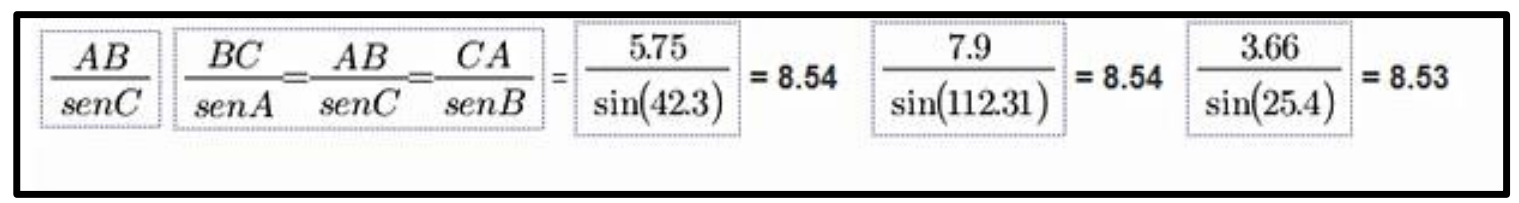

Figura 71-Resposta de An para o item 2 da atividade 5

Para o item 3, An escreve A partir da lei dos senos obtemos a proporção dos lados $e$ com ela podemos encontrar o valor de um ângulo (sic), o valor de um lado em um triangulo (sic) qualquer usando o seno dos angulos (sic) do triangulo. Ela não escreve exatamente o que é a Lei dos Senos e assim como na atividade anterior, fala o que se pode fazer com ela. Continua ainda associando a proporcionalidade somente aos lados e não aos lados e senos dos ângulos opostos. Podemos dizer que An sabe fazer, parece compreender, mas não sabe 
registrar de forma escrita. Ou seja, fez a narrativa, integrou dinamicamente as representações simbólicas, mas não soube converter corretamente para a representação linguística.

Para o item 1, Dio fez os seguinte registro de representação visual:

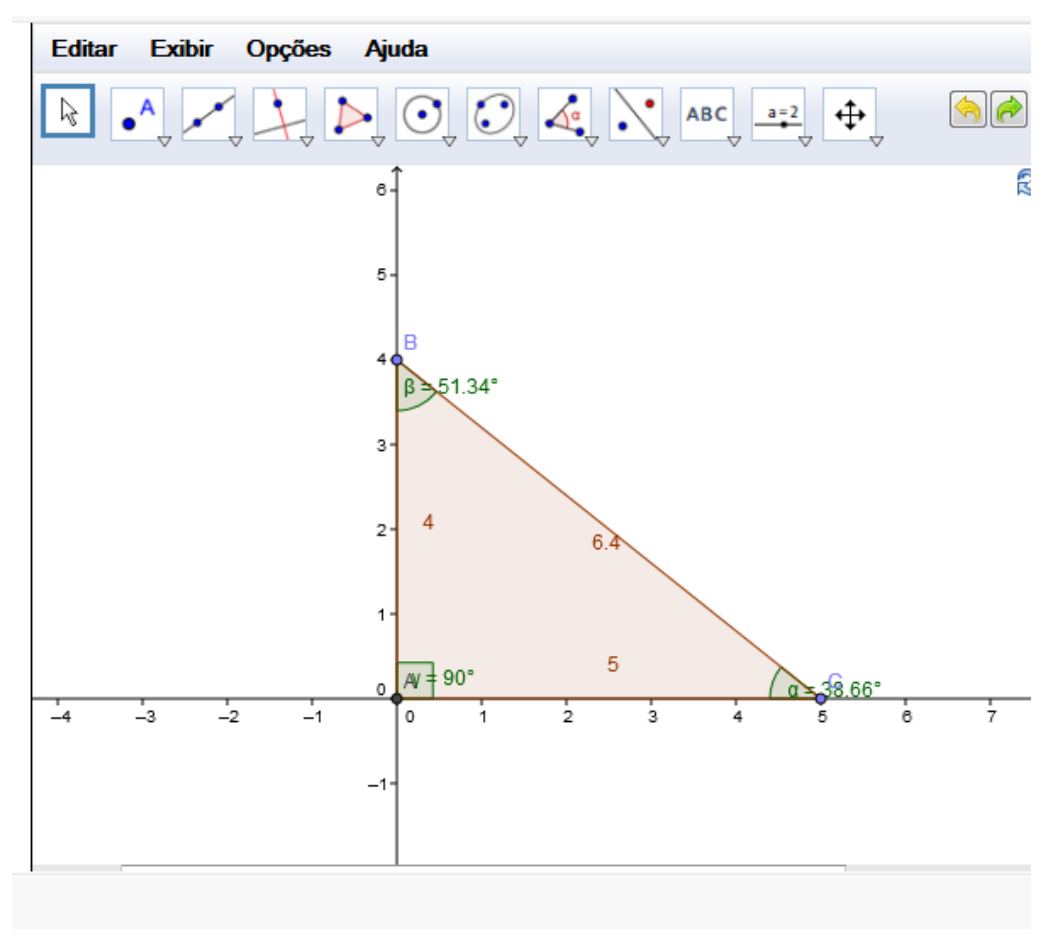

Figura 72-Resposta de Dio para o item 1 da atividade 5

Como se pode ver na Figura 72, Dio fez um triângulo retângulo. Assim como Die e Cley, Dio parece associar também a lei dos senos apenas ao triângulo retângulo. Para o item 2, Dio usou o editor de equações e os dados do triângulo que estava no ambiente GeoGebra para fazer as seguintes razões: $\frac{4}{\sin (38,66)}=\frac{6.4}{\sin (90)}=\frac{5}{\sin (51,34)}$. Ele não usa a função que possibilita mostrar o resultado das razões. Para o item 3, Dio escreve que todos os lados de um triangulo (sic) dividido pelo seno oposto é (sic) igual. Ele não usou a ferramenta de mostrar resultado e mesmo assim inferiu que $\frac{4}{\sin (38,66)}$ é igual a $\frac{6.4}{\sin (90)}$ que é igual a $\frac{5}{\sin (51,34)}$. Ele deve ter chegado a essa conclusão a partir da atividade anterior em que disse o cateto de um triangulo dividido pelo seno oposto é igual para qualquer um dos lados. Dio sabe fazer as representações, parece compreender, mas não sabe registrar de forma escrita. Ou seja, fez a narrativa, integrou as representações, mas não soube converter corretamente para a representação linguística.

Para o item 1, Mar fez o seguinte registro de representação visual: 


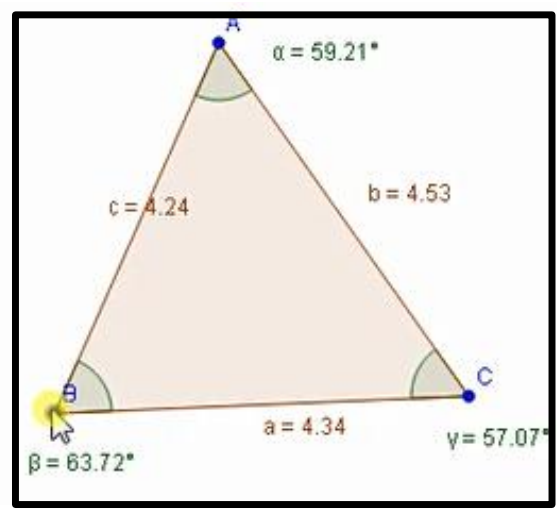

Figura 73-Resposta de Mar para o item 1 da atividade 5

Para o item 2, Mar usou o editor de equações e os dados do triângulo que estava no ambiente GeoGebra para fazer as seguintes razões: $\frac{4,53}{\sin (63,72)}=5,05, \frac{6.44,34}{\sin (59,21)}=5,05$ e $\frac{4,24}{\sin (57,07)}=5,05$. Movimentou um pouco os vértices e pareceu perceber que os resultados eram sempre iguais. Para o item 3, Mar escreve o que está na Figura 74.

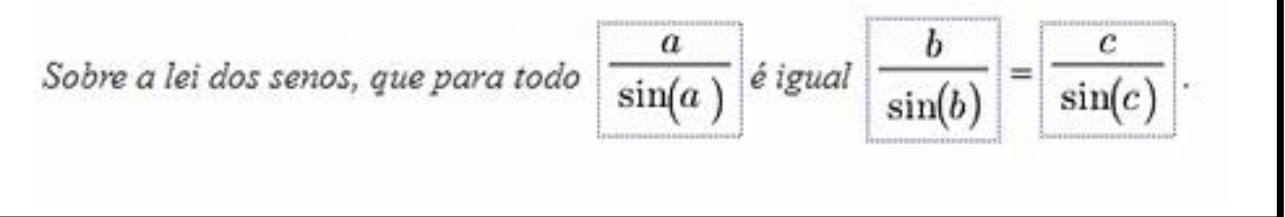

Figura 74-Resposta de Mar para o item 3 da atividade 5

Mar, apesar de omitir a palavra triângulo, mostra que sabe fazer, parece compreender e sabe registrar de forma escrita. Ou seja, fez a narrativa, integrou dinamicamente as representações e soube fazer a representação linguística que mesclava texto e símbolos matemáticos (fez um texto dinâmico). Todavia, essa representação não evidenciou que ele compreendeu que as igualdades estavam relacionadas com a unidade de sentido "proporcionais".

Essa atividade era onde queríamos evidenciar de fato as principais diferenças entre as produções da narrativa no ambiente estático e dinâmico. Com exceção de Cley, parece que todos demonstraram ter compreendido o que é a Lei dos Senos. Todavia, as repostas de Mar e Dio para o item 3 foram as que melhor evidenciaram tal compreensão. Pode-se ver claramente a conversão para o registro de representação linguístico nas respostas do estudante Mar. No tópico seguinte "Produção das narrativas nos dois ambientes" falaremos mais sobre essas diferenças. 
As atividades 6 e 7 tinham propósito de que os estudantes pudessem compreender a justificativa da Lei dos Senos.

Para a atividade 6

Considere a seguinte figura

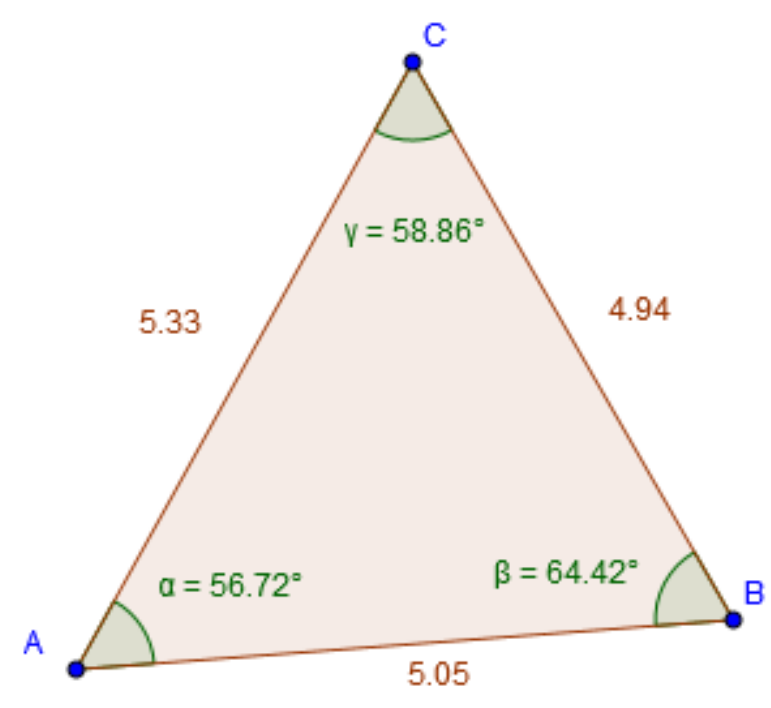

a) O que é o seno de um ângulo?

b) Pode escrever o que é na figura anterior o seno do ângulo Â (alfa)?

Para o item a, Die (est) demonstra saber o que é o seno de um ângulo quando escreve Em um triângulo retângulo o seno é a divisão do cateto oposto pela hipotenusa. Entretanto, no item b, Die escreve $\operatorname{sen} \hat{A}=\frac{4,94}{\operatorname{sen}(56,72)}$. A conversão que Die fez está na Tabela 7:

\begin{tabular}{|l|c|c|}
\hline \multicolumn{1}{|c|}{ Registros } & \multicolumn{1}{|c|}{$\begin{array}{c}\text { Registro de } \\
\text { representação } \\
\text { linguística }\end{array}$} & $\begin{array}{c}\text { Registro de } \\
\text { representação } \\
\text { simbólica }\end{array}$ \\
\hline $\begin{array}{l}\text { Signos (ou unidades de } \\
\text { sentido) }\end{array}$ & Triângulo retângulo & \\
\hline $\begin{array}{l}\text { Signos (ou unidades de } \\
\text { sentido) }\end{array}$ & Divisão & \\
\hline $\begin{array}{l}\text { Signos (ou unidades de } \\
\text { sentido) }\end{array}$ & Cateto oposto & 4,94 \\
\hline $\begin{array}{l}\text { Signos (ou unidades de } \\
\text { sentido) }\end{array}$ & Hipotenusa & Sen(56,72) \\
\hline
\end{tabular}

Tabela 7-Tradução simbólica feita por Die 
A Tabela 7 mostra que ele associa o cateto oposto com lado oposto do triângulo. Já a hipotenusa ele associa com o próprio seno do ângulo $\alpha$.

Para o item "a", Cley (est) usa os registros de representação simbólica e linguística (Figura 75).

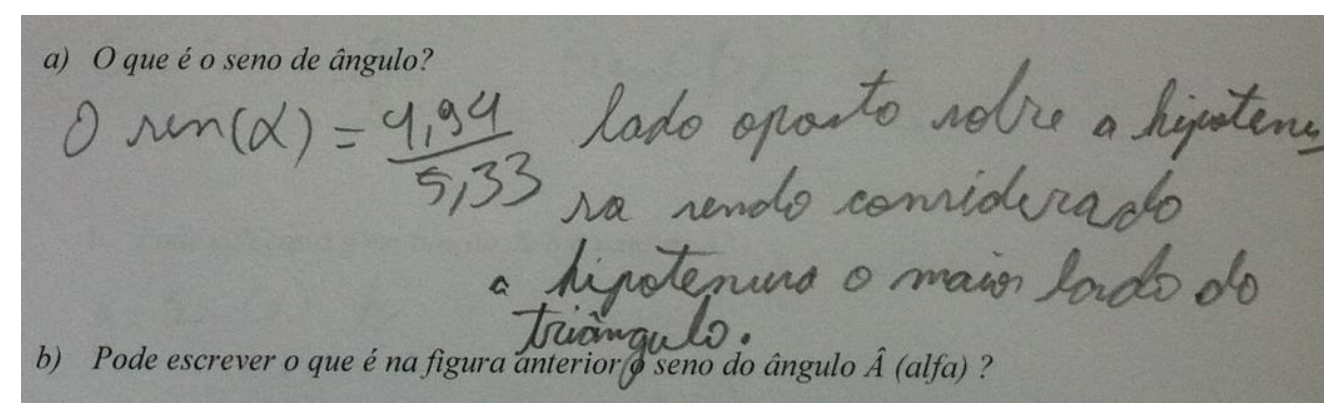

Figura 75-Resposta de Cley para o item a da atividade 6

Cley faz a seguinte conversão:

\begin{tabular}{|l|c|c|}
\hline \multicolumn{1}{|c|}{ Registros } & \multicolumn{1}{|c|}{$\begin{array}{c}\text { Registro de } \\
\text { representação } \\
\text { linguística }\end{array}$} & $\begin{array}{c}\text { Registro de } \\
\text { representação } \\
\text { simbólica }\end{array}$ \\
\hline $\begin{array}{l}\text { Signos (ou unidades } \\
\text { de sentido) }\end{array}$ & Lado oposto & 4,94 \\
\hline $\begin{array}{l}\text { Signos (ou unidades } \\
\text { de sentido) }\end{array}$ & Sobre & \\
\hline $\begin{array}{l}\text { Signos (ou unidades } \\
\text { de sentido) }\end{array}$ & Hipotenusa & 5,33 \\
\hline
\end{tabular}

Tabela 8-Tradução simbólica feita por Cley

Cley continua relacionando cateto oposto com lado oposto, mas dessa vez estabelece um critério para ser hipotenusa: ser o maior lado do triângulo. Isso nos leva a acreditar que Cley acha que os elementos hipotenusa e cateto oposto estão explícitos em qualquer triângulo. Para o item b, Cley apenas representa simbolicamente o que havia escrito no item anterior e digita $\operatorname{sen}(\alpha)=\frac{4,94}{5,33}$.

Para o item a, An (din) escreve: E a razão do valor do cateto oposto ao ângulo observado, dividido pela hipotenusa do triangulo(sic) (isso em um triangulo (sic) retângulo). Em relação ao item $\mathrm{b}$, An escreve: A minha noção de seno vem de um triangulo retangulo(sic), que possui dois catetos e uma hipotenusa (lado oposto ao angulo de noventa graus). Devido a isso não consigo calcular o seno do angulo alfa. A estudante percebe que o seno do ângulo está relacionado com o triângulo retângulo. Como o triângulo da figura não é 
retângulo e não há as unidades de sentido "cateto oposto" e "hipotenusa" explícitas na figura, então a estudante diz que não consegue calcular o seno de alfa.

Para o item a, Mar (din), assim como Die, demonstra conhecer a definição do seno de um ângulo quando digita $O$ seno é o cateto oposto sobre hipotenusa. Todavia, incialmente, ele havia colocado que $O$ seno do ângulo é o lado oposto a ele. Ao fazer a atividade 7, ele percebe a altura do triângulo e volta na página anterior para escrever corretamente. Apesar disso, para o item b, Mar escreve, incialmente, Sen do $\hat{A}(a l f a)=5,64 \frac{51,97}{\sin (5.64)}$. Depois apaga a divisão e deixa somente Sen do $\hat{A}(a l f a)=5,64$. Ou seja, continua achando que o seno de um ângulo é o lado oposto a ele. A Figura 76 estava na tela do GeoGebra de Mar.

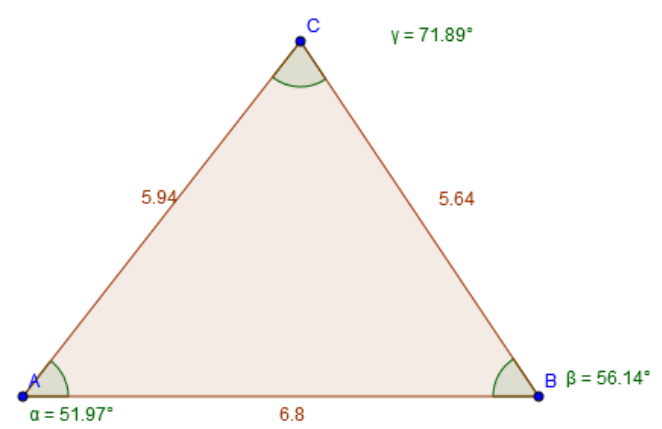

Figura 76-Triângulo que estava na tela do GeoGebra de Mar na atividade 6

É importante também lembrar que Mar escreveu incialmente a razão $\frac{51,97}{\sin (5.64)}$. Ele havia escrito que $O$ seno é o cateto oposto sobre hipotenusa. Ao que parece o estudante fez a conversão da seguinte maneira:

\begin{tabular}{|l|c|c|}
\hline \multicolumn{1}{|c|}{ Registros } & \multicolumn{1}{|c|}{$\begin{array}{c}\text { Registro de } \\
\text { representação } \\
\text { linguística }\end{array}$} & $\begin{array}{c}\text { Registro de representação } \\
\text { simbólica }\end{array}$ \\
\hline $\begin{array}{l}\text { Signos (ou unidades de } \\
\text { sentido) }\end{array}$ & Cateto oposto & 51,97 \\
\hline $\begin{array}{l}\text { Signos (ou unidades de } \\
\text { sentido) }\end{array}$ & Sobre & \\
\hline $\begin{array}{l}\text { Signos (ou unidades de } \\
\text { sentido) }\end{array}$ & Hipotenusa & $\operatorname{Sin}(5,64)$ \\
\hline
\end{tabular}

Tabela 9-Tradução simbólica feita por Mar

Ou seja, colocou no numerador a medida do ângulo $\alpha$ e no denominador o seno do lado oposto ao ângulo. 
Para o item a, Dio (din) escreve corretamente: cateto oposto sobre hipotenusa. Já para o item b, Dio escreve $\sin ($ alf $a)=\frac{6,52}{7,32}=54,54$. O triângulo que estava na tela do GeoGebra de Dio está na Figura 77.

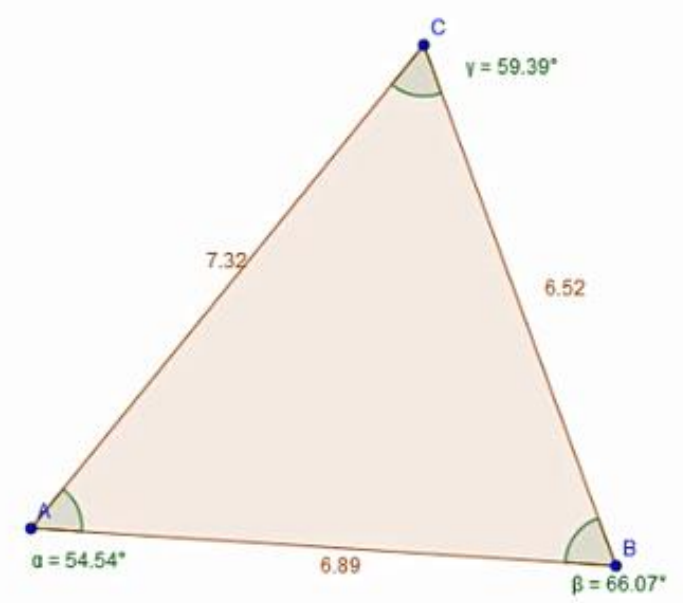

Figura 77-Triângulo que estava na tela do GeoGebra de Dio na atividade 6

O estudante fez a conversão da seguinte maneira:

\begin{tabular}{|l|c|c|}
\hline \multicolumn{1}{|c|}{ Registros } & $\begin{array}{c}\text { Registro de representação } \\
\text { linguística }\end{array}$ & $\begin{array}{c}\text { Registro de } \\
\text { representação } \\
\text { simbólica }\end{array}$ \\
\hline $\begin{array}{l}\text { Signos (ou } \\
\text { unidades de } \\
\text { sentido) }\end{array}$ & Cateto oposto & 6,52 \\
\hline $\begin{array}{l}\text { Signos (ou } \\
\text { unidades de } \\
\text { sentido) }\end{array}$ & Sobre & \\
\hline $\begin{array}{l}\text { Signos (ou } \\
\text { unidades de } \\
\text { sentido) }\end{array}$ & Hipotenusa & 7,32 \\
\hline
\end{tabular}

Tabela 10-Tradução simbólica feita por Dio

Dio, assim como Cley, relaciona cateto oposto com lado oposto e parece estabelecer o mesmo critério para hipotenusa: ser o maior lado do triângulo. O lado AC $(7,32)$ era de fato a hipotenusa do triângulo retângulo (implícito na figura) relativo ao ângulo $\alpha$, mas ele não parece ter identificado isso conscientemente. Sem efetuar a divisão, Dio coloca que ela é igual a 54,54, ou seja, igual ao ângulo (alfa). 
Para fazermos nossas análises finais dessa atividade, precisamos retomar quais eram os objetivos. Tratava-se de uma atividade necessária para a compreensão da justificativa do teorema que viria na atividade seguinte. Para isso era necessário saber se o estudante sabia de fato o que era o seno, explicitando em registro linguístico e relacionando com o registro de representação visual. De fato, não foi pedido para se calcular o seno do ângulo e sim dizer o que era. Percebeu-se que os estudantes sabem representar usando registro linguístico a definição de seno de um ângulo. Todavia, apesar de saber qual a definição de seno do ângulo, eles não demonstram compreender bem o conceito. Isso confirma o que Duval (2004) citado por Kluppel e Brandt (2014, p.120) diz:

Entre as principais dificuldades na aprendizagem da Geometria, Duval (2004) afirma
que os conceitos não ocupam o primeiro lugar. O que para o autor dificulta a
aprendizagem da geometria é a proximidade entre os tratamentos relevantes e
irrelevantes dentro de um mesmo registro, e a falta de coordenação entre tratamentos
que provém de diferentes registros o mesmo mecanismo.

Como compreender bem o conceito seno e a Lei dos Senos se o estudante não sabe identificar e relacionar a unidade de sentido hipotenusa no registro de representação linguística e visual? Esperava-se que a estudante explicitasse as unidades de sentido "cateto oposto" e "hipotenusa", traçando uma altura do triângulo. Isso era importante para a compreensão da justificativa que viria na atividade seguinte.

Talvez a questão tenha induzido o estudante a achar que na figura havia, explicitamente, todos os elementos necessários para que ele pudesse dar a resposta. Os estudantes devem ter achado que todos os dados para a resolução de uma atividade estavam explícitos no enunciado (na representação linguística, simbólica ou visual), porque em geral as atividades em sala não têm abordado as construções geométricas. Quando a unidade de sentido não está explícita no registro de representação visual, o estudante precisa construí-la ou imaginá-la. Para isso, era necessário que os estudantes tomassem consciência da desconstrução dimensional que é complexa, porque ela se faz contra a percepção, isto é, contra o reconhecimento imediato de unidades figurais $2 \mathrm{~d} / 2 \mathrm{~d}$ que se impõem à primeira vista e que bloqueiam o reconhecimento de outras unidades (DUVAL, 2011). Um exemplo de desconstrução que os estudantes deveriam fazer está representado na Figura 78. 


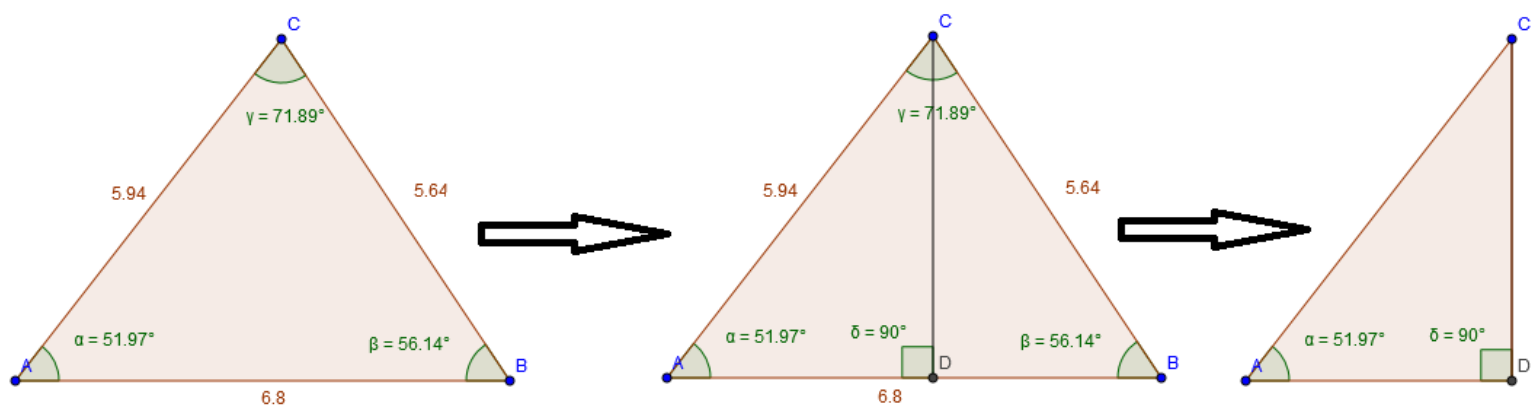

Figura 78-Desconstrução necessária para a identificação das unidades de sentido hipotenusa e cateto oposto

Concordamos com Duval (2011, p.144) quando diz que "O que é impressionante não é o que eles explicam, mas o que eles não identificam porque não observam". Veremos na atividade seguinte o que acontece quando explicitamos no registro de representação visual as unidades de sentido cateto oposto e hipotenusa.

Para a atividade 7 ,

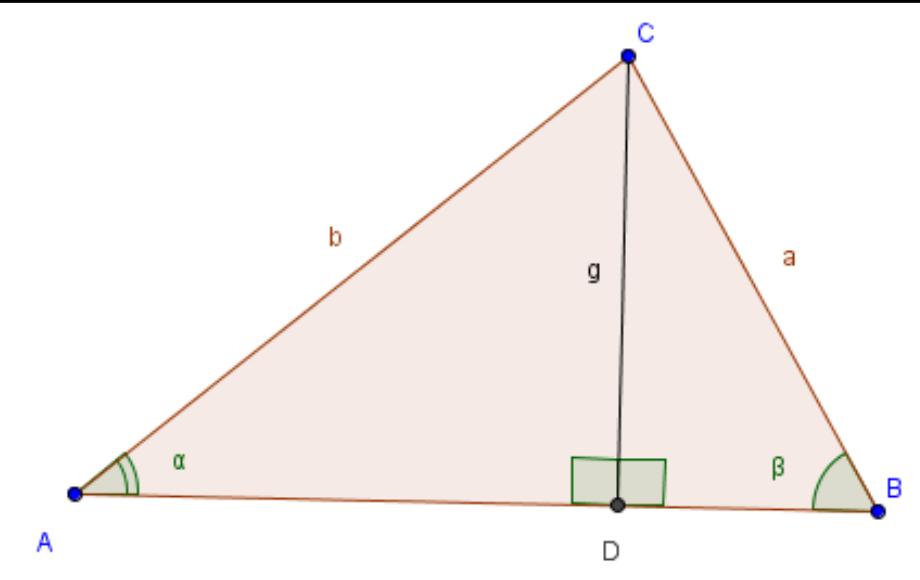

a) Olhando para figura anterior, poderia dizer o que é o seno do ângulo A ? E o seno do ângulo B? (escreva usando símbolos matemáticos)

b) Pode colocar o $g$ em função de $b$ e seno de A?

c) Pode colocar o $\mathrm{g}$ em função de a e seno de B?

d) O que você observa?

Para o item a, Die (est) escreve $\operatorname{sen} \hat{\mathrm{A}}=\frac{g}{b}$ e $\operatorname{sen} \hat{B}=\frac{g}{a}$. Para o item $\mathrm{b}$, escreve $g=$ senA.b. O item c, escreve $g=\operatorname{senB} . a$. Finalmente, para o item d, escreve que o lado $g$ é igual ao produto dos senos dos ângulos opostos a ele pelas hipotenusas. Todas as respostas do estudante estão corretas. De fato, no item d esperávamos que ele fizesse mais um tratamento nas equações dos itens b e c, igualando as equações, da seguinte forma: 
$\operatorname{sen} A \cdot b=\operatorname{sen} B \cdot a$

$$
\frac{b}{\operatorname{sen} B}=\frac{a}{\operatorname{sen} A}
$$

Para o item a, Cley (est) escreve $\operatorname{sen}(\alpha)=\frac{g}{b}$ e $\operatorname{sen}(\beta)=\frac{g}{a}$. Para o item b, escreve: $g=\operatorname{sen}(\alpha) . b . \mathrm{O}$ item c, escreve $g=\operatorname{sen}(\beta) . a$. Finalmente, para o item d, escreve: Pode-se obter o valor de $g$ fazendo $g$ em função de a e $\operatorname{sen}(\beta)$ ou $g$ em função de b e $\operatorname{sen}(\alpha)$. Assim como Die, as respostas também estão corretas.

Já An (din), no item a, digita $\operatorname{sen} A=\frac{C D}{A C}$ e $\operatorname{sen} B=\frac{C D}{B C}$. Para os itens b e c, a estudante usa as letras que designavam os segmentos do triângulo. Assim, digita $\operatorname{sen} A=\frac{g}{b} \operatorname{logo}$ $g=\operatorname{sen} A^{*} b$. No item $\mathrm{c}$, digita $\operatorname{sen} B=\frac{g}{a} \operatorname{logo} g=\operatorname{sen} B^{*} a . \quad$ Finalmente, para o item $\mathrm{d}$, escreve que podemos obter o valor de um lado apenas pegando o valor do seno de seu angulo (sic) oposto e multiplicando-o pelo lado oposto ao que se quer saber a medida. E sempre teremos: $g$ dividido por sen A que e igual a g dividido por sen B. Assim obtemos a lei dos senos, e a parir (sic) dessa lei podemos calcular o valor da medida e da proporção dos lados de um triangulo (sic). Apesar de não ser a resposta que esperávamos, a primeira parte está correta. Mas, no final ela diz: E sempre teremos: $g$ dividido por sen A que e igual a $g$ dividido por sen B. Assim obtemos a lei dos senos, e a parir (sic) dessa lei podemos calcular o valor da medida e da proporção (sic) dos lados de um triangulo. Essa resposta é bem próxima do que havíamos esperado. Ela escreve $g$ dividido por sen A que é igual a g dividido por sen $B$. Qual foi o tratamento que ela fez nas equações para inferir isso? Ao que parece, ela fez:

$$
\operatorname{sen} B=\frac{g}{a} \rightarrow a=\frac{g}{\operatorname{sen} B} \quad \text { e } \operatorname{sen} A=\frac{g}{b} \rightarrow b=\frac{g}{\operatorname{sen} A}
$$

Mas, como inferiu que $\frac{g}{\operatorname{sen} A}=\frac{g}{\operatorname{sen} B}$ ? Percebe-se que a estudante não possui muita clareza no uso da propriedade transitiva (Se $a=b$ e $b=c$, então $a=c$ ).

Mar (din), inicialmente digita, $O$ sen do $\hat{A}(A)$, sen do $\hat{A}(B)=g$. Na realidade, ele usa Â para representar a palavra ângulo. Ou seja, ele diz que ambos os senos dos ângulos são iguais a g. Depois de refletir algum tempo nos outros itens, ele volta e digita: $O$ sen do $(A)=$ $g / b$ e o seno do $(B)=g / a$. Para o item b, inicialmente digita Sim, pois ao traçar uma reta perpendicular no triângulo, criamos dois triângulos e o lado g se torna um cateto oposto 
sobre a hipotenusa $b$, se tornando se de A. Para o item c, também digita inicialmente Sim, pois ao traçar uma reta perpendicular no triângulo, criamos dois triângulos e o lado g se torna um cateto oposto sobre a hipotenusa a, se tornando se de A. Nesses momentos, parece haver o fenômeno de "objetivação" porque o estudante parece tomar consciência de que traçar a altura era necessário para explicitar as unidades de sentido "cateto oposto" e "hipotenusa". Ressalta-se que na atividade anterior em que não estavam explícitas tais unidades de sentido, o estudante relacionou cateto oposto com lado oposto e hipotenusa com o maior lado do triângulo.

Quando chega ao item d, percebe que tem que usar registros de representação simbólicos e muda as respostas dos itens b e c para:
b) $\operatorname{Sen}(A)=g / b \quad g=\operatorname{sen}(A) \cdot b$
c) $\operatorname{Sen}(B)=g / a g=\operatorname{sen}(B) \cdot a$

No item d, Mar escreve: Observei que ambas equações são iguais, ou seja sen (B).a= sen (A).b, mesmo alterando a posição dos senos iremos chegar no mesmo resultado. Se ele tivesse feito mais um pequeno tratamento nos registros poderia obter o que esperávamos:

$$
\begin{aligned}
\operatorname{sen} A \cdot b & =\operatorname{sen} B \cdot a \\
\frac{b}{\operatorname{sen} B} & =\frac{a}{\operatorname{sen} A}
\end{aligned}
$$

No item a, Dio (din) digita $\sin ($ alfa $)=\frac{g}{b}$ e $\sin ($ beta $)=\frac{g}{a}$. Para o item $b$, inicialmente Dio coloca apenas: Sim, é só isolar o que se pede. Após uma breve intervenção do professor, ele faz: $g=\sin (a l f a) . b$ e $g=\sin ($ beta). $a$. Para o item $\mathrm{b}$, Dio escreve seno de beta multiplicado por a é igual a altura do triângulo e seno de beta multiplicado por b é igual a altura do triângulo.

Nessa atividade queríamos que os estudantes entendessem uma justificativa para a Lei dos Senos. Não se tratava de uma demonstração completa e formal. A ideia era que eles pudessem relacionar as representações visual e simbólica para obter as seguintes equações:

$$
\operatorname{sen}(A)=\frac{g}{b} \rightarrow g=b \cdot \operatorname{sen}(A)
$$




$$
\operatorname{sen} B=\frac{g}{a} \rightarrow g=a \cdot \operatorname{sen}(B)
$$

Depois disso, fariam alguns tratamentos nas equações para obter:

$$
\frac{b}{\operatorname{sen} B}=\frac{a}{\operatorname{sen} A}
$$

Como pudemos perceber nas análises, os estudantes chegaram muito próximo da última equação. Talvez eles pudessem compreender toda a justificativa, se tivéssemos colocado outro item que os orientasse para um novo tratamento nas equações $g=b$. $\operatorname{sen}(A)$ e $g=a$. $\operatorname{sen}(B)$. No último item foi colocado $O$ que você observa? Esperávamos que antes de responderem, fariam o tratamento em que igualariam as duas equações e dividiriam ambos $\begin{array}{llll}\text { os } & \text { lados } & \operatorname{sen}(\mathrm{A}) \cdot \operatorname{sen}(\mathrm{B}), & \text { obtendo }\end{array}$ $\frac{b}{\operatorname{sen} B}=\frac{a}{\operatorname{sen} A}$.

Apesar de não concluírem como esperávamos, há de se destacar que com essa atividade, os estudantes conseguiram identificar as unidades de sentido cateto oposto e hipotenusa no registro de representação visual. Para isso, eles identificaram as unidades figurais a partir das designações verbais do enunciado. Depois, integraram as unidades figurais para fazer as representações simbólicas.

Ao final desta análise, é possível concluir que a maior parte dos estudantes conseguiu compreender o que é a Lei dos Senos. No entanto, nenhum estudante mostrou compreender a justificativa. Ao contrário do que imaginávamos inicialmente, a atividade não deu condições para tal compreensão.

No tópico seguinte, faremos as análises mais relacionadas com as diferenças entre as produções das narrativas nos dois ambientes.

\subsection{Produção das Narrativas nos dois ambientes}

A análise da categoria Produção das narrativas nos dois ambientes buscou responder às seguintes questões apresentadas na metodologia:

- Permitem as três atividades cognitivas: formação, tratamento e conversão?

- De que forma permite a integração entre os diferentes registros de representação do objeto matemático? 
- É possível se expressar matematicamente?

- É possível fazer as atividades com diferentes tipos de conversões?

- Há dificuldades de manipulação dos recursos? Quais?

- É possível por meio da narrativa do estudante identificar a "ordem cronológica" em que foi feita? Ou seja, de que forma pode-se perceber o elemento historicidade na narrativa produzida pelo estudante? Isso influencia a compreensão da narrativa por parte do professor?

- O ambiente contribui ou dificulta a identificação, por parte do estudante, das unidades de sentido dos diferentes registros?

- De que forma as funcionalidades do GGBOOK superam alguns limites do GeoGebra?

De maneira geral, o que se constatou com os dados obtidos nos dois ambientes é que ambos permitem as três atividades cognitivas: formação, tratamento e conversão. Todavia, cada ambiente possui características que dificultam ou facilitam tais atividades.

Para a atividade de formação dos registros de representação visual não se percebeu maiores dificuldades em ambos os ambientes. Basicamente, para essa representação era necessário apenas fazer um triângulo e traçar uma altura. No ambiente GGBOOK, os estudantes usaram as ferramentas do GeoGebra para construir o triângulo. Para isso, selecionaram a opção triângulo da barra de ferramentas e com três cliques em lugares distintos criaram a figura. É importante salientar que no processo de criação de um polígono no GeoGebra, a linha é feita automaticamente, não sendo necessário que o usuário se preocupe em fazê-la, diferentemente do ambiente estático, em que os estudantes precisam traçar três segmentos de retas com extremos comuns dois a dois. Assim, constata-se que o processo de construção da representação do triângulo nos dois ambientes é diferente. Apesar da janela GeoGebra do GGBOOK possuir a ferramenta "caneta" que permite desenhos à mão livre, as construções são feitas, de maneira geral, a partir de uma definição. Por exemplo, para a construção do triângulo, usou-se a definição: três pontos não alinhados determinam um triângulo. Já no ambiente estático, em geral, trata-se da produção/repetição de um desenho já visto anteriormente, ou seja, pode-se produzir o desenho sem, necessariamente, saber as propriedades. No entanto, para o item 1 da atividade 5, Cley (est) usou um esquadro para produzir a representação de um triângulo retângulo. De certa forma, isso evidencia que ele conhecia uma propriedade do triângulo retângulo: ter um ângulo reto $\left(90^{\circ}\right)$. Portanto, ele não parece ter feito a simples reprodução de um desenho, porque fez, usando instrumentos tradicionais, a construção da figura triângulo. 
É difícil afirmar qual dos dois ambientes possui mais dificuldades ou facilidades para a explicitação do registro de representação visual. Isso porque o estudante pode possuir uma imagem mental de uma figura, mas não saber quais as propriedades que a definem e assim não conseguir produzi-la no GGBOOK. Por outro lado, esse mesmo estudante pode também não conseguir reproduzir o desenho no ambiente estático, se não possuir habilidades para desenhar ou manipular os instrumentos de desenho. É evidente que o caso do triângulo é simples, mas se tomarmos como exemplo uma parábola, a situação será bem mais complexa. O que se pode concluir é que, levando-se em consideração a amostra dessa experimentação, em que todos os estudantes conheciam as propriedades básicas do triângulo e sabiam operar o GeoGebra, o processo de explicitação do registro de representação visual do triângulo foi mais rápido no ambiente GGBOOK do que no ambiente estático.

No que diz respeito à atividade de formação dos registros de representação simbólicos, percebeu-se que ambos os ambientes possibilitaram tal explicitação. No entanto, no ambiente dinâmico foi mais trabalhoso. Vejamos um exemplo. O caso em que An (din) teve que fazer a seguinte representação:

$$
\frac{A B}{\operatorname{sen} C} \frac{B C}{\operatorname{sen} A}=\frac{A B}{\operatorname{sen} C}=\frac{C A}{\operatorname{sen} B}=\frac{5.75}{\sin (42.3)}=8.54 \frac{7.9}{\sin (112.31)}=8.54 \frac{3.66}{\sin (25.4)}=8.53
$$

Figura 79-Representação simbólica feita por An para o item 2 da atividade 5

Para fazer tal representação simbólica no ambiente texto ela teve que clicar no ícone que representa a fração, depois clicou no espaço que representa o numerador e digitou BC. Depois clicou no denominador e digitou senA. Colocou o cursor na frente da fração e digitou “=”. Clicou novamente no ícone que representa a fração, depois clicou no espaço que representa o numerador e digitou $\mathrm{AB}$. Em seguida, clicou no denominador e digitou senC. Colocou o cursor na frente da fração e digitou " =". Clicou novamente no ícone que representa a fração, depois clicou no espaço que representa o numerador e digitou CA. Depois clicou no denominador e digitou senB. Para a segunda parte, em que ela insere na fração os dados que estavam na janela GeoGebra e mostra o resultado da divisão, ela teve que fazer o seguinte procedimento:

- Clicou no ícone que representa a fração, depois clicou no espaço que representa o numerador, pressionou a tecla "ctrl" e, no ambiente GeoGebra, clicou na medida do lado BC, inserindo o valor. Depois clicou no denominador e inseriu "sin", clicando 
sobre o ícone que o representa. Apertou a tecla "ctrl” e, no ambiente GeoGebra, clicou na medida do ângulo cujo vértice é A, inserindo o valor. Colocou o cursor dentro da fração e clicou no ícone “=”, aparecendo assim, o resultado.

Para fazer as outras frações, o procedimento técnico foi o mesmo. Lendo os procedimentos, pode parecer muito trabalhoso, mas não é. Com exceção do procedimento de apertar a tecla "ctrl", os demais são bastante intuitivos e os estudantes não levaram muito tempo para executá-los. É evidente que no ambiente estático é mais rápido. Todavia, tal vantagem é relativa, porque existem benefícios na produção da representação simbólica no ambiente dinâmico em relação ao estático, sobretudo quando as representações estão integradas. Quando isso acontece e se faz uma alteração num registro de representação visual, todo o registro de representação simbólico se ajusta, não precisando ser feito novamente. Outra vantagem é o resultado automático das operações, não sendo necessários cálculos ou uso da calculadora.

Também é preciso destacar as vantagens das formas de se fazer a representação simbólica no ambiente texto do GGBOOK em relação ao GeoGebra. Para fazer representação de An (Figura 78) no GeoGebra, seria necessário digitar o comando $\backslash \operatorname{frac}\{\mathrm{BC}\}\{\operatorname{sen}(\mathrm{A})\}=\backslash \operatorname{frac}\{\mathrm{AB}\}\{\operatorname{sen}(\mathrm{C})\}=\backslash \operatorname{frac}\{\mathrm{AC}\}\{\operatorname{sen}(\mathrm{B})\}$ para gerar $\frac{B C}{\operatorname{sen}(A)}=\frac{A B}{\operatorname{sen}(C)}=$ $\frac{A C}{\operatorname{sen}(B)}$. Se quisesse inserir os valores e mostrar o resultado, deveria digitar o comando: $\backslash \operatorname{frac}\{\mathrm{a}\}\{\operatorname{sen}(\alpha)\}=\mathrm{a} / \operatorname{sen}(\alpha)$. Na realidade, não seria só digitar o comando. O processo é mais complicado, porque era também necessário inserir os dados no comando, clicando sobre as medidas. Além disso, para que se mostre o resultado é preciso colocar o comando a $/ \operatorname{sen}(\alpha)$ dentro de uma caixa no editor, de forma que o GeoGebra reconheça como variáveis associadas às medidas e faça o cálculo (Figura 80).

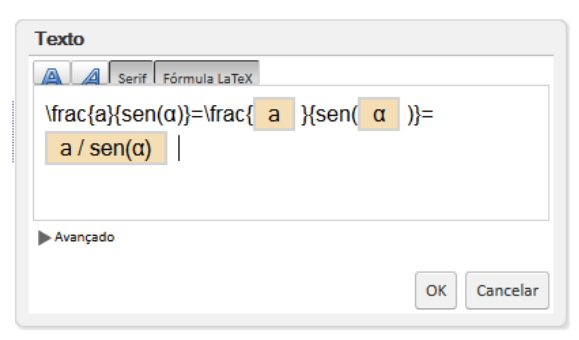

Figura 80-Comandos que precisam ser inseridos no editor de texto do Geogebra

Ou seja, era necessário conhecer um novo registro de representação simbólica: a linguagem LaTeX. 
Em relação à formação dos registros de representação linguísticos, ambos ambientes permitiram sem maiores dificuldades. O editor de texto do GGBOOK possui ferramentas que permitem inserir algumas características no registro de representação linguístico, tais como colocar negrito, itálico, mudar tamanho, cor ou tipo de fonte (17 opções diferentes). Apesar de não terem sido usadas pelos estudantes, tais ferramentas poderiam ser usadas nos registros linguísticos para dar algumas especificidades ao texto. Por exemplo, colocar negrito ou fonte maior em algum trecho que se queira dar maior destaque. Isso também poderia ser feito no ambiente estático. Todavia, no ambiente GGBOOK, o estudante poderia decidir pela alteração do formato sem ter que, necessariamente, apagar o que fez anteriormente. No ambiente estático para alterar as características de um registro linguístico, é necessário apagar o anterior e fazer novamente.

Percebeu-se que ambos os ambientes permitem as atividades de conversão e integração entre os diferentes registros. Por outro lado, há uma grande diferença entre os dois ambientes que estava relacionada com a simultaneidade. Ou seja, casos em que a integração ocorre ao mesmo tempo e que, quando se altera uma, pode-se ver a alteração na outra ocorrendo no mesmo instante. A produção de representações que estão integradas simultaneamente pode ser feita automaticamente ou de forma separada. Por exemplo, pode-se digitar no campo de entrada do GeoGebra a equação $f(x)=x-2$. Como isso, aparecem automaticamente na tela as representações simbólica (equação) e visual (reta). Por outro lado, o caso da atividade 4 feita no GGBOOK é um exemplo de atividade em que as representações são integradas simultaneamente, mas foram feitas de forma separadas.

No ambiente estático não há integração simultânea dos registros de representação, ou seja, a integração pode ser feita, mas de maneira separada, em momentos diferentes e não é possível ver a alteração nas representações ocorrendo ao mesmo tempo. Para que tal integração seja perceptível, o estudante precisa, em muitos casos, de usar algum "conectivo" que remeta uma representação à outra. Por exemplo, vejamos a Figura 81. 


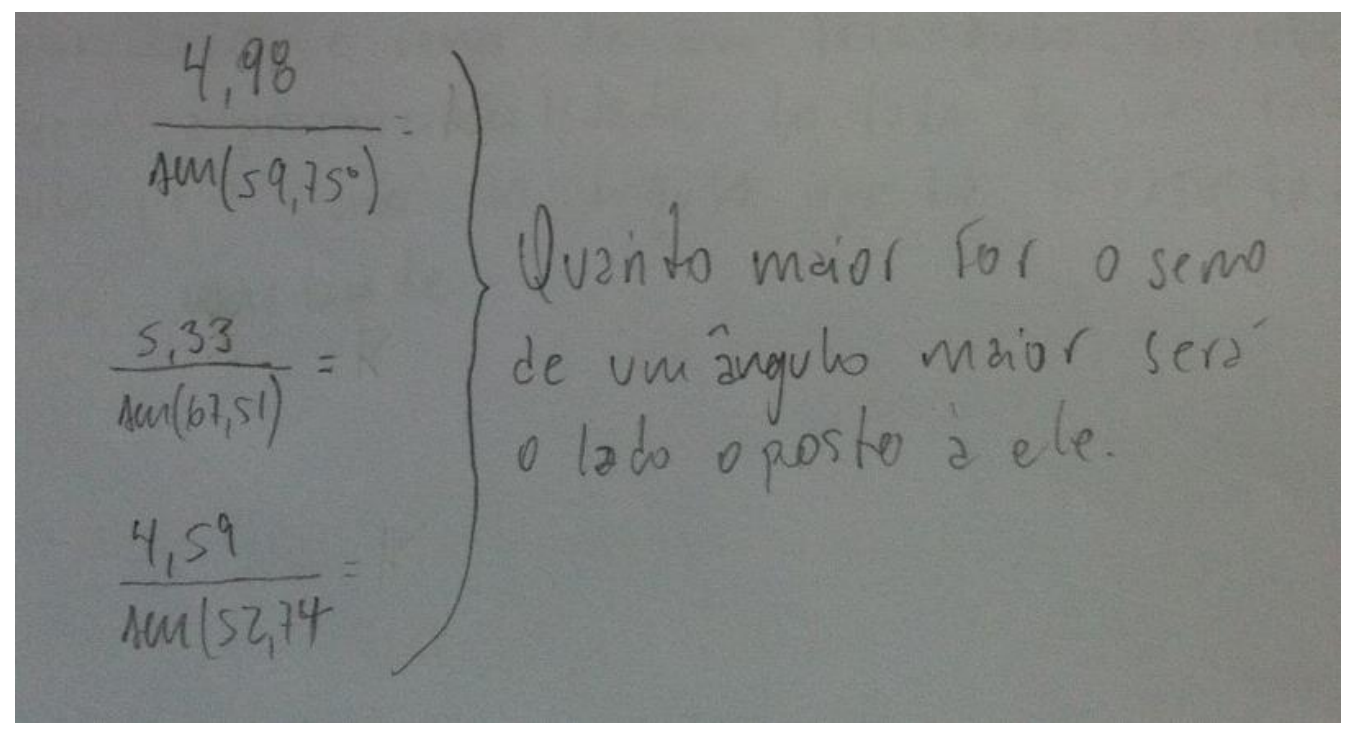

Figura 81-Conectivo usado por Die para integrar as representações simbólica e linguística

Die usa o símbolo de chaves para conectar as representações simbólica e linguística. Ao que pareceu, ele quis fazer uma conversão (tradução linguística). Todavia, na maioria dos casos, os estudantes não explicitam o conectivo e a percepção de como a integração está acontecendo só pode ocorrer pela identificação da ordem em que cada uma aparece. Isso não é fácil, porque nem sempre os registros de representação aparecem numa disposição em que é possível identificar qual foi feito primeiro. Por exemplo, vejamos a Figura 82:

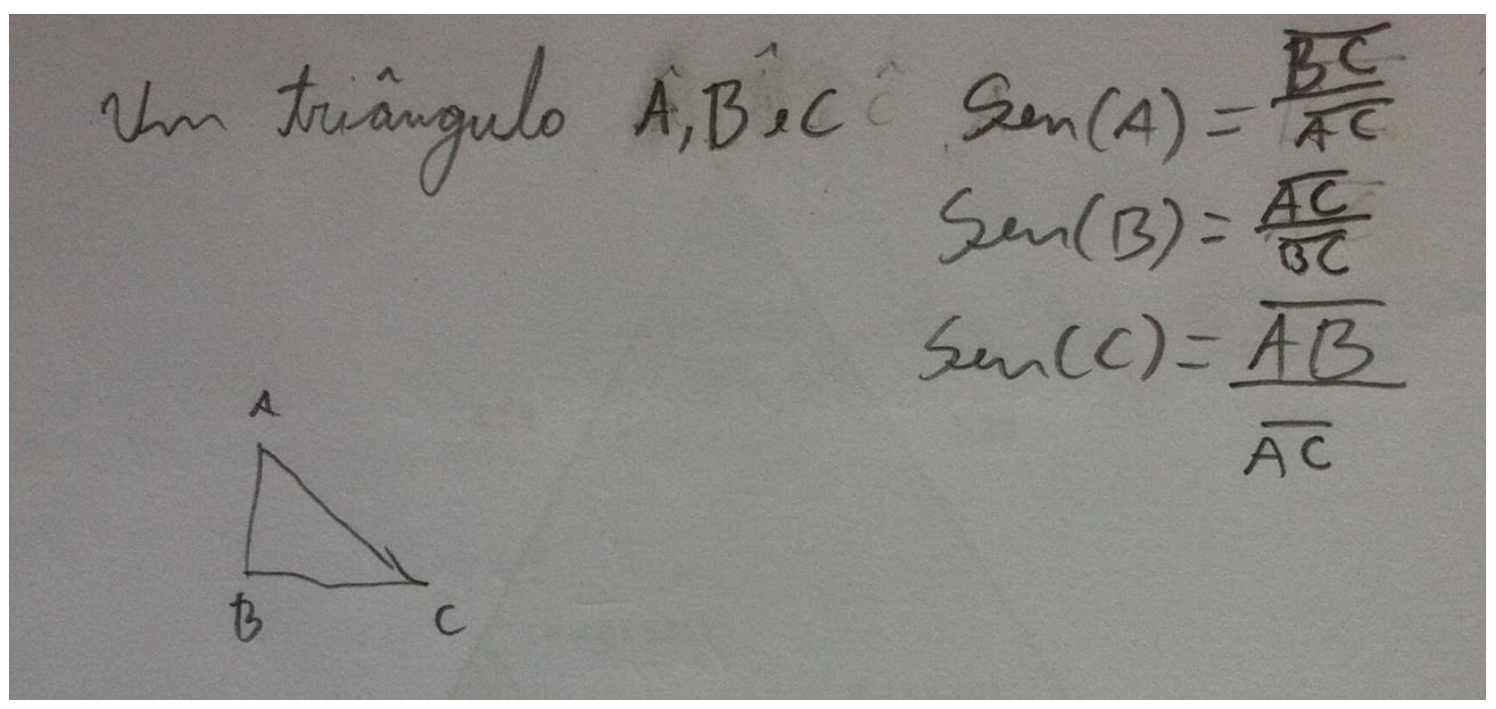

Figura 82-Diferentes representações feitas por Cley para atividade 2

Cley fez três registros de representação para explicar o que entende sobre a Lei dos Senos. Como se pode ver, a simples disposição em que os objetos aparecem não permite identificar com certeza qual foi a ordem em que foram feitos. Pela disposição, pareceu que, 
primeiramente foi feita a representação linguística (Um triângulo A, B e C) e depois a simbólica (frações), porque estão no mesmo nível da folha. Por último, a representação visual (triângulo). No entanto, por meio do vídeo, pôde-se perceber que a ordem foi: representação linguística, visual e simbólica. Uma provável explicação para isso, é que ele tenha feito a conversão do registro linguístico para o visual do objeto triângulo. Depois identificou, no registro visual, as unidades de sentido "cateto oposto" e "hipotenusa", relacionou com o conceito "seno". Finalmente, fez a representação simbólica do conceito seno para mostrar o que entendia por "Em todo triângulo, as medidas dos lados são proporcionais aos senos dos ângulos opostos".

O GGBOOK permite tanto a integração simultânea como não simultânea. Isso vai depender tanto da forma como as atividades foram elaboradas quanto da forma com que os estudantes as respondem. Por exemplo, como nas atividades 1 e 2 havia apenas um registro de representação, então não poderia existir no enunciado a integração simultânea de representações. Nem mesmo esperava-se que os estudantes fizessem uma integração simultânea nas respostas. Já na atividade 4 havia, no enunciado da atividade, a integração simultânea das representações simbólica e visual. Mesmo sem haver uma orientação para manipular o registro visual, Dio e Mar manipularam e perceberam a alteração na representação simbólica da janela de texto. Pelas análises feitas na categoria anterior, constatou-se que tal característica contribuiu para percepção de que os resultados das razões alterariam, mas os cocientes permaneceriam iguais. Isso, por sua vez, contribuiu para uma melhor compreensão do que se pretendia como resposta para o enunciado: "Escreva com suas palavras o que você entendeu". No ambiente estático, a atividade foi colocada da mesma forma do ambiente GGBOOK. As análises da resposta de Cley mostram que ele pode não ter percebido que, se variasse o triângulo, os resultados das razões alterariam, mas os cocientes permaneceriam iguais. Na realidade, acreditamos que ele nem pensou em fazer variar a representação visual para perceber os invariantes na representação simbólica. Para fazer isso, ele teria que desenhar outro triângulo, medir lados e ângulos e fazer razões. Pouco provável que pensasse nisso, porque isso não é feito nas aulas com as quais está acostumado.

Para a atividade 5 do GGBOOK, não há no enunciado a integração simultânea das representações. Todavia, esperava-se que o estudante ao produzir as respostas fizesse a integração das representações de forma simultânea. Essa é uma característica fundamental das Narrativas Matemáticas Dinâmicas. Com isso, acreditávamos que a compreensão fosse ocorrendo ao mesmo tempo em que o estudante estava fazendo e integrando as representações 
e não simplesmente representasse aquilo que já (supostamente) havia compreendido. Isso se confirmou na análise da atividade de An. Mas não constatamos isso apenas com a atividade 5. De fato, num primeiro momento a análise da produção da atividade 5 pode parecer que ela serviu apenas para comunicar algo que ela já havia compreendido, ou seja, a representação foi usada apenas para comunicar. Todavia, essa análise não pode ser feita sem levar em consideração as análises das atividades anteriores. Todas as atividades das páginas anteriores foram elaboradas de forma que o estudante fosse fazendo as conversões para que pudesse compreender a Lei dos Senos. Para converter, ela teria que fazer uma representação de algo que ainda não compreendia bem. Ao analisar a atividade 1 de An, foi possível constatar que ela consegue identificar algumas unidades de sentido (proporcionais, medidas de lados e ângulos) na representação linguística e convertê-las para a representação simbólica, todavia não sabia expressar de forma correta a representação linguística da Lei dos Senos (ver Figura $83)$.

Em todo triangulo a medida seus lados podem ser representadas por: $\left.\left.\frac{\text { ladoa }}{\operatorname{senb}}\right]+\frac{\text { ladob }}{\operatorname{senc}}\right]+\left[\frac{\text { lado }}{\operatorname{sena}}\right.$

Figura 83-atividade 1 feita por An

Já na atividade 2, em que para responder é necessário fazer conversão linguística, ela novamente consegue identificar as unidades de sentido e, apesar de omitir a unidade de sentido "seno", expressa corretamente a representação linguística da Lei dos Senos ao escrever Ela representa a lei dos senos, que estabelece a proporcionalidade dos lados de um triângulo em relação aos ângulos (sic) opostos a esse lado. $\mathrm{Na}$ atividade 3, a partir das representações linguística e visual, foi solicitado que se fizesse a representação simbólica. Nessa atividade, apesar de não considerar os senos dos ângulos opostos, ela já associa corretamente a unidade de sentido "proporcionais" do registro de representação linguístico com sua equivalente no registro simbólico.

A proporcionalidade dos lados de um triangulo é dada por:

$\left.\left.\left.\frac{C B}{\operatorname{sen} A}\right] \frac{C B}{\operatorname{sen} A}=\frac{B A}{\operatorname{sen} Y}=\frac{A C}{\operatorname{sen} B}\right] \frac{B A}{\operatorname{sen} Y}\right] \frac{B A}{\operatorname{sen} Y}$


$\mathrm{Na}$ atividade 4, em que é solicitado que ela faça a representação linguística do conceito a partir das representações simbólica e visual, percebe-se que ela já associa a representação linguística da unidade de sentido "proporcionais" com "razão". Assim, o que se percebe é que a estudante vai tomando consciência do conceito ao mesmo tempo em que vai representando e fazendo as conversões. A atividade 5 é o ponto culminante em que é explicitado qual o objeto que está sendo estudado. A partir do que foi feito nas atividades anteriores, a estudante precisaria fazer os três registros de representações do objeto. An não apenas faz as três representações como também conectou as representações simbólica e visual, integrando-as de forma simultânea e dinâmica (Figura 85).

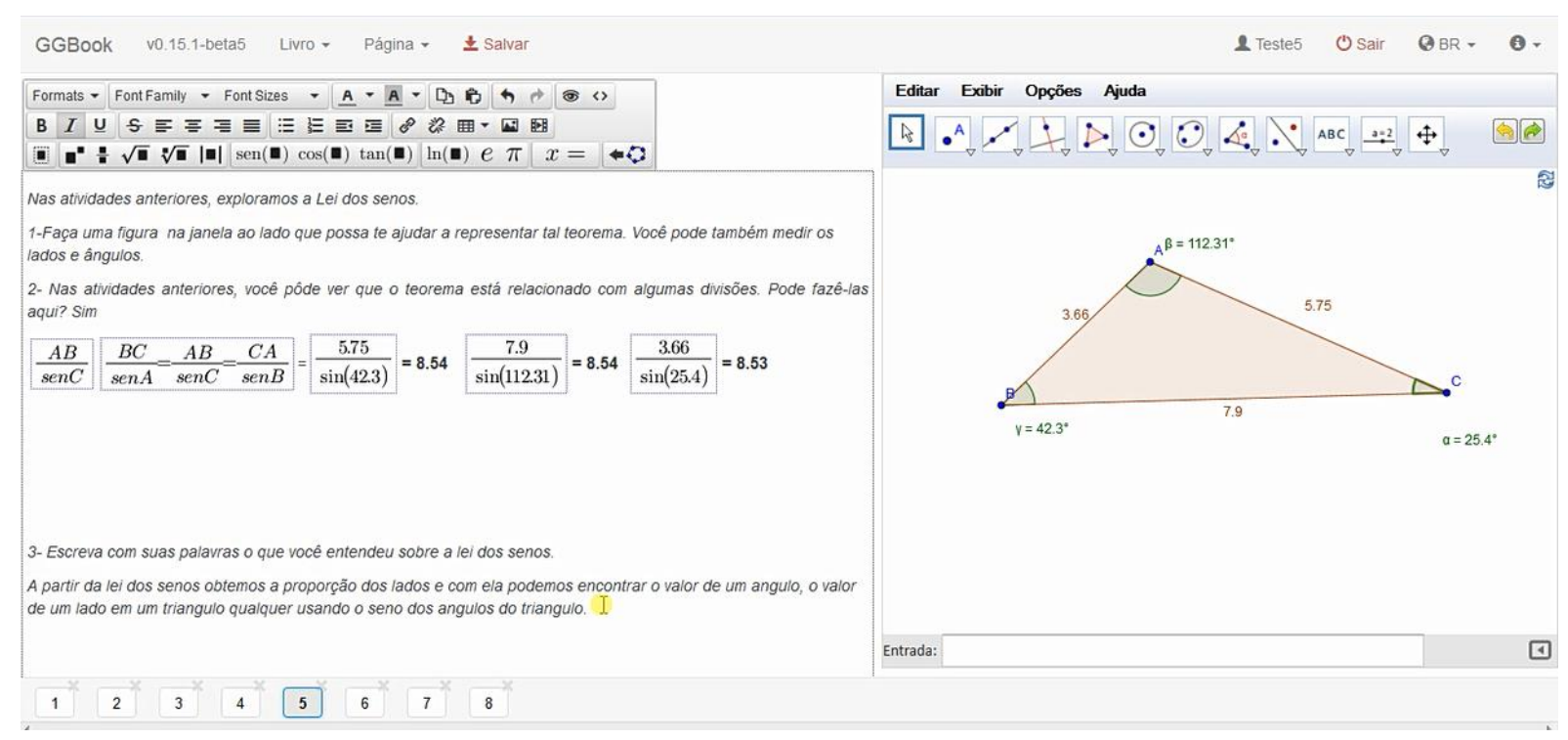

Figura 85-Atividade 5 feita por An

A integração entre as representações linguística e simbólica no ambiente Texto do GGBOOK foi simples. Tomemos por exemplo a representação feita por Mar (Figura 86).

$$
\text { Sobre a lei dos senos, que para todo } \frac{a}{\sin (a)} \text { é igual } \frac{b}{\sin (b)}=\frac{c}{\sin (c)} \text {. }
$$

Figura 86-Atividade 5 feita por Mar

Para fazer tal integração, Mar foi digitando naturalmente e nos momentos em que era necessário fazer uma representação simbólica, ele clicava nos ícones que representavam os símbolos que precisava. Tal integração não seria tão simples se tivesse usado apenas o GeoGebra, pois, para fazê-la ele precisaria digitar o seguinte comando LaTeX: Sobre $\backslash$; $\backslash$; lei 
।; $\operatorname{dos} \backslash ; \quad$ senos $\backslash ; \quad$ que $\backslash ; \quad$ para $\backslash ; \quad$ todo $\backslash ; \quad \backslash \operatorname{frac}\{\mathrm{a}\}\{\operatorname{sen}(\mathrm{a})\} \quad \backslash ; \quad$ él;igual $\backslash ; \quad \mathrm{a} \backslash ;$ $\backslash$ frac $\{b\}\{\operatorname{sen}(b)\}=\backslash$ frac $\{c\}\{\operatorname{sen}(c)\}$. Esse exemplo mostra que o processo de produção de texto dinâmicos no GGBOOK é mais simples que no GeoGebra. Todavia, para melhorar o editor de equações é preciso ainda inserir novos símbolos (gregos, por exemplo).

As atividades 6 e 7 feitas no GGBOOK não são elaboradas com representações integradas simultaneamente. As conexões são feitas por meio de referências do tipo “considere a figura ao lado". Também não se esperava que os estudantes integrassem as representações de forma simultânea para respondê-las. Todavia, o processo de compreensão também deveria ocorrer ao mesmo tempo em que estavam integrando as representações, ou seja, também nessas atividades a representação não poderia ser usada apenas para comunicar. Para isso, na atividade 7, o estudante deveria fazer conversões e tratamentos no registro simbólico. Mediante os procedimentos já explicados para se produzir uma representação simbólica, percebe-se que os tratamentos do registro simbólico feitos no GGBOOK levam mais tempo do que no ambiente estático. Todavia, isso não pareceu comprometer o processo de compreensão ou comunicação.

Apesar de termos percebido que a integração simultânea das representações contribuiu para que os estudantes percebessem as relações, não há garantias de que isso ocorrerá sempre. Tomemos, por exemplo, a análise da atividade 5 feita por Cley no ambiente estático. Arriscamo-nos a dizer que, mesmo que ele tivesse integrado simultaneamente as representações simbólica e visual no GGBOOK, ainda poderia concluir da maneira como concluiu: $O$ valor do seno de um ângulo pode ser medido por cateto oposto dividido pelo valor da hipotenusa, podendo ser usados para quaisquer triângulos obtendo assim o valor do seno e do seu ângulo. Isso porque ele acha que as unidades de sentido cateto oposto é o que está oposto ao ângulo e hipotenusa é o maior lado. Não haveria nada na integração que ele fez que contradissesse o que ele concluiu. O que se percebe é que a integração simultânea é mais importante quando tratamos as representações mais com função de objetivação do que de comunicação. Todavia, quando o estudante faz integração simultânea de representações, ele possibilita ao professor ter uma melhor compreensão dos modos de pensamento dele.

Insistimos que a produção das Narrativas Matemáticas Dinâmicas não pode ser vista apenas na atividade 5. Tal narrativa ocorre ao longo das páginas do BOOK do GGBOOK. No decorrer de todas as atividades é possível ver o estudante expressando seu entendimento, os significados e suas construções relacionadas ao tema de estudo, constituindo-se assim numa oportunidade de organizarem-se de forma ordenada no tempo e evolvendo sua produção, seu 
registro e socialização (SHEFFER, 2001). Eles buscam explicitar, de maneira organizada, suas representações mentais. Isso permitiu ao professor a interpretação global de um modo de pensamento do estudante.

É fato que não é em todas as páginas que ocorre a principal característica das Narrativas Matemáticas Dinâmicas: a integração simultânea das representações. Tal característica é mais explícita nas atividades 4 e 5 . Todavia, quando estamos falando de integração das representações não estamos limitando apenas às integrações simultâneas. Duval (2011) fala da necessidade de uma visão sinóptica de todas as variações feitas para poder fazer as comparações necessárias nas representações e poder interpretá-las. Para a interpretação global da Narrativa Matemática feita pelo estudante, a integração das representações deve ser vista como um todo no BOOK do GGBOOK. A disposição das páginas do GGBOOK contribuiu tanto para a produção da narrativa quanto para a visão sinóptica do estudante e do professor sobre a narrativa. Vejamos como isso acontece no BOOK com as atividades ${ }^{38}$ feitas por Dio. Ao abrir as atividades, na primeira página temos:

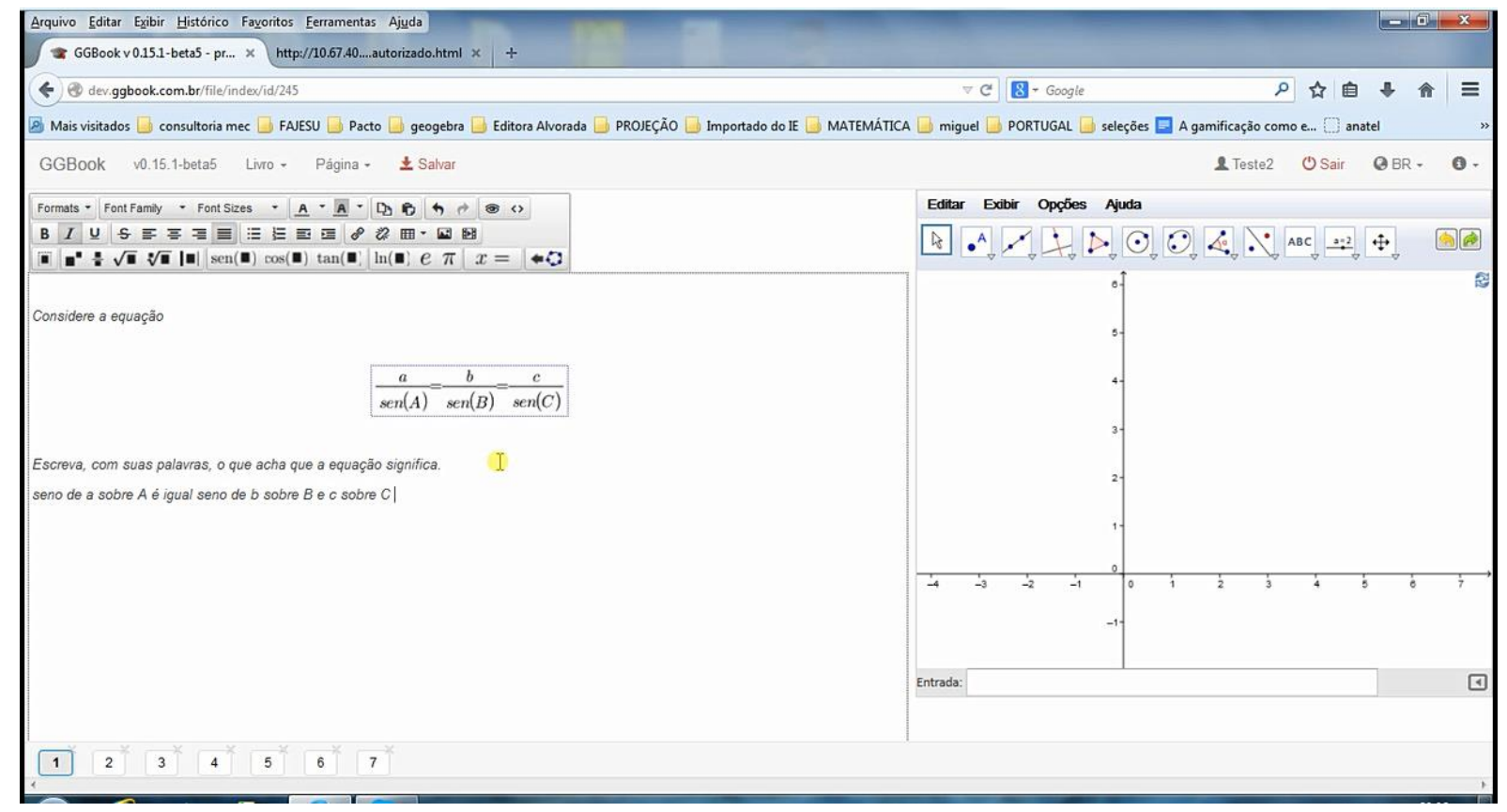

Figura 87-Página 1 do BOOK de atividade de Dio

Nessa primeira atividade, percebe-se que ele consegue fazer a pura tradução linguística da expressão simbólica. É evidente que isso não evidencia a compreensão do objeto Lei dos Senos. Vejamos o que ele fez na página 2:

\footnotetext{
${ }^{38}$ Não faremos análises minuciosas das atividades dele, porque já fizemos isso no tópico anterior.
} 
$\leftarrow$ Q dev.ggbook.com.brffilefinderrid/245

(4) 8 - Google

○会自》命三

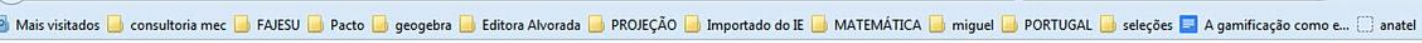

GGBook v0.15.1. beta5 Limo. Página - \pm Salar 2 Teste2 OSair OBR. O

Formats - Font Fanily - Font Sizes - A - A - D D B C $C$

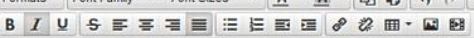

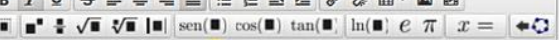

Editar Exibir Opçées Ajuda

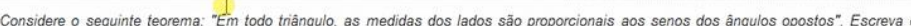

que você lêt, usando simbolos matemáticos.

tenho algumas lembranngas mas näo me recordd

Figura 88-Página 2 do BOOK de atividades de Dio

A resposta tenho algumas lembranças mas não me recordo mostra que ele não consegue identificar unidades no registro de partida (língua materna) de forma a converter para o registro simbólico. De certa forma, evidencia que ele ainda não compreende bem o objeto e nem conseguiu ver nenhuma relação com a atividade anterior. Ao clicar na página 3 do rodapé, temos:

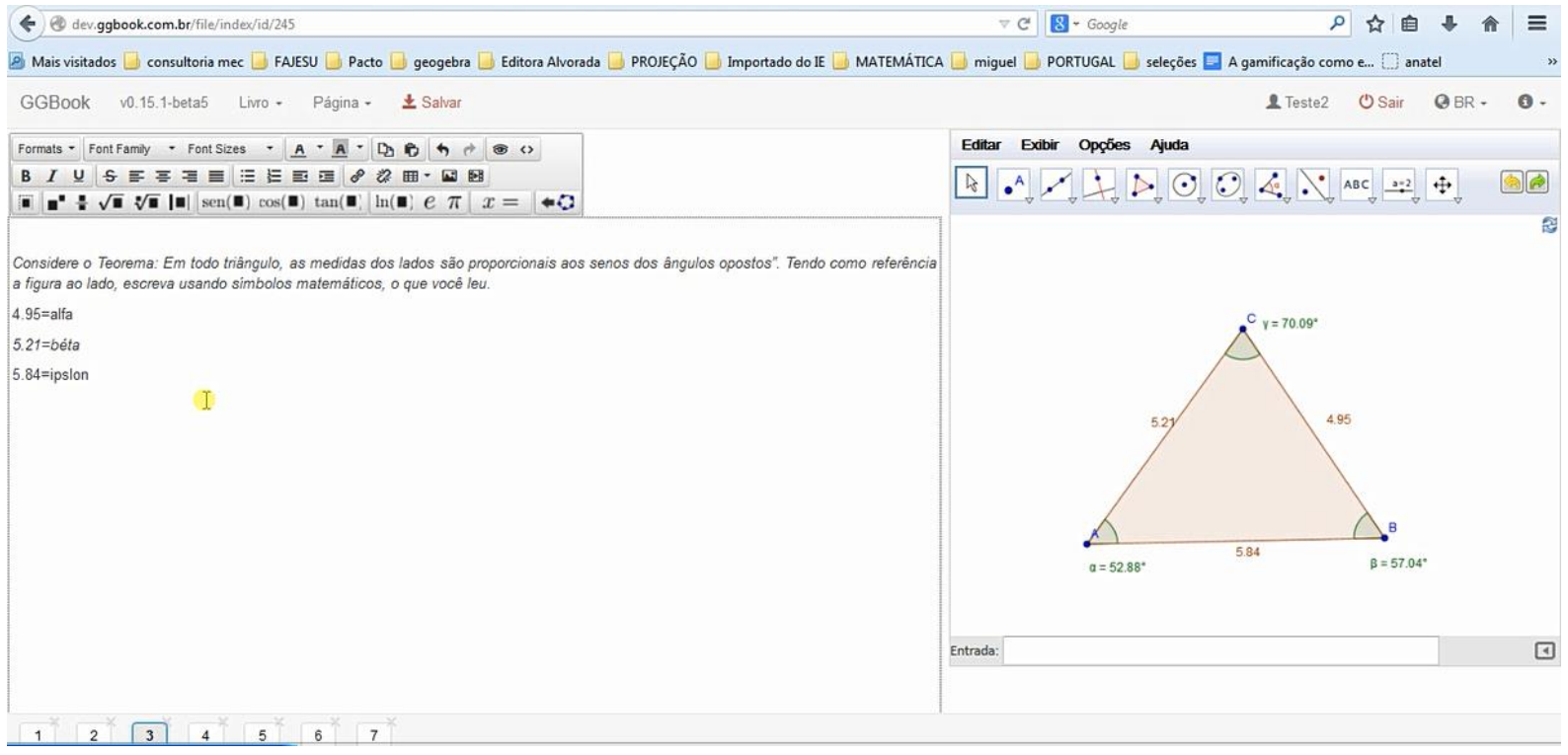

Figura 89-Página 3 do BOOK de atividades de Dio

Nessa atividade, há uma representação visual auxiliar, mas ele parece continuar não identificando as unidades de sentido pertinentes para poder fazer a conversão para o registro simbólico. De toda forma, já aparecem algumas evoluções, porque ele identifica na 
representação visual e representa, simbolicamente, os lados e ângulos opostos. Ao clicar na página 4 , temos:

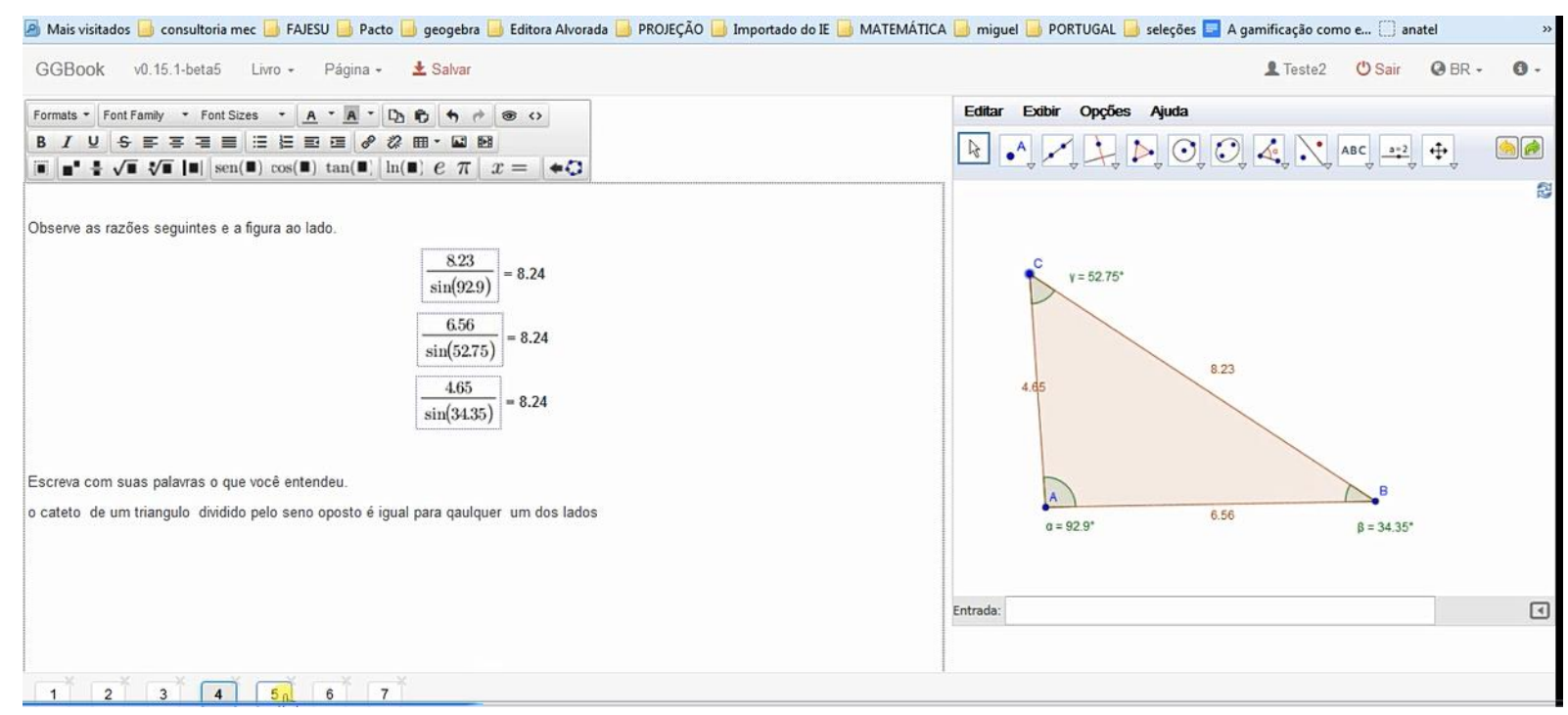

Figura 90-Página 4 do BOOK de atividades de Dio

Nessa atividade, integram-se simultaneamente as representações simbólica e visual e isso faz com que o estudante perceba algumas unidades de sentido pertinentes para a conversão para o registro linguístico. A representação que ele fez (diferentemente da página 1) já é mais próxima do que se espera para evidenciar a compreensão da Lei dos Senos. Vejamos o que ele fez na página 5:

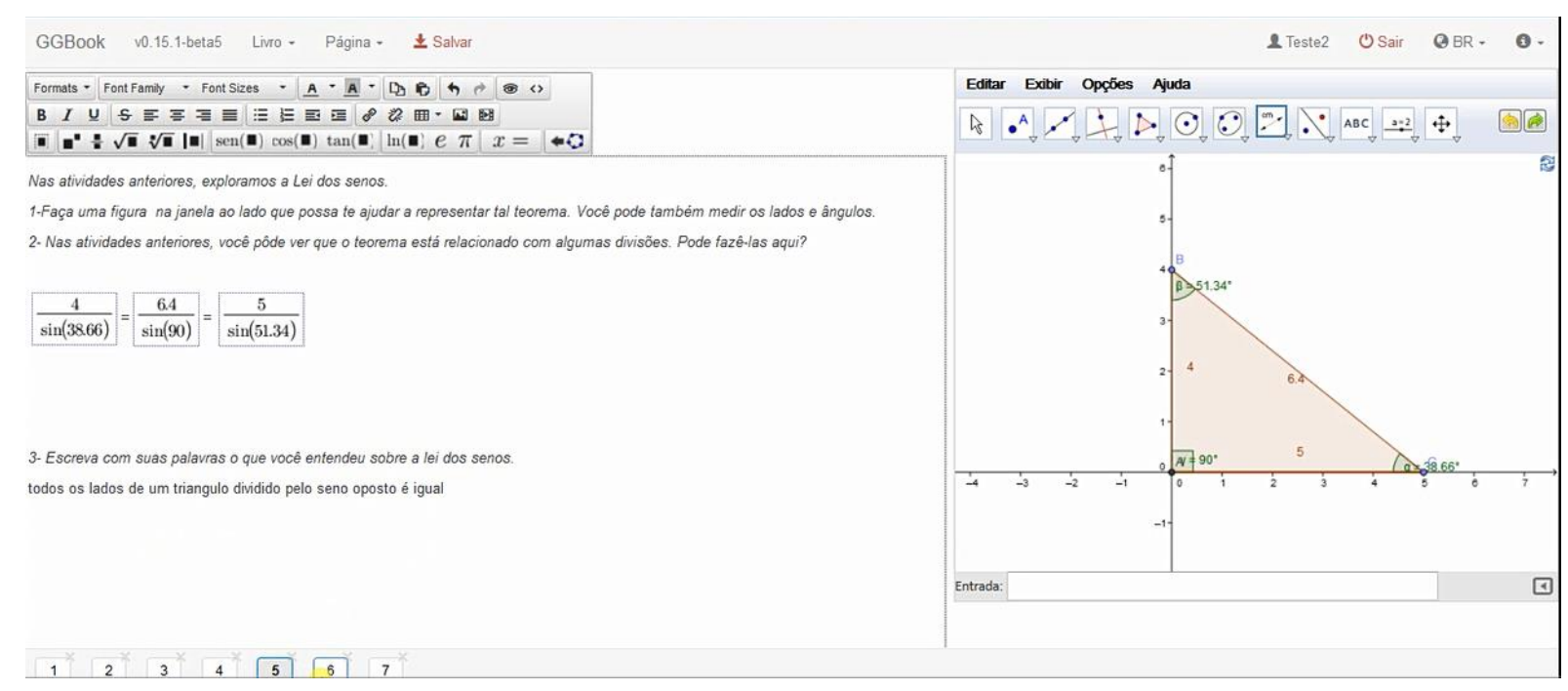

Figura 91-Página 5 do BOOK de atividades de Dio

Nessa atividade, foi explicitado o objeto que estávamos estudando. Havia apenas 3 enunciados discursivos e o estudante deveria fazer três representações (visual, simbólica e linguística) de forma integrada para mostrar o que entendeu. Apenas com as imagens não é possível ver como Dio integrou as atividades anteriores para poder fazer esta, mas é de se 
esperar que ele tenha relacionado todas as conversões das páginas anteriores para produzir as respostas da atividade da página 5 .

Nas atividades 6 e 7, o objetivo era que o estudante pudesse compreender uma justificativa do objeto estudado. Vejamos o que Dio fez na página 6.

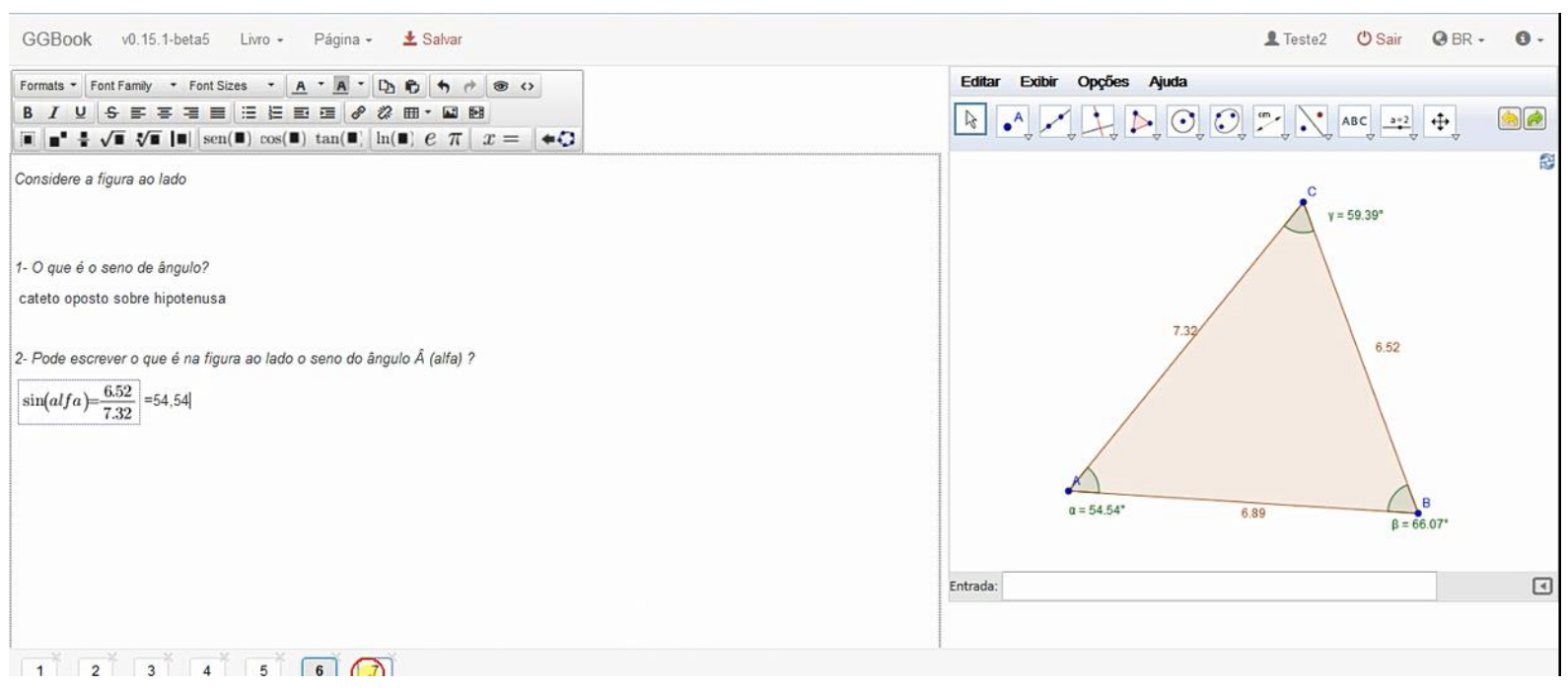

Figura 92-Página 6 do BOOK de atividades de Dio

Conforme já relatado na categoria anterior, a resposta de Dio mostra que ele possuía o conceito de seno, mas não sabia integrar os registros visual, simbólico e linguístico de forma a mostrar que compreendia o que era o seno. A principal dificuldade estava relacionada com a incorreta identificação da unidade de sentido cateto oposto. O lado AC $(7,32)$ era a hipotenusa do triângulo retângulo (implícito na figura) relativo ao ângulo $\alpha$, mas ele não parece ter identificado conscientemente. Tal dificuldade foi superada quando na atividade seguinte (Figura 93) explicita-se uma altura do triângulo.

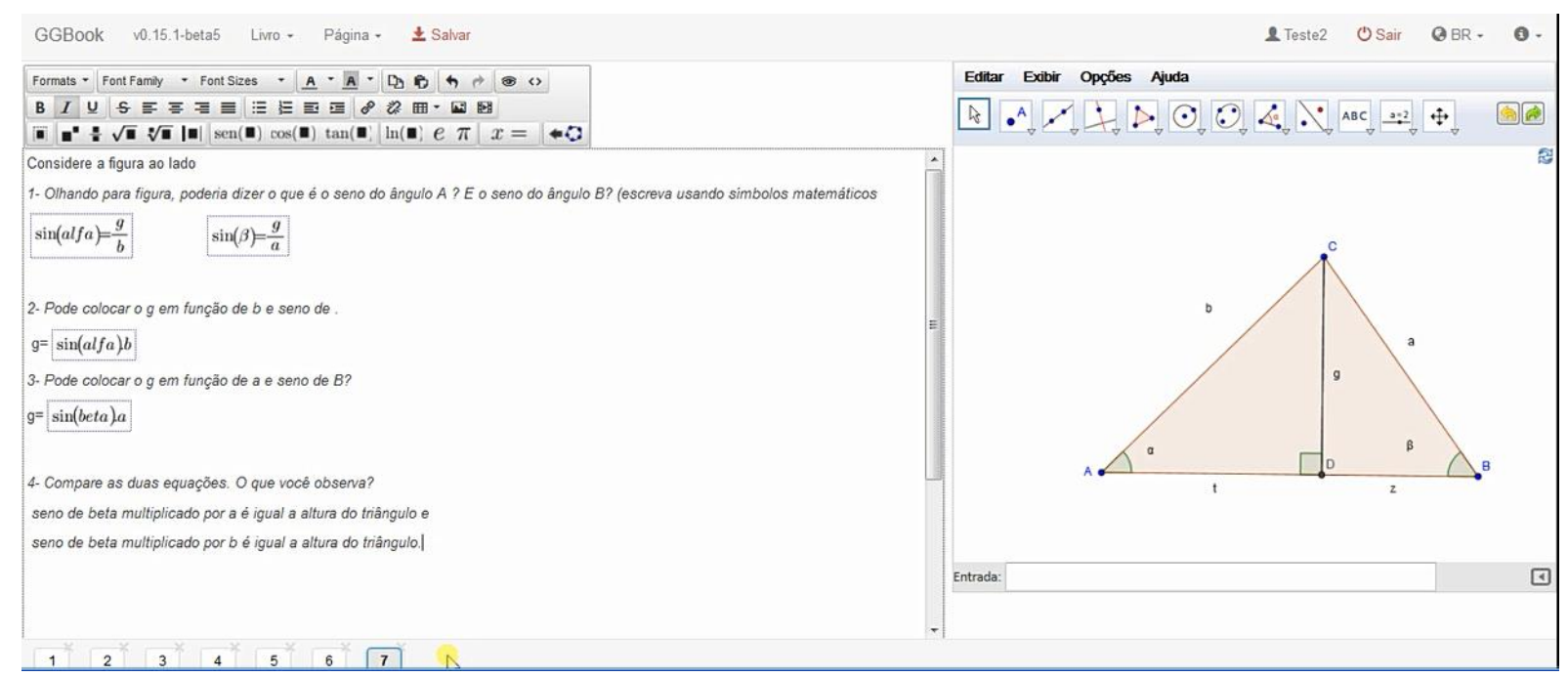

Figura 93-Página 7 do BOOK de atividades de Dio 
Percebe-se que Dio já não considera mais o lado CB como cateto oposto e já consegue identificar corretamente as unidades de sentido no registro de representação visual para converter para o registro de representação simbólica e mostrar o que é o seno dos ângulos A e o seno do ângulo B. O que demonstra uma tomada de consciência em relação ao conceito de seno. Após isso, faz as transformações necessárias e conclui explicitando com um registro de representação linguístico o que entendeu. Conforme relatamos anteriormente, não era exatamente a conclusão que esperávamos, mas foi uma conclusão coerente com o que lhe foi solicitado.

O que acabamos de fazer foi mostrar como é possível fazer uma interpretação global das representações feitas por Dio. O conjunto de todas essas representações feito em todas as páginas do GGBOOK é que chamamos de Narrativa Matemática Dinâmica. Tal interpretação poderia ser feita também no ambiente estático ou apenas usando o GeoGebra? Não da mesma forma. Até porque a matemática baseada no uso de lápis e papel é qualitativamente diferente da matemática que se baseia no uso de softwares (BORBA; VILLARREAL, 2005). Além disso, "A natureza das representações e as possíveis formas de explorar conexões entre elas dependem da tecnologia utilizada" (BORBA; SCUCUGLIA; GADANIDIS, 2014, p.52). Vejamos algumas diferenças:

- A disposição das páginas do GGBOOK permite que se possa "navegar" de uma para outra rapidamente. Isso contribuiu para que pudéssemos ir e voltar de uma página para outra e compará-las. No GeoGebra teríamos que maximizar e minimizar janelas;

- No GGBOOK pode-se movimentar (alterar) algumas representações feitas pelo estudante e analisar se ele as integrou coerentemente. Isso foi feito várias vezes nas análises das atividades dos estudantes que trabalharam no ambiente dinâmico. No ambiente estático não se pode alterar dinamicamente as representações e perceber como o estudante fez as relações. Conforme relatamos anteriormente tal limite pode ter influenciado para que os estudantes que trabalharam no ambiente estático não tivessem percebido as invariâncias nas representações visual e simbólica da atividade 4

- O layout do GGBOOK tem espaços adequados e específicos para cada registro de

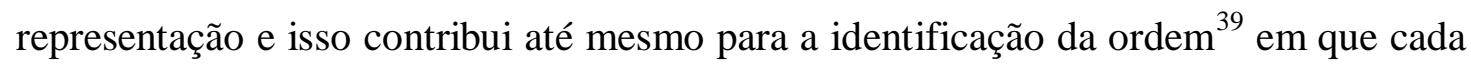
representação foi feita. No GeoGebra o espaço destinado ao texto fica dentro da janela

\footnotetext{
${ }^{39}$ Elemento fundamental para a identificação da historicidade da narrativa
} 
de visualização, ou seja, dentro do espaço para o registro de representação visual. Não existe barra de rolagem na janela de visulização e isso limita bastante a visualização dos objetos. Já no ambiente estático, a análise da atividade 2 de Cley (ambiente estático) mostrou que a identificação da ordem em que as representações foram feitas não é fácil;

- O editor de texto e equações do GGBOOK permite que o estudante possa se expressar matematicamente de forma mais intuitiva. No GeoGebra para que o estudante possa expressar registros discursivos simbólicos precisa saber LaTeX. Se ele colocar comandos errados, gerará representações equivocadas e isso pode influenciar a interpretação por parte do professor. Outra consequência da dificuldade em relação ao LaTeX é que o estudante pode ter certa representação mental, mas por não saber usar tal ferramenta, pode não fazer as representações e com isso deixar de ter suas atividades interpretadas pelo professor ou interpretadas de forma incorreta;

- A análise que fizemos no item anterior pode ser feita também comparando as formas de se fazerem os registros visuais no GGBOOK e no ambiente estático. O GeoGebra do GGBOOK permite que o estudante possa fazer as representações visuais, sem exigir muitas habilidades manuais. $\mathrm{O}$ ambiente estático pode necessitar de habilidades manuais até mesmo para manipular um compasso. É comum os estudantes usarem o registro de representação discursivo para explicar uma representação visual que não conseguiram fazê-la. Isso nem sempre é suficiente para que o professor possa interpretar o que o estudante quis dizer;

- O GGBOOK não exige muitas habilidades manuais para fazer e integrar representações. Por outro lado, pode necessitar de conhecimentos conceituais para fazer as representações, sobretudo, as visuais. Mas, para representar um conceito no ambiente estático isso também não é necessário? Ou basta apenas ter habilidade para desenhar? Saber desenhar uma figura não significa, necessariamente, que já se desenvolveu a primeira atividade cognitiva: formação das representações. O estudante pode ter desenhado uma figura como uma simples atividade de reprodução de algo que já viu. Nesse caso, a interpretação do registro de representação feita pelo professor pode ficar comprometida. A interpretação pode ser mais fidedigna quando se garante que foi feita de forma integrada e a partir de conhecimentos conceituais. 
- Outra vantagem do GGBOOK é o fato de as construções feitas no GeoGebra ficarem salvas. Ao acessar as atividades feitas pelo estudante na plataforma, o professor pode ver toda a construção feita no GeoGebra, sem a necessidade de ter que buscar o arquivo em alguma pasta.

Dessa forma, concluímos que o GGBOOK contribuiu tanto para a produção e integração de representações de forma a facilitar o trabalho do estudante, quanto do professor na análise/interpretação daquilo que o estudante fez. É fato que existem aspectos que precisam ser melhorados e outros fatores que precisam ser levados em consideração para que as contribuições possam ser efetivas. Falaremos sobre isso no capítulo seguinte. 


\section{CONSIDERAÇÕES FINAIS}

Ao começarmos esse trabalho tínhamos a seguinte indagação: Como uma plataforma que integra um editor de texto e equações com o GeoGebra pode auxiliar na construção de Narrativas Matemáticas Dinâmicas e, consequentemente, na construção do conhecimento matemático?

Implicitamente, nessa pergunta havia um anseio do pesquisador em ter um ambiente que permitisse o acesso às incompreensões do estudante para melhor interpretação. No decorrer da pesquisa, percebeu-se que apenas o ambiente não permitiria isso. Dessa forma, na qualificação foi sugerido pela banca que pesquisássemos sobre a Teoria das Representações Semióticas. A teoria "caiu como uma luva", pois o ambiente nos ajudaria a identificar as incompreensões e a teoria nos ajudaria a interpretá-las e compreendê-las. Foi isso o que aconteceu. Ao final do trabalho, percebemos duas grandes contribuições.

A primeira contribuição é mais teórica e diz respeito ao conceito que propusemos e validamos: a Narrativa Matemática Dinâmica. Acreditamos realmente que se trata de um conceito novo e necessário. As características específicas de tal narrativa não eram abrangidas pelas Narrativas Matemáticas "convencionais" que chamamos de Estáticas. A grande diferença entre os dois tipos de narrativas está na integração dinâmica e simultânea dos diferentes registros de representação que ocorre na Narrativa Matemática Dinâmica. Isso permite a identificação, a distinção e a relação entre as unidades de sentidos pertinentes em cada representação, que são de fundamental importância para a compreensão em Matemática. Tal característica faz com que a Narrativa Matemática Dinâmica não tenha apenas a função de comunicação, mas, sobretudo, a função de objetivação.

Visualizamos contribuições das Narrativas Matemáticas Dinâmicas para os estudos na área de Educação Matemática, em especial, nos campos da Informática e Educação Matemática, da Análise de Erros, da Comunicação em Matemática, da Formação de Professores e da Psicologia da Educação Matemática. Nesse último campo, acreditamos que o conceito pode contribuir muito para os estudos sobre Representações Semióticas, sobretudo no que diz respeito às conversões e aos tratamentos dos diferentes registros.

Para que o conceito Narrativas Matemáticas Dinâmicas fosse validado, foi necessário o desenvolvimento de um recurso tecnológico que foi chamado de GGBOOK. A segunda contribuição foi exatamente esse recurso, que não é útil apenas para pesquisa na área de Educação Matemática. A análise dos dados mostrou que o GGBOOK contribuiu tanto para a 
produção e integração das representações de forma a facilitar o trabalho do estudante, quanto do professor na análise/interpretação daquilo que o estudante fez. Ou seja, ele tem a dupla possibilidade:

- Permitir que se possam desenvolver compreensões a respeito de objetos matemáticos e comunicá-los;

- Auxiliar o trabalho do professor para uma interpretação mais fácil e factível das compreensões ou incompreensões dos estudantes por meio de suas representações.

O desenvolvimento da plataforma GGBOOK foi um trabalho difícil. Liderar um projeto de desenvolvimento de um software educativo é um trabalho muito complexo, sobretudo, se esse software é livre e a equipe de desenvolvedores não recebe pagamentos para o trabalho. Não que isso tenha influenciado no comprometimento e empenho da equipe. Todavia, isso influencia diretamente no cumprimento dos prazos e cronogramas. Afinal, os programadores tinham outros trabalhos que "pagavam as contas" e o projeto GGBOOK não era prioridade absoluta. Outra dificuldade foi a dependência que tínhamos do GeoGebra. O software muda constantemente. Trabalhávamos numa versão e logo saía outra. O trabalho de desenvolvimento praticamente tinha que ser recomeçado. $\mathrm{O}$ momento em que decidimos fazer o trabalho de forma mais independente do grupo do GeoGebra foi determinante para que o projeto se desenvolvesse mais rapidamente. Mesmo assim, tais dificuldades fizeram com que tivéssemos que mudar nosso cronograma várias vezes, sobretudo, nas atividades de experimentação. Havíamos programado fazer alguns testes pilotos do GGBOOK em escolas públicas de Portugal, durante o estágio de doutorado sanduíche na Universidade de Lisboa, mas isso não foi possível devido ao fato de não termos uma versão estável. Também tivemos que adiar o desenvolvimento de algumas funcionalidades que havíamos pensado inicialmente. Listamos a seguir:

- Video no ambiente texto;

- Compartilhamento das atividades; e

- Ferramenta de revisão para indentificação, passo a passo, da produção da narrativa.

Acreditamos que as potencialidades do GGBOOK serão ampliadas com a implementação das funcionalidades que ainda não foram desenvolvidas. A inserção de vídeo digital no ambiente texto poderá dar um salto de qualidade muito grande no GGBOOK, sobretudo porque tais recursos, "[...] podem ser concebidos enquanto narrativas ou textos multimodais, que compilam diversos modos de comunicação como oralidade, escrita, imagens 
dinâmicas, espaços, formas de gestualidade e movimentos" (BORBA; SCUCUGLIA; GADANIDIS, 2014, p.30). Assim, o professor poderá preparar vídeos e disponibilizar aos estudantes por meio da plataforma. Os estudantes, por sua vez, também poderão fazer vídeos com suas dúvidas e, quando a ferramenta de compartilhamento estiver funcionando, poderão compartilhá-las tanto com o professor quanto com os colegas. Além dessas funcionalidades, novas ideias surgiram. Uma delas é a criação de links para diferentes páginas do GGBOOK. Assim, poderíamos fazer conexões entre as representações em diferentes páginas.

Estamos confiantes de que a versão que desenvolvemos e testamos nos mostrou que estamos no caminho certo. Temos boas expectativas em relação ao futuro e visualizamos a produção de livros de Matemática verdadeiramente digitais e dinâmicos, por meio do GGBOOK. Livros digitais com Narrativas Matemáticas Dinâmicas, explorando diferentes assuntos de várias maneiras e integrando várias tendências da Educação Matemática, tais como a História da Matemática, a Modelagem e a Resolução de Problemas. Livros em que os estudantes possam de fato interagir com as diferentes representações dos objetos matemáticos, com propósito de aprender e comunicar. O que se tem atualmente, em termos de livros digitais de Matemática, são simples arquivos PDF cuja vantagem em relação ao papel, praticamente, se limita à ecológica. Esses livros digitais de Matemáticas e de diversas outras áreas, possuem várias representações numa mesma página: frases em língua natural, fórmulas, figuras geométricas, gráficos cartesianos etc. A conexão entre tais representações ficam a cargo do leitor, como se atividade de conversão fosse algo espontâneo (DUVAL, 2011). Além da possibilidade de criação de livros dinâmicos de Matemática, vislumbramos também o uso do GGBOOK em outros dispositivos da internet, tais como o MOODLE e a Wikipédia.

É evidente que o desenvolvimento não foi encerrado com o término dessa pesquisa. Atualmente temos outros pesquisadores trabalhando com o GGBOOK. Ferreira (2015) pesquisa técnicas da Gamificação para a formação de professores para o uso do GGBOOK. Coomans (2015) pesquisa aspectos de ergonomia cognitiva que podem ser usados para melhorar o GGBOOK. O próximo passo é abrir o código para que mais pessoas possam contribuir, trabalhando no desenvolvimento e, com isso, as contribuições possam chegar de fato ao estudante.

A plataforma GGBOOK foi concebida a partir do pressuposto construcionista de que as pessoas aprendem melhor descobrindo "[...] por si mesmas o conhecimento específico de que precisam" (PAPERT, 1994, p.125). Apesar de ser um recurso da internet, ela não foi concebida para que seu uso seja somente a distância. O próprio experimento que fizemos foi 
presencial. A plataforma segue uma tendência blended-learning, “[...] que pode ser traduzido como ensino misturado, ensino de modalidades combinadas, sugerindo uma articulação entre o presencial e o virtual" (BORBA; SCUCUGLIA; GADANIDIS, 2014, p. 77).

É preciso alertar que mesmo com a plataforma GGBOOK totalmente desenvolvida, com todas as funcionalidades que desejamos, ela sozinha não ensinará coisa alguma. Assim como qualquer outro recurso tecnológico é necessário criar situações adequadas de uso. Para a plataforma GGBOOK, o que propomos é que suas atividades sejam feitas por meio de Narrativas Matemáticas Dinâmicas e para que seja possível a criação de atividades com as características dessa narrativa, é preciso preparar o professor. Uma formação que pretenda preparar o professor para o uso eficaz do GGBOOK precisa partir de alguns pressupostos:

- É necessário desenvolver o conhecimento técnico da ferramenta. Isso pressupõe saber usar o GeoGebra e o editor de texto e equações;

- É necessário desenvolver o conhecimento sobre os princípios da ferramenta. Isso pressupõe saber que a integração das representações é condição necessária para a compreensão em Matemática. No caso do GGBOOK o princípio fundamental é a integração dinâmica e simultânea das representações.

Para o desenvolvimento do conhecimento técnico é preciso propor atividades que construam habilidades relacionadas com o ambiente GeoGebra e o ambiente Texto. Em relação ao ambiente GeoGebra, as habilidades que se esperam que sejam construídas são:

- Saber usar as funcionalidades da barra de ferramentas:

○ construir pontos, retas, polígonos, círculos, cônicas etc;

○ mostrar áreas, comprimentos, distâncias, medidas de ângulos etc.

- Saber usar as funcionalidades do campo de entrada:

- por meio de comando escrito, construir pontos, retas, polígonos, círculos, cônicas etc;

- por meio de comando escrito, mostrar áreas, comprimentos, distâncias, medidas de ângulos etc.

- Saber executar comandos mais técnicos: inserir texto, imagens, comando deslizante, ampliar, reduzir, esconder etc.

Em relação ao ambiente Texto, as habilidades que se esperam que sejam construídas são:

- Saber usar funcionalidades de formatação de texto: 
- alterar fonte, tamanho de texto, alinhamento, listas e tabelas.

- Saber organizar recursos multimídia dentro de um texto:

○ inserção de vídeos e imagens disponíveis na internet.

- Saber usar funcionalidades do editor de equações

Existe também uma habilidade que está relacionada com os dois ambientes:

- Saber inserir objetos (números, ângulos, coordenadas etc) do GeoGebra no módulo de equações do ambiente Texto.

Para o desenvolvimento do conhecimento sobre os princípios da ferramenta é preciso propor atividades que mostrem como a integração das representações é condição necessária para a compreensão em Matemática. Assim, é preciso atividades que permitam a construção das seguintes habilidades:

- Saber representar um conceito matemático através dos três registros de representação: linguístico, simbólico e visual;

- Saber relacionar os diferentes registros de representação de um conceito matemático;

- Saber fazer, coerentemente, tratamentos e conversões nos diferentes registros.

Finalmente, concluímos dizendo que mesmo uma formação com esses propósitos pode não garantir a correta e coerente interpretação global por parte do professor das produções dos estudantes. Isso porque para interpretar é preciso "complementar com o que os alunos dizem ou mal dizem" (DUVAL, 2011, p.82). Estamos considerando "interpretar" também com o propósito de compreender e para isso, em muitos casos, o professor terá que interpretar o que não foi representado. E mesmo que tenha sido representado, talvez não se possa compreender, porque "Comunicação não garante compreensão" (MORIN, 2000). O mesmo autor diz que compreender significa intelectualmente aprender em conjunto, comprehendere, abraçar junto (o texto e contexto, as partes e o todo, o múltiplo e o uno) e pode ser distinguida de duas formas:

- Compreensão intelectual ou objetiva que está associada às coisas anônimas ou materiais. Para atingirmos tal compreensão precisamos de inteligibilidade e explicação: "Explicar é considerar o que é preciso conhecer como objeto e aplicar-lhe todos os meios objetivos do conhecimento" (MORIN, 2000, p.94).

- Compreensão humana intersubjetiva que está associada ao conhecimento de sujeito a sujeito. A explicação é insuficiente para essa compreensão, pois tal compreensão vai além da explicação. Para que ela aconteça é necessário um “[...] processo de empatia, 
de identificação e de projeção. Sempre intersubjetiva, a compreensão pede abertura, simpatia e generosidade" (MORIN, 2000, p.95).

É comum achar que os objetos da Matemática estão relacionados apenas com a compreensão intelectual ou objetiva. Nós não acreditamos nisso, porque enquanto professores de Gente (e não apenas de Matemática), não conseguimos separar o objeto matemático do sujeito homem. Assim, para compreender as compreensões/incompreensões em Matemática é preciso também compreender o sujeito homem, suas relações com o outro, sua história e cultura. É preciso interpretar outros meios semióticos, como os gestos. Enfim, é preciso compreender “[...] não só aos outros como a si mesmo, a necessidade de se auto-examinar, de analisar a autojustificação, pois o mundo está cada vez mais devastado pela incompreensão, que é o câncer do relacionamento entre seres humanos" (MORIN, 2000). É imprescindível uma formação que não se baseie apenas no SABER, mas, sobretudo, no SER. Isso fará com que se QUEIRA compreender. PRIMEIRA condição NECESSÁRIA para compreender! 


\section{REFERÊNCIAS BIBLIOGRÁFICAS}

ARAÚJO, L. C. L. DE; NÓBRIGA, J. C. C. Aprendendo matemática com o Geogebra. São Paulo: Editora Exato, 2010.

ARCAVI, A.; HADAS, N. Computer Mediated Learning: An Example of an Approach. International Journal of Computers for Mathematical Learning, v. 5, n. 1, p. 25-45, 1 abr. 2000.

ÁVILA, G.; ARAÚJO, L.C.L. Cálculo: Ilustrado, prático e descomplicado. Rio de Janeiro: LTC, 2012.

BARDIN, L. Análise de conteúdo. Lisboa: Edições 70, 2007.

BARUFI, M. C. B.; BROLEZZI, A. História da Matemática e Ensino de Cálculo: Reflexões sobre o Pensamento Reverso. Guarapuava, PR: SBHMat, v. 1, p. 50, 2007.

BELLEMAIN, F. Geometria Dinâmica: diferentes implementações, papel da manipulação direta e usos na aprendizagem. International Conference on Graphics Engineering for Arts and Design. Anais...: 4. In: NTERNATIONAL CONFERENCE ON GRAPHICS ENGINEERING FOR ARTS AND DESIGN. São Paulo: USP, 2001

BELLEMAIN, F. O paradigma micromundo. In: LUIZ MARIANO CARVALHO; LUIZ CARLOS GUIMARÃES (Eds.). História e tecnologia no ensino de matemática. Rio de Janeiro: IME-UERJ, 2003. v. 1p. 49-60.

BELLEMAIN, F; CORREIA, E.M. Geometria Dinâmica: fundamentos epistemológicos. EGraFIA 2004, 2004.

BORBA, M. C.; VILLARREAL, M. V. Humans-With-Media and the Reorganization of Mathematical Thinking: information and communication technologies, modeling, experimentation and visualization. v. 39. [s.1.] New York: Springer, 2005.

BORBA, M. DE C.; SCUCUGLIA, R. S. R. DA; GADANIDIS, G. Fases das tecnologias digitais em Educação Matemática: Sala de aula e internet em movimento. 1. ed. Belo Horizonte: Autêntica, 2014.

BRANDÃO, L. DE O.; ISOTANI, S. Uma ferramenta para ensino de Geometria Dinâmica na Internet: iGeom. Anais do Workshop de Informática na Escola, v. 1, n. 1, p. 410-421, 1 jan. 2003.

CARRAHER, D. Aprendizagem de conceitos matemáticos com o auxílio do computador. In: ALENCAR, E. S. (Ed.). Novas contribuições da psicologia aos professores de ensino e aprendizagem. São Paulo: Cortez, 1992. p. 169-201.

CARTER, K. The place of story in the study of teaching and teacher education. Educational researcher, p. 5-18, 1993.

CONNELLY, F. M.; CLANDININ, D. J. Stories of experience and narrative inquiry. Educational researcher, v. 19, n. 5, p. 2-14, 1990. 
COOMANS, S. Predective evaluation of effective educational software design: development of a pedagogical usability grid for mathematical software of discovering learning, a case study on GGBook. Master Thesis for the European Master in media engeneering for education-France/Spain/Portugal/Brasil: Euromine, 2015.

DUVAL, R. Graphiques et equations: l'Articulation de deux registres. Annales de Didactique et de Sciences cognitives. Anais...1988

DUVAL, R. Registros de representações semióticas e funcionamento cognitivo da compreensão em matemática. In: MACHADO, S. D. A. Aprendizagem em matemática: registros de representação semiótica. Campinas: Papirus, p. 11-33, 2008.

DUVAL, R. Semiósis e Pensamento Humano: Registros semióticos e aprendizagens intelectuais. Tradução L. F LEVY; M.R.A SILVEIRA. 1. ed. São Paulo: Livraria da Física, 2009.

DUVAL, R. Ver e Ensinar a Matemática de outra forma. Entrar no modo matemático de pensar: os registros de representações semióticas. São Paulo: PROEM, 2011. v. 1

EVES, H. W. Introdução à história da matemática. [s.1.] Editora da Unicamp, 2004.

FEIO, E. DOS S. P. Matemática e linguagem: um enfoque na conversão da língua natural para a linguagem matemática. 2009. 102 f. Dissertação de mestrado em Educação em Ciências e Matemática- UFPA, Pará, 2009.

FERREIRA, A. B. H. Novo Aurélio século XXI: o dicionário de língua portuguesa. Rio de Janeiro: Nova Fronteira, 1999.

FERREIRA, B. O uso significativo da gamificação como estratégia didática na capacitação de professores para o uso softwares educativos. Dissertação de mestrado em Educação-Brasília: Universidade de Brasília, 2015.

FLORES, C. R. Registros de representação semiótica em matemática: história, epistemologia, aprendizagem. Bolema, Rio Claro, 2006, v. 19, p. 77-102, 2006.

FRANCO, M. L. P. B. Análise de conteúdo. [s.1.] Brasília-Líber Livro, 2008. v. 6

FREITAS, M. T. M.; FIORENTINI, D. As possibilidades formativas e investigativas da narrativa em educação matemática. Horizontes, v. 25, n. 1, p. 63-71, jun. 2007.

GALVÃO, C. Narrativas em educação. Ciência \& Educação, v. 11, n. 2, p. 327-345, 2005.

GRAVINA, M. A. Geometria Dinâmica: uma nova abordagem para o aprendizado da Geometria. Anais do VII Simpósio Brasileiro de Informática na Educação, v. 1, p. 1-13, 1996.

HARGIE, O. D. The importance of teacher questions in the classroom. Educational Research, v. 20, n. 2, p. 99-102, 1978.

HESSEN, J. Teoria do conhecimento. [s.1.] São Paulo-Martins fontes, 2003. 
HOHENWARTER, M. GeoGebra-a software system for dynamic geometry and algebra in the plane. Master's thesis-Salzburg: University of Salzburg, 2002.

HOHENWARTER, M. GeoGebra - didactic materials and applications for teaching mathematics. $\mathrm{PhD}$-Salzburg: University of Salzburg, 2006.

HOHENWARTER, M.; LAVICZA, Z. Mathematics teacher development with ICT: towards an International GeoGebra Institute. Proceedings of the British Society for Research into Learning Mathematics, v. 27, n. 3, p. 49-54, 2007.

ISOTANI, S. Desenvolvimento de ferramentas no iGeom: utilizando a geometria dinâmica no ensino presencial e a distância. 2005. 110 f. Dissertação de Mestrado em Ciências da Computação-USP_-S.P: Universidade de São Paulo, 2005.

ISOTANI, S.; BRANDÃO, L. DE O. Como Usar a Geometria Dinâmica? O Papel do Professor e do Aluno Frente às Novas TecnologiasAnais do Workshop de Informática na Escola. Anais...2006 Disponível em: <http://www.brie.org/pub/index.php/wie/article/view/882>. Acesso em: 12 maio. 2014

KALEFF, A. M. M. Registros semióticos e obstáculos cognitivos na resolução de problemas introdutórios às geometrias não-euclidianas no âmbito da formação de professores de matemática. Boletim de Educação Matemática, v. 20, n. 28, p. 69-94, 2007.

KAPUT, J. Towards a theory of symbol use in mathematics. In: C. JANVIER (Ed.). . Problems of representation in the teaching and learning of mathematics. L.E. A: Hillsdale, 1987. p. 159-195.

KLUPPEL, G. T.; BRANDT, C. F. Reflexões sobre o Ensino da Geometria em Livros Didáticos à Luz da Teoria de Representações Semióticas segundo Raymond Duval. In: As contribuições da teoria das representações semióticas para o ensino e pesquisa na educação matemática. Ijuí: Unijuí, 2014. p. 113-134.

LACERDA, R. DE A. Proposta de um modelo para análise de requisitos de software educativo. 114 f. Dissertação de mestrado em Educação-Brasília: Universidade de Brasília, 14 dez. 2007.

LACERDA SANTOS, G. ALGUNS PRINCÍPIOS PARA SITUAÇÕES DE ENGENHARIA DE SOTWARES EDUCATIVOS. Revista Inter Ação, v. 34, n. 1, p. 17-36, 2009.

LACERDA SANTOS, G. A problemática da inclusão digital de professores do ensino fundamental. In: CONGRESSO INTERNACIONAL DE EDUCAÇÃO NO BRASIL. Porto Seguro-BA, 2013.

MATHIAS, C. E. Educação matemática de deficientes visuais: uma proposta por meio de sons, ritmos e atividades psicomotoras-Projeto DRUMMATH. Anais do X Encontro Nacional de Educação Matemática, 2010.

MATTOS, F.; MORAES, T.; GUIMARÃES, L. Tecnologias de Informação na Comunicação de Objetos Matemáticos. In: JAHN, A. P.; ALLEVATO, N. S. G. (Eds.). . Tecnologias e Educação Matemática: ensino, aprendizagem e formação de professores. Recife: SBEMDNE, 2010. v. 1p. 227-242. 
MENEZES, L. Matemática, linguagem e comunicação. out. 2000. Disponível em http://repositorio.ipv.pt/handle/10400.19/899. Acesso em 10 abril 2012.

MORAES, R. Análise de conteúdo. Revista Educação, v. 22, n. 37, p. 7-32, 1999.

MOREIRA, L. M. Investigações em Ensino de Ciências. Encontro sobre Teoria e Pesquisa em Ensino de Ciência s - Linguagem, Cultura e Cognição, v. 1, p. 193-232, 1996.

MOREIRA, M. A. Teorias de Aprendizagem. São Paulo: EPU, 1999.

MORIN, E. Os setes saberes necessários à educação do futuro. São Paulo: Cortez Editora, 2000 .

MÜLLER, T. J.; LIEBAN, D. E. Construção de utilitários com o software GeoGebra: uma proposta de divulgação da geometria dinâmica entre professores e alunos. Revista do Instituto GeoGebra Internacional de São Paulo. ISSN 2237-9657, v. 1, n. 1, p. 37 - 50, 12 mar. 2012.

NEMIROVSKY, R. Mathematical narratives, modeling, and algebra. In: Approaches to Algebra. [s.1.] Springer, 1996. p. 197-220.

NÓBRIGA, J. C. C.; LACERDA SANTOS, G.; ARAÚJO, L. C. L.; FERREIRA, B. S.; LIMA. GGBook: One interface wich integrates the text and graphic environments in the Geogebra (Anais do ICME 2012). In: 12 TH INTERNATIONAL CONGRESS ON MATHEMATICAL EDUCATION. Seul: 2012a Disponível em: $<$ http://www.academia.edu/6633172/GGBook_One_interface_wich_integrates_the_text_and_ graphic_environments_in_the_Geogebra_Anais_do_ICME_2012_>. Acesso em: 12 maio. 2014

NÓBRIGA, J. C. C. ; LACERDA SANTOS, G.; ARAÚJO, L. C. L.; FERREIRA, B. S.; LIMA. GGBOOK: uma interface que integrará os ambientes de texto e gráfico no GeoGebra. Revista do Instituto GeoGebra Internacional de São Paulo. ISSN 2237-9657, v. 1, n. 1, p. $03-12,12$ mar. 2012b.

NOTARE, M. R. Comunicação e aprendizagem matemática on-line : um estudo com o editor científico ROODA exata. 201 f. Tese de doutorado em Informática na Educação-Rio Grande do Sul: UFRGS, 2009.

NOTARE, M. R.; BEHAR, P. A. O Editor Científico ROODA Exata Anais do Workshop de Informática na Escola. Anais...2009 Disponível em: <http://www.brie.org/pub/index.php/wie/article/view/2160>. Acesso em: 12 maio. 2014

PAPERT, S. A máquina das crianças: repensando a escola na era da informática. Tradução Sandra Costa. Porto Alegre: Artmed, 1994.

PREINER, J. Introducing dynamic mathematics software to mathematics teachers: The case of GeoGebra. 264 f. Dissertação de mestrado em Educação Matemática-Salzburg: University of Salzburg, 2008.

RIESSMAN, C. K. Narrative analysis. California: Sage, 1993. 
RODRIGUES, D. W. L. Uma avaliação comparativa de interfaces homem-computador em programas de geometria dinâmica.2002. 161 f. Dissertação (Dissertação de Mestrado em Ergonomia-UFSC), Santa Catarina, 2002.

SANTAELLA, L. O Que é Semiótica. São Paulo: BRASILIENSE, 2002.

SANTOS, A. C. C. DOS. Recursos didáticos e representações da geometria espacial da $4^{\text {a }}$ série do Ensino fundamental de uma escola em Campo Grande, MS.186 f. Dissertação de Mestrado em Educação-Mato Grosso do Sul: UFMS, 2003.

SANTOS, E. T.; SOLA, J. I. R. A proposal for an on-line library of descriptive geometry problems. Journal for Geometry and Graphics, v. 5, n. 1, p. 93-100, 2001.

SCHEFFER, N. F. Sensores, informática e o corpo: a noção de movimento no ensino fundamental. 242 f. Tese de Doutorado em Educação Matemática-Rio Claro -SP: UNESP, 2001 .

SHEFFER, N. F.; BRESSAN, J. Z.; CORRÊA, R. M. Narrativas matemáticas: linguagem verbal e não-verbal, a argumentação e os registros de representação na discussão do tema funções com auxílio de tecnologias. In: JAHN, A. P.; ALLEVATO, N. S. G. (Eds.). Tecnologias e Educação Matemática: ensino, aprendizagem e formação de professores. 1. ed. Recife: SBEM-DNE, 2010. v. 7p. 45-61.

SOMMERVILLE, I. Engenharia de Software. 6. ed. [s.1.] Editora Pearson Education, 2003.

SOUSA, L. O Teorema das Quatro Cores. out. 2001. Disponível em http://hdl.handle.net/10400.19/647 Acesso em: 10 dezembro 2014 


\section{APÊNDICE A: RELATÓRIOS DO GGBOOK $2013^{40}$}

Data: 15 de maio de 2013

Análises da Experimentação

1-Layout

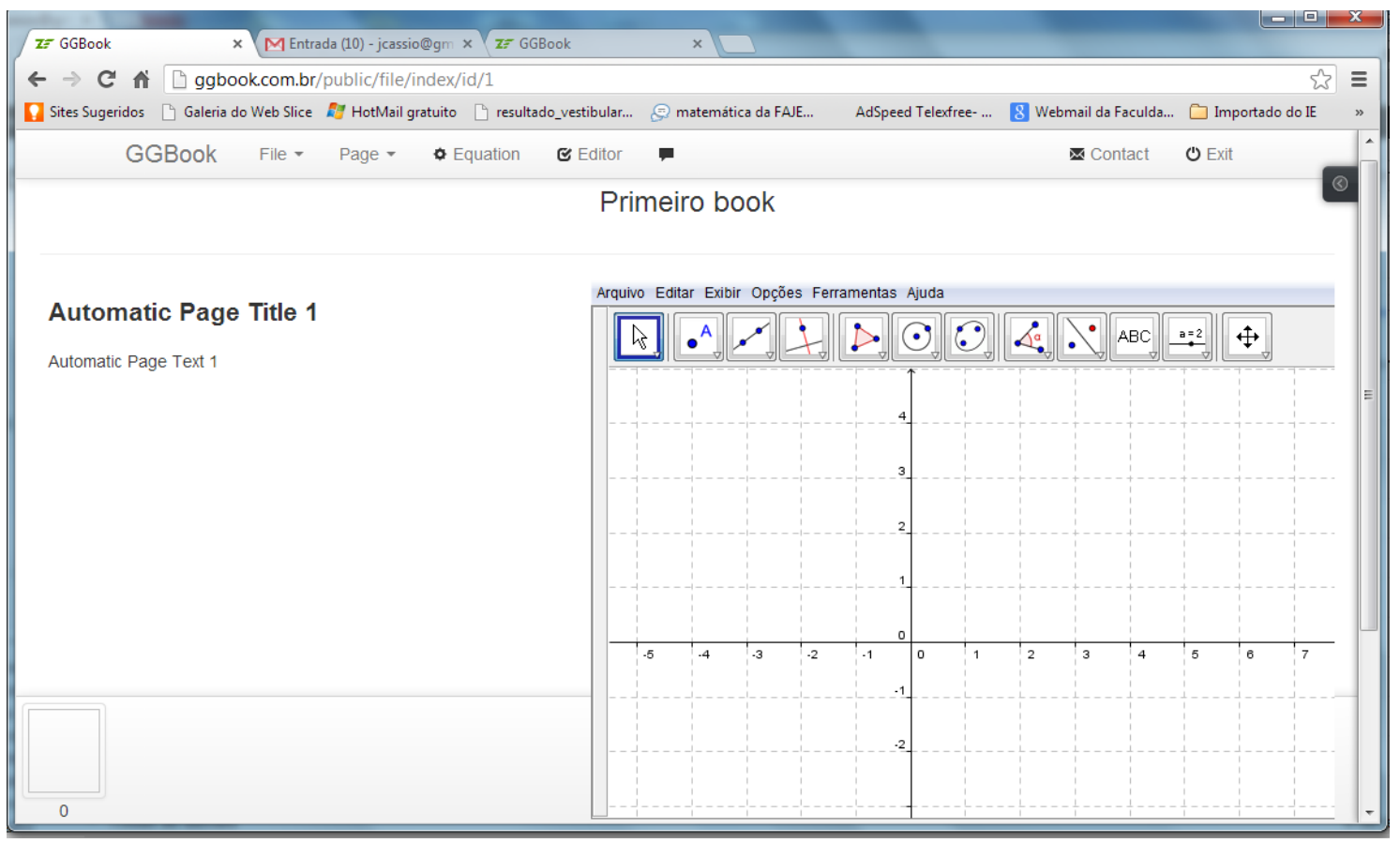

-A janela do geogebra está sobrepondo o espaço para as páginas do livro na parte inferior; -Deixar como default a janela do geogebra sem eixos e sem malha;

- Na barra flutuante de edição de texto é preciso as ferramentas: alinhamento, sublinhar, cor e fontes.

- A barra flutuante de equações tem muitas ferramentas. Algumas desnecessárias. Ela está feia na tela. Talvez fosse melhor fazer uma barra com menu deslizante (tipo a barra de ferramentas do geogebra). Entende? Ou tirar algumas daquelas ferramentas. Não precisamos de somatório, matrizes, produtório, integral, determinante. O que não for operação $(<,>$, pi, e, i, infinito, etc) poderia ficar um outro ícone (tipo símbolos). Entende?

\footnotetext{
${ }^{40}$ Como os Relatórios são muito pessoais, foram transcritos em linguagem mais coloquial, ou seja, numa linguagem mais próximos da realidade dos pesquisadores.
} 


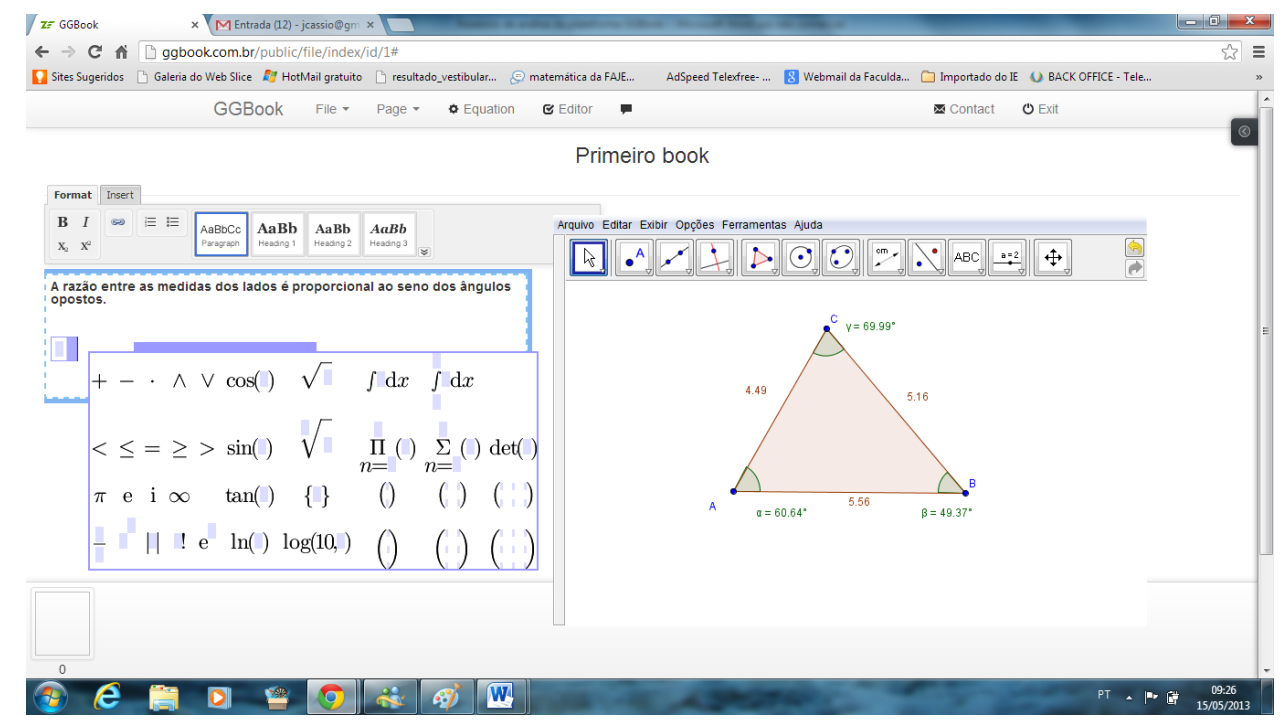

-Está inserindo os valores sem maiores dificuldades. É preciso lembrar que a ferramenta mover do geogebra tem que está ativada. Tal ferramenta poderia ser ativada automaticamente quando clicássemos na janela de visualização. É possível? Como faço para ocultar a barra de ferramentas de equações?

- O seno some do denominador quando altero o triângulo. O resultado aparece num lugar que não foi onde eu determinei. Vejam:

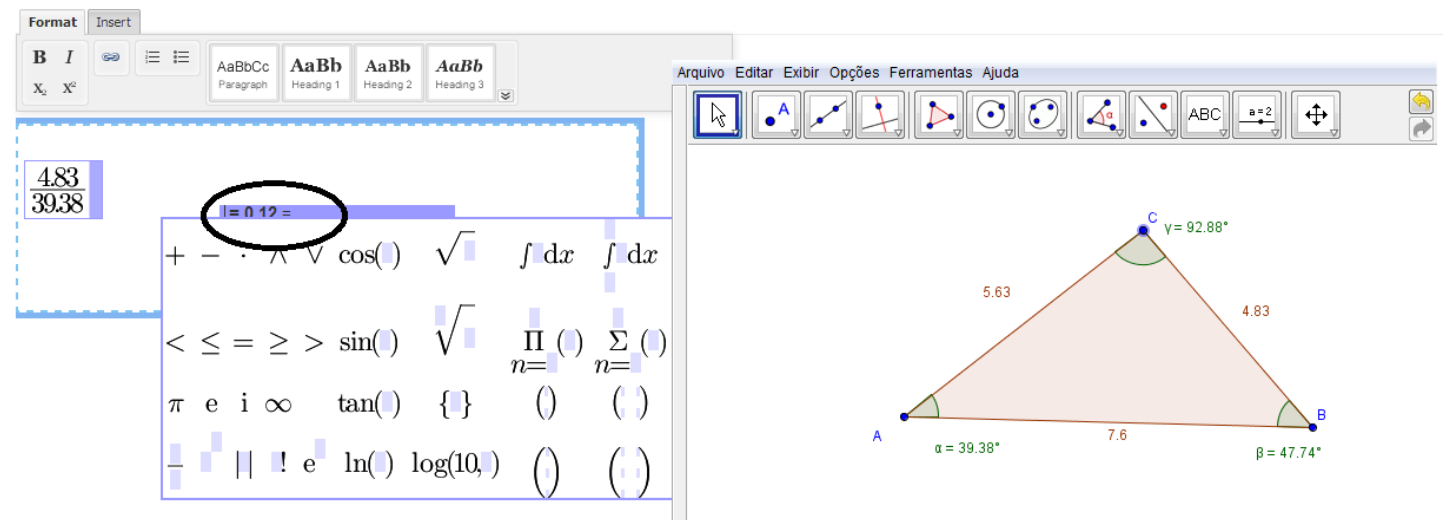

-Calculou a razão entre a medida de um lado e o ângulo oposto. Considerou o ângulo um número real. O resultado está "correto", mas não representa a realidade.

- Inseri o seno em uma raiz e ele sumiu novamente, ficando apenas o ângulo.

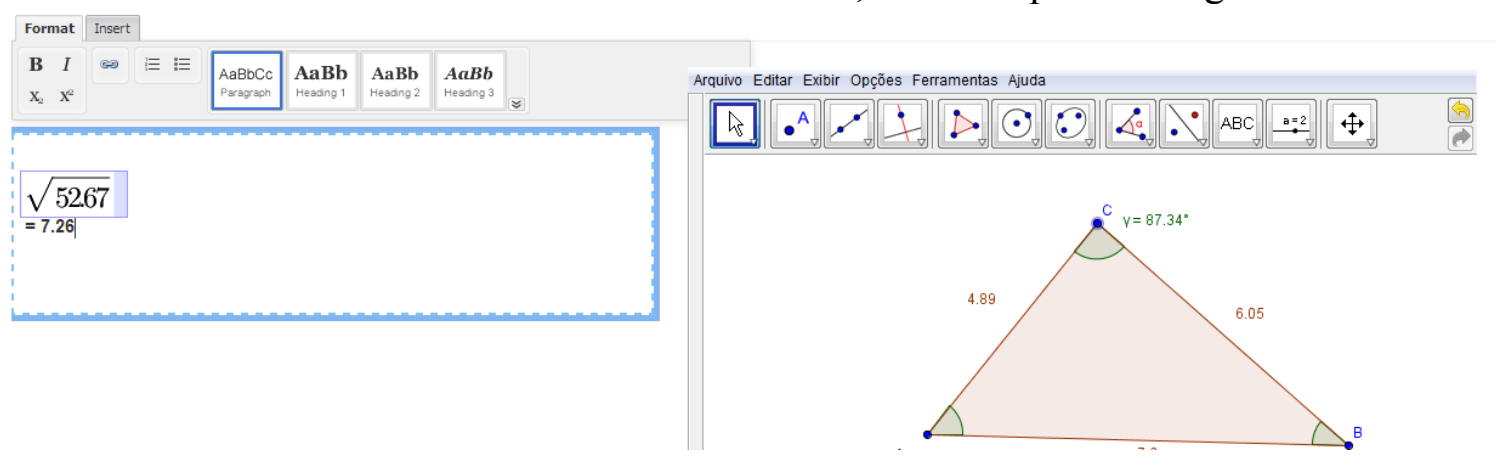

-Não calcula seno, cosseno e tangente. Sempre some, ficando somente o ângulo.

- A potência não funciona, ou seja, não mostra resultado corretamente. Tentei inserir um valor na base e digitar 2 no expoente, mas não gerou resultado. 
-Não calculou uma operação simples. Por exemplo, na figura abaixo eu tinha colocado para somar todos os lados e dividir por um. Não mostrou o resultado. Quando movimente a figura, sumiu os dois valores dos lados do triângulo que tinha colocado no numerador.

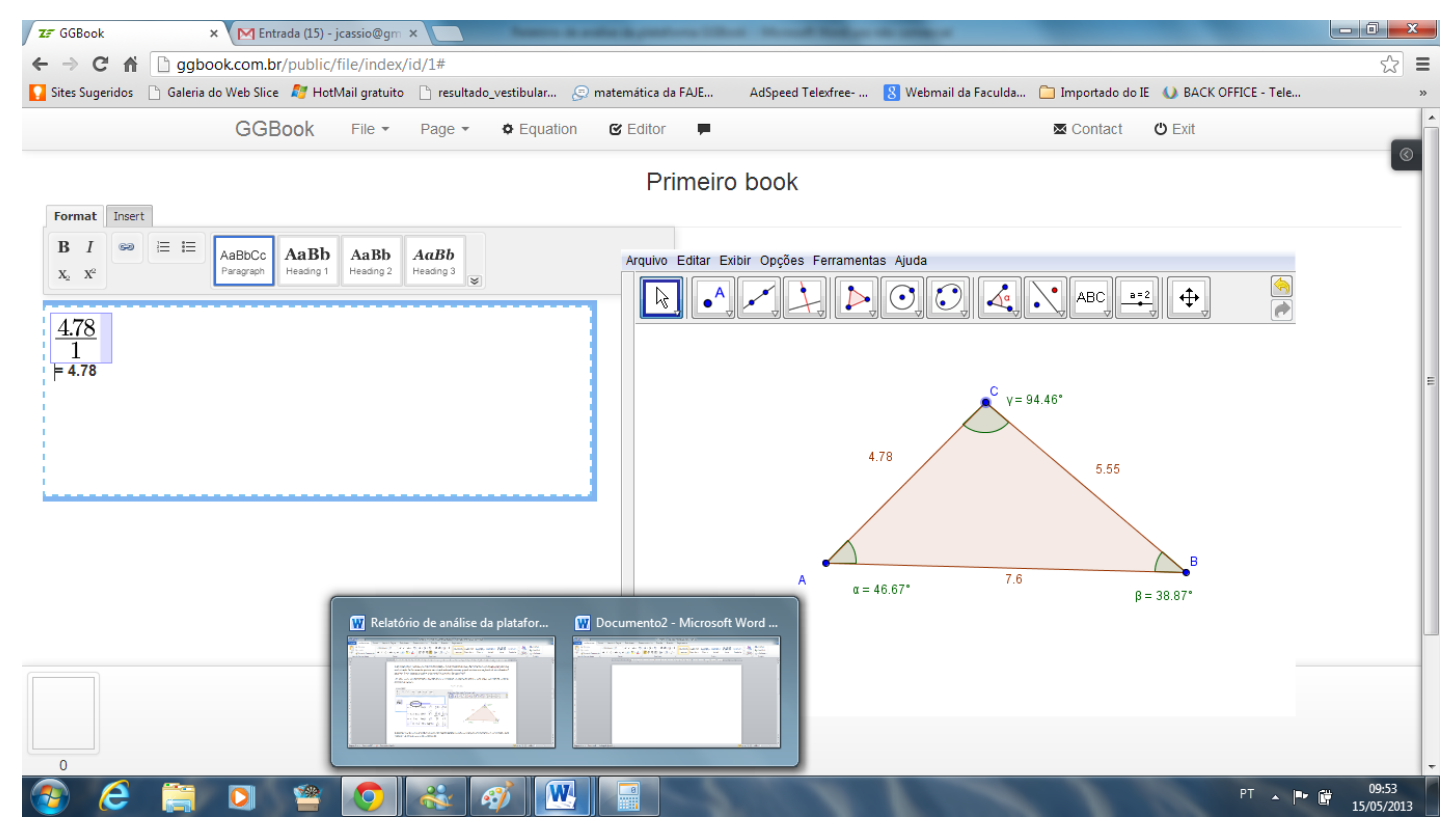

- Insiro uma equação, depois insiro valores na equação, movimento a figura, os valores são modificados. Depois quero inserir uma nova equação. Aparece a seguinte mensagem.

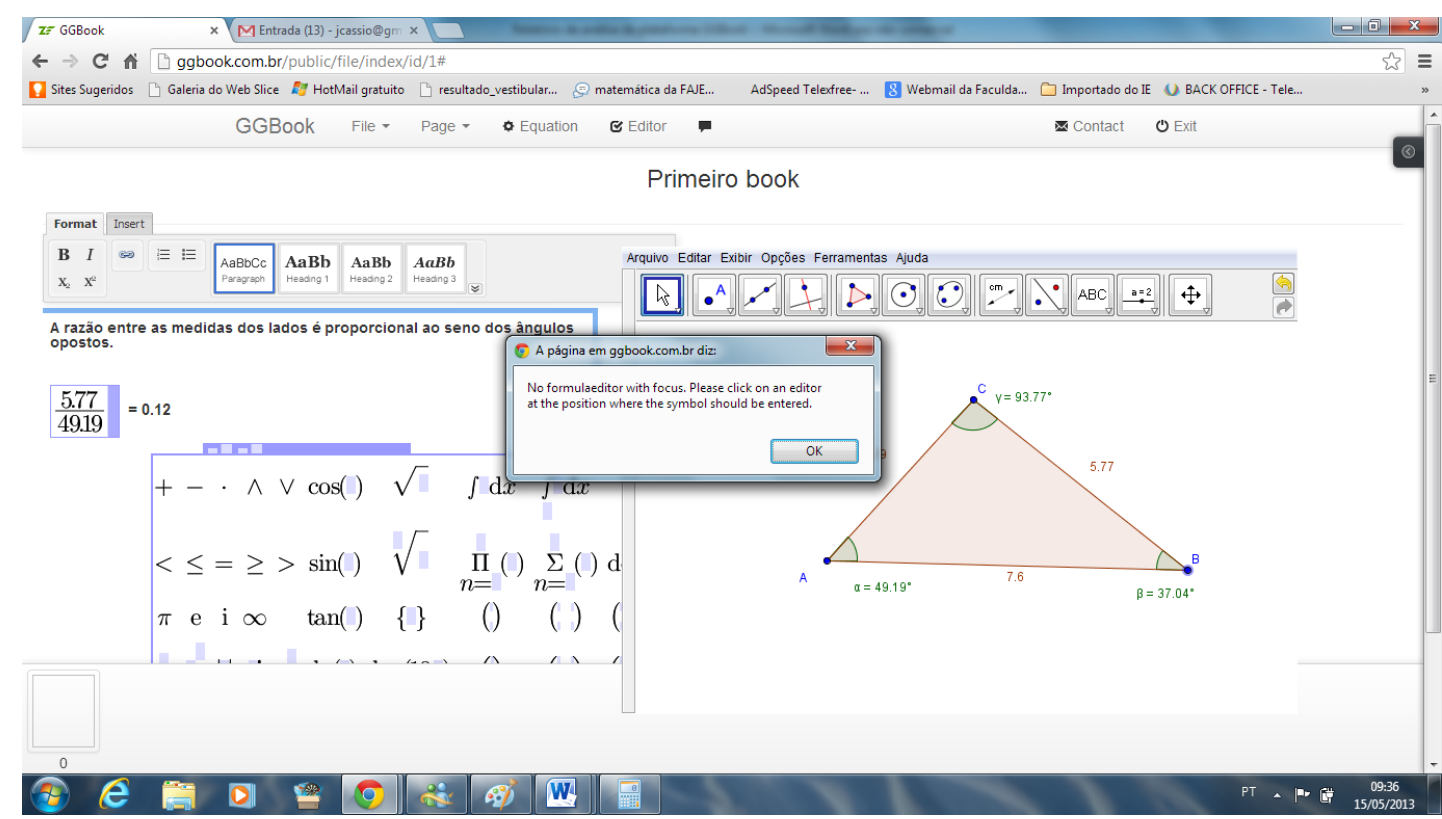

-As vezes clico na ferramenta de equação e aparece um retângulo grande e não consigo inserir nenhum símbolo. Veja: 


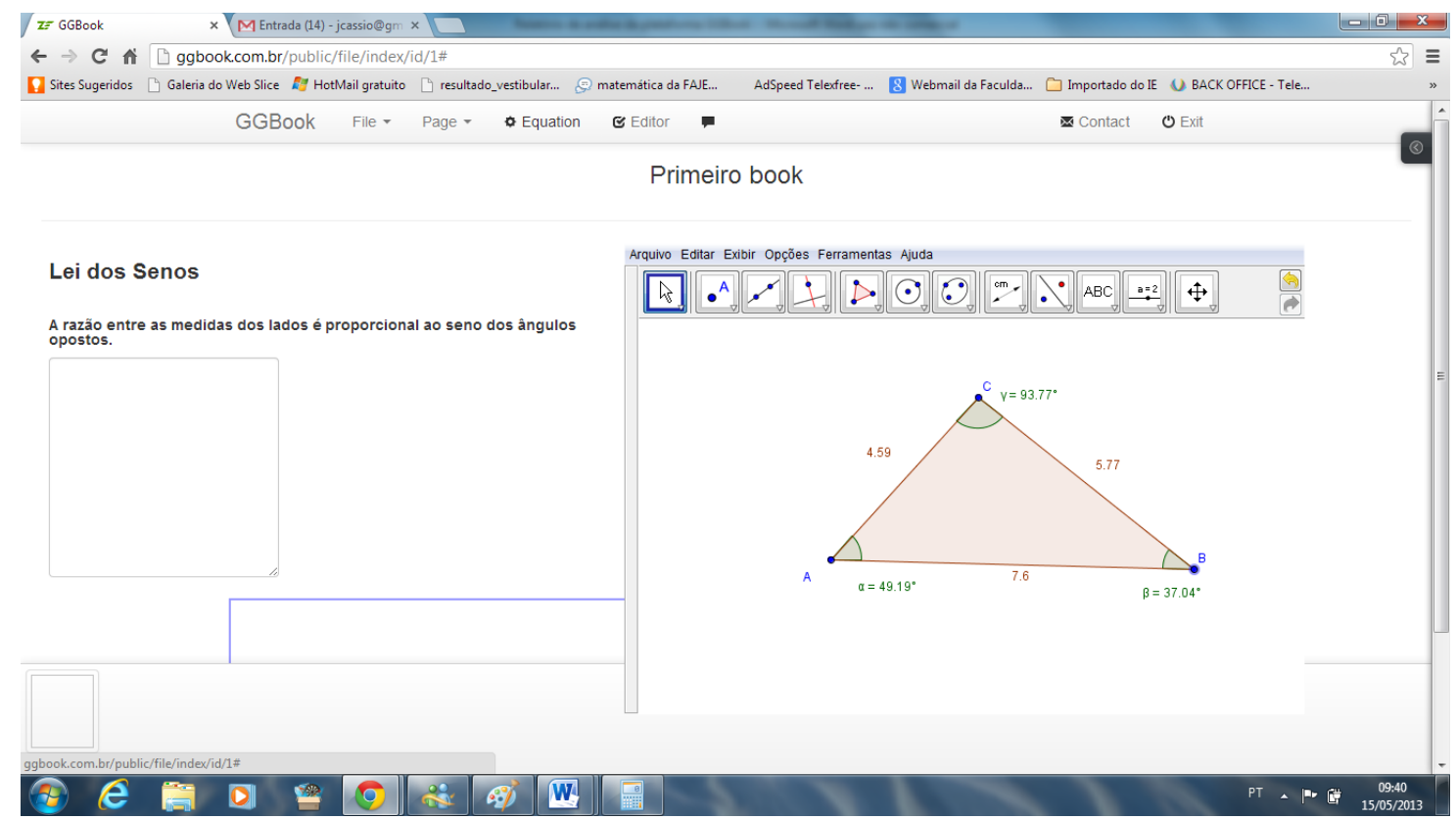

-Calculou o resultado de uma raiz quadrada, mas o resultado ficou num lugar estranho na tela:

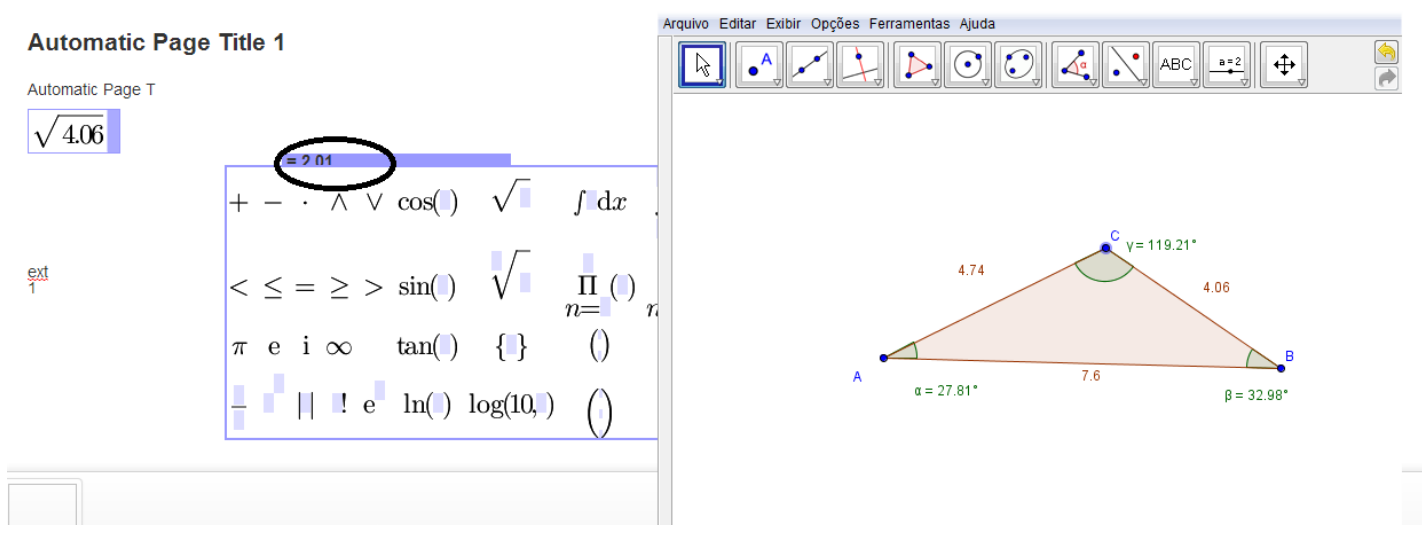

-Calculou uma divisão corretamente.

-Calculou corretamente o resultado de uma operação dentro da outra. Por exemplo:

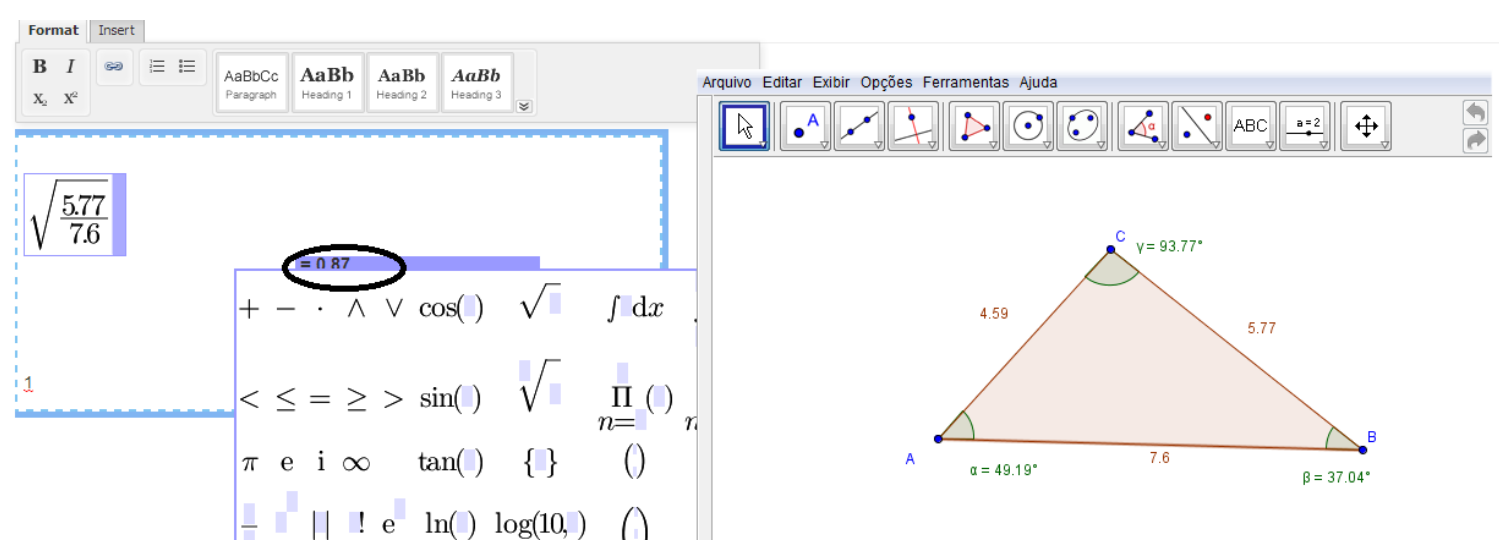


- Não tenho a opção de gravar o arquivo ggbook. Consigo salvar o arquivo geogebra, mas o ggbook ainda não. Quando isso ficará possível?

-Aceita a inserção de uma nova página, mas não aparece as opções de texto e geogebra. Quando volto para a página anterior o arquivo do geogebra que estava trabalhando sumiu. -A ferramenta comentário não funciona ou não sei usar. 


\section{APÊNDICE B: RELATÓRIOS DO GGBOOK 2013 (2 SEMESTRE)}

Data: 22 de maio de 2013

Análises da Experimentação

Usabilidade

Enfim, consegui fazer a lei dos senos, mas tive que usar "manhas". Detalharei abaixo:

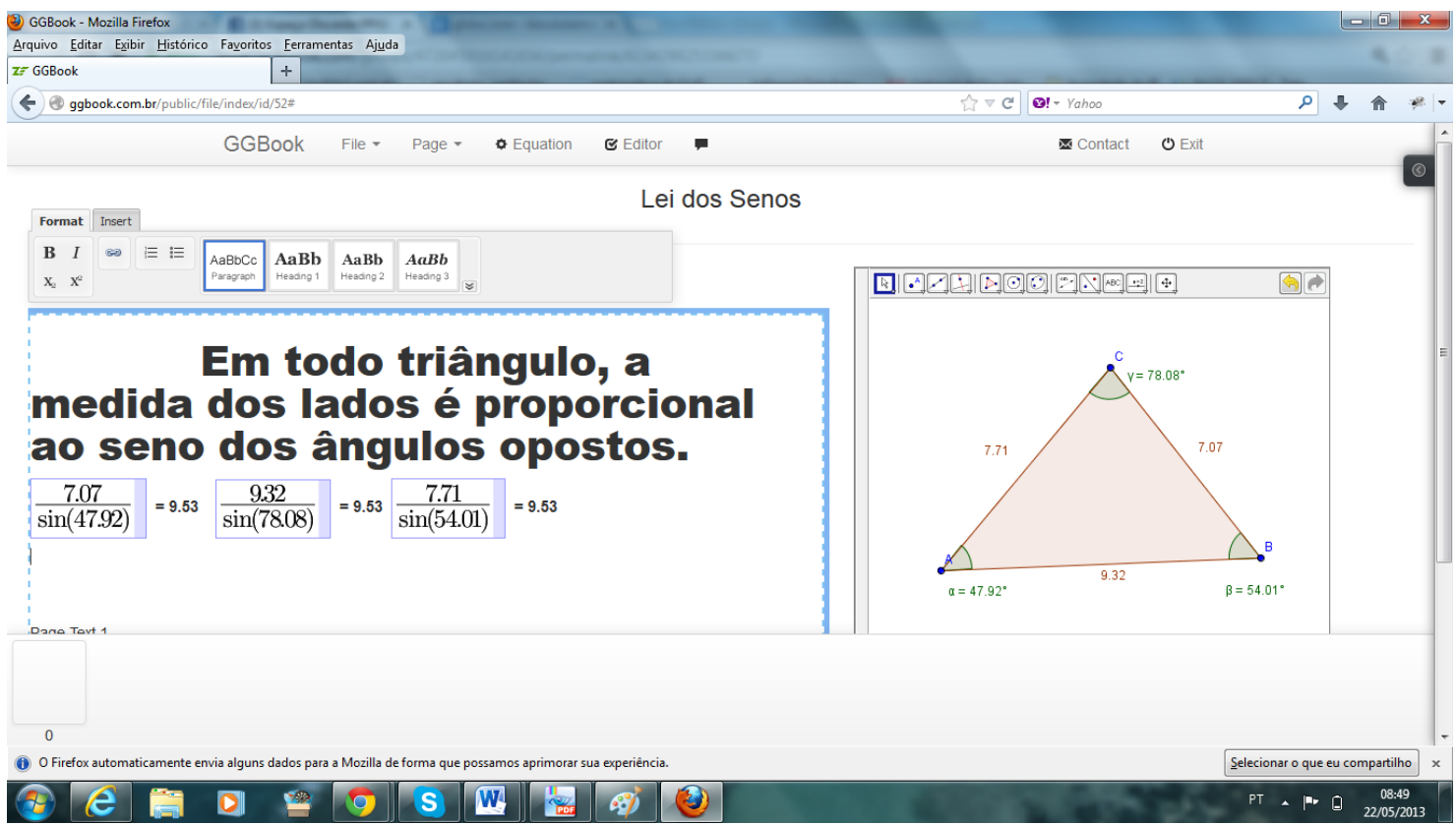

- Em alguns momentos, não consigo fazer o cursor no ambiente texto se movimentar. Não consigo digitar no ambiente texto. Uma manha que descobri, foi minimizar a tela e maximizar novamente. Aí o cursor funciona e consigo digitar.

- Quando crio uma nova página, não consigo inserir na nova página a equação no ambiente texto.

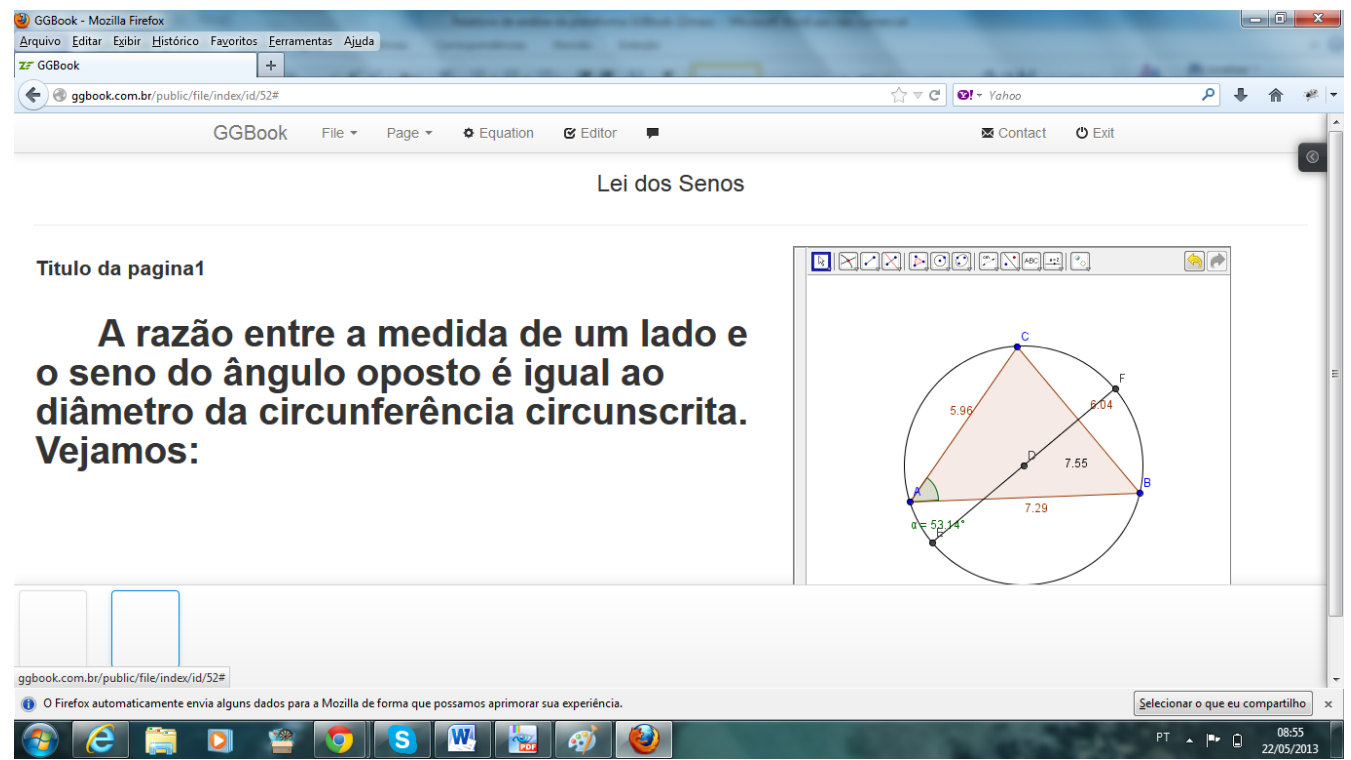


-Quando retorno para a página anterior, as equações somem.

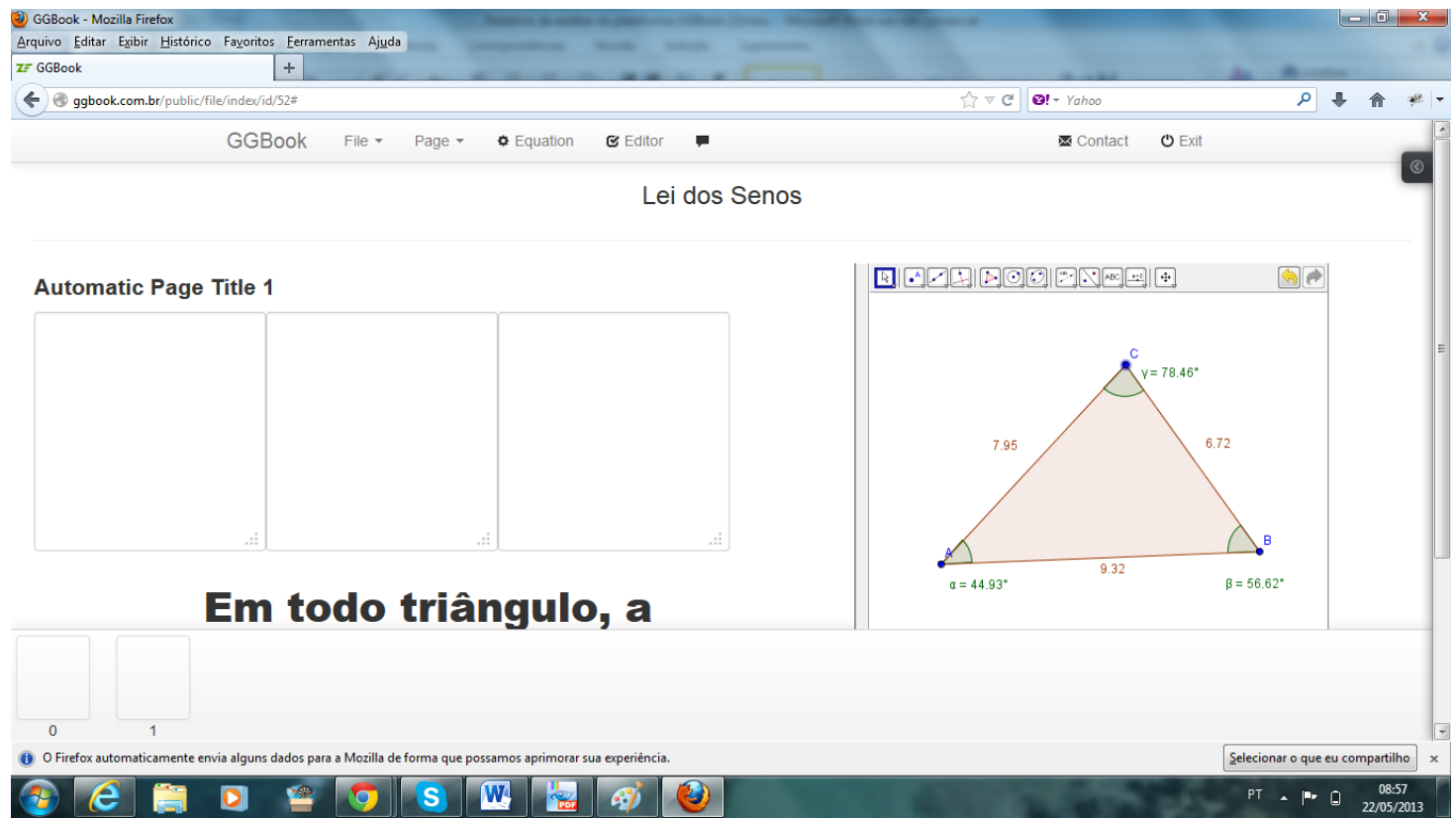

-Na figura acima não dá para ver toda a tela. Vejam abaixo:

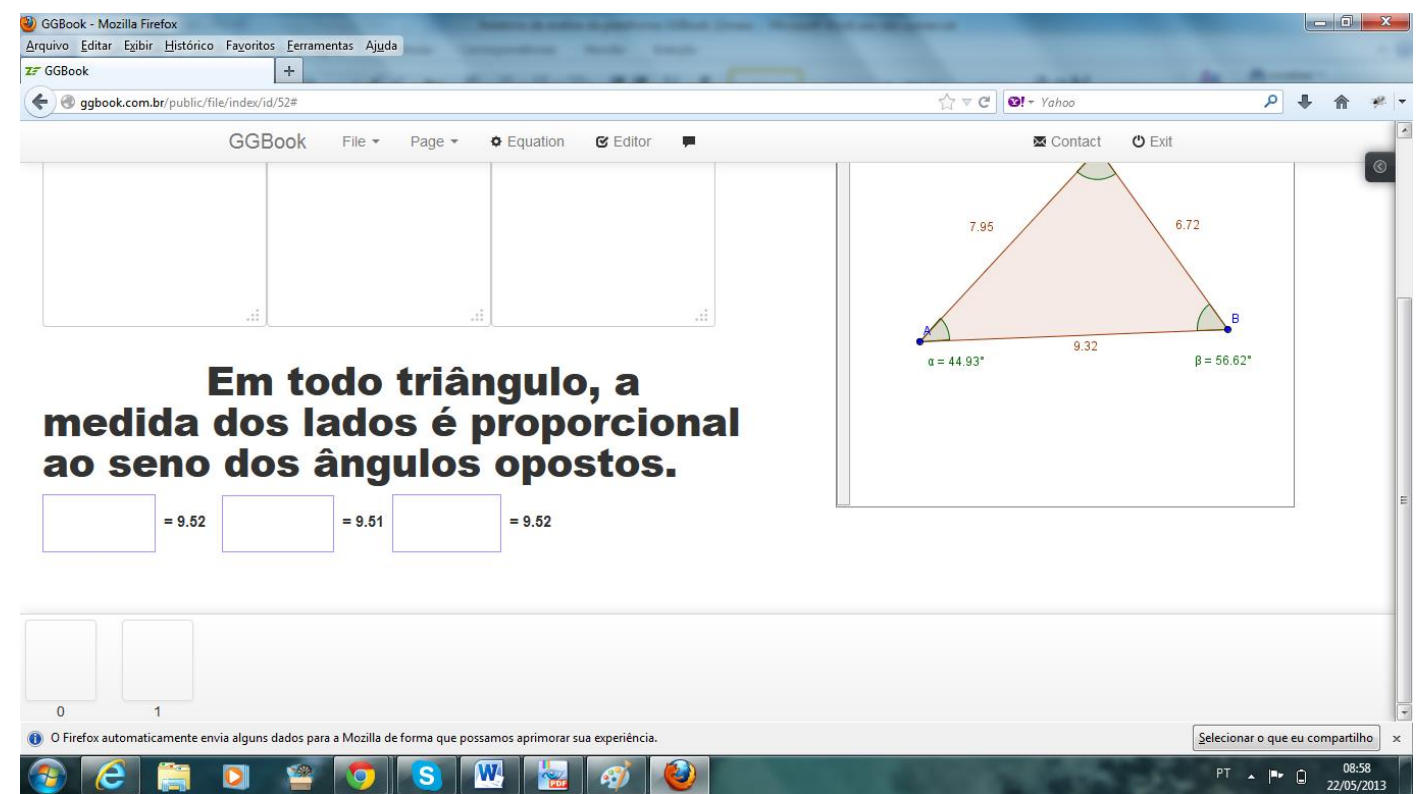

Apesar das equações não estarem visíveis, os resultados são atualizados quando movimento o triângulo.

-Quando abro um arquivo book (demora muito para abrir), não visualizo as equações e também não consigo inserir novas. Vejam a imagem que fica: 


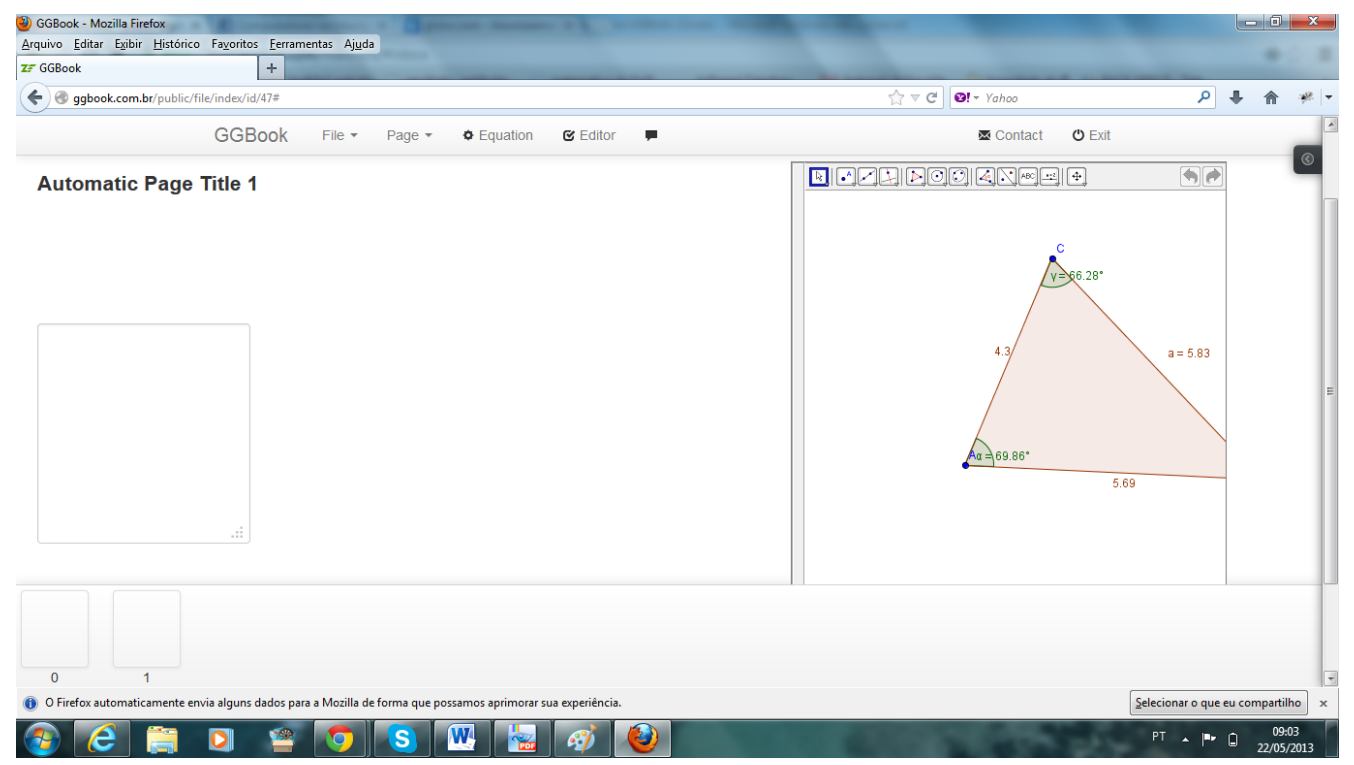

Testando para outras situações

-Soma, Divisão, multiplicação e subtração: Efetua a soma, divisão e subtração de maneira correta.

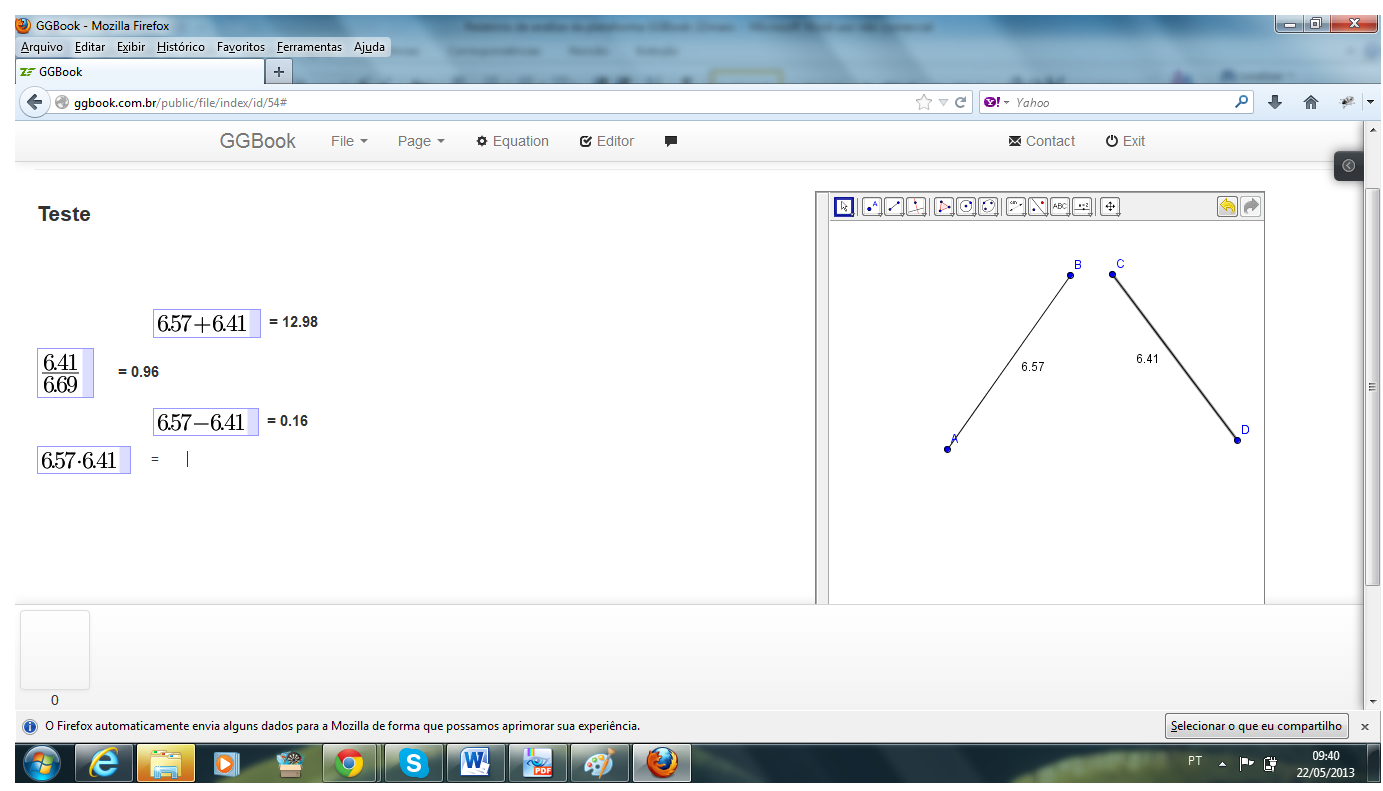




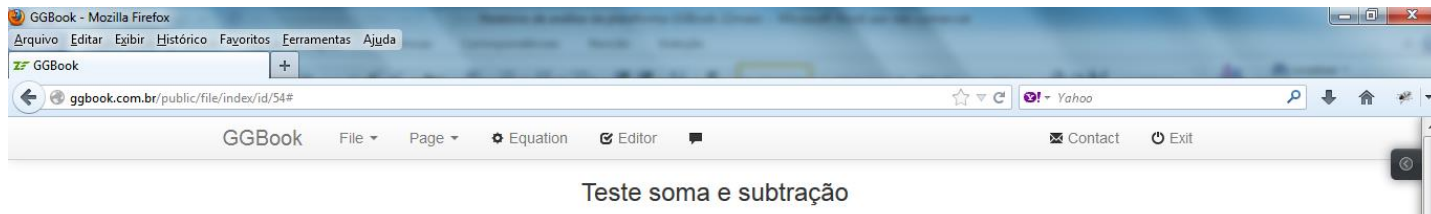

Teste

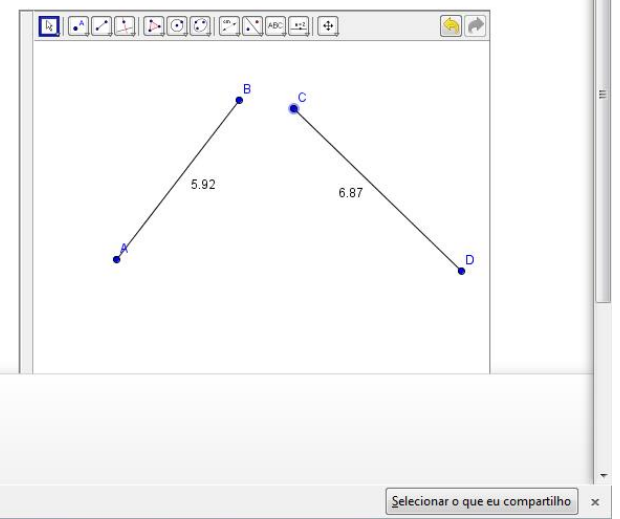

- O Firefox automaticamente envia alguns dados para a Mozilla de forma que possamos aprimorar sua experiência.

(A) 2 D

Às vezes dá um bug, desaparecendo algum valor da soma.

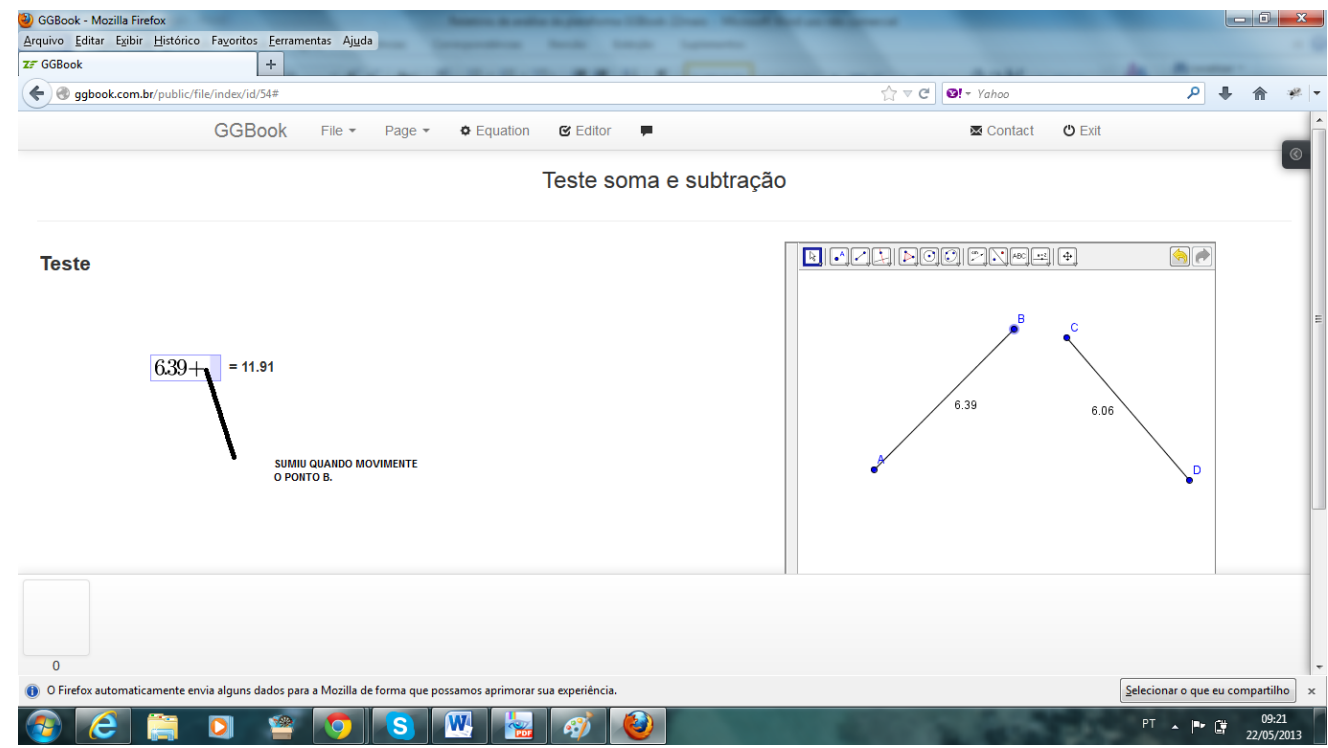

Não efetua a multiplicação (aliás é melhor mudar o ícone da multiplicação para " $\mathrm{x}$ " ao invés de ponto). 


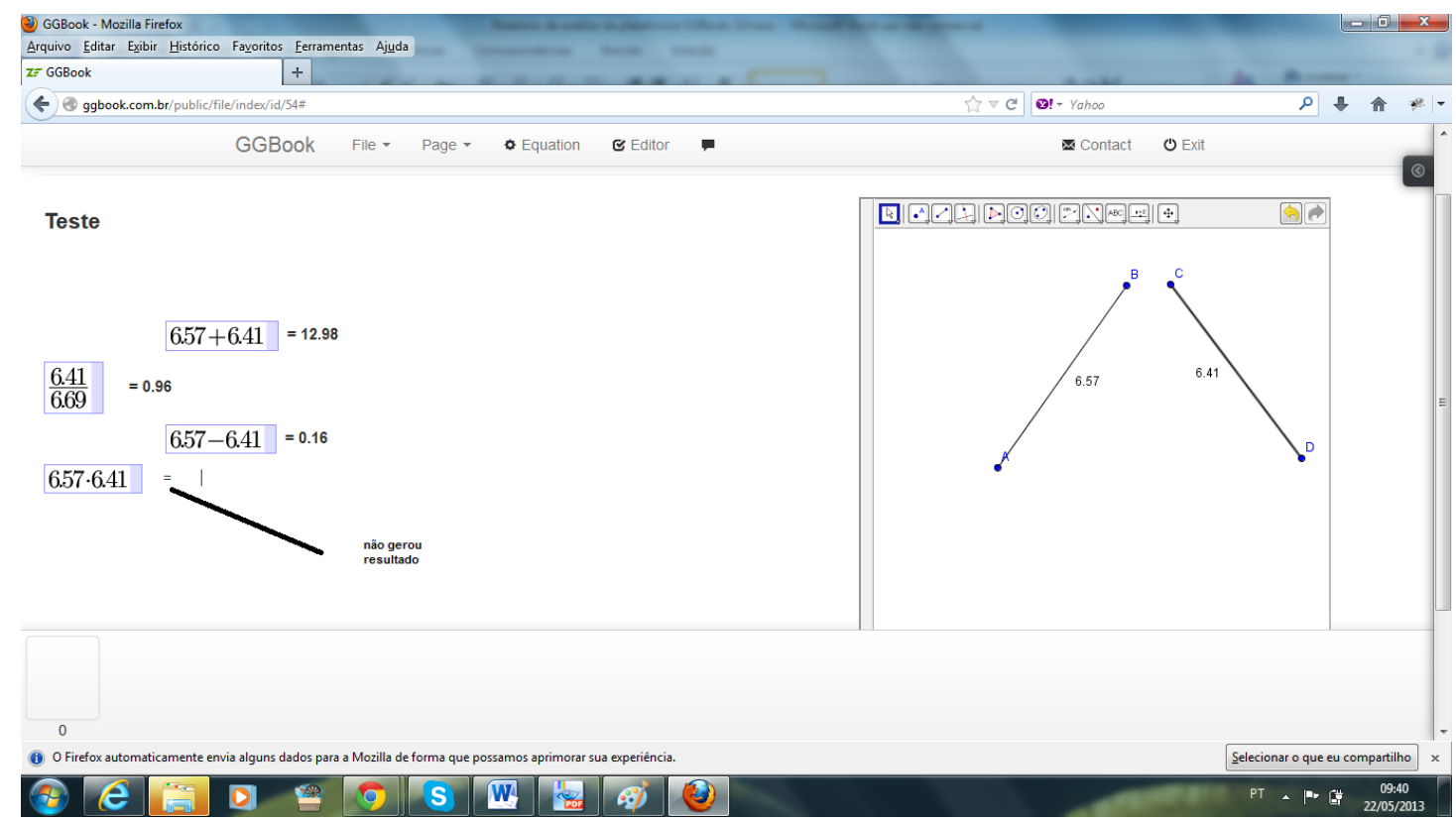

-Calcula corretamente raízes quadradas.

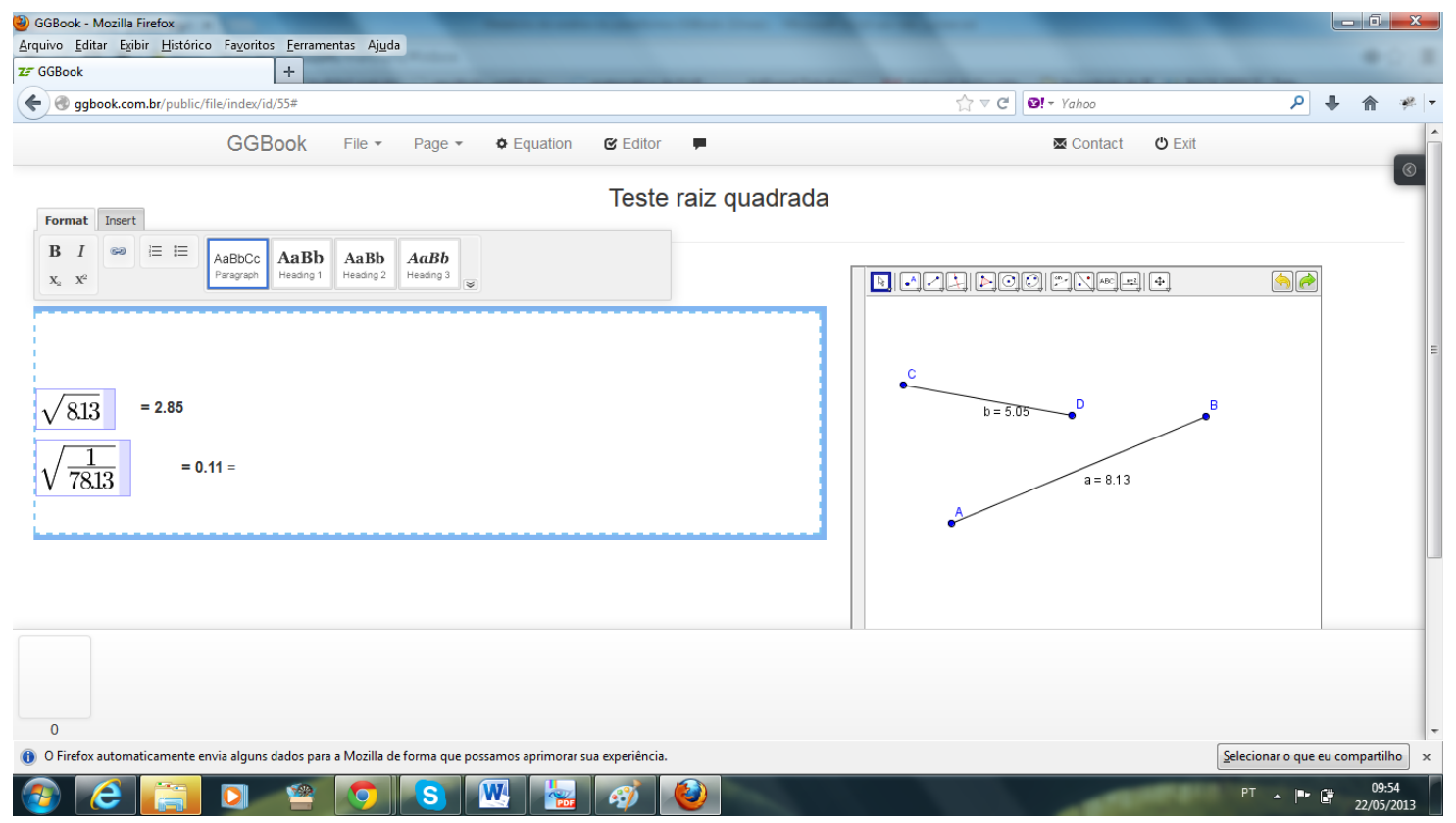

-Potência não funciona

Relatório de análise da plataforma GGBook

Data: 12 de julho de 2013

O relatório a seguir tem o objetivo de apresentar as correções e implementações que precisam ser feitas na plataforma GGBOOK de forma a oferecer condições mínimas de testes.

\section{Em relação a tela inicial, depois que logamos.}

a. Possibilidade de criar arquivos já colocando nomes; 
b. Não consegui deletar um arquivo criado anteriormente;

c. Não consegui copiar (duplicar) os "books", de forma que o professor possa fazer books iguais para estudantes diferentes;

d. A tela do geogebra está sobrepondo o espaço das páginas do livro. Os ícones dos botões estão grandes. Diminuir para que caibam todos na tela.

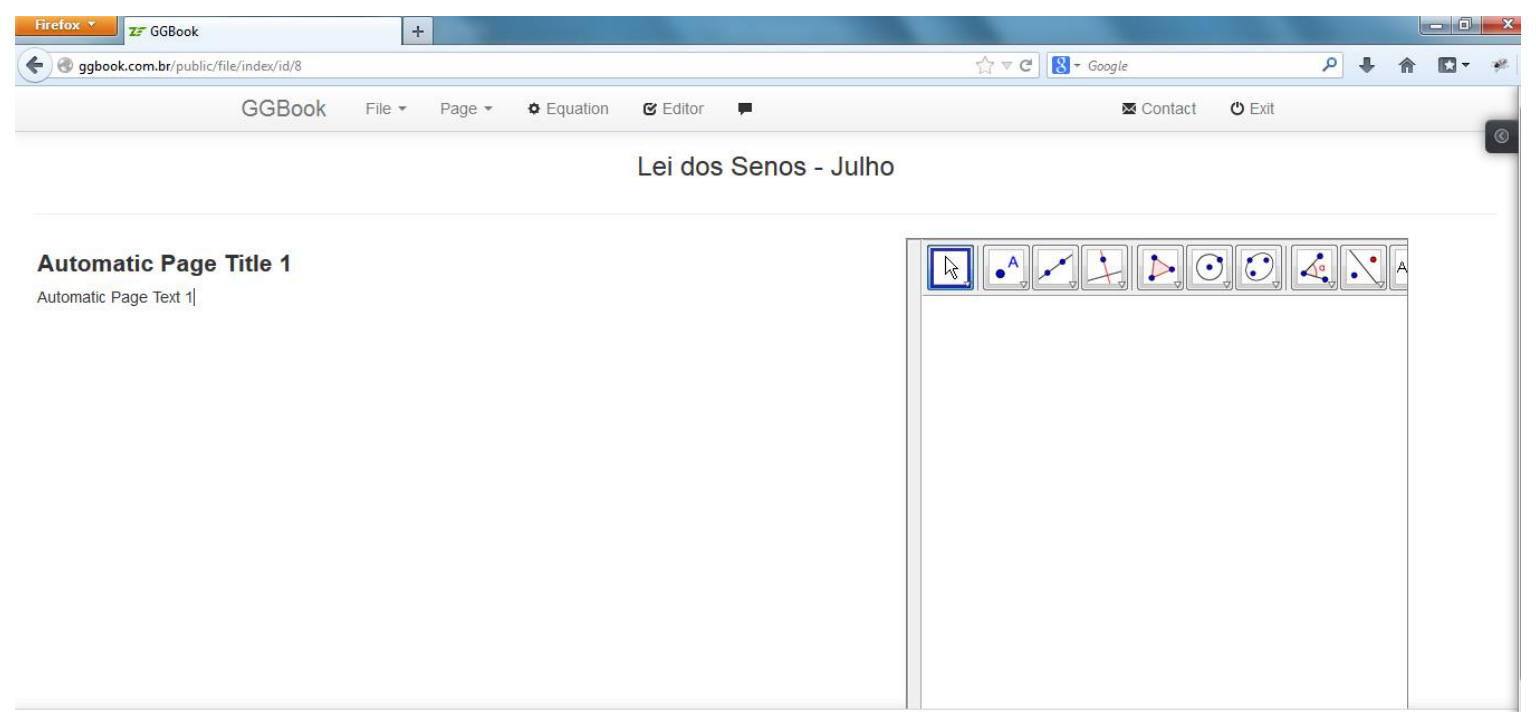

\section{Usabilidade e integração entre os ambientes}

a. Aceita a inserção de valor, mas estão ocorrendo erros que antes não ocorriam. Inserção de um número do numerador e não atualização do resultado. Vejam na figura abaixo:

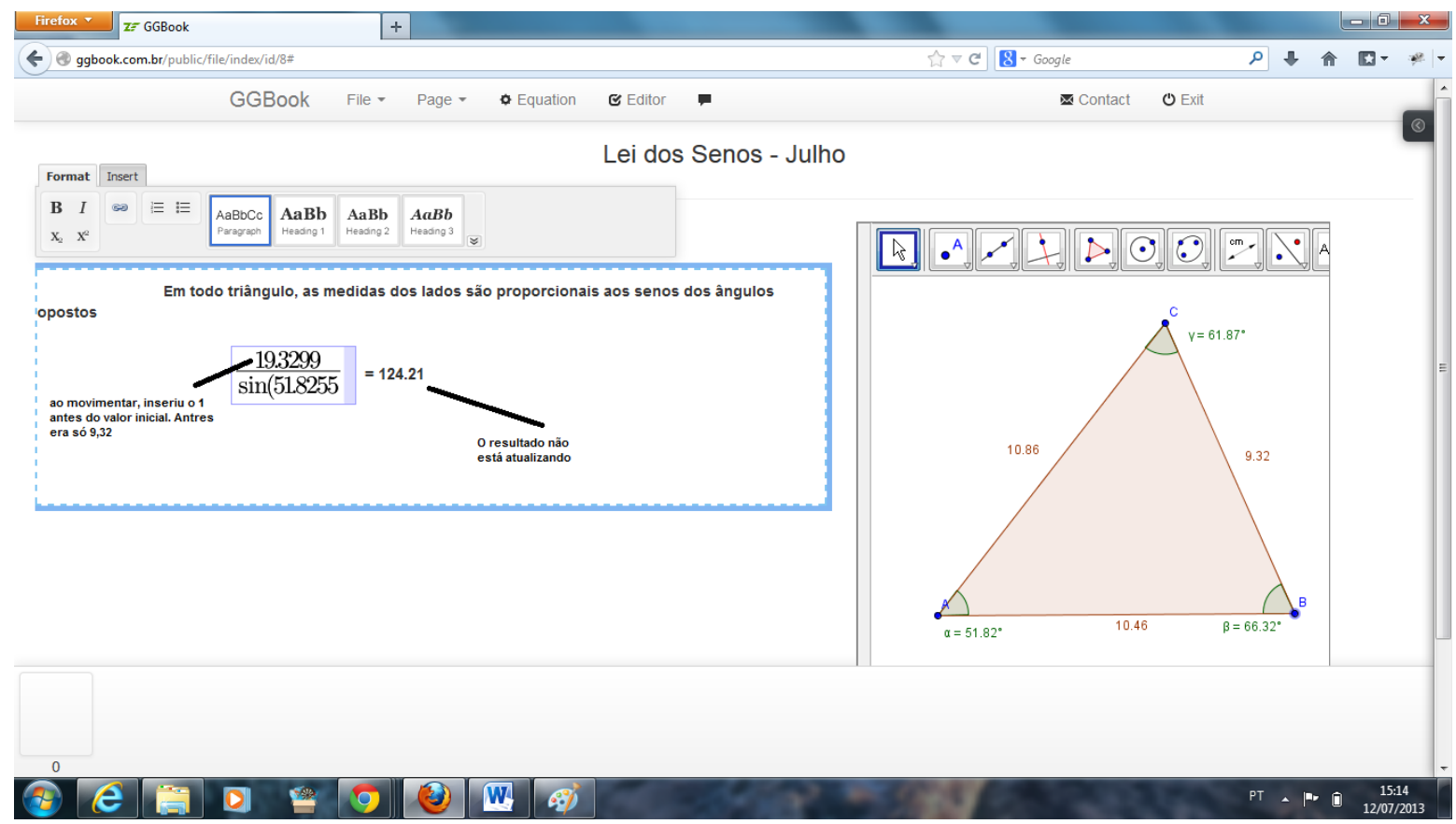

b. No relatório anterior, havia pedido para que quando gerasse o resultado, o cursor saísse de dentro da caixa, porque ao movimentar o objeto na tela do geogebra inserem-se novos objetos dentro da caixa, gerando problemas. Tais problemas permanecem; 
c. Para operações simples de adição, subtração, multiplicação e divisão estão ocorrendo bugs que antes não ocorriam: não gera resultado da multiplicação, não atualiza resultados, etc;

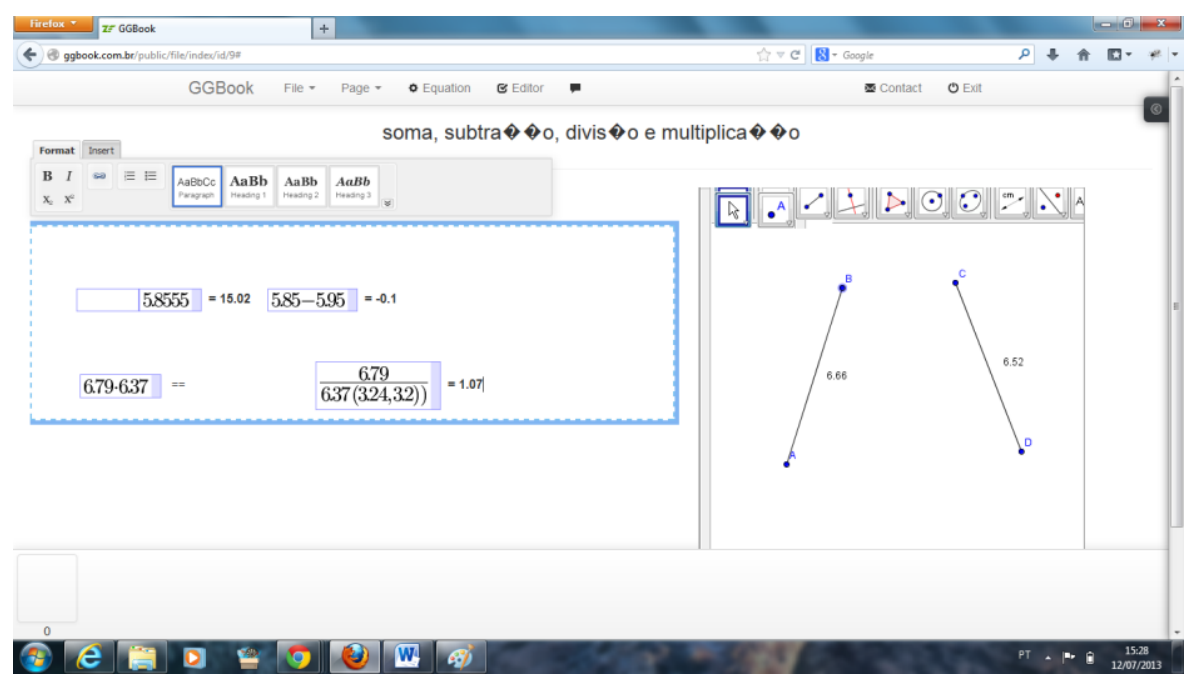

d. Ao abrir um arquivo anterior, a figura feita no ambiente geogebra aparece normalmente, mas o que foi feito no ambiente texto aparece com problemas:

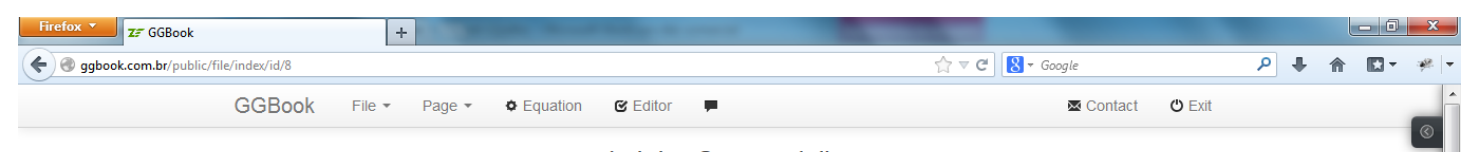

Lei dos Senos - Julho

Lei dos Senos - parte 1

opostos

Em todo triângulo, as medidas dos lados säo proporcionais aos senos dos ângulos

$17.547 .333=124.217 .7949 .4844=12.57 \quad 10.1717 .531 \quad=19.34$
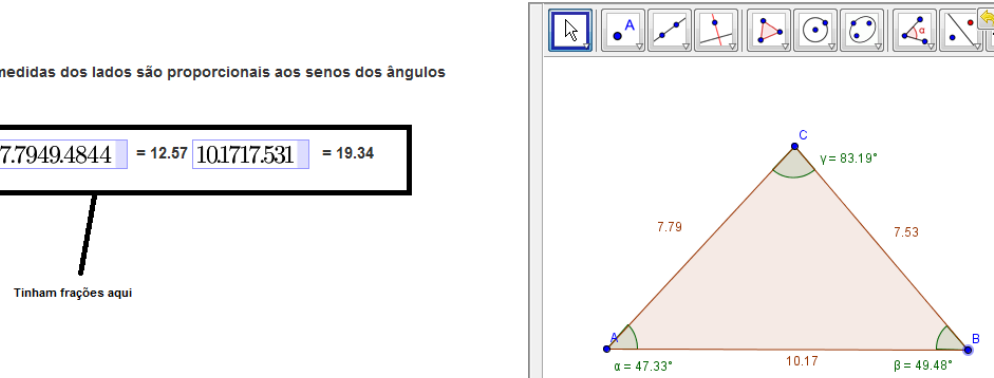

(2)

e. Não consigo inserir uma equação na página 2 do book.

f. Quando volto para a primeira página, o que foi feito no ambiente texto desaparece, ficando apenas o resultado estático. 


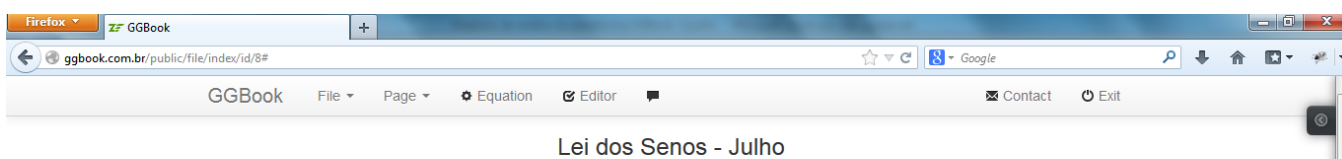

Lei dos Senos - Julho

Lei dos Senos - parte 1

\begin{tabular}{|l|l|l|l|l|l|}
\hline &
\end{tabular}

Em todo triângulo, as medidas dos lados são proporcionais aos senos dos ângulos opostos

[] $=124.21$

[1] $=12.57$

II] $=19.34$

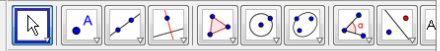

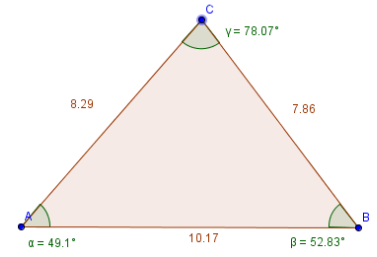

$\sqrt{2}$

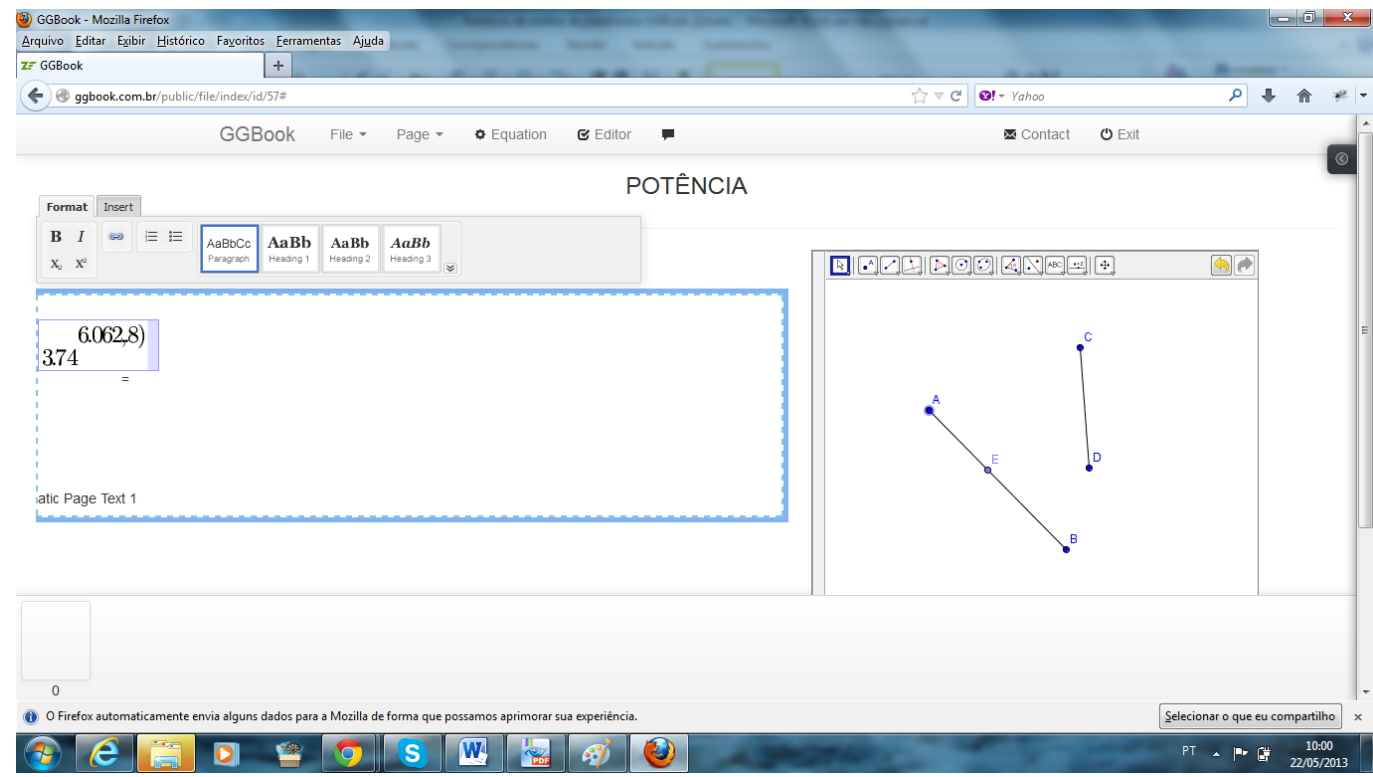

-Não calculou o resultado abaixo: 


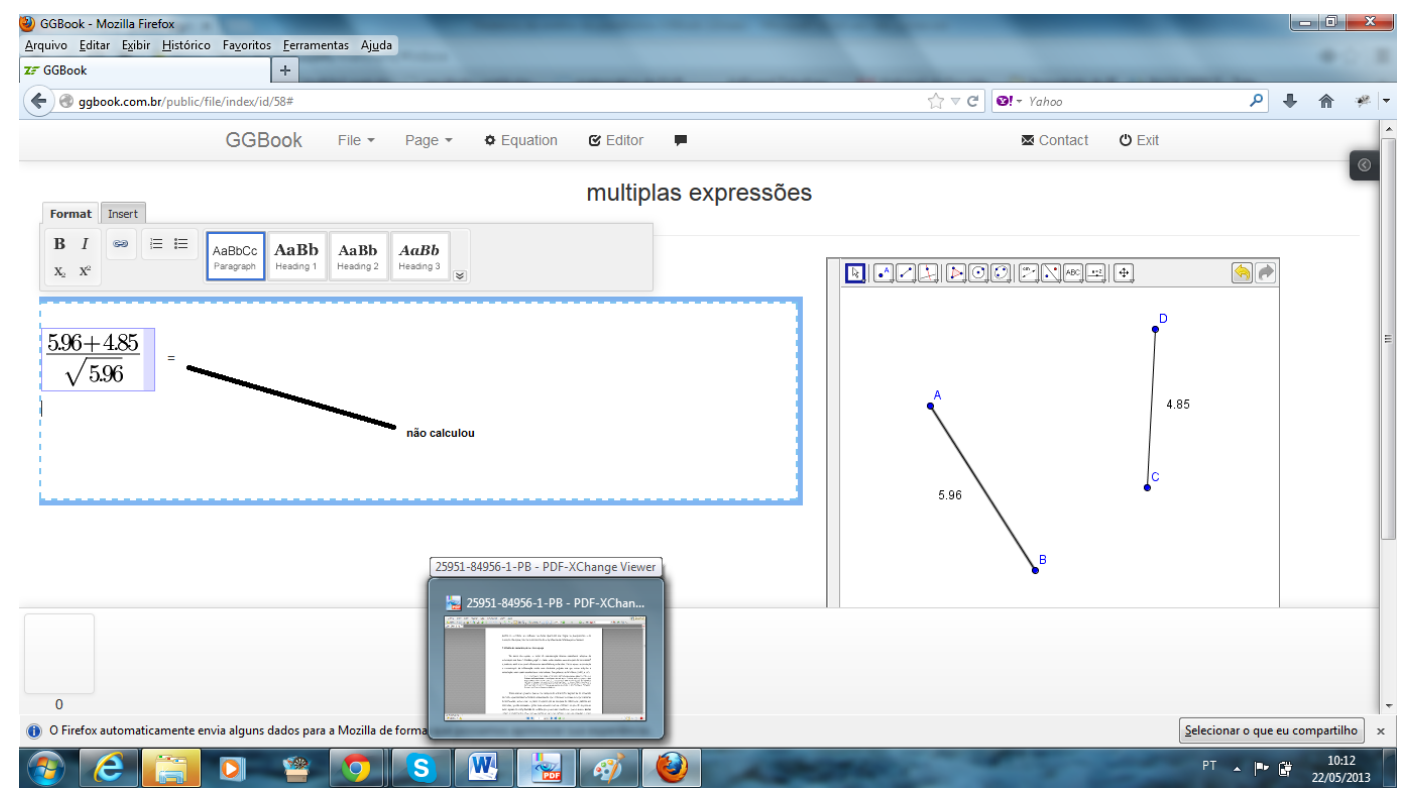

Outros problemas

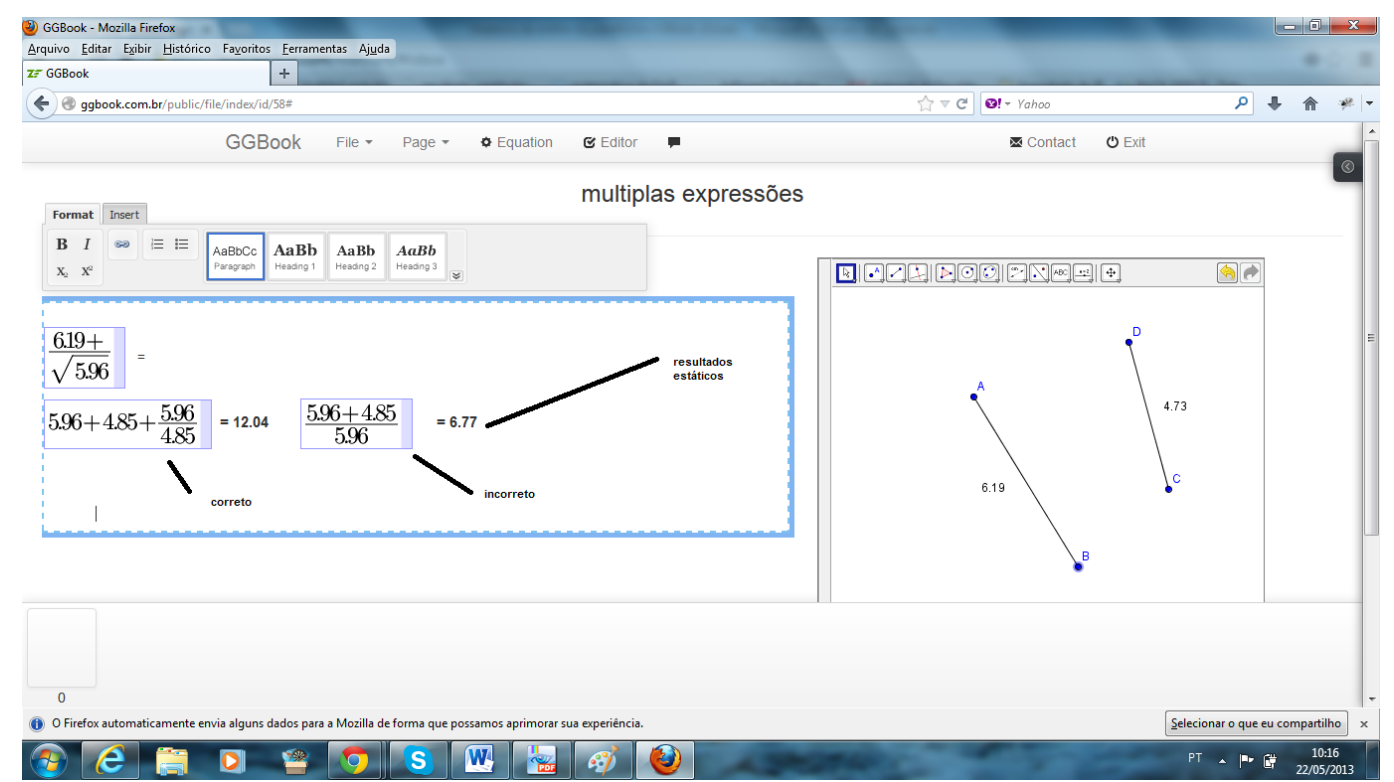

Relatório de análise da plataforma GGBook

Data: 12 de junho de 2013

O relatório a seguir tem o objetivo de apresentar as correções e implementações que precisam ser feitas na plataforma GGBOOK de forma a oferecer condições mínimas de testes.

\section{Em relação a tela inicial, depois que logamos.}

a. Possibilidade de copiar "books", de forma que o professor possa fazer books iguais para estudantes diferentes;

b. Ferramenta para apagar books. A ferramenta "remove" em file não funciona ou não sei como usar; 


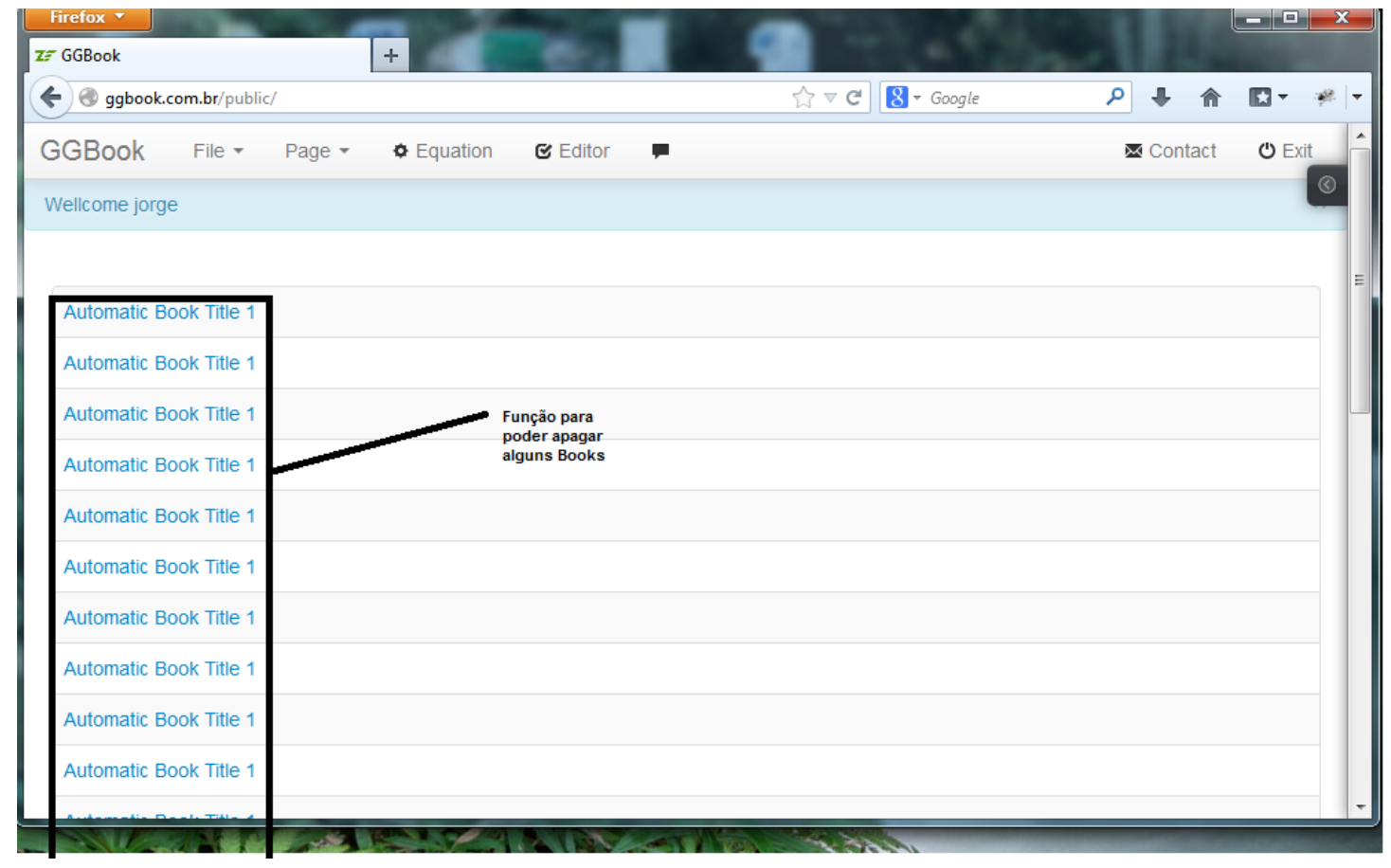

c. Ao clicar em file e depois em New, abrir uma caixa para poder nomear o book. Fica difícil achar o arquivo na lista.

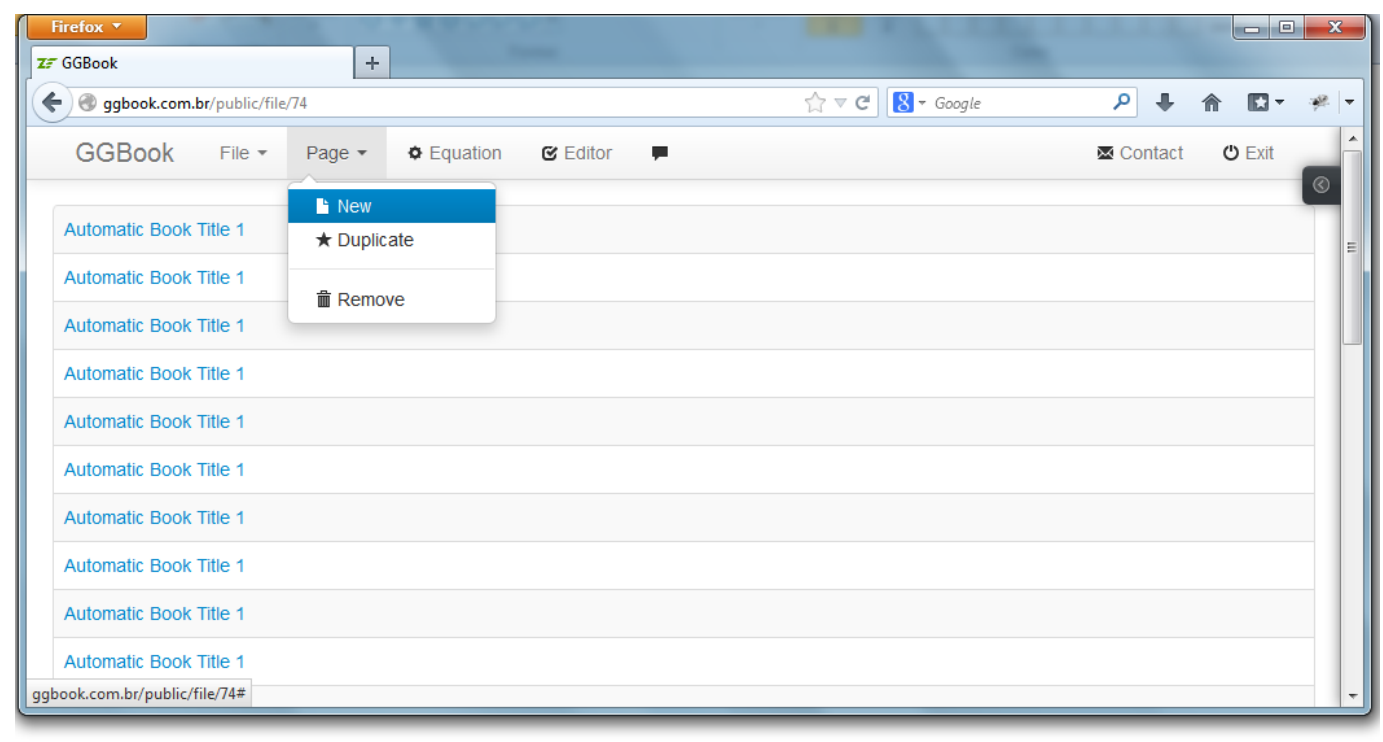

\section{Usabilidade e integração entre os ambientes}

a. Quando gerar o resultado, o cursor deve sair de dentro da caixa, porque ao movimentar o objeto na tela do geogebra inserem-se novos objetos dentro da caixa, gerando problemas. 


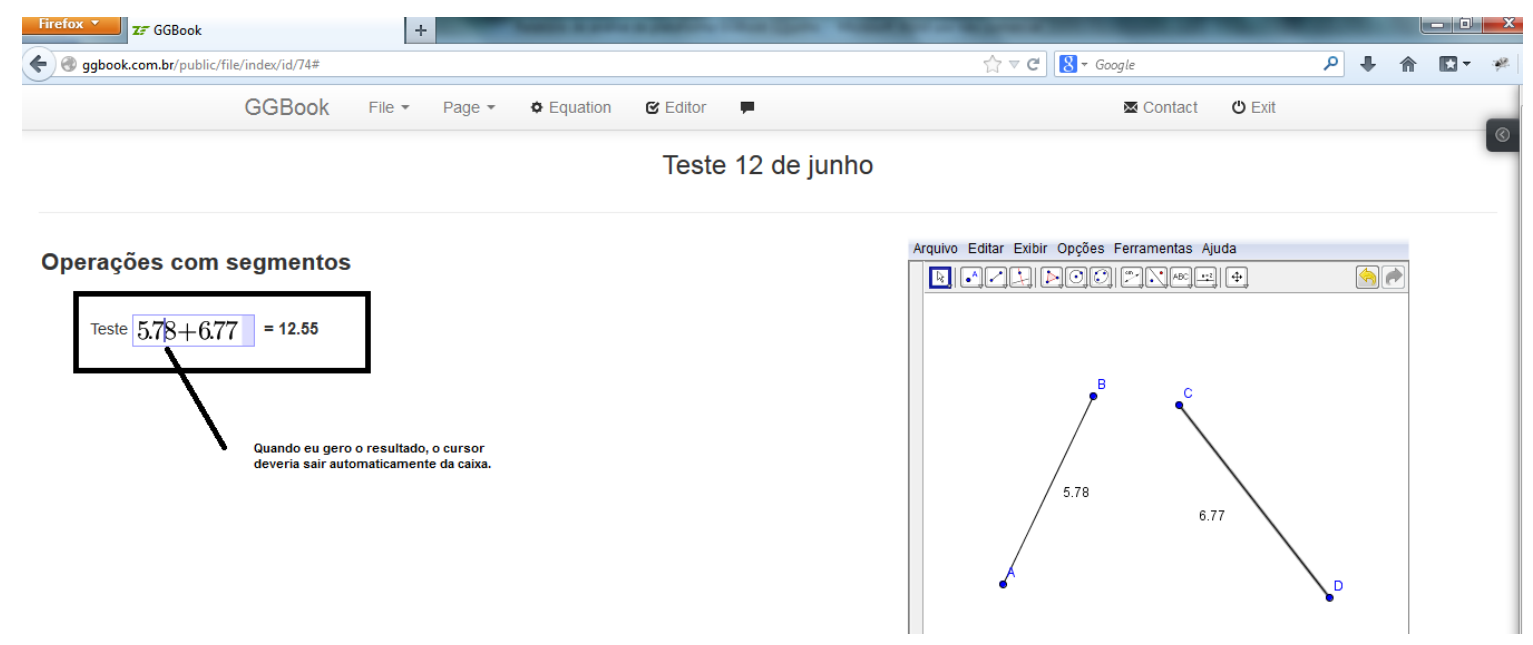

b. O valor do $2^{\circ}$ objeto some quando movimento o primeiro. Veja abaixo. Isso não acontece quando movimento o $2^{\circ}$ objeto.
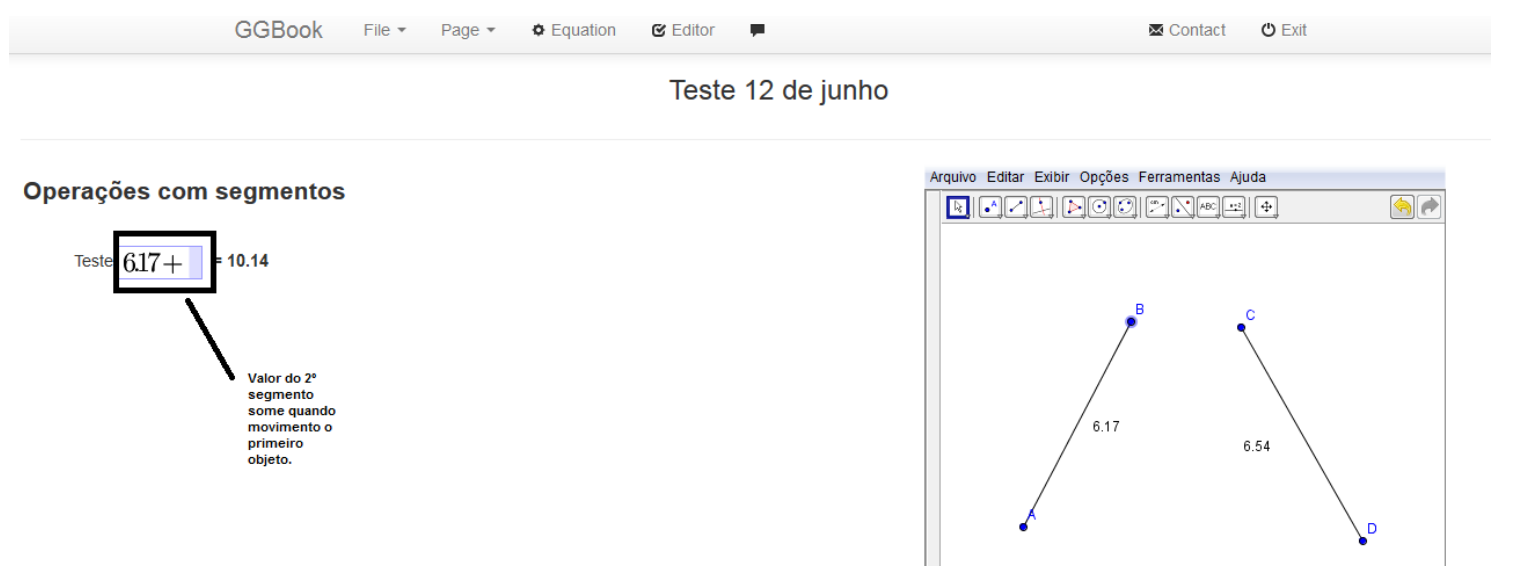

c. Alguns outros bugs: Quando apago, faço novamente e movimento os objetos na tela do geogebra, aparece o resultado anterior. Não consigo apagá-lo. Aí gera uma série de bugs.

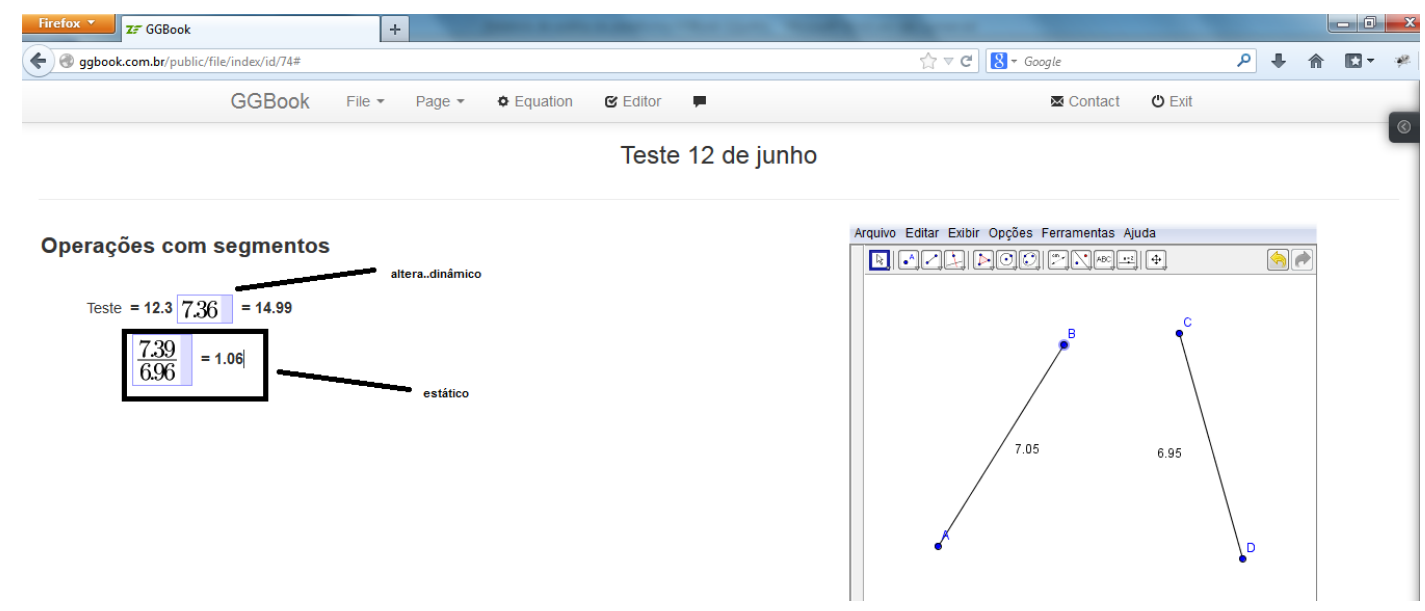


d. Faço uma soma e subtração num mesmo cálculo. O resultado inicial fica correto, mas quando mudo o objeto na janela do geogebra, acontecem bugs (some a última medida);

e. Resultados incorretos para uma divisão com soma no numerador;

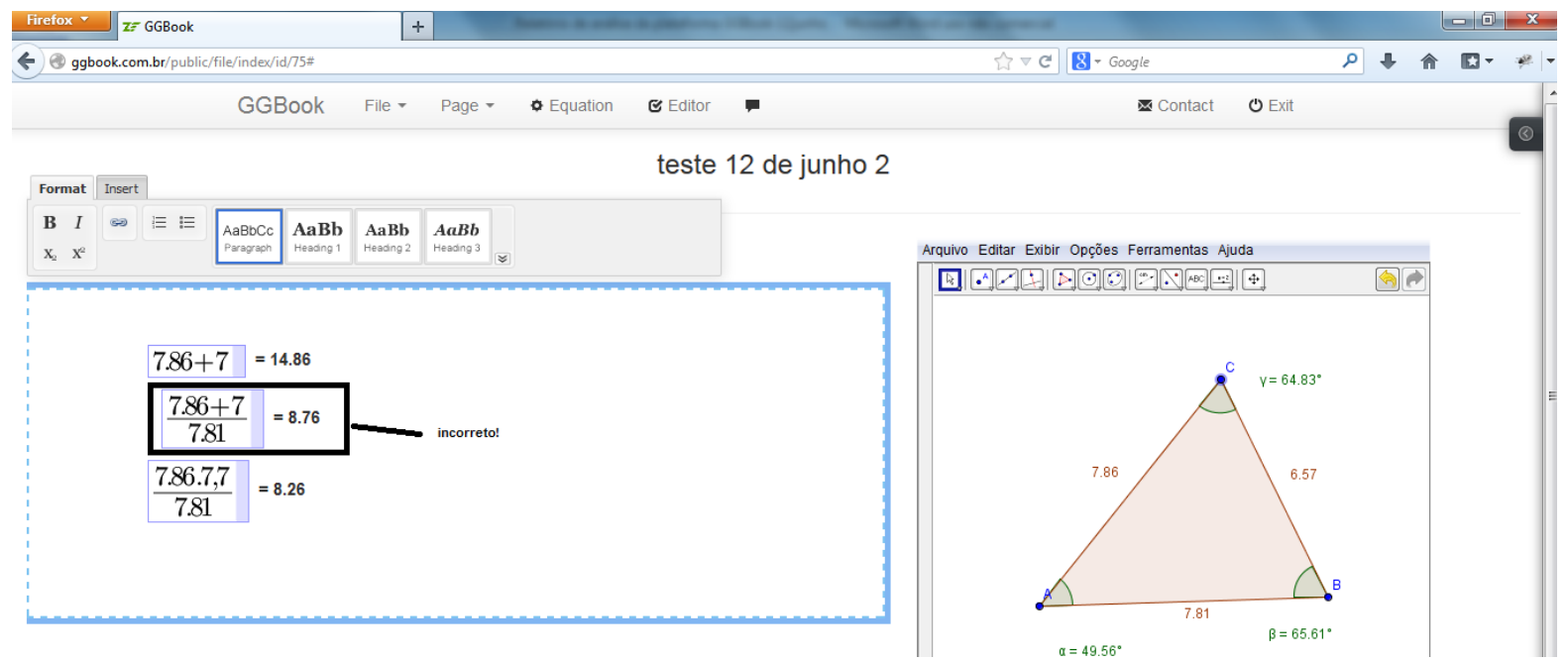

f. Às vezes, alguns objetos num mesmo book ficam dinâmicos e outros estáticos. Vejam:
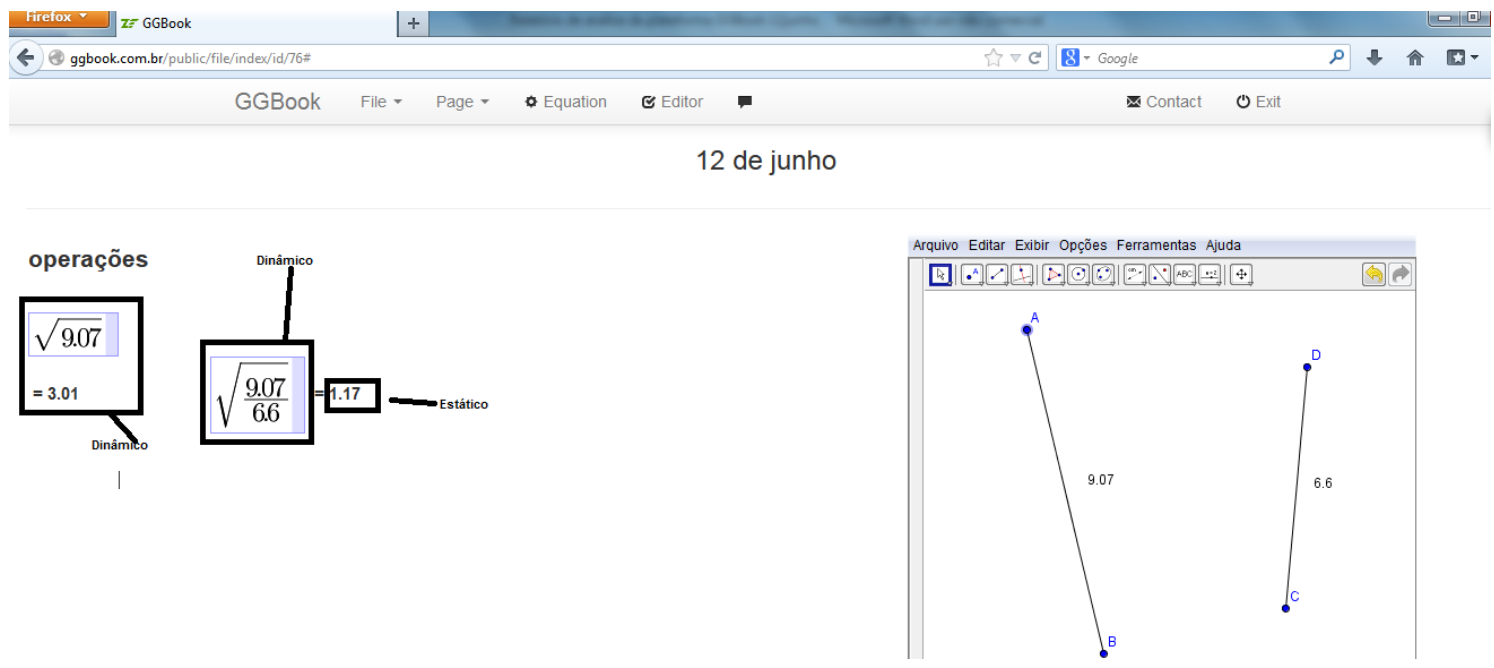

g. Não consigo digital um número dentro de uma caixa de operação. Por exemplo, quero dividir a medida de um segmento da já nela do geogebra por 2, não consigo inserir o 2 no denominador.

h. Não mostra o resultado de potências e quando mostra está errado. 


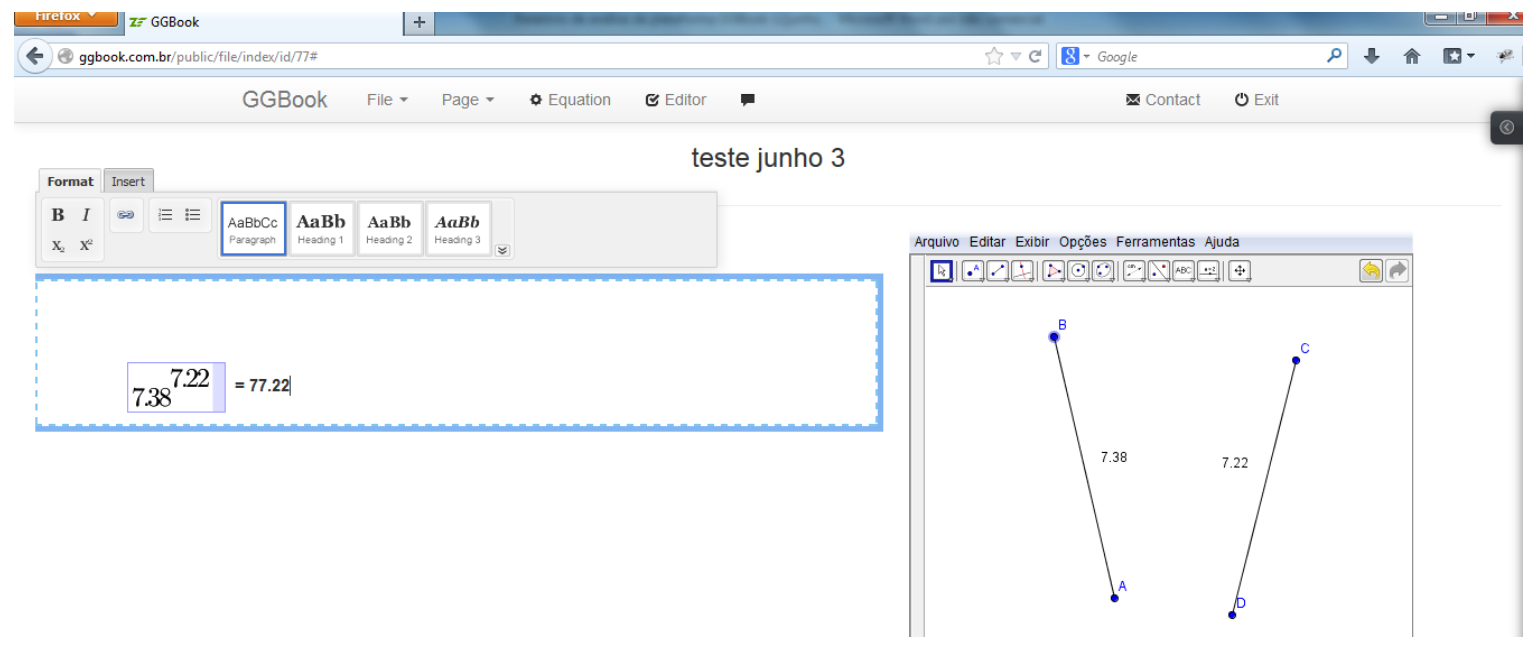

i. Não efetua a multiplicação (aliás é melhor mudar o ícone da multiplicação para " $\mathrm{x}$ " ao invés de ponto).

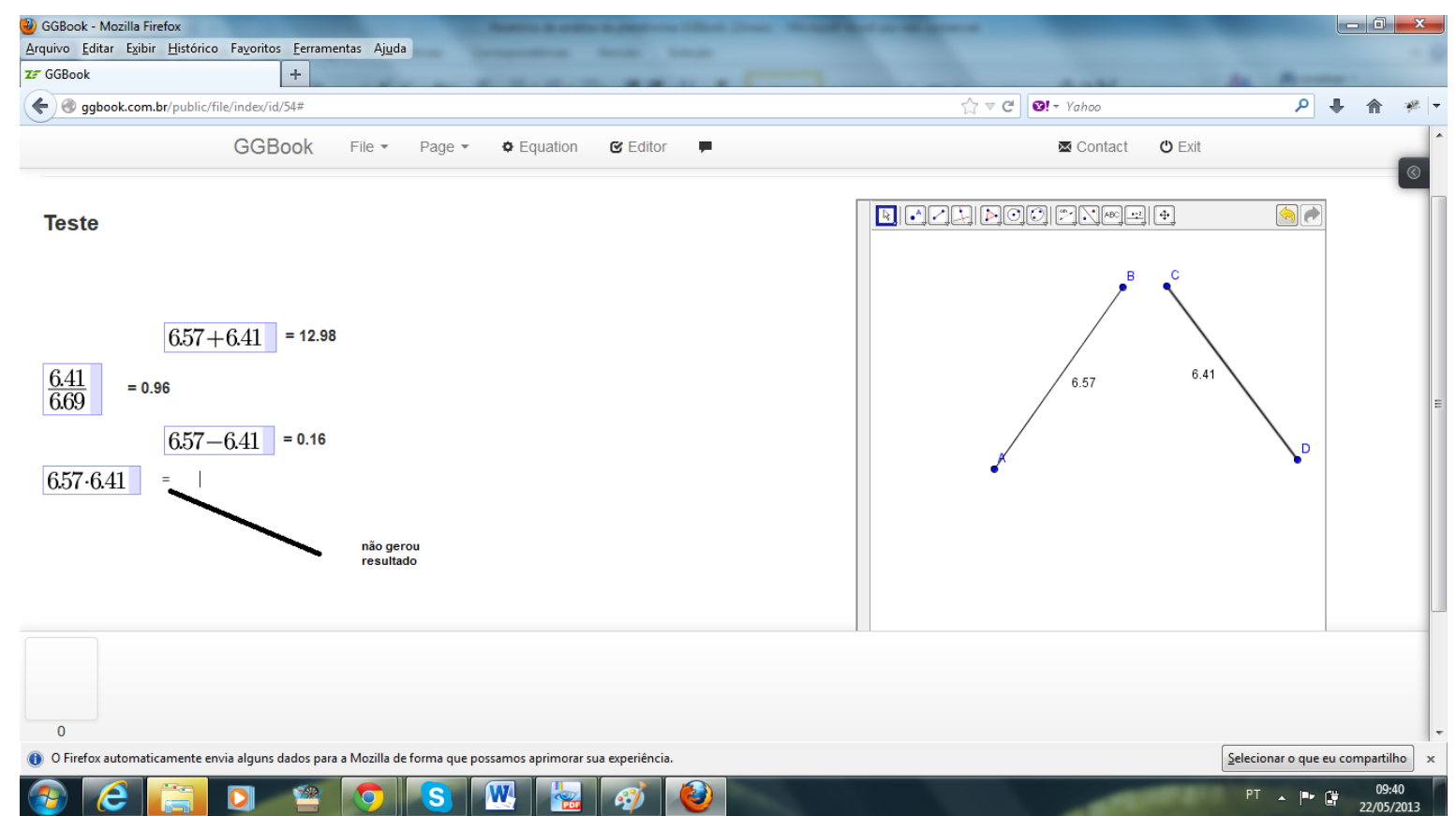

-Antes mostrava resultado correto de fração com raiz no denominador. Agora não mostra mais. 

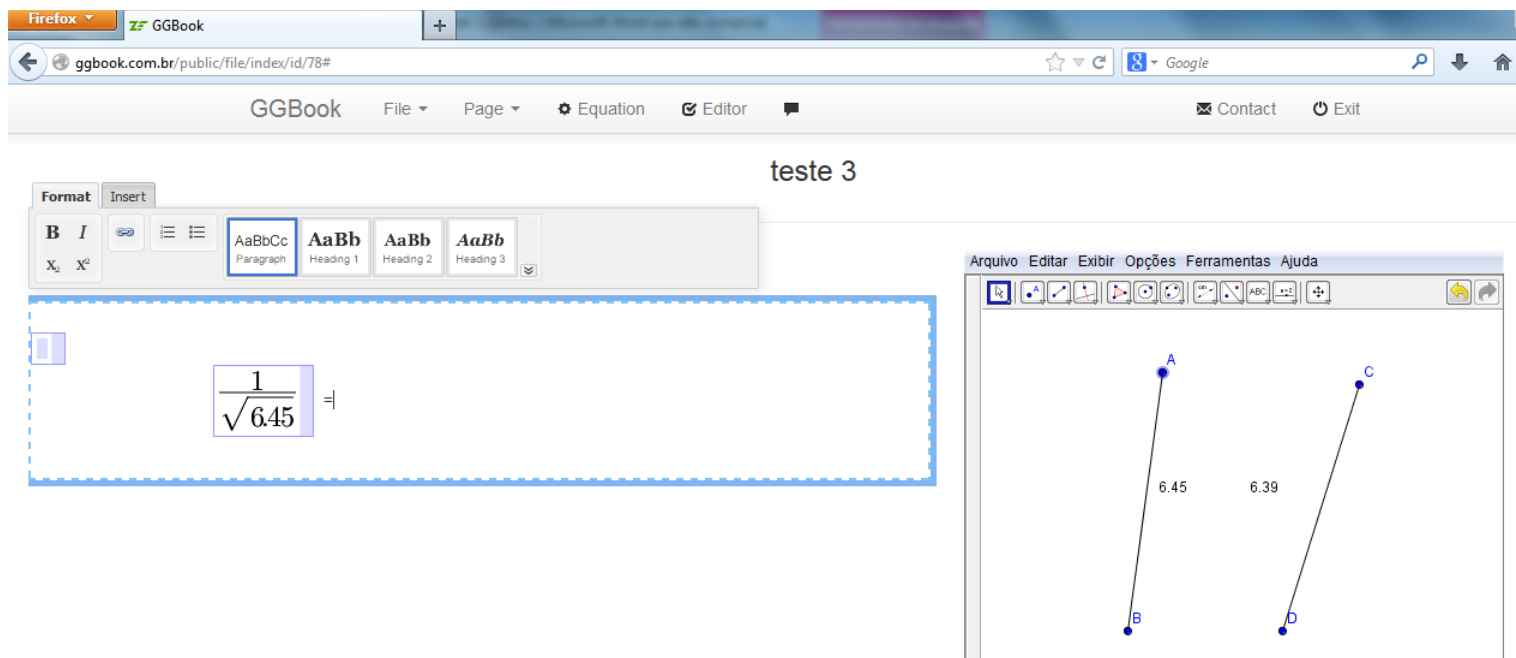

-Não calculou o resultado abaixo:

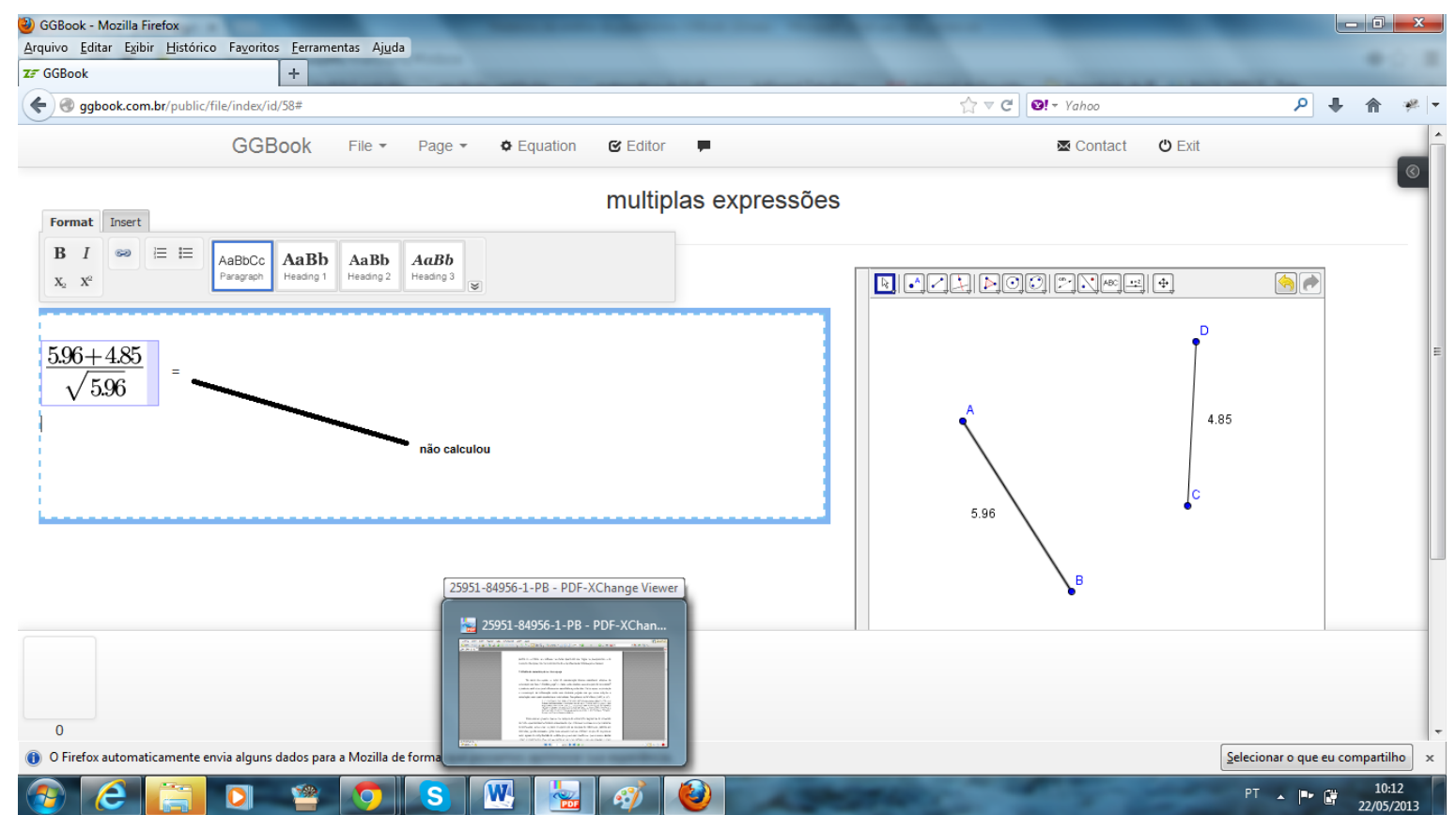

j. Outros problemas 


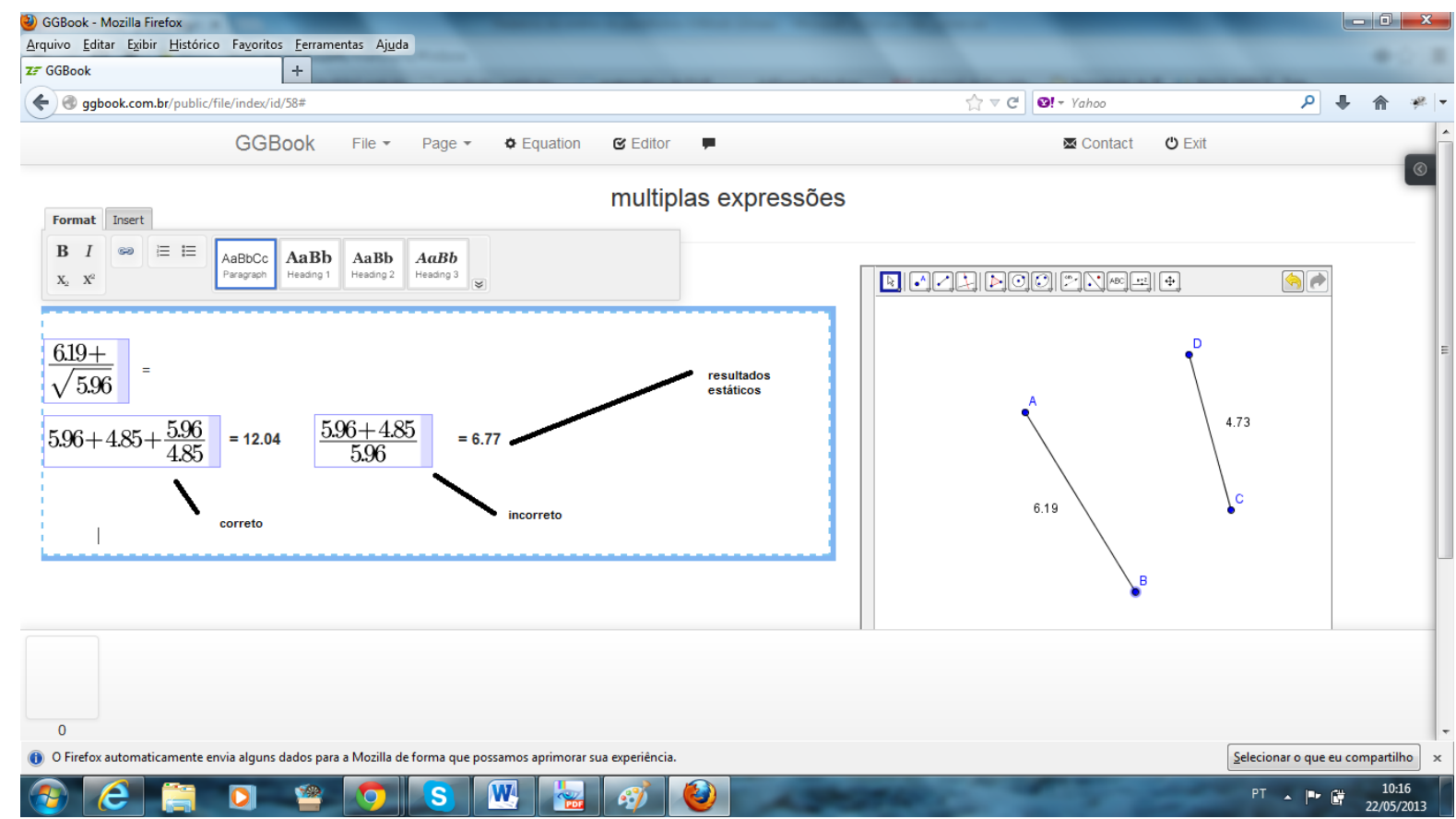

k. A ferramenta equações não funciona na $2^{\mathrm{a}}$ página. Quando volto para a primeira página, os valores nas operações ficam estáticos, mas os resultados ficam dinâmicos. Vejam:

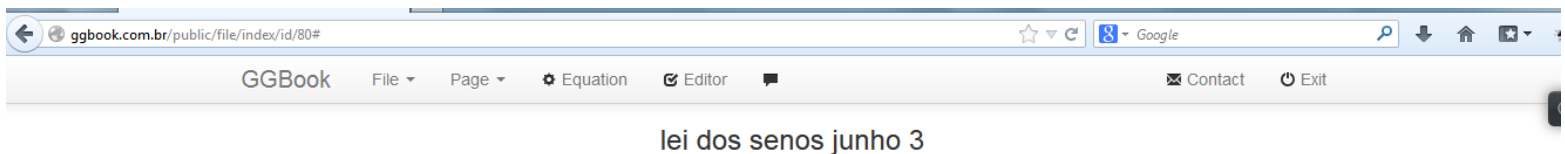

lei dos senos junho 3

Lei dos senos

[T|⿴囗十

Em todo triângulo a medida dos lados é proporcional ao seno dos ângulos opostos
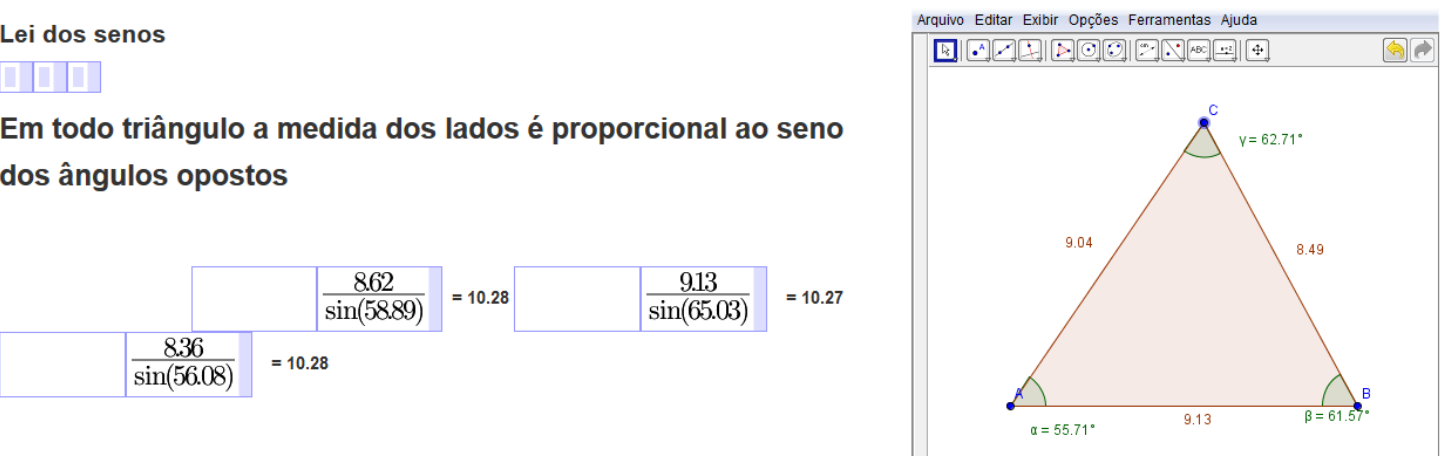

1. Quando fecho o book lei dos senos junho 3 e abro novamente, nem mais os resultados ficam dinâmicos. Tudo no ambiente texto fica estático. 


\section{Aspectos estéticos}

a. Tela do geogebra e espaço para páginas do book estão sobrepostos

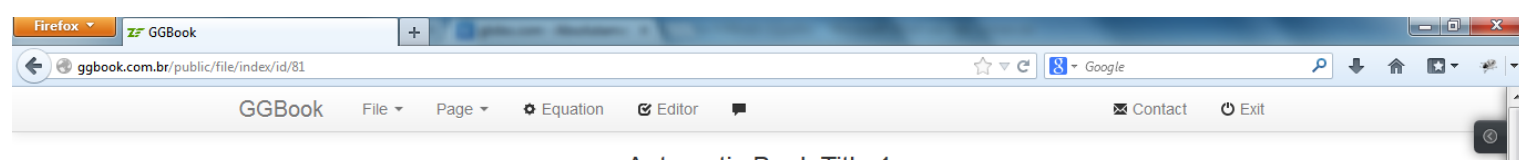

Automatic Book Title 1

Automatic Page Title 1

Automatic Page Text 1

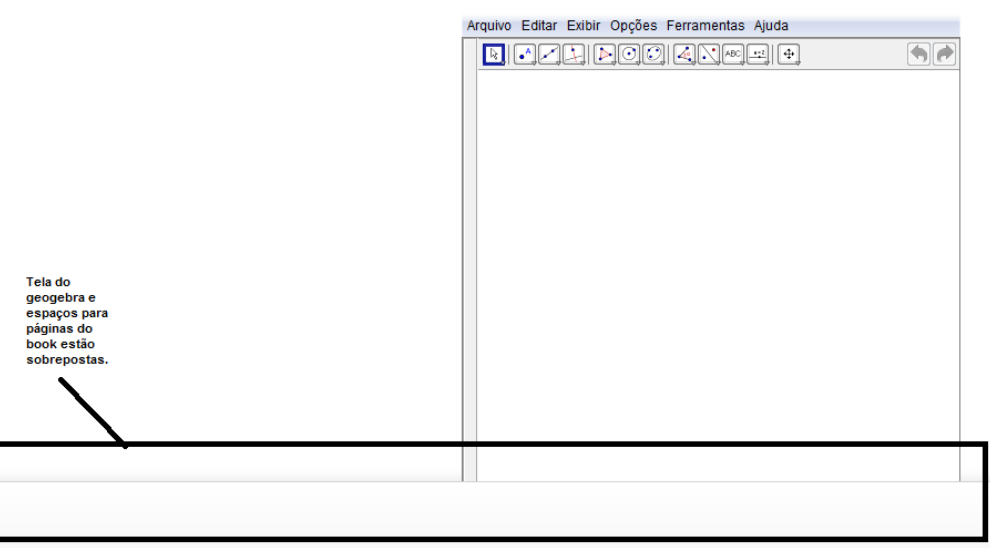

(4) $C$ D D

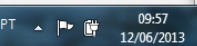

b. A barra de ferramentas de texto deveria ter: mais tipos de fontes (com possibilidade de poder escolher antes de usar. Do jeito que está, preciso digitar, selecionar o texto e depois clicar na opção); tamanhos variados das fontes; sublinhar; opções de alinhamento e cores;

6. A ferramenta comentário

Essa ferramenta deveria funcionar nos dois ambientes, de forma que o professor pudesse colocar feedbacks nas construções dos estudantes. Bem, para teste ela não é imprescindível. Podem focar no conserto dos problemas relatados acima.

Relatório de análise da plataforma GGBook

Data: 13 de julho de 2013

O relatório a seguir tem o objetivo de apresentar as correções e implementações que precisam ser feitas na plataforma GGBOOK de forma a oferecer condições mínimas de testes.

\section{Experimentando para a Lei dos Senos}

a. As duas primeiras razões funcionam corretamente e os valores atualizam, mas a partir da $3^{\mathrm{a}}$ razão sempre ficam estáticos (tentei 3 vezes); 


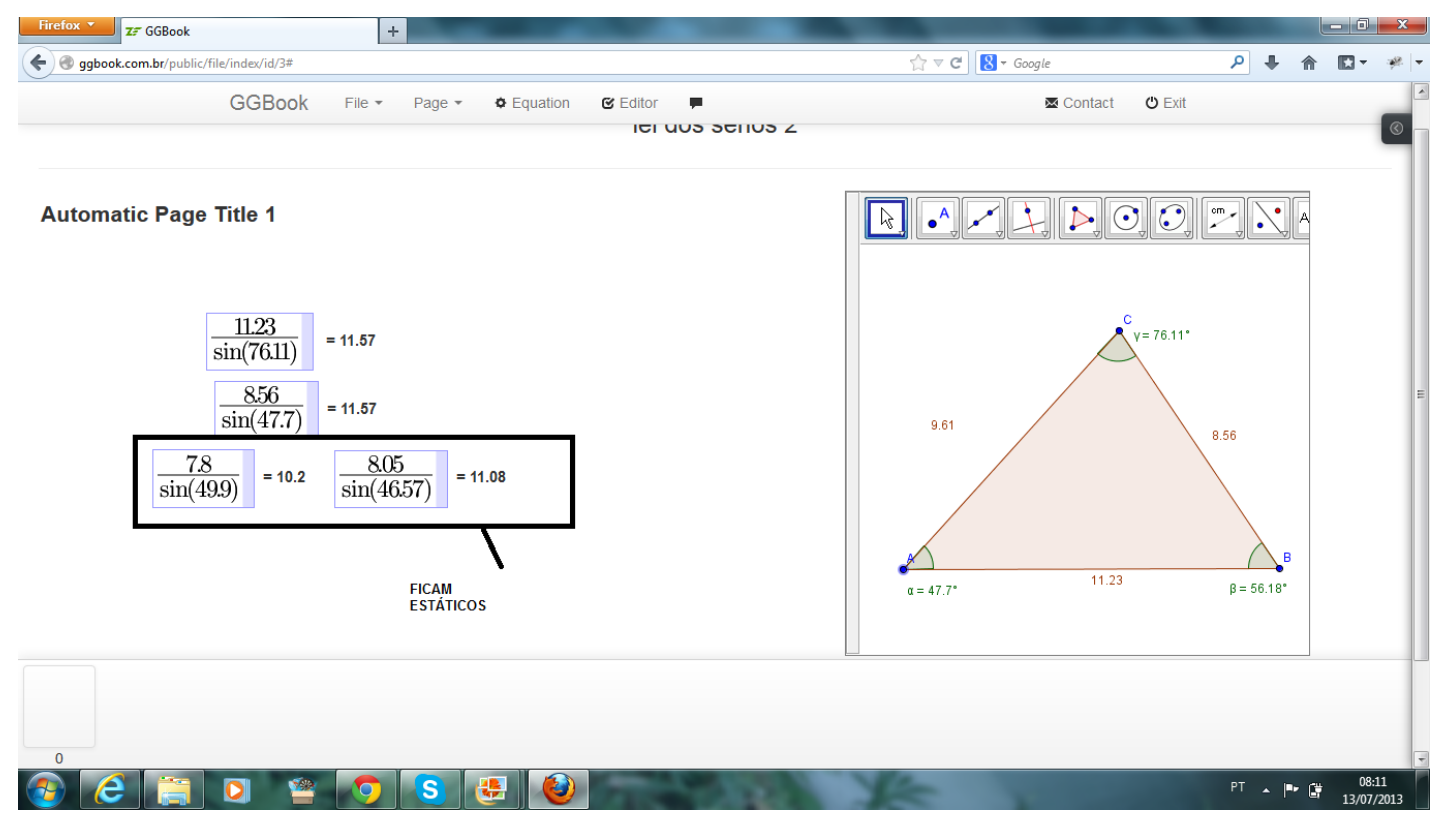

b. Sempre a partir do $3^{\circ}$ cálculo, os resultados ficam estáticos;

c. A $2^{\mathrm{a}}$ página continua não aceitando a inserção de equação;

d. A tela do geogebra está sobrepondo o espaço das páginas do livro. Os ícones dos botões estão grandes. Diminuir para que caibam todos na tela.

e. Para operação de adição está funcionando, mas quando movimento um objeto, some uma parcela:

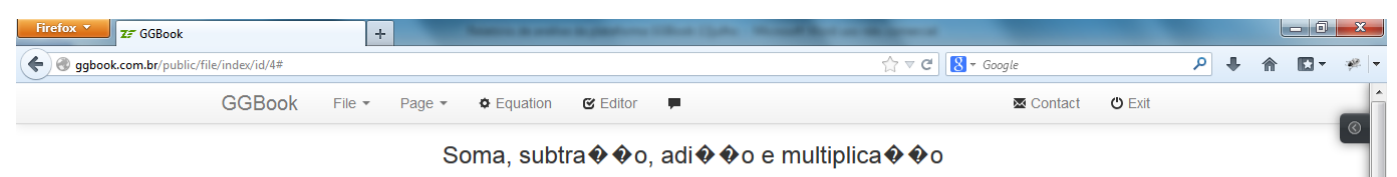

Automatic Page Title 1
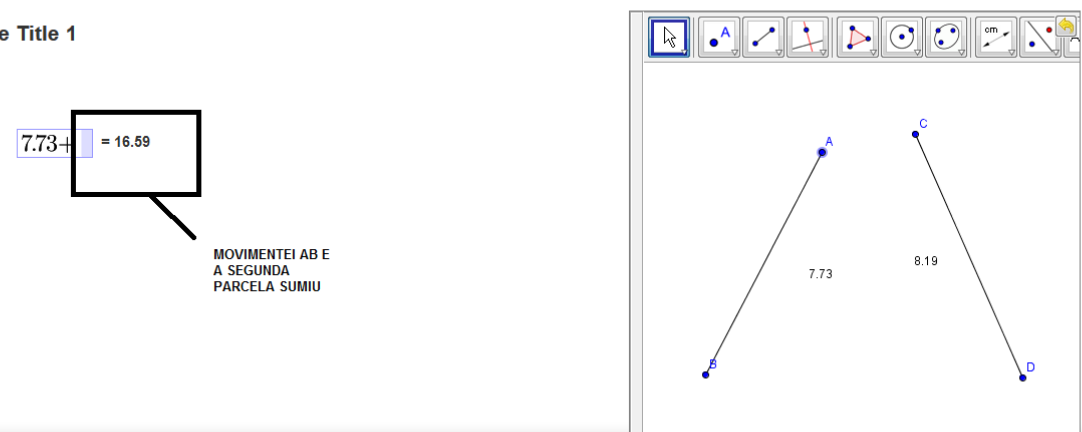

(9) e E D D D O

f. Estão acontecendo bugs na subtração;

g. Não aceita inserção de valores na potência e radicais;

Ao abrir um arquivo anterior, percebi que os valores permaneceram! Ao alterar o objeto na janela do geogebra, percebi que os valores atualizaram, mas o resultado não. Já achei isso uma evolução muito boa!! 


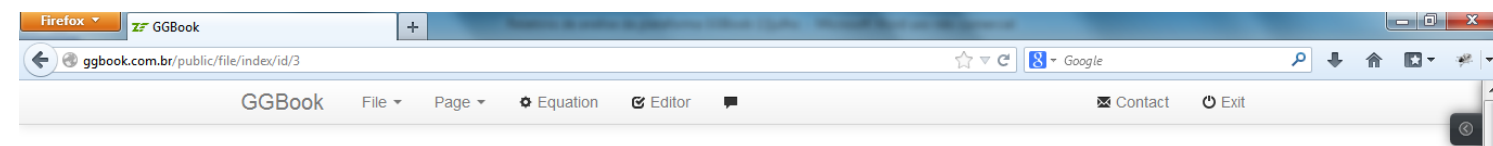

lei dos senos 2

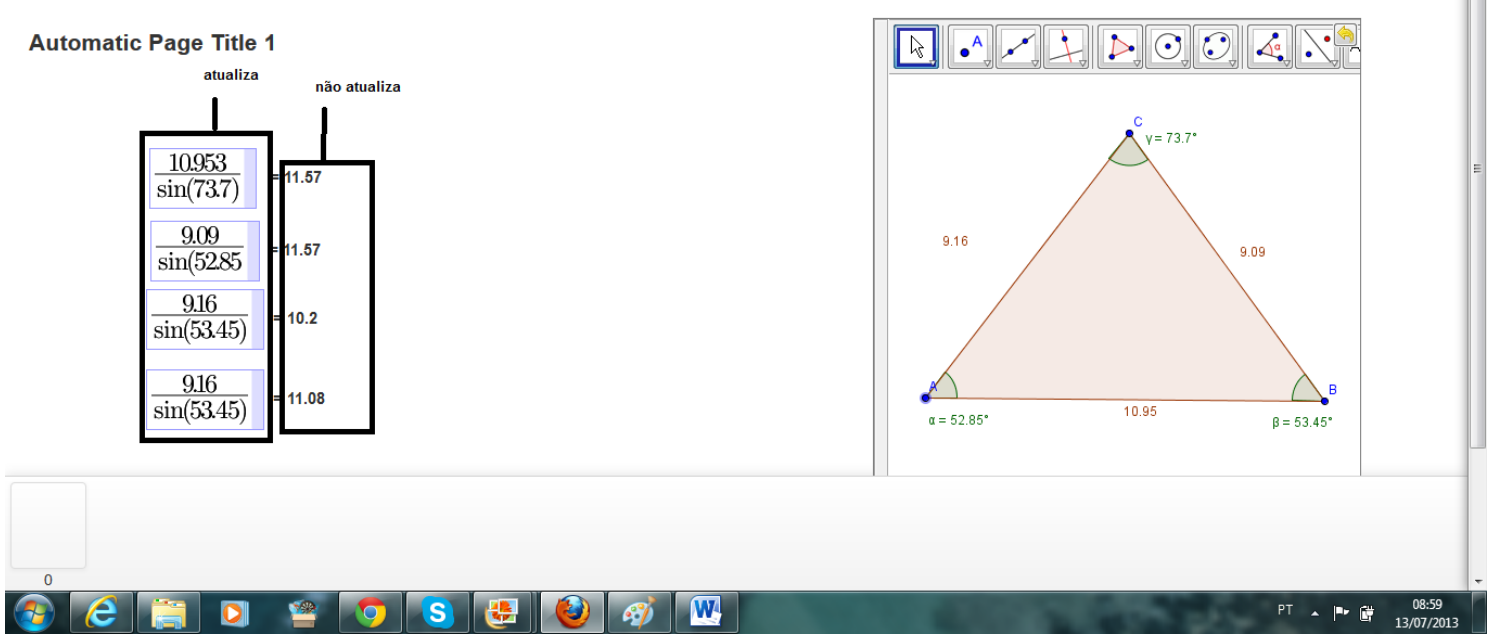

Relatório de análise da plataforma GGBook

Data: 20 de julho de 2013

O relatório a seguir tem o objetivo de apresentar as evoluções, correções e implementações que precisam ser feitas na plataforma GGBOOK de forma a oferecer condições mínimas de experimentação.

Testes feitos no MOZILLA

\section{Em relação a tela inicial, depois que logamos.}

a. Possibilidade de criar arquivos já colocando nomes;

b. Ainda não conseguimos deletar um arquivo criado anteriormente;

c. Ainda não conseguimos copiar (duplicar) os "books", de forma que o professor possa fazer books iguais para estudantes diferentes;

d. Para quê o botão "remove" em file e "page"?

e. Ao criar um novo arquivo, a plataforma não abre exibindo o texto e o geogebra. É preciso mandar atualizar;

f. A tela do geogebra está sobrepondo o espaço das páginas do livro. Os ícones dos botões estão grandes. Diminuir para que caibam todos na tela. 


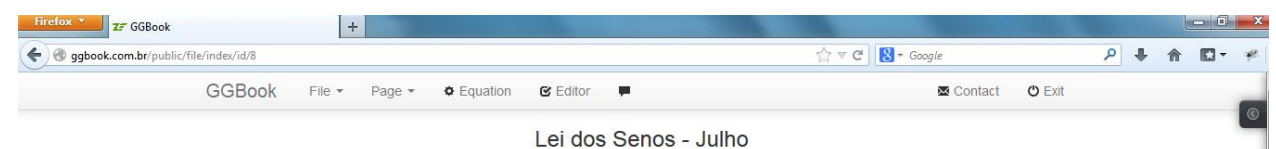

Lei dos Senos - Julho

Automatic Page Title 1 Automatic Page Text 11

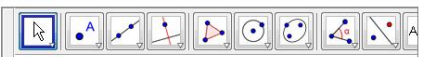

g. Precisamos ter mais opções na barra flutuante de texto: centralizar, alinhamento justificado, tamanho e tipo da fonte, sublinhar;

\section{Usabilidade e integração entre os ambientes}

a. Em relatórios anteriores, havia pedido para que quando gerasse o resultado, o cursor saísse de dentro da caixa, porque ao movimentar o objeto na tela do geogebra inserem-se novos objetos dentro da caixa, gerando problemas. Tais problemas permanecem;
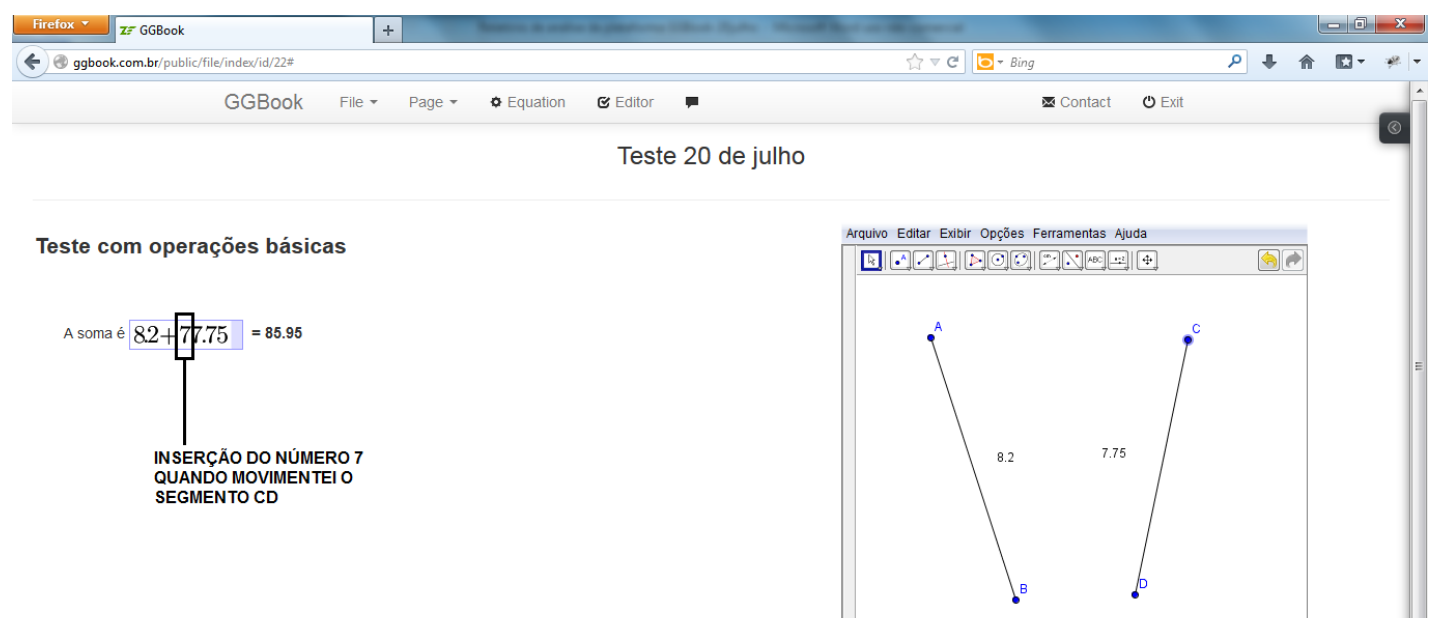

(4) E D D E O

b. As operações simples de adição, subtração, multiplicação, divisão, potenciação estão funcionando bem. Todavia tem problemas para expressões maiores. Vejam o exemplo: 


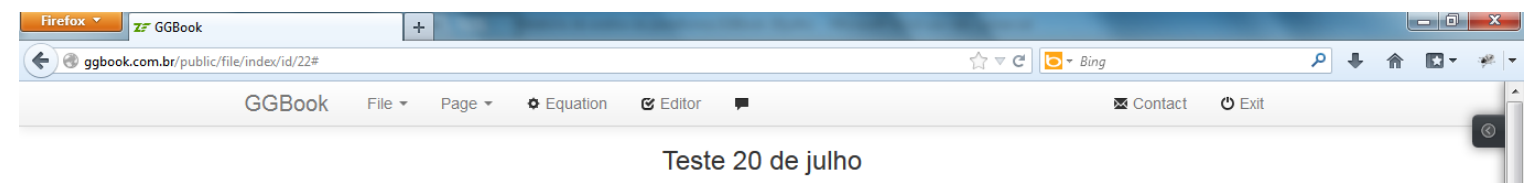

Titulo da pagina2
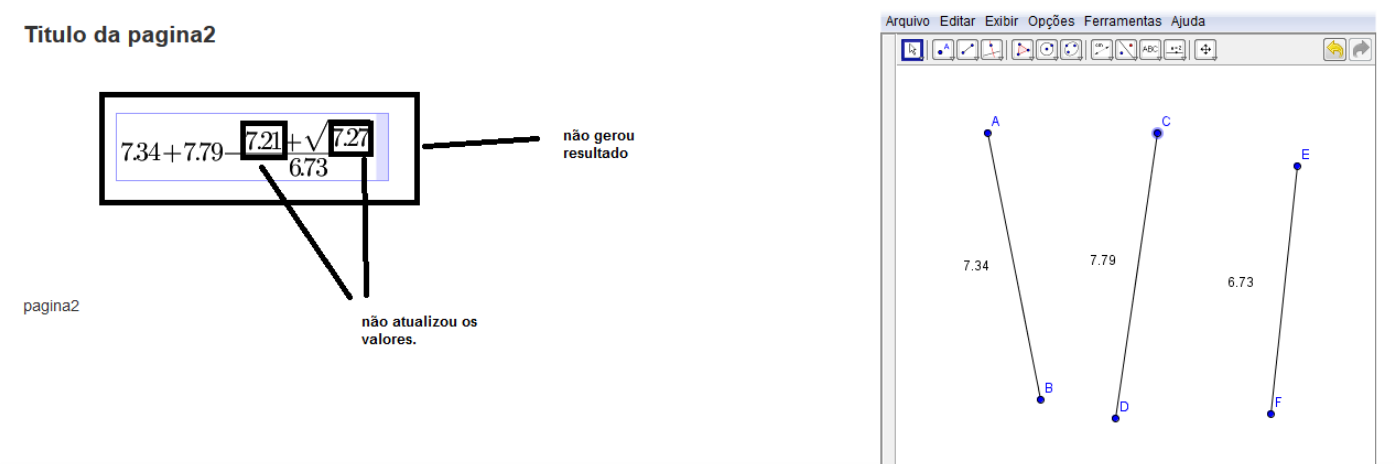

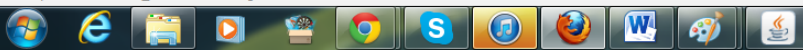

c. "Operações dentro de operações" também funcionam. Exemplo: Fração dentro de uma raiz; Todavia não consigo digitar um expoente de uma potência dentro de uma raiz. Vejam:

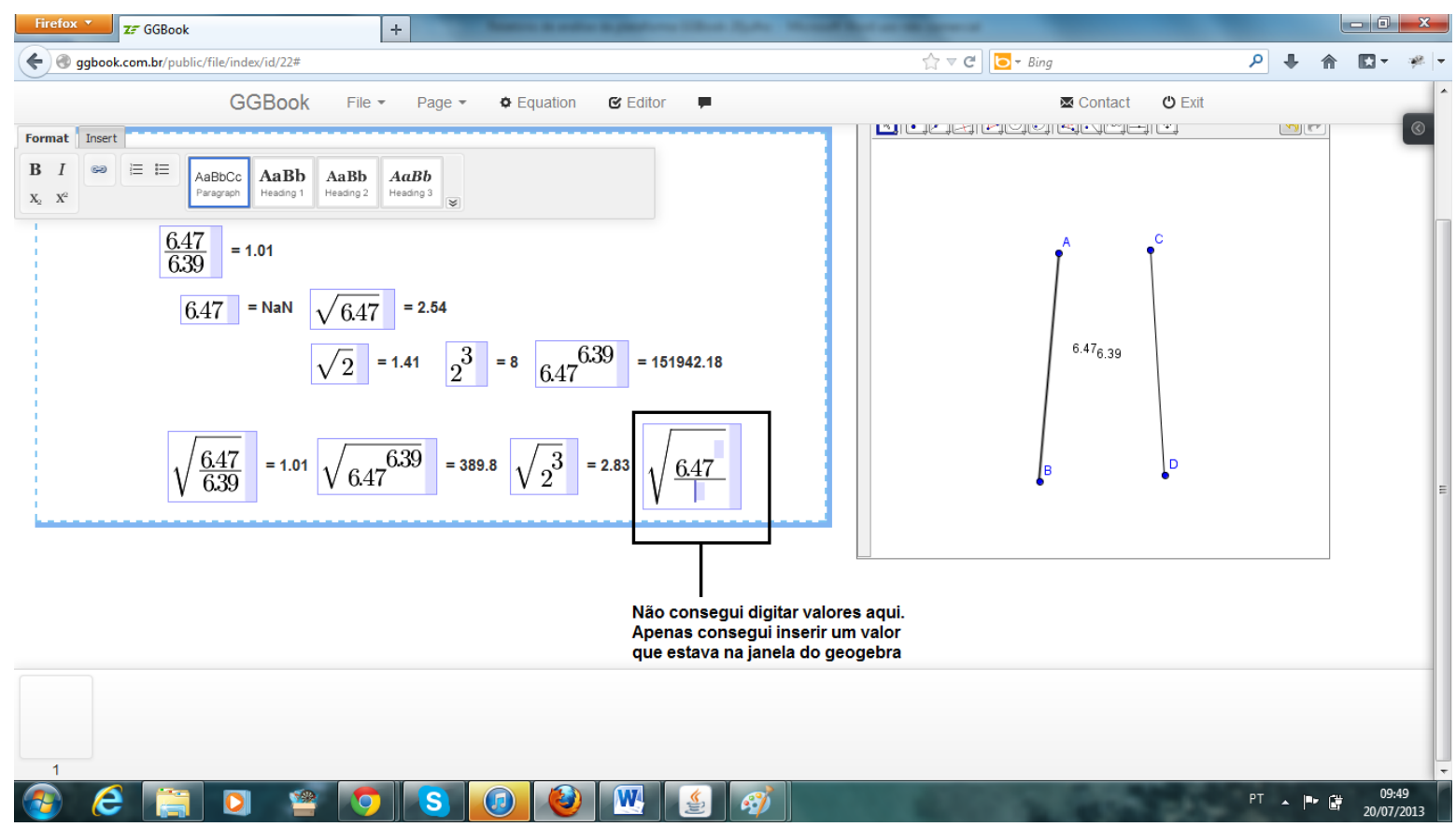

d. Quando abro uma nova página, não consigo abrir a caixa de texto. Tenho que mandar atualizar a página para poder editar o texto. Quando volto para a primeira página, os dados que estava em raízes ficam desconfigurados; 


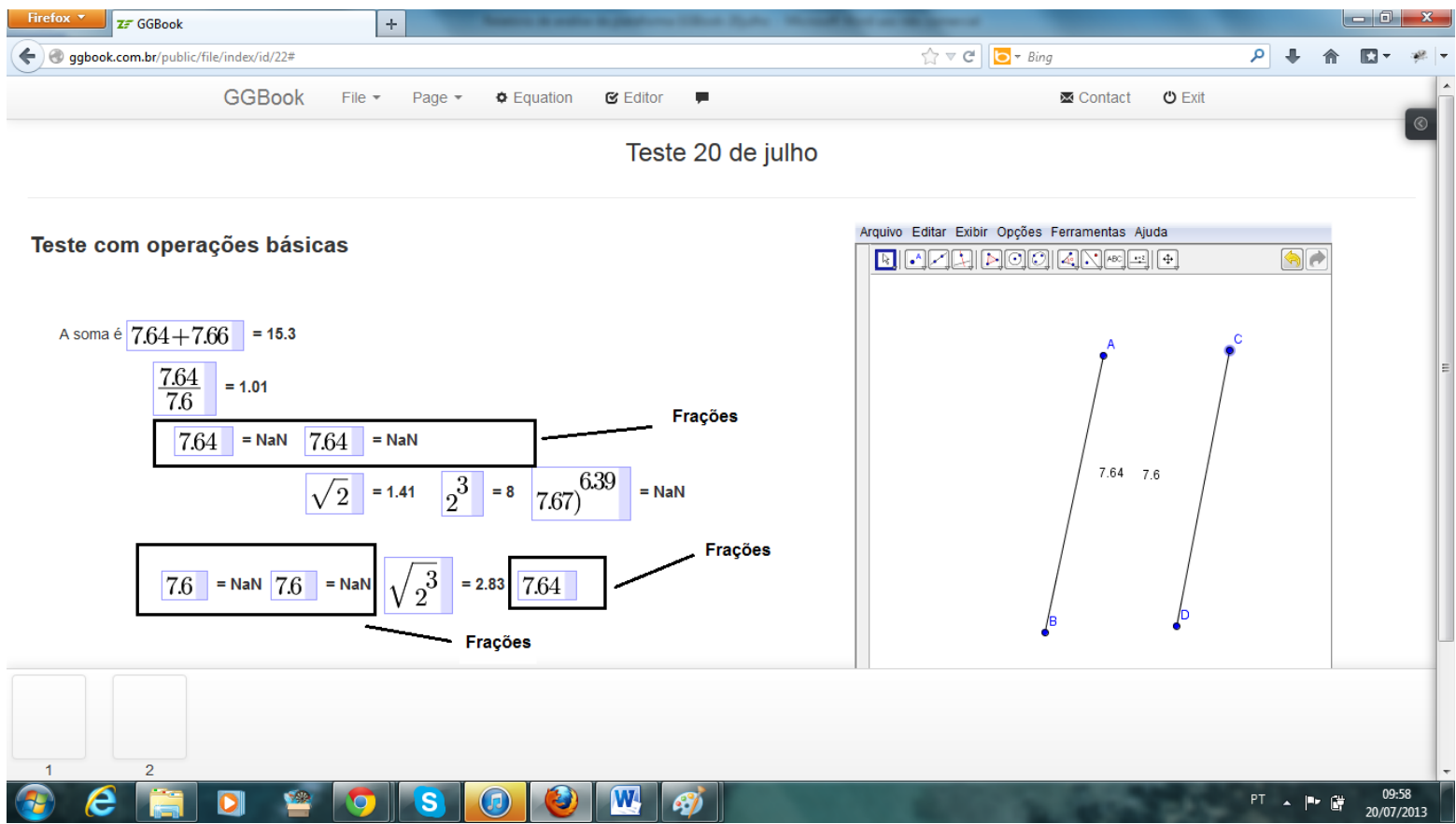

e. Soma ângulos, mas ocorre bugs quando movimentamos os objetos. Veja:

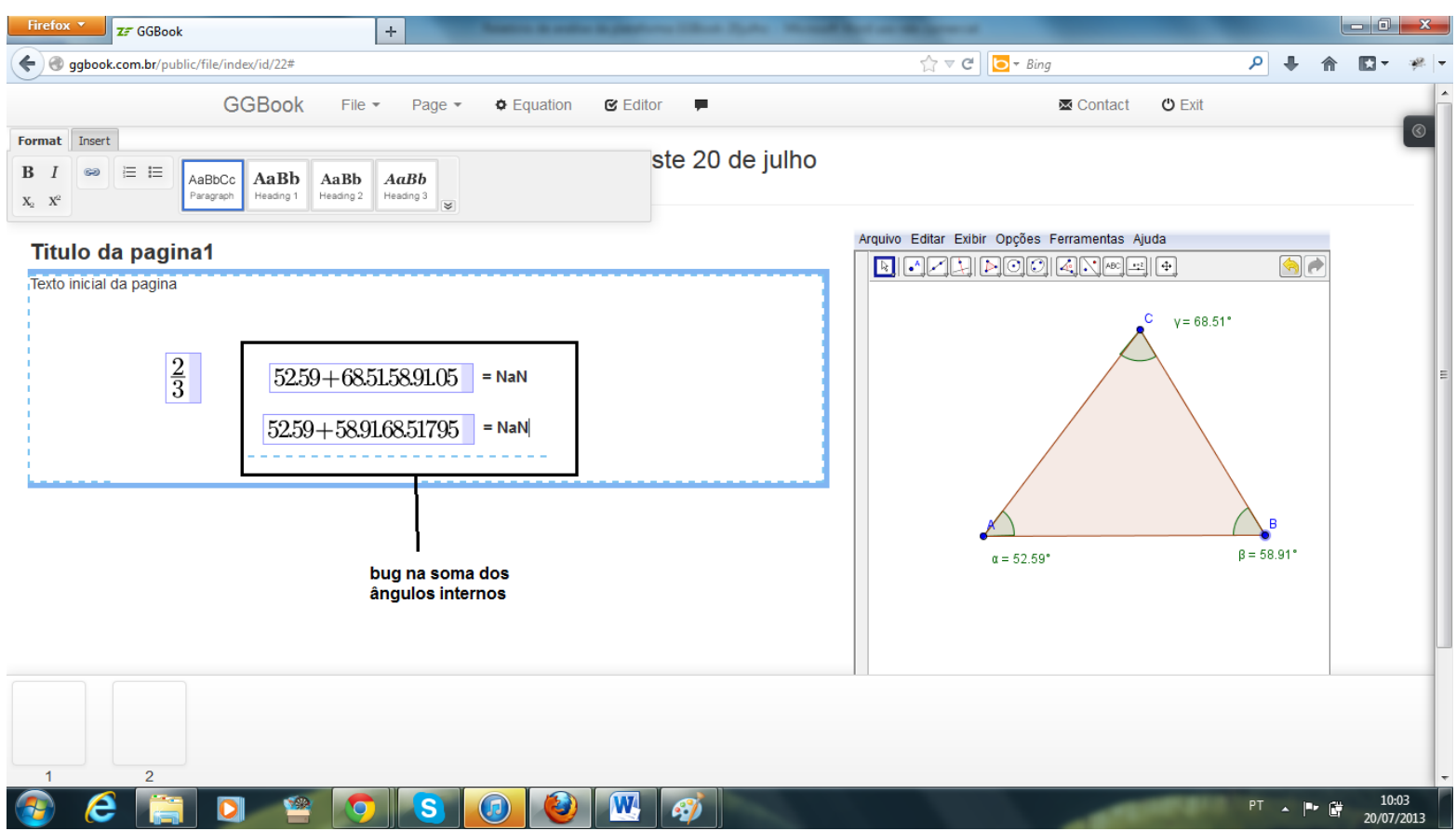

f. Os objetos feitos no geogebra não ficam salvos na página 2;

g. Não consigo abrir um arquivo do geogebra na janela 2, mas quando salvo um arquivo feito na página 1 e salvo no desktop, consigo abrir o arquivo na página 2. O MELHOR: QUANDO FECHO A PLATAFORMA E DEPOIS ABRO NOVAMENTE OS ARQUIVOS DO GEOGEBRA ABREM NAS DUAS JANELAS! NA PRIMEIRA, OS ARQUIVOS DE TEXTO CONTINUAM DINÂMICOS, NA SEGUNDA JANELA OS TEXTOS FICAM ESTÁTICOS! 
Relatório de análise da plataforma GGBook

Data: 31 de agosto de 2013

O relatório a seguir tem o objetivo de apresentar as evoluções, correções e implementações que precisam ser feitas na plataforma GGBOOK de forma a oferecer condições mínimas de experimentação.

Testes feitos no MOZILLA

\section{Em relação a tela inicial, depois que logamos.}

a. A tela do geogebra está sobrepondo o espaço das páginas do livro. Além disso, está com botões grandes e sem a barra de menu

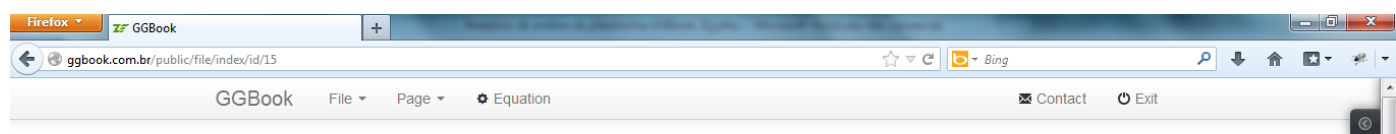

lei

Automatic Page Title 1 Automatic Page Text 1

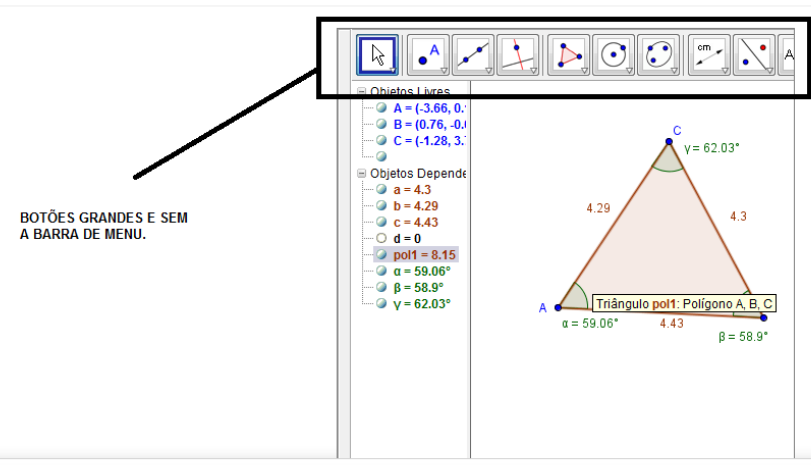

(4) E D D

b. Quando altero um objeto no geogebra, um número "nada a ver" entra na equação

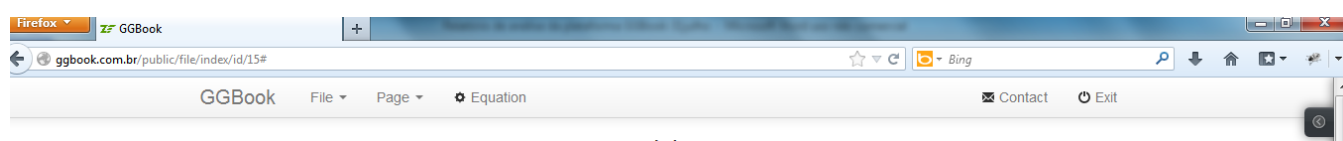

lei
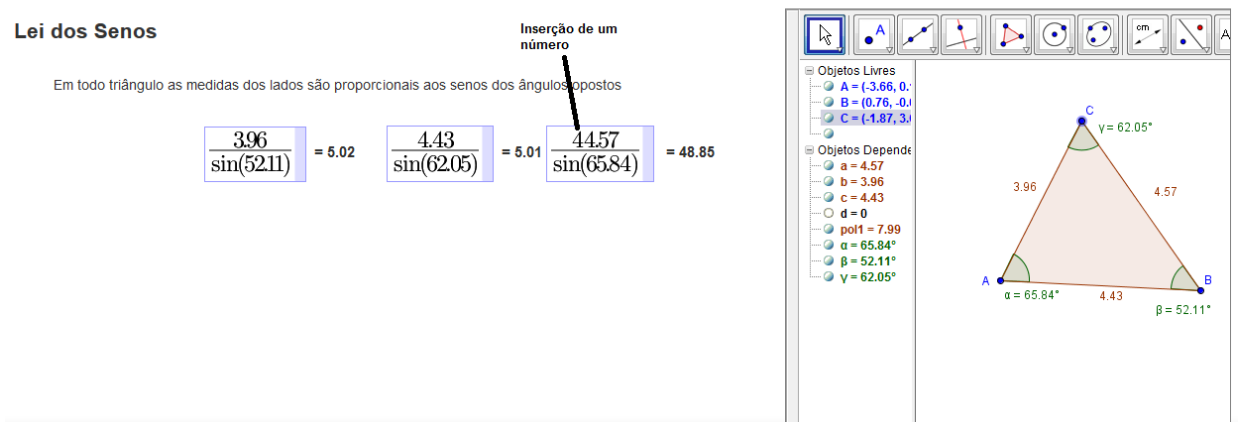
c. Quando crio uma nova janela, não consigo abrir a caixa para editar os textos. Tenho que atualizar a página para poder editar;

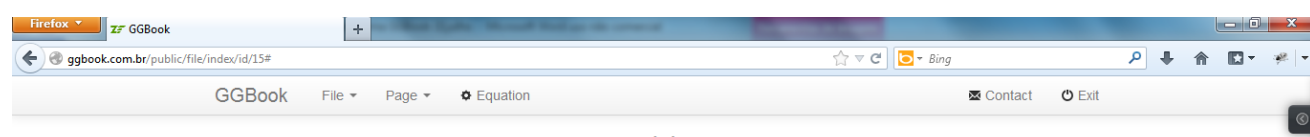

lei
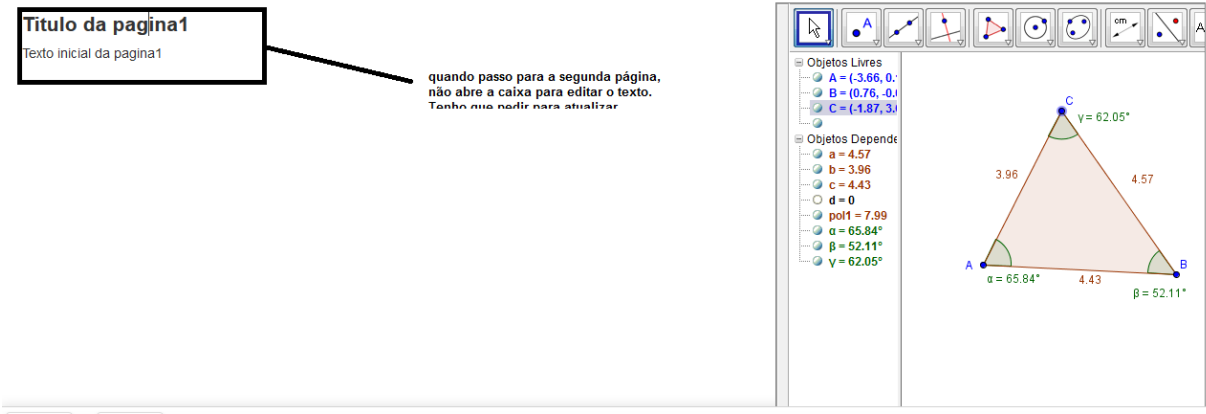

(4) C 3 D D

d. Para quê o botão "remove" em file e "page"?

e. Ao criar um novo arquivo, a plataforma não abre exibindo o texto e o geogebra. É preciso mandar atualizar;

f. O botão de potência gera uma fração e não está gerando resultado da multiplicação (tem como mudar o botão da multiplicação para * ?)

g. Precisamos ter mais opções na barra flutuante de texto: centralizar, alinhamento justificado, tamanho e tipo da fonte, sublinhar;

h. Em relatórios anteriores, havia pedido para que quando gerasse o resultado, o cursor saísse de dentro da caixa, porque ao movimentar o objeto na tela do geogebra inserem-se novos objetos dentro da caixa, gerando problemas. Tais problemas permanecem;

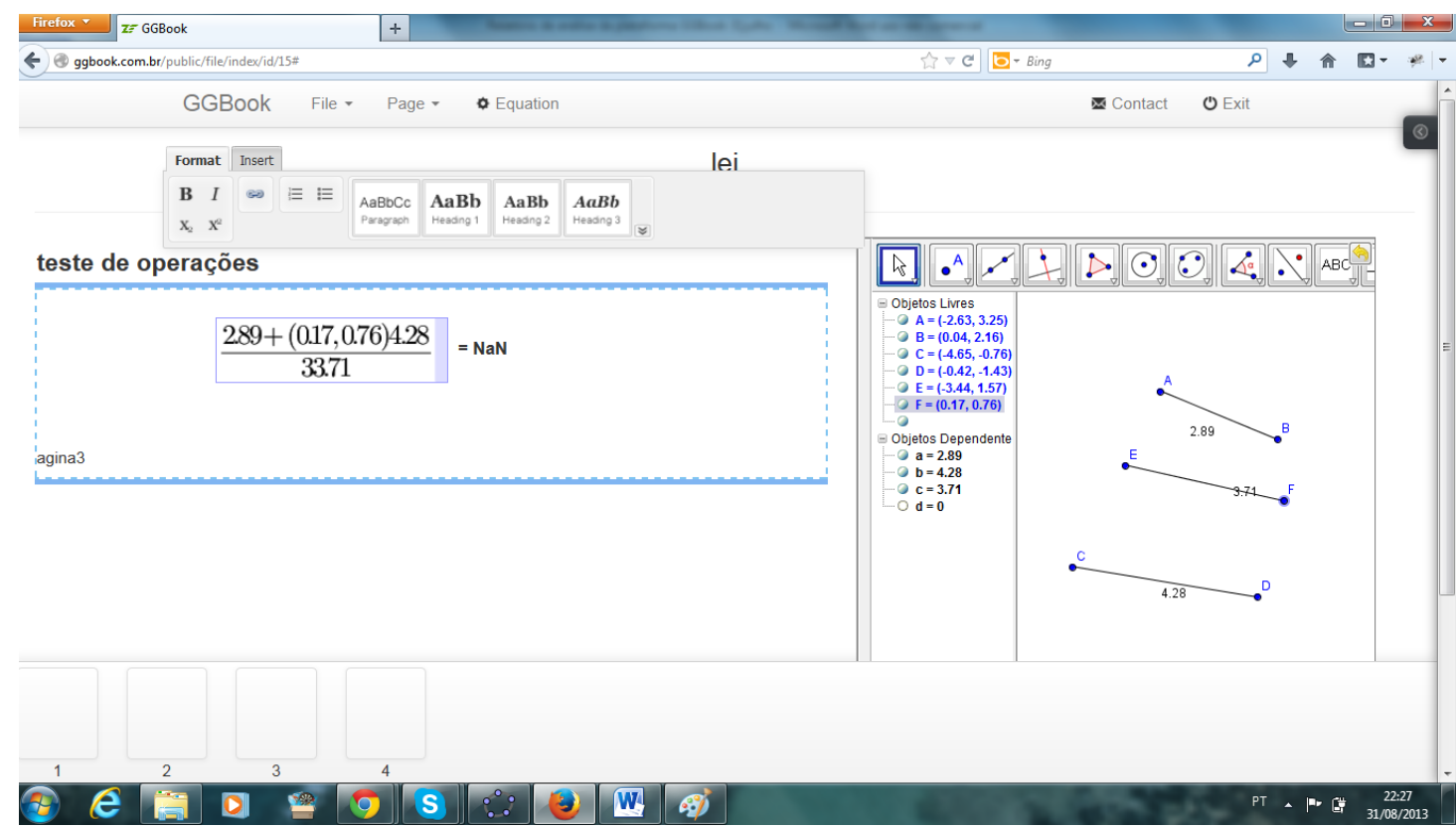


i. As operações simples de adição, subtração e divisão estão funcionando bem. Todavia tem problemas para expressões maiores.

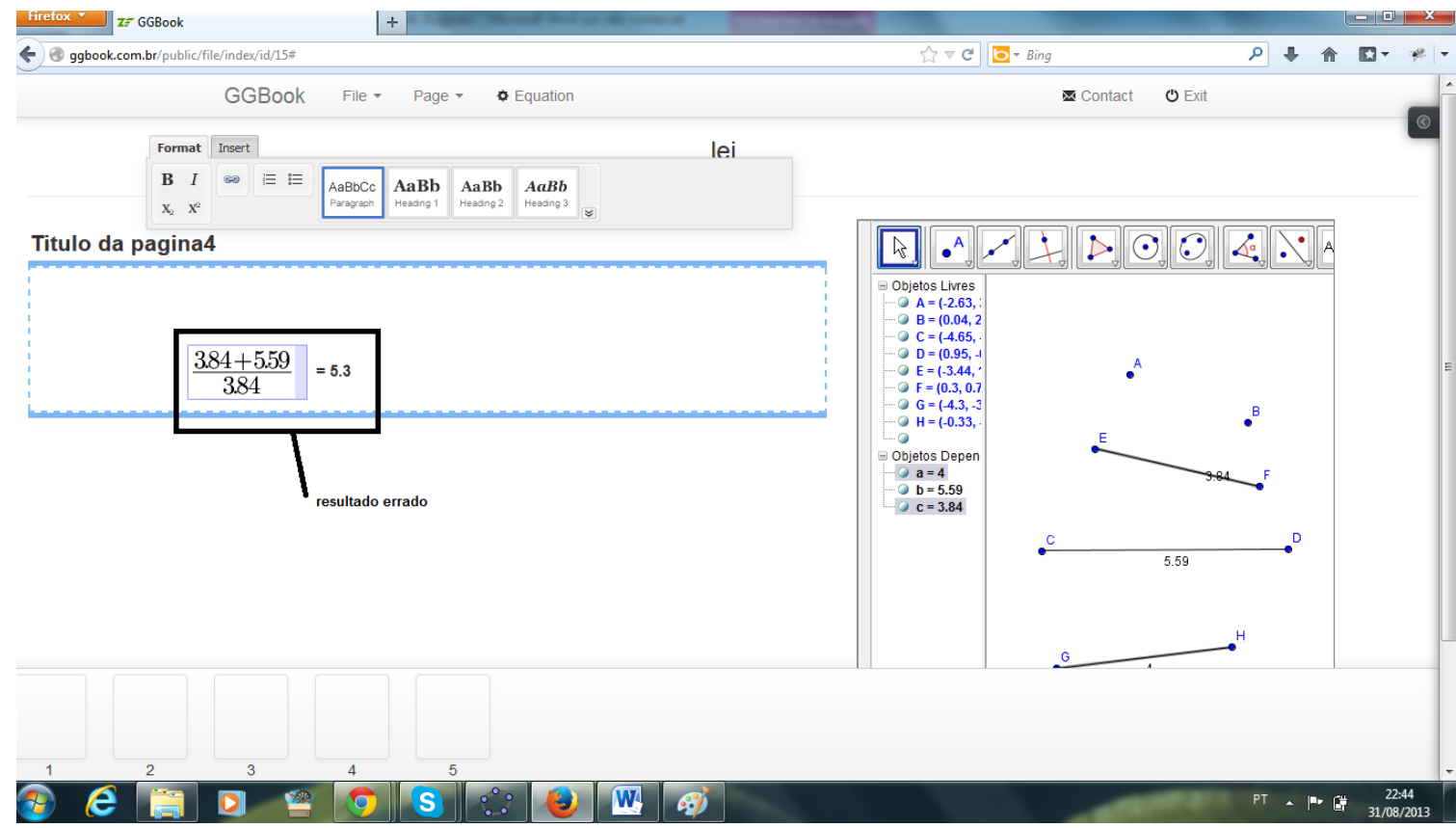

j. Soma ângulos, mas ocorre bugs quando movimentamos os objetos. Veja:

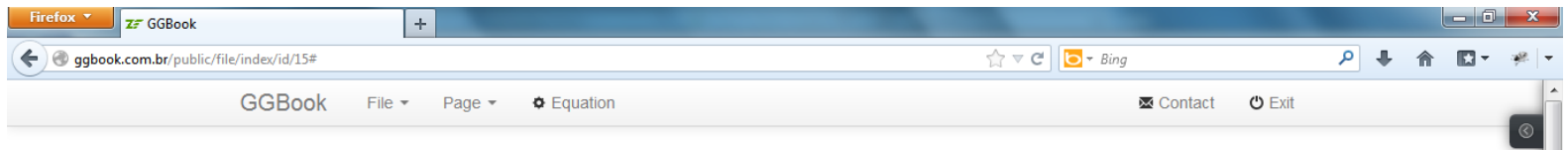

lei

Titulo da pagina5

$46.92+69.02 .64 .06 .82=\mathrm{NaN}$

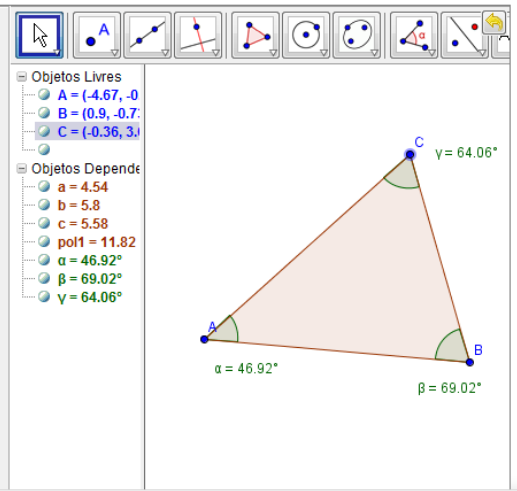




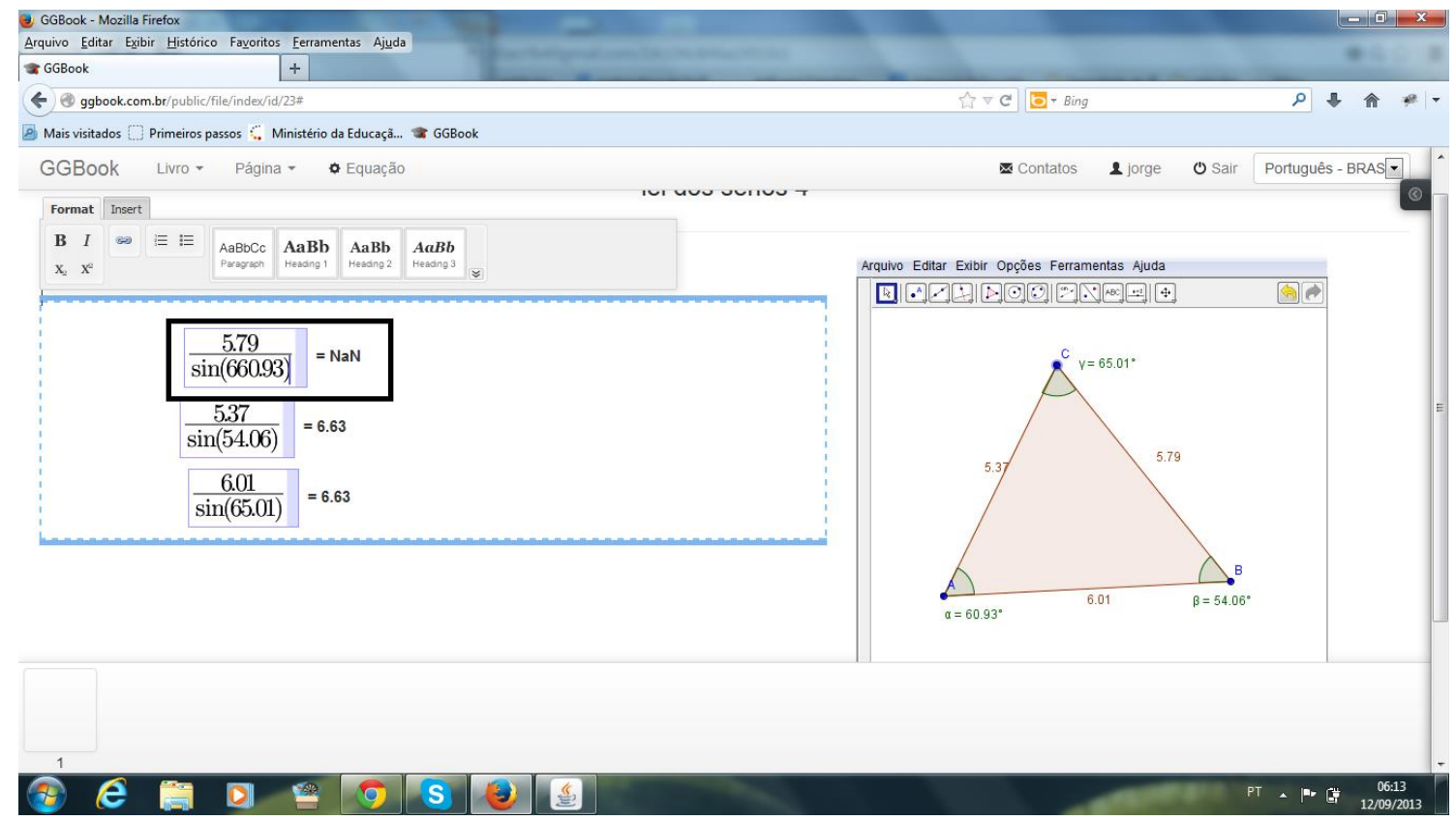

Eu repeti o mesmo procedimento que fiz ontem de manhã. Ontem funcionou bem, mas hoje rolou o mesmo problema. Na hora de fazer o cálculo fica ok. Mas quando mexo no geogebra, ele insere o número. É sempre da mesma maneira:

- Se tem 60,93 quando altero o geogebra, ele insere o mesmo número ficando 660,93;

- Se tem 70,93 quando altero o geogebra, ele insere o mesmo número ficando 770,93;

Entenderam?

Só acontece na primeira página.

Outro problema é que para inserir a equação na $2^{\mathrm{a}}$ página, sempre é preciso atualizar.

Esse problema será corrigido para a apresentação?

\section{Problemas no GGBOOK}

Data: 11 de dezembro de 2013

O relatório a seguir tem o objetivo de apresentar correções e implementações que precisam ser feitas na plataforma GGBOOK de forma a oferecer condições mínimas de experimentação. 
Testes feitos no MOZILLA. Seria bom que as próximas versões já funcionassem no Chrome também.

1. Em relação a tela inicial, depois que logamos.

a. Não consigo remover um book criado. Mesmo clicando no botão remover, o book não é deletado.

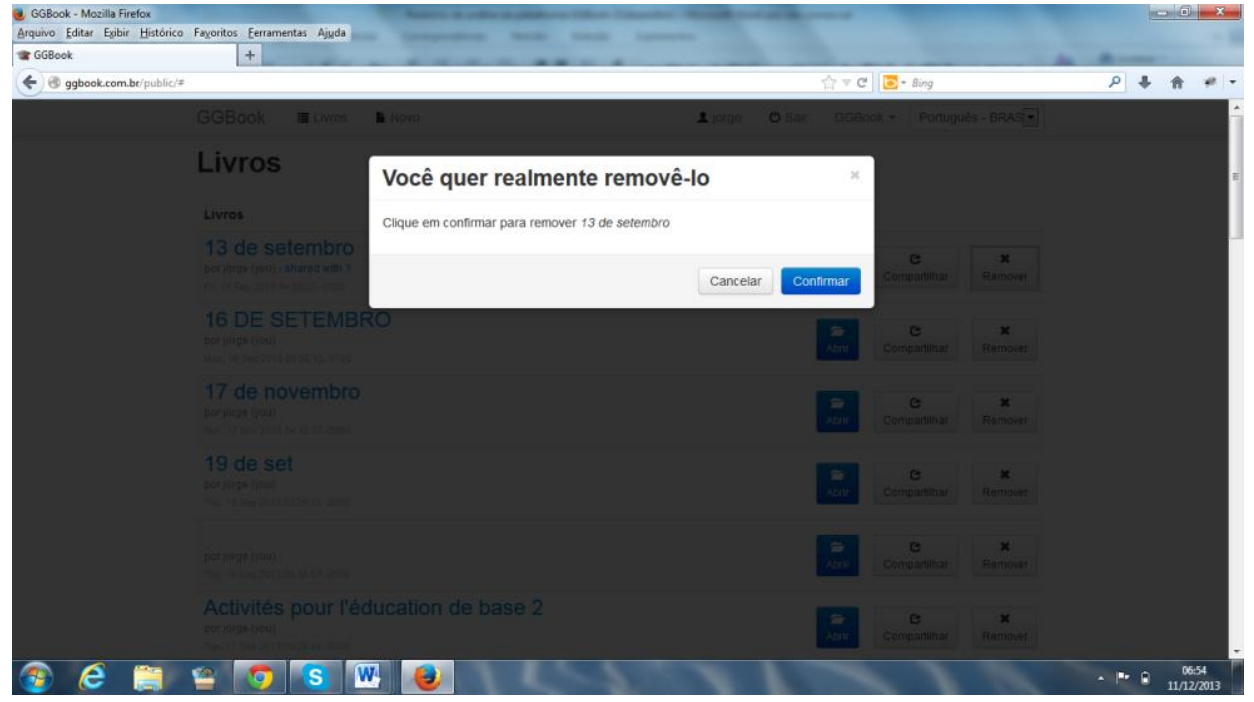

2. Usabilidade e integração entre os ambientes

a. Em relação à seleção das ferramentas de equações é preciso verificar o local onde se clica para a seleção de determinadas ferramentas. Por exemplo, quando quero selecionar a potência, se clico do lado esquerdo dela aparece fração. Veja a figura:

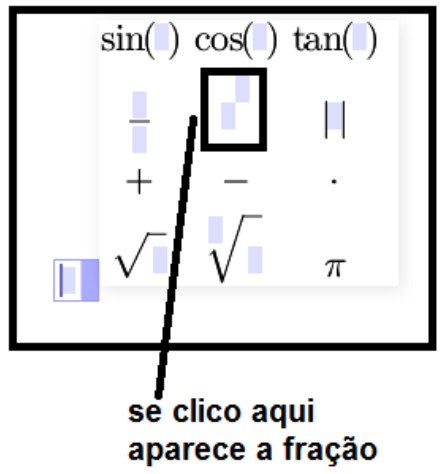


Para aparecer a potência tenho que clicar do direito do símbolo. O mesmo ocorre para a subtração.

b. Quando estou no ambiente de equação a barra flutuante de ferramentas de texto não deveria aparecer. Ela, inclusive, atrapalha.

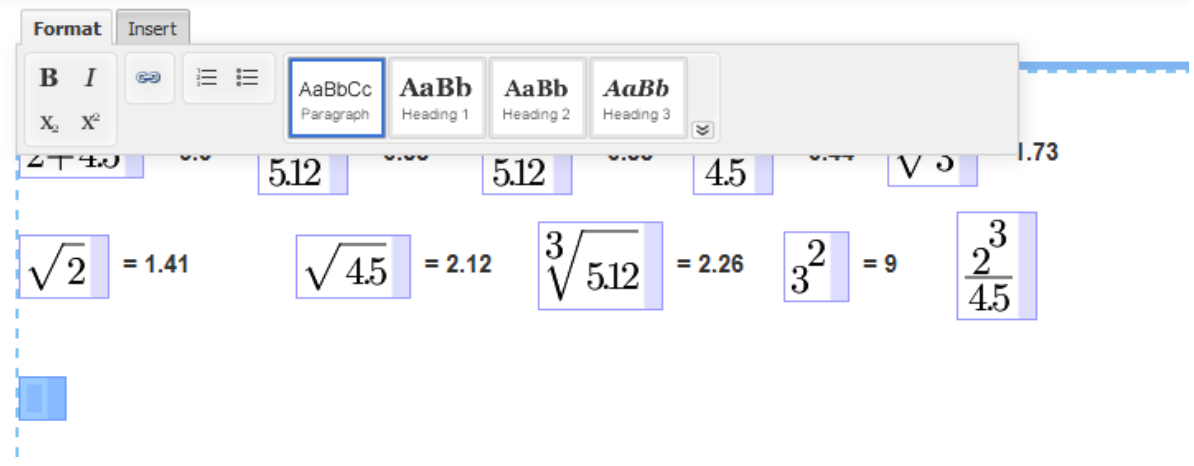

c. As operações simples de adição, subtração, potência e divisão estão funcionando bem. Multiplicação não funciona (não mostra o resultado)

d. Fiz um teste somando as medidas dos lados e ângulos de triângulo. Os resultados estavam corretos, mas ao movimentar a figura, deram problemas. Vejam:

Teste 11 de dezembro

multiplas operações

$3.493 .7265 .157=$ NaN é igual ao perimetro 91.08346 .294442 .6396 $3.72+5.153 .4963 .9=\mathrm{NaN}$

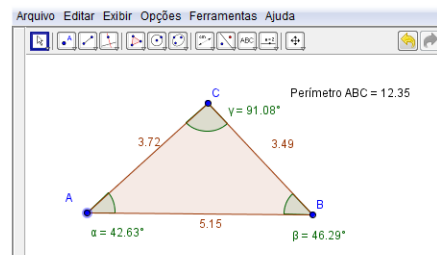

e. Não gera resultados para algumas expressões:

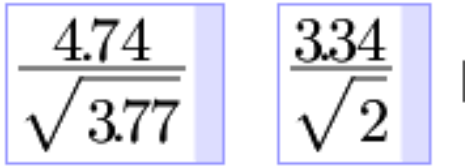

f. Em certas ocasiões não atualiza os valores quando deformamos a figura no geogebra. Vejam: 


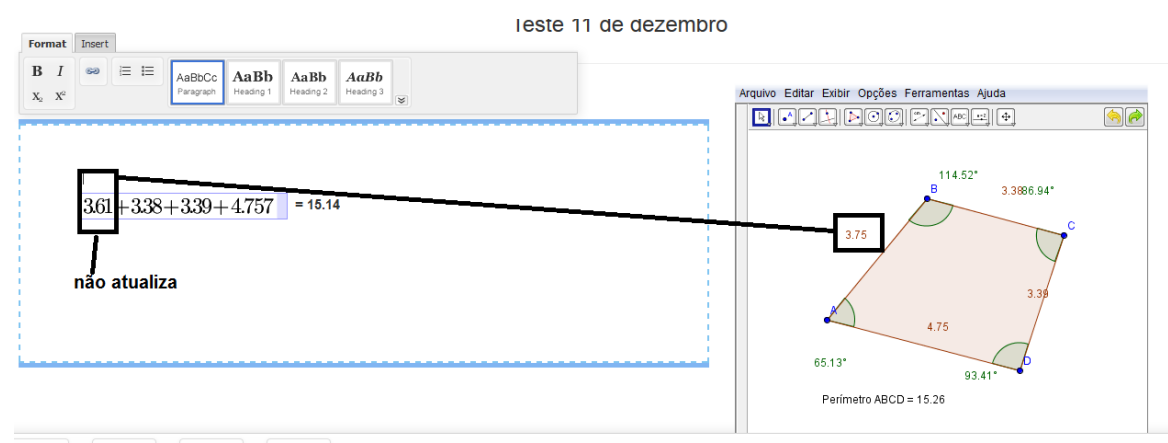

g. Continua o problema de inserir um número que não tem na a ver. Vejam na figura abaixo:

Teste 11 de dezembro
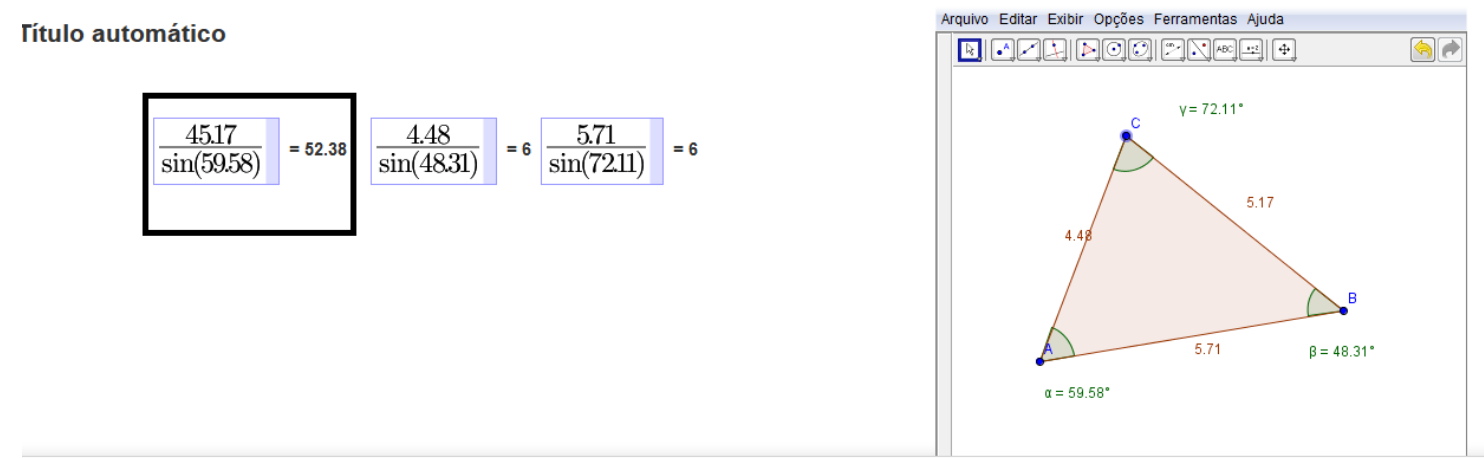

Na hora de fazer o cálculo fica ok. Mas quando mexo no geogebra, ele insere o número. É sempre da mesma maneira:

- Se tem 60,93 quando altero o geogebra, ele insere o mesmo número ficando 660,93;

- Se tem 70,93 quando altero o geogebra, ele insere o mesmo número ficando 770,93;

Entenderam?

h. Deleto uma operação com resultado na janela de texto, mas quando mexo alguma figura no geogebra o resultado aparece novamente. 


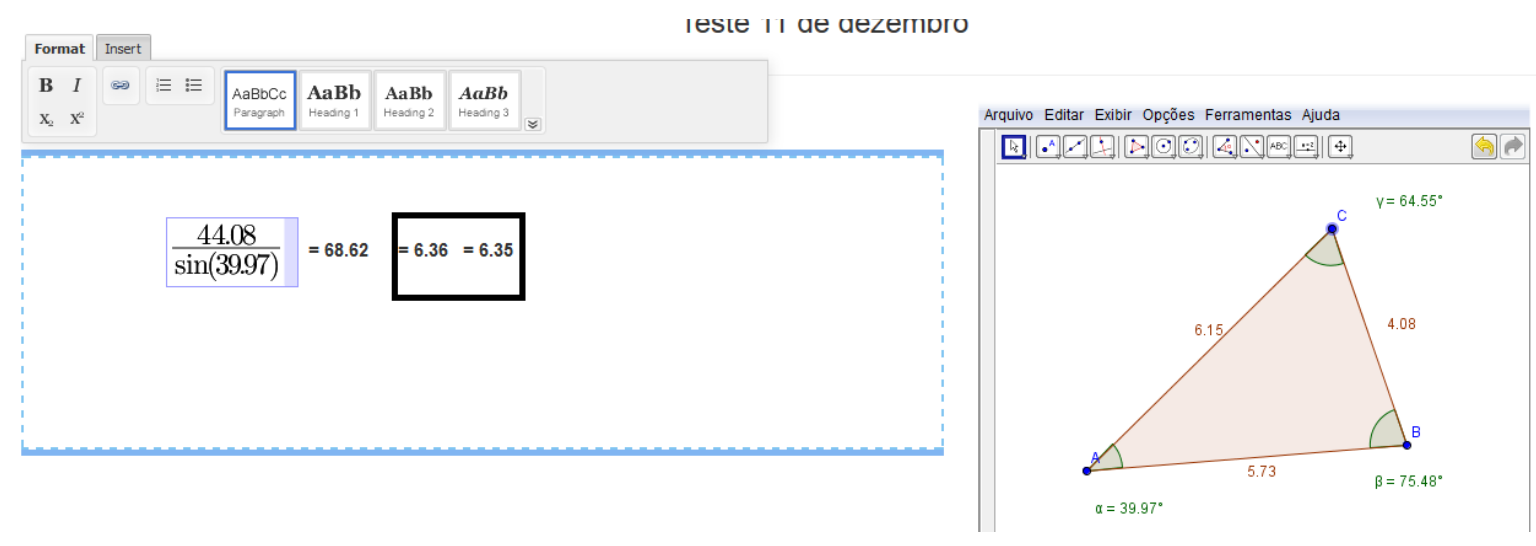

Outros ajustes

i. Preciso de uma opção para deletar uma página do Book

j. Preciso de uma opção de compartilhamento em que eu possa compartilhar um book para diferentes pessoas e que elas possam trabalhar de maneira independente. Da forma como está não dá para o professor saber qual usuário fez as modificações. Entendem? O que sugiro é que ao compartilhar o arquivo para diferentes pessoas, o ggbook já copie o arquivo feito. Entendem? 


\section{APÊNDICE C- RELATÓRIOS DO GGBOOK 2014}

Data: 12 de fevereiro de 2014

O relatório a seguir tem o objetivo:

- Apresentar considerações sobre as implementações que foram feitas.

- Apresentar correções e implementações que precisam ser feitas na plataforma GGBOOK de forma a oferecer condições mínimas de experimentação.

Testes feitos no MOZILLA.

Para fazer o teste, simulei a criação de um livro sobre razão áurea.

1. Usabilidade e integração entre os ambientes

a. Para logar está tranquilo. Para carregar o geogebra quando solicitei a criação de um novo livro demorou cerca de 1 minuto.

b. Tab não funciona.

c. Para construir a atividade não tive problema algum. Consegui compartilhar.

d. Ao testar o arquivo compartilhado, percebi que não poderia ver o vídeo colocado. Só aparecerá quando duplicar?

e. Uma equação que coloquei, desapareceu na página 2. Aí percebi que da forma como está era preciso criar a cópia.

f. Para ver o vídeo é preciso clicar em "editing”. Isso não é intuitivo. Ele pode esquecer de clicar novamente quando for para a página 2. Não conseguirá editar, colocar textos, etc

g. Percebi a inserção de algo na equação da página 2 que não havia colocado:

$$
\frac{A B}{A C}=\quad \frac{A C}{B C}
$$

h. Às vezes, não consigo colocar o cursor dentro da equação: 


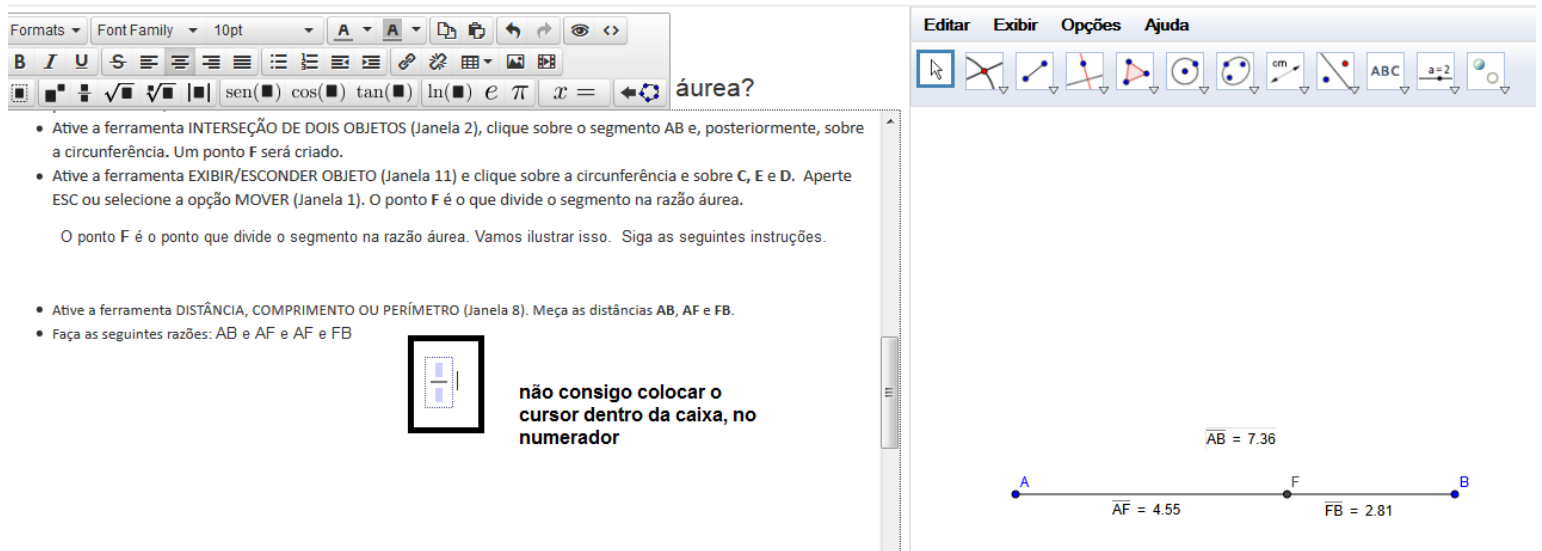

i. Depois que compartilhei a atividade, não consegui mais inserir valores nas equações. Nem quando estava vendo o arquivo compartilhado (como Miguel), nem na minha conta mesmo.

Razão áurea

Retângulo áureo

Atividades

- Verifique se o retângulo ao lado é áureo.

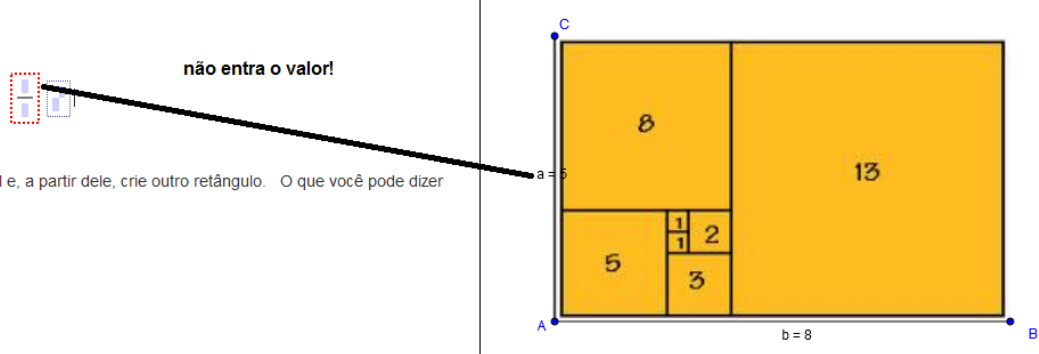

2. Não funciona a edição de equações na atividade "razão áurea". Isso aconteceu depois que compartilhei. Ok?

3. Quando abro um novo livro aí funciona. 


\section{APENDICE D: TERMO DE CONSENTIMENTO}

O laboratório Ábaco da Faculdade de Educação da Universidade de Brasília-UnB, coordenado pelo Prof. Dr. Gilberto Lacerda dos Santos, está desenvolvendo uma plataforma educativa para o ensino de Matemática: O GGBOOK.

O GGBOOK é uma plataforma educativa para o ensino de matemática. O nome GGBOOK é uma integração dos termos "GGB" e "BOOK". GGB vem das extensões dos arquivos do software educativo GeoGebra e BOOK é a palavra "livro", em inglês. A ideia é que a plataforma sirva como um livro digital dinâmico que integra múltiplas representações. Para que possamos validar a ferramenta, é necessária a experimentação com estudantes. Isso fornecerá dados para as análises.

O sigilo do nome dos estudantes será preservado.

Desde já, agradecemos.

Prof. Dr Gilberto Lacerda dos Santos

Prof. Jorge Cássio Costa Nóbriga

$\mathrm{Eu}$, minhas atividades desenvolvidas no GGBOOK. autorizo as análises das 